\title{
Parcerias entre a Administração Pública e o Terceiro Setor:
} sistematização e regulação

Tese apresentada ao Programa de Pósgraduação stricto sensu em Direito da Universidade de São Paulo - USP como requisito parcial para a obtenção do grau de Doutor em Direito do Estado.

Área de concentração: Direito do Estado

Orientadora: Professora Doutora Maria Sylvia Zanella Di Pietro 


\section{Parcerias entre a Administração Pública e o Terceiro Setor: sistematização e regulação}

Tese apresentada ao Programa de Pósgraduação stricto sensu em Direito da Universidade de São Paulo - USP como requisito parcial para a obtenção do grau de Doutor em Direito do Estado.

Aprovado em:

Banca examinadora:
Professora Doutora Maria Sylvia Zanella Di Pietro (orientadora) Instituição: Universidade de São Paulo - USP Julgamento:
Professor(a) Doutor(a):
Instituição: Universidade de São Paulo - USP Julgamento:
Professor(a) Doutor(a):
Instituição: Universidade de São Paulo - USP Julgamento:
Professor(a) Doutor(a):
Instituição:
Julgamento:

Professor(a) Doutor(a):

Instituição:

Julgamento: 
Dedico o presente trabalho ao meu amor, minha esposa Juliana, pela luz dos olhos teus. 


\section{AGRADECIMENTOS}

À minha orientadora, Professora Doutora Maria Sylvia Zanella Di Pietro, pela oportunidade em desenvolver o presente trabalho ao me acolher no Programa de Pósgraduação da USP e pela orientação segura e paciente.

À Professoressa Laura Castaldi, orientadora do meu Estágio de Doutorando junto à Università Degli Studi di Siena, pela acolhida incondicional e pelos auxílios pessoal e acadêmico durante a minha estada na Itália.

À CAPES, pelo apoio financeiro com a concessão de bolsa pelo PDEE - Programa de Doutorado no País com Estágio no Exterior, permitindo minha estada durante o segundo semestre de 2009 na Itália, realizando pesquisas junto à Università Degli Studi di Siena.

Aos Professores Doutores Heleno Taveira Tôrres e Luís Eduardo Schoueri, da USP, e James Marins, da PUCPR, pelo incentivo durante o processo seletivo para a obtenção da bolsa junto à CAPES.

À minha família e aos meus amigos, pela paciência e pelo incentivo.

À minha amada esposa Juliana, por tudo o que temos passado e passaremos juntos. 


\section{RESUMO}

Souza, Leandro Marins de. Parcerias entre a Administração Pública e o Terceiro Setor: sistematização e regulação. 2010. 288 f. Tese (Doutorado) - Faculdade de Direito, Universidade de São Paulo, São Paulo, 2010.

Traça a interseção de dois temas que, embora estejam sempre em voga, nos últimos 20 anos têm sido alvo de acalorados debates: Estado e sociedade civil. O relacionamento entre o Estado e a sociedade civil é assunto em constante modificação, buscando-se sempre o seu equilíbrio em dado momento da vida social. Relação marcada pelo autoritarismo em sua origem, atualmente debate-se a legitimação da participação da sociedade civil na ação administrativa como instrumento de efetivação da cidadania e, assim, da Democracia. É o movimento da Nova Administração Pública, inserindo o discurso do consenso em seu relacionamento com a sociedade civil e propondo uma Administração Pública Consensual ou Paritária, em que o cidadão é considerado partícipe de decisões de interesse público desde a sua concepção até a sua execução e controle. A Administração Pública não mais se impõe sobre o cidadão - somente -, mas com ele se relaciona de modo a atingir o bem maior que é o interesse público. Neste contexto, paralelamente ganha forças um novo conceito de organização da sociedade civil, chamado Terceiro Setor. À medida que ganham volume as atividades desenvolvidas voluntariamente pela iniciativa privada, sem fins lucrativos, para fazer frente a direitos fundamentais ou em defesa do conteúdo constitucional, a relevância de sua atuação é cada dia mais considerada. Sobretudo diante da legitimação constitucional de atuação da iniciativa privada em ações de conteúdo social, deixando claro que neste tema não há monopólio estatal, fortalece-se o apelo pelo desenvolvimento de ferramentas consensuais de atuação compartida entre a Administração Pública e o Terceiro Setor. Insere-se o debate das parcerias entre a Administração Pública e o Terceiro Setor no contexto da Administração Pública Consensual ou Paritária, de modo a buscar a sua legitimação legislativa através da análise sistemática das ferramentas atualmente existentes para a formalização deste relacionamento e, sobretudo, da proposta de uma reformulação do atual regime jurídico com vistas à regulação das parcerias entre a Administração Pública e o Terceiro Setor.

\section{Palavras-chave}

Administração Pública; Terceiro Setor; Direito do Estado; parcerias. 


\begin{abstract}
Souza, Leandro Marins de. Public Administration and Third Sector partnerships: systematization and regulation. 2010. $288 \mathrm{f}$. Thesis (Doctoral) - Faculdade de Direito, Universidade de São Paulo, São Paulo, 2010.

It traces the intersection of two topics that have been the subject of heated debate in the last 20 years, although they are always in vogue: State and civil society. The relationship between State and civil society is in constant change, seeking always the equilibrium at a given moment of social life. Relationship marked by authoritarianism in its origin, nowadays the legitimacy of civil society's participation in the administrative action as a tool for effective citizenship and democracy is debated. It is the movement of New Public Management, introducing the consensus discourse in its relationship with civil society and proposing a Consensual or Joint Public Management, in which the citizen is considered a participant in the decisions of public interest since its conception to its implementation and control. The public administration no longer imposes your power on the citizen - only but it relates with him in order to achieve the greater goal which is the public interest. In this context a new concept of civil society organization called Third Sector gain forces. While the private voluntary no profit actions grown up in order to respond to fundamental rights or in defense of the constitutional content, the relevance of its work is increasingly considered. Mainly because of the constitutional legitimacy of social private action, making it clear that this issue is not a State monopoly, the call for the development of tools for consensual activities shared between the public administration and the Third Sector is increased. Introduce the discussion of partnerships between public administration and Third Sector in the context of Consensual or Joint Public Management in order to seek its legislative legitimization through the systematic analysis of the currently existing tools to formalize this relationship and, especially, the actual legal regime reformulation proposal to regulate the partnerships between the public administration and the Third Sector.
\end{abstract}

Keywords

Public Administration; Third Sector; non-profit organizations; partnerships. 


\section{LISTA DE ABREVIATURAS E SIGLAS}

ONG - Organização Não Governamental

PIB - Produto Interno Bruto

PROCON - Promotoria de Defesa do Consumidor

ADI - Ação Direta de Inconstitucionalidade

DJ - Diário da Justiça

RE - Recurso Extraordinário

RESP - Recurso Especial

CF - Constituição Federal

OSCIP - Organização da Sociedade Civil de Interesse Público

PPP - Parceria Público-Privada

TCU - Tribunal de Contas da União

CLT - Consolidação das Leis do Trabalho

INCRA - Instituto Nacional da Colonização e Reforma Agrária

SUS - Sistema Único de Saúde

OGU - Orçamento Geral da União

LDO - Lei de Diretrizes Orçamentárias

IN - Instrução Normativa

MP - Ministério Público ou Ministério do Planejamento

MF - Ministério da Fazenda

SICONV - Sistema de Convênios

STN - Secretaria do Tesouro Nacional

CEAS/CEBAS - Certificado de Entidade Beneficente de Assistência Social

SNJ - Secretaria Nacional de Justiça do Ministério da Justiça

SICAP - Sistema de Cadastro e Prestação de Contas

CNES - Cadastro Nacional de Entidades de Utilidade Pública

ONLUS - Organizzazione Non Lucrativa di Utilità Sociale 


\section{SUMÁRIO}

CAPÍTULO 1. INTRODUÇÃO...............................................................................

CAPÍTULO 2. ADMINISTRAÇÃO PÚBLICA: DO AUTORITARISMO AO

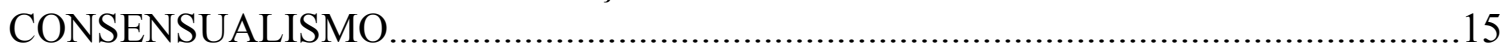

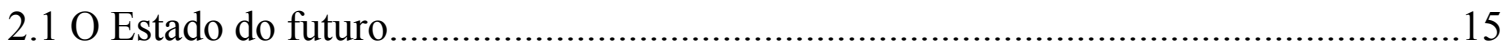

2.1.1 Fim do Estado Social de Direito: crise fiscal do Estado ou cumprimento de sua

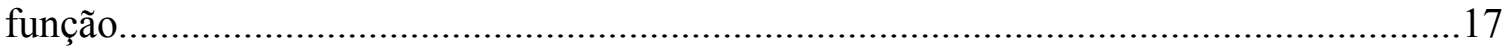

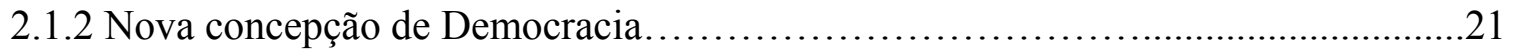

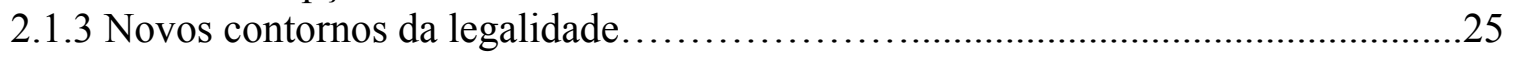

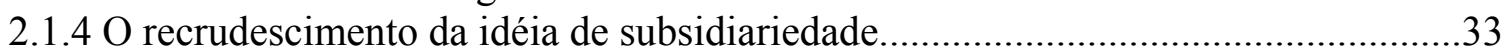

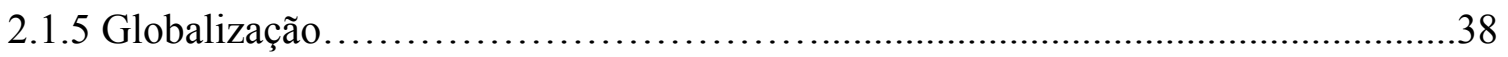

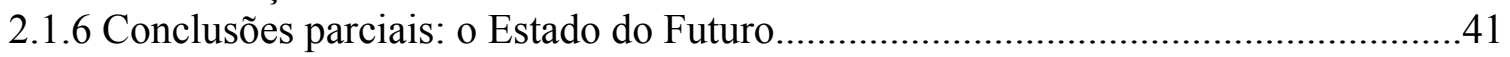

2.2 A nova Administração Pública e o novo Direito Administrativo................................44

2.2.1 A nova Administração Pública......................................................... 47

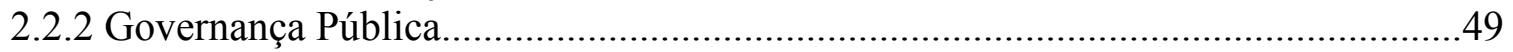

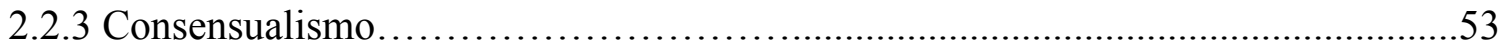

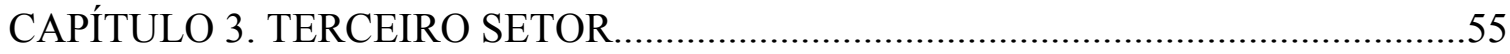

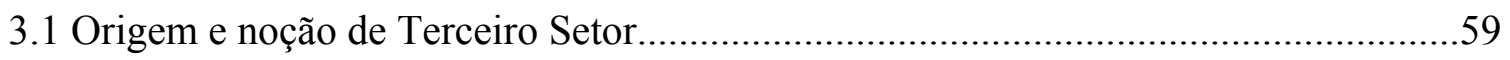

3.2 Fundamentos constitucionais do Terceiro Setor no Brasil e seu espaço de

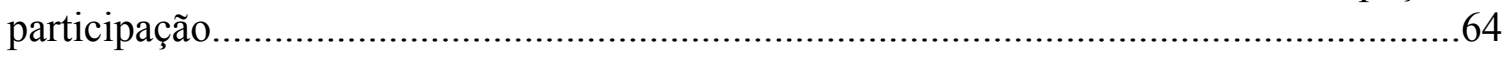

3.3 Natureza jurídica das atividades inseridas no espaço de participação do Terceiro

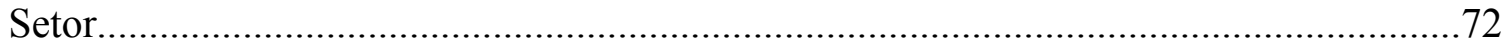

3.3.1 Natureza jurídica da atividade prestacional do Terceiro Setor..................................74

3.3.2 Natureza jurídica da atividade jurídica do Terceiro Setor........................................90

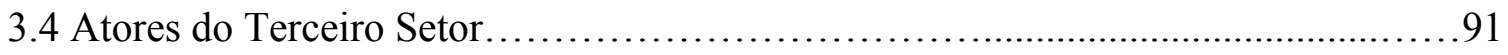

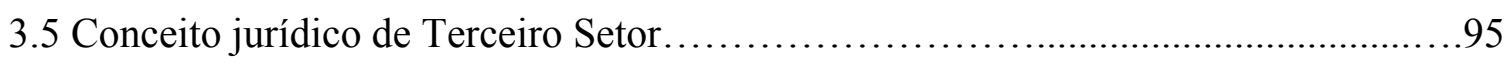

CAPÍTULO 4. PARCERIAS ENTRE A ADMINISTRAÇÃO PÚBLICA E O

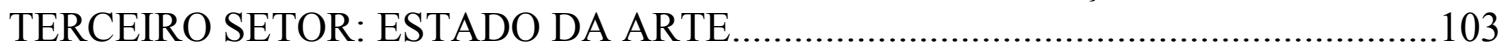

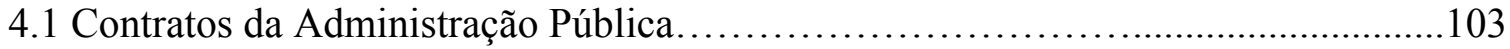

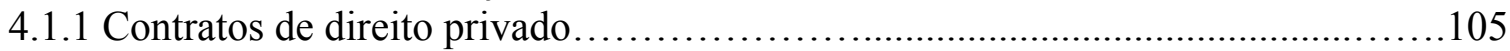

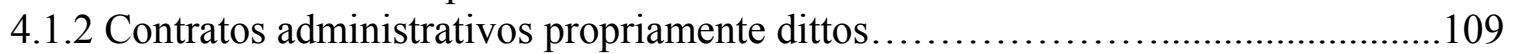

4.1.3 Contratos administrativos de delegação de competências administrativas..............114

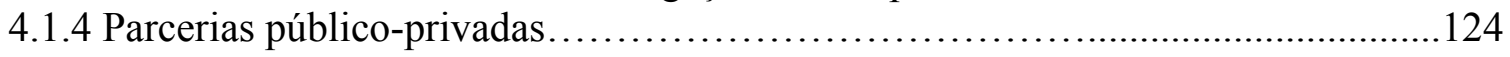

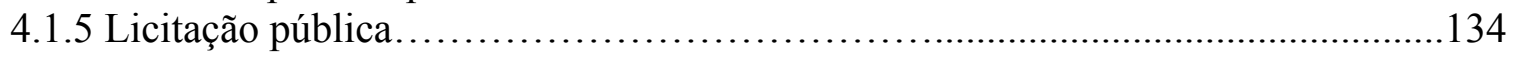

4.2 Repasses financeiros para entidades do Terceiro Setor...........................................157

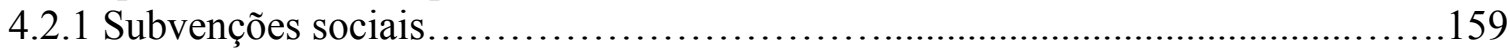

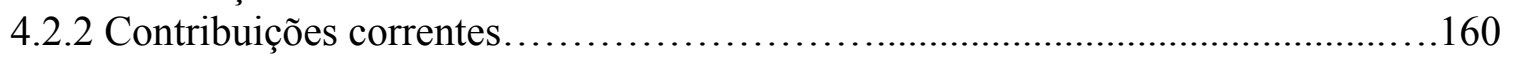


4.3 Convênios.

4.4 Contratos de Repasse.

4.5 Termos de Parceria.

CAPÍTULO 5. PARCERIAS ENTRE A ADMINISTRAÇÃO PÚBLICA E O TERCEIRO SETOR: EM DIREÇÃO A UMA PROPOSTA

5.1 Do reposicionamento das relações entre Administração Pública e Terceiro Setor.

5.2 Os conflitos legislativos que intimidam o desenvolvimento das parcerias e as

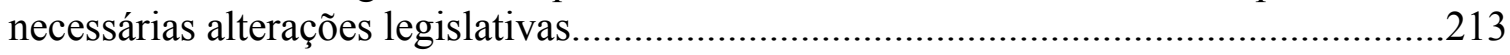

5.2.1 Convivência de títulos e qualificações: pela unificação do regime........................214

5.2.2 Seleção do parceiro privado: necessidade de previsão específica...........................217

5.2.3 Incompatibilidades legislativas quanto ao destino dos recursos repassados..........223

5.2.4 Pluralidade de órgãos certificadores: pela unificação da certificação....................225

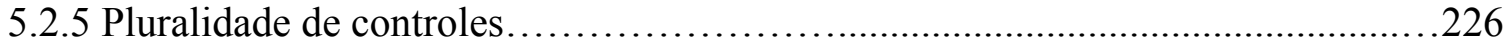

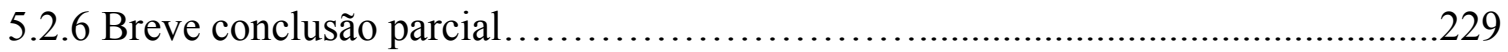

5.3 Propostas de alteração do atual modelo de relacionamento entre a Administração Pública e o Terceiro Setor: exposição de motivos.

5.4 Proposta de Anteprojeto de Lei sobre as parcerias entre a Administração Pública e o Terceiro Setor. 


\section{CAPÍTULO 1. INTRODUÇÃO}

É inegável que o Direito Público brasileiro, na esteira de diversos acontecimentos, tem passado por profundas discussões voltadas à análise da necessidade de alteração de alguns paradigmas.

O ponto central destes debates, afirma-se sem pestanejar, diz respeito à definição do papel do Estado e sua inter-relação com a sociedade civil. Como afirma Caio Tácito "os costumes e as perspectivas alteram no tempo as relações sociais". ${ }^{1}$

Mais uma etapa do ciclo de alteração de modelos de participação do Estado que remonta ao Estado Absolutista, passa pelo Estado Liberal a partir do século XVIII e deságua no Estado Social no século XX, observa-se a partir da década de 90 do século passado movimento que busca a redefinição do papel do Estado.

Os motivos apontados como causa desta necessidade detectada são vários, e todos dão conta da oportunidade de se encontrar modelo alternativo ao vigente. É um momento de reforma irreversível da Administração Pública brasileira, que se dirige à idéia de Estado Subsidiário, Estado Consensual, Estado Paritário ${ }^{2}$, todos eles pressupondo a idéia de participação efetiva da sociedade civil na ação administrativa.

É a partir desta premissa, que se desenvolve no primeiro capítulo, que o presente trabalho se desenrola; a partir da idéia de legitimação das ferramentas consensuais da Administração Pública no cenário da Nova Administração Pública, pretende-se reposicionar o Terceiro Setor como importante ator social no desempenho de suas funções, cujo papel pode ser desenvolvido isoladamente ou através de parcerias com a Administração Pública. Demonstra-se que o monopólio da ação social pelo Estado não mais se sustenta, sendo imperativa a aproximação da Administração Pública e do Terceiro Setor. Aliás, a própria Constituição brasileira de 1988 é expressa em dotar as entidades sem fins lucrativos de competência compartida com o Estado em determinados temas, os chamados serviços públicos sociais. ${ }^{3}$

\footnotetext{
${ }^{1}$ TÁCITO, Caio. Constituições reconstituídas. In: Temas de direito público (estudos e pareceres). Rio de Janeiro : Renovar, 2002, $3^{\circ}$ vol., p. 1.

${ }^{2}$ Cf. BENVENUTI, Feliciano. Per um Diritto Amministrativo Paritario. In: Studi in onore di Enrico Guicciardi. Padova : CEDAM, 1975, pp. 807-851.

3 "No quadro contemporâneo, o direito público passa a espelhar duas vertentes específicas, que se refletem nas Constituições do final do século: a política de privatização e o fortalecimento da associação entre a iniciativa privada e o serviço público, a par da comunhão entre nações e regiões, superando barreiras nacionais ou limitações federativas" (TÁCITO, Caio. Transformações do Direito Administrativo. In:

Temas de direito público (estudos e pareceres). Rio de Janeiro : Renovar, 2002, $3^{\circ}$ vol., p. 13).
} 
No entanto, antes de se adentrar efetivamente ao tema das parcerias entre a Administração Pública e o Terceiro Setor, objeto principal da presente tese, importa efetuar aproximação metodológica de conteúdo jurídico sobre o tema do Terceiro Setor propriamente. Para tanto se buscará encontrar a definição do espaço de participação do Terceiro Setor, ou seja, qual o conteúdo material das atividades desenvolvidas pelas entidades a ele pertencentes de acordo com o nosso ordenamento jurídico constitucional.

Vale que se diga, como será visto, que as estatísticas dão conta da importância do Terceiro Setor no contexto brasileiro e mundial, a justificar a aplicação do adágio de que $o$ direito deve acompanhar os fatos.

O crescimento das atividades desenvolvidas pelo Terceiro Setor e a sua afirmação como importante ator no trato das questões sociais ${ }^{4}$ exige estudos jurídicos específicos sobre o tema, desde a formulação de um conceito jurídico do instituto, passando pelas formas de organização possíveis, pelos títulos e qualificações existentes e a repercussão destas considerações todas na relação do Terceiro Setor com os órgãos da Administração Pública.

A imbricação do Terceiro Setor com o Estado, originada justamente da natureza complementar que suas atividades devem ter, acaba por repercutir de forma bastante sensível nas configurações das parcerias - em sentido amplo - que podem ser firmadas entre eles. Para tanto é imprescindível o aperfeiçoamento das ferramentas disponíveis em nosso sistema jurídico para a formalização destas parcerias.

Mais do que isso, o cenário se torna crítico no que tange às ferramentas de controle e fiscalização das verbas públicas destinadas às entidades do Terceiro Setor. Embora nosso ordenamento jurídico esteja repleto de instrumentos de acompanhamento da utilização destas verbas - e possivelmente por conta disso -, a insegurança quanto à sua aplicação ainda reina e de certa forma se comprova pelos inúmeros escândalos envolvendo desvio de recursos públicos por entidades sem fins lucrativos.

Este cenário, a toda evidência, não é salutar para o Estado, que não consegue se utilizar adequadamente das inúmeras ferramentas de controle de que dispõe e acaba por deixar de fiscalizar efetivamente estas atividades; tampouco é salutar para as próprias

\footnotetext{
4 "Esta interacción Estado- Sociedad viene confirmada por el Tribunal Constitucional, para el que la configuración del Estado como Estado Social de Derecho 'viene así a culminar una evolución en la que la consecución de los fines de interés general no es absorbida por el Estado, sino que se armoniza con una actuación mutua Estado-Sociedad" (CABRA DE LUNA, Miguel Ángel; LORENZO GARCIA, Rafael de. El Tercer Sector en España: ámbito, tamaño y perspectivas. Revista Española del Tercer Sector, n. 1, out.dez. 2005. Disponível na Internet: <http://www.fundacionluisvives.org/rets/1/index.html>. Acesso em: 15 jan. 2009).
} 
entidades do Terceiro Setor, as sérias, que acabam com a imagem maculada e contaminada por instituições aproveitadoras; também não favorece a própria sociedade, que além de enfrentar o mau uso das verbas públicas que deveriam ser destinadas a suas necessidades e muitas vezes não são, acabam por perder a atuação séria de inúmeras entidades manchadas pelos equívocos daquelas que não o são. Este cenário, em certa parte, fomentado pela dificuldade de se manter um arsenal coerente de fiscalização das entidades sem fins lucrativos. Muitas leis e muitas ferramentas que confundem a atuação fiscalizatória.

É neste quadro que se verifica a necessidade de aproximação dos estudos ora propostos com a realidade internacional. Embora se saiba que não se pode esperar encontrar no exterior o modelo ideal a ser adotado no Brasil, a fonte estrangeira pode trazer inspiração para auxiliar na solução de nosso emaranhado legal e institucional no que tange ao marco regulatório do Terceiro Setor e, principalmente, de suas relações com a Administração Pública.

A própria doutrina, nacional e estrangeira, está de acordo com esta constatação:

Apesar da inegável relevância do papel da voluntariedade da sociedade civil para uma melhor oferta de serviços públicos por parte do Terceiro Setor, a exemplo do que ocorre nos Estados Unidos, no nosso modo de entender, uma legislação eficiente no que diz respeito aos contratos a serem celebrados entre o Estado e as instituições não lucrativas, a exemplo do que ocorre na Alemanha, também será de fundamental importância para legitimar legal e politicamente o papel do Terceiro Setor como fornecedor de serviços públicos, mormente na sociedade brasileira em que a falta de controle nos gastos dos recursos públicos tem sido apontada como um dos maiores problemas da Administração Pública e causa de muitos problemas sociais, inclusive a má distribuição da renda; ${ }^{5}$

Um tópico de especial relevo na atualidade é o atinente ao financiamento público das entidades privadas integrantes do Terceiro Setor, necessários para a sua manutenção e para o desenvolvimento de suas atividades.

É o campo das transferências ou dos repasses de recursos financeiros de origem pública a organizações privadas sem fins lucrativos, comumente referidas como ONGs. Tais recursos vêm crescendo em soma e em importância no Brasil, principalmente a partir do advento da Reforma do Aparelho do Estado, datada de 1995. (...)

$\mathrm{O}$ assunto é polêmico e demanda um esforço grandioso, não somente para o seu enfrentamento do ponto de vista dogmático, mas também para a busca e para a proposição de soluções dos problemas que atualmente reproduzem-se em escala de progressão geométrica em nosso país; ${ }^{6}$

\footnotetext{
${ }^{5}$ FERREIRA FILHO, José Alexandre. Examinando o papel do terceiro setor como provedor de serviços públicos e sua relação com o estado de bem estar social: uma análise comparativa entre as experiências recentes dos Estados Unidos, Alemanha, França e Brasil. Revista Economia, Negócios e Finanças, ano 1, n. 1, jul.-dez. 2002, p. 27.

${ }^{6}$ OLIVEIRA, Gustavo Justino de. OSCIPS e licitação: ilegalidade do Decreto n. 5.504, de 05.08.05. Revista

Eletrônica sobre a Reforma do Estado, Salvador : IBDP, n. 12, dez.-jan.-fev. 2008, pp. 1-3.
} 
Por ello, repito, es imprescindible reelaborar totalmente el sistema del control público sobre las fundaciones. El actual protectorado no alcanza a resolver ni la mitad de los problemas que tiene planteados.

Esa reestructuración debería cuando menos traducirse en un proceso decidido de unificación de los servicios del protectorado frente a la dispersión hoy existente. Dispersión que, como he señalado, es no sólo disfuncional sino también en no pocas ocasiones totalmente injustificada. (...)

Pero seguramente ha de darse un paso más. Y ese no es otro que el de tender hacia un control público, externo e independiente. No vinculado, en consecuencia, a un departamento específico, sino dotado de autonomía y con suficientes recursos humanos y económicos. (...)

Creo, pues, que debe tenderse hacia la creación de una suerte de agencia pública e independiente de control sobre las fundaciones. ${ }^{7-8}$

Sobretudo em virtude da escassez de trabalhos jurídicos especificamente a respeito do tema, a importância de sua escolha fica ainda mais latente. E daqui já se extrai o segundo motivo a demonstrar a importância do tema escolhido, qual seja a ausência de estudos jurídicos que sistematizem as questões relativas ao Terceiro Setor.

Os objetivos a que esta tese se propõe são: (i) reposicionamento do papel do Terceiro Setor no desenvolvimento de ações de interesse público, de forma autônoma ou em parceria com a Administração Pública, sobretudo a partir da influência dos novos conceitos propostos pela Administração Pública Consensual; (ii) definição de um espaço de participação do Terceiro Setor, juridicamente considerado através da nossa Constituição de 1988, definindo materialmente o seu âmbito de atuação autônoma ou através de parcerias; (iii) sistematização do atual regime jurídico aplicável às parcerias entre a Administração Pública e o Terceiro Setor e descrição crítica das formas possíveis de parceria entre a Administração Pública e o Terceiro Setor existentes no Brasil; e (iv) apresentação de propostas legislativa e estrutural para as parcerias entre Administração Pública e Terceiro Setor, inclusive através da análise da experiência estrangeira.

Insere-se o presente trabalho, portanto, na tentativa de sistematização e posterior proposta de regulação do tema das parcerias entre a Administração Pública e o Terceiro Setor, passando por outros temas afetos ao assunto principal com vistas a auxiliar o início

\footnotetext{
${ }^{7}$ MAÑAS, José Luis Piñar. Tercer Sector, sector público y fundaciones. Revista Española del Tercer Sector, n. 1, out.-dez. 2005. Disponível na Internet: <http://www.fundacionluisvives.org/rets/1/index.html $>$. Acesso em: 15 jan. 2009. Também sobre a necessária reforma legislativa do Terceiro Setor, desta feita na Itália, cf. CORBELLA, Luigi. Riforma del Terzo Settore: il confronto necessario fra enti e legislatore. Terzo Settore: le regole per il non profit, Milano : Il Sole 24 Ore, n. 1, jan. 2007, pp. 51-54.

8 Para um resumo sobre as ferramentas legislativas de vários países da União Européia em relação ao Terceiro Setor, confira: VAN DER PLOEG, Tymen J.. Legislación del tercer sector social en la Unión Europea. Revista Española del Tercer Sector, n. 9, mai.-ago. 2008. Disponível na Internet: $<\mathrm{http}$ ://www.fundacionluisvives.org/rets/1/index.html $>$. Acesso em: 15 jan. 2009. Também sobre o cenário europeu do Terceiro Setor, cf. QUELHAS, Ana Paula Santos. A refundação do papel do Estado nas políticas sociais, Coimbra : Almedina, 2001.
} 
da caminhada por um marco regulatório do Terceiro Setor no Brasil. ${ }^{9}$

9 "Hodiernamente, intensa é a discussão acerca do estabelecimento de um Marco Regulatório do Terceiro Setor no Brasil. Os temas que demanda reflexão e regulamentação pelo Legislativo são bastante variados, e versam, notadamente (a) sobre a necessidade de uniformização das certificações e das titulações estatais das entidades do Terceiro Setor; (b) melhor detalhamento normativo acerca da tributação do Terceiro Setor (imunidades e isenções); (c) ajustes nas formas e nos mecanismos de fiscalização e de controle das entidades do Terceiro Setor, com especial reforço da obrigatoriedade de transparência de suas atividades e na prestação de suas contas, e (d) melhores bases normativas para a formação de parcerias entre Estado, empresas e entidades do Terceiro Setor" (OLIVEIRA, Gustavo Justino. Direito do Terceiro Setor. Revista de Direito do Terceiro Setor - RDTS, Belo Horizonte : Fórum, ano 1, n. 1, jan.-jun. 2007, p. 23). 


\section{CAPÍTULO 2. ADMINISTRAÇÃO PÚBLICA: DO AUTORITARISMO AO CONSENSUALISMO}

\subsection{O Estado do futuro}

Inicia-se a abordagem do presente trabalho com a autorizada constatação de Ives Gandra da Silva Martins, para quem “o Estado Moderno está, em sua formulação clássica de soberania absoluta, falido, devendo ceder campo a um Estado diferente, no futuro". ${ }^{10}$

Observa-se a partir da década de 90 do século passado nova busca pela remodelação do papel do Estado, dando continuidade ao movimento cíclico representado pelos Estados Absolutista, Liberal e Social. ${ }^{11}$

Busca-se através deste movimento um ajustamento do Estado às novas aspirações sociais, tal qual ocorreu desde o surgimento do Estado; o Estado, criação social, é sensível aos pleitos da sociedade que rege. Não o fosse e estaria instalada a ingovernabilidade, o que justifica considerar o Estado como ente cambiante de acordo - mais ou menos - com os humores da sociedade em que está inserido.

No que toca a esta última onda de debates sobre um novo paradigma de atuação estatal, os motivos que a justificam são diversos.

\footnotetext{
${ }^{10}$ MARTINS, Ives Gandra da Silva. O Estado do futuro. In: (coord.). O Estado do futuro. São Paulo : Pioneira : Associação Internacional de Direito e Economia, 1998, p. 19.

11 Preferimos adotar a postura de Diogo de Figueiredo Moreira Neto (MOREIRA NETO, Diogo de Figueiredo. O futuro do Estado: do pluralismo à desmonopolização do poder. In: MARTINS, Ives Gandra da Silva (coord.). O Estado do futuro. São Paulo : Pioneira : Associação Internacional de Direito e Economia, 1998, p. 45) e abandonar o recorrente recurso ao historicismo e a leis evolutivas, deixando de lado a análise do percurso histórico-evolutivo e partindo das tendências atualmente ventiladas para o Estado do futuro. Sobre este percurso histórico, sugerem-se as seguintes leituras: BOBBIO, Norberto. Estado, governo, sociedade: para uma teoria geral da política. 9a ed. São Paulo : Paz e Terra, 2001, trad. Marco Aurélio Nogueira; BONAVIDES, Paulo. Curso de direito constitucional. 12a ed., São Paulo : Malheiros, 2002; BONAVIDES, Paulo. Do Estado liberal do Estado social. $7^{\mathrm{a}}$ ed., São Paulo : Malheiros, 2001; DALLARI, Dalmo de Abreu. Elementos de teoria geral do Estado. 23 ${ }^{\mathrm{a}}$ ed., São Paulo : Saraiva, 2002; GOZZI, Gustavo. Estado Contemporâneo. In: BOBBIO, Norberto et al. (coord.). Dicionário de política. $11^{\mathrm{a}}$ ed. Brasília : UnB, 1998, vol. 1, trad. Carmem C. Varriale et al.; HELLER, Herman. Teoria del Estado. México : Fondo de Cultura Económica, 1990, trad. Luis Tobio; MATTEUCI, Nicola. Liberalismo. In: BOBBIO, Norberto et al. (coord.). Dicionário de política. 11 a ed. Brasília : UnB, 1998, vol. 1, trad. Carmem C. Varriale et al.; MOREIRA, Alexandre Mussoi. A transformação do Estado: neoliberalismo, globalização e conceitos jurídicos. Porto Alegre : Livraria do Advogado, 2002; REGONINI, Gloria. Estado do Bem-estar. In: BOBBIO, Norberto et al. (coord.), Dicionário de política. 11 a ed. Brasília : UnB, 1998, vol. 1, trad. Carmem C. Varriale et al.; SCHIERA, Pierangelo. Estado moderno, In: BOBBIO, Norberto et al. (coord.), Dicionário de política, $11^{\mathrm{a}}$ ed. Brasília : UnB, 1998, vol. 1, trad. Carmem C. Varriale et al.; SILVA, José Afonso. Curso de direito constitucional positivo. $18^{\mathrm{a}}$ ed. São Paulo : Ed. Malheiros, 2000. Sobre as alterações no papel do Estado como campo fértil para o desenvolvimento do Terceiro Setor, já nos manifestamos em: SOUZA, Leandro Marins de. Tributação do terceiro setor no Brasil. São Paulo : Dialética, 2004.
} 
Maria Sylvia Zanella Di Pietro ${ }^{12}$ aponta o crescimento desmesurado do Estado Social de Direito e suas conseqüências como um dos motivos para a revisitação do tema a partir do final do século passado. Para a autora, na medida em que o Estado Social de Direito deslocou a preocupação da liberdade para a igualdade ao migrar do ideal de individualismo - imperante no Estado Liberal - para o ideal de socialização, vendo aumentar o rol de suas atribuições, ocorreu "um crescimento desmesurado do Estado, que passou a atuar em todos os setores da vida social, com uma ação interventiva que coloca em risco a própria liberdade individual, afeta o princípio da separação dos Poderes e conduz à ineficiência na prestação de serviços" ${ }^{\prime 13}$. O Estado Social de Direito, além de não conseguir assegurar o bem comum, outorgou tantas responsabilidades ao Estado que acabou por invadir a esfera individual dos cidadãos.

Em resposta a esta realidade decorrente do desgaste da idéia de Estado Social de Direito, inserem-se no debate dois conceitos que buscam encontrar respostas aos anseios sociais que clamam pela renovação da relação Estado-sociedade civil. Fortalece-se a voz da democracia como pleito à participação do cidadão nas decisões de interesse social e, pari passu, o ideal de legalidade como implementação da justiça material com fundamento no ordenamento jurídico. "Daí hoje falar-se em Estado Democrático de Direito, que compreende o aspecto da participação do cidadão (Estado Democrático) e o da justiça material (Estado de Direito)"14.

Mas a própria idéia de Estado Democrático de Direito ganha novos elementos que encetam a necessidade de ainda revisitar este conceito, característica própria do processo de reforma do Estado, "processo in fieri, em andamento, longe de ser concluído" segundo a feliz expressão novamente de Maria Sylvia Zanella Di Pietro ${ }^{15}$.

Um destes elementos, que ganha força a ponto de ter sido incluído na ordem constitucional de alguns países ${ }^{16}$, é o chamado princípio da subsidiariedade, que em largas

\footnotetext{
${ }^{12}$ DI PIETRO, Maria Sylvia Zanella. Parcerias na Administração Pública. 5a ed. São Paulo : Atlas, 2006, p. 26.

${ }^{13}$ Ibidem, p. 29.

${ }^{14}$ Ibidem, pp. 32-33, destaques no original.

15 Ibidem, p. 17.

${ }^{16}$ A Constituição italiana de 1947, com a alteração da Lei Constitucional n. 3/2001, promoveu a acolhida do princípio da subsidiaridade em seu artigo 118, nos seguintes termos: "Art. 118. Le funzioni amministrative sono attribuite ai Comuni salvo che, per assicurarne l'esercizio unitario, siano conferite a Province, Città metropolitane, Regioni e Stato, sulla base dei principi di sussidiarietà, differenziazione ed adeguatezza. (...) Stato, Regioni, Città metropolitane, Province e Comuni favoriscono l'autonoma iniziativa dei cittadini, singoli e associati, per lo svolgimento di attività di interesse generale, sulla base del principio di sussidiarietà". "Art. 118. As funções administrativas são atribuídas aos Municípios exceto aquelas que, para assegurar a unidade do exercício, são conferidas às Províncias, às Cidades metropolitanas, às Regiões e ao Estado, com base nos princípios da subsidiariedade, diferenciação e adequação. (...) O Estado, as Regiões, as
} 
passadas propõe a supremacia da iniciativa privada sobre a iniciativa estatal, conceito que se ramifica em algumas idéias que posteriormente serão melhor explicitadas.

Odete Medauar ${ }^{17}$ aponta outros motivos de superação do modelo de Estado vigente, tais como: a) o cumprimento, ao menos parcial, da função para a qual foi concebido o Estado Social; b) crescimento das despesas sociais e encolhimento das receitas do Estado Social; c) ingovernabilidade do Estado; d) globalização; e) neoliberalismo; f) privatização.

Em abordagem que analisa o futuro do Estado com fundamento em quatro tendências dominantes - globalização, participação, subsidiaridade e descentralização -, Diogo de Figueiredo Moreira Neto e Paulo Rabello de Castro as atribui ao advento do pluralismo. $^{18}$

São todos, portanto, elementos apontados como responsáveis pela atual tendência de renovação do papel do Estado e que interferem, não há dúvidas, na relação entre o Estado e a sociedade civil. Útil para a compreensão da interferência de cada elemento nas alterações da concepção de Estado, passa-se à análise individualizada de alguns destes fatores indicados pela doutrina.

\subsubsection{Fim do Estado Social de Direito: crise fiscal do Estado ou cumprimento de sua função}

Um dos motivos apontados correntemente como causa às novas tendências de configuração da noção de Estado diz respeito ao fim do ideal de Estado Social de Direito.

Como evolução da concepção de Estado Liberal de Direito, justamente em resposta às injustiças perpetradas por este ideal e impulsionado pelos constantes movimentos sociais ocorridos, surge o chamado Estado Social de Direito.

Caracteriza-se pela ruptura sistemática promovida nos ideais da concepção liberalista de Estado de Direito, atribuindo-lhe a noção de integração social e transformando-a em Estado material de Direito. Deixa-se de lado a condição de Estado

Cidades metropolitanas, as Províncias e os Municípios promovem a iniciativa autônoma dos cidadãos, individualmente ou associados, para o desenvolvimento de atividades de interesse geral, com base no princípio da subsidiariedade" (ITÁLIA. La Costituzione italiana. Con introduzione di Saulle Panizza e Roberto Romboli. Corredata da: struttura del texto della Costituzione italiana, articoli della Costituzione, in ordine numérico, interessati da leggi costituzionali e di revisione costituzionale intervenute trai 11948 e il 2008. Aggiornata a giugno 2008. Pisa : PLUS, 2008, pp. 68-69, tradução nossa).

${ }^{17}$ MEDAUAR, Odete. O Direito Administrativo em evolução. $2^{\mathrm{a}}$ ed. São Paulo : RT, 2003, pp. 89 e ss.

${ }^{18}$ MOREIRA NETO, Diogo de Figueiredo; CASTRO, Paulo Rabello de. O futuro do Estado: do pluralismo à desmonopolização do poder. In: MARTINS, Ives Gandra da Silva (coord.). O Estado do futuro. São Paulo : Pioneira : Associação Internacional de Direito e Economia, 1998, pp. 45-61. 
Legal para, integrando e buscando a realização de justiça social, materializar os anseios da comunidade e a sua participação efetiva no desenvolvimento do bem-estar social almejado através da aplicação irrenunciável do primado do Direito.

O Estado Social de Direito conceitualmente se destina à afirmação dos direitos sociais e à aplicação de objetivos de justiça social. Surge no início do século XX, mais precisamente quando do surgimento da primeira Constituição considerada social, que é a mexicana de 1917, e que teve como fonte inspiradora a Constituição de Weimar, da Alemanha, mesmo que date de $1919 .{ }^{19}$

A partir de então, incentivado pela vertente social do constitucionalismo alemão que trouxe a reboque a Constituição mexicana, aliando-se à grave situação econômica e social em que se encontrava a Europa após a Primeira Guerra Mundial (1914-1918), às decorrências da própria vertente liberal e aos movimentos socialistas de fins do século XIX e início do século XX, consagra-se o Estado Social de Direito. Desenvolve-se, "nas primeiras décadas do século $\mathrm{XX}$, um surto intervencionista que já não poderia ser contido" 20 .

A idéia de intervencionismo do Estado para garantir direitos sociais e econômicos começa a se robustecer no âmbito do Estado Social, já a Constituição mexicana de 1917 dando sinais deste fenômeno ao prever dois novos grupos de direitos: os sociais e os econômicos.

O Estado Liberal havia deixado profundas cicatrizes sociais, e suas idéias não mais se sustentavam diante da necessidade de serem restauradas as condições de igualdade suprimidas pelo ideal de liberdade. No entanto e da mesma forma, a auto-regulação somada a preocupações sociais não eram suficientes para fazer frente ao verdadeiro rombo herdado do Estado Liberal.

Foi necessário, portanto, que o Estado assumisse o compromisso e a iniciativa de efetivar a aplicação das reivindicações sociais para tentar amenizar o poço de miséria e desigualdades posto a seus cuidados, mediante sua intervenção em prol da sociedade. Passa o Estado a intervir no domínio econômico e social, sobretudo após a Segunda Guerra Mundial, definindo-se a consolidação do Estado Social.

\footnotetext{
19 "Embora cronologicamente a Constituição Mexicana de 1917 tenha sido a primeira, a matriz do constitucionalismo social será a Constituição de Weimar, de 1919, na Alemanha (MOREIRA, Alexandre Mussoi. A transformação do Estado: neoliberalismo, globalização e conceitos jurídicos. São Paulo : Livraria do Advogado, 2002, p. 29).

${ }^{20}$ DALLARI, Dalmo de Abreu. Elementos de teoria geral do Estado. $25^{\text {a }}$ ed. São Paulo : Saravia, 2006, p. 281. $2^{\mathrm{a}}$ tir.
} 
Quando o Estado, coagido pela pressão das massas, pelas reivindicações que a impaciência do quarto estado faz ao poder político, confere, no Estado constitucional ou fora deste, os direitos do trabalho, da previdência, da educação, intervém na economia como distribuidor, dita o salário, manipula a moeda, regula os preços, combate o desemprego, protege os enfermos, dá ao trabalhador e ao burocrata a casa própria, controla as profissões, compra a produção, financia as exportações, concede crédito, institui comissões de abastecimento, provê necessidades individuais, enfrenta crises econômicas, coloca na sociedade todas as classes na mais estreita dependência de seu poderio econômico, político e social, em suma, estende sua influência a quase todos os domínios que dantes pertenciam, em grande parte, à área de iniciativa individual, nesse instante o Estado pode, com justiça, receber a denominação de Estado social. ${ }^{21}$

E é no contexto do Estado Social que surge o Estado de Bem-Estar Social (Welfare

State), cuja característica principal é o asseguramento de certas condições mínimas vitais (saúde, educação, moradia, alimento, renda, entre outros) como direitos. ${ }^{22}$ Desde o início do século XX observavam-se propostas que tinham feição assistencialista. ${ }^{23}$. Aponta-se que na Inglaterra, entre 1905 e 1911, foram aprovadas medidas de inspiração visivelmente sociais e, ao mesmo tempo, assistenciais, tais como um seguro nacional de saúde. ${ }^{24}$ No decorrer dos anos 20 e 30 as idéias para a consagração do Welfare State continuam se desenvolvendo, sobretudo tendo em vista as decorrências das guerras que assolaram o mundo e demandaram despesas públicas significativas.

Mas é preciso chegar à Inglaterra dos anos 40 para encontrar a afirmação explícita do princípio fundamental do Welfare state: independentemente da sua renda, todos os

${ }^{21}$ BONAVIDES, Paulo. Do Estado liberal ao Estado social. $7^{\mathrm{a}}$ ed. São Paulo : Malheiros, 2001, p. 186. "Assumindo amplamente o encargo de assegurar a prestação dos serviços fundamentais a todos os indivíduos, o Estado vai ampliando sua esfera de ação. E a necessidade de controlar os recursos sociais e obter o máximo proveito com o menor desperdício, para fazer face às emergências da guerra, leva a ação estatal a todos os campos da vida social, não havendo mais qualquer área interdita à intervenção do Estado. Terminada a guerra, ocorre ainda um avanço maior do intervencionismo, pois inúmeras necessidades novas impõem a iniciativa do Estado em vários setores: na restauração dos meios de produção, na reconstrução das cidades, na readaptação das pessoas à vida social, bem como no financiamento de estudos e projetos, sugeridos pelo desenvolvimento técnico e científico registrado durante a guerra" (DALLARI, Dalmo de Abreu. Elementos de teoria geral do Estado. 25a ed. São Paulo : Saravia, 2006, p. 283. $2^{\mathrm{a}}$ tir.).

${ }^{22}$ Gosta Esping-Andersen, embora discordante do conceito por achar limitador e generalizante, observa que "uma definição comum nos manuais é a de que ele envolve responsabilidade estatal no sentido de garantir o bem-estar básico dos cidadãos" (ESPING-ANDERSEN, Gosta. As três economias políticas do Welfare State. Lua Nova - Revista de Cultura e Política, n. 24, set. 1991, p. 98).

${ }^{23} \mathrm{Na}$ verdade, algumas medidas isoladas de cunho que pode ser considerado assistencialista ocorreram antes mesmo do século XX. Gustavo Gozzi aponta que "as primeiras formas de Welfare visavam, na realidade, a contrastar o avanço do socialismo, procurando criar a dependência do trabalhador ao Estado, mas, ao mesmo tempo, deram origem a algumas formas de política econômica, destinadas a modificar irreversivelmente a face do Estado contemporâneo. A lei que instituía pensões de invalidez e velhice, aprovada na Alemanha de 1889, permitia uma contribuição de 50 marcos, por conta do Tesouro imperial, para toda pessoa que recebesse uma pensão. Depois, os seguros sociais, que se tornaram também extensivos a outras categorias de trabalhadores, e não só aos operários, constituíram uma forma de redistribuição da renda entre os núcleos familiares" (GOZZI, Gustavo. Estado Contemporâneo. In: BOBBIO, Norberto et al. (coord.). Dicionário de política. $11^{\mathrm{a}}$ ed. Brasília : UnB, 1998, p. 403, vol. 1, trad. Carmem C. Varriale et al.).

${ }^{24}$ Cf. REGONINI, Gloria. Estado do Bem-estar. In: BOBBIO, Norberto et al. (coord.). Dicionário de política. $11^{\mathrm{a}}$ ed. Brasília : UnB, 1998, pp. 416-419, vol. 1, trad. Carmem C. Varriale et al. . 
cidadãos, como tais, têm direito de ser protegidos - com pagamento de dinheiro ou com serviços - contra situações de dependência de longa duração (velhice, invalidez...) ou de curta (doença, desemprego, maternidade...). ${ }^{25}$

E a partir deste momento histórico o conceito do Estado de Bem-Estar Social passou a ganhar contornos universalizantes, tomando formas as mais variadas para a difusão do mesmo conceito: o Estado assistencial, também chamado de Estado providência. Mesmo adotando as mais diversas formas, alguns países tendo como característica intervir mais e outros menos, alguns instituindo tributação bastante pesada para fazer frente a seu caráter assistencial outros encontrando outras fórmulas, de modo geral o Estado de Bem-Estar Social se espraiou por todo o mundo ${ }^{26-27}$.

Alguns doutrinadores defendem que o aumento da necessidade de intervenção do Estado, aliado a diversos outros fatores como, por exemplo, o crescimento populacional superior ao ingresso de receitas para o Estado, faz eclodir o que se tem chamado de crise fiscal do Estado. ${ }^{28}$

Por conta desta crise fiscal do Estado, a adaptação necessária para a manutenção da estrutura de benefícios estatais se faz premente. No entanto, as dificuldades encontradas em se manter orçamento público capaz de arcar com os direitos garantidos pelo Estado do Bem-Estar Social demonstram que outra solução deve ser viabilizada. Isto porque

alguns Estados são obrigados a limitar a intervenção assistencial, quando o aumento da carga fiscal gera em amplos estratos da opinião pública uma atitude favorável à volta à contribuição baseada no princípio contratualista. Estes elementos têm feito com que se fale de uma nova fase na história do Estado assistencial, marcada por profunda crise e por uma possível tendência a desaparecer. ${ }^{29}$

\footnotetext{
${ }^{25}$ Ibidem, p. 417.

${ }^{26}$ Para abordagem sobre as características próprias de cada welfare state, cf. ESPING-ANDERSEN, Gosta. O futuro do welfare state na nova ordem mundial. Lua Nova - Revista de Cultura e Política, n. 35, 1995, pp. 73-111.

${ }^{27}$ Gloria Regonini traça as benesses oriundas do Welfare State: "O aumento mais ou menos linear destas intervenções trouxe algumas conseqüências importantes sobre cujo significado falaremos em seguida: aumentou a cota do produto nacional bruto destinada à despesa pública; as estruturas administrativas voltadas para os serviços sociais tornaram-se mais vastas e complexas; cresceu em número e importância política a classe ocupacional dos 'profissionais do Welfare'; foram aperfeiçoadas as técnicas da descoberta e avaliação das necessidades sociais; tornou-se mais claro o conhecimento do impacto das várias formas de assistência na redistribuição da renda e na estratificação social” (REGONINI, Gloria. Estado do Bem-estar. In: BOBBIO, Norberto et al. (coord.). Dicionário de política. $11^{\text {a }}$ ed. Brasília : UnB, 1998, p. 417, vol. 1, trad. Carmem C. Varriale et al.).

28 “As despesas públicas não conseguem prover, devido à diferença crescente entre as saídas necessárias e as entradas insuficientes, à distribuição de recursos que satisfaçam as aspirações de uma área cada vez mais vasta de indivíduos, cuja reprodução social só pode ser esperada da expansão das despesas sociais por parte do Estado" (GOZZI, Gustavo. Estado Contemporâneo. In: BOBBIO, Norberto et al. (coord.). Dicionário de política. $11^{\mathrm{a}}$ ed. Brasília : UnB, 1998, p. 405, vol. 1, trad. Carmem C. Varriale et al.).

${ }^{29}$ REGONINI, Gloria. Loc. cit.
} 
Outros doutrinadores apontam que o fim do Estado Social de Direito se deve ao fato de o seu ciclo ter se encerrado justamente porque alcançou, ainda que parcialmente, os fins a que se destinava. Baldassare, citado por Odete Medauar, dá nota dos méritos do Estado Social:

[O Estado Social] trata-se de forma de organização política que marcou fase de grande valor na história da humanidade, pois é o primeiro sistema político de grandes dimensões que tentou conjugar democracia (no sentido mais geral de abertura potencial do governo a grande número de pessoas) com liberdade individual; o Estado dessa época fechou as experiências de sistemas políticos substancialmente oligárquicos para iniciar as experiências de sistemas potencialmente abertos. ${ }^{30}$

De qualquer modo, a concepção de Estado Social de Direito se mostrou de certa forma insuficiente para a implementação do Estado Material de Direito a que se propunha, vindo a sofrer críticas e, naturalmente, a ser reformulada. ${ }^{31}$

\subsubsection{Nova concepção de Democracia}

Um dos conceitos mais importantes criados pela Ciência do Direito nos últimos tempos, determinante de uma evolução social que clama cada vez mais por participação popular nas ações do Estado, é o de Estado Democrático de Direito.

Canotilho explica o fundamento deste conceito, ao estabelecer que

o Estado constitucional não é nem deve ser apenas um Estado de direito. Se o princípio do Estado de direito se revelou como uma 'linha Maginot' entre 'Estados que têm uma constituição' e 'Estados que não têm uma constituição', isso não significa que o Estado Constitucional moderno possa limitar-se a ser apenas um Estado de direito. Ele tem de estruturar-se como Estado de direito democrático, isto é, como uma ordem de domínio legitimada pelo povo. A articulação do 'direito' e do 'poder' no Estado constitucional significa, assim, que o poder do Estado deve organizar-se e exercer-se em termos

\footnotetext{
${ }^{30}$ BALDASSARE, Antonio. Lo Stato sociale: uma formula in evoluzione. In: BALDASSARE; CERVANTI (org.). Critica dello Stato sociale. Roma-Bari : Laterza, 1982, p. 40, apud MEDAUAR, Odete. O direito administrativo em evolução. $2^{a}$ ed. São Paulo : RT, 2003, pp. 89-90. Continua a autora: "Menciona-se ainda, nesse aspecto, o papel positivo desempenhado pelo Estado-providência na amortização de efeitos de crises, pois a economia mundial na entrou em espiral recessiva semelhante à de 1930; haveria uma função anticíclica dos sistemas de proteção social; além de que já propiciou considerável redução das desigualdades (nos países menos desenvolvidos esse resultado ocorreu em pequena monta)" (Ibidem, p. 90).

31 "Ao longo da era contemporânea, o direito ocidental sagrou o Estado constitucional como auge da evolução formal do fenômeno estatal. A constitucionalidade se tornou um dos valores essenciais à civilização ocidental. Mas há o risco de sobrevir o malogro jurídico do Ocidente, se o Estado de direito se converter em uma forma legal vazia de seus valores fundamentais, sendo a lei reduzida a instrumento de realização de políticas eleitorais ou até de desideratos pessoais do grupo político dominante" (BARROS, Sérgio Resende de. Contribuição dialética para o constitucionalismo. Campinas : Millennium, 2008, p. 140).
} 
democráticos. O princípio da soberania popular é, pois, uma das traves mestras do Estado constitucional. O poder político deriva do 'poder dos cidadãos' ${ }^{32}$.

O Estado Democrático de Direito se funda no princípio da soberania popular, dando a conotação de que as atividades do Estado visam especialmente a realizar o princípio democrático como garantia geral dos direitos fundamentais da sociedade.

Não basta, para a configuração do Estado Democrático de Direito, a união dos conceitos de Estado Democrático e de Estado de Direito, justamente porque a estes se acrescenta a concepção da busca pela materialização dos direitos fundamentais através da transformação do status quo social para a caracterização daquele que pode ser considerado verdadeiramente novo conceito. ${ }^{33}$

É exatamente neste ponto que se pode dimensionar a importância do art. $1^{\mathrm{o}}$ da Constituição da República Federativa do Brasil, de 1988, ao dispor que a República Federativa do Brasil, formada pela união indissolúvel dos Estados e Municípios e do Distrito Federal, constitui-se em Estado Democrático de Direito.

Extravasa-se através deste dispositivo a promessa de que a organização do Estado brasileiro será norteada pela eterna busca da justiça social.

É, portanto, o Estado Democrático de Direito instrumento garantidor da representatividade dos direitos fundamentais da pessoa humana, através da previsão constitucional da efetivação destes anseios através da aplicação de uma justiça social fundada na dignidade e na possibilidade de evolução legítima do grupo social e de seus elementos. "A tarefa fundamental do Estado Democrático de Direito consiste em superar as desigualdades sociais e regionais e instaurar um regime democrático que realize a justiça social" ${ }^{34}$.

Um dos princípios do Estado Democrático de Direito, através do qual pretende a instauração do sistema de direitos fundamentais e a aplicação do princípio da justiça social, é o princípio democrático. Este vem a ser, basicamente, a procura pela consagração

\footnotetext{
${ }^{32}$ CANOTILHO, J. J. Gomes. Direito constitucional e teoria da Constituição. $5^{\text {a }}$ ed. Coimbra : Almedina, pp. 97-98.

33 “'O Estado Democrático de Direito busca superar o Estado liberal e o Estado social pela concreção material tanto da liberdade formal quanto da igualdade social pelas relações econômicas em que se produz - e pelas relações políticas em que se conduz - a existência social. O que impõe definir de qual direito se fala quando se trata de sujeitar o Estado do direito. Mesmo porque pouco valem a legitimidade e o controle obtidos pela submissão do Estado ao direito, se o direito se reduz à lei que o Estado põe. A que direito deve o Estado ser submetido? Na atualidade, a principal substância moral do Estado de direito - inseparável da democracia - é a dignidade humana como expressão axiológica da natureza humana" (BARROS, Sérgio Resende de. Contribuição dialética ao constitucionalismo. Campinas : Millennium, 2008, p. 235).

${ }^{34}$ SILVA, José Afonso da. Curso de direito constitucional positivo. $18^{\mathrm{a}}$ ed. São Paulo : Malheiros, p. 126.
} 
de seus objetivos através da constituição de uma democracia representativa $e$ participativa. $^{35}$

Para se ter exata noção da aplicação do conceito de democracia na Constituição de um governo democrático, faz-se interessante a análise do que ensina John Rawls a respeito, ao dizer que

a constituição define um justo procedimento político e abrange restrições que ao mesmo tempo protegem as liberdades básicas e garantem a sua prioridade. O resto pertence à etapa legislativa. Uma constituição deste tipo está em conformidade com a idéia tradicional de um governo democrático, abrindo espaço, ao mesmo tempo, para a instituição da revisão dos processos à luz da constituição ('judicial review'). Essa concepção da constituição não a baseia, em primeiro lugar, sobre os princípios de justiça ou sobre os direitos fundamentais (ou naturais). A base dessa constituição é antes formada pelas concepções da pessoa e da cooperação social que têm mais probabilidade de estar em harmonia com a cultura pública de uma sociedade democrática moderna ${ }^{36}$.

O Estado Democrático de Direito, que carrega a moderna vertente da democracia, nasce como contraposição ao Estado Absolutista e busca a defesa dos caros preceitos de liberdade e igualdade dos cidadãos através da sua participação na vida do Estado. ${ }^{37}$

Na busca pela efetivação destes preceitos vêm sendo promovidas constantes alterações na configuração do Estado, tendentes a encontrar formas de participação condizentes com os anseios sociais e, além isso, com o momento histórico-social em que se inserem.

O conceito de democracia, diga-se por oportuno, evoluiu sobremaneira em relação àquele formulado quando de sua instituição. Em primeiro momento, o conceito de democracia reveste-se de conteúdo meramente formal, representando tão somente forma de governo na qual o povo detém parcela de participação ${ }^{38}$.

35 Cf. BONAVIDES, Paulo. Teoria constitucional da democracia participativa: por um direito constitucional de luta e resistência; por uma nova hermenêutica; por uma repolitização da legitimidade, $2^{\mathrm{a}}$ ed. São Paulo : Malheiros, 2003; ALLEGRETTI, Umberto. L'amministrazione dall'attuazione costituzionale alla democrazia partecipativa. Milano : Giuffrè, 2009.

${ }^{36}$ RAWLS, John. Justiça e democracia. São Paulo : Ed. Martins Fontes, 2000, pp. 193-194, trad. de Irene A. Paternot.

${ }^{37}$ Nas palavras de Dalmo Dallari (DALLARI, Dalmo de Abreu. Elementos de teoria geral do Estado. 25 ed. São Paulo : Saravia, 2006, p. 151, 2 $2^{\mathrm{a}}$ tir.): “A preocupação primordial foi sempre a participação do povo na organização do Estado, na formação e na atuação do governo, por se considerar implícito que o povo, expressando livremente sua vontade soberana, saberá resguardar a liberdade e a igualdade".

38 Veja-se a respeito do conceito de democracia as notas de Misabel Abreu Machado Derzi à obra do professor Aliomar Baleeiro (DERZI, Misabel Abreu Machado. Notas. In: BALEEIRO, Aliomar. Limitações constitucionais ao poder de tributar. $7^{\mathrm{a}}$ ed. Rio de Janeiro : Ed. Forense, 1999, pp. 5 e ss.). Também a este respeito cf.: BOBBIO, Norberto et al.. Democracia. In: (coord.). Dicionário de Política. $8^{\mathrm{a}}$ ed. Brasília : Ed. UnB, 1995, pp. 319-329, vol. 1, trad. Carmem C. Varriale et al. 
Hodiernamente, no entanto, "passa-se a enfocar a democracia como uma 'técnica de igualdade'. Não só os privilégios de raça, crença ou linhagem devem ser abolidos, mas se caminha em busca de uma igualdade sócio-econômico-material”"39.

A democracia, portanto, que nasce com idéias formais de participação do povo, tende a encontrar ferramentas de participação efetiva, pressupondo que quanto mais efetiva a participação social, maior legitimidade se dá às ações do Estado e, conseqüentemente, mais próximo da igualdade material se chega.

Passa-se, então, das idéias de democracia direta, semidireta e representativa, prevalentes nos Estados Democráticos até então, à discussão de uma democracia participativa $^{40}$ como forma de dar nova roupagem ao instituto da democracia, fortalecendo-a através de instrumentos de efetiva participação dos cidadãos nas decisões políticas da sociedade em que se inserem.

Em sua vertente moderna, a propósito, é chamada por doutrinadores de democracia administrativa $^{41}$ com a expressa intenção de desmonopolização do poder do Estado, sobretudo pela constatação de que as noções de democracia precisavam se modernizar para acolher a idéia de que o cidadão deixou de ser súdito perante o Estado. É “uma nova forma de cidadania, definida 'administrativa' para indicar que diz respeito especificamente à relação com a Administração". 42

As concepções modernas consideram que não basta ao cidadão participar do processo eletivo dos seus representantes no poder para que esteja caracterizada a democracia. Não basta também, nesta nova idéia de democracia, assegurar formas de

\footnotetext{
${ }^{39}$ DERZI, Misabel Abreu Machado. Notas. In: BALEEIRO, Aliomar. Limitações constitucionais ao poder de tributar. $7^{\mathrm{a}}$ ed. Rio de Janeiro : Ed. Forense, 1999, p. 8.

40 "Não há democracia sem participação" (BONAVIDES, Paulo. Teoria constitucional da democracia participativa: por um direito constitucional de luta e resistência; por uma nova hermenêutica; por uma repolitização da legitimidade. $2^{\mathrm{a}}$ ed. São Paulo : Malheiros, 2003, p. 51). "A condição de partícipe é titularizada por todos os cidadãos, nas suas mais variadas formas de expressão, em toda a diversidade de interesses, em toda sua diferenciação plural. Essa multiplicidade é a marca designativa da democracia participativa, vislumbrando, os teóricos que se debruçam sobre a matéria, 'a evolução do próprio conceito de povo', que deixa de ser uma massa homogênica e se materializa na 'noção de povo real, do povo heterogêneo, feito de grupos sociais diferenciados e de categorias diversas de profissionais" (FERNANDES, Luciana de Medeiros. Reforma do Estado e Terceiro Setor. Curitiba : Juruá, 2009, p. 284, grifos no original).

${ }_{41}^{4}$ MEDAUAR, Odete. O Direito Administrativo em evolução. 2a ed. São Paulo : RT, 2003, p. 100.

${ }^{42}$ ARENA, Gregorio. Cittadini attivi. Roma-Bari : Laterza, 2006, p. 145, tradução nossa. No original: "Una nuova forma di cittadinanza, definita 'amministrativa' per indicare che attiene specificamente al rapporto con l'amministrazione". "A moderna tendência do direito público marca, pela modalidade acima exposta de novos institutos jurídicos, a transição do Direito Administrativo que, absorvendo a ação participativa dos administrados, valoriza o princípio da cidadania e coloca o indivíduo e a empresa em presença da Administração Pública, como colaboradores privilegiados para a consecução do interesse público" (TÁCITO, Caio. Direito Administrativo Participativo. In: de Janeiro : Renovar, 2002, $3^{\circ}$ vol., p. 24). . Temas de direito público (estudos e pareceres). Rio
} 
exercício de democracia direta, insuficientes para a democracia participativa. A efetivação desta nova democracia vai além, exigindo instrumentos de legitimação dos cidadãos no exercício do poder. ${ }^{43}$

O problema, sob este ponto de vista, não se resolve através de inimagináveis formas de "democracia direta", ou seja, não se resolve pensando em uma participação direta dos cidadãos nas instituições mas, mais do que isso, enfatizando a participação direta dos cidadãos no exercício das funções. ${ }^{44}$

Esta nova concepção de democracia exige um repensar no modelo de atuação do Estado e sua reconfiguração de modo a consagrar o exercício da cidadania ativa. ${ }^{45}$

\subsubsection{Novos contornos da legalidade}

Plasmado inicialmente como uma garantia aos cidadãos contra o absolutismo reinante de modo a impedir o cometimento de abusos pelo soberano contra os seus súditos, atualmente o princípio da legalidade tem adotado nova roupagem.

O princípio da legalidade tem origem no movimento liberal oitocentista europeu, cuja influência culminou na definição do Estado de Direito ${ }^{46}$. Em especial através dos

\footnotetext{
43 “As formações sociais intermediárias entre o indivíduo e o Estado, enquanto 'desenvolvimento democrático' da liberdade do indivíduo e da própria sociedade, constituem uma 'forma' irrenunciável da democracia e do exercício da soberania popular, como a própria Corte constitucional reconheceu quando afirmou que a soberania popular consagrada no artigo 1 da Constituição se articula em uma pluralidade de formações, associações, organizações e instituições" (TIBERI, Giulia. La dimensione costituzionale del Terzo settore. In: CITTADINO: Caterina (org.). Dove lo Stato non arriva: pubblica amministrazione e terzo settore. Firenze : Passigli, 2008, p. 34, tradução nossa). No original: "Le formazioni sociali intermedie tra l'individuo e lo Stato, in quanto 'svolgimento democratico' della libertà dell'individuo e della società stessa, costituiscono una 'forma' irrinunciabile della democracia e di esercizio della sovranità popolare, come la stessa Corte costituzionale ha riconosciuto quando ha affermato che la sovranità popolare consacrata nell'art. 1 della Costituzione si articola in una pluralità di formazioni, associazioni, organizzazioni e istituzioni".

${ }^{44}$ BENVENUTI, Feliciano. Il nuovo cittadino: tra libertà garantita e libertà attiva. Venezia : Marsilio, 1994, p. 22, tradução nossa. No original: "Il problema, da questo punto di vista, non si risolve attraverso ininmmaginabili forme di 'democrazia diretta' e cioè non si risolve pensando a una partecipazione diretta dei cittadini alle istituzioni ma, piuttosto, ponendo l'accento sulla partecipazione diretta dei cittadini all'esercizio delle funzioni".

${ }^{45}$ Cf. ARENA, Gregorio. Cittadini attivi. Roma-Bari : Laterza, 2006. Ainda: "A cidadania ativa é pressuposto básico para a efetivação do princípio da subsidiariedade. Na sua efetuação, as instâncias privadas precisam trabalhar para a coletividade, pelo que devem realizar tarefas de interesse geral, operando-se de modo e por razões conjugadas. A solidariedade é necessária, sendo que a própria participação do Estado ocorrerá para a efetivação da solidariedade entre os componentes da sociedade" (BARACHO, José Alfredo de Oliveira. O princípio da subsidiariedade: conceito e evolução. Rio de Janeiro : Forense, 1997, p. 64).

46 "Esta é a principal inovação deste período liberal, que aqui quero salientar. Ao contrário do que se verificava no Estado Absoluto, toda a actividade da Administração Pública, e não apenas o Fisco, passa agora a estar sujeita à lei." (ESTORNINHO, Maria João. A fuga para o direito privado. Coimbra : Almedina, 1999, p. 33)
} 
teóricos R. Von Mohl e F. J. Stahl na Alemanha e Carré de Malberg na França, objetiva-se “emoldurar e limitar o poder do Estado pelo Direito", na feliz expressão de Chevallier. ${ }^{47}$

Diante dos abusos cometidos pelo Estado absolutista, iniciaram-se insurgências no sentido de limitar a atuação estatal de modo a garantir, fundamentalmente, a propriedade e a liberdade dos cidadãos.

Em superação à doutrina do "Estado de polícia", na qual o direito serve de instrumento ilimitado da ação do Estado e, portanto, permite a atuação do soberano de acordo com suas vontades e sem dotar os cidadãos de garantias ${ }^{48}$, surge na Alemanha a doutrina do Rechtsstaat.

Surge com o intuito de fazer submeter o Estado a um regime de Direito: toda atuação do Estado deve estar fundada sobre uma norma jurídica; o poder é emoldurado pelo Direito. Assim, suas principais características são a submissão da Administração ao Direito, garantida pela existência de um controle jurisdicional, e a subordinação da lei à Constituição. De instrumento de atuação do Estado, como o era no Estado de Polícia, o Direito passa a vetor de limitação da atuação do Estado e garantia de direitos aos cidadãos.

A doutrina do Rechtsstaat foi incorporada na França, principalmente pelos estudos de Carré de Malberg, que muito embora tenha sofrido influência da construção alemã tratou de adaptá-la à realidade francesa, mormente às tradições herdadas da Revolução. Tanto que a proposta francesa apresentava diferenças substanciais, a começar por se definir Estado Legal: a lei não é somente o limite da atividade administrativa, mas sua condição, reduzindo a função administrativa à execução das leis; a lei prevalece sobre a Constituição.

Observa-se, portanto, que o Estado Legal francês se direcionava a fazer prevalecer a lei, enquanto o Estado de Direito alemão se voltava à salvaguarda dos cidadãos. Esta diferença ensejou que a teoria do Estado de Direito servisse como referência para a denunciação de uma soberania parlamentar no Estado Legal francês, oriunda da supremacia das leis do Parlamento, que redundou na assunção da necessidade de controle de constitucionalidade das leis.

\footnotetext{
${ }^{47}$ CHEVALLIER, Jacques. L'État de Droit. Paris : Montchrestien, 1992, p. 11. Sobre a construção da teoria do Estado de Direito, consulte-se a mesma obra (pp. 11-23, 31-35).

48 "O Estado de polícia é aquele em que o poder da autoridade administrativa, de um modo discricionário e com liberdade de decisão mais ou menos completa, aplica aos cidadãos todas as medidas que ele julga útil de dispender por sua própria iniciativa, com vistas a fazer frente às circunstâncias e atender a cada momento os fins aos quais se propôs" (CARRÉ DE MALBERG, apud CHEVALLIER, Jacques. Ibidem, p. 16, tradução nossa). O próprio Chevallier (loc. cit.) termina: "O Estado de polícia é, por isso, forjado ao belprazer do Príncipe: não há verdadeiro limite jurídico à ação do poder, nem verdadeira proteção dos cidadãos contra o poder".
} 
Sobretudo influenciada pelo princípio da separação dos poderes erigido por Montesquieu, atribui-se função específica de criação das leis ao Legislativo e de execução das leis ao Executivo. Assim, o Poder Legislativo (Parlamento) estaria dotado de supremacia em relação ao Poder Executivo. ${ }^{49}$

O Estado se submete ao Direito, sendo mero executor das leis do Parlamento que, inobservadas, passariam por controle jurisdicional; este é o regime visualizado pela doutrina do Estado de Direito, apontada como origem do princípio da legalidade que, na simplicidade de seus termos, significaria a submissão da Administração Pública à lei, em sentido de vinculação positiva (pode fazer tudo o que a lei permitir).

Este seria o nascedouro do princípio da legalidade, que se confunde, em certa medida, com o nascimento do próprio Direito Administrativo. ${ }^{50}$

No entanto, como dito anteriormente todas estas balizas tidas como consistentes para o Direito Administrativo estão sendo colocadas à prova. As justificativas normalmente apontadas para o seu surgimento são postas em cheque, assim como os próprios fundamentos do princípio da legalidade.

Criticando esta origem milagrosa do Direito Administrativo relacionada à subordinação do poder à lei e da vinculação da Administração Pública a determinados direitos individuais, conforme narra a história oficial, Binenbojm ${ }^{51}$ a julga falsa. Para ele:

a associação da gênese do direito administrativo ao advento do Estado de direito e do princípio da separação de poderes na França pós-revolucionária caracteriza erro histórico e reprodução acrítica de um discurso de embotamento da realidade repetido por sucessivas gerações, constituindo aquilo que Paulo Otero denominou ilusão garantística da gênese. $\mathrm{O}$ surgimento do direito administrativo, e de suas categorias jurídicas peculiares (supremacia do interesse público, prerrogativas da Administração, discricionariedade, insindicabilidade do mérito administrativo, dentre outras), representou antes uma forma de reprodução e sobrevivência das práticas administrativas do Antigo Regime que a sua superação. A

\footnotetext{
49 "Para isso era necessário, em primeiro lugar, assegurar que a Administração Pública ficasse subordinada às leis do Parlamento e, desta forma, impedida de interferir nos domínios que a sociedade civil, para ela própria, quisesse reservar. É, assim, consagrado o princípio da legalidade da Administração Pública" (ESTORNINHO, Maria João. A fuga para o direito privado. Coimbra : Almedina, 1999, p. 32).

50 “Após a Revolução Francesa verifica-se um fenómeno que, à primeira vista, pode parecer 'paradoxal' (VASCO PEREIRA DA SILVA) porque, em nome do princípio da separação entre a Administração e a Justiça, acaba por se instituir uma verdadeira indiferenciação entre as funções de administrar e julgar. $\mathrm{Na}$ realidade, o que se consagra não é apenas a separação entre a função administrativa e a função judicial, impedindo que os tribunais e as entidades administrativas interfiram reciprocamente nas respectivas actividades, mas consagra-se também a impossibilidade de os tribunais conhecerem dos litígios que eventualmente surjam entre a Administração e os particulares. É precisamente a partir desse especial entendimento do princípio da separação dos poderes que se vão criar os tribunais administrativos e que, num segundo momento, como fruto da própria actuação destes, vai surgir o Direito Administrativo". (Ibidem, pp. 31-32).

${ }^{51}$ BINENBOJM, Gustavo. Uma teoria do Direito Administrativo: direitos fundamentais, democracia e constitucionalização. Rio de Janeiro : Renovar, 2006, pp. 9-11.
} 
juridicização embrionária da Administração Pública não logrou subordiná-la ao direito; ao revés, serviu-lhe apenas de revestimento e aparato retórico para sua perpetuação fora da esfera de controle dos cidadãos. O direito administrativo não surgiu da submissão do Estado à vontade heterônoma do legislador. Antes, pelo contrário, a formulação de novos princípios gerais e novas regras jurídicas pelo Conseil d’État, que tornaram viáveis soluções diversas das que resultariam da aplicação mecanicista do direito civil aos casos envolvendo a Administração Pública, só foi possível em virtude da postura ativista e insubmissa daquele órgão administrativo à vontade do Parlamento. ${ }^{52}$

E realmente, analisando com cautela a formatação original da teoria do Estado de Direito, que sob o pressuposto da teoria da separação dos poderes com vistas a fazer submeter a Administração à lei cunhou o princípio da legalidade de modo a fazer aplicar ao Estado normas especiais àquelas de direito privado, forjadas pela jurisprudência de um órgão intestino ao Poder Executivo ${ }^{53}$ (Conselho de Estado), demonstra que a origem da legalidade e do próprio Direito Administrativo não é tão simples quanto a quase matemática expressão comum do princípio da legalidade, qual seja a de que significa a submissão do Estado ao Direito.

Esta concepção criadora do Estado de Direito, que jungia a Administração ao contencioso administrativo de competência do Conselho de Estado, aparenta muito mais uma ambigüidade autovinculativa ${ }^{54}$ do que a definição da vinculação à legalidade ou a aplicação do princípio da separação de poderes: o Estado se torna juiz de si mesmo.

Ambigüidade que, a propósito, é bem observada por Estorninho: "Disciplina que se queria que fosse ao mesmo tempo instrumento de liberalismo e meio de realização da actividade administrativa, protecção do cidadão contra o executivo e meio de realização da vontade desse mesmo executivo" ${ }^{\text {} 55}$.

Vê-se, pois, que a origem do Direito Administrativo traz a reboque a idéia de princípio da legalidade em seu sentido de vinculação positiva, como uma herança institucional dada como certa durante estes duzentos anos. Teria nascido o Direito Administrativo sob o pretexto de que se deveria moldar a atuação da Administração

\footnotetext{
52 Ibidem, p. 11.

${ }^{53}$ Expressão em itálico utilizada por BINENBOJM, Gustavo. Ibidem, p. 12.

${ }^{54}$ Observa Paulo Otero (OTERO, Paulo. Legalidade e administração pública: o sentido da vinculação administrativa à juridicidade. Coimbra : Almedina, 2003, p. 271) que "a idéia clássica de que a Revolução Francesa comportou a instauração do princípio da legalidade administrativa, tornando o Executivo subordinado à vontade do Parlamento expressa através da lei, assenta num mito repetido por sucessivas gerações: a criação do direito administrativo pelo Conseil d'État, passando a Administração Pública a pautarse por normas diferentes daquelas que regulavam a actividade jurídico-privada, não foi um produto da vontade da lei, antes se configura como uma intervenção decisória autovinculativa do Executivo sob proposta do Conseil d'État". O autor vai além, ao dizer que "a invocação do princípio da separação foi um simples pretexto" (ibidem, p. 275), no que é seguido por Binenbojm (op. cit., p. 13).

${ }^{55}$ ESTORNINHO, Maria João. A fuga para o direito privado. Coimbra : Almedina, 1999, p. 33.
} 
Pública pela lei, permitindo que esta só agisse de acordo com as normas que autorizassem e preordenassem os seus atos. A Administração Pública teria, portanto, por espólio a vinculação positiva à lei.

Calha a afirmação de Rogério Soares, no entanto, para que se tenha em mente o trespasse atual deste dogma com vistas a melhor elucidar a vinculação da atividade administrativa à lei, mormente tendo em conta que, como foi visto, a origem do princípio da legalidade é mais movediço do que se costumou acreditar:

Interessa esclarecer a evolução desta vinculação da Administração pela lei. É que o direito administrativo actual encontra-se numa época de crise, à busca de uma exacta conformação de si mesmo, de uma justa correspondência à sociedade a que se dirige e, apesar de tudo, ainda sobrecarregado com esquemas e institutos que representam a herança de outras épocas, que ele teve de aceitar sem benefício de inventário, e a que ainda se apega, sem muitas vezes ter consciência da via por que entraram no seu património. ${ }^{56}$

Se assim o é, urge que se alinhe na determinação do conteúdo da legalidade em seu sentido evolutivo, mormente para que se alcance conclusão em definir o espaço de participação normativa da Administração Pública diante da verdadeira conformação da legalidade.

Não se pode deixar de considerar, de todo modo, que como todos os institutos jurídicos o princípio da legalidade não é uno; verdadeiramente inexiste o princípio da legalidade, senão princípios da legalidade definidos no tempo e no espaço. Cada sociedade define a sua legalidade de acordo com suas características, tendo na variável tempo outro elemento de definição. Assim é que não se pode considerar o princípio da legalidade de uma sociedade marcadamente liberal, em que o âmbito de atuação do Estado é deliberadamente minorado, de modo igual ao princípio da legalidade de uma sociedade com viés social, com um Estado interventivo.

Afora esta intervenção paralela, o fato é que o discurso de que o princípio da legalidade significa a submissão da Administração à lei não corresponde ao efetivo conteúdo deste princípio, sobretudo na prática. $^{57}$

\footnotetext{
${ }^{56}$ SOARES, Rogério Ehrhardt. Interesse público, legalidade e mérito. Coimbra, 1955, pp. 45-46, apud, ESTORNINHO, Maria João. Ibidem, p. 30, n.r. 31.

57 Odete Medauar bem observa que "o princípio da legalidade traduz-se, de modo simples, na seguinte fórmula: 'A Administração deve sujeitar-se às normas legais'. Essa aparente simplicidade oculta questões relevantes quanto ao modo de aplicar, na prática, esse princípio" (MEDAUAR, Odete. Direito administrativo moderno. $10^{a}$ ed. São Paulo : RT, 2006, p. 124).
} 
A começar pelas próprias adaptações sofridas ao longo do tempo com vistas a "permitir" a atuação administrativa (partindo da premissa de que a legalidade limitaria sobremaneira esta atuação) ${ }^{58}$, a começar pela discricionariedade administrativa. ${ }^{59}$

Havendo uma margem de atuação administrativa livre à escolha do administrador, evidente que a discricionariedade administrativa serve como válvula de escape ao princípio da legalidade, de modo a ampliar a liberdade de atuação da Administração. Sobretudo quando se observa que a grande maioria dos atos administrativos tende a ser dotada de natureza discricionária, de fato este instituto só pode ser tido como reflexo da inaplicabilidade da legalidade originalmente concebida.

E por uma série de motivos é possível compreender a necessidade de criação de instrumentos que, como a discricionariedade, "suavizem" a legalidade.

Em assim não sendo, certamente seria impossível o atuar administrativo, haja vista ser impossível à lei em sentido formal prever todas as hipóteses da vida social de modo a permitir que a Administração dispusesse de arcabouço legal completo para a sua atuação. Como bem expressa Odete Medauar, "a submissão total da Administração à lei é irrealizável e provavelmente nunca se realizou" ${ }^{\prime 60}$.

Assim, em diversas situações o legislador passou a legislar de forma geral e indeterminada, deixando ao administrador a complementação da norma através da aplicação de sua discricionariedade.

Aliás, diga-se desde já que não é difícil caracterizar a discricionariedade como uma forma, mesmo que indireta, de outorga de poderes normativos à Administração Pública. Imaginando-se o conteúdo da delegação de poderes discricionários em determinadas situações, pode-se bem ver uma carga normativa considerável.

Conclui-se, portanto, que por questões de ordem prática (desamarrar a atuação da Administração Pública) ou jurídica (impossibilidade de a lei em sentido formal prever

\footnotetext{
58 "Se as exigências da legalidade se estendessem a todos os elementos da actividade administrativa, esta seria puramente passiva; o papel da Administração reduzir-se-ia à elaboração mecânica dos actos particulares impostos pela norma geral; toda a liberdade de apreciação, toda a iniciativa lhe estariam proibidas. Na realidade não é assim; a submissão da Administração ao direito deixa subsistir a seu favor uma zona de liberdade: é o poder discricionário" (RIVERO, Jean. Direito Administrativo. Coimbra : Almedina, 1981, p. 93, trad. Rogério Ehrhardt Soares).

59 "Com o tempo, ocorreu o empenho da Administração na obtenção de poderes livres, o que gerou os contrapesos ao princípio da legalidade ou zonas de ampla liberdade, refletidas na discricionariedade e nos atos de governo, muitas vezes fundamentadas no chamado poder de supremacia especial" (MEDAUAR, Odete. Direito administrativo moderno. $10^{\mathrm{a}}$ ed. São Paulo : RT, 2006, p. 145).

${ }^{60}$ MEDAUAR, Odete. Loc. cit. Alexandre Santos Aragão (ARAGÃO, Alexandre Santos. Princípio da legalidade e poder regulamentar no Estado Contemporâneo. Revista de Direito Administrativo, vol. 225, jul.-set. 2001, p. 116) concorda, ao dizer que "o objetivo almejado pelo liberalismo do século XVIII, do absoluto império da lei, nunca foi atingido".
} 
todas as hipóteses de atuação da Administração Pública) ${ }^{61}$ a discricionariedade surge como instituto de relativização da legalidade.

Se desde o início da construção do princípio da legalidade, por assim dizer, na formulação da teoria do Estado de Direito, a discricionariedade já se aplicava a casos específicos $^{62}$ sob os fundamentos de possibilitar a atuação da Administração Pública e da impossibilidade de a lei formal prever todas as hipóteses de sua atuação, não é de se estranhar que esta tendência, diante da evolução social, só tenha aumentado.

Não somente em relação à discricionariedade mas a outras formas de buscar a efetividade da atuação estatal, em resposta às constantes evoluções tecnológicas e imbricações sociais, cada vez mais complexas e dinâmicas, mormente após o fenômeno da globalização que auxilia para a redução das distâncias através das facilidades de comunicação e transporte oriundas, sobretudo, das transferências de tecnologia, o fato é que a legalidade tem sofrido profundas adaptações a ponto de se falar em crise da lei formal. $^{63}$

Como bem observa Giuffrè ${ }^{64}$, dando conta desta crise, a exacerbação legislativa e o pluralismo de fontes normativas (em especial em países submetidos a ordenamentos supraestatais), assim como a complexidade da sociedade contemporânea, relegam o Parlamento a uma função de coordenação e arbitragem entre os legitimados a normatizar, assim como representante dos interesses gerais.

Para ele, a erosão da função normativa é visível pelo poder normativo concedido à Administração Pública, que goza de autonomia constitucionalmente garantida, extraindo-se da Constituição margens de competência à Administração Pública, que deixa de ter somente poder de auto-organização para deter poder concreto de perseguição dos objetivos públicos, mais difíceis de serem sintetizados em sede parlamentar.

O mesmo autor aponta que a rápida evolução social exige atualização difícil de ser conseguida pelo Poder Legislativo, apontando a tendência no crescimento do número de agências e autoridades independentes em determinados setores, mormente em virtude de: a) deterem o conhecimento especializado; b) conjugarem competências normativa, executiva e contenciosa;

${ }^{61}$ Cf. DI PIETRO, Maria Sylvia Zanella. Discricionariedade administrativa na Constituição de 1988. $2^{\mathrm{a}}$ ed., São Paulo : Atlas, 2001.

${ }^{62}$ A propósito, cf. Maria Sylvia Zanella Di Pietro (ibidem, p. 27), para quem a discricionariedade no Estado Liberal "era vista como um tipo de atividade administrativa que não admitia controle judicial".

${ }^{63}$ Sobre a crise da lei formal, cf. BINENBOJM, Gustavo. Uma teoria do Direito Administrativo: direitos fundamentais, democracia e constitucionalização. Rio de Janeiro : Renovar, 2006, pp. 125 e ss.

${ }^{64}$ GIUFFRĖ, Felice. Declínio del Parlamento-legislatore. In: LABRIOLA, Silvano (org.). Le autorità indipendenti.. Milano : Giuffrè, 1999, pp. 177-214. 
Também no sentido de apontar a crise do Poder Legislativo ${ }^{65}$, Sérvulo Correia entende que atualmente a aplicação da soberania popular (conseqüentemente da representatividade que dela advém) deveria fazer alargar a reserva de lei do Parlamento a toda atividade da Administração, já que o Estado de Direito pressupõe uma juridificação normativa do exercício do poder, o que, com o perecimento da monarquia constitucional (que dispunha de legitimação da competência normativa paralela da Administração), deveria fazer com que o Parlamento fosse legitimado à edição de normas que conformasse os atos da Administração ou os autorizasse.

Mas reconhece que na estrutura constitucional contemporânea são diversos os graus de definição da intervenção parlamentar.

Em princípio porque não se pacificou o entendimento quanto às vantagens $\mathrm{e}$ inconvenientes do alargamento da intervenção parlamentar na cobertura integral da definição dos fins e dos meios da atividade administrativa no Estado Social de Direito: a) uns entendem que o Parlamento é o órgão representativo do povo e deveria ser dotado da suprema direção política do Estado e da reserva absoluta do painel normativo das liberdades e dos direitos fundamentais; b) outros entendem que o Parlamento é ineficaz na produção dos critérios de base necessários, haja vista a complexidade técnica crescente da estrutura da sociedade.

Indiscutível, portanto, o fato de que a concepção original de legalidade passa por reformulações profundas a ponto de se questionar, inclusive, o papel do próprio Poder originalmente apontado como o único competente à representação legislativa da sociedade, o Legislativo.

Esta renovação do conteúdo do princípio da legalidade leva necessariamente à formulação de conceitos no sentido de compreender, agora, qual seria o potencial de exteriorização dos efeitos da lei aplicáveis à Administração Pública, ou seja, em que medida esta está limitada pela lei.

\footnotetext{
${ }^{65}$ SÉRVULO CORREIA, José Manuel. O princípio da legalidade administrativa no direito comparado. In: Legalidade e autonomia contratual nos contratos administrativos. Coimbra : Almedina, 1987, pp. 33-55. Em outra passagem, tratando da extensão quanto às matérias e do grau da sua reserva de competência legislativa, aponta que "neste plano se reflecte com toda a crueza a antinomia entre a necessidade de evitar a sobrecarga excessiva do supremo órgão de representação popular - que, enterrado num número infinito de minudências, poderá perder a visão do perfil e da hierarquia das grandes questões nacionais - e a exigência histórica da ultrapassagem do mero âmbito dos problemas de liberdade e propriedade como objecto da produção normativa do parlamento".
} 
Eisenmann ${ }^{66}$ sugere a existência de quatro noções do princípio da legalidade, muito bem resumidas por Odete Medauar:

a) a Administração pode realizar todos os atos e medidas que não sejam contrários à lei; b) a Administração só pode editar atos ou medidas que sejam contrários à lei; c) somente são permitidos atos cujo conteúdo seja conforme a um esquema abstrato fixado por norma legislativa; d) a Administração só pode realizar atos ou medidas que a lei ordena fazer. ${ }^{67}$

Estas quatro noções, em seus extremos, podem ser resumidas em duas noções suficientes à análise pretendida: noção mínima (relação de não-contrariedade ou compatibilidade: o ato administrativo não pode ser contrário à norma) e noção máxima (relação de conformidade: o ato administrativo deve ser exatamente conforme à regulamentação legislativa).

Observa-se tendência em se dotar a Administração Pública de poderes normativos próximos à noção de compatibilidade proposta por Eisenmann. Segundo esta compatibilidade, a Administração Pública estaria livre para atuar desde que seus atos sejam compatíveis com o ordenamento jurídico.

E esta nova roupagem dada ao princípio da legalidade, justificada de forma coerente em cotejo com os fenômenos sociais que exigem a adaptação do Direito à realidade dos fatos, como já dito interfere sobremaneira na forma de atuação da Administração Pública. Permite-se maior grau de liberdade de sua atuação a partir do momento que se atribui à legalidade conceito mais amplo a que se pode dar o nome de juridicidade.

Neste conceito de juridicidade, a legalidade representaria a submissão da Administração Pública não mais à lei em sentido formal, mas ao Direito, ou seja, à totalidade do sistema normativo ${ }^{68}$ (lei formal, Constituição, princípios constitucionais e normas da própria Administração ${ }^{69}$ ).

\subsubsection{O recrudescimento da idéia de subsidiariedade}

66 EISENMANN, Charles. O Direito Administrativo e o princípio da legalidade. Revista de Direito Administrativo, vol. 56, abr.-jun. 1959, pp. 47-70, traduzido da revista "Études et Documents", Conseil d`Etat, fascículo n. ${ }^{\circ} 11$, p. 47 e ss., por Ruth Barbosa Goulart.

${ }^{67}$ MEDAUAR, Odete. Direito administrativo moderno. $10^{\mathrm{a}}$ ed., São Paulo : RT, 2006, p. 124.

${ }^{68}$ Cf. SANTAMARÍA PASTOR, Juan Alfonso. Princípios de derecho administrativo. $3^{\mathrm{a}}$ ed., Editorial Centro de Estúdios Ramón Areces, vol. I, p. 91.

${ }^{69}$ MEDAUAR, Odete. Op. cit., pp. 123-124. 
Conceito que assume importância nos debates sobre o reposicionamento do Estado é o do princípio da subsidiariedade. Talhado pela doutrina social da igreja católica entre os séculos XIX e XX, passa a tomar contornos de juridicidade com a assunção expressa por alguns ordenamentos jurídicos durante o século XX e início deste século XXI.

Desde a Encíclica Rerum Novarum (1981), passando pelas Encíclicas Quadragesimo Anno (1931) e Mater et Magistra (1961), e encontrando sua mais recente manifestação na Encíclica Centesimus Annus (1991), o princípio da subsidiaridade foi criado sob o argumento da injustiça de "retirar dos agrupamentos de ordem inferior, conferindo-as a uma coletividade bem mais vasta e elevada, funções que elas próprias poderiam exercer". ${ }^{70}$

Conforme Baracho, o princípio da subsidiaridade, "apesar de estar inserido no Direito Administrativo, é largamente tributário do Direito Canônico. (...) aplica-se em numerosos domínios, seja no administrativo ou no econômico"71. Sílvia Faber Torres entende que se trata de princípio "aplicável na organização hierárquica da sociedade" ${ }^{72}$

De qualquer forma, sendo ou não aplicável à estrutura da própria Igreja Católica, o fato é que o princípio da subsidiariedade tem inspirado bastante os debates sobre a definição do papel do Estado. A idéia central do princípio da subsidiariedade está na valorização dos direitos individuais, garantindo à iniciativa privada, no seu extrato social mais simples, autonomia de ação. Defende, assim, que as ações cujo exercício seja possível pelas esferas sociais mais simples não sofram interferência das esferas sociais mais complexas; podendo o indivíduo, por si só, desenvolver determinada atividade, esta atividade não deve ser conferida à coletividade, ao passo que esta coletividade, sendo capaz de suprir as suas necessidades de forma autônoma, não deve sofrer a interferência estatal no desempenho destas atividades. "O princípio de subsidiariedade é uma garantia contra a arbitrariedade, procura inclusive suprimi-la". ${ }^{73}$

“Apesar de sugerir uma função de suplência, convém ressaltar que compreende, também, a limitação da intervenção de órgão ou coletividade superior. Pode ser

\footnotetext{
${ }^{70}$ BARACHO, José Alfredo de Oliveira. O princípio da subsidiariedade: conceito e evolução. Rio de Janeiro : Forense, 1997, p. 26. Para uma análise crítica sobre o princípio da subsidiariedade, cf. GABARDO, Emerson. Interesse público e subsidiariedade: o Estado e a sociedade civil para além do bem e do mal. Belo Horizonte : Fórum, 2009.

${ }_{71}$ BARACHO, José Alfredo de Oliveira. Op. cit., pp. 25-26.

${ }^{72}$ TORRES, Ś́lvia Faber. O princípio da subsidiariedade no direito público contemporâneo. Rio de Janeiro : Renovar, 2001, p. 34.

${ }^{73}$ BARACHO, José Alfredo de Oliveira. Op. cit., p. 30.
} 
interpretado ou utilizado como argumento para conter ou restringir a intervenção do Estado". ${ }^{74}$

Com a idéia de "gradatividade de deveres e de obrigações" subsidiariedade expressa sua concepção de centralidade do indivíduo como elemento primário na origem do poder e das organizações sociais; é dado a ele, em primeiro lugar, a possibilidade de suprir as suas próprias necessidades, bem como a ele é garantido o apoio das demais esferas sociais para que consiga a auto-sustentação.

Há portanto, no conceito de subsidiariedade, conteúdo dúplice: um conteúdo positivo e um conteúdo negativo. O conteúdo positivo estaria representado pela noção de apoio das organizações mais complexas à autonomia das organizações menos complexas. O conteúdo negativo, por sua vez, tem como referência a limitação da atuação dos grupos mais complexos em situações em que grupos menos complexos consigam se auto tutelar; serve como forma de limitar "os excessos que possam ser cometidos pelo ente maior em detrimento do menor"

O princípio da subsidiariedade pode ser conceituado como aquele "pelo qual as decisões, legislativas ou administrativas, devem ser tomadas no nível político mais baixo possível, isto é, por aquelas que estão o mais próximo possível das decisões que são definidas, efetuadas e executadas". ${ }^{77}$

Maria Sylvia Zanella Di Pietro afirma que

algumas idéias são inerentes ao princípio da subsidiariedade: de um lado, a de respeito aos direitos individuais, pelo reconhecimento de que a iniciativa privada, seja através dos indivíduos, seja através das associações, tem primazia sobre a iniciativa estatal; em consonância com essa idéia, o Estado deve abster-se de exercer atividades que o particular tem condições de exercer por sua própria iniciativa e com seus próprios recursos; em conseqüência, sob esse aspecto, o princípio implica uma limitação à intervenção estatal. De outro lado, o Estado deve fomentar, coordenar, fiscalizar a iniciativa privada, de tal modo a permitir aos particulares, sempre que possível, o sucesso na condução de seus empreendimentos. E uma terceira idéia ligada ao princípio da subsidiariedade seria a de parceria entre público e privado, também dentro do objetivo de subsidiar a iniciativa privada, quando ela seja deficiente. ${ }^{78}$

\footnotetext{
${ }^{74}$ Ibidem, p. 26.

${ }^{75}$ MOREIRA NETO, Diogo de Figueiredo; CASTRO, Paulo Rabello de. O futuro do Estado: do pluralismo à desmonopolização do poder. In: MARTINS, Ives Gandra da Silva (coord.). O Estado do futuro. São Paulo : Pioneira : Associação Internacional de Direito e Economia, 1998, p. 57.

${ }^{76}$ Ibidem, p. 57. "Os alcances da subsidiariedade manifestam-se sob dupla perspectiva: negativo-positivo. Na primeira situa-se como limite à intervenção estatal; na segunda manifesta-se como justificação da intervenção estatal" (BARACHO, José Alfredo de Oliveira. O princípio da subsidiariedade: conceito e evolução. Rio de Janeiro : Forense, 1997, p. 50).

${ }^{77}$ Ibidem, p. 92.

${ }^{78}$ DI PIETRO, Maria Sylvia Zanella. Parcerias na Administração Pública. 5a ed. São Paulo : Atlas, 2006, pp. 33-34, destaques no original.
} 
A importância jurídica do princípio está em assumir o pluralismo social ${ }^{79} \mathrm{e}$, mais do que isso, o centralismo do indivíduo no arranjo social, dotando-o de responsabilidade primária na solução de seus próprios problemas e prevendo o fomento das esferas sociais gradativamente mais complexas diante de dificuldades das esferas sociais menos complexas. Interfere, portanto, na organização social e política, impactando sobremaneira na relação Estado-sociedade civil e conseqüentemente na definição do papel do Estado perante a sociedade.

O impacto da inserção deste princípio nos debates sobre a redefinição do papel do Estado pode se refletir em diversas tendências, segundo Maria Sylvia Zanella Di Pietro ${ }^{80}$ : a) privatização; b) ampliação da atividade administrativa de fomento; c) crescimento das parcerias entre o setor público e o privado; d) desregulamentação; e) alteração no conceito de interesse público. ${ }^{81}$

A transformação da subsidiariedade de um conceito doutrinário a um princípio jurídico é representada pela sua inserção no Tratado da União Européia, de 1992. Em três dispositivos o Tratado que instituiu a União Européia fala expressamente em subsidiariedade.

Inicialmente nos considerandos, onde consta que os governantes que naquele documento criavam a União Européia estavam "resolvidos a continuar o processo de criação de uma união cada vez mais estreita entre os povos da Europa, em que as decisões sejam tomadas ao nível mais próximo possível dos cidadãos, de acordo com o princípio da subsidiariedade $" 82$.

${ }^{79}$ Cf. MOREIRA NETO, Diogo de Figueiredo; CASTRO, Paulo Rabello de. O futuro do Estado: do pluralismo à desmonopolização do poder. In: MARTINS, Ives Gandra da Silva (coord.). O Estado do futuro. São Paulo : Pioneira : Associação Internacional de Direito e Economia, 1998, pp. 45-61.

${ }^{80}$ DI PIETRO, Maria Sylvia Zanella. Parcerias na Administração Pública, $5^{\mathrm{a}}$ ed. São Paulo : Atlas, 2006, pp. 35 e ss.

81 "Dentre os diversos problemas, de difícil transposição, para uma sociedade justa, pressupõe-se que a realização das liberdades recusa a intervenção estatal, enquanto a efetivação de certa igualdade implica intervenção estatal. A idéia de subsidiariedade seria a recusa radical das duas teorias opostas, com a aceitação de formas dotadas de solidariedade, sendo que a idéia de subsidiariedade seria o eixo central, que permitiria ultrapassar a dicotomia e efetuar a passagem para nova forma de existência política, social, econômica e jurídica. A questão política está vinculada à definição do perfil do Estado, desde que a não-ingerência ou a ingerência por instâncias públicas são igualmente indispensáveis, pelo que se impõe traçar a fronteira, com a definição de critérios e as justificações necessárias. O princípio de subsidiariedade pressupõe a sociedade civil assentada em certos parâmetros, voltados para o interesse geral, sendo que esse efetiva-se através de ações livres, em parte pela ação pública" (BARACHO, José Alfredo de Oliveira. O princípio da subsidiariedade: conceito e evolução. Rio de Janeiro : Forense, 1997, p. 63).

${ }^{82}$ UNIÃO EUROPÉIA. Tratado da União Européia. Jornal Oficial n. C 191 de 29 de julho de 1992. Disponível em: <http://eur-lex.europa.eu/pt/treaties/dat/11992M/htm/11992M.html>. Acesso em: $03 \mathrm{fev}$ 2010. 
Em segundo lugar, ao tratar dos objetivos da União Européia em seu artigo B consta expressamente o respeito ao princípio da subsidiariedade nos seguintes termos: "Os objectivos da União serão alcançados de acordo com as disposições do presente Tratado e nas condições e segundo o calendário nele previstos, respeitando o princípio da subsidiariedade, tal como definido no artigo 3o-B do Tratado que institui a Comunidade Europeia". 83

Por fim, através da inserção do citado artigo 3-B no Tratado que instituiu a Comunidade Européia ${ }^{84}$, o Tratado da União Européia de 1992 prevê o seguinte (artigo G5):

Artigo 3o-B

A Comunidade actuará nos limites das atribuições que lhe são conferidas e dos objectivos que lhe são cometidos pelo presente Tratado.

Nos domínios que não sejam das suas atribuições exclusivas, a Comunidade intervem apenas, de acordo com o princípio da subsidiariedade, se e na medida em que os objectivos da acção encarada não possam ser suficientemente realizados pelos Estados-membros, e possam pois, devido à dimensão ou aos efeitos da acção prevista, ser melhor alcançados ao nível comunitário.

A acção da Comunidade não deve exceder o necessário para atingir os objectivos do presente Tratado. ${ }^{85}$

Outro exemplo que bem demonstra a tendência de inserção do princípio da subsidiariedade nos ordenamentos jurídicos se encontra na Constituição italiana, que a partir de 2001 é expressa em acolhê-lo. Por obra da Legge Costituzionale n. 3/2001, foi inserido na Constituição italiana o princípio da subsidiaridade horizontal, dando a seguinte redação ao seu artigo 118:

Art. 118. As funções administrativas são atribuídas aos Municípios salvo aquelas que, para assegurar o seu exercício unitário, sejam conferidas a Províncias, Cidades Metropolitanas, Regiões e ao Estado, com base no princípio da subsidiariedade, diferenciação e adequação.

(...)

O Estado, as Regiões, as Cidades Metropolitanas, as Províncias e os Municípios promoverão a iniciativa autônoma dos cidadãos, individualmente ou associados, para o desenvolvimento de atividades de interesse geral, com base no princípio da subsidiariedade. ${ }^{86}$

${ }^{83}$ Ibidem.

84 COMUNIDADE ECONÔMICA EUROPÉIA. Tratado da Comunidade Econômica Européia. 1957. Disponível em: < http://eur-lex.europa.eu/pt/treaties/index.htm>. Acesso em: 03 fev 2010.

${ }^{85}$ UNIÃO EUROPÉIA. Tratado da União Européia. Jornal Oficial n. C 191 de 29 de julho de 1992. Disponível em <http://eur-lex.europa.eu/pt/treaties/dat/11992M/htm/11992M.html>. Acesso em: $03 \mathrm{fev}$ 2010.

${ }^{86}$ ITÁLIA. La Costituzione italiana. Con introduzione di Saulle Panizza e Roberto Romboli. Corredata da: struttura del texto della Costituzione italiana, articoli della Costituzione, in ordine numérico, interessati da leggi costituzionali e di revisione costituzionale intervenute trai 11948 e il 2008. Aggiornata a giugno 2008. Pisa : PLUS, 2008, pp. 68-69, tradução nossa. No original: “Art. 118. Le funzioni amministrative sono 
Esta tendência de inserção do princípio da subsidiariedade nos ordenamentos jurídicos nos âmbitos nacional e internacional reflete diretamente no modo de atuação do Estado, ao que se tem dado o nome de Estado Subsidiário. ${ }^{87}$

\subsubsection{Globalização}

Elemento que não pode ficar de fora de qualquer análise contemporânea sobre as alterações no papel do Estado, a globalização é fenômeno que repercute inapelavelmente neste contexto $^{88}$. Não pode ser considerada uma novidade, pois

tem surgido em alguns períodos como resultado da difusão cultural, ampliação de fronteiras políticas, desenvolvimento de atividades econômicas ou de propagação religiosa. A globalização já foi cultural, pelo poder do exemplo, como se deu no mundo helênico; foi política, pelo poder da espada, como no mundo romano; foi econômica, pelo poder das riquezas, como no mundo ibérico dos descobrimentos, e religiosa, pelo poder da fé, como no mundo cristão. Outros movimentos globalizantes apresentaram combinações desses interesses, como o da expansão do Islã e o do imperialismo, sendo que este último se

attribuite ai Comuni salvo che, per assicurarne l'esercizio unitario, siano conferite a Province, Città metropolitane, Regioni e Stato, sulla base dei principi di sussidiarietà, differenziazione ed adeguatezza. (...) Stato, Regioni, Città metropolitane, Province e Comuni favoriscono l'autonoma iniziativa dei cittadini, singoli e associati, per lo svolgimento di attività di interesse generale, sulla base del principio di sussidiarietà". Sobre a importância deste princípio em cotejo com a atuação do Terceiro Setor, veja-se a seguinte constatação de Cafaggi: "Os princípios da subsidiariedade, da adequação e da diferenciação, que encontraram formal reconhecimento na Carta constitucional recentemente reformada, constituem, junto à disciplina dos níveis essenciais das prestações relativas a direitos civis e sociais, à tutela da concorrência e do pluralismo, a referência sobre a qual as regiões deverão escrever e reescrever os caracteres fundantes dos seus sistemas de saúde e sócio-assistenciais e em particular da relação público-privada" (CAFAGGI, Fabrizio. Modelli di governo e riforma dello stato sociale. In: CAFAGGI, Fabrizio (org.). Modelli di governo, riforma dello stato sociale e ruolo del terzo settore. Bologna : Il Mulino, 2002, p. 71). No original: "I principi di sussidiarietà, adeguatezza e differenziazione, che hanno trovato formale riconoscimento nella Carta costituzionale di recente riformata, costituiscono, insieme alla disciplina dei livelli essenziali delle prestazioni concernenti diritti civili e sociali, alla tutela della concorrenza e del pluralismo, il perno su cui le regioni dovranno scrivere o riscrivere i caratteri fondativi dei loro sistemi sanitari e socio-assistenziali e in particolare del rapporto pubblico-privato".

${ }^{87}$ DI PIETRO, Maria Sylvia Zanella. Parcerias na Administração Pública. 5a ed. São Paulo : Atlas, 2006, pp. 33 e ss.

88 “A globalização da Economia, que favorece os Estados mais desenvolvidos e com maior tecnologia e capitais a dominar o mercado mundial, a tecnologia substitutiva do homem pela máquina, o desemprego estrutural, além do conjuntural tópico, a consciencialização da sociedade quanto aos seus direitos, com pequena percepção de seus deveres, a multiplicação das minorias que desejam impor seu estilo de vida, o narcotráfico, com seu poder destrutivo dos valores da sociedade, a falência do Estado e a obsolescência do Direito, a corrupção endêmica entre políticos e burocratas, a falta de estadistas universais, os conflitos regionais e os de caráter religioso, a ruptura do direito por grupos, como os sem-terra no Brasil, a perda de valores por parte da sociedade e a falta de esperança de uma solução a curto prazo, a longevidade sem horizontes e o fracasso do Estado Providência, com seu potencial desconsertador, desequilibrador dos orçamentos fiscais de todos os países, os desequilíbrios ambientais e muitos outros fatores, estão a exigir um repensar do modelo do Estado futuro para a sobrevivência da humanidade no século XXI" (MARTINS, Ives Gandra da Silva. O Estado do Futuro. In: Direito e Economia, 1998, p. 24). . São Paulo : Pioneira : Associação Internacional de 
desdobrou em manifestações específicas, como o inglês, o norte-americano e, por último, o soviético. $^{89}$

No entanto, a proporção deste fenômeno iniciado em meados da década de 80 do século passado, pronunciado na década de 90 e instalado incontestavelmente, que ignora fronteiras territoriais, econômicas, sociais, políticas, etc., permite dotá-lo do merecimento de receber a alcunha de globalização com exclusividade. ${ }^{90}$

E esta globalização, em larga medida potencializada pelas evoluções tecnológicas, tem como características marcantes a aproximação dos povos pelas facilidades comunicacionais e de obtenção da informação. $\mathrm{O}$ acesso à informação com maior velocidade e de melhor qualidade repercute na conscientização dos cidadãos, que passam a ficar cada vez mais exigentes com as respostas que demandam. Os cidadãos tornam-se mais conscientes e exigentes de papel ativo nas decisões que dizem respeito à sociedade em que se inserem e de eficiência nos serviços de que são usuários. Efeitos da Era do Conhecimento, cujos desdobramentos "são fantásticos e vertiginosos: as populações passam a ter acesso a todo tipo de informação, tomam consciência de seus interesses, reivindicam participação e, cada vez mais, se organizam e exigem eficiência no seu atendimento". 91

Vários desdobramentos são tidos como conseqüência da globalização, alguns considerados negativos e outros positivos. Odete Medauar ${ }^{92}$ resume as conseqüências nas seguintes:

a) esvaziamento da soberania e da autonomia do Estado-nação, que não pode decidir por si só suas políticas;

b) internacionalização do Estado, que se torna executor de diretrizes de organizações internacionais;

c) criação de blocos regionais;

\footnotetext{
${ }^{89}$ MOREIRA NETO, Diogo de Figueiredo; CASTRO, Paulo Rabello de. O futuro do Estado: do pluralismo à desmonopolização do poder. In: MARTINS, Ives Gandra da Silva (coord.). O Estado do futuro. São Paulo : Pioneira : Associação Internacional de Direito e Economia, 1998, p. 52.

90 "Embora se invoque um precedente em Marco Polo, em Colombo, nos armadores de Veneza, nas navegações européias, na doutrina mercantilista, trata-se de realidade típica de fins do século XX e primórdios do século XXI, sem possibilidade de cotejo com restritas práticas de comércio mundial ocorridas em épocas remotas" (MEDAUAR, Odete. Direito administrativo em evolução. $2^{\mathrm{a}}$ ed. São Paulo : RT, 2003, p. 94).

${ }_{91}$ MOREIRA NETO, Diogo de Figueiredo; CASTRO, Paulo Rabello de. Op. cit., p. 53. Sobre a influência da era da informação sobre a atuação estatal, cf. HEEKS, Richard. Reinventing government in the information age. London : New York : Routledge, 1999.

${ }^{92}$ MEDAUAR, Odete. Op. cit., pp. 94 e ss.
} 
d) internacionalização do direito, com a abertura dos sistemas jurídicos nacionais a diplomas internacionais como forma de harmonização de soluções, bem vinda para alguns assuntos mas prejudicial para outros;

e) ascensão crescente do mercado, que acaba refletindo nas decisões dos governantes, influenciadas sobremaneira pelas questões econômicas;

f) desemprego estrutural decorrente da marginalização de parcela da população mundial em relação ao mercado;

g) déficit democrático decorrente de decisões tomadas ao arrepio do processo legislativo próprio, considerado muito lento para dar resposta a determinadas questões no ritmo imposto pela globalização.

Os dois desdobramentos apontados por Diogo de Figueiredo Moreira Neto e Paulo Rabello de Castro e anteriormente citados são importantes e merecem melhores tintas: participação e eficiência.

A elevação do nível de informação na sociedade do conhecimento ${ }^{93}$ - causa e efeito da globalização - acaba por despertar maior consciência social. Não basta para os cidadãos a escolha dos seus governantes; paulatinamente as sociedades demandam a criação de esferas de participação nas decisões que as afetam. A busca da legitimidade das decisões políticas deve passar pela criação de novos canais de atuação social, fruto da própria demanda social neste sentido.

Está-se, de certo modo, diante de uma tendência de maior peso que as demais e, sobre isso, diretamente influente sobre a legitimidade das decisões políticas, representando uma retomada da ação e da responsabilidade da sociedade na condução desses processos, durante tanto tempo sacrificada sob o influxo avassalador das ditaduras, das ideologias de esquerda e de direita, das burocracias e das tecnocracias que dominaram o século XX. ${ }^{94}$

As formas de participação política tradicionais já não são suficientes para os cidadãos considerarem aperfeiçoada a sua cidadania; a simples representação política já tão desgastada há tanto tempo, sofre golpe avassalador com o fortalecimento do fenômeno da

\footnotetext{
93 "Tendo o homem do século XX descortinado a relevância de seus direitos e alargado suas aspirações em face do conhecimento e da cultura a que teve acesso, cada vez mais percebe ser menos fácil atingir suas aspirações e mais difícil o Estado suprir suas insuficiências, razão pela qual é um potencial revolucionário, mesmo nas sociedades mais estáveis. O homem do século XX é um homem que aprende a conhecer seus direitos, a comparar seu estado atual com outros que estão em melhor situação, a desejar exercê-los em toda a amplidão, segundo o auto-retrato valorizado que faz de si mesmo, mas que não vê como realizá-los e como o Estado protegê-lo" (MARTINS, Ives Gandra da Silva. O Estado do Futuro. In: São Paulo : Pioneira : Associação Internacional de Direito e Economia, 1998, pp. 21-22).

${ }^{94}$ MOREIRA NETO, Diogo de Figueiredo; CASTRO, Paulo Rabello de. O futuro do Estado: do pluralismo à desmonopolização do poder. In: MARTINS, Ives Gandra da Silva (coord.). O Estado do futuro. São Paulo : Pioneira : Associação Internacional de Direito e Economia, 1998, p. 54.
} 
globalização e suas conseqüências. De outro norte, a participação direta da sociedade nas decisões políticas, ideal paradigma da democracia grega, encontra dificuldades de implementação.

Fortalece-se a idéia de criação de novas ferramentas de participação indireta, valorizando e facilitando o acesso aos instrumentos tradicionais (referendo, plebiscito e iniciativa popular) e oportunizando renovados foros de participação social, vindo ao encontro da sociedade plural em que se encontra a realidade atual.

Assim, no horizonte prescrutável da instituição estatal, é de se esperar o prosseguimento da tendência à pluralização das instituições participativas, não só multiplicando e facilitando a aplicação das mais tradicionais, como sejam o referendo, o plebiscito e a iniciativa popular, como ampliando o uso das que estão despontando, como a coleta de opinião, o debate público, a audiência pública, o colegiado misto e a delegação atípica, esta última, outorgada às chamadas entidades intermédias, que tanto podem ser, indistintamente, pessoas de direito público como pessoas de direito privado, importando mais sua situação a meio caminho entre a sociedade, destinatária das ações políticas, e o Estado, como seu aparato instrumental, para cumprir a missão de reaproximá-los em novas bases, depois do agudo abalo de confiança do qual resultou a crise do Estado deste fim de século. ${ }^{95}$

Some-se a isso a exigência da eficiência na resposta às necessidades sociais, que também é apontada como desdobramento dos fenômenos da globalização e da participação. A cobrança dos cidadãos migra da costumeira responsabilização do Estado para uma idéia de responsabilização pela eficiência na prestação dos serviços, independente de quem o preste. Não importa se o serviço é prestado diretamente pelo Estado ou não; o que importa é que o serviço seja prestado de forma rápida e com qualidade. $^{96}$

Observa-se, portanto, que a globalização e suas conseqüências têm papel importante nos debates atuais sobre a redefinição do papel do Estado, seja sob a ótica da participação, seja sob a ótica da eficiência, ou considerando todos os demais reflexos possíveis de serem extraídos deste fenômeno.

\subsubsection{Conclusões parciais: o Estado do Futuro}

Como bem observa Ives Gandra da Silva Martins,

\footnotetext{
95 Ibidem, p. 55.

96 "E aqui se chega à palavra-chave da globalização: eficiência. Não mais apenas como meio de reduzir o trabalho humano ou de aumentar os lucros na atividade empresarial, mas, além disso, produzir bens e serviços de melhor qualidade, mais rapidamente e em maior quantidade passa a ser um imperativo de sobrevivência, num mundo em que as demandas não podem deixar de ser atendidas a contento, seja pelas organizações privadas, seja pelas públicas” (Ibidem, p. 53).
} 
o certo é que o perfil do Estado futuro está em plena mudança. Do Estado Clássico surgido do constitucionalismo moderno, após as Revoluções Americana e Francesa, para o Estado Plurinacional, que adentrará o século XXI, há um abismo profundo. As categorias jurídicas que hoje o conformam, diferem e em muito daquelas que o plasmaram nos séculos XIX e $\mathrm{XX}$, o mesmo se dizendo da conformação social, das funções políticas e administrativas e da concepção filosófica da individualidade, de tal forma que um choque permanente se faz entre cada indivíduo que vive em sociedade e a própria estrutura política desta sociedade, que impõe restrições para a convivência possível. ${ }^{97}$

Forte nestas constatações e em novos - melhor dizendo, renovados - conceitos como os dos princípios da subsidiariedade, da cidadania e da participação popular, dentre outros, aponta-se para estrutura estatal que legitima a iniciativa privada na condução das questões que o cidadão (isolado ou em associação) tem condições de resolver por si só.

É o que se chama de Estado Subsidiário ${ }^{98}$ : ficam a cargo do Estado as atividades indelegáveis e outorga-se primazia à iniciativa privada no desenvolvimento das demais atividades.

Destas constatações se extrai que esta remodelação tem implicações diretas e contundentes em conceitos bastante caros ao Direito Administrativo, mormente em virtude da redefinição dos espaços de participação a reboque da delimitação do papel do Estado.

A alteração da configuração do Estado que estamos vivendo nesta proposta de Estado Subsidiário produz inovações de ordem prática que devem ser acompanhadas pelo Direito, e ainda mais de perto pelo Direito Administrativo. O surgimento de novas realidades derivadas deste contexto tem propiciado, indene de dúvidas, novos temas de enfrentamento para o Direito Administrativo, que não obstante se deparar com a realidade do aumento da participação privada nas atividades estatais encontra espaço para se expandir.

É neste momento que se observa que uma das "novidades" decorrentes desta crise do modelo então vigente de atuação estatal, vinculada estreitamente com o conceito de privatização - em sentido amplo - que nutre as reformas propostas, encontra-se no campo social.

A aproximação Estado-administrado, sob a influência dos ideais impostos pelo Estado Democrático de Direito que exigem o incentivo à participação popular e o fomento

\footnotetext{
${ }^{97}$ MARTINS, Ives Gandra da Silva. O Estado do Futuro. In: São Paulo : Pioneira : Associação Internacional de Direito e Economia, 1998, p. 14.

${ }^{98}$ DI PIETRO, Maria Sylvia Zanella. Parcerias na Administração Pública. $5^{\mathrm{a}}$ ed. São Paulo : Atlas, 2006, pp. 33 e ss.. Odete Medauar (MEDAUAR, Odete. Direito administrativo em evolução, $2^{\mathrm{a}}$ ed. São Paulo : RT, 2003, p. 93) aponta para outras nomenclaturas que têm sido utilizadas para designar este Estado do início do século XXI.
} 
à iniciativa privada de interesse público, enseja a organização da sociedade civil em torno de questões de interesse social.

A sociedade civil se organiza e passa a figurar como participante direta nas ações de cariz social, cuja atribuição originária no Estado Social competia ao próprio Estado. Como aponta Miguel Reale

De mais a mais, o Estado não deve se reduzir à economia, cabendo-lhe atuar, com igual força e dedicação, em prol dos valores existenciais da educação, da saúde, do meio ambiente e da cultura, de preferência mediante processos ou planos em parceria com a iniciativa privada, comprovadamente mais criadora. ${ }^{99}$

$\mathrm{O}$ atual momento mostra, verdadeiramente, uma crise na concepção de Estado. Estamos em uma fase de transição que aponta para a concepção do Estado inteligente ${ }^{100}$, em contrapartida ao Estado mínimo e à mão invisível de Adam Smith.

Este Estado inteligente, ao se preocupar em dar conta de determinados setores estratégicos para a sociedade, estaria necessariamente voltado ao desenvolvimento social, aqui se apontando o importante papel das organizações do Terceiro Setor por força de sua natureza eminentemente social ${ }^{101}$.

E o Estado inteligente teria como novo papel

agregar aliados ao esforço de enfrentar os problemas sociais. O Estado deve gerar iniciativas que promovam a participação ativa neste esforço dos atores sociais básicos, empresa privada, sindicatos, universidades e da sociedade civil em todas as suas expressões. Um Estado inteligente na área social não é um Estado mínimo, nem ausente, nem de ações pontuais de base assistencial, mas um Estado com uma "política de Estado", não de partidos, mas sim de educação, saúde, nutrição, cultura, orientado para superar as graves iniqüidades, capaz de impulsionar a harmonia entre o econômico e o social, promotor da sociedade civil, com um papel sinergizante permanente. ${ }^{102}$

É nesta direção que se aponta quando se verifica a necessidade de reformulação do papel do Estado, orientando os estudos na busca do chamado Estado do futuro.

\footnotetext{
${ }^{99}$ REALE, Miguel. O renascimento do liberalismo. In: MARTINS, Ives Gandra da Silva (coord.). O Estado do Futuro. São Paulo : Pioneira : Associação Internacional de Direito e Economia, 1998, p. 43.

${ }^{100}$ KLIKSBERG, Bernardo. Repensando o Estado para o desenvolvimento social: superando dogmas e convencionalismos. São Paulo : Cortez, 1998, p. 45, trad. Joaquim Ozório Pires da Silva.

101 Bernardo Kliksberg (ibidem, p. 67) apreende a importância das organizações do Terceiro Setor como ferramentas de obtenção dos objetivos do Estado inteligente, assim asseverando: “O Estado deve ser o fator convocante da formação de meta-redes, que integrem, junto com os organismos públicos da área social, as regiões e os municípios, as ONGs, fundações empresariais privadas, movimentos sindicais, organizações sociais religiosas, Universidades, organizações de vizinhos, outros atores da sociedade civil e as comunidades pobres organizadas".

${ }^{102}$ Ibidem, pp. 47-48.
} 


\subsection{A nova Administração Pública e o novo Direito Administrativo}

Em paralelo às alterações sofridas na concepção de Estado, que impactam na definição do seu papel e de sua relação com a sociedade civil, observa-se a ocorrência, indene de dúvidas, de profundas mutações no Direito Administrativo, a ponto de se poder afirmar a existência de um novo Direito Administrativo. ${ }^{103}$

Alterações que, como bem observa a pioneira ${ }^{104}$ na detecção integrada destas mutações, Odete Medauar, atuam como espécie de controle de validade das concepções tradicionais $^{105}$ do Direito Administrativo.

Tendo como objeto regular a estrutura e o funcionamento da Administração Pública e considerando que esta integra a organização estatal ${ }^{106}$, é fato que o Direito Administrativo sofrerá alterações constantes de modo a se manter cumpridor de suas funções. O novo relacionamento entre Estado e sociedade, as constantes e cada vez mais ágeis revoluções tecnológicas, o fenômeno da globalização, entre outros motivos e alguns ainda inexistentes, fazem deste ramo do Direito em especial uma disciplina em constante revitalização. “A história do Direito Administrativo se desdobra em fases sucessivas em paralelo com o desenvolvimento político, econômico e social". 107

Não há que se falar em crise, portanto, pois o que ocorre é a adequação de seus conceitos e fórmulas à realidade social que rege - que não é a passada nem a futura -, justamente com vistas a não perder o compasso e, via de conseqüência, aí sim, justificar alegações no sentido da existência de uma crise do Direito Administrativo. ${ }^{108}$

\footnotetext{
${ }^{103}$ Expressões em itálico utilizadas por Diogo de Figueiredo Moreira Neto (MOREIRA NETO, Diogo de. Mutações do direito administrativo revisitadas: novas considerações, avaliação e controle das transformações. In: ___ Mutações do Direito Público. Rio de Janeiro : Renovar, 2006, p. 223). Para dar a nota das mutações, vale a seguinte passagem do autor: "É inegável que o Direito Administrativo não é mais aquele que as várias gerações de bacharéis, e até mesmo, muitos das mais recentes, aprenderam nos bancos universitários. Há, indubitavelmente, um novo Direito Administrativo em emergência e que ainda está se definindo no torvelinho das transformações, que continuam a nos surpreender por serem incrivelmente céleres e profundas" (ibidem, p. 223).

104 Assim nos dá conta Moreira Neto (ibidem, p. 224): "Essas mudanças, transformações ou mutações, qualquer que seja a denominação que se empreste ao fenômeno, foram detectadas por alguns autores da Disciplina a partir do Segundo Pós-Guerra, que as trataram, porém, eventual e fragmentariamente, cabendo o mérito de primeiro vir a estudá-las integradamente, já com a preocupação científica de identificar-lhes as causas e definir-lhes as tendências, para nosso orgulho, à destacada jurista brasileira ODETE MEDAUAR, que, em 1992, pioneiramente, publicou a obra Direito Administrativo em Evolução".

${ }^{105}$ MEDAUAR, Odetel $O$ direito administrativo em evolução. $2^{\mathrm{a}}$ ed. São Paulo : RT, 2003, pp. 265-266.

106 Expressões conceituais em itálico utilizadas por Odete Medauar (MEDAUAR, Odete. Direito administrativo moderno. $10^{a}$ ed. São Paulo : RT, 2006, p. 25).

107 TÁCITO, Caio. Transformações do Direito Administrativo. In: (estudos e pareceres). Rio de Janeiro : Renovar, 2002, vol. 3, p. 10. . Temas de Direito Público ${ }_{108}$ Marçal Justen Filho (JUSTEN FILHO, Marçal. Curso de direito administrativo. $2^{\mathrm{a}}$ ed. São Paulo : Saraiva, 2006, p. 17) nomina esta atualização do Direito Administrativo como Direito Administrativo pós-
} 
O fato é que os paradigmas devem e estão sendo revistos a bem da renovação e da perenidade do Direito Administrativo, a começar, como visto, pela revisão de seu instituto mais caro e tradicional, tido como sua verdadeira coluna vertebral ao longo dos últimos duzentos anos $^{109}$ e por vezes considerado o verdadeiro propulsor de sua existência ${ }^{110}$ : o princípio da legalidade.

Evidentemente, do Estado Absolutista ao Estado Subsidiário a configuração do Estado tem sofrido profundas alterações, a reboque das quais devem vir alterações nas ferramentas do Direito Administrativo úteis à adequação das atividades da Administração Pública. Mas Direito Administrativo e Administração Pública não andaram sempre juntos.

Considerando que o Direito Administrativo surge sob a influência da Revolução Francesa, no século XVIII, é fato que durante o período que se costuma chamar de Estado Absolutista os conceitos de Direito Administrativo e Administração Pública andaram dissociados.

Neste período, estando o poder concentrado nas mãos do soberano a Administração Pública existia exclusivamente a seu serviço, não havendo que se falar na regulamentação das suas atividades com vistas a resguardar direitos dos cidadãos. ${ }^{111}$ A Administração Pública era, portanto, ferramenta de exercício do poder pelo soberano.

Por sua vez, no Estado Liberal - em que o Direito Administrativo foi forjado no intuito de, ao menos na concepção tradicional, limitar a atuação do soberano pela legalidade, garantindo aos súditos a liberdade e a igualdade -, a Administração Pública tinha a função de execução das leis ${ }^{112}$, sendo ferramenta formal de garantia dos direitos assegurados aos cidadãos.

moderno, cuja expressão "indica a necessidade de tomar em vista as alterações sociais, econômicas e políticas contemporâneas. Mais precisamente, trata-se de admitir a impossibilidade de compreender a realidade contemporânea (denominada ou não 'pós-moderna') a partir de conceitos e fórmulas elaborados para explicar e compreender o Estado e o Direito de cem anos atrás".

109 OTERO, Paulo. Legalidade e administração pública: o sentido da vinculação administrativa à juridicidade. Coimbra : Almedina, 2003, p. 16.

${ }_{110}$ Cf. ESTORNINHO, Maria João. A fuga para o direito privado. Coimbra : Almedina, 1999, pp. 31 e ss.

111 "Até então, o absolutismo reinante e o enfeixamento de todos os poderes governamentais nas mãos do Soberano não permitiam o desenvolvimento de quaisquer teorias que visassem a reconhecer direitos aos súditos, em oposição às ordens do Príncipe" (MEIRELLES, Hely Lopes. Direito Administrativo brasileiro. $26^{\mathrm{a}}$ ed. São Paulo : Malheiros, 2001, p. 45, atual. por Eurico de Andrade Azevedo, Délcio Balestero Aleixo e José Emmanuel Burle Filho,).

112 “O projeto de 89 [1789, Revolução Francesa] postula, na verdade, a radical supressão de toda potestade administrativa, reservando exclusivamente à lei a autoridade de restringir a natural liberdade dos sujeitos. Uma vez formada a vontade comum e ordenada no texto legal, a administração deveria limitar-se a fazê-la recair sobre os cidadãos, seus criadores indiretos, do modo mais neutro e mecânico possível, abstendo-se rigorosamente de imputar-lhes quaisquer obrigações adicionais" (MANNORI, Luca; SORDI, Bernardo. Storia del diritto amministrativo. $4^{\mathrm{a}}$ ed. Roma-Bari : Laterza, 2006, p. 231, tradução nossa). No original: "Il progetto dell' 89 postula, in effetti, il radicale azzeramento di ogni vera potestà amministrativa, riservando esclusivamente alla legge l'autorità di comprimere la naturale liberta dei soggetti. Uma volta formata la 
Durante o Estado Social, ao contrário, o Direito Administrativo adaptou suas ferramentas para uma Administração Pública de atividades bastante interventivas, executora de ações nas esferas econômica e social a ponto de ser chamada de Administração Social, que "se incumbia da promoção das classes não proprietárias; assumia um estratégico papel de mediação entre os interesses do 'trabalho' e os do 'capital', da 'propriedade' e da 'pobreza","113. Mais do que isso

Se está delineando uma nova tipologia de atividade administrativa. Toma forma uma administração chamada em protagonismo e diretamente a produzir "bens públicos", a fornecer prestações, a destinar serviços, não mais somente jurídicos mas econômicos e sociais: uma administração de prestação começa a ladear as tradicionais funções de regulação e a administração imperativa que nos é familiar. ${ }^{114}$

E agora, após passar por reconfigurações de adequação às formatações estatais que exigiam uma Administração Pública autoritária, executora ou interferente, novos conceitos que vieram a reboque das propostas de alteração do papel do Estado, determinam uma adaptação do Direito Administrativo e, conseqüentemente, a formatação de uma nova Administração Pública.

Inúmeras construções teóricas que intentam explicar o papel do Estado no atual cenário mundial poderiam ser arroladas. Por via de conseqüência, diversas seriam as novas configurações jurídico-institucionais da Administração Pública, possivelmente mais adequadas a fazer frente aos novos fins e tarefas estatais. ${ }^{115}$

Esta nova Administração Pública, que se desenvolve sob a ótica de um Estado Garantidor, tomaria a forma de uma Administração Pública Garantidora, cujo objetivo é, para além da prestação material direta das necessidades sociais, a garantia da execução

volontà comune e consegnatala al texto legale, l'amministrazione avrebbe dovuto limitarsi a farla 'retomber' sul capo dei singoli cittadini, suoi artefici indiretti, nel modo più neutro e meccanico possibile, astenendosi rigorosamente dall'aggiungervi qualsiasi obbligazione ulteriore".

113 Ibidem, p. 404, tradução nossa. No original: "L'“amministrazione sociale' si faceva carico della promozione delle classi non proprietarie; assumeva uno strategico ruolo di mediazione tra gli interessi del 'lavoro' e quelli del 'capitale', della 'proprietà'e della 'povertà'”.

114 Ibidem, p. 407, tradução nossa. No original: "Si sta delineando uma nuova tipologia de attività amministrativa. Prende forma un'amministrazione chiamata in prima persona e direttamente a produrre 'beni pubblici', a fornire prestazioni, a erogare servizi, non più soltanto giuridici ma economici e sociali: un'amministrazione di erogazione inizia ad affiancarsi ai tradizionali compiti di regolazione e all'amministrazione imperativa che ci è familiare".

${ }^{115}$ OLIVEIRA, Gustavo Justino de; SCHWANKA, Cristiane. A Administração consensual como a nova face da Administração Pública no séc. XXI: fundamentos dogmáticos, formas de expressão e instrumentos de ação. In: XVII ENCONTRO PREPARATÓRIO PARA O CONGRESSO NACIONAL DO CONPEDI, 2008, Salvador. Anais eletrônicos, p. $126 . \quad$ Disponível $\quad$ em: $<$ http://conpedi.org/manaus/arquivos/anais/salvador/gustavo_henrique_justino_de_oliveira.pdf $>$. Acesso em: 08 fev 2010. 
“das práticas administrativas em direção ao interesse público e à democracia"116.

\subsubsection{A nova Administração Pública}

A burocracia foi tida como o modelo ideal de gestão durante boa parte do século $\mathrm{XX}$, especialmente sob o argumento da superioridade técnica; a partir dos anos 70 começa a ganhar força a idéia de organização pós-burocrática, fundada em valores como flexibilidade e participação, movimento ao qual se deu o nome de gerencialismo. $^{117}$ Principalmente pela velocidade e heterogeneidade dos fatos, a superioridade técnica que fundamentou a manutenção da organização burocrática acaba por não se sustentar, dando lugar a instrumentos gerenciais mais flexíveis e dinâmicos.

A partir da década de 90 do século passado começou a ocorrer uma migração das idéias de gerencialismo, até então aplicadas no setor privado, para a administração pública, no movimento estadunidense que se chamou de "reinventando o governo" por influência do homônimo livro de Osborne e Gaebler ${ }^{118}$. Consolida-se, portanto, no setor público, a idéia de nova administração pública ${ }^{119}$, organização pós-burocrática ou uma burocracia flexivel. $^{120}$

Nesse âmbito, a organização burocrática - centralizada, hierárquica, autoritária e baseada em regras, discliplina e divisão do trabalho - estaria, supostamente, cedendo espaço para a organização pós-moderna. Essa forma de organização é caracterizada pela descentralização, pela estruturação em rede e pelo uso intensivo de tecnologias de informação. ${ }^{121}$

Surge o conceito de Estado gerencial, por absorver as idéias da nova administração pública fundadas no gerencialismo. Este Estado gerencial é "um corpo político e administrativo permeado por movimentos simultâneos de descentralização e

\footnotetext{
116 PAULA, Ana Paula Paes de. Por uma nova gestão pública: limites e potencialidades da experiência contemporânea. Rio de Janeiro : FGV, 2005, p. 21.

${ }_{117}$ Cf. Ibidem, pp. 54 e ss.

118 Sobre a obra de Osborne e Gaebler, cf. SHAFRITZ, Jay M.; RUSSELL, E.W. Introducing public administration. New York : Longman, 1996, pp. 119 e ss.

119 "Surgida em uma época na qual a sociedade começou a requisitar o espaço tomado pelo Estado na gestão do interesse público, a nova administração pública absorveu a seu modo um discurso que enfatiza a democracia e a participação, ou seja, a dimensão sociopolítica da gestão" (PAULA, Ana Paula Paes de. Op. cit., p. 22). Cf. BARZELAY, Michael. The new public management: improving research and policy dialogue. New York : Russel Sage Foundation, 2001.

${ }^{120}$ Cf. PAULA, Ana Paula Paes de. Op. cit., pp. 60 e ss.

121 Ibidem, p. 94. Sobre o tema, cf. a interessante coletânea: EGLER, Tamara Tania Cohen (org.).
} Ciberpólis: redes no governo da cidade. Rio de Janeiro : 7Letras, 2007. 
recentralização e também por relações competitivas, tanto horizontais como verticais, nas quais o poder é flexibilizado e se encontra disperso". ${ }^{22}$

Ocorre que este novo formato de administração gerencialista também passa a receber críticas, sobretudo pela ausência de solução democrática: as decisões estratégicas se mantêm centralizadas e os cidadãos continuam sem instrumentos efetivos de participação nas questões públicas. ${ }^{123}$ Além disso não logra resolver o problema central da burocracia clássica, qual seja "o seu caráter formal e auto-referente", ação na eficiência, mas na auto proteção contra o administrado.

Fala-se, então, em crise da nova administração pública, logo rebatida sob o argumento de que a sua modelagem envereda justamente para o foco na cidadania; "estaria se movendo para a dimensão política da gestão já que enfatiza questões como transparência, participação, eqüidade e justiça". ${ }^{125}$

Paralelamente à vertente econômica da nova administração pública, gerencialista, que pode muito bem ser representada pelas ações de privatização, descentralização, regulação, etc., tomou corpo a preocupação da nova administração pública com a vertente social.

Entraram na pauta de discussões ferramentas de realização da cidadania por meio da participação social no seio da administração pública, tais como os fóruns temáticos, os conselhos gestores, o orçamento participativo e outras práticas inclusivas da opinião social no atuar administrativo. ${ }^{126}$

${ }^{122}$ PAULA, Ana Paula Paes de. Op. cit., p. 98.

123 "Tal como a burocracia flexível, o Estado gerencial tende a se negar como uma forma de exercer o poder, mas continua desempenhando esse papel através de mecanismos sutis de controle: move-se assim para uma 'zona cinzenta', que combina consentimento e controle difuso. Em conseqüência, temos um Estado despolitizado e um déficit democrático, pois apesar do discurso de democratização, as decisões estratégicas continuam a ser tomadas pelos administradores das organizações públicas e privadas. Assim, o poder dos representantes políticos e dos cidadãos é solapado e, em decorrência, a resistência da sociedade organizada se enfraquece e seu envolvimento no projeto de reconstrução social fica comprometido" (Ibidem, p. 98)

${ }^{124}$ BENTO, Leonardo Valles. Governança e governabilidade na reforma do Estado: entre eficiência e democratização, Barueri : Manole, 2003, p. 90.

${ }^{125}$ PAULA, Ana Paula Paes de. Por uma nova gestão pública: limites e potencialidades da experiência contemporânea. Rio de Janeiro : FGV, 2005, p. 100.

${ }^{126}$ Ana Paula Paes de Paula (PAULA, Ana Paula Paes de. Op. cit., p. 23) chama este movimento de administração pública societal: "Tomando essa tese como referência, focalizamos o caso brasileiro, cuja recente reforma do Estado se organizou em torno de duas orientações políticas: a vertente gerencial, que, inspirada no movimento internacional pela reforma do Estado, implementa a administração pública gerencial; e a vertente societal, que busca formas de organização e administração do Estado que incluem a participação da sociedade, procurando construir uma gestão pública social. Analisando os antecedentes e as características dessas vertentes, formulamos duas hipóteses: - a vertente gerencial não foi bem-sucedida na abordagem da dimensão sociopolítica, pois ao focalizar a nova administração pública como modelo de gestão, deixou a desejar no que se refere à democratização do Estado brasileiro. Questões que envolvem as relações entre o Estado e a sociedade não foram suficientemente tratadas, permanecendo as características centralizadoras e autoritárias que marcaram a história político-administrativa do país; - a vertente societal busca construir e 
Estas ferramentas podem ser tidas como reflexo evolutivo de uma das tipologias propostas pelos defensores da nova administração pública, intitulada orientação para o serviço público, que seria uma "abordagem diferenciada por sua oposição ao modo burocrático de gestão e também por focalizar mais a cidadania do que o consumo de serviços públicos". 127

Evolução da corrente reformada designada orientação para o usuário, em que o cidadão era considerado consumidor do serviço público ${ }^{128}$ e que foi criticada especialmente por isto, a corrente da orientação para o serviço público agrega à preocupação com a qualidade do serviço prestado ao conceito de cidadania, focalizando em instrumentos de participação popular com vistas a dar resposta aos interesses da comunidade. "Ao contrário da concepção gerencial com foco no cliente, a gerência orientada ao cidadão reconhece as especificidades da administração pública relativamente à administração privada, entre elas a primazia dos valores democráticos, a participação, a transparência e o engajamento sobre a eficiência". ${ }^{129}$

Estas concepções que orientam a chamada nova administração pública se inserem no contexto do conceito de governança, cujo mote principal pode ser caracterizado como a conjugação dos "benefícios do mercado com um estilo de governo mais focado nas questões sociais",130.

\subsubsection{Governança Pública}

O termo governança, que "se insere na constelação de idéias produzidas pela

implementar um projeto político capaz de subverter o padrão autoritário das relações entre o Estado e a sociedade no Brasil. Guardados alguns limites, a tentativa de inserir a dimensão sociopolítica em suas experiências de gestão está abrindo possibilidades para a renovação do modelo de gestão pública à medida que traz novas propostas para se repensar as instituições políticas e a dinâmica administrativa".

${ }^{127}$ Ibidem, pp. 99-100. Sobre os sistemas alternativos de idéias relacionados à nova administração pública, cf. FERLIE, Ewan et al. A nova administração pública em ação. Brasília : Editora Universidade de Brasília, 1999, pp. 26 e ss., trad. De Sara Rejane de Freitas Oliveira.

128 "Resumindo o modelo consumerista de administração pública, seus elementos podem ser enumerados da seguinte maneira: (1) administração orientada para o mercado; utilização de mecanismos de mercado - os paramercados - como forma de alocação de recursos; (2) mudança da gestão hierárquica do tipo comando e controle para a gestão por contrato; flexibilização de procedimentos e avaliação por metas; (3) horizontalização (downsizing) na administração, com redução das instâncias e graus de hierarquia; (4) descentralização administrativa, vale dizer, desconcentração; (5) separação entre um núcleo formulador de estratégias e a parte operacional ou de implementação; (6) parcerias entre o setor estatal e o setor privado não lucrativo, mediante contratos de gestão; (7) opinião do usuário como forma de feedback; preocupação com a qualidade e a excelência do serviço" (BENTO, Leonardo Valles. Governança e governabilidade na reforma do Estado: entre eficiência e democratização. Barueri : Manole, 2003, p. 91).

${ }^{129}$ Ibidem, p. 94.

${ }^{130}$ PAULA, Ana Paula Paes de. Por uma nova gestão pública: limites e potencialidades da experiência contemporânea. Rio de Janeiro : FGV, 2005, p. 78. 
globalização" ${ }^{, 131}$ ressurge no último quarto do século $\mathrm{XX}^{132}$ como o

processo de organização e administração das sociedades humanas, no respeito e valorização das diversidades. (...) Nesta perspectiva, o poder não existe mais para a custódia de uma ordem - cristã na Europa - mas para melhorar a condição humana. (...) A governança se insere na busca contínua de melhores sistemas de gestão de pessoas e recursos. Para a governança a decisão, ao invés de propriedade e poder de alguém (indivíduo ou grupo) deve resultar de uma negociação em curso entre os atores sociais, constituídos como parceiros de um vasto jogo, cujo terreno pode ser uma empresa, um Estado, uma organização, a resolução de um problema. ${ }^{133}$

A governança, portanto, é um conceito aplicado como técnica de gestão que propõe, no âmbito da administração pública, a implementação de políticas que visem o atingimento das metas através de canais de interlocução com os diversos atores sociais, desmonopolizando as ações até então centralizadas nas mãos do Estado.

Segundo Leonardo Valles Bento, "governança diz respeito aos pré-requisitos institucionais para a otimização do desempenho administrativo, isto é, o conjunto dos instrumentos técnicos de gestão que assegure a eficiência e a democratização das políticas públicas". 134

Eli Diniz a conceitua como

a capacidade da ação estatal na implementação de políticas e na consecução de metas coletivas. Refere-se ao conjunto dos mecanismos e procedimentos para lidar com a

${ }^{131}$ DEFARGES, Philippe Moreau. La gouvernance. $3^{\mathrm{a}}$ ed., Paris : Presses Universitaires de France, 2008, p. 6, tradução nossa. No original: “La gouvernance s'inscrit dans la constellation d'idées produites par la mondialisation". Cf. também GIULIANI, Barbara. New public governance e diritto amministrativo nel governo del território. Bari : Cacucci, 2006.

132 "O conceito de governança tem natureza mais complexa. Aparece pela primeira vez nos relatórios do Banco Mundial, no início dos anos 90, como resposta à necessidade de promover a regulação do mercado, tanto no seio dos Estados que se deparavam com o declínio do 'Welfare State', como daqueles cujo comércio internacional era perturbado pela globalização" (QUERMONNE, Jean-Louis. Gouvernance et gouvernment: deux lectures d'une politique institutionnelle européenne. In: IHL, Olivier (coord.). Les "sciences" de l'action publique. Grenoble : Presses universitaires de Grenoble, 2006, p. 122, tradução nossa). No original: "Le concept de gouvernance est de nature plus complexe. Apparu pour la première fois dans les rapports de la Banque Mondiale, au début dês années 1990, il répondait au souci de promouvoir la régulation du marche, tantôt au sein dês États confrontes au déclin du 'Welfare state', tantôt à l'échelle dês échanges internationaux bouleversés par la mondialisation".

${ }^{133}$ DEFARGES, Philippe Moreau. Op. cit., pp. 6-7, tradução nossa. No original: "La gouvernance, ce serait justement ce processus d'organisation et d'administration dês societés humaines, dans le respect et l'épanouissement dês diversités. (...) Dans cette perspective, le pouvoir n'a plus pour raison d'être la garde d'un ordre - chrétien en Europe - mais d'améliorer la condition humaine. (...) La gouvernance s'inscrit dans cette quête permanente de meilleurs systèmes de gestion des hommes et des ressources. Pour la gouvernance, la decision, au lieu d'être la propriété et le pouvoir de quelqu'un (individu ou groupe), doit résulter d'une négociation permanente entre lês acteurs sociaux, constitués em partenaires d'um vaste jeu, lê terrain de jeu pouvant être une entreprise, un État, une organisation, um problème à résoudre".

${ }^{134}$ BENTO, Leonardo Valles. Governança e governabilidade na reforma do Estado: entre eficiência e democratização. Barueri : Manole, 2003, p. 85. 
dimensão participativa e plural da sociedade, o que implica expandir e aperfeiçoar os meios de interlocução e de administração do jogo de interesses. ${ }^{135}$

Para Defarges "a governança pode ser analisada como um sistema democrático de gestão. Ela incorpora, em uma perspectiva de gestão, os ingredientes da democracia"136 ${ }^{\text {. O }}$ autor aponta estes ingredientes como:

- um pacto fundador: o contrato social ao qual os homens aderiram, na origem da democracia moderna, que os submete a uma disciplina comum, cuja característica se encontra na idéia de governança, ou seja, um espaço regulado de onde todos podem e devem participar;

- a igualdade: na democracia como na governança, as regras do jogo garantem a igualdade dos jogadores e a lei substitui a autoridade como princípio da ordem social;

- a participação: na governança, assim como na democracia, a participação é essencial e deve ser contínua, não limitada a participações eleitorais.

A governança pressupõe a convicção de que o Estado não mais monopoliza o interesse público; outros atores sociais assumem importância na busca do interesse público e novos arranjos institucionais devem ser criados para que as capacidades destes atores sejam reunidas para este fim. Novamente Defarges aponta duas evoluções indicadas pela idéia de governança:

- fronteiras entre o público e o privado: público e privado se interpenetram, este sendo chamado a participar e a assumir tarefas públicas; ${ }^{137}$

- o interesse geral como construção multiforme, aberta e permanente: o conceito de governança rompe com a idéia de que o interesse público é monopólio estatal, redefinindo-o como um compromisso constantemente negociado pelas partes interessadas. $^{138}$

${ }^{135}$ DINIZ, Eli. Governabilidade, governance e reforma do Estado: considerações sobre o novo paradigma. Revista do Serviço Público, ano 47, v. 120, n. 2, mai.-ago. 1996, p. 12.

${ }^{136}$ DEFARGES, Philippe Moreau. La gouvernance, $3^{\mathrm{a}}$ ed., Paris : Presses Universitaires de France, 2008, p. 19, tradução nossa. No original: "La gouvernance peut être analysée comme un système démocratique de gestion. Elle reprend, dans une perspective de management, les ingrédients de la démocratie".

137 "Público e privado se interpenetram. O público solicita a participação do privado (...) O setor privado é levado a assumir tarefas públicas (...) O público, que deixa de ser sagrado, não está mais acima da sociedade, mas é uma de suas dimensões (...) Público e privado não podem mais serem separados por uma fronteira imutável. Um é nada sem o outro" (ibidem, p. 32, tradução nossa. No original: "Public et prive s'interpénètrent. Le public requiert la participation du privé (...) Le privé se trouve conduit à assumer des tâches publiques (...) Le public, désacralisé, n'est plus au-dessus de la société, il en est une des dimensions (...) Public et privé ne peuvent pas être séparés par une frontière immuable. L'un n'est rien sans l'autre".

${ }_{138}$ "Com a governança, o interesse geral não é mais dado, ordenado de cima, circunscrito a um círculo determinado. Ao contrário, ele é criado e executado, pertencendo temporariamente àqueles que o exploram" (ibidem, p. 33, tradução nossa. No original: “Avec la gouvernance, l'intérêt general n'est plus donné, arrêté 
A idéia de governança se insere na realidade estatal ${ }^{139}$, propondo alterações assim identificadas por Quermonne:

1 - implica uma pluralidade de atores públicos, semi-públicos e privados: governantes, administrações, agências independentes, parceiros sociais, grupos de interesses, empresas multinacionais, movimentos associativos, ONG... que podem se situar em níveis territoriais diferentes (governança multinível); 2 - utiliza um rol de instrumentos marcados pela flexibilidade: consulta, concertação, coordenação, parcerias, diálogo social, recomendação, programação, avaliação, operação em redes...; 3 - tende ao desempenho e para tanto privilegia a especialização, o que não a deixa totalmente protegida de uma deriva tecnocrática, tudo em nome de uma pretensão de ordem ética (a boa governança). ${ }^{140}$

Esta boa governança, que se traduziria na "condução responsável dos assuntos do Estado" "141, engloba o conceito de boa administração, inclusive objeto de diplomas legais no âmbito internacional ${ }^{142}$, que teria como conteúdo a busca de um bom relacionamento entre a administração pública e os cidadãos, fundado na colaboração e na busca da efetivação dos direitos civis e sociais, de forma simples, transparente, participativa, eficaz, eficiente e econômica, pois assim entendida incidirá radicalmente sobre a qualidade de vida. $^{143}$

Em largas passadas, o percurso evolutivo das idéias que inspiram a atuação da administração pública e que deságuam nas atuais concepções de participação popular estão aqui demonstradas. Mas não é somente este percurso que forma a moldura na qual entendemos se encaixarem as parcerias entre o Estado e o terceiro setor, que serão melhor analisadas posteriormente.

d'em haut, enferme dans une sphère. Au contraire, il se construit et circule, appartenant termporairement à celui qui l'exploite".

139 Sobre as diferenças entre o conceito de governo (gouvernment) e governança (gouvernance) confira: QUERMONNE, Jean-Louis. Gouvernance et gouvernment: deux lectures d'une politique institutionnelle européenne. In: IHL, Olivier (coord.). Les “sciences" de l'action publique. Grenoble : Presses universitaires de Grenoble, 2006, pp. 121-131.

${ }^{140}$ Ibidem, p. 122, tradução nossa. No original: "1/ elle implique une pluralité d'acteurs publics, semi-publics et prives: gouvernants, administrations, agences indépendantes, partenaires sociaux, groupes d'intérêts, entreprises multinationales, mouvements associatifs, ONG... qui peuvent se situer à des niveaux territoriaux différents (multi-level governance); 2/ elle utilize une palette d'instruments marqués par la flexibilité: consultation, concertation, coordination, partenariat, dialogue social, recommandation, programmation, évaluation, fonctionnement em réseaux...; $3 /$ elle tend à la performance et fait une large place à cette fin à l'expertise, ce quin e l'a met pás toujours à l'abri d'une derive technocratique, tout em lui assignant une prétention d'ordre éthique (la good governance)" (destaques no original).

${ }^{141}$ CANOTILHO, J. J. Gomes. "Brancosos" e interconstitucionalidade: itinerários dos discursos sobre a historicidade constitucional. $2^{\mathrm{a}}$ ed. Coimbra : Almedina, 2008, p. 327.

${ }^{142}$ Citem-se a este título a Convenção de Cotonu (art. $9^{\circ}$ ) e a Carta dos Direitos Fundamentais da União Européia (art. 41).

${ }^{143}$ Cf. SORACE, Domenico. La buona amministrazione. In: RUOTOLO, Marco (coord.). La Costituzione há 60 anni: la qualità della vita sessant'anni dopo. Napoli : Editoriale Scientifica, 2008, pp. 119-135; FREITAS, Juarez. Discricionariedade administrativa e o direito fundamental à boa Administração Púlbica. $2^{\mathrm{a}}$ ed. São Paulo : Malheiros, 2009. 


\subsubsection{Consensualismo}

Fenômeno bastante presente nos debates sobre a nova Administração Pública baseada na idéia de governança pública é o da Administração Consensual, significando

um novo caminho, no qual a Administração Pública passa a valorizar (e por vezes privilegiar) uma forma de gestão cujas referências são o acordo, a negociação, a coordenação, a cooperação e a colaboração. Isso em setores e atividades preferencial ou exclusivamente reservados ao tradicional modo de administrar: a administração por via impositiva ou autoritária. ${ }^{144}$

Portanto, em substituição ao tradicional modelo autoritário de atuação do Estado, representativo da relação de poder em que se fundava a interface com o cidadão, passa-se a modelo que privilegia a ação administrativa concertada, acordada com os seus destinatários. "A Administração aprendeu que é preferível ter o particular como participante (quase co-autor) do que como mero destinatário ou subordinado" ${ }^{145}$, preferindo a ação consensual à imperativa. Assim, "a Administração renunciaria ao emprego de seus poderes com base na imperatividade e unilateralidade, aceitando realizar acordos com os particulares destinatários da aplicação concreta desses poderes, ganhando assim uma colaboração ativa dos administrados". ${ }^{146}$

144 OLIVEIRA, Gustavo Justino. Contrato de gestão. São Paulo : RT, 2008, p. 33. "A atividade administrativa consensual indica aquela particular escolha no agir administrativo tendente não somente à conclusão de contratos no sentido clássico do termo, segundo as regras ordinárias do direito privado, mas também voltada à busca do consenso, através da criação de módulos convencionais (dos mais genéricos pactos políticos, pactos administrativos, intenções, aos mais particulares acordos procedimentais, à evidenza pública, por exemplo)" (PERFETTI, Luca R. Corso di diritto amministrativo. $2^{\mathrm{a}}$ ed. Padova : CEDAM, 2008 , p. 466, tradução nossa). No original: "La c. d. attività amministrativa consensuale indica quella particolare scelta nell'agire amministrativo tesa non soltanto alla conclusione di contratti nel senso classico del termine, secondo le ordinarie regole del diritto privato, ma anche volta alla ricerca del consenso, attraverso la creazione di moduli convenzionali (dai più generici patti politici, patti amministrativi, intese, ai più particolari accordi procedimentali, all'evidenza pubblica, per esempio)".

${ }^{145}$ ESTORNINHO, Maria João. Requiem pelo contrato administrativo. Coimbra : Almedina, 1990, p. 60.

146 RAMÓN-FERNANDEZ, Tomaz; GARCÍA DE ENTERRIA, Eduardo. Curso de derecho administrativo. $9^{\text {a }}$ ed. Madrid : Civitas, 1999, vol. 1, apud OLIVEIRA, Gustavo Justino. Op. cit., p. 36. Há quem considere as atividades consensuais da Administração Pública uma forma de recuperação da autoridade da Administração Pública, na medida em que a ação acordada garantiria a atuação do parceiro privado, diferentemente da ação coativa, sujeita a desobediência e execução forçada: "Se diz que o cada vez mais freqüente recurso a formas de acordo é exigência de uma recuperação de autoridade por parte da Administração Pública em um contexto social que privilegia a obtenção do consenso relativamente à imposição de medidas coativas" (PERICU, G. L'attività consensuale dell'amministrazione pubblica. In: MAZZAROLLI, L. et al. (coord.). Diritto amministrativo. $3^{\text {a }}$ ed. Bologna : Monduzzi, 2001, cap. IV, p. 1616, tradução nossa). No original: "Si è detto che il sempre più frequente ricorso a simili forme di accordo è mosso dall'esigenza di un recupero di autorità da parte della p.a. in un contesto sociale che privilegia l'acquisizione del consenso rispetto all'imposizione di misure coattive". Também sobre o tema do consenso 
Aponta-se para a assunção, pela Administração Pública, de "um novo modo de agir, não mais centrado sobre o ato como instrumento exclusivo de definição e atendimento do interesse público, mas como atividade aberta à colaboração de indivíduos. Passa a ter relevo o momento do consenso e da participação" "147; ocorre uma "escolha dos poderes públicos de se afastarem cada vez mais da sombra da aministração autoritária, em favor de uma administração que busca o debate, a mediação e o consenso". ${ }^{148}$

O consenso e a mediação, ao orientarem a atuação da Administração Pública e aproximarem dela o cidadão, sugere o reconhecimento de autonomias de parte a parte e, via de conseqüência, legitima a utilização da expressão “Administração paritária para caracterizar esta forma de administrar, fundada em módulos negociais" ${ }^{149}$.

cf. SCOCA, Franco Gaetano. Autorità e consenso. In: Autorità e consenso nell'attività amministrativa. Milano : Giuffrè, 2002, pp. 21-48.

${ }^{147}$ MEDAUAR, Odete. O direito administrativo em evolução. $2^{\text {a }}$ ed. São Paulo : RT, 2003, p. 211.

${ }^{148}$ LUPPI, Silvia A. Frego. Il principio di consensualità nell'agire amministrativo alla luce della legislazione e della giurisprudenza più recenti. Diritto amministrativo: rivista trimestrale, Milano : Giuffrè, anno XVI, n. 3, 2008, pp. 695-696, tradução nossa. No original: “(...) scelta dei pubblici poteri di allontanare sempre più lo spettro dell'amministrazione autoritaria, in favore di un'amministrazione che cerca il confronto, la mediazione e il consenso".

149 OLIVEIRA, Gustavo Justino. Contrato de gestão. São Paulo : RT, 2008, p. 33. "E a doutrina aponta uma tendência na direção da construção de um 'direito à paridade' entre cidadão e administração pública como conseqüência do novo princípio da 'paridade das armas', 'tendência que se presume destinada a encontrar ulterior expressão na difusão do modo de administração 'por acordos"," (LUPPI, Silvia A. Op. cit., pp. 710711, tradução nossa). No original: "E la dottrina rileva una tendenza verso la costruzione di un 'diritto alla parità' tra cittadino e pubblica amministrazione quale esito del nuovo principio della 'parità delle armi', 'tendenza che è presumibilmente destinata a trovare ulteriore espressione nel diffondersi del modo di amministrazione "per accordi,",. 


\section{CAPÍTULO 3. TERCEIRO SETOR}

Paralelamente ao debate destas novas concepções que vêm propiciando a inserção dos temas da Reforma do Estado e da Reforma do Aparelho do Estado na ordem do dia e efetivamente dando nova roupagem ao Direito Administrativo e à Administração Pública modernos, incontestavelmente deve se inserir o "surgimento" 150 do Terceiro Setor.

Quando se fala em Terceiro Setor - e o que ora se diz será objeto de análise específica em tópicos posteriores - logo se deve traçar cotejo analítico com a atividade estatal. Isto porque a atividade desenvolvida pelo Terceiro Setor, por suas características e locus de atuação, assume importante paralelismo em relação à atuação do Estado. É inafastável, portanto, que se faça breve análise evolutiva da relação entre Estado e sociedade e da própria intervenção estatal na sociedade, com o fito de localizar o desenvolvimento do Terceiro Setor.

Como observa Gustavo Justino de Oliveira,

é possível afirmar que o recente interesse pelo Terceiro Setor é uma das decorrências das políticas reformistas de Estado, ocorridas nas últimas décadas do século XX, as quais provocaram, em muitos casos, o desmantelamento das estruturas públicas voltadas à prestação de serviços sociais à comunidade. ${ }^{151}$

Como foi abordado no capítulo anterior, a segunda metade do século $\mathrm{XX}$, em especial suas últimas décadas, foi marcada por intensos debates que derivaram direta ou indiretamente para a controvérsia sobre o relacionamento entre Estado e sociedade civil.

Resumindo o quanto foi exposto anteriormente e aproximando da realidade do Terceiro Setor, o fato é que a crise do Estado e a emergência da participação da sociedade civil $^{152}$, situações originadas em meados do século passado e acentuadas nos seus últimos

\footnotetext{
${ }^{150}$ As aspas se devem ao fato de entendermos que o Terceiro Setor verdadeiramente não surge a partir dos fatores analisados, mas sem dúvida é influenciado seu crescimento por eles. Em nossa defesa as palavras de Luiz Eduardo Soares (SOARES, Luiz Eduardo. Prefácio. In: COELHO, Simone de Castro Tavares. Terceiro setor: um estudo comparado entre Brasil e Estados Unidos. São Paulo : SENAC, 2000, p. 11): "O 'Terceiro Setor', no Brasil, não é uma realidade nova nem pouco importante, ainda que seja precária e bastante recente a consciência que atribui unidade e um sentido relativamente homogêneo às práticas que as abordagens tradicionais identificavam exclusivamente à filantropia ou à solidariedade cívica”.

${ }^{151}$ OLIVEIRA, Gustavo Justino de. Direito do Terceiro Setor. Revista de Direito do Terceiro Setor RDTS, Belo Horizonte : Fórum, ano 1, n. 1, jan.-jun. 2007, p. 17.

${ }^{152}$ Não sendo o objeto da presente tese a discussão sobre o conceito de sociedade civil, nos apoiamos no conceito geral de Habermas: "Hoje em dia, o termo sociedade civil não inclui mais a economia constituída através do direito privado e dirigida através do trabalho, do capital e dos mercados de bens, como ainda acontecia na época de Marx e do marxismo. O seu núcleo institucional é formado por associações e organizações livres, não estatais e não econômicas, as quais ancoram as estruturas de comunicação da esfera pública nos componentes sociais do mundo da vida. A sociedade civil compõe-se de movimentos,
} 
anos e no início deste século XXI, propiciaram o que pode ser considerado como uma "busca da redemarcação do espaço público"153.

É neste momento que se observa que uma das "novidades" decorrentes desta crise do modelo então vigente de atuação estatal, vinculada estreitamente com o conceito de privatização - em sentido amplo - que nutre as reformas propostas, encontra-se no campo social.

A aproximação Estado-administrado, sob a influência dos ideais impostos pelo Estado Social e Democrático de Direito que exigem o incentivo à participação popular e o fomento à iniciativa privada de interesse público, enseja a organização da sociedade civil em torno de questões de interesse social.

A sociedade civil se organiza e passa a figurar como participante direta nas ações de cariz social, cuja atribuição originária no Estado Social competia ao próprio Estado; “a intensificação das relações entre Estado e sociedade civil parece dominar o cenário mundial, configurando um fenômeno irreversível"154.

Surge, desta forma, movimento teórico que propõe a atribuição de funções de coresponsabilidade entre o Estado, o mercado ${ }^{155}$ e os cidadãos (que podem ser representados por entidades de natureza privada, integrantes da sociedade civil, em sua atuação perante o Estado e o próprio mercado, sem criar cláusulas estanques para tanto) no exercício de atividades de interesse público e que, até então, estavam relegadas à função estatal. Isto não significa dizer que o Estado se desresponsabiliza da sua função de execução das atividades socialmente relevantes; abre-se espaço, no entanto, para um movimento de coresponsabilidade na execução, sem afastar a responsabilidade originária do Estado pela adequada satisfação das necessidades sociais. ${ }^{156}$

organizações e associações, os quais captam os ecos dos problemas sociais que ressoam nas esferas privadas, condensam-nos e os transmitem, a seguir, para a esfera pública política. O núcleo da sociedade civil forma uma espécie de associação que institucionaliza os discursos capazes de solucionar problemas, transformandoos em questões de interesse geral no quadro de esferas públicas. Esses designs discursivos refletem, em suas formas de organização, abertas e igualitárias, certas características que compõem o tipo de comunicação em torno da qual cristalizam, conferindo-lhe continuidade e duração" (HABERMAS, Jürgen. Direito e Democracia: entre facticidade e validade. Rio de Janeiro : Tempo Brasileiro, 1997, v. 2, p. 101).

153 OLIVEIRA, Gustavo Justino de. Direito do Terceiro Setor. Revista de Direito do Terceiro Setor RDTS, Belo Horizonte : Fórum, ano 1, n. 1, jan.-jun. 2007, p. 12.

154 Ibidem, p. 13.

155 Sobre as parcerias entre o mercado e o Terceiro Setor, cf. CRUZ, Rachel Pellizzoni da. A prática da responsabilidade social empresarial no Brasil: dilemas e perspectivas. Revista de Direito do Terceiro Setor - RDTS, Belo Horizonte : Fórum, ano 1, n. 1, jan.-jun. 2007, pp. 97-112. Sobre a responsabilidade social da empresa no contexto do Terceiro Setor, cf. ARAÚJO, Geraldo Bonnevialle Braga. A responsabilidade social da empresa e as fundações privadas. Revista de Direito do Terceiro Setor, Belo Horizonte : Fórum, ano 1, n. 1, jan.-jun. 2007, pp. 113-132.

156 "Se é incorreto afirmar que a responsabilidade estatal na execução dessas atividades socialmente relevantes foi integralmente transferida ao setor privado, certo é que ao menos foi incentivada a co- 
Em largas passadas, o conceito de Terceiro Setor origina-se do desenvolvimento de organizações privadas com adjetivos públicos ${ }^{157}$, portanto agregando características do Primeiro Setor (Estado) e do Segundo Setor (mercado), mas se afastando da burocracia estatal e das ambições do mercado.

Esta característica intermediária lhes permite a prestação de serviços de interesse social, que verdadeiramente seriam função primitiva do Estado (função típica mas não exclusiva do Estado, na feliz expressão de Maria Sylvia Zanella Di Pietro) ${ }^{158}$.

Analisa-se, neste momento, um novo fenômeno que se espraia e tem sua influência significativa na determinação das funções do Estado. Como se observa, novas formas de parceria, juridicamente consideradas, têm surgido por conta da evolução deste fenômeno. ${ }^{159}$ É o Direito se adaptando à realidade dos fatos.

É fruto da evolução histórica da intervenção econômica e social do Estado, e sobretudo da adaptação dele mesmo às realidades que lhe são impostas. Assim como surgiu a doutrina liberal em meados do século XVIII, que evoluiu para as concepções sociais de Estado e repercutiu nos Estados de Bem-Estar Social, hoje se observa que o modelo adotado não se presta adequadamente à consecução do Estado ideal. Estado ideal, inclusive, que não existe, senão através das adaptações que a própria realidade social impõe às instituições políticas e jurídicas.

Não se está a advogar a infalibilidade de uma proposta calcada na atribuição de coresponsabilidades entre o Estado, o mercado e os cidadãos (cuja aproximação jurídica será objeto de estudo a posteriori), como são os debates sobre o Terceiro Setor. O que se diz e se acredita, é que a proposta de desenvolvimento do Terceiro Setor é simplesmente o fruto

responsabilidade das entidades privadas (mormente as não-lucrativas) para a prática dessas atividades" (OLIVEIRA, Gustavo Justino de. Op. cit., p. 17). "Veementemente, não se concorda que o Estado, sob o argumento de democratização, publicização, eficiência, respeito à capacidade e à iniciativa particular, abandone os deveres que lhe são próprios, por natureza e por determinação constitucional, sendo transferidas à 'sociedade' todas (ou a maior parte) as (das) obrigações, em troca de fomento livre de restrições, com liberdade maior gozada paradoxalmente pelos governos disponibilizadores dos recursos, que, inclusive, os dirigirão, e não pela própria coletividade, na medida em que eles se enraízam nas organizações sociais como normatizadas - ou que eles promovam essas modificações estruturais mediante normas jurídicas violentadoras da Constituição" (FERNANDES, Luciana de Medeiros. Reforma do Estado e Terceiro Setor. Curitiba : Juruá, 2009, p. 455). “Às cooperativas sociais não é bom que se transformem em um 'substituto' da administração pública no planejamento e realização do Estado social” (MICHIARA, Paolo. Le convenzioni tra pubblica amministrazione e terzo settore: considerazioni sulle procedure selettive a concorrenza limitata nell'ambito dei rapporti a collaborazione necessaria. Roma : Istituto Editoriale Regione Italiane S.R.L., 2005, pp. 404-405, tradução nossa. No original: "La cooperazione sociale non è bene che si transformi in un 'sostituto' della pubblica amministrazione nella progettazione e realizzazione dello stato sociale".

157 PAES, José Eduardo Sabo. Fundações e Entidades de Interesse Social: aspectos jurídicos, administrativos, contábeis e tributários. Brasília: Brasília Jurídica, 1999, p. 45.

${ }_{158}^{15}$ DI PIETRO, Maria Sylvia Zanella. Direito Administrativo. 19a ed. São Paulo: Atlas, 2006, p. 481.

${ }^{159}$ Vide, por exemplo, a Lei n. ${ }^{\circ}$ 9.790/99. 
da evolução histórica; é uma doutrina que "surge" (ou renasce) como alternativa atual para as deformidades dos sistemas anteriores.

Críticas virão de todos os lados e sob todos os enfoques ${ }^{160}$ - e já vieram aos borbotões -, mas há de se convir que os críticos do modelo liberal também existiram, assim como os críticos do Estado social. É assim que os institutos se aperfeiçoam e a realidade traça seu leito, que às vezes acaba por se desviar para se adaptar a alguns obstáculos que lhe são impostos.

O papel das organizações do Terceiro Setor como instrumento de efetivação das necessidades sociais é patente, e toma contornos de imprescindibilidade sobretudo em face da chamada globalização. ${ }^{161}$ A proposta de reordenação da atividade estatal aponta para a sociedade em rede ${ }^{162}$, fruto da sociedade policêntrica que se desenvolveu especialmente pelo fenômeno da globalização e que legitima diversos atores às demandas sociais apresentadas.

É o Terceiro Setor, portanto, realidade que vem a reboque das novas noções de Estado, ou seja, da própria evolução do conceito de participação e interferência estatais.

A ratificar sua importância, faz-se mister que sejam trazidos à colação alguns apontamentos sobre a vasta utilização deste instrumento, tanto no Brasil como em outros países, mesmo que a sua regulação seja ainda imprecisa e incipiente, sobretudo em nosso país.

Eduardo Szazi traz números bastante expressivos da participação do Terceiro Setor no Brasil, ao dizer que

recentes pesquisas apontam que o Terceiro Setor gastou no Brasil cerca de 10,9 bilhões de reais em despesas operacionais no ano de 1995, o que corresponde a 1,5\% do PIB daquele ano. Parcela significativa dos recursos $(61,1 \%)$ foi gerada pelas próprias entidades: o governo contribuiu com $12,8 \%$ e os Doadores Privados, com os restantes 26,1\%, computadas as doações em moeda e bens de pessoas físicas e jurídicas e o valor do trabalho voluntário $^{163}$.

\footnotetext{
${ }^{160}$ Para diferentes enfoques sobre o tema, cf.: MONTAÑO, Carlos. Terceiro setor e questão social: crítica ao padrão emergente de intervenção social. São Paulo : Cortez, 2002; DEMO, Pedro. Solidariedade como efeito de poder. São Paulo : Cortez; Instituto Paulo Freire, 2002; KURZ, Robert. Para além de Estado e Mercado. In:__. Os últimos combates. $4^{\mathrm{a}}$ ed. Petrópolis-RJ : Vozes, 1998, pp. 151-157; PEREIRA, Luiz Carlos Bresser. Reforma do Estado para a cidadania: a reforma gerencial brasileira na perspectiva internacional. São Paulo : Ed. 34; Brasília : ENAP, 1998; FERNANDES, Rubem César. Privado porém público: o Terceiro Setor na América Latina. $3^{\text {a }}$ ed. Rio de Janeiro : Relume Dumará, 2002.

${ }_{161}$ Sobre a interface entre globalização, subsidiariedade e Terceiro Setor, cf. BASSANINI, Franco. Postfazione. In: CITTADINO, Caterina (org.). Dove lo Stato non arriva: pubblica amministrazione e terzo settore. Firenze : Passigli, 2008, pp. 353-376.

${ }^{162}$ CASTELLS, Manuel. A era da informação: a sociedade em rede. $5^{\mathrm{a}}$ ed., São Paulo : Paz e Terra, 2001, v. 1 .

${ }^{163}$ SZAZI, Eduardo. Terceiro Setor: regulação no Brasil. São Paulo : Peirópolis, 2000, p. 21.
} 
E continua o autor, dando conta de que "nos Estados Unidos, o Terceiro Setor representa 6,3\% do PIB e detinha, em 1988, ativos equivalentes a 670 bilhões de dólares" $" 164$.

Caballería também apresenta estatísticas que corroboram com o antes expressado, dando conta da importância do Terceiro Setor no cenário mundial:

En el Reino Unido, en 1995 el gasto de las organizaciones del tercer sector representaba un $6,6 \%$ del PIB y dicho sector ocupaba a 16 millones de voluntarios (equivalentes en horas de trabajo a unos 1,7 millones de empleados a tiempo completo) y a 1,5 millones de asalariados a tiempo completo que, sumados a los anteriores, representan en total el 12,3\% del empleo global de la economía. En los siete países estudiados en detalle por SALAMON y ANHEIER en 1996 (EE. UU., Reino Unido, Francia, Alemania, Italia, Hungría y Japón), el gasto operativo del sector representaba de media el 4,5\%del PIB 'y cuatro veces las ventas brutas de General Motors, la mayor compañía privada del mundo'. En la Fase II del mismo estudio, referida a 1995 y ampliada a 22 países (incluida España), se concluye que el gasto del sector no lucrativo alcanza un promedio del 4,6\% del PIB en dichos países y que el empleo en este sector representa de media el $4,8 \%$ del empleo total en ellos, porcentaje que en España es del $4,5 \%{ }^{165}$.

Estas considerações demonstram a importância do tema, cujos contornos têm sido renovados com veemência pela Reforma do Aparelho do Estado a ponto de torná-lo realidade irreversível.

\subsection{Origem e noção de Terceiro Setor}

Uma das tarefas mais difíceis, porém indispensável para o presente trabalho, é exatamente a definição, em seu sentido conceitual, do que vem a ser o Terceiro Setor.

O cientista social americano Lester Salamon, um dos mais respeitados articulistas sobre o Terceiro Setor, faz a ressalva de que há uma dificuldade séria de natureza conceitual sobre o tema: "A diversidade do setor é tão assombrosa, que nos induz a passar por alto as consideráveis similitudes que também existem nele". ${ }^{166}$ Tentaremos, no

\footnotetext{
${ }^{164}$ Ibidem, p. 21.

${ }^{165}$ CABALLERÍA, Marcos Vaquer. La acción social: un estudio sobre la actualidad del Estado social de Derecho. Valencia : Tirant lo Blanch, 2002, p. 201. Para estudo aprofundado sobre as dimensões do Terceiro Setor no mundo, consulte: SALAMON, Lester M. et al. Global Civil Society: dimensions of the nonprofit sector. Bloomfield : Kumarian Press, 2004. Para aprofundar a legislação norte americana sobre o Terceiro Setor: FISHMAN, James J.; SCHWARZ, Stephen. Nonprofit organizations: cases and materials. $2^{\mathrm{a}}$ ed. New York : Foundation Press, 2000.

${ }^{166}$ SALAMON, Lester. Estratégias para o fortalecimento do terceiro setor. In: IOSCHPE, Evelyn Berg (org.). $3^{\text {o }}$ setor: desenvolvimento social sustentado. Rio de Janeiro : Paz e Terra, 1997, p. 93. Simone de Castro Tavares Coelho (COELHO, Simone de Castro Tavares. Terceiro setor: um estudo comparado entre Brasil e
} 
presente trabalho, apresentar um conceito de Terceiro Setor sob a ótica jurídica; no entanto, neste primeiro momento nos limitaremos a uma noção do Terceiro Setor. ${ }^{167}$

O termo Terceiro Setor faz alusão, necessariamente, à existência de dois setores que lhe sejam antecedentes. Expressão importada do cenário sociológico norte-americano e traduzida do original third sector ${ }^{168}$, pressupõe o Estado como o primeiro setor e o mercado como o segundo setor, ou vice-versa. ${ }^{169}$ Exemplo claro desta idéia é a afirmação de Fernandes, quando diz que “a idéia de um 'terceiro setor' supõe um 'primeiro' e um 'segundo', e nesta medida faz referência ao Estado e ao mercado. A referência, no entanto, é indireta, obtida pela negação - 'nem governamental, nem lucrativo"'. ${ }^{170}$

Outros, por sua vez, criticam a utilização do termo por entenderem que historicamente as ações que fazem parte do Terceiro Setor, localizando-se no seio da sociedade civil, são anteriores aos próprios conceitos de Estado e mercado. O correto seria, segundo estes autores, considerá-lo como o primeiro setor. ${ }^{171}$

E daí já se pode extrair outra característica usualmente encontrada nos debates teóricos sobre o Terceiro Setor que é a relação intrínseca que guarda com o conceito de

Estados Unidos. São Paulo : SENAC, 2000, p. 58) também dá conta da dificuldade desta conceituação: "Em geral, os autores optam por uma determinada denominação, citam outras tantas, e nisso finda a discussão. Essa multiplicidade de denominações apenas demonstra a falta de precisão conceitual, o que, por sua vez, revela a dificuldade de enquadrar toda a diversidade de organizações em parâmetros comuns".

${ }^{167}$ Acolhemos a sugestão doutrinária de Alexandre Santos de Aragão em sua obra sobre os serviços públicos: “Preliminarmente, faz-se mister justificar o título e o objeto do Capítulo - 'Noção', e não 'Conceito' de serviço público. A nomenclatura adotada decorre da dificuldade, pelo menos neste momento expositivo ainda propedêutico, de um fenômeno tão multifacetado e dinâmico como os serviços públicos ser apreendido em um conceito, o que pressupõe uma delimitação factual em princípio atemporal e permanente. Já a 'noção' evolui de acordo com as contradições a ela inerentes, sendo mais adequada para tratarmos do tema sob uma perspectiva inicial necessariamente mais abrangente, impedindo o seu enclausuramento a priori em apenas uma concepção" (ARAGÃO, Alexandre Santos de. Direito dos serviços públicos. Rio de Janeiro : Forense, 2007, p. 75).

168 “O termo 'terceiro setor' foi utilizado pela primeira vez por pesquisadores nos Estados Unidos na década de 70, e a partir da década de 80 passou a ser usado também pelos pesquisadores europeus" (COELHO, Simone de Castro Tavares. Op. cit., p. 58). Em nota de rodapé continua a autora: "segundo Seibel e Anheier, os americanos seriam Etzioni (1973), Levitt (1973), Nielson (1975) e a Filer Commision (1975); os europeus seriam Douglas (1983), Reese (1987), Reichard (1988) e Ronge (1988)".

169 É o que apontam, por exemplo, os seguintes autores: THOMPSON, Andrés A. Do compromisso à eficiência? Os caminhos do terceiro setor na América Latina. In: IOSCHPE, Evelyn Berg (org.). $3^{\circ}$ setor: desenvolvimento social sustentado. Rio de Janeiro : Paz e Terra, 1997, pp. 41-48; KISIL, Marcos. Organização social e desenvolvimento sustentável: projetos de base comunitária. In: IOSCHPE, Evelyn Berg (org.). $3^{\circ}$ setor: desenvolvimento social sustentado. Rio de Janeiro : Paz e Terra, 1997, p. 155; PAES, José Eduardo Sabo. Fundações e entidades de interesse social. $4^{\mathrm{a}}$ ed. Brasília : Brasília Jurídica, 2003, p. 88; CARDOSO, Ruth. Fortalecimento da sociedade civil. In: IOSCHPE, Evelyn Berg (org.). $\mathbf{3}^{\circ}$ setor: desenvolvimento social sustentado. Rio de Janeiro : Paz e Terra, 1997, p. 8. Simone Coelho (op. cit., pp. 5859), por sua vez, aponta que "os autores que a ela recorrem [denominação terceiro setor] consideram o mercado como primeiro setor e a área governamental como segundo, e essas organizações - que têm características dos dois setores - vêm a ser o terceiro setor".

${ }^{170}$ FERNANDES, Rubem César. Privado porém público: o Terceiro Setor na América Latina. $3^{\mathrm{a}}$ ed. Rio de Janeiro : Relume-Dumará, 2002, p. 127.

${ }^{171}$ Cf. MONTAÑO, Carlos. Terceiro setor e questão social: crítica ao padrão emergente de intervenção social. São Paulo : Cortez, 2002, p. 55. 
sociedade civil. Fernandes novamente nos dá referência desta conexão: "Marcando um espaço de integração cidadã, a sociedade civil distingue-se, pois, do Estado; mas, caracterizando-se pela promoção de interesses coletivos, diferencia-se também da lógica do mercado. Forma, por assim dizer, um 'Terceiro Setor'", ${ }^{172}$

O locus de desenvolvimento que o conceito de Terceiro Setor tem costumado adotar é além do Estado e do mercado ${ }^{173}$, ou entre o público e o privado. ${ }^{174}$

Em verdade, os elementos que figuram o conceito do Terceiro Setor são inúmeros e não convergem para um entendimento sólido. Realmente, a dificuldade em conceituar o Terceiro Setor acaba por gerar um sem-número de considerações que divergem radicalmente umas das outras, mais por falta de fixação de métodos para a definição e pela variedade de elementos que realmente é ínsita à realidade do Terceiro Setor, do que por equívoco de parte a parte.

Asseverando que o tema carece de um conceito unificador, Lester Salamon traça alguns parâmetros de pesquisa que dão a nota deste seu conceito, entendendo como participantes do Terceiro Setor as organizações

que não integram o aparelho governamental; que não distribuem lucros a acionistas ou investidores, nem têm tal finalidade; que se autogerenciam e gozam de alto grau de autonomia interna; e que envolvem um nível significativo de participação voluntária. ${ }^{175}$

Simone de Castro Tavares Coelho, ao traçar a definição de Terceiro Setor, se utiliza de diversos elementos e acaba por citar o já transcrito conceito de Salamon:

O terceiro setor pode ser definido como aquele em que as atividades não seriam nem coercitivas nem voltadas para o lucro. Além disso, como veremos mais detalhadamente no próximo capítulo, suas atividades visam ao atendimento de necessidades coletivas e, muitas vezes, públicas. (...) Genericamente, a literatura agrupa nessas denominações todas as organizações privadas, sem fins lucrativos, e que visam à produção de um bem coletivo. (...) Portanto, essa característica [de "prestação de serviço público"] deve vir sempre casada com outras duas: serem privadas, o que as difere das instituições governamentais; e sem fins lucrativos, o que as diferencia das empresas inseridas no mercado. Além das

\footnotetext{
${ }^{172}$ FERNANDES, Rubem César. O que é o terceiro setor? In: IOSCHPE, Evelyn Berg (org.). $3^{\circ}$ setor: desenvolvimento social sustentado. Rio de Janeiro : Paz e Terra, 1997, p. 27.

${ }^{173}$ Como sustentam, por exemplo, Robert Kurz (KURZ, Robert. Para além de Estado e Mercado. In: Os últimos combates. $4^{\mathrm{a}}$ ed. Petrópolis-RJ : Vozes, 1998) e Rubem César Fernandes (FERNANDES, Rubem César. Privado porém público: o Terceiro Setor na América Latina. $3^{\mathrm{a}}$ ed. Rio de Janeiro : RelumeDumará, 2002, p. 19).

${ }^{174}$ PEREIRA, Luiz Carlos Bresser. Reforma do Estado para a cidadania: a reforma gerencial brasileira na perspectiva internacional. São Paulo : Ed. 34; Brasília : ENAP, 1998, p. 235. O autor também denomina as entidades constituintes do terceiro setor de públicas não-estatais.

${ }^{175}$ SALAMON, Lester. Estratégias para o fortalecimento do terceiro setor. In: IOSCHPE, Evelyn Berg (org.). $3^{\circ}$ setor: desenvolvimento social sustentado. Rio de Janeiro : Paz e Terra, 1997, p. 93.
} 
características acima - fora do Estado e sem fins lucrativos -, Lester Salamon e Helmuth Anheier, procurando sistematizar melhor os contornos desse grupo de instituições, acrescentaram os pontos a seguir. Essas organizações são estruturadas. São autogovernadas. Envolvem indivíduos num significativo esforço voluntário. (...) Para que os contornos do que estamos denominando terceiro setor fiquem mais nítidos, é necessário ressaltar ainda um fator distintivo dessas organizações, um fator que não se apresenta nas empresas privadas e nas agências governamentais: o trabalho voluntário. ${ }^{176}$

Ruth Cardoso, não obstante deixar de conceituar o Terceiro Setor, deixa vestígios de como o faria, ao asseverar - além de entendê-lo como ferramenta de fortalecimento da sociedade civil - que "são vários os termos que temos utilizado para caracterizar este espaço que não é Estado nem mercado e cujas ações visam ao interesse público: iniciativas sem fins lucrativos, filantrópicas, voluntárias". 177

Rubem César Fernandes arrisca um conceito bastante complexo, entendendo que

o Terceiro Setor é composto de organizações sem fins lucrativos, criadas e mantidas pela ênfase na participação voluntária, num âmbito não-governamental, dando continuidade às práticas tradicionais da caridade, da filantropia e do mecenato e expandindo o seu sentido para outros domínios, graças, sobretudo, à incorporação do conceito de cidadania e de suas múltiplas manifestações na sociedade civil. ${ }^{178}$

Já Andrés A. Thompson é confessadamente mais simplista, ao entender que o Terceiro Setor seriam "todas aquelas instituições sem fins lucrativos que, a partir do âmbito privado, perseguem propósitos de interesse público". ${ }^{179}$

O conceito formulado por Edson José Rafael é o seguinte:

O Terceiro Setor recebe várias denominações, sendo as mais usuais Setor Solidário, Setor Coletivo e Setor Independente. É, por excelência, um setor solidário, onde alguns velam por muitos, onde o individual dá lugar ao coletivo, e recebe a denominação de Setor Independente por se mostrar eqüidistante do Poder Estatal e do Poder Econômico, gerador de riquezas. (...) As entidades jurídicas não governamentais, sem finalidade lucrativa, objetivando o bem da coletividade, inserem-se neste setor. $\mathrm{O}$ terceiro setor jamais procura auferir lucros e, em razão disto, não pode ser inserido dentro das atividades mercantis usuais, com regulamentação específica e própria. O Terceiro Setor é gênero do qual são

\footnotetext{
176 COELHO, Simone de Castro Tavares. Terceiro setor: um estudo comparado entre Brasil e Estados Unidos. São Paulo : SENAC, 2000, p. 40, 58, 60 e 69.

177 CARDOSO, Ruth. Fortalecimento da sociedade civil. In: IOSCHPE, Evelyn Berg (org.). $3^{\circ}$ setor: desenvolvimento social sustentado. Rio de Janeiro : Paz e Terra, 1997, p. 7.

${ }^{178}$ FERNANDES, Rubem César. O que é o Terceiro Setor? In: IOSCHPE, Evelyn Berg (org.). $3^{\circ}$ setor: desenvolvimento social sustentado. Rio de Janeiro : Paz e Terra, 1997, p. 27.

${ }^{179}$ THOMPSON, Andrés A. Do compromisso à eficiência? Os caminhos do terceiro setor na América Latina. In: IOSCHPE, Evelyn Berg (org.). $3^{\mathbf{o}}$ setor: desenvolvimento social sustentado. Rio de Janeiro : Paz e Terra, 1997, p. 42.
} 
espécies todas as sociedades civis sem fins lucrativos, inserindo-se aqui a quase totalidade das fundações, em especial as fundações particulares. ${ }^{180}$

José Eduardo Sabo Paes também conceitua o Terceiro Setor, de forma bastante genérica:

Em termos do direito brasileiro, configuram-se como organizações do Terceiro Setor, ou ONGs - Organizações Não-Governamentais, as entidades de interesse social sem fins lucrativos, como as associações, as sociedades e as fundações de direito privado, com autonomia e administração própria, cujo objetivo é o atendimento de alguma necessidade social ou a defesa de direitos difusos ou emergentes. Tais organizações e agrupamentos sociais cobrem um amplo espectro de atividades, campos de trabalho ou atuação, seja na defesa dos direitos humanos, na proteção do meio ambiente, assistência à saúde, apoio a populações carentes, educação, cidadania, direitos da mulher, direitos indígenas, direitos do consumidor, direitos das crianças etc. ${ }^{181}$

A diversidade de elementos constantes dos conceitos de Terceiro Setor transcritos é flagrante. No entanto, como dito anteriormente, em trabalho que se pretende jurídico não há como simplesmente considerar o Terceiro Setor como fato dado e consumado, tampouco como adotar conceito outro que não tenha sido avaliado sob o prisma jurídico.

Volvendo ao festejado conceito de Lester Salamon, entendemos que para uma conceituação jurídica do Terceiro Setor há alguns elementos normalmente levados em consideração nas definições e que devem ser afastados. Como será visto a partir do próximo tópico, o conceito jurídico de Terceiro Setor é mais amplo do que normalmente se apregoa, justamente em virtude de o ordenamento jurídico brasileiro não exigir todos estes elementos para uma conceituação jurídica do Terceiro Setor.

É o que também assevera Marcos Vaquer Caballería, com base no ordenamento espanhol, quando ao analisar o conceito corrente de Terceiro Setor aponta o seguinte:

Na minha opinião, sem embargo, uma definição jurídica do [terceiro] setor deve ser mais ampla e prescindir de alguns de ditos elementos (sem prejuízo de que ocorram habitualmente) porque o ordenamento não os exige (ao menos o español e o italiano, que são os que estudou sistemáticamente que ora escreve). ${ }^{182}$

\footnotetext{
${ }^{180}$ RAFAEL, Edson José. Fundações e direito: $3^{\circ}$ setor. São Paulo : Companhia Melhoramentos, 1997, pp. 5-6.

${ }^{181}$ PAES, José Eduardo Sabo. Fundações e entidades de interesse social. $4^{\mathrm{a}}$ ed. Brasília : Brasília Jurídica, 2003, p. 89.

${ }^{182}$ CABALLERÍA, Marcos Vaquer. La acción social: un estudio sobre la actualidad del Estado social de Derecho. Valencia : Tirant Lo Blanch, 2002, p. 207, tradução nossa. No original: "En mi opinión, sin embargo, una definición jurídica del sector debe ser mas lata y prescindir de algunos de dichos elementos (sin perjuicio de que concurran habitualmente) porque no los exige el ordenamiento (al menos el español y el italiano, que son los que ha estudiado sistemáticamente quien esto suscribe)".
} 
Imperativa, portanto, a formulação conceitual do nosso objeto de estudo - o Terceiro Setor - sob o prisma jurídico, não sem antes traçar a fundamentação constitucional que o sustenta.

\subsection{Fundamentos constitucionais do Terceiro Setor no Brasil e seu espaço de participação}

A Constituição da República Federativa do Brasil de 1988 veio a consolidar as possibilidades de atuação da iniciativa privada em matéria social paralelamente à atuação estatal. ${ }^{183}$ Foi o fortalecimento da legitimidade da participação do Terceiro Setor na sociedade brasileira, motivo que também deve ser levado em consideração quando se observa seu crescimento na década de 90 .

A importância da Constituição de 1988 para o setor é marcante, tanto é que alguns autores se manifestam no sentido de que o Terceiro Setor surge para

dar cumprimento aos objetivos fundamentais da República, previstos no artigo $3^{\circ}$ da Constituição, quais sejam a construção de uma sociedade livre, justa e solidária, a erradicação da pobreza e da marginalização, a redução das desigualdades sociais e regionais e a promoção do bem de todos, sem qualquer tipo de discriminação. ${ }^{184}$

Desde o Preâmbulo de nosso Texto Magno a importância de sua vertente social se irradia:

Nós, representantes do povo brasileiro, reunidos em Assembléia Nacional Constituinte para instituir um Estado Democrático, destinado a assegurar o exercício dos direitos sociais e individuais, a liberdade, a segurança, o bem-estar, o desenvolvimento, a igualdade e a justiça como valores supremos de uma sociedade fraterna, pluralista e sem preconceitos, fundada na harmonia social e comprometida, na ordem interna e internacional, com a solução pacífica das controvérsias, promulgamos, sob a proteção de Deus, a seguinte Constituição da República Federativa do Brasil. ${ }^{185}$

Em primeiro lugar quando os representantes do povo brasileiro se reúnem para a instituição de um Estado Democrático, que lido na sua acepção moderna só pode ser concebido como um Estado de Democracia Representativa e Participativa.

\footnotetext{
${ }^{183}$ Para um histórico constitucional sobre o tema, cf. SOUZA, Leandro Marins de. Tributação do terceiro setor no Brasil. São Paulo : Dialética, 2004, pp. 75-94.

${ }^{184}$ SZAZI, Eduardo. Terceiro setor: regulação no Brasil. $3^{\mathrm{a}}$ ed. São Paulo : Peirópolis, 2003, p. 23.

${ }^{185}$ BRASIL. Constituição da República Federativa do Brasil, de 05 de outubro de 1988. Brasília, DF: Senado, 1988, preâmbulo.
} 
E esta participação que se insere no conceito de Estado Democrático que a nossa Constituição permite interpretar em seu preâmbulo assume duas vertentes de importante conteúdo para a definição do espaço de participação do Terceiro Setor: a participação no exercício dos direitos e a participação na garantia dos direitos. Auxilia nesta compreensão o trecho do citado preâmbulo que estabelece que nosso Estado Democrático está "destinado a assegurar o exercício dos direitos sociais e individuais, a liberdade, a segurança, o bem-estar, o desenvolvimento, a igualdade e a justiça", aliado ao fato de que esta democracia, por expressa dicção de nossa Constituição, objetiva a construção de uma sociedade fraterna, pluralista e sem preconceitos, o que pode ser traduzido como uma sociedade baseada no mutualismo e na diversidade de atores, ou seja, uma sociedade solidária. Reunindo os conceitos podemos - para fins de fundamentar a assertiva - resumir dizendo que a nossa Democracia Solidária se destina à garantia do exercício dos direitos sociais e individuais e à garantia da liberdade, da segurança, do bem-estar, do desenvolvimento, da igualdade e da justiça, o que implica dizer que a Constituição outorga o direito de participação social tanto no exercício de direitos quanto na defesa dos valores constitucionais. A nossa democracia é solidária, por expressa dicção constitucional, também na garantia da liberdade, o que outorga à sociedade a função de coresponsabilidade na defesa desta garantia. Da mesma forma a segurança, o bem-estar, o desenvolvimento, a igualdade e a justiça devem ser garantidas pela nossa Democracia Solidária. E no que tange à função de assegurar a justiça, em especial, entendemos se encontrar o fundamento constitucional máximo para a legitimação do Terceiro Setor como ferramenta de advocacy ${ }^{186}$, ou seja, a "luta por direitos e mobilização social" ${ }^{187} \mathrm{O}$ asseguramento da segurança, do bem-estar, do desenvolvimento, da igualdade e, principalmente, da justiça, não existe sem a garantia da aplicação da Constituição. É nesta seara que se encontra a legitimação da participação da sociedade civil na defesa dos direitos constitucionais, uma das expressões da nossa Democracia Solidária.

Não é à toa que o artigo $1^{\circ}$, II, da Constituição, estabelece que a cidadania é um dos fundamentos da República Federativa do Brasil, além de o seu parágrafo único consignar

\footnotetext{
${ }^{186} \mathrm{Na}$ defesa desta idéia cf. PIOVESAN, Flávia; BARBIERI, Carla Bertucci. Terceiro Setor e direitos humanos. In: CARVALHO, Cristiano; PEIXOTO, Marcelo Magalhães (coord.). Aspectos jurídicos do Terceiro Setor. $2^{a}$ ed. São Paulo : APET : MP Editora, 2008, pp. 102-103.

${ }^{187}$ TREZZA, Valéria Maria. O papel das organizações da sociedade civil na democracia. Revista de Direito do Terceiro Setor - RDTS, Belo Horizonte : Fórum, ano 3, n. 6, jul.-dez. 2009, p. 13. A autora (ibidem, p. 19) confirma que: "mesmo após a democratização, a presença deste tipo de organização continua a ser forte na consolidação da democracia, no controle social do poder estatal, na cobrança pelo respeito aos direitos previstos na Constituição de 1988 e no estímulo à participação cidadã".
} 
que o povo exerce o poder direta ou indiretamente. ${ }^{188}$ Não há dúvida de que a participação social direta nos assuntos de interesse da República brasileira, inclusive como forma de assegurar a cidadania em que está se fundamenta, é princípio basilar de nosso Estado Democrático.

Não bastasse tanto a Constituição estabelece, em seu artigo $3^{\circ}$, os objetivos fundamentais da República Federativa do Brasil, dentre os quais se insere o disposto em seu inciso I, parte final: construir uma sociedade solidária. ${ }^{189}$

Uma análise convergente destes dispositivos citados encontra a seguinte conclusão: a República Federativa do Brasil tem como um de seus objetivos a construção de uma sociedade solidária baseada na participação social como expressão do exercício da cidadania e do Estado Democrático em que se constitui.

O mesmo artigo $3^{\circ}$ estabelece como objetivos da República Federativa do Brasil a construção de uma sociedade livre e justa. Liberdade, em sua acepção contemporânea, não se limita à sua concepção física tampouco ao seu elemento positivo; não basta, para se concretizar esta liberdade constitucional, a sociedade ser considerada livre para fazer o que bem entender. A liberdade atual pressupõe a criação de condições materiais para os cidadãos desenvolverem os seus potenciais. ${ }^{190}$ Da mesma forma, uma sociedade justa, inserida no contexto de um Estado Democrático, pressupõe a participação social no exercício dos direitos e no controle da aplicação constitucional.

Destas constatações se extrai a legitimação constitucional do Terceiro Setor, verdadeiro instrumento de efetivação dos objetivos da República Federativa do Brasil; pode-se dizer, assim, que um dos princípios constitucionais que rege o Terceiro Setor é o princípio da solidariedade ${ }^{191}$ ou princípio da participação social, encontrado na análise convergente dos dispositivos acima citados.

Vale como confirmação o ensinamento de Gustavo Justino de Oliveira, para quem

\footnotetext{
188 “Art. $1^{\text {o }}$ A República Federativa do Brasil, formada pela união indissolúvel dos Estados e Municípios e do Distrito Federal, constitui-se em Estado Democrático de Direito e tem como fundamentos: (...) II - a cidadania; (...). Parágrafo único. Todo o poder emana do povo, que o exerce por meio de representantes eleitos ou diretamente, nos termos desta Constituição" (BRASIL. Constituição da República Federativa do Brasil, de 05 de outubro de 1988. Brasília, DF: Senado, 1988).

189 “Art. $3^{\circ}$ Constituem objetivos fundamentais da República Federativa do Brasil: I - construir uma sociedade livre, justa e solidária” (BRASIL. Constituição da República Federativa do Brasil, de 05 de outubro de 1988. Brasília, DF: Senado, 1988, grifo nosso).

${ }^{190}$ Cf. SEN, Amartya. Development as freedom. New York : Anchor Books, 1999.

191 Sobre a solidariedade no regime constitucional italiano, cf. GIUFFRÈ, Felice. La solidarietà nell'ordinamento costituzionale. Milano : Giuffrè, 2002.
} 
é possível sustentar que o Terceiro Setor é o resultado da combinação do exercício da cidadania com a efetiva participação direta dos cidadãos - individual ou de modo associativo - nos assuntos de interesse da sociedade, sempre com fundamento na busca pela solidariedade entre os indivíduos. Sendo assim, os elementos fundantes do Terceiro Setor encontram-se previstos expressamente na Constituição de 1988. A cidadania é tida como um dos fundamentos da República Federativa do Brasil (art. $1^{\circ}$, inc. II); a participação direta dos cidadãos nos assuntos públicos possui suporte no art. $1^{\circ}$, parágrafo único; a solidariedade é elencada como um dos objetivos fundamentais da República Federativa do Brasil (art. $3^{\circ}$, inc. I). Ao lado disso, é inegável que a própria noção de Estado Democrático de Direito, previsto na Constituição Brasileira no art. $1^{\circ}$, caput, é absolutamente determinante para a conceituação de Terceiro Setor, principalmente diante da obrigatória democratização do Estado de Direito. ${ }^{192}$

Além disso, outro princípio constitucional fundamenta a atuação do Terceiro Setor: o princípio da liberdade de associação. Considerado como o "núcleo constitucional do Terceiro Setor" ${ }^{\prime 193}$, o princípio da liberdade de associação foi aperfeiçoado pelo artigo $5^{\circ}$ da Constituição brasileira de $1988^{194}$, bastante mais amplo e esclarecido que as constituições anteriores; além disto, cite-se o princípio da liberdade de associação sindical previsto no artigo $8^{\circ}$ da Constituição. ${ }^{195}$

Em seu sentido positivo, a Constituição assegura a liberdade de associação para fins lícitos (art. $5^{\circ}$, inc XVII), ressalvando a associação para fins paramiliares; em seu sentido negativo, assegura que ninguém pode ser compelido a se associar ou manter-se associado (art. $5^{\circ}$, inc XX). A Constituição ainda outorga autonomia às associações, quando impede a interferência estatal em seu funcionamento e para a sua criação (art. $5^{\circ}$, XVIII).

Somando o princípio da solidariedade ou participação social ao princípio da liberdade de associação temos os fundamentos constitucionais para o Terceiro Setor no Brasil.

Para uma correta compreensão constitucional do Terceiro Setor, tão importante quanto os seus princípios constitucionais fundantes são os dispositivos garantidores dos direitos fundamentais dos cidadãos, os dispositivos de vertente social inseridos na

192 OLIVEIRA, Gustavo Justino de. Direito do Terceiro Setor. Revista de Direito do Terceiro Setor RDTS, Belo Horizonte : Fórum, ano 1, n. 1, jan.-jun. 2007, p. 26.

${ }^{193}$ Ibidem, p. 26.

194 “Art. 5. ' Todos são iguais perante a lei, sem distinção de qualquer natureza, garantindo-se aos brasileiros e aos estrangeiros residentes no País a inviolabilidade do direito à vida, à liberdade, à igualdade, à segurança e à propriedade, nos termos seguintes: (...) XVII - é plena a liberdade de associação para fins lícitos, vedada a de caráter paramilitar; XVIII - a criação de associações e, na forma da lei, a de cooperativas independem de autorização, sendo vedada a interferência estatal em seu funcionamento; XIX - as associações só poderão ser compulsoriamente dissolvidas ou ter suas atividades suspensas por decisão judicial, exigindo-se, no primeiro caso, o trânsito em julgado; XX - ninguém poderá ser compelido a associar-se ou a permanecer associado; XXI - as entidades associativas, quando expressamente autorizadas, têm legitimidade para representar seus filiados judicial ou extrajudicialmente" (BRASIL. Constituição da República Federativa do Brasil, de 05 de outubro de 1988. Brasília, DF: Senado, 1988, grifo nosso).

195 “Art. 8. ' É livre a associação profissional ou sindical (...)”(ibidem, grifo nosso). 
Constituição, aqueles que especificam a participação da sociedade no provimento das necessidades sociais, outros que expressamente prevêem o princípio da justiça social como balizador das relações sociais, entre outros, que somados fixam os espaço de participação do Terceiro Setor.

A começar pelo artigo $6^{\circ}$, que arrola os direitos sociais dos cidadãos para depois tratar deles individualmente, in verbis: “Art. 6. 'São direitos sociais a educação, a saúde, o trabalho, o lazer, a segurança, a previdência social, a proteção à maternidade e à infância, a assistência aos desamparados, na forma desta Constituição".

A grande diferença que se percebe no texto da Constituição de 1988 é exatamente a sua preocupação com as questões sociais, voltando-se a garantir antes o bem-estar e a justiça social do que qualquer outro interesse privatista. É o que se observa textualmente dos artigos $170^{196}$ e $193^{197}$, que ao tratarem da ordem econômica e social estabelecem como seus princípios a existência digna, a justiça social, o primado do trabalho, o bemestar social, entre outros com o mesmo grau de importância. São conceitos que permeiam os debates teóricos do Terceiro Setor.

De qualquer forma, mesmo sendo importantes tais dispositivos para a análise ora proposta, maior detidão ainda deve ser dispensada àqueles dispositivos que prevêem a participação da iniciativa privada em atividades consideradas de interesse social.

A seguridade social, por exemplo, que compreende ações relativas à saúde, à previdência social e à assistência social, é expressamente de responsabilidade tanto do Estado como da própria sociedade. O artigo 194, da Constituição Federal, dispõe in verbis que "a seguridade social compreende um conjunto integrado de ações de iniciativa dos poderes públicos e da sociedade, destinadas a assegurar os direitos relativos à saúde, à previdência e à assistência social".

Mais especificamente na área da saúde, que é de relevância pública, o artigo $197^{198}$ é enfático ao dispor que sua execução deve ser feita também por pessoa física ou jurídica

\footnotetext{
196 “Art. 170. A ordem econômica, fundada na valorização do trabalho humano e na livre iniciativa, tem por fim assegurar a todos existência digna, conforme os ditames da justiça social, observados os seguintes princípios" (ibidem).

197 “Art. 193. A ordem social tem como base o primado do trabalho, e como objetivo o bem-estar e a justiça sociais" (ibidem).

198 “Art. 197. São de relevância pública as ações e serviços de saúde, cabendo ao poder público dispor, nos termos da lei, sobre sua regulamentação, fiscalização e controle, devendo sua execução ser feita diretamente ou através de terceiros e, também, por pessoa física ou jurídica de direito privado" (ibidem).
} 
de direito privado, inclusive através de serviços assistenciais e da participação da comunidade, conforme expressa o artigo $198 .^{199}$

Aliás, o artigo 199 da Constituição de 1988 faz expressa menção à participação de instituições privadas filantrópicas e sem fins lucrativos em ações de assistência à saúde:

Art. 199. A assistência à saúde é livre à iniciativa privada.

$\S 11^{\circ}$ As instituições privadas poderão participar de forma complementar do sistema único de saúde, segundo diretrizes deste, mediante contrato de direito público ou convênio, tendo preferência as entidades filantrópicas e as sem fins lucrativos.

$\S 2 .^{\circ}$ É vedada a destinação de recursos públicos para auxílios ou subvenções às instituições privadas com fins lucrativos.

$\S 3 .^{\circ}$ É vedada a participação direta ou indireta de empresas ou capitais estrangeiros na assistência à saúde no País, salvo nos casos previstos em lei.

No mesmo sentido, na área da assistência social ${ }^{200}$ a possibilidade de participação da iniciativa privada é imperativo constitucional, o que se observa pela leitura do artigo 204, da Constituição Federal:

Art. 204. As ações governamentais na área da assistência social serão realizadas com recursos do orçamento da seguridade social, previstos no art. 195, além de outras fontes, e organizadas com base nas seguintes diretrizes:

(...)

II - participação da população, por meio de organizações representativas, na formulação das políticas e no controle das ações em todos os níveis.

Tem-se, até aqui, que o desenvolvimento do Terceiro Setor a partir da Constituição de 1988 tem motivo de ser. Efetivamente, os dispositivos constitucionais que abrem margem à participação da iniciativa privada em ações de interesse social têm larga evolução em 1988, legitimando a atuação destas instituições e incentivando a participação da sociedade nas questões sociais.

Não é diferente quando se trata do direito à educação:

\footnotetext{
199 “Art. 198. As ações e serviços públicos de saúde integram uma rede regionalizada e hierarquizada e constituem um sistema único, organizado de acordo com as seguintes diretrizes: (...) II - atendimento integral, com prioridade para as atividades preventivas, sem prejuízo dos serviços assistenciais; III - participação da comunidade" (ibidem).

${ }^{200} \mathrm{O}$ artigo 203 estabelece o alcance da assistência social: "Art. 203. A assistência social será prestada a quem dela necessitar, independentemente de contribuição à seguridade social, e tem por objetivos: I - a proteção à família, à maternidade, à infância, à adolescência e à velhice; II - o amparo às crianças e adolescentes carentes; III - a promoção da integração ao mercado de trabalho; IV - a habilitação e reabilitação das pessoas portadoras de deficiência e a promoção de sua integração à vida comunitária; V - a garantia de um salário mínimo de benefício mensal à pessoa portadora de defíciência e ao idoso que comprovem não possuir meios de prover à própria manutenção ou de tê-la provida por sua família, conforme dispuser a lei" (ibidem).
} 
Art. 205. A educação, direito de todos e dever do Estado e da família, será promovida e incentivada com a colaboração da sociedade, visando ao pleno desenvolvimento da pessoa, seu preparo para o exercício da cidadania e sua qualificação para o trabalho.

Fundamentada nos ditames de solidariedade e cidadania, a Constituição de 1988 invoca a colaboração da sociedade para a promoção da educação, inclusive prevendo formas de repasse de verbas a escolas particulares de natureza filantrópica e sem finalidade lucrativa, a exemplo do quanto é feito com as escolas públicas. ${ }^{201}$

Semelhante regulamentação socorre matérias como a cultura, o desporto e o meio ambiente, todos elevados à condição de direito constitucionalmente garantido e provido mediante a participação da sociedade. ${ }^{202}$

E a Constituição de 1988 vai além, enfatizando a responsabilidade conjunta do Estado e da sociedade na promoção de ações sociais para a infância, os adolescentes e os idosos em seus artigos 227 e $230^{203}$, confirmando sua vocação social e a afirmação de que, realmente, abre bastante espaço para o desenvolvimento das atividades que atualmente têm sido atribuídas ao Terceiro Setor.

Inclusive, o artigo 227 da Constituição Federal de $1988^{204}$, ao atribuir ao Estado, à família e à sociedade o dever de assegurar às crianças e adolescentes o direito à vida, à saúde, à alimentação, à educação, ao lazer, à profissionalização, à cultura, à dignidade, ao

201 “Art. 213. Os recursos públicos serão destinados às escolas públicas, podendo ser dirigidos a escolas comunitárias, confessionais ou filantrópicas, definidas em lei, que: I - comprovem finalidade não lucrativa e apliquem seus excedentes financeiros em educação; II - assegurem a destinação de seu patrimônio a outra escola comunitária, filantrópica ou confessional, ou ao poder público, no caso de encerramento de suas atividades" (ibidem).

202 “Art. 215. O Estado garantirá a todos o pleno exercício dos direitos culturais e acesso às fontes da cultura nacional, e apoiará e incentivará a valorização e a difusão das manifestações culturais. (...) Art. 216. Constituem patrimônio cultural brasileiro os bens de natureza material e imaterial, tomados individualmente ou em conjunto, portadores de referência à identidade, à ação, à memória dos diferentes grupos formadores da sociedade brasileira, nos quais se incluem: (...) $\S 1 .^{\circ} \mathrm{O}$ poder público, com a colaboração da comunidade, promoverá e protegerá o patrimônio cultural brasileiro, por meio de inventários, registros, vigilância, tombamento e desapropriação, e de outras formas de acautelamento e preservação. (...) $\S 3 .^{\circ}$ A lei estabelecerá incentivos para a produção e o conhecimento de bens e valores culturais. (...) Art. 217. É dever do Estado fomentar práticas desportivas formais e não formais, como direito de cada um, observados: (...) $\S$ 3. ${ }^{\circ} \mathrm{O}$ poder público incentivará o lazer, como forma de promoção social. (...) Art. 225. Todos têm direito ao meio ambiente ecologicamente equilibrado, bem de uso comum do povo e essencial à sadia qualidade de vida, impondo-se ao poder público e à coletividade o dever de defendê-lo e preservá-lo para as presentes e futuras gerações. (...) VI - promover a educação ambiental em todos os níveis de ensino e a conscientização pública para a preservação do meio ambiente" (ibidem).

203 “Art. 230. A família, a sociedade e o Estado têm o dever de amparar as pessoas idosas, assegurando sua participação na comunidade, defendendo sua dignidade e bem-estar e garantindo-lhes o direito à vida" (ibidem).

204 “Art. 227. É dever da família, da sociedade e do Estado assegurar à criança e ao adolescente, com absoluta prioridade, o direito à vida, à saúde, à alimentação, à educação, ao lazer, à profissionalização, à cultura, à dignidade, ao respeito, à liberdade e à convivência familiar e comunitária, além de colocá-los a salvo de toda forma de negligência, discriminação, exploração, violência, crueldade e opressão.

$\S 1 .^{\circ} \mathrm{O}$ Estado promoverá programas de assistência integral à saúde da criança e do adolescente, admitida a participação de entidades não governamentais e obedecendo aos seguintes preceitos" (ibidem). 
respeito, à liberdade e à convivência familiar e comunitária, faz expressa menção à participação de entidades não governamentais.

Por fim, além de a Constituição Federal de 1988 repetir o dispositivo que já aparecia em Constituições anteriores, que representa a isenção religiosa do Estado brasileiro e abre margem à colaboração de interesse público entre os entes federativos e os cultos religiosos ou igrejas (artigo 19) ${ }^{205}$, é relevante o disposto em seus artigos 150, VI, $c$, e $195, \S 7^{\circ}$, que diz respeito à instituição de imunidades tributárias a entidades que figuram entre as participantes do Terceiro Setor, in verbis:

Art. 150. Sem prejuízo de outras garantias asseguradas ao contribuinte, é vedado à União, aos Estados, ao Distrito Federal e aos Municípios: (...)

VI - instituir impostos sobre: (...)

c) patrimônio, renda ou serviços dos partidos políticos, inclusive suas fundações, das entidades sindicais dos trabalhadores, das instituições de educação e de assistência social, sem fins lucrativos, atendidos os requisitos da lei; (...)

$\S 4 .^{\circ}$ As vedações expressas no inciso VI, alíneas $b$ e $c$, compreendem somente o patrimônio, a renda e os serviços relacionados com as finalidades essenciais das entidades nelas mencionadas.

Art. 195. A seguridade social será financiada por toda a sociedade, de forma direta e indireta, nos termos da lei, mediante recursos provenientes dos orçamentos da União, dos Estados, do Distrito Federal e dos Municípios, e das seguintes contribuições sociais: (...)

$\S 7 .^{\circ}$ São isentas de contribuição para a seguridade social as entidades beneficentes de assistência social que atendam às exigências estabelecidas em lei.

Extraímos, destas considerações fundamentadas na Constituição Federal de 1988, que o Terceiro Setor encontra âmbito de atuação constitucionalmente delimitado; das noções principiológicas que fundamentam a atuação do Terceiro Setor, como o princípio da solidariedade social antes apresentado, passando pelos objetivos da República Federativa do Brasil, pelo princípio da liberdade de associação, chegando mais especificamente aos dispositivos que expressamente prevêem uma regulamentação constitucional da atuação de entidades sem fins lucrativos em determinadas áreas, verificase que juridicamente é sustentável a fixação de um espaço de participação do Terceiro Setor.

E destes elementos podemos dizer que o dito espaço de participação do Terceiro Setor está no exercício de direitos fundamentais e na defesa do conteúdo constitucional.

205 “Art. 19. É vedado à União, aos Estados, ao Distrito Federal e aos Municípios: I - estabelecer cultos religiosos ou igrejas, subvencioná-los, embaraçar-lhes o funcionamento ou manter com eles ou seus representantes relações de dependência ou aliança, ressalvada, na forma da lei, a colaboração de interesse público" (ibidem). 
Ao Terceiro Setor é dada a função constitucional, fundada na idéia de Democracia Solidária, de executar ações que visem à prestação e à garantia dos direitos fundamentais, ${ }^{206}$ assim como, como expressão máxima da sociedade justa e solidária proposta por nossa República Federativa, que visem à defesa do conteúdo constitucional, garantindo-se o nosso Estado Constitucional.

\subsection{Natureza jurídica das atividades inseridas no espaço de participação do Terceiro} Setor

Como sustentado no tópico anterior, é possível extrair da Constituição Federal de 1988 a existência de um espaço de participação do Terceiro Setor, ou seja, um conteúdo constitucional material dedicado a delimitar a atuação das entidades privadas sem fins lucrativos a ponto de permitir a sua caracterização minimamente unívoca para fins da caracterização de um Terceiro Setor.

Esta definição é importante na medida em que auxilia, para o presente trabalho, na definição de um dos nossos objetos de estudo; para além dos limites deste trabalho, auxilia na sistematização deste objeto de estudo, cuja autonomia vem ganhando forças nos últimos anos. $^{207}$

Este espaço de participação do Terceiro Setor, como apresentado, pode ser dividido em duas vertentes de atuação: (i) exercício de direitos fundamentais; e (ii) defesa do conteúdo constitucional.

O chamado exercício de direitos fundamentais significaria a execução de atividades destinadas à promoção ou garantia de um direito fundamental, inseridas materialmente na função constitucional outorgada ao Terceiro Setor.

${ }^{206}$ Cf. SCHOENMAKER, Janaína. O Terceiro Setor e a proteção dos direitos fundamentais. Revista de Direito do Terceiro Setor - RDTS, Belo Horizonte : Fórum, ano 1, n. 2, jul.-dez. 2007, pp. 25-50; BRAGA, Luziânia C. Pinheiro. Organizações da Sociedade Civil de Interesse Público (OSCIP): promoção e construção de (novos) direitos e assessoria jurídica de caráter suplementar. In: OLIVEIRA, Gustavo Justino de (coord.). Terceiro Setor, empresas e Estado: novas fronteiras entre o público e o privado. Belo Horizonte : Fórum, 2007, pp. 261-280.

207 "Diante de toda a argumentação levada a efeito neste trabalho, parece evidente que somente a um ramo jurídico especial e autônomo cumpriria o adequado estudo, entre outros aspectos: (a) do conceito de Terceiro Setor; (b) das formas de constituição, organização e funcionamento das entidades privadas não lucrativas que dele fazem parte; (c) das diferentes finalidades sociais dessas entidades; (d) das possíveis certificações estatais que podem ser conferidas a essas entidades, assim como os efeitos decorrentes dessas certificações; (e) das atividades de relevância pública por tais entidades desenvolvidas; (f) das formas de atuação isolada ou colaborativas (em parceria) dessas entidades; (g) das relações de trabalhos travadas entre tais entidades e as pessoas físicas, com especial destaque ao voluntariado; (h) da tributação dessas entidades; (i) das formas e dos instrumentos de fiscalização e de controle dessas entidades" (OLIVEIRA, Gustavo Justino de. Direito do Terceiro Setor. Revista de Direito do Terceiro Setor - RDTS, Belo Horizonte : Fórum, ano 1, n. 1, jan.-jun. de 2007, p. 34). 
A outra vertente de atuação do Terceiro Setor constitucionalmente prevista seria a defesa do conteúdo constitucional, que ao contrário do conteúdo positivo do exercício de direitos fundamentais estaria destinada ao exercício da atividade de advocacy, assim entendido como a atividade de "defesa de direitos e a construção de novos direitos". ${ }^{208}$ São duas formas de atuação distintas: a primeira de conteúdo prestacional e a segunda de conteúdo garantidor.

Ambas as faces de atuação do Terceiro Setor constitucionalmente asseguradas e ora apontadas não podem ser consideradas como sua exclusividade; tanto as atividades prestacionais do Terceiro Setor quanto aquelas garantidoras podem ser desenvolvidas por outros atores de nosso cenário social.

Veja-se, por exemplo, que a prestação de atividades de saúde, que se inclui como uma faceta da atuação prestacional constitucionalmente consagrada ao Terceiro Setor já que tem como conteúdo material um direito fundamental, não é exclusividade sua. Ao próprio Estado é outorgada esta responsabilidade assim como empresas podem se imiscuir nesta atividade.

Exemplo de atividade garantidora que pode ser desenvolvida pelo Terceiro Setor é a defesa dos direitos do consumidor, embora seja atividade também passível de atuação do próprio Estado (órgãos de proteção do consumidor, como o Procon).

Importa destacar, também, que a atividade prestacional do Terceiro Setor na área dos direitos fundamentais está delimitada pelos artigos $5^{\circ}$ a 17 , da Constituição Federal de 1988, além da extensão constitucional dos direitos sociais contida no Título VIII (Da Ordem Social).

A separação formal destes dispositivos relativos aos direitos sociais é mera questão de técnica legislativa. ${ }^{209} \mathrm{O}$ que se vê, na acepção de José Afonso da Silva, é que os direitos sociais insculpidos nos artigos $6^{\circ}$ a 11 da Constituição são conteúdo da ordem social estabelecida no Título VIII da Constituição (artigos 193 a 232). ${ }^{210}$

\footnotetext{
${ }^{208}$ PIOVESAN, Flávia; BARBIERI, Carla Bertucci. Terceiro Setor e direitos humanos. In: CARVALHO, Cristiano; PEIXOTO, Marcelo Magalhães (coord.). Aspectos jurídicos do Terceiro Setor. $2^{\mathrm{a}}$ ed. São Paulo : APET : MP Editora, 2008, p. 103.

209 José Afonso da Silva entende que "cindindo-se a matéria, como se fez, o constituinte não atendeu aos melhores critérios metodológicos, mas dá ao jurista a possibilidade de extrair, daqui e de lá, aquilo que constitua o conteúdo dos direitos relativos a cada um daqueles objetos sociais, deles tratando aqui, deixando para tratar, na ordem social, de seus mecanismos e aspectos organizacionais" (SILVA, José Afonso da. Curso de direito constitucional positivo. $18^{a}$ ed. São Paulo : Malheiros, 2000, p. 288).

${ }^{210}$ Nos dizeres do autor: "Mas não ocorre uma separação radical, como se os direitos sociais não fossem algo ínsito na ordem social. $\mathrm{O}$ art. $6^{\circ}$ mostra muito bem que aqueles são conteúdo desta, quando diz que são direitos sociais a educação, a saúde, o trabalho, a moradia, o lazer, a segurança, a previdência social, a
} 
Portanto, os artigos $6^{0}$ a 11 da Constituição Federal são explícitos em definir os direitos sociais por ela abarcados, quais sejam a educação, a saúde, o trabalho, a moradia, o lazer, a segurança, a previdência social, a proteção à maternidade e à infância, a assistência aos desamparados. E quando o faz, remete-se à regulamentação da própria Constituição para a completa definição dos direitos sociais, ao dizer que assim o serão na forma desta Constituição.

Esta remissão é que aproxima o capítulo da ordem social à definição dos direitos sociais. $\mathrm{O}$ artigo $6^{\mathrm{o}}$ da Constituição se remete às definições de seu Título VIII para a completa delimitação dos direitos sociais previstos no ordenamento jurídico brasileiro. E no Título VIII a Constituição vai além da regulamentação dos direitos sociais insculpidos no artigo $6^{\circ}$, estendendo o rol dos direitos sociais através da inclusão dos tópicos cultura, desporto, ciência e tecnologia, comunicação social, meio ambiente e índios.

Mas além dos chamados direitos sociais previstos nos artigos $6^{\circ}$ a 11 e no Título VIII, da Constituição, pertencem ao espaço de participação prestacional do Terceiro Setor os direitos e garantias individuais e coletivos previstos no artigo $5^{\circ}$, além dos direitos civis (artigos 12 e 13) e dos direitos políticos (artigos 14 a 17), embora nestas matérias a atividade prestacional seja bastante reduzida.

A atividade garantidora - ou jurídica - afeta ao Terceiro Setor, por sua vez, deve ter como conteúdo material todo o texto constitucional.

Resta saber, então, qual a natureza jurídica das atividades constitucionalmente outorgadas ao Terceiro Setor, ou seja, aquelas atividades inseridas constitucionalmente em seu espaço de participação.

\subsubsection{Natureza jurídica da atividade prestacional do Terceiro Setor}

A começar com o conteúdo prestacional da atividade possível de ser desenvolvida pelo Terceiro Setor, não há dúvida de que insere dentre as possibilidades de prestação de serviços ao cidadão. Ao passo que consideramos que esta atividade prestacional está limitada materialmente, na atuação do Terceiro Setor, pelo conteúdo dos direitos fundamentais, impende inseri-la na delimitação constitucional dos tipos de atividades que podem ser desenvolvidas em nossa sociedade e a sua natureza, para posteriormente

proteção à maternidade e à infância, a assistência aos desamparados, na forma desta Constituição. Esta forma é dada precisamente no título da ordem social" (ibidem, p. 288). 
definirmos qual a sua natureza jurídica e, via de conseqüência, qual o impacto desta conclusão no regime jurídico a que tais atividades devem se submeter.

Para tanto devemos partir de um dos paradigmas mais intrincados do Direito Administrativo brasileiro, que expressa a repartição das esferas de ação do Estado e da sociedade, que é a dicotomia entre serviço público e atividade econômica.

Paulo Modesto resume a explicação deste paradigma da seguinte forma:

A dicotomia serviço público/atividade de exploração econômica tem base na clássica dicotomia entre Estado/Sociedade e entre interesse público/interesse privado. De fato, como em outros países, é tradicional no direito administrativo brasileiro a identificação entre os órgãos do Estado e as tarefas públicas. Segundo este paradigma, a administração pública de todos os Poderes, nas diversas unidades da Federação, monopoliza a prestação de serviços de natureza pública. Por outro lado, os particulares são detentores do domínio sobre a atividade econômica em sentido estrito, cumprindo ao Estado tarefas de agente normativo e regulador da atividade econômica, com funções de fiscalização, incentivo e planejamento. Ao Estado é vedado substituir os particulares na atuação direta na economia, salvo em casos excepcionais envolvendo a segurança nacional ou a relevante interesse coletivo, definido em lei. Os particulares podem exercitar atividade públicas apenas como delegados do Estado. ${ }^{211}$

Trazendo a explicação para o conteúdo constitucional temos que o artigo 175 outorga ao Estado a prestação de serviços públicos, diretamente ou por delegação através de licitação. ${ }^{212} \mathrm{O}$ Estado, então, seria o detentor ordinário da competência constitucional de prestação de serviços públicos, enquanto os particulares só poderia atuar nesta esfera emcaráter excepcional, por delegação, submetendo-se ao regime de direito público.

$\mathrm{O}$ artigo 173, por sua vez, em análise conjunto com o artigo 170, outorga à iniciativa privada a exploração ordinária da atividade econômica. O Estado, neste caso, tem severas restrições constitucionais, podendo explorar diretamente uma atividade econômica somente em situações excepcionais. ${ }^{213}$

\footnotetext{
${ }^{211}$ MODESTO, Paulo. Reforma do Estado, formas de prestação de serviços ao público e parcerias públicoprivadas: demarcando as fronteiras dos conceitos de serviço público, serviços de relevância pública e serviços de exploração econômica para as parcerias público-privadas. Revista Eletrônica de Direito Administrativo Econômico, Salvador : Instituto de Direito Público da Bahia, n. 2, mai.-jun.-jul. 2005. Disponível na Internet: <http://www.direitodoestado.com.br>. Acesso em: 08 mar. 2010.

212 "Art. 175. Incumbe ao Poder Público, na forma da lei, diretamente ou sob regime de concessão ou permissão, sempre através de licitação, a prestação de serviços públicos" (BRASIL. Constituição da República Federativa do Brasil, de 05 de outubro de 1988. Brasília, DF: Senado, 1988).

213 "Art. 170. A ordem econômica, fundada na valorização do trabalho humano e na livre iniciativa, tem por fim assegurar a todos existência digna, conforme os ditames da justiça social, observados os seguintes princípios: (...). Art. 173. Ressalvados os casos previstos nesta Constituição, a exploração direta de atividade econômica pelo Estado só será permitida quando necessária aos imperativos da segurança nacional ou a relevante interesse coletivo, conforme definidos em lei" (BRASIL. Constituição da República Federativa do Brasil, de 05 de outubro de 1988. Brasília, DF: Senado, 1988).
} 
Considerando estas características, qual seria a natureza jurídica das atividades prestacionais em matéria de direitos fundamentais, desempenhadas pelo Terceiro Setor por determinação constitucional? Seriam serviços públicos ou atividade econômica? Ou uma terceira espécie?

Para tanto, mister adentrarmos inicialmente na complicada tentativa de definição conceitual de serviços públicos. ${ }^{214}$ Como nos orienta Maria Sylvia Zanella Di Pietro, há quem considere o serviço público em sentido amplo, abrangendo todas as atividades do Estado, e quem o considere em sentido restrito.

Restritos são os conceitos que confinam o serviço público entre as atividades exercidas pela Administração Pública, com exclusão das funções legislativa e jurisdicional; e, além disso, o consideram como uma das atividades administrativas, perfeitamente distinta do poder de polícia do Estado. ${ }^{215}$

A exclusão das atividades legislativas e jurisdicionais é explicada por Alexandre Santos de Aragão sob o argumento da necessidade de "haver algo quantitativa e qualitativamente comum aos regimes jurídicos dessas diversas atividades que justifique a colocação de todas elas sob o mesmo conceito geral"216, e continua asseverando que

por essas razões, desde já devemos, por total diversidade de regimes jurídicos, excluir do conceito de serviço público as atividades legislativas (edição de normas gerais e abstratas pelo Poder Legislativo) e jurisdicionais (composição definitiva de conflitos), voltando-se a pesquisa doravante apenas às atividades administrativas. ${ }^{217}$

Restringindo a esfera dos serviços públicos às atividades administrativas, ou seja, aos serviços desenvolvidos pela Administração Pública, cabe ainda a ressalva feita por Maria Sylvia Zanella Di Pietro, acima citada, de que o serviço público é uma das atividades administrativas, distinta do poder de polícia do Estado. ${ }^{218}$ Estas restrições

\footnotetext{
214 "Não é tarefa fácil definir o serviço público, pois a sua noção sofreu consideráveis transformações no decurso do tempo, quer no que diz respeito aos seus elementos constitutivos, quer no que concerne à sua abrangência" (DI PIETRO, Maria Sylvia Zanella. Direito Administrativo. 19a ed. São Paulo : Atlas, 2006, p. 110).

${ }_{215}$ Ibidem, p. 111, negrito no original.

${ }^{216}$ ARAGÃ O, Alexandre Santos de. Direito dos serviços públicos. Rio de Janeiro : Forense, 2007, p. 130.

${ }^{217}$ Ibidem, p. 130.

${ }^{218}$ A autora cita a distinção entre atividade jurídica e atividade social: "Parte-se da distinção entre atividade jurídica e atividade social. Na primeira, consoante ensinamento de Caio Tácito (1975:198-199) 'atende-se à preservação do direito objetivo, à ordem pública, à paz e à segurança coletivas'; corresponde ao poder de polícia. Na atividade social, ao contrário, 'a Administração cuida de assuntos de interesse coletivo, visando ao bem-estar e ao progresso social, mediante o fornecimento de serviços aos particulares'. Equivale aos serviços públicos propriamente ditos" (DI PIETRO, Maria Sylvia Zanella. Op. cit., p. 111, destaques no original).
} 
trariam ao conteúdo do conceito de serviço público a limitação às atividades materiais. É exatamente neste sentido que Maria Sylvia Zanella Di Pietro o conceitua, como

toda atividade material que a lei atribui ao Estado para que a exerça diretamente ou por meio de seus delegados, com o objetivo de satisfazer concretamente às necessidades coletivas, sob regime jurídico total ou parcialmente público. ${ }^{219}$

Observe-se que neste conceito não se incluem as outras atividades administrativas, como o poder de polícia, o fomento e a intervenção.

Os elementos da definição adotada pela autora ${ }^{220}$, a qual utilizamos doravante, são os seguintes: a) elemento subjetivo: "o serviço público é sempre incumbência do Estado, conforme está expresso, aliás, no artigo 175 da Constituição Federal, e sempre depende do Poder Público" ${ }^{221}$, direta ou indiretamente mediante concessão ou permissão; b) elemento formal: regime jurídico definido por lei; c) elemento material: necessidades públicas.

Estes elementos também podem ser encontrados no conceito proposto por Alexandre Santos de Aragão, para quem

serviços públicos são as atividades de prestação de utilidades econômicas a indivíduos determinados, colocadas pela Constituição ou pela Lei a cargo do Estado, com ou sem reserva de titularidade, e por ele desempenhadas diretamente ou por seus delegatários, gratuita ou remuneradamente, com vistas ao bem-estar da coletividade. ${ }^{222}$

Temos, por estes conceitos, que o serviço público será assim considerado se, mesmo sem reserva de titularidade, seja desempenhado pelo Estado (ou seu delegatário); significa dizer que materialmente o serviço público não é exclusividade estatal

o poder público pode deixar que o particular exerça livremente a atividade, lado a lado com a Administração Pública (caso do ensino, da ação sanitária e social), repartindo entre uns e outros a satisfação da mesma necessidade. Daí a classificação dos serviços públicos em exclusivos e não exclusivos do Estado. ${ }^{223}$

Existem, então, os serviços públicos cujo Estado é o titular exclusivo, e aqueles que embora possam ser prestados pelo Estado também o podem ser pela iniciativa privada. Os

\footnotetext{
${ }^{219}$ Ibidem, p. 114, negrito no original.

${ }^{220}$ Ibidem, pp. 114 e ss.

${ }^{221}$ Ibidem, p. 115.

${ }^{222}$ ARAGÃO, Alexandre Santos de. Direito dos serviços públicos. Rio de Janeiro : Forense, 2007, p. 157, destaques no original.

${ }^{223}$ DI PIETRO, Maria Sylvia Zanella. Op. cit., p. 110, negrito no original.
} 
serviços públicos exclusivos serão considerados serviço público quando prestado pelo Estado ou por delegatário. Mas isto não significa que os serviços públicos não exclusivos, quando prestados pela iniciativa privada, continuam se enquadrando no conceito de serviços públicos. Os serviços públicos não exclusivos só podem ser considerados serviço público quando desempenhados pelo Estado ou por delegatário; quando desempenhados pela iniciativa privada no exercício de seu direito próprio, constitucionalmente previsto, não há que se considerá-lo serviço público. "O importante para o conceito é a responsabilidade do Estado sobre a atividade, a sua obrigação em prestá-la, com ou sem exclusão da atuação por direito próprio dos empresários privados". ${ }^{224}$

Já fazendo a interface com o Terceiro Setor podemos, neste momento, considerar que quando o Estado desenvolve atividades prestacionais em matéria de direitos fundamentais, está prestando serviço público. ${ }^{225}$ Quando o Estado desempenha esta atividade prestacional através de delegatária, está prestando serviço público. Quando a iniciativa privada presta serviços relativos aos direitos fundamentais, no entanto, atividade não exclusiva do Estado, não há que se falar em serviços públicos porque está exercendo direito próprio, não por delegação.

Afastada, portanto, a caracterização das atividades prestacionais desenvolvidas pelo Terceiro Setor, no âmbito de seu espaço de participação, na categoria de serviços públicos. Resta saber se tais atividades devem ser consideradas como atividade econômica ou estamos diante de uma categoria própria.

Para tanto partimos da seguinte noção apresentada por Eros Roberto Grau:

Inexiste, em um primeiro momento, oposição entre atividade econômica e serviço público; pelo contrário, na segunda expressão está subsumida a primeira. Podemos afirmar que a prestação de serviço público está voltada à satisfação de necessidades, o que envolve a utilização de bens e serviços, recursos escassos. Daí por que serviço público é um tipo de atividade econômica. $^{226}$

A reforçar esta idéia, Marçal Justen Filho aponta que

\footnotetext{
${ }^{224}$ ARAGÃO, Alexandre Santos de. Op. cit., p. 161.

${ }^{225}$ Estes serviços públicos se enquadram na classificação de serviços públicos sociais: "Serviço público social é o que atende a necessidades coletivas em que a atuação do Estado é essencial, mas que convivem com a iniciativa privada, tal como ocorre com os serviços de saúde, educação, previdência, cultura, meio ambiente: são tratados na Constituição no capítulo da ordem social e objetivam atender aos direitos sociais do homem, considerados direitos fundamentais pelo artigo $6^{\circ}$ da Constituição" (DI PIETRO, Maria Sylvia Zanella. Op. cit., p. 123).

226 GRAU, Eros Roberto. Constituição e serviço público. In: Direito Constitucional: estudos em homenagem a Paulo Bonavides. São Paulo : Malheiros, 2003, p. 250.
} 
A questão do serviço público apresenta uma faceta econômica, na medida em que envolve uma alocação de recursos materiais (escassos) para satisfação de certas necessidades humanas. Como esses recursos materiais comportam diferentes destinações, impõe-se escolher um destino para eles, dentre os diversos possíveis. Considerando o tema sob o prisma da opção por uma certa destinação para os recursos materiais, tem de reconhecer-se que o serviço público apresenta uma manifestação de cunho econômico. Aliás, sob esse enfoque não há maior diferença entre serviço público e atividade econômica. Em todos os casos, encontra-se diante da relação entre recursos materiais escassos e fins potencialmente excludentes entre si a satisfazer. ${ }^{227}$

Estas constatações se prestam a demonstrar que os conceitos de serviço público e atividade econômica não são um modelo de soma zero ${ }^{228}$, ou seja, não se pode dizer que tudo o que é serviço público não é atividade econômica, e vice-versa. Os conceitos se interpenetram, embora a importância de definir a que categoria pertence cada atividade desenvolvida, com repercussão sobre o regime jurídico aplicado. Ou seja, embora se diga que os serviços públicos não deixem de ser atividade econômica, não deixa de ser serviço público e de se submeter, portanto, ao regime jurídico de direito público.

Mas e quanto às atividades prestacionais desenvolvidas pelo Terceiro Setor, que como vimos não é serviço público - salvo quando na condição de delegatária -, podemos inseri-las na categoria das atividades econômicas? Em nosso sentir não é a melhor solução.

A Constituição Federal é bastante clara ao regulamentar o regime jurídico em que se inserem as atividades econômicas, criando o Título específico (Título VII da Constituição) intitulado Da ordem econômica e financeira, especialmente no Capítulo I Dos princípios gerais da atividade econômica.

Este Título da Ordem Econômica é expressamente voltado, portanto, à regulação da categoria jurídica das atividades econômicas, cuja titularidade é da iniciativa privada (art. 173) e que pode ser exercida em regime de exceção pelo Poder Público.

Ocorre que os dispositivos constitucionais que definem a atuação da iniciativa privada e do Estado no exercício de atividades econômicas indica que estas estão delimitadas pela noção de atividades empresariais, ou seja, voltadas à obtenção de lucro. É o que se observa de diversas passagens constitucionais.

\footnotetext{
${ }^{227}$ JUSTEN FILHO, Marçal Justen. Teoria geral das concessões de serviço público. São Paulo : Dialética, 2003 , p. 19.

${ }^{228}$ Expressão utilizada por Paulo Modesto (MODESTO, Paulo. Reforma do Estado, formas de prestação de serviços ao público e parcerias público-privadas: demarcando as fronteiras dos conceitos de serviço público, serviços de relevância pública e serviços de exploração econômica para as parcerias público-privadas. Revista Eletrônica de Direito Administrativo Econômico, Salvador : Instituto de Direito Público da Bahia, n. 2, mai-jun-jul. 2005. Disponível na Internet: $<$ http://www.direitodoestado.com.br $>$. Acesso em: 08 de março de 2010.
} 
A começar pelo artigo 172, que faz expressa menção à expressão lucros, elemento que não está presente na atuação das entidades do Terceiro Setor. O artigo 173, II, por sua vez, estabelece que as empresas públicas e as sociedades de economia mista se submeterão ao regime jurídico das empresas privadas. $\mathrm{O}$ mesmo artigo, em seu $\S 4^{\circ}$, outorga à lei, no âmbito da regulamentação da ordem econômica, a repressão ao aumento arbitrário dos lucros. Estes dispositivos dão indícios bastante claros de que o objeto da regulamentação proposta pela Constituição Econômica ${ }^{229}$ são as atividades lucrativas. Como ilustra José Afonso da Silva

a ordem econômica, configurada na Constituição, prevê apenas algumas medidas e princípios que, bem lembrou Josaphat Marinho em termos válidos ainda, 'poderão sistematizar o campo das atividades criadoras e lucrativas e reduzir desigualdades e anomalias diversas, na proporção em que as leis se converterem em instrumentos reais de correção das contradições de interesses privados. Mas, desses princípios e medidas advêm soluções de transição, apenas moderadoras dos excessos do capitalismo. São fórmulas tecnocráticas e neocapitalistas, que não suprimem as bases da ordem econômica individualista, fundada no poder privado de domínio dos meios de produção e dos lucros respectivos. ${ }^{230}$

Reforça esta idéia o entendimento de Eros Roberto Grau, para quem “pretende o capital reservar para sua exploração, como atividade econômica em sentido estrito, todas as matérias que possam ser, imediata ou potencialmente, objeto de profícua especulação lucrativa". 231

O mesmo autor, aliás, em trecho de voto proferido em julgamento do Pleno do Supremo Tribunal Federal, manifesta entendimento de que a atividade econômica deve ser entendida como atividade empresarial. ${ }^{232}$

\footnotetext{
${ }^{229}$ Expressão utilizada por José Afonso da Silva para significar a "parte da Constituição Federal que contém os direitos que legitimam a atuação dos sujeitos econômicos, o conteúdo e limites desses direitos e a responsabilidade que comporta o exercício da atividade econômica" (SILVA, José Afonso da. Curso de Direito Constitucional Positivo. $18^{\mathrm{a}}$ ed. São Paulo : Malheiros, 2000, p. 769)

${ }^{230}$ Ibidem, pp. 766-767.

${ }^{231}$ GRAU, Eros Roberto. A ordem econômica na Constituição de 1988. $5^{\text {a }}$ ed. São Paulo : Malheiros, 2000, p. 140. Também sobre o tema da lucratividade, embora de forma indireta, trata Marçal Justen Filho, para quem "a lucratividade da entidade estatal tem de ser compatível com sua natureza funcional. A entidade deverá produzir benefícios para a sociedade, satisfazendo interesses coletivos relevantes e promovendo a segurança nacional. Ademais disso, deverá ser um instrumento - indireto - de cumprimento por parte do Estado de seus compromissos com a sociedade" (JUSTEN FILHO, Marçal. Curso de Direito Administrativo. $2^{\text {a }}$ ed. São Paulo : Saraiva, 2006, p. 576).

232 "Por isso não é adversa à Constituição a existência ou desenvolvimento de uma atividade econômica sem que a propriedade do bem empregado no processo produtivo ou comercial seja concomitantemente detida pelo agente daquela atividade --- o que também é afirmado por FÁBIO KONDER COMPARATO. Dizendoo de outro modo: o conceito de atividade econômica [enquanto atividade empresarial] prescinde da propriedade dos bens de produção" (SUPREMO TRIBUNAL FEDERAL, ADI 3366-2, Tribunal Pleno, Relator para acórdão Min. Eros Grau, DJ 02/03/2007).
} 
Vale também, em defesa do quanto sustentado, trecho do voto do Ministro Carlos Velloso no julgamento do Recurso Extraordinário n. 424-227-3, para quem:

no que concerne à distinção que deve ser feita, relativamente às empresas públicas que exercem atividade empresarial das empresas públicas prestadoras de serviço, reporto-me ao voto que proferi por ocasião do julgamento do RE 230.072/RS: '(...) Srs. Ministros, o meu entendimento, que vem de longe, mencionado, aliás, pelo eminente Ministro Sepúlveda Pertence, é no sentido de distinguir empresa pública que presta serviço público de empresa pública que exerce atividade econômica, atividade empresarial, concorrendo com empresas privadas. ${ }^{233}$

As menções que equiparam a atividade econômica à atividade empresarial têm como conseqüência a aceitação do elemento lucro como indispensável à configuração do conjunto de atividades a que se destina a ordem econômica constitucional. Vejamos.

Não obstante o conceito de empresa não ser unânime no ordenamento jurídico brasileiro, o Código Civil, no Livro II de sua Parte Especial (art. 966 a art. 1.195) incluiu em seu objeto de regulamentação o que chama de Direito de Empresa ${ }^{234}$.

Inicialmente, o artigo 966 do Código Civil atual conceitua o que considera empresário, que seria "quem exerce profissionalmente atividade econômica organizada para a produção ou a circulação de bens ou de serviços”. Delimitando ainda a conceituação do que seja empresário, o diploma legal determina, no parágrafo único deste mesmo artigo, que "não se considera empresário quem exerce profisssão intelectual, de natureza científica, literária ou artística, ainda com o concurso de auxiliares ou colaboradores, salvo se o exercício da profissão constituir elemento de empresa".

Importante também para delimitar o novo contexto trazido pelo Código Civil de 2002, em seu artigo 967, ao estabelecer que “é obrigatória a inscrição do empresário no Registro Público de Empresas Mercantis da respectiva sede, antes do início de sua atividade".

É nestes termos que o Código Civil adota a teoria da empresa em nosso ordenamento jurídico. Veja-se, no entanto, que apesar de adotar a teoria da empresa não formula conceito do que seja empresa, como antes dito.

Não obstante a inexistência de conceito legal determinado de empresa, a doutrina tem se debruçado em sua tentativa e tem reconhecido a importância de sua delimitação, e o

\footnotetext{
${ }^{233}$ SUPREMO TRIBUNAL FEDERAL, Recurso Extraordinário n. 424.227-3, Segunda Turma, Relator Min. Carlos Velloso, DJ 10/09/2004.

${ }^{234}$ Fábio Ulhoa Coelho entende que o nome mais adequado para o Direito Comercial, atualmente, seria Direito Empresarial, em face do âmbito de abrangência deste ramo do conhecimento jurídico (COELHO, Fábio Ulhoa. Curso de direito comercial. $6^{a}$ ed. São Paulo : Saraiva, 2002, vol. 1, p. 13).
} 
conceito legal de empresário auxilia sobremaneira nessa tão almejada possibilidade de conceituação. "Do referido conceito, por via transversa, chega-se ao entendimento do que vem a ser empresa". 235

Notadamente com base nisso, a doutrina tem se inclinado em entender a empresa como a atividade desenvolvida pelo empresário ${ }^{236}$. O empresário seria o sujeito de direito, pessoa física, cuja finalidade seria o exercício de empresa; logo esta se configuraria, conforme o próprio conceito de empresário trazida pelo Código Civil, como a atividade econômica exercida profissionalmente e organizada para a produção ou a circulação de bens ou de serviços.

Apesar de o raciocínio poder parecer um tanto lógico, é importante que se frise que este conceito não reflete a discussão doutrinária em torno deste tema. Mas antes de se completar a variedade de discussões que circunscrevem o conceito de empresa, em sucintas palavras faz-se mister ir adiante nos dispositivos do Código Civil, exatamente com o intuito de buscar elementos para tanto.

Isto se faz através do exame do artigo 982, do Código Civil, que, ao estabelecer que "salvo as exceções expressas, considera-se empresária a sociedade que tem por objeto o exercício de atividade própria de empresário sujeito a registro (art. 967); e, simples, as demais", delimita a dicotomia entre empresário e sociedade empresária, portanto, entre pessoa física que exerce atividade empresarial e sociedade que exerce atividade empresarial $^{237}$. Mas não somente em virtude do artigo 982 se estabelece a dicotomia, haja vista estar estreitamente relacionado com o artigo 981 que dispõe: "celebram contrato de sociedade as pessoas que reciprocamente se obrigam a contribuir, com bens ou serviços, para o exercício de atividade econômica e a partilha, entre si, dos resultados".

Esta sociedade, para ser dotada da característica de sociedade empresária deve se constituir na forma de um dos tipos regulados nos dispositivos que se encontram entre os artigos 1.039 e 1.092 do Código Civil, quais sejam especificamente: (i) sociedade em nome coletivo (art. 1.039 e ss.); (ii) sociedade em comandita simples (art. 1.045 e ss.); (iii) sociedade limitada (art. 1.052 e ss.); (iv) sociedade anônima (art. 1.089 com remissão à Lei n. ${ }^{\circ}$ 6.404/76); e (v) sociedade em comandita por ações (art. 1.090 e ss.).

\footnotetext{
${ }^{235}$ BERTOLDI, Marcelo M.; RIBEIRO, Marcia Carla Pereira. Curso Avançado de Direito Comercial. $3^{\text {a }}$ ed. São Paulo : RT, 2006, p. 50.

${ }^{236}$ Ibidem.

${ }^{237}$ NERY JÚNIOR, Nelson; NERY, Rosa Maria de Andrade. Novo Código Civil e legislação extravagante anotados. São Paulo : RT, 2002, p. 347.
} 
Este é o norte trazido pelo Código Civil no que diz respeito à sua contribuição para a formulação de um conceito de empresa. No entanto, como já foi dito este conceito tem sido objeto de inúmeros debates por parte da doutrina.

Como dito, a doutrina não consegue estabelecer parâmetro seguro para definir empresa, tampouco a legislação o faz. Mesmo com os conceitos trazidos pelo Código Civil, a conceituação de empresa permanece campo dos mais tortuosos a ser percorrido, não tendo sido estabelecido elemento norteador perene para se alcançar esta empreitada.

No entanto, inclina-se a doutrina atual em considerar dois elementos críticos cujos conteúdos seriam fundamentais à conceituação de empresa. O primeiro deles, e também o mais debatido ao longo dos tempos, diz respeito ao conteúdo econômico da empresa, qual seja a obtenção de lucro. O segundo elemento que se tem considerado indispensável à conceituação de empresa é o interesse social de que se reveste ${ }^{238}$.

O primeiro elemento de conceituação da empresa ora debatido, qual seja o seu conteúdo econômico, o que nos importa. Alguns autores fazem expressa referência à obtenção de lucro como elemento indissociável do conceito de empresa. Assim o faz Carvalho de Mendonça, que chega a asseverar que o conteúdo jurídico da empresa e seu conteúdo econômico não se confundem, considerando empresa "a organização técnicoeconômica que se propõe a produzir, mediante a combinação dos diversos elementos, natureza, trabalho e capital, bens ou serviços destinados à troca (venda), com a esperança de realizar lucros",239.

Também tomando como possível fundamento para a conceituação de empresa seu conteúdo econômico exteriorizado no intuito lucrativo, Marcia Carla Pereira Ribeiro assevera que pode ser considerada "a empresa no sentido de meio do qual se utiliza o empresário para a obtenção do lucro" 240 .

Assim, observa-se que quando se fala em atividades econômicas na Constituição Federal, para fins de compreender o conteúdo de nossa Ordem Econômica, deve-se considerar somente as atividades desenvolvidas com finalidade lucrativa.

Outros argumentos reforçam esta tese.

A Lei $n^{\circ}$ 4.137/62, que trata especificamente da repressão ao abuso do poder econômico, apresenta conceituação de empresa como sendo "toda organização de natureza

\footnotetext{
${ }^{238}$ Cf. RIBEIRO, Marcia Carla Pereira. Sociedade de Economia Mista e Empresa Privada: estrutura e função. Curitiba : Juruá, 1999, pp. 170 e ss.

${ }^{239}$ MENDONÇA, J. X. Carvalho de. Tratado de Direito Comercial brasileiro $5^{\text {a }}$ ed., Livraria Freitas Bastos, 1953, vol. 1, p. 492.

${ }^{240}$ RIBEIRO, Marcia Carla Pereira. Op. cit., p. 170.
} 
civil ou mercantil, destinada à exploração por pessoa física ou jurídica de qualquer atividade com fins lucrativos".

Além disso, observa-se que o artigo 173, quando faz menção à exploração direta de atividades econômicas pelo Estado, outorga esta possibilidade somente às empresas públicas e às sociedades de economia mista e suas subsidiárias, em momento algum abrindo margem à interpretação no sentido de que as fundações públicas também estariam abrangidas pelos dispositivos da Ordem Econômica. Por quê? Porque as fundações públicas não têm como objetivo o desenvolvimento de atividades econômicas, com finalidade lucrativa conforme desiderato constitucional.

Vale ainda ressaltar, pela pertinência no tema, a total inadequação, diga-se, até mesmo, vedação (ainda que implícita), de intervenção no domínio econômico pelo Estado através de Fundações Públicas. Nestes casos, a Constituição deixa claro que serão apropriadas as empresas públicas e as sociedades de economia mista, conforme determina o art. 173, $\S 1^{\circ}$. Isso se explica facilmente, em face da proibição do intuito de lucro nas Fundações, que se caracterizam como entidades de fins não-lucrativos. ${ }^{241}$

Fosse a Ordem Econômica destinada tanto às atividade lucrativas como àquelas não-lucrativas, a Constituição teria feito menção a outras formas de organização jurídica do Estado para o desempenho de atividades econômicas. Não o sendo, estabeleceu a utilização somente das formas jurídicas com intuito lucrativo.

Por fim, pode-se dizer que não faria sentido que a Ordem Econômica se voltasse à regulamentação de atividades sem fins lucrativos, pois criaria uma sobreposição de conceitos com serviços públicos desempenhados pelo Estado; os serviços públicos sociais, por exemplo, seriam serviços públicos ou atividade econômica? Quando o Estado atuasse na área da educação, estaria prestando serviço público ou desempenhando atividade econômica?

De todas as considerações até então expostas, temos que as atividades prestacionais desenvolvidas pelas entidades do Terceiro Setor em seu espaço de participação não podem ser consideradas como atividades econômicas.

Tem-se, portanto, até aqui, que as atividades prestacionais desenvolvidas pelo Terceiro Setor em seu espaço de participação não são consideradas serviços públicos salvo quando delegatária do Poder Público - tampouco atividades econômicas. A inserção do espaço de participação do Terceiro Setor, materialmente, no capítulo dos direitos

${ }^{241}$ SILVANO, Ana Paula Rodrigues. Fundações Públicas e Terceiro Setor. Rio de Janeiro : Lumen Juris, 2003 , p. 40. 
fundamentais, que contém os direitos sociais previstos nos $\operatorname{artigos}^{\mathrm{o}}$ a 11 e regulamentados nos artigos 193 a 232, autoriza a conclusão de que, fundado no quanto exposto até o momento, estas atividades dispõem de natureza jurídica própria e, para alguns, de "regime jurídico peculiar". ${ }^{242}$

Como bem destaca Alexandre Santos de Aragão, "uma questão que se coloca é se essas atividades podem ser colocadas sob a mesma categoria jurídica, independentemente de serem prestadas pelo Estado ou por particulares por direito próprio (não como delegatários estatais)". ${ }^{243} \mathrm{O}$ próprio autor apresenta resposta no sentido de que

a Constituição indica em sentido negativo ao, por exemplo, tratar dos serviços de saúde prestados pelo Estado como "serviços públicos de saúde" (art. 198), mas se valendo da nomenclatura distinta de "serviços de relevância pública" quando deseja abranger também os casos em que a saúde é prestada pela iniciativa privada (art. 197, CF). ${ }^{244}$

É exatamente nesta linha o entendimento de Paulo Modesto, que defende que

essas atividades de regime jurídico peculiar são os serviços de relevância pública, referidos expressamente na Constituição Brasileira em duas passagens (art. 129, II e art. 197), mas cujo regime pode ser extraído de um número significativo de normas. São atividades sociais em que a atuação do Estado é obrigatória e a atuação do particular ocorre por direito próprio (assistência à saúde, educação, produção e proteção cultural, desporto, defesa do meio ambiente, pesquisa científica e tecnológica, entre outros setores). ${ }^{245}$

E realmente a Constituição, ao utilizar esta expressão serviços de relevância pública nas duas passagens citadas, abre margem à interpretação quanto à existência de uma categoria específica de serviços por ela albergada. A interpretação destes dispositivos auxiliará na conclusão quanto à extensão deste conceito.

O artigo 129, II, da Constituição Federal de 1988, assim dispõe in verbis:

\footnotetext{
${ }^{242}$ MODESTO, Paulo. Reforma do Estado, formas de prestação de serviços ao público e parcerias públicoprivadas: demarcando as fronteiras dos conceitos de serviço público, serviços de relevância pública e serviços de exploração econômica para as parcerias público-privadas. Revista Eletrônica de Direito Administrativo Econômico, Salvador : Instituto de Direito Público da Bahia, n. 2, mai.-jun.-jul. 2005, p. 7. Disponível na Internet: $<\mathrm{http}: / /$ www.direitodoestado.com.br $>$. Acesso em: 08 mar. 2010.

${ }^{243}$ ARAGÃO, Alexandre Santos de. Direito dos serviços públicos. Rio de Janeiro : Forense, 2007, p. 182.

${ }^{244}$ Ibidem, p. 182. O autor, no entanto, posteriormente inclui estas atividades no conceito de atividades econômicas: "Em outras palavras, a Constituição as considera serviços públicos quando essas atividades são prestadas pelo Estado, e serviços de relevância pública quando exploradas por particulares, mantido, nesse caso, o regime jurídico privado e as regras de livre iniciativa, sem prejuízo, naturalmente, em alguns casos (principalmente saúde e educação), da forte regulação sobre elas incidente, inclusive mediante a sujeição a autorizações administrativas prévias e operativas, constituindo-se como atividades econômicas privadas de interesse público" (ibidem, p. 182).

${ }^{245}$ MODESTO, Paulo. Op. cit., p. 7.
} 
Art. 129. São funções institucionais do Ministério Público:

(...)

II - zelar pelo efetivo respeito dos Poderes Públicos e dos serviços de relevância pública aos direitos assegurados nesta Constituição, promovendo as medidas necessárias a sua garantia.

Já o artigo 197 reza:

Art. 197. São de relevância pública as ações e serviços de saúde, cabendo ao Poder Público dispor, nos termos da lei, sobre sua regulamentação, fiscalização e controle, devendo sua execução ser feita diretamente ou através de terceiros e, também, por pessoa física ou jurídica de direito privado.

Destas únicas passagens do texto constitucional que utilizam a expressão serviços de relevância pública, podemos extrair dois conteúdos diversos: (i) o primeiro deles é subjetivo, querendo significar todos aqueles que prestam serviços de relevância pública; e (ii) o segundo é objetivo, ao incluir expressamente os serviços de saúde como serviços de relevância pública. ${ }^{246}$

Analisando isoladamente os dispositivos, temos que o primeiro encerra uma conclusão suficientemente clara no sentido de que a expressão serviços de relevância pública não é sinônima de serviços públicos nem de atividade econômica. Isto porque a Constituição delega ao Ministério Público a função de zelar pelo respeito aos direitos nela assegurados tanto em relação ao Poder Público quanto em relação às pessoas que prestem serviços de relevância pública - conteúdo subjetivo do conceito. Quisesse a Constituição que os serviços de relevância pública significassem os serviços públicos ou as atividades econômicas desempenhados pelo Poder Público, bastaria fazer remissão a este. Não o tendo feito, deixou claro que os serviços de relevância pública não se limitam aos serviços públicos ou às atividades econômicas desenvolvidas pelo Estado. Do mesmo dispositivo se extrai que nem toda ação do Poder Público pode ser considerada como serviço de relevânci pública; do contrário, bastaria à Constituição fazer referência a este conceito, sem menção expressa ao Poder Público. ${ }^{247}$

\footnotetext{
246 "Na Constituição brasileira há explícita referência aos serviços de relevância pública em duas normas: art. 129, II e art. 197. Na primeira norma, o conceito é empregado em sentido subjetivo, para referir as entidades privadas que prestam serviço de relevância pública. Na segunda, o conceito é empregado em sentido objetivo, para referir as ações e os serviços de saúde, seja quando prestados pelo Poder Público, seja quando prestados por pessoa física ou jurídica de direito privado" (Ibidem, p. 21).

${ }^{247}$ Neste sentido: "É o que se percebe da disposição do artigo 129, III, que confere ao Ministério Público a missão de zelar pelos direitos constitucionais em face (a) do Poder Público, e (b) dos serviços de relevância pública. Ora, se serviços de relevância pública e serviços públicos fossem sinônimos, não haveria
} 
Já do artigo 197 se extrai que, além de os serviços de saúde serem considerados de relevância pública, também a atuação do Poder Público, de pessoas físicas e jurídicas de direito privado pode se dar em matérias consideradas de relevância pública. Logo, o conceito de serviço de relevância pública não se molda pelo seu agente, mas pelo seu conteúdo.

Podem ser tidos como serviços de relevância pública tanto serviços prestados pelo Estado, quanto aqueles prestados por pessoas físicas ou jurídicas de direito privado, desde que, pelo seu conteúdo, sejam assim considerados.

E o fato de a Constituição ter expressamente incluído os serviços de saúde no conceito de serviço de relevância pública indica que este é o gênero do qual aqueles são uma espécie.

Não nos parece a melhor conclusão a de entender este dispositivo como limitador da compreensão do conceito de serviço de relevância pública aos serviços de saúde. ${ }^{248}$ Com efeito, partindo principalmente da função constitucional outorgada ao Ministério Público no artigo $127^{249}$, da Constituição Federal, é de se concluir que o artigo 129, quando definiu como função institucional do Ministério Público zelar pelo respeito dos serviços de relevância pública aos direitos assegurados nesta Constituição, utilizou-se de conceito aberto. Até porque

desarrazoado seria imaginar que a Constituição, reputando como de relevância pública apenas os serviços de saúde, reputaria irrelevantes todos os demais serviços públicos a exemplo dos de segurança pública, de educação, de telecomunicações, de correios, de

necessidade da dupla previsão, pois bastaria referir a necessidade de observância pelo Poder Público do respeito aos direitos constitucionais, para se abranger todos os serviço públicos, ainda quando prestados por regime de concessão ou permissão. Da mesma forma, nem todos os serviços públicos seriam de relevância pública, pois, nessa hipótese, bastaria ao legislador constituinte ter previsto a proteção destes, para abranger todas as atuações do Poder Público. Assim, esse preceito permite intuir que (a) os serviços de relevância pública podem ser públicos ou privados e (b) nem todos os serviços públicos são de relevância pública" (WEICHERT, Marlon Alberto. Saúde e federação na Constituição brasileira. Rio de Janeiro : Lumen Júris, 2004, pp. 127-128).

248 “A Constituição Federal, entretanto, dá margem à dubiedade ou multiplicidade de interpretações no tocante à atuação do Ministério Público como defensor do povo quando se tratar de hipótese de zelar pelo efetivo respeito dos serviços de relevância pública aos direitos nela assegurados. A divergência torna-se possível em razão do fato de que apenas as ações e serviços de saúde são classificados pela Constituição como serviços de relevância pública (art. 197), o que é suficiente para que alguns sustentem, baseados na literalidade expressada no texto, que não estariam incluídos no rol da atuação do Ministério Público a defesa dos direitos assegurados e eventualmente desrespeitados por outros serviços públicos (p. ex., educação, transporte coletivo, etc.) pois de relevância pública não seriam, embora se trate de serviços públicos" (GOMES, Maurício Augusto. Ministério Público e serviços de relevância pública na Constituição e na revisão constitucional. Revista Justitia, São Paulo : APMP, n. 161, jan.-mar. 1993, p. 23. Disponível na Internet: <http://www.revistajustitia.com.br/revistas/58w8z5.pdf>. Acesso em: 15 mar. 2010).

249 “Art. 127. O Ministério Público é instituição permanente, essencial à função jurisdicional do Estado, incumbindo-lhe a defesa da ordem jurídica, do regime democrático e dos interesses sociais e individuais indisponíveis". 
transportes públicos, de fornecimento de água e de energia elétrica, de radiodifusão, e tantos outros. ${ }^{250}$

E considerando que anteriormente definimos o espaço de participação do Terceiro Setor, no que tange a atividades prestacionais, como sendo aqueles serviços destinados à promoção de um direito fundamental, não corremos o risco de incorrer em erro ao dizer que as ações prestacionais desenvolvidas pelo Terceiro Setor se enquadram no conceito de serviços de relevância pública. Dissemos anteriormente que nem todos os serviços públicos e atividades econômicas desempenhados pelo Estado são considerados de relevância pública; podemos dizer que nem todas as atividades econômicas desenvolvidas pela iniciativa privada são de relevância pública; mas também podemos afirmar categoricamente que todas as ações prestacionais desenvolvidas pelo Terceiro Setor, considerando o seu espaço de participação constitucionalmente delimitado, se enquadram no conceito de serviço de relevância pública.

Vêm em nossa defesa os conceitos de serviços de relevância pública propostos pela doutrina:

Um serviço essencial especial, respeitante aos direitos assegurados na Constituição Federal, principalmente rotulados como direitos sociais. $\mathrm{O}$ constituinte considerou como direitos sociais a educação, a saúde, o trabalho, a moradia, o lazer, a segurança, a previdência social, a proteção à maternidade e à infância, a assistência aos desamparados (art. $6^{\circ} \mathrm{CF}$ ), que tem relação direta com a dignidade da pessoa humana, fundamental no Estado Democrático de Direito (art. $\left.1^{\circ}, \mathrm{III}, \mathrm{CF}\right) .^{251}$

A qualificação de determinado serviço como de relevância pública implica em considerar tal serviço como essencial à sociedade, também obriga o Poder Público a prestigiá-lo nas hipóteses de confronto com outros direitos, bem como o dever de regulamentar, fiscalizar e controlar as ações da iniciativa privada na prestação desses serviços, e na legitimidade do Ministério Público para zelar, inclusive judicialmente, pela sua adequada prestação, especialmente na observância dos direitos constitucionais. ${ }^{252}$

Tudo o que se referir à dignidade da pessoa humana, à construção de uma sociedade justa, livre e solidária, à promoção do bem comum e à erradicação da pobreza são serviços de

\footnotetext{
${ }^{250}$ GOMES, Maurício Augusto. Op. cit., p. 25. Cf. também PERES, Paula Rodrigues. A responsabilidade civil do estado em virtude de erro médico cometido na prestação do serviço público de saúde. Âmbito Jurídico, Rio Grande, n. 72, 01/01/2010. Disponível na Internet: <http://www.ambitojuridico.com.br/site/index.php?n_link=revista_artigos_leitura\&artigo_id=7040>. Acesso em: 14 mar. 2010.

${ }^{251}$ SANTIN, Valter Foleto. Controle judicial da segurança pública: eficiência do serviço na prevenção e repressão ao crime. São Paulo : RT, 2004, pp. 54-55.

${ }^{252}$ WEICHERT, Marlon Alberto. Saúde e federação na Constituição brasileira. Rio de Janeiro : Lumen Juris, 2004, p. 135.
} 
relevância pública, pois ligados diretamente aos princípios constitucionais elencados nos artigos $1^{\circ}$ e $3^{\circ} .{ }^{253}$

Também se aventura na conceituação deste pouco conhecido instituto o administrativista Paulo Modesto, para quem

são atividades de relevância pública as atividades consideradas essenciais ou prioritárias à comunidade, não titularizadas pelo Estado, cuja regularidade, acessibilidade e disciplina transcendem necessariamente à dimensão individual, obrigando o Poder Público a controlá-las, fiscalizá-las e incentivá-las de modo particularmente intenso. ${ }^{254}$

Para concluirmos, portanto, entendemos possível dizer que enquanto desenvolve atividade prestacional dentro de seu espaço constitucional de participação, o Terceiro Setor estará desenvolvendo serviço público social na condição de delegatário do Estado ou serviço de relevância pública no exercício de direito próprio ${ }^{255}$.

É de bom alvitre lembrar que não entendemos que os serviços de relevância pública sejam monopólio das entidades do Terceiro Setor; podem, também, serviços públicos e atividades econômicas serem considerados serviços de relevância pública. Nestes casos o status de relevância pública serviria como adjetivo que traria a reboque uma tutela especial, principalmente por parte do Ministério Público. Para finalizar:

${ }^{253}$ ARAÚJO, Luiz Alberto David. O conceito de "relevância pública" na Constituição Federal de 1988. In: DALLARI, Sueli Gandolfi. O conceito constitucional de relevância pública. Brasília : Organização Panamericana de Saúde, 1992, p. 25, apud WEICHERT, Marlon Alberto. Saúde e federação na Constituição brasileira. Rio de Janeiro : Lumen Juris, 2004, p. 133.

${ }^{254}$ MODESTO, Paulo. Reforma do Estado, formas de prestação de serviços ao público e parcerias públicoprivadas: demarcando as fronteiras dos conceitos de serviço público, serviços de relevância pública e serviços de exploração econômica para as parcerias público-privadas. In: Revista Eletrônica de Direito Administrativo Econômico, Salvador : Instituto de Direito Público da Bahia, n. 2, mai.-jun.-jul. 2005, p. 19, negrito no original. Disponível na Internet: $<\mathrm{http}: / / \mathrm{www}$.direitodoestado.com.br $>$. Acesso em: 08 mar. 2010.

${ }^{255}$ "Friso, entretanto, que é possível também reconhecer um sentido objetivo para o terceiro setor, associando-o à prestação dos serviços de relevância pública. Assim, em termos jurídicos objetivos, enquanto conjunto de atividades, o terceiro setor pode ser definido como esfera de ação livre à iniciativa particular, voltada à administração de serviços de relevância pública, realizada por instituições privadas sem fins lucrativos, em nome próprio e sob responsabilidade própria, ou por organizações estatais, sem caráter substitutivo da atividade privada, sem excepcionalidade, mas também sem prerrogativas especiais ou dominantes de Poder Público. Trata-se de conceito evidentemente polêmico, por incorporar no âmbito do terceiro setor, tradicionalmente associado com exclusividade à sociedade civil, entes estatais sem caráter autoritativo, voltados a setores sociais e culturais (ex. museus, creches, centros de pesquisa etc), destituídos de prerrogativas exorbitantes do direito comum dos simples particulares, embora subordinados a deveres especiais, inerentes a condição estatal dessas atividades" (MODESTO, Paulo.Op. cit., p. 25, destaques no original). Ousamos divergir do autor no que tange à inclusão dos entes estatais no conceito de Terceiro Setor com fundamento no desenvolvimento de atividades de relevância pública, hipótese que para nós se enquadra no conceito de serviços públicos sociais (de relevância pública), submetidos ao regime jurídico de direito público. 
É neste sentido que é possível reconhecer que na Constituição Federal uma terceira categoria, uma terceira espécie de atividade, as atividades de relevância pública, que cumpre ainda explorar mais detalhadamente na legislação dos entes federativos nos próximos anos, definindo controles e responsabilidades, estímulos e condicionamentos, restrições e ações afirmativas para uma parceria efetiva, fora dos marcos conceituais tradicionais do serviço público.

Os serviços de relevância pública não são serviços públicos, mas também não são atividades de exploração econômica. Constituem zona jurídica intermediária, rol de atividades que dispensa título especial de autorização tanto para o Estado quanto para os particulares, mas que cumpre papel relevante no fornecimento de utilidade vitais para os cidadãos, sendo especialmente protegida na Constituição Federal (v.g., art. 129, II). Tratase de domínio em que a atividade de execução direta de serviços e a atividade de fomento administrativo, mediante outorga de títulos especiais, apoio financeiro e acordo de parceria encontra lugar privilegiado para coexistir, rompendo-se em definitivo a dicotomia de soma zero que isolava a atuação dos particulares e do Estado em zonas distintas e mutuamente excludentes. ${ }^{256}$

\subsubsection{Natureza jurídica da atividade jurídica do Terceiro Setor}

Definida a natureza jurídica das atividades prestacionais desenvolvidas pelo Terceiro Setor, resta saber a natureza das suas atividades quando o seu espaço de participação não está no exercício de direitos fundamentais, mas na defesa do conteúdo constitucional.

Seriam as chamadas atividades jurídicas do Terceiro Setor, apropriando-se da classificação proposta pela doutrina administrativista na abordagem dos serviços públicos.

Como dito anteriormente, entendemos que as atividades prestacionais desenvolvidas pelo Terceiro Setor relacionadas a direitos fundamentais devem ser consideradas como serviços públicos por delegação ou serviços de relevância pública. Ocorre que ao Terceiro Setor também é assegurada constitucionalmente a participação em atividades não-prestacionais, mas sim de defesa do conteúdo constitucional. São atividades que têm como finalidade não a prestação de um serviço direto ao público alvo, mas a defesa ou a garantia dos direitos e deveres constitucionalmente consagrados.

Exemplo desta atuação está nas associações de defesa dos direitos dos consumidores, que não têm finalidade prestacional mas de cunho representativo; têm como função a garantia da observância dos direitos constitucionalmente outorgados ao consumidor nas relações de consumo, princípio geral da atividade econômica previsto no artigo 170, V, da Constituição Federal de 1988.

Aqui também podem ser incluídas as associações de defesa do meio ambiente, que se prestam a assegurar a observância a princípio geral da atividade econômica previsto no

${ }^{256}$ Ibidem, p. 25, negritos no original. 
artigo 150, VI, da Constituição Federal de 1988, bem como a direito social conforme artigo 225.

Uma entidade que combata a exploração infantil ou que exija o cumprimento de determinado direito perante setor empresarial específico, uma instituição de defesa dos direitos de minorias ou que defenda o pacto federativo, enfim, toda aquela que se destine à defesa ou à garantia de direito constitucional.

Assim também as instituições que se destinem a exigir o cumprimento de dever constitucional, como as associações que exigem a transparência na Administração Pública ou aquelas que exigem o fornecimento de medicamentos para pacientes da saúde pública.

Enfim, este é o contexto em que se insere a atuação do Terceiro Setor em seu viés não-prestacional.

Estas atividades, que não podem ser consideradas como serviço público, tampouco como atividade econômica, e enquanto não-prestacionais não se enquadram como serviços de relevância pública, têm natureza jurídica diversa. Estas atividades podem ser tidas como aquelas

que promovem, desde pontos de vista situados na sociedade civil, a advocacy - isto é, a defesa de direitos e a construção de novos direitos - e a promoção de atividades teóricas e práticas em torno de temas de interesse geral, difuso e comum, como o desenvolvimento sustentável, a expansão de idéias-valores (como a ética na política), a universalização da cidadania, o ecumenismo (lato sensu), a paz, a experimentação de novos padrões de relacionamento econômico e de novos "modelos" socioprodutivos e a inovação social. ${ }^{257}$

\subsection{Atores do Terceiro Setor}

De todo o exposto até o presente momento, em especial diante do espaço de participação do Terceiro Setor proposto e da característica de ausência de finalidade lucrativa das suas atividades, embora não seja o intuito do presente trabalho faz-se mister delinear quais as formas jurídicas que podem assumir as entidades ${ }^{258}$ do Terceiro Setor. Lembre-se que o conceito de ausência de finalidade lucrativa para as pessoas jurídicas relaciona-se com a impossibilidade de ser distribuído eventual resultado positivo para os seus instituidores ${ }^{259}$. No caso da pessoa física, a ausência de finalidade lucrativa consiste na promoção graciosa, voluntária, não-remunerada das atividades em referência.

${ }^{257}$ BARBIERI, Carla Bertucci. Terceiro setor: desafios e perspectivas constitucionais. Curitiba : Juruá, 2008 , p. 60.

${ }^{258}$ Organizadas sob a forma de pessoa jurídica.

${ }^{259}$ Cf. SOUZA, Leandro Marins de. Tributação do terceiro setor no Brasil. São Paulo : Dialética, 2004. 
Há quem entenda que

juridicamente, entidades privadas sem fins lucrativos podem assumir duas formas distintas: a de sociedade civil sem fins lucrativos, também denominada associação civil, ou a de fundação. A existência dessas duas formas não é casual. Correspondem a duas manifestações típicas do chamado 'espírito comunitário', razão de ser do Terceiro Setor: o associar e o dar. ${ }^{260}$

O conteúdo material de atuação do Terceiro Setor que defendemos, no entanto, permite a adoção de outras formas jurídicas de organização previstas em nossa legislação, conforme passamos a demonstrar.

Antes, no entanto, importa dizer que em trabalho anterior defendemos que as formas jurídicas de organização passíveis de serem utilizadas pelo Terceiro Setor seriam as associações civis (incluindo os sindicatos), as fundações privadas e as cooperativas sociais (criadas pela Lei n. 9.867/99). ${ }^{261}$

E realmente, as formas clássicas de entidades privadas sem fins lucrativos existentes em nosso ordenamento jurídico são a associação civil e a fundação privada, mas não são as únicas.

Conforme se extrai do Código Civil Brasileiro, as pessoas jurídicas de direito privado previstas ordinariamente em nosso ordenamento jurídico são as seguintes:

Art. 44. São pessoas jurídicas de direito privado:

I - as associações;

II - as sociedades;

III - as fundações.

IV - as organizações religiosas; (Incluído pela Lei $\mathrm{n}^{\circ} 10.825$, de 22.12.2003)

$\mathrm{V}$ - os partidos políticos. (Incluído pela Lei $\mathrm{n}^{\mathrm{o}} 10.825$, de 22.12.2003)

As sociedades a que faz menção o artigo 44, II, transcrito, são aquelas reguladas pelo Livro II, da Parte Especial, do Código Civil ${ }^{262}$, que é justamente o Livro intitulado “Do Direito de Empresa”. E especialmente no Título II, do Livro II, da Parte Especial do Código Civil, encontra-se o artigo 981, que apresenta conceito de sociedade:

\footnotetext{
${ }^{260}$ FALCÃO, Joaquim; CUENCA, Carlos. Diretrizes para nova legislação do Terceiro Setor. In: (coord.). Mudança social e reforma legal: estudos para uma nova legislação do terceiro setor. Brasília, DF : Conselho da Comunidade Solidária : UNESCO, 1999, p. 47.

${ }^{261}$ SOUZA, Leandro Marins de. Tributação do terceiro setor no Brasil. São Paulo : Dialética, 2004.

${ }^{262} \mathrm{O}$ próprio artigo $44 \mathrm{faz}$ menção a isto, em seu $\S 2^{\circ}$ dispondo: "§ $2^{\circ}$ As disposições concernentes às associações aplicam-se subsidiariamente às sociedades que são objeto do Livro II da Parte Especial deste Código. (Incluído pela Lei n ${ }^{\circ} 10.825$, de 22.12.2003)"
} 
Art. 981. Celebram contrato de sociedade as pessoas que reciprocamente se obrigam a contribuir, com bens ou serviços, para o exercício de atividade econômica e a partilha, entre si, dos resultados.

Como se observa deste dispositivo, a sociedade a que faz menção o Código Civil é aquela que promova a partilha dos resultados entre os interessados, ou seja, com finalidade lucrativa. São as empresas, o que é suficiente para excluir esta categoria do conceito de Terceiro Setor. Diga-se, por oportuno, que dentre as sociedades de que trata o Código Civil estão as cooperativas, especificamente em seus artigos 1093 e seguintes. E muito embora haja quem defenda a inclusão das cooperativas no conceito de Terceiro Setor, discordamos frontalmente em virtude de a sua constituição se destinar especificamente à divisão do produto do trabalho entre os cooperados, o que se assemelha à distribuição de lucros das sociedades, gênero do qual é espécie (sociedade simples, nos termos do artigo 982, parágrafo único, do Código Civil). Vale outra ressalva neste ponto, pois a Lei n. ${ }^{\circ}$ 9.867/99 criou uma espécie de pessoa jurídica diversa, que preferimos compreender como uma qualificação para uma sociedade cooperativa. E esta qualificação, a nosso ver, permite incluir as cooperativas sociais, como são chamadas, no conceito de Terceiro Setor. Isto porque tal qualificação se dá para cooperativas especiais que preencham determinados requisitos, dentre os quais a finalidade de inserção de pessoas em desvantagem no mercado de trabalho. Sendo óbvio que a inserção no mercado de trabalho (direito social) pressupõe o auferimento de renda e, no sistema cooperativo, dos lucros da atividade cooperada, entendemos que os pressupostos para a sua inclusão no conceito estão preenchidos. $^{263}$

Mas o artigo 44, além das sociedades, arrola as associações e fundações, antes citadas como as formas clássicas de organizações sem fins lucrativos. Valem, aqui, algumas ressalvas.

Primeiramente, entendemos que os sindicatos se incluem no conceito de associação e, por estar vinculado aos direitos sociais previstos nos artigos $6^{\circ}$ a 11 , da Constituição Federal, estão abrangidos pelo conceito de Terceiro Setor. ${ }^{264}$

Além disso, a menção do Código Civil às fundações merece melhores esclarecimentos. Em primeiro lugar porque neste conceito estão incluídas as fundações privadas, as fundações públicas e as fundações públicas de natureza privada. Entendemos

${ }^{263}$ Cf. SOUZA, Leandro Marins de. Terceiro setor e cooperativas sociais. In: SZAZI, Eduardo (org.). Terceiro Setor: temas polêmicos 2. São Paulo : Peirópolis, 2005, pp. 172-173.

${ }^{264}$ Cf. SOUZA, Leandro Marins de. Tributação do terceiro setor no Brasil. São Paulo : Dialética, 2004. 
que somente podem se enquadrar no conceito de Terceiro Setor as primeiras, por serem as únicas que preenchem o requisito da constituição voluntária, ou seja, a criação sponte propria pela iniciativa privada. As fundações públicas e as fundações públicas de natureza privada, cuja criação é feita por lei ou depende de autorização legislativa, atuam como longa manus do Estado.

Temos, até aqui, que do artigo 44 pode se extrair como formas jurídicas possíveis de serem adotadas pelas entidades do Terceiro Setor a associação civil (inciso I) e a fundação privada (inciso II), além da figura sui generis das cooperativas sociais. No entanto, outras duas figuras foram incluídas no rol das pessoas jurídicas de direito privado e merecem a nossa atenção: as organizações religiosas (inciso IV) e os partidos políticos (inciso V).

Não sendo o foco do presente trabalho, não nos alongaremos no regime jurídico destas duas pessoas jurídicas. Sendo entidades sem fins lucrativos, basta saber se materialmente as suas atividades se enquadram no espaço de participação do Terceiro Setor.

A começar com as organizações religiosas, a importância de seu papel se justifica pela inclusão da liberdade de culto dentre os direitos e garantias individuais e coletivos, no artigo $5^{\circ}$ da Constituição, nos seguintes termos:

VI - é inviolável a liberdade de consciência e de crença, sendo assegurado o livre exercício dos cultos religiosos e garantida, na forma da lei, a proteção aos locais de culto e a suas liturgias.

Pelo conteúdo do artigo $5^{\circ}$, VI, da Constituição, o exercício de cultos religiosos realizado por organizações religiosas é atividade prestacional relativa a direito fundamental, estando, portanto, incluída no espaço de participação do Terceiro Setor. ${ }^{265}$

Por sua vez, os partidos políticos se inserem no espaço de participação do Terceiro Setor por serem expressão do exercício dos direitos políticos. Não à toa estão previstos justamente no Título II, da Constituição Federal, intitulado Dos direitos fundamentais.

A corroborar a importância da atuação das organizações religiosas e dos partidos políticos, importa lembrar que gozam de imunidade tributária a impostos, nos termos do

${ }^{265}$ Cf. ANDRADE, Alessandro Purcino. As organizações religiosas como pessoas jurídicas de direito privado. Revista de Direito do Terceiro Setor - RDTS, Belo Horizonte : Fórum, ano 3, n. 5, jan.-jun. 2009 , pp. 93-113; GERONE, Acyr de. As organizações religiosas e o Terceiro Setor. In: OLIVEIRA, Gustavo Justino de (coord.). Direito do Terceiro Setor. Belo Horizonte : Fórum, 2008, pp. 127-161. 
artigo 150, da Constituição Federal ${ }^{266}$, ao lado das entidades de educação e de assistência social e dos sindicatos.

Em resumo, as formas jurídicas que podem adotar as entidades do Terceiro Setor são: i) associação civil ${ }^{267}$; ii) fundação privada; iii) cooperativa social; iv) organização religiosa; e v) partido político.

\subsection{Conceito jurídico de Terceiro Setor}

Como adiantamos, a conceituação do Terceiro Setor não é tarefa fácil, seja em virtude de sua origem histórica ${ }^{268}$, seja pela diversidade de elementos que se costuma considerar na sua abordagem ${ }^{269}$. Diversidade que, em verdade, decorre propriamente da diversidade de atores que fazem parte deste setor, justificando a dificuldade de se encontrar um quadro homogêneo que permita a sua identificação conceitual.

De qualquer forma, é imprescindível que enfrentemos esta dificuldade em prol da metodologia do trabalho a que nos propomos; sem a definição do que seja o Terceiro Setor não há como abordarmos, com lindes teóricos, as parcerias que tais entidades podem firmar com o Estado. Justificada, portanto, a abordagem que ora propomos.

Portanto, com base nos elementos até então desenvolvidos, passa-se à proposta de um conceito jurídico do Terceiro Setor.

\footnotetext{
266 “Art. 150. Sem prejuízo de outras garantias asseguradas ao contribuinte, é vedado à União, aos Estados, ao Distrito Federal e aos Municípios: VI - instituir impostos sobre: (...) b) templos de qualquer culto; c) patrimônio, renda ou serviços dos partidos políticos, inclusive suas fundações, das entidades sindicais dos trabalhadores, das instituições de educação e de assistência social, sem fins lucrativos, atendidos os requisitos da lei".

${ }^{267}$ Vale a importante ressalva de Rodrigo Xavier Leonardo: “Ainda que as associações sem fins econômicos possam ser funcionalmente estruturadas para o desenvolvimento de atividades no chamado Terceiro Setor e, mais do que isto, estejam aptas para a qualificação como organizações sociais ou como Oscips, não há uma estrita correspondência entre a estrutura e função traçada pelo Código Civil com aquela encontrada na legislação do Terceiro Setor (Lei n. 9.637/98 e Lei n. 9.790/99). Acredita-se que isto está longe de ser uma constatação a ser criticada. É importante que o espaço para criação e funcionamento de organizações civis sem fins lucrativos não seja coextensivo ao marco legal do Terceiro Setor. Os objetivos da liberdade de associação são muito mais amplos e não podem ser restritos a este ou aquele projeto político circunscrito no tempo e no espaço" (LEONARDO, Rodrigo Xavier. A reforma do direito das associações sem fins econômicos pela Lei n. 11.127 de 2005 e o Terceiro Setor. Revista de Direito do Terceiro Setor - RDTS, Belo Horizonte : Fórum, ano 1, n. 1, jan.-jun. 2007, pp. 50-51).

268 "Em razão da origem histórica do terceiro setor, já se pode prever que a tarefa de conceituá-lo não se mostra das mais simples" (BARBIERI, Carla Bertucci. Terceiro setor: desafios e perspectivas constitucionais. Curitiba : Juruá, 2008, p. 57).

269 "Cremos ter ficado demonstrado que, mesmo ao nível europeu, o conceito de 'economia social' ou de 'terceiro sector', está ainda longe de atingir estabilidade e univocidade dogmático-conceitual, predominando sobretudo noções fornecidas pelas ciências econômicas e sociais, adaptadas às características nacionais de cada país" (LOPES, Licínio. As instituições particulares de solidariedade social. Coimbra : Almedina, 2009, p. 224)
} 
Primeiramente, frise-se que o advento do Terceiro Setor, novo fenômeno cujo estudo de forma isolada - e como novidade - se justifica exatamente por se encontrar um matiz constitucional para seu desenvolvimento, é fruto de evolução da ideologia que permeia nosso constitucionalismo. Do absolutismo ao Estado social, passando pelo Estado liberal e pelo Estado providência, o campo de inserção do Terceiro Setor foi sendo trilhado por nossas Constituições, à medida que as funções do Estado se conformavam aos movimentos constitucionais brasileiros.

E com a Constituição de 1988 o que houve foi a confirmação plena da assunção, por parte do Estado brasileiro, da necessidade de participação da iniciativa privada em campos de atuação anteriormente sob a guarda privativa do Estado.

Sempre com fulcro nos objetivos fundamentais da República insculpidos no artigo $3^{\text {o }}$ da Constituição de 1988, quais sejam uma sociedade livre, justa e solidária, a erradicação da pobreza e da marginalização, a redução das desigualdades sociais $e$ regionais e a promoção do bem de todos, sem qualquer tipo de discriminação, bem como nos princípios da ordem econômica e social, passou-se a atribuir à iniciativa privada a coresponsabilidade nas atividades de provimento de direitos fundamentais, mas, ressalte-se, sem retirar do Estado a função precípua de provimento e fiscalização destas atividades.

Desenvolvem-se, nesta senda, as atividades privadas de provimento dos direitos fundamentais, paralelamente à atuação estatal. É de se observar, contudo, que a Constituição Federal de 1988 - assim como as anteriores - não exige que as atividades de natureza social advindas da iniciativa privada sejam sem finalidade lucrativa. Ela abre espaço, sim, para que se desenvolvam atividades privadas tanto com finalidades lucrativas quanto sem finalidades lucrativas para o provimento de direitos fundamentais em conjunto com a atuação estatal.

A possibilidade de desenvolvimento de atividades sociais com finalidade lucrativa é a própria contrapartida do Estado em favor da iniciativa privada, diante da atribuição de co-responsabilidade a que esta é submetida. Ou seja, com relação a estas atividades o só fato de se permitir o auferimento de lucro, somado aos mecanismos de fiscalização necessariamente criados pelo Estado, já confirmam a indispensável contrapartida estatal oriunda da manutenção de sua função precípua de prestação de serviços de relevância pública. A finalidade lucrativa para a atividade privada é o incentivo estatal para a promoção dos direitos fundamentais.

No entanto, ao possibilitar largamente o desenvolvimento de instituições privadas sem fins lucrativos para a promoção dos direitos fundamentais em conjunto com o Estado 
- espaço de participação prestacional do chamado Terceiro Setor -, a necessária contrapartida estatal não é, por óbvio, o auferimento de lucro. Por conta da relevância pública destas atividades, a responsabilidade do Estado na promoção dos direitos fundamentais deve se confirmar através de subsídios, incentivos fiscais, repasse de verbas, etc., além, é claro, do dever de fiscalização que lhe é ínsito. Mais uma vez está a se justificar o estudo apartado do Terceiro Setor.

É de se ressaltar que a Constituição de 1988 em diversas oportunidades invoca a participação da iniciativa privada despersonalizada na prestação de direitos fundamentais. Assim o é quando faz menção à participação da coletividade, da sociedade e, mais especificamente quando trata da saúde, de pessoas físicas. É por conta disso que o conceito jurídico de Terceiro Setor, com base no ordenamento jurídico brasileiro, deve abranger a atuação de pessoas físicas e, como coletivo de pessoas físicas, dos movimentos sociais.

Neste ponto específico concordamos com o conceito de Tarso Cabral Violin, para quem o Terceiro Setor

engloba as pessoas jurídicas de direito privado sem fins lucrativos de benefício público e as de benefício mútuo, as pessoas físicas voluntárias e as que trabalham profissionalmente nessas entidades, e os movimentos sociais. Ou seja, tudo o que não faz parte nem do mercado nem do Estado em sentido estrito. Assim, voluntários, associações que atuam endogenamente ou de forma exógena, fundações privadas, institutos privados sem fins lucrativos, movimentos sociais ou qualquer agrupamento sem personalidade jurídica, sindicatos, cooperativas, fazem parte do 'terceiro setor'. Note-se que esta é uma concepção bastante ampla de 'terceiro setor', não seguida por parte da doutrina. ${ }^{270}$

O autor insere as pessoas físicas voluntárias e os movimentos sociais no conceito do Terceiro Setor, o que, para nós, é consoante ao nosso texto constitucional para fins de homogeneização da expressão que pretendemos conceituar. Discordamos do autor, no entanto, quando inclui as cooperativas neste conceito, por entendermos que estas, apesar de a legislação dizer que não atuam com fins lucrativos, têm a finalidade de distribuir o superávit entre os cooperados (conceito de lucro).

\footnotetext{
${ }^{270}$ VIOLIN, Tarso Cabral. O "Terceiro Setor" e as cooperativas sociais. In: OLIVEIRA, Gustavo Justino de (coord.). Direito do Terceiro Setor: atualidades e perspectivas, Curitiba : OAB/PR, 2006, p. 198, destaque nosso. Também neste sentido, neste ponto, o seguinte conceito: "Terceiro Setor é a parte da sociedade civil onde, através de pessoas jurídicas de direito privado sem fins econômicos, ou de movimentos sociais, são executadas ações de caráter altruísta, ou de prestação de serviços, sem intuito de lucro, voltadas, sobretudo, para o desenvolvimento holístico e sistêmico do indivíduo, da família, das instituições e das políticas públicas sociais, sendo essas ações não exclusivas do Estado e não essenciais do mercado" (GERONE, Acyr de. As organizações religiosas e o terceiro setor. In: OLIVEIRA, Gustavo Justino de (coord.). Direito do Terceiro Setor. Belo Horizonte : Fórum, 2008, pp. 152-153; GERONE, Acyr de. As organizações religiosas e o terceiro setor. In: Revista de Direito do Terceiro Setor - RDTS, Belo Horizonte : Fórum, ano 2, n. 3 , jan.-jun. 2008, p. 79).
} 
Como se vê da doutrina, a maioria prefere excluir do conceito as pessoas físicas e movimentos sociais, exigindo a institucionalização como requisito. É como entende Ana Paula Rodrigues Silvano, utilizando o termo entidades privadas como delimitador de seu conceito: "Entidades privadas sem finalidade lucrativa que, objetivando o bem da coletividade, prestam serviços privados de caráter ou interesse público". ${ }^{271}$

No mesmo sentido o conceito proposto por Gustavo Justino de Oliveira:

Conjunto de atividades voluntárias, desenvolvidas por organizações privadas nãogovernamentais e sem ânimo de lucro (associações ou fundações), realizadas em prol da sociedade, independentemente dos demais setores (Estado e mercado), embora com eles possa firmar parcerias e deles possa receber investimentos (públicos e privados). ${ }^{272}$

Importa ressaltar que também em relação ao que foi chamado de espaço de participação do Terceiro Setor os autores divergem, alguns adotando conceito ampliativo, outros mais restritivo. Como visto no conceito acima transcrito, Gustavo Justino de Oliveira adota conceito amplo ao entender que para a caracterização do espaço material de atuação do Terceiro Setor basta que as atividades sejam realizadas em prol da sociedade.

Não destoa desta concepção ampla o conceito trazido por Josenir Teixeira, para quem o Terceiro Setor é o

conjunto de atividades voluntárias realizadas em prol da sociedade, desenvolvidas por entidades privadas (associações ou fundações), sem fins lucrativos, independentemente dos demais setores (o Primeiro, representado pelo Estado e o Segundo, composto pela iniciativa privada lucrativa), embora com estes possam firmar parcerias e deles receber repasses financeiros. ${ }^{273}$

Rodrigo Pironti de Aguirre Castro também apresenta concepção ampla da atuação do Terceiro Setor, sendo este a

\footnotetext{
${ }^{271}$ SILVANO, Ana Paula Rodrigues. Fundações Públicas e Terceiro Setor. Rio de Janeiro : Lumen Júris, 2003, p. 58.

${ }^{272}$ OLIVEIRA, Gustavo Justino de. Estado contratual, direito ao desenvolvimento e parceria público-privada. In: TALAMINI, Eduardo et al. (coord.). Parceria público privada: uma abordagem multidisciplinar. São Paulo : Revista dos Tribunais, 2005, p. 86; OLIVEIRA, Gustavo Justino de. Direito do Terceiro Setor. In: Revista de Direito do Terceiro Setor - RDTS, Belo Horizonte : Fórum, ano 1, n. 1, jan.-jun. 2007, pp. 1617. Expressamente neste sentido é o entendimento de Maria Tereza Fonseca Dias: "[Terceiro Setor é o ] Conjunto de pessoas jurídicas de direito privado, institucionalizadas e constituídas conforme a lei civil, sem fins lucrativos, que perseguem finalidades de interesse público" (DIAS, Maria Tereza Fonseca. Terceiro Setor e Estado: legitimidade e regulação: por um novo marco jurídico. Belo Horizonte : Fórum, 2008, p. 114).

${ }^{273}$ TEIXEIRA, Josenir. Parcerias entre o Estado e o Terceiro Setor na saúde. Revista de Direito do Terceiro Setor, Belo Horizonte : Fórum, ano 1, n. 1, jan.-jun. 2007, p. 54.
} 
conformação de atividades voluntárias, implementadas por organizações privadas sem fins lucrativos, não governamentais, com a preocupação do atendimento aos anseios da sociedade, que ocorre de forma autônoma, muito embora possa ter auxílio financeiro e firmar parcerias com os demais setores. ${ }^{274}$

Este autor delimita o campo material de desenvolvimento do Terceiro Setor com a expressão atendimento aos anseios da sociedade. Em sentido semelhante se manifesta Marcela Zen: "Integram o Terceiro Setor aquelas entidades privadas, sem fins lucrativos, que realizam atividades complementares às atividades públicas, visando à satisfação do bem comum". 275

Há, por sua vez, quem prefira apresentar conceito formal de Terceiro Setor, incluindo no seu rol todas as entidades instituídas como associação civil ou fundação privada, conceito que materialmente é ainda mais amplo por não apresentar qualquer limitação. Neste sentido é o conceito de Alexandre Ciconello: "Do ponto de vista jurídico, é mais adequado falar do universo das entidades sem fins lucrativos, mais especificamente das associações e fundações". ${ }^{276}$ Também nestes termos, Maria das Graças Bigal Barboza e Ana Maria Viegas da Silva:

O terceiro setor é constituído por entidades de interesse social, com finalidade econômica, podendo prospectar superávit sem, no entanto, objetivar lucros. (...) Genericamente, tratase de qualquer pessoa jurídica constituída pela iniciativa privada como entidade sem fins lucrativos. (...) As Organizações Não Governamentais constituem-se - por meio de estatuto - como associações ou fundações, e são conhecidas como entidades do terceiro setor. ${ }^{277}$

${ }^{274}$ CASTRO, Rodrigo Pironti Aguirre de. O sistema de controle interno e as entidades do terceiro setor: perspectiva gerencial e o princípio da eficiência. In: OLIVEIRA, Gustavo Justino de (coord.). Direito do Terceiro Setor. Belo Horizonte : Fórum, 2008, p. 167; CASTRO, Rodrigo Pironti Aguirre de. Terceiro Setor e responsabilidade social. In: OLIVEIRA, Gustavo Justino de (coord.). Direito do Terceiro Setor: atualidades e perspectivas. Curitiba : OAB/PR, 2006, p. 152.

${ }^{275}$ ZEN, Marcela Rosa Leonardo. Licitação e Terceiro Setor: reflexões sobre o concurso de projetos da Lei das OSCIPs. In: OLIVEIRA, Gustavo Justino de (coord.). Direito do Terceiro Setor. Belo Horizonte : Fórum, 2008, p. 76; ZEN, Marcela Rosa Leonardo. Licitação e Terceiro Setor: reflexões sobre o concurso de projetos da Lei das OSCIPs. Revista de Direito do Terceiro Setor - RDTS, Belo Horizonte : Fórum, ano 2, n. 4, jul.-dez. 2008, p. 66. Também apresenta conceito amplo Cláudia Fernanda de Oliveira Pereira: "A expressão Terceiro Setor é comumente utilizada para designar o conjunto de entidades da sociedade civil de fins públicos e sem objetivo de lucro, as quais coexistem com o Estado, Primeiro Setor, e com o mercado, Segundo Setor" (PEREIRA, Cláudia Fernanda de Oliveira. Os tribunais de contas e o Terceiro Setor: aspectos polêmicos do controle. In: OLIVEIRA, Gustavo Justino de (coord.). Terceiro Setor, Empresas e Estado: novas fronteiras entre o público e o privado. Belo Horizonte : Fórum, 2007, p. 309).

${ }^{276}$ CICONELLO, Alexandre. O conceito legal de público no Terceiro Setor. In: SZAZI, Eduardo (org.). Terceiro setor: temas polêmicos 1. São Paulo : Peirópolis, 2004, p. 55.

${ }^{277}$ SILVA, Maria das Graças Bigal Barboza da; SILVA, Ana Maria Viegas da. Terceiro Setor: Gestão das entidades sociais. Belo Horizonte : Fórum, 2008, p. 23. Em sentido semelhante a este conceito formal, Edson José Rafael apresenta o seguinte conceito: “O Terceiro Setor é, pois, gênero do qual são espécies todas as sociedades civis sem fins lucrativos, quais sejam: as fundações, as associações, as escolas particulares, os institutos, as cooperativas, os clubes de recreação, os clubes de futebol, de basquete, etc.." (RAFAEL, Edson José. Fundações e direito: $3^{\circ}$ setor. São Paulo : Melhoramentos, 1997, p. 34). No entanto, em outra passagem da mesma obra o autor inclui conteúdo material em seu conceito, nos seguintes termos: "Inserem- 
Há outros autores que preferem delimitar materialmente o conceito. José Delgado entende que materialmente o Terceiro Setor se volta à execução de práticas sociais, complementando ainda que tais serviços se assemelham aos prestados pelo Poder Público: "o terceiro setor é desenvolvido por instituições com preocupações voltadas para a execução de práticas sociais, sem fins lucrativos, gerando, direta ou indiretamente, bens e serviços que se assemelham aos prestados pelo Poder Público". 278

José Eduardo Sabo Paes define como objetivo do Terceiro Setor o aperfeiçamento da sociedade civil: "conjunto de organismos, organizações ou instituições sem fins lucrativos dotados de autonomia e administração própria que apresentam como função e objetivo principal atuar voluntariamente junto à sociedade civil visando ao seu aperfeiçoamento". 279

Interessante conceito apresenta Marcos de Azevedo, especialmente pelo seu conteúdo material: "Pode-se definir Terceiro Setor como a sociedade civil, legalmente organizada, sem fins lucrativos, mobilizando-se voluntariamente para consecução de um fim público e coletivo". ${ }^{280}$ Segundo o autor a finalidade das entidades do Terceiro Setor seria a consecução de um fim público e coletivo. Esta afirmação abre espaço para debate clássico consistente na abrangência da atuação material das entidades para fins de enquadrá-las no conceito jurídico de Terceiro Setor; mais especificamente, se o conceito de Terceiro Setor engloba as entidades que desenvolvem ações de interesse coletivo ou se somente aquelas que atuam em busca do interesse público.

Temos que o melhor conceito jurídico de Terceiro Setor envolve tanto as ações de interesse público quanto as ações de interesse coletivo, desde que inseridas no seu espaço constitucional de participação. Como afirma Carla Bertucci Barbieri, “evidentemente que nem todas as organizações do terceiro setor (que atendam aos requisitos acima apontados)

se, neste setor, quaisquer iniciativas privadas na criação de entidades jurídicas não-governamentais a perseguir o bem comum da coletividade, com marcante interesse público, sem qualquer finalidade lucrativa" (Ibidem, p. 33). Também fazendo menção formal, Tomáz de Aquino Resende assim conceitua o Terceiro Setor: "TERCEIRO SETOR é aquele que congrega as organizações que, embora quase sempre prestem serviços públicos, produzam e comercializem bens e serviços, não são estatais, nem visam lucro financeiro para os associados ou administradores com os empreendimentos efetivados, estando incluídas aqui, portanto, as associações e fundações" (RESENDE, Tomáz de Aquino. Roteiro do Terceiro Setor. 2a ed. Belo Horizonte : Fundação Newton Paiva, 2003, p. 20). Veja-se que este autor faz menção expressa à prestação de serviços públicos por tais entidades.

${ }^{278}$ DELGADO, José Augusto. Reflexões sobre o sistema tributário aplicado ao Terceiro Setor. Revista Fórum de Direito Tributário - RFDT, Belo Horizonte, ano 3, n. 17, set.-out. 2005, p. 13.

279 PAES, José Eduardo Sabo. Fundações e entidades de interesse social: aspectos jurídicos, administrativos, contábeis e tributários. $4^{\text {a }}$ ed. Brasília : Brasília Jurídica, 2003, p. 88.

${ }^{280}$ AZEVEDO, Marcos de. O terceiro setor e o direito ambiental. ONG`s: desenvolvimento, estratégia de atuação e gestão. São José do Rio Preto : Meio Jurídico, 2006, p. 6. 
apresentados fins públicos. E, pelo rol apresentado anteriormente, verifica-se que boa parte, talvez a maior, dessas organizações não apresenta fins públicos". ${ }^{281}$ Quanto ao alcance material da atuação do Terceiro Setor, Boaventura de Souza Santos segue este entendimento:

[Terceiro Setor é o] conjunto de organizações sociais que não são nem estatais nem mercantis, ou seja, organizações sociais que, por um lado, sendo privadas, não visam a fins lucrativos, e, por outro lado, sendo animadas por objetivos sociais, públicos ou coletivos, não são estatais. ${ }^{282}$

Em outra oportunidade, propusemos o seguinte conceito de Terceiro Setor:

O Terceiro Setor é, no nosso sentir, de acordo com o percurso evolutivo dos movimentos constitucionais brasileiros e, sobretudo, com a Constituição Federal de 1988, toda ação, sem intuito lucrativo, praticada por pessoa física ou jurídica de natureza privada, como expressão da participação popular, que tenha por finalidade a promoção de um direito social ou seus princípios. ${ }^{283-284}$

Por força do quanto expusemos até aqui, entendemos que este conceito merece atualização; em parte fomos inspirados pelo trabalho de Fernando Borges Mânica que, propondo revisão conceitual do Terceiro Setor, chegou à conclusão de que o Terceiro Setor pode ser tido como o "conjunto de pessoas jurídicas de direito privado, de caráter voluntário e sem fins lucrativos, que (i) desenvolvam atividades de defesa e promoção dos direitos fundamentais ou (ii) prestem serviços de interesse público". ${ }^{285}$

281 BARBIERI, Carla Bertucci. Terceiro setor: desafios e perspectivas constitucionais. Curitiba : Juruá, 2008 , p. 60 .

${ }^{282}$ SANTOS, Boaventura de Sousa. Para uma reinvenção solidária e participativa do Estado. In: PEREIRA, Luiz Carlos Bresser; WILHEIM, Jorge; SOLA, Lourdes (orgs.). Sociedade e Estado em transformação. São Paulo : Brasília : Unesp/ENAP, 1999, pp. 250-251.

${ }^{283}$ SOUZA, Leandro Marins de. Tributação do terceiro setor no Brasil. São Paulo : Dialética, 2004, p. 96; SOUZA, Leandro Marins de. Terceiro setor e cooperativas sociais. In: SZAZI, Eduardo (org.). Terceiro Setor: temas polêmicos 2. São Paulo : Peirópolis, 2005, pp. 172-173.

${ }^{284}$ Com definição materialmente também específica e fazendo menção aos direitos sociais, Eduardo Szazi apresenta o seguinte conceito: "Conjunto de agentes privados com fins públicos, cujos programas visavam atender direitos sociais básicos e combater a exclusão social e, mais recentemente, proteger o patrimônio ecológico brasileiro" (SZAZI, Eduardo. Terceiro setor: regulação no Brasil. $3^{\text {a }}$ ed., São Paulo : GIFE : Peirópolis, 2003, p. 22).

${ }^{285}$ MÂNICA, Fernando Borges. Panorama histórico-legislativo do Terceiro Setor no Brasil: do conceito de Terceiro Setor à Lei das OSCIP. In: OLIVEIRA, Gustavo Justino de (coord.). Terceiro Setor, Empresas e Estado: novas fronteiras entre o público e o privado. Belo Horizonte : Fórum, 2007, p. 175; MÂNICA, Fernando Borges. Panorama histórico-legislativo do Terceiro Setor no Brasil: do conceito de Terceiro Setor à Lei das OSCIP. In: OLIVEIRA, Gustavo Justino de (coord.). Direito do Terceiro Setor: atualidades e perspectivas. Curitiba : OAB/PR, 2006, p. 26. Em trabalho anterior o autor havia apresentado o seguinte conceito: "Conjunto de pessoas jurídicas de direito privado, constituídas de acordo com a legislação civil sob a forma de associações ou fundações, as quais desenvolvam (i) atividades de defesa e promoção de quaisquer 
Desta nossa revisão conceitual e com vistas a fixar premissa para o presente trabalho, entendemos possível conceituar o Terceiro Setor como toda ação voluntária, sem intuito lucrativo, praticada por pessoa física ou jurídica de natureza privada, que tenha por finalidade a prestação ou a garantia de direito fundamental, ou a defesa do conteúdo constitucional. $^{286}$

direitos previstos pela Constituição ou (ii) prestem serviços de interesse público" (MÂNICA, Fernando Borges. Terceiro Setor e imunidade tributária. Belo Horizonte : Fórum, 2005, p. 65).

${ }^{286}$ Interessante citar os seguintes conceitos apresentados pela doutrina jurídica, que fazem menção específica à natureza jurídica das atividades desenvolvidas pelo Terceiro Setor, em especial para a relevância pública de suas ações: "Os entes que integram o Terceiro Setor são entes privados, não vinculados à organização centralizada ou descentralizada da Administração Pública, mas que não almejam, entretanto, entre seus objetivos sociais, o lucro e que prestam serviços em áreas de relevante interesse social e público" (ROCHA, Sílvio Luís Ferreira da. Terceiro Setor. São Paulo : Malheiros, 2003, p. 13); "Pessoas privadas de fins públicos, sem finalidade lucrativa, constituídas voluntariamente por particulares, auxiliares do Estado na persecução de atividades de conteúdo social relevante" (MODESTO, Paulo. Reforma do marco legal do Terceiro Setor no Brasil. In: FALCÃO, Joaquim; CUENCA, Carlos (org.). Mudança social e reforma legal: estudos para uma nova legislação do Terceiro Setor. Brasília : Conselho da Comunidade Solidária : UNESCO : BID : FBB, 1999, p. 146). 


\section{CAPÍTULO 4. PARCERIAS ENTRE A ADMINISTRAÇÃO PÚBLICA E O TERCEIRO SETOR: ESTADO DA ARTE}

Antes de se adentrar à análise propositiva de reformulação do atual cenário normativo relativo às parcerias ${ }^{287}$ entre a Administração Pública e o Terceiro Setor, mister que se conheça o estado da arte normativo em que nos encontramos.

\subsection{Contratos da Administração Pública}

De início vale a ressalva de Tarso Cabral Violin a respeito do tema, para quem

muito se discute sobre as organizações sociais e as OSCIPs, e seus respectivos acordos com a Administração Pública, via contratos de gestão e termos de parceria. Entretanto, a doutrina nacional pouco se aprofunda quando o tema é relativo às contratações realizadas entre as entidades do "terceiro setor" e a Administração Pública, assim como aos convênios administrativos firmados entre o Poder Público e essas organizações. ${ }^{288}$

E realmente, embora não estejam no discurso corrente das parcerias entre a Administração Pública e o Terceiro Setor, o convênio e o contrato - principalmente este, do qual nos ocuparemos agora - devem ser analisados sob esta ótica.

Nos termos do artigo $2^{\circ}$, parágrafo único, da Lei n. 8666/93, contrato é "todo e qualquer ajuste entre órgãos ou entidades da Administração Pública e particulares, em que haja um acordo de vontades para a formação de vínculo e a estipulação de obrigações recíprocas, seja qual for a denominação utilizada".

Este conceito legal de contrato encontrado na Lei de Licitações é amplo, aproximando-se do conceito de contratos da Administração Pública, como gênero, significando "todos os contratos celebrados pela Administração Pública, seja sob regime de direito público, seja sob regime de direito privado". ${ }^{289}$

Marçal Justen Filho acolhe o conceito amplo de contrato administrativo, entendendo-o como gênero, porém prefere "definir contrato administrativo como o

\footnotetext{
${ }^{287} \mathrm{Na}$ acepção ampla proposta por Maria Sylvia Zanella Di Pietro, significando "todos os ajustes entre setor público e setor privado, para a consecução de fins de interesse comum, como concessões, permissões, convênios, contratos de gestão, terceirização e quaisquer outras modalidades admissíveis perante o nosso ordenamento jurídico" (DI PIETRO, Maria Sylvia Zanella. Parcerias na administração pública: concessão, permissão, franquia, terceirização, parceria público-privada e outras formas. $5^{\mathrm{a}}$ ed. São Paulo : Atlas, 2006, p. 13).

${ }^{288}$ VIOLIN, Tarso Cabral. Terceiro setor e as parcerias com a Administração Pública: uma análise crítica. Belo Horizonte : Fórum, 2006, p. 224.

${ }^{289}$ DI PIETRO, Maria Sylvia Zanella. Direito administrativo. $19^{a}$ ed. São Paulo : Atlas, 2006, p. 257.
} 
acordo de vontades destinado a criar, modificar ou extinguir direitos e obrigações, tal como facultado legislativamente e em que pelo menos uma das partes atua no exercício da função administrativa". 290

Maria Sylvia Zanella Di Pietro, por sua vez, entende que

a expressão contrato administrativo é reservada para designar tão-somente os ajustes que a Administração, nessa qualidade, celebra com pessoas físicas ou jurídicas, públicas ou privadas, para a consecução de fins públicos, segundo regime jurídico de direito público. ${ }^{291}$

A autora entende que o contrato administrativo é espécie do gênero contrato, em que também se encontram os contratos de direito privado, porém cada qual com suas peculiaridades. Não sendo objeto da presente análise as distinções entre cada espécie contratual, basta saber qual é o objeto possível para os contratos administrativos, de modo a verificar a viabilidade de formalizarem parcerias entre a Administração Pública e o Terceiro Setor.

A Administração Pública dispõe da ferramenta contratual para alcançar o interesse público, seja quando lança mão de contratos administrativos, seja quando se utiliza do expediente de contratos de direito privado. ${ }^{292}$ "Em ambas as hipóteses haverá interesse e finalidade pública como pressupostos do contrato". 293 De qualquer forma,

quando se cuida do tema contratual, verifica-se que, no que se refere às sujeições impostas à Administração, não diferem os contratos de direito privado e os administrativos; todos eles obedecem a exigências de forma, de procedimento, de competência, de finalidade;

\footnotetext{
${ }^{290}$ JUSTEN FILHO, Marçal. Curso de direito administrativo. $2^{\mathrm{a}}$ ed. São Paulo : Saraiva, 2006, p. 284, destaques no original.

${ }^{291}$ DI PIETRO, Maria Sylvia Zanella. Direito administrativo. 19a ed. São Paulo : Atlas, 2006, p. 257, destaques no original.

${ }^{292}$ Expressões utilizadas por Maria Sylvia Zanella Di Pietro (ibidem, p. 262), que ainda subdivide os contratos administrativos em i) contratos tipicamente administrativos e ii) contratos que têm paralelo no direito privado. Sobre o tema, calha a seguinte citação de Hely Lopes Meirelles: "Não é, portanto, o objeto, nem a finalidade pública, nem o interesse público, que caracterizam o contrato administrativo, pois o objeto é normalmente idêntico ao do Direito Privado (obra, serviço, compra, alienação, locação) e a finalidade e o interesse público estão sempre presentes em quaisquer contratos da Administração, sejam públicos ou privados, como pressupostos necessários de toda atuação administrativa. É a participação da Administração, derrogando normas de Direito Privado e agindo publicae utitlitatis causa, sob a égide do Direito Público, que tipifica o contrato administrativo. (...) A Administração pode realizar contratos sob normas predominantes do Direito Privado - e freqüentemente os realiza - em posição de igualdade com o particular contratante, como pode fazê-lo com supremacia do Poder Público. Em ambas as hipóteses haverá interesse e finalidade pública como pressupostos do contrato, mas, no primeiro caso, o ajuste será de natureza semipública (contrato administrativo atípico, como já o conceituou o extinto TFR), e somente no segundo haverá contrato administrativo típico”. (MEIRELLES, Hely Lopes. Direito administrativo brasileiro. 26a ed. São Paulo : Malheiros, 2001, pp. 202-203, destaques no original).

${ }^{293}$ Ibidem, p. 203, destaques no original.
} 
precisamente por essa razão é que alguns autores acham que todos os contratos da Administração são contratos administrativos. ${ }^{294}$

Apresentando classificação um pouco diversa, Marçal Justen Filho entende o contrato administrativo como gênero do qual são espécies

os contratos administrativos de delegação de atribuições administrativas (por exemplo, concessão de serviço público), há os contratos administrativos propriamente ditos (por exemplo, o contrato de obra pública) e há os contratos de direito privado praticados pela Administração (por exemplo, o contrato de seguro). ${ }^{295}$

Utilizando esta classificação, importa sabermos se as três categorias apresentadas são ferramentas possíveis à formalização de uma parceria entre a Administração Pública e o Terceiro Setor.

\subsubsection{Contratos de direito privado}

Em primeiro lugar avaliemos a possibilidade de parcerias entre a Administração Pública e o Terceiro Setor através de contratos de direito privado. Escolhemos tratar desta hipótese em primeiro lugar justamente por permitir uma análise mais objetiva, deixando para os próximos tópicos as matérias mais suscetíveis a discussões.

Esta espécie contratual é utilizada pela Administração Pública quando o fim almejado pela avença não está diretamente ligado ao interesse geral. ${ }^{296}$ Ou então

abrange os contratos subordinados preponderantemente ao direito privado, em que a vinculação ao desempenho de função administrativa não acarreta alteração substancial do regime jurídico. São os contratos referidos no art. $62, \S 3^{\circ}$, I, da Lei n. 8.666/93, que se subordinam essencialmente ao regime de direito privado. ${ }^{297}$

O dispositivo legal citado estabelece, in verbis:

\footnotetext{
${ }^{294}$ DI PIETRO, Maria Sylvia Zanella. Direito administrativo. 19a ed. São Paulo : Atlas, 2006, p. 262.

${ }^{295}$ JUSTEN FILHO, Marçal. Curso de direito administrativo. $2^{\text {a }}$ ed. São Paulo : Saraiva, 2006, pp. 285286.

296 "Quando a Administração celebra contrato cujo objeto apenas indiretamente ou acessoriamente diz respeito ao interesse geral (na medida em que tem repercussão orçamentária, quer do lado da despesa, quer do lado da receita), ela se submete ou pode submeter-se ao direito privado; por exemplo, para comprar materiais necessários a uma obra ou serviço público, para colocar no seguro os veículos oficiais, para alugar um imóvel necessário à instalação de repartição pública, enfim, para se equipar dos instrumentos necessários à realização da atividade principal, esta sim regida pelo direito público" (DI PIETRO, Maria Sylvia Zanella. Op. cit., p. 264).

${ }^{297}$ JUSTEN FILHO, Marçal. Op. cit., p. 289.
} 
$\S 3^{\mathrm{o}}$ Aplica-se o disposto nos arts. 55 e 58 a 61 desta Lei e demais normas gerais, no que couber:

I - aos contratos de seguro, de financiamento, de locação em que o Poder Público seja locatário, e aos demais cujo conteúdo seja regido, predominantemente, por norma de direito privado;

II - aos contratos em que a Administração for parte como usuária de serviço público.

A própria Lei de Licitações, portanto, trata de criar diferenciação entre os contratos administrativos e os contratos de direito privado, que recai especialmente sobre as chamadas cláusulas exorbitantes. Considerando a natureza eminentemente privada da relação, estes contratos acabam por não admitir a inclusão das prerrogativas de que é dotada a Administração Pública, ou as admitem com limites. ${ }^{298}$ Por isso, inclusive, o dispositivo citado é expresso em afirmar a aplicação de certas prerrogativas à Administração Pública no que couber. Nestas situações, cláusulas de privilégio em favor da Administração Pública que existem até implicitamente em contratos administrativos poderiam inviabilizar a avença, motivo que exige a adaptação de modo a fazer aplicar regime jurídico de direito privado ou híbrido.

Vale transcrever os dispositivos mencionados pelo artigo $62, \S 3^{\circ}$, I, da Lei $n$. 8.666/93, acima citado, para dar a dimensão das prerrogativas aplicáveis aos referidos contratos no que couber:

Art. 55. São cláusulas necessárias em todo contrato as que estabeleçam:

I - o objeto e seus elementos característicos;

II - o regime de execução ou a forma de fornecimento;

III - o preço e as condições de pagamento, os critérios, data-base e periodicidade do reajustamento de preços, os critérios de atualização monetária entre a data do adimplemento das obrigações e a do efetivo pagamento;

IV - os prazos de início de etapas de execução, de conclusão, de entrega, de observação e de recebimento definitivo, conforme o caso;

V - o crédito pelo qual correrá a despesa, com a indicação da classificação funcional programática e da categoria econômica;

VI - as garantias oferecidas para assegurar sua plena execução, quando exigidas;

VII - os direitos e as responsabilidades das partes, as penalidades cabíveis e os valores das multas;

VIII - os casos de rescisão;

IX - o reconhecimento dos direitos da Administração, em caso de rescisão administrativa prevista no art. 77 desta Lei;

$\mathrm{X}$ - as condições de importação, a data e a taxa de câmbio para conversão, quando for o caso;

XI - a vinculação ao edital de licitação ou ao termo que a dispensou ou a inexigiu, ao convite e à proposta do licitante vencedor;

XII - a legislação aplicável à execução do contrato e especialmente aos casos omissos;

${ }^{298}$ Sobre o tema cf. DI PIETRO, Maria Sylvia Zanella. Op. cit., p. 263 e ss. 
XIII - a obrigação do contratado de manter, durante toda a execução do contrato, em compatibilidade com as obrigações por ele assumidas, todas as condições de habilitação e qualificação exigidas na licitação.

Art. 58. O regime jurídico dos contratos administrativos instituído por esta Lei confere à Administração, em relação a eles, a prerrogativa de:

I - modificá-los, unilateralmente, para melhor adequação às finalidades de interesse público, respeitados os direitos do contratado;

II - rescindi-los, unilateralmente, nos casos especificados no inciso I do art. 79 desta Lei;

III - fiscalizar-lhes a execução;

IV - aplicar sanções motivadas pela inexecução total ou parcial do ajuste;

$\mathrm{V}$ - nos casos de serviços essenciais, ocupar provisoriamente bens móveis, imóveis, pessoal e serviços vinculados ao objeto do contrato, na hipótese da necessidade de acautelar apuração administrativa de faltas contratuais pelo contratado, bem como na hipótese de rescisão do contrato administrativo.

$\S 1^{\circ}$ As cláusulas econômico-financeiras e monetárias dos contratos administrativos não poderão ser alteradas sem prévia concordância do contratado.

$\S 2^{\circ} \mathrm{Na}$ hipótese do inciso I deste artigo, as cláusulas econômico-financeiras do contrato deverão ser revistas para que se mantenha o equilíbrio contratual.

Art. 59. A declaração de nulidade do contrato administrativo opera retroativamente impedindo os efeitos jurídicos que ele, ordinariamente, deveria produzir, além de desconstituir os já produzidos.

Parágrafo único. A nulidade não exonera a Administração do dever de indenizar o contratado pelo que este houver executado até a data em que ela for declarada e por outros prejuízos regularmente comprovados, contanto que não lhe seja imputável, promovendo-se a responsabilidade de quem the deu causa.

Art. 60. Os contratos e seus aditamentos serão lavrados nas repartições interessadas, as quais manterão arquivo cronológico dos seus autógrafos e registro sistemático do seu extrato, salvo os relativos a direitos reais sobre imóveis, que se formalizam por instrumento lavrado em cartório de notas, de tudo juntando-se cópia no processo que lhe deu origem.

Parágrafo único. É nulo e de nenhum efeito o contrato verbal com a Administração, salvo o de pequenas compras de pronto pagamento, assim entendidas aquelas de valor não superior a $5 \%$ (cinco por cento) do limite estabelecido no art. 23, inciso II, alínea "a" desta Lei, feitas em regime de adiantamento.

Art. 61. Todo contrato deve mencionar os nomes das partes e os de seus representantes, a finalidade, o ato que autorizou a sua lavratura, o número do processo da licitação, da dispensa ou da inexigibilidade, a sujeição dos contratantes às normas desta Lei e às cláusulas contratuais.

Parágrafo único. A publicação resumida do instrumento de contrato ou de seus aditamentos na imprensa oficial, que é condição indispensável para sua eficácia, será providenciada pela Administração até o quinto dia útil do mês seguinte ao de sua assinatura, para ocorrer no prazo de vinte dias daquela data, qualquer que seja o seu valor, ainda que sem ônus, ressalvado o disposto no art. 26 desta Lei. 
Vale repisar que estas cláusulas, especialmente a contida no artigo $58^{299}$, serão aplicadas aos contratos de direito privado da Administração Pública somente no que couber, pois a própria Lei de Licitações assume que estes são regidos predominantemente pelo direito privado.

Não há dúvidas de que a Administração Pública e o Terceiro Setor podem firmar contratos desta natureza. Ocorrerá, por exemplo, na hipótese de uma entidade sem fins lucrativos da área de educação ser locadora de imóvel de sua propriedade para a instalação de órgão municipal. Neste caso, ocorrendo a hipótese prevista no artigo $24, \mathrm{X}$, da Lei $\mathrm{n}$. $8666 / 93^{300}$, que estabelece dispensa de licitação para as locações de imóveis cuja localização seja determinante para a Administração Pública, o contrato será regido pelas normas de direito privado e algumas normas de direito público. Não ocorrendo a situação de dispensa de licitação, a Administração Pública, na condição de locatária do bem imóvel, deverá promover licitação nos moldes da Lei n. 8666/93, podendo ou não uma entidade do Terceiro Setor se sagrar vencedora da licitação caso disponha da melhor oferta de acordo com os termos propostos pelo Poder Público enquanto locatário.

Outra possibilidade de contrato de direito privado entre a Administração Pública e o Terceiro Setor ocorrerá caso uma instituição filantrópica ceda em comodato uma quadra poliesportiva de que dispõe, para a utilização por alunos de escola da rede estadual de ensino vizinha à entidade em determinado período do dia.

Exemplo em sentido inverso pode ser colhido da doutrina de Maria Sylvia Zanella Di Pietro, que ensina que "quando a lei permite o comodato de bem público, pode

\footnotetext{
299 “O $\S 3^{\circ}$ do art. 62 alude à aplicação aos contratos privados da Administração Pública de alguns dispositivos específicos e à incidência das 'demais normas gerais' sobre contratos administrativos. As regras dos arts. 55, 60 e 61 não apresentam maior controvérsia. Disciplinam requisitos de forma na contratação. Inexiste conflito entre esses princípios e os do direito privado. Seu efeito mais sensível é tornar obrigatórias formalidades que no direito privado seriam meramente facultativas. A maior dificuldade reside na aplicação do art. 58 e 'demais normas gerais' de direito administrativo. A alteração unilateral dos contratos é incompatível com o funcionamento dessas atividades. Não será admitida a imposição compulsória de alterações contratuais - o particular poderá a tanto se opor, preferindo a rescisão do contrato. Assim, por exemplo, uma seguradora particular não pode ser constrangida a manter um contrato de seguro se a Administração deliberar ampliar o objeto segurado ou os riscos incidentes. Mas as demais competências anômalas - tal como a físcalização reforçada, o regime especial de recebimento de bens e a própria extinção por decisão unilateral da Administração Pública - podem ser exercitadas, uma vez que não geram risco de comprometimento da iniciativa privada" (JUSTEN FILHO, Marçal. Curso de direito administrativo. $2^{\mathrm{a}}$ ed. São Paulo : Saraiva, 2006, p. 310).

300 “Art. 24. É dispensável a licitação: (...) X - para a compra ou locação de imóvel destinado ao atendimento das finalidades precípuas da administração, cujas necessidades de instalação e localização condicionem a sua escolha, desde que o preço seja compatível com o valor de mercado, segundo avaliação prévia".
} 
estabelecer para a Administração a faculdade de exigi-lo de volta por motivo de interesse público". 301

Poderá ocorrer, da mesma forma, demanda de aquisição esporádica de determinado material de uso da Administração Pública que possa ser fornecido por entidade sem fins lucrativos, dando ensejo à assinatura de contrato de compra e venda entre a Administração Pública e o Terceiro Setor. Neste caso, além do regime de direito comum - Código Civil -, o contrato de direito privado firmado entre a Administração Pública e o Terceiro Setor deverá se submeter aos artigos 14 a 16, da Lei n. 8666/93, e aos artigos 55 e 58 a 61, no que couber.

As normas contidas nessa lei [8666/93] a respeito da compra (arts. 14 a 16) e da alienação (arts. 17 a 19) não derrogam o direito comum; apenas estabelecem determinadas exigências, que dele exorbitam, concernentes ao procedimento prévio que a Administração deverá observar para concretizar o contrato: no caso de comporá, essas exigências dizem respeito à indicação de recursos financeiros, ao princípio da padronização, ao registro de preços, à pesquisa de mercado; quanto à alienação, exige-se demonstração do interesse público, prévia avaliação, licitação e autorização legislativa, nas hipóteses que especifica. Trata-se da já referida aplicação, a todos os contratos da Administração, das sujeições próprias do regime jurídico administrativo, e que têm por objetivo, basicamente, assegurar a observância da legalidade e o respeito ao interesse público. ${ }^{302}$

Estes exemplos servem para demonstrar a possibilidade de existirem contratos de direito privado firmados entre a Administração Pública e o Terceiro Setor, que devem ser incluídos no conceito amplo de parcerias para justificar a sua abordagem no presente trabalho.

São contratos regidos predominantemente por normas de direito privado, mas que se sujeitam ao regime jurídico administrativo pelo conteúdo de interesse público de que se revestem.

\subsubsection{Contratos administrativos propriamente ditos}

Também chamados de contratos administrativos de colaboração ${ }^{303}$,

\footnotetext{
${ }^{301}$ DI PIETRO, Maria Sylvia Zanella. Direito administrativo $19^{\mathrm{a}}$ ed. São Paulo : Atlas, 2006, p. 263, destaque no original.

${ }^{302}$ Ibidem, pp. 265-266, destaque no original.

303 JUSTEN FILHO, Marçal. Op. cit., p. 289; MEIRELLES, Hely Lopes. Direito administrativo brasileiro. $26^{\mathrm{a}}$ ed. São Paulo : Malheiros, 2001, p. 203.
} 
são aqueles cujo objeto reside em prestações realizadas entre particulares e a Administração Pública, sujeitos a um regime jurídico próprio, definido preponderantemente na Lei n. 8.666/93. Essa categoria abrange também as concessões administrativas da Lei n. 11.079, mesmo que a elas não se aplique, rigorosamente, a disciplina da Lei n. $8.666 .^{304}$

Conforme nos ensina Maria Sylvia Zanella Di Pietro,

o contrato administrativo visa à prestação de serviço público, não no sentido restrito de 'atividade exercida sob regime jurídico exorbitante', mas no sentido mais amplo, que abrange toda atividade que o Estado assume, por lhe parecer que a sua realização era necessária ao interesse geral e que a iniciativa privada era insuficiente para realizar adequadamente. ${ }^{305}$

Este sentido amplo de serviço público a que faz menção a autora pode ser compreendido como o interesse público, constante do conceito proposto por Celso Antônio Bandeira de Mello:

À vista das considerações precedentemente feitas, pode-se conceituar contrato administrativo da seguinte forma: é um tipo de avença travada entre a Administração e terceiros na qual, por força de lei, de cláusulas pactuadas ou do tipo de objeto, a permanência do vínculo e as condições preestabelecidas assujeitam-se a cambiáveis imposições de interesse público, ressalvados os interesses patrimoniais do contratante privado. $^{306}$

Expressivo desta realidade também é o conceito de Hely Lopes Meirelles: "contrato administrativo é o ajuste que a Administração Pública, agindo nessa qualidade, firma com particular ou outra entidade administrativa para a consecução de objetivos de interesse público, nas condições estabelecidas pela própria Administração". ${ }^{307}$

Como dito no tópico anterior, o contrato administrativo difere do contrato de direito privado basicamente em virtude de prever prerrogativas ao Poder Público ${ }^{308}$, que podem ser resumidas nas seguintes possibilidades ${ }^{309}$ :

\footnotetext{
304 JUSTEN FILHO, Marçal. Op. cit., p. 290. Trataremos, neste tópico, somente dos contratos regulados pela Lei 8.666/93, deixando os contratos da Lei 11.079/2004 para tópico específico

${ }^{305}$ DI PIETRO, Maria Sylvia Zanella. Direito administrativo. 19a ed. São Paulo : Atlas, 2006, p. 264.

${ }^{306}$ MELLO, Celso Antônio Bandeira de. Curso de direito administrativo. $18^{\text {a }}$ ed. São Paulo : Malheiros, 2005, pp. 580-581.

${ }^{307}$ MEIRELLES, Hely Lopes. Op. cit., pp. 201-202.

308 "O Contrato Administrativo distingue-se do contrato de direito privado por ser firmado pela Administração Pública, tendo objetivos de interesse público e por prever condições diferenciadas ao Poder Público" (SOUTO, Marcos Juruena Villela. Contratos administrativos no Brasil. In: Direito administrativo em debate. Rio de Janeiro : Lumen Juris, 2004, p. 136). "Da sua característica essencial, consubstanciada na participação da Administração com supremacia de poder, resultam para o contrato administrativo certas peculiaridades que os contratos comuns, sujeitos às normas do Direito Privado, não ostentam. Tais peculiaridades constituem, genericamente, as chamadas cláusulas exorbitantes, explícitas ou
} 

a) exigência de garantia;
b) alteração unilateral do contrato;
c) extinção unilateral do contrato;
d) continuidade do contrato;
e) controle do contrato;
f) aplicação de penalidades contratuais;
g) anulação;
h) retomada do objeto.

Os contratos administrativos propriamente ditos são regulados pela Lei n. 8666/93, que define o seu objeto da seguinte forma:

Art. $1^{\circ}$ Esta Lei estabelece normas gerais sobre licitações e contratos administrativos pertinentes a obras, serviços, inclusive de publicidade, compras, alienações e locações no âmbito dos Poderes da União, dos Estados, do Distrito Federal e dos Municípios.

Parágrafo único. Subordinam-se ao regime desta Lei, além dos órgãos da administração direta, os fundos especiais, as autarquias, as fundações públicas, as empresas públicas, as sociedades de economia mista e demais entidades controladas direta ou indiretamente pela União, Estados, Distrito Federal e Municípios.

Art. $2^{-}$As obras, serviços, inclusive de publicidade, compras, alienações, concessões, permissões e locações da Administração Pública, quando contratadas com terceiros, serão necessariamente precedidas de licitação, ressalvadas as hipóteses previstas nesta Lei.

Parágrafo único. Para os fins desta Lei, considera-se contrato todo e qualquer ajuste entre órgãos ou entidades da Administração Pública e particulares, em que haja um acordo de vontades para a formação de vínculo e a estipulação de obrigações recíprocas, seja qual for a denominação utilizada.

Aqueles contratos, portanto, que por sua natureza admitam a fruição de prerrogativas por parte da Administração Pública, serão considerados contratos administrativos. Os contratos administrativos propriamente ditos, por sua vez, podem ser considerados como

um acordo de vontades destinado a criar, modificar ou extinguir direitos $e$ obrigações, tal como facultado legislativamente e em que uma das partes, atuando no exercício da função administrativa, é investida de competências para

implícitas em todo contrato administrativo" (MEIRELLES, Hely Lopes. Direito administrativo brasileiro. $26^{a}$ ed. São Paulo : Malheiros, 2001, p. 203)

309 Cf. SOUTO, Marcos Juruena Villela. Contratos administrativos no Brasil. In: Direito administrativo em debate. Rio de Janeiro : Lumen Juris, 2004, p. 137; DI PIETRO, Maria Sylvia Zanella. Direito administrativo. $19^{a}$ ed. São Paulo : Atlas, 2006, pp. 273-280. 


\section{inovar unilateralmente as condições contratuais e em que se assegura a intangibilidade da equação econômico-financeira original. ${ }^{310}$}

E continua o autor, ainda sobre a dificuldade de diferenciar os contratos de direito privado dos contratos administrativos propriamente ditos, nos seguintes termos:

É extremamente problemático estabelecer um critério diferencial entre os contratos privados praticados pela Administração e os contratos administrativos propriamente ditos. A diferenciação não pode fundar-se no grau de vinculação entre a avença e a promoção dos direitos fundamentais, pois o contrato de direito privado também é uma via para tanto. A melhor solução é reconhecer a impossibilidade de submissão integral de certos segmentos do mercado às regras de direito público. A questão reside não na natureza ou no objeto do contrato propriamente dito, mas no setor da iniciativa privada a que a contratação se relaciona. ${ }^{311}$

Podemos usar como exemplos de contratos administrativos propriamente ditos, os contratos de obra e os contratos de serviço, previstos nos artigos $1^{\circ}$ e $2^{\circ}$, da Lei 8666/93, acima transcritos.

A mesma lei, em seu artigo $6^{\circ}$, I e II, define respectivamente obra como "toda construção, reforma, fabricação, recuperação ou ampliação, realizada por execução direta ou indireta" e serviço como "toda atividade destinada a obter determinada utilidade de interesse para a Administração, tais como: demolição, conserto, instalação, montagem, operação, conservação, reparação, adaptação, manutenção, transporte, locação de bens, publicidade, seguro ou trabalhos técnico-profissionais".

Os artigos $7^{\circ}$ a 13, da Lei de Licitações, estabelecem o regime específico aplicável a estas hipóteses contratuais, tais como a exigência de projetos básico e executivo prévios à execução, portanto exigindo a aprovação prévia do projeto básico e dos respectivos orçamentos, além das modalidades de execução das obras e serviços (empreitada por preço global, empreitada por preço unitário, tarefa e empreitada integral), dos serviços considerados especializados, etc.

Aproximando este regime geral aqui exposto do foco do presente trabalho, não há dúvidas de que os contratos administrativos propriamente ditos servem como espécie de parceria entre a Administração Pública e o Terceiro Setor.

A título de exemplo podemos citar a contratação, sujeita a licitação, de obra de reforma de estabelecimento público de saúde a fim de que se transforme em unidade de atendimento exclusivo a pessoas portadoras de necessidades físicas especiais, adaptando

\footnotetext{
${ }^{310}$ JUSTEN FILHO, Marçal. Curso de direito administrativo. $2^{\text {a }}$ ed. São Paulo : Saraiva, 2006, p. 296.

${ }^{311}$ Ibidem, pp. 308-309.
} 
fisicamente toda a estrutura do prédio a estas necessidades decorrentes das características dos destinatários dos serviços do hospital. A inclusão de portadores de necessidades especiais, de forma geral, é matéria que se encaixa perfeitamente no que chamamos de espaço de participação do Terceiro Setor, como anteriormente analisado. Nada impede, portanto, que exista entidade sem fins lucrativos especializada na adaptação de espaços físicos aos portadores de necessidades especiais, que envolve conhecimentos específicos de profissionais habilitados e envolvidos com o tema, para muito além do simples conhecimento técnico da construção civil. E nada impede, ainda, que esta entidade participe da licitação e se sagre vencedora, firmando contrato de obra pública com a Administração para referida reforma.

No campo dos serviços podemos imaginar a hipótese de determinado órgão ambiental, desenvolvendo determinado projeto, se deparar com a necessidade de um levantamento das espécies de fauna existentes em dada região, lançando mão de procedimento licitatório para a contratação de executor deste serviço. Como o meio ambiente, em suas vertentes educacional, conservacionista, de pesquisa, etc., também se enquadra no espectro material de atuação do Terceiro Setor, muito provavelmente existirão entidades sem fins lucrativos habilitadas a participar desta licitação e, sagrando-se vencedoras, firmar contrato administrativo para este serviço.

Ainda um exemplo de serviços passíveis de serem contratados entre a Administração Pública e o Terceiro Setor, neste caso considerados serviços técnicos especializados, ${ }^{312}$ encontra-se na possibilidade de a Administração Pública realizar concurso, licitação ou contratação com dispensa de licitação, para a contratação de serviços de restauração do acervo histórico de um museu, podendo se valer dos serviços de entidade do Terceiro Setor para tanto.

Temos, então, que a possibilidade de a Administração Pública e o Terceiro Setor firmarem contratos administrativos propriamente ditos é bastante clara, e dependerá, entre outras coisas, da adequação das necessidades do Poder Público e do objeto social da entidade. $^{313}$

\footnotetext{
${ }^{312}$ Lei 8666/93: "Art. 13. Para os fins desta Lei, consideram-se serviços técnicos profissionais especializados os trabalhos relativos a: (...) VII - restauração de obras de arte e bens de valor histórico.”

${ }^{313}$ Veja-se como entendeu o Tribunal de Contas da União, citando Maria Sylvia Zanella Di Pietro, em caso relativo à participação de OSCIP em processo licitatório: "9. No entanto, reconheço que a questão não é pacífica. Parece haver, inclusive, certa tendência a se aceitar que elas possam participar de licitações na Administração Pública, desde que a atividade a ser contratada esteja prevista no Estatuto: 'Não é que elas não possam ser contratadas. Eventualmente elas podem, se a prestação de serviços e o fornecimento de bens estiver prevista dentre seus objetivos institucionais. Só que, em se tratando de contrato, está sujeito à
} 


\subsubsection{Contratos administrativos de delegação de competências administrativas}

Outra forma de parceria possível entre a Administração Pública e o Terceiro Setor, ainda no âmbito dos contratos da Administração Pública, é através da assinatura de contratos administrativos de delegação de competências administrativas, que

compreende os contratos cujo objeto é a delegação a particulares do exercício de competências administrativas. O objeto da contratação é a atribuição de título jurídico para que um terceiro desempenhe funções tipicamente estatais, desencadeando relações jurídicas de direito público perante os administrados. Estão regidos preponderantemente pelas Leis n. 8.987/95 e 11.079/2004 (no tocante à chamada "concessão patrocinada", tema ao qual se voltará a tratar adiante). ${ }^{314}$

A Constituição Federal, no já citado artigo 175, outorga ao Poder Público, direta ou indiretamente, nestes casos através de concessão ou permissão, a prestação de serviços públicos, nos seguintes termos:

Art. 175. Incumbe ao Poder Público, na forma da lei, diretamente ou sob regime de concessão ou permissão, sempre através de licitação, a prestação de serviços públicos.

Parágrafo único. A lei disporá sobre:

I - o regime das empresas concessionárias e permissionárias de serviços públicos, o caráter especial de seu contrato e de sua prorrogação, bem como as condições de caducidade, fiscalização e rescisão da concessão ou permissão;

II - os direitos dos usuários;

III - política tarifária;

IV - a obrigação de manter serviço adequado.

E é justamente a Lei n. 8987/95 que regula as concessões e permissões de serviços públicos, nos termos do seu artigo $1^{\text {o: }}$ “Art. $1^{1^{\circ}}$ As concessões de serviços públicos e de obras públicas e as permissões de serviços públicos reger-se-ão pelos termos do art. 175 da

licitação. Se a Administração Pública aceita contratar Oscip para fornecimento de bens e serviços, tem que haver licitação em que a entidade participe em igualdade de condições com outros possíveis interessados. (Maria Sylvia Zanella Di Pietro, Palestra 'As Organizações Sociais e as Organizações da Sociedade Civil de Interesse Publico (Leis nº 9.637/98 e 9.790/99)', proferida no seminário 'O Ministério Público e a Fiscalização das Entidades Não Governamentais de Interesse Público', retirada do site do Ministério Público do Estado de São Paulo)" (Tribunal de Contas da União. Representação: TC-002.993/2007-5. Apenso: TC003.830/2007-4. Acórdão 1021-22/07. Ata n 22/2007 - Plenário. Data da Sessão: 30/5/2007 - Ordinária. Ministro Relator Marcos Vinicios Vilaça). A mesma conclusão, a nosso ver, pode ser aplicada a associações civis e fundações privadas não qualificadas como OSCIP.

314 JUSTEN FILHO, Marçal. Curso de direito administrativo, 2a ed., São Paulo : Saraiva, 2006, p. 290. Trataremos, neste tópico, somente dos contratos regulados pela Lei 8.987/95, deixando os contratos da Lei 11.079/2004 para tópico específico. 
Constituição Federal, por esta Lei, pelas normas legais pertinentes e pelas cláusulas dos indispensáveis contratos".

Materialmente a lei define o seu objeto no artigo $2^{\circ}$, conceituando da seguinte forma:

Art. $2^{\circ}$ Para os fins do disposto nesta Lei, considera-se:

I - poder concedente: a União, o Estado, o Distrito Federal ou o Município, em cuja competência se encontre o serviço público, precedido ou não da execução de obra pública, objeto de concessão ou permissão;

II - concessão de serviço público: a delegação de sua prestação, feita pelo poder concedente, mediante licitação, na modalidade de concorrência, à pessoa jurídica ou consórcio de empresas que demonstre capacidade para seu desempenho, por sua conta e risco e por prazo determinado;

III - concessão de serviço público precedida da execução de obra pública: a construção, total ou parcial, conservação, reforma, ampliação ou melhoramento de quaisquer obras de interesse público, delegada pelo poder concedente, mediante licitação, na modalidade de concorrência, à pessoa jurídica ou consórcio de empresas que demonstre capacidade para a sua realização, por sua conta e risco, de forma que o investimento da concessionária seja remunerado e amortizado mediante a exploração do serviço ou da obra por prazo determinado;

IV - permissão de serviço público: a delegação, a título precário, mediante licitação, da prestação de serviços públicos, feita pelo poder concedente à pessoa física ou jurídica que demonstre capacidade para seu desempenho, por sua conta e risco.

Vale que sejam trazidos alguns conceitos doutrinários da concessão de serviços públicos a fim de cotejo com o conceito legal. De acordo com Marçal Justen Filho,

a concessão comum de serviço público é um contrato plurilateral de natureza organizacional e associativa, por meio do qual a prestação de um serviço público e temporariamente delegada pelo Estado a um sujeito privado que assume seu desempenho diretamente em face dos usuários, mas sob controle estatal e da sociedade civil, mediante remuneração extraída do empreendimento. ${ }^{315}$

O próprio autor, no entanto, reconhece que sua posição é "absolutamente isolada na doutrina e na jurisprudência, que entendem que a concessão é pactuada apenas entre o poder concedente e o concessionário". 316

Vale trazer, neste sentido, o conceito amplo proposto por Maria Sylvia Zanella Di Pietro, para quem

pode-se definir concessão, em sentido amplo, como o contrato administrativo pelo qual a Administração confere ao particular a execução remunerada de serviço público ou de obra

\footnotetext{
${ }^{315}$ Ibidem, p. 510, destaques no original.

${ }^{316}$ Ibidem, p. 510, nota de rodapé n. 14.
} 
pública, ou the cede o uso de bem público, para que o explore pelo prazo e nas condições regulamentares e contratuais. ${ }^{317}$

Celso Antônio Bandeira de Mello propõe o seguinte conceito, agregando outros elementos relacionados à assunção de responsabilidade do concessionário, à remuneração do serviço e à cobrança de tarifas dos usuários:

Concessão de serviço público é o instituto através do qual o Estado atribui o exercício de um serviço público a alguém que aceita prestá-lo em nome próprio, por sua conta e risco, nas condições fixadas e alteráveis unilateralmente pelo Poder Público, mas sob garantia contratual de um equilíbrio econômico-financeiro, remunerando-se pela própria exploração do serviço, em geral e basicamente mediante tarifas cobradas diretamente dos usuários do serviço. ${ }^{318}$

Dos conceitos ora apresentados identificamos polêmicas que se acentuam quando se pretende fazer a análise do instituto das concessões sob o prisma de uma entidade do Terceiro Setor na condição de concessionária.

A começar pelo próprio objeto das concessões, que em princípio não aponta para maiores tergiversações: os serviços públicos. É elemento concordante dos conceitos o fato de o Estado atribuir a um sujeito privado o exercício de um serviço público. É de se observar, no entanto, que a doutrina é discordante quanto à possibilidade de uma entidade do Terceiro Setor se tornar concessionária de serviço público, haja vista a natureza das atividades.

Como dissemos em tópico anterior em que nos debruçamos em definir um espaço de participação do Terceiro Setor, em se tratando de atividade prestacional estas entidades desenvolvem ações em matéria de serviços de relevância pública na promoção de direitos fundamentais. Estes mesmos serviços de relevância pública prestados pelo Terceiro Setor, quando desempenhados pelo Estado, podem ser qualificados como serviços públicos, a que parte da doutrina chama de serviços públicos sociais. ${ }^{319}$ A matéria em que Estado e Terceiro Setor atuam em suas atividades prestacionais, neste caso, é a mesma; há um compartilhamento de titularidade, esta não sendo exclusiva do Estado nem do Terceiro

317 DI PIETRO, Maria Sylvia Zanella. Direito administrativo. 19a ed. São Paulo : Atlas, 2006, p. 294, destaques no original. A autora utiliza o conceito em sentido amplo para abrangrer as espécies de concessão, quais sejam, a concessão de serviço público, a concessão patrocinada, a concessão administrativa, a concessão de obra pública e a concessão de uso de bem público.

318 MELLO, Celso Antônio Bandeira de. Curso de direito administrativo. $18^{\text {a }}$ ed. São Paulo : Malheiros, 2005 , p. 658 , destaques no original.

319 "Serviço público social é o que atende a necessidades coletivas em que a atuação do Estado é essencial, mas que convivem com a iniciativa privada, ta 1 como ocorre com os serviços de saúde, educação, previdência, cultura, meio ambiente" (DI PIETRO, Maria Sylvia Zanella. Op. cit., p. 123, destaque no original). 
Setor. Por esta razão, parcela da doutrina entende que estes serviços públicos sociais não podem ser objeto de concessão de serviço público. Conforme entende Celso Antônio Bandeira de Mello, "só há concessão de serviço público quando o Estado considera o serviço em causa como próprio e como privativo do Poder Público". ${ }^{320}$ E continua o autor dizendo que

Por isto não caberia cogitar de outorga de concessão a alguém para que preste serviços de saúde ou de educação, já que nem uma nem outra destas atividades se constituem em serviços privativos do Estado. Quando desempenhadas por ele, submetem-se ao regime próprio dos serviços públicos, mas, consoante dantes deixou-se registrado (Capítulo XIV, n. 19), seu desempenho é "livre" para os particulares, na forma do disposto, respectivamente, nos arts. 199 e $209 \mathrm{da} \mathrm{CF}^{321}$

Como se observa, o fundamento material para este entendimento pela impossibilidade de concessão de serviços públicos que não sejam de titularidade exclusiva do Estado estaria no fato de a iniciativa privada ser dotada de titularidade originária para a prestação de tais serviços, o que retiraria a possibilidade de delegação.

Esta conclusão remete à conseqüência de que, em se tratando de serviços públicos sociais por exemplo, ou a iniciativa privada exercita seu direito próprio à execução destas atividades por si só, ou o Estado exercita este direito próprio por si só, sem prejuízo de desenvolverem atividades paralelas. Mas estas atividades nunca se cruzariam com vistas a dar efetividade ao interesse público. Fazendo uma análise um pouco mais aguda, entendendo o Poder Público que determinada atividade de cunho social que desenvolva não lhe é financeiramente viável ou não lhe é conveniente prestar, ${ }^{322}$ a concessão deste serviço público não é uma alternativa para tanto.

Trazendo para o mundo dos fatos a fim de solicitar a ajuda sempre ilustrativa dos exemplos, mostrando-se inconveniente a administração pública de determinado museu municipal, serviço público social vinculado ao direito social à cultura e ao lazer, propõe-se que à municipalidade não socorra o instituto da concessão de serviço público porque esta atividade é livre, também, à iniciativa privada. Não seria dada a oportunidade, ao Poder

\footnotetext{
${ }^{320}$ MELLO, Celso Antônio Bandeira de. Op. cit., p. 667, destaques no original.

${ }^{321}$ MELLO, Celso Antônio Bandeira de. Ibidem, nota de rodapé n. 11, destaques no original.

322 "Pela concessão, o poder público se desonera da prestação de serviços públicos de sua titularidade em relação aos quais não tem condições financeiras ou não entende ser conveniente a sua prestação direta" (ARAGÃO, Alexandre Santos de. Direito dos serviços públicos. Rio de Janeiro : Forense, 2007, p. 568).
} 
Público, de utilizar este instrumento para delegar a administração deste bem público a um particular de modo a efetivar um valor constitucional fundamental. ${ }^{323}$

É, aliás, conclusão que também se extrai de leitura de trecho da obra de Alexandre Santos de Aragão:

Também não poderá ser objeto de delegação a particular o exercício de atividades não monopolizadas pelo Estado, que podem ser livremente desempenhadas por agentes privados, observadas apenas as normas de poder de polícia incidentes sobre a atividade. $\mathrm{O}$ direito ao exercício dessas atividades integra a esfera da iniciativa privada, não havendo como o poder público contratualmente criar esse direito em favor desse ou daquele particular. Não pode criar um direito que o particular já tem. ${ }^{324}$

Mas este mesmo autor nos oferece entendimento em sentido contrário na seguinte passagem:

Tradicionalmente considera-se ser essencial à conceituação de determinado contrato como concessão de serviço público que a atividade dele objeto seja reservada ao Estado; que o particular só possa explorá-la mediante a concessão, mas, nos casos acima, a atividade em si (estacionamento, teatro etc.) não é exclusiva do Estado. O que é exclusivo do Estado é a possibilidade de elas serem exploradas em bens públicos.

O ponto central desses contratos é a titularidade do Estado sobre o bem, não sobre a atividade, razão pela qual alguns poderiam ver esses contratos mais como concessão de uso de bem público que de serviço público. Todavia, mesmo as concessões de serviços públicos também são sempre complexas, no sentido de geralmente implicarem na realização de alguma obra pública e utilização ou até modificação de bens públicos.

Naqueles contratos a realização de obras públicas sobre bens públicos é mais relevante do que geralmente é nas demais concessões de serviços públicos. Estão, assim, mais próximos das concessões de serviços públicos precedidos da realização de obra pública (art. $2^{\circ}$, III, Lei n. 8.987/95), e não de uma concessão pura e simples de uso de bem público. A Lei n. 8.987/95 é-lhes, portanto, plenamente aplicável.

Essas concessões complexas - concomitantemente de bem, de obra e de serviços públicos atenuam a exigência de as atividades objeto de concessões de serviços públicos deverem ser titularizadas com exclusividade pelo Estado.

Integram a inegável tendência contemporânea de tornar passível de gestão delegada privada não apenas os serviços públicos econômicos (titularizados pelo Estado) - seu objeto clássico -, como também as atividades econômicas stricto sensu e os serviços públicos sociais e culturais que a iniciativa privada pode explorar por direito próprio, isto é, sobre os quais não há publicatio.

(...)

Nos casos dos serviços públicos sociais e culturais, ao invés de ser transferido ao particular o direito de exercer uma atividade que, sem a concessão, lhe seria vedada, lhe é conferido o direito de explorar determinada atividade com o apoio (através de suporte financeiro, da cessão de bens públicos etc.) do Estado. Em outras palavras, a atividade em si poderia ser

\footnotetext{
323 “A concessão de serviço público é um instrumento de implementação de políticas públicas. Não é, pura e simplesmente, uma manifestação da atividade administrativa contratual do Estado. Mais ainda, é um meio para realização de valores constitucionais fundamentais" (JUSTEN FILHO, Marçal. Curso de direito administrativo. $2^{a}$ ed. São Paulo : Saraiva, 2006, p. 509).

${ }^{324}$ ARAGÃO, Alexandre Santos de. Op. cit., p. 562.
} 
explorada pelo particular livremente ou sujeita apenas à fiscalização de poder de polícia, mas para ele poder explorá-la com o apoio (e correspectivamente com a interferência) do Estado, ele precisa da concessão.

Como veremos nos dois próximos capítulos, a gestão privada dessas atividades é uma das principais causas do surgimento de algumas das mais recentes modalidades de delegação de serviços públicos, a exemplo das concessões administrativas, previstas na Lei das PPPs, e dos contratos de gestão com organizações sociais. Nada impede, contudo, como visto, que também seja possível a delegação de atividades sem publicatio no marco da Lei n. $8.987 / 95 .^{325}$

Quer nos parecer que a razão esteja ao lado deste autor. Mesmo a titularidade dos serviços públicos sociais não sendo exclusividade do Estado, é de se considerar que da mesma forma não é exclusividade da iniciativa privada. Isto significa dizer que Estado e Terceiro Setor podem, por exercício de direito próprio, desenvolver tais atividades paralelamente. Mesmo não havendo titularidade exclusiva do Estado, a titularidade compartida outorga parcela de participação estatal que confirma a natureza de serviço público destas atividades. E neste ponto, havendo serviço público desenvolvido pelo Estado, ao menos materialmente não há óbice à delegação através da concessão de serviços públicos. Justifica-se, ainda, a concessão, como extensão da possibilidade de atuação da iniciativa privada nestas atividades: por si só em exercício de direito próprio ou com o apoio do Estado através da concessão.

Utilizando exemplos comparativos, se o Poder Público pode delegar em concessão a exploração de estacionamento em imóvel público, também pode delegar a exploração de teatro em imóvel público. Não vemos, assim, óbice material à concessão de serviços públicos sociais do Poder Público a instituição do Terceiro Setor.

Diga-se, aliás, que o melhor exemplo desta possibilidade advém de dispositivo constitucional. O artigo 223, ao prever a complementariedade dos sistemas privado, público e estatal de serviço de radiodifusão sonora e de sons e imagens, expressamente prevê a concessão de serviço público não exclusivo do Estado:

Art. 223. Compete ao Poder Executivo outorgar e renovar concessão, permissão e autorização para o serviço de radiodifusão sonora e de sons e imagens, observado o princípio da complementaridade dos sistemas privado, público e estatal.

${ }^{325}$ Ibidem, pp. 572-574. 
Embora seja regime jurídico específico desta espécie de serviço público, é elemento que demonstra a impossibilidade de se sustentar a necessidade de titularidade exclusiva do Estado como condição à concessão de serviços públicos. ${ }^{326}$

Outra polêmica que ronda a concessão de serviços públicos sociais diz respeito à possibilidade ou não de concessão de serviços gratuitos. Para dar o tom dos debates, vejase comentário comparativo de Alexandre Aragão, comentando o contexto de surgimento dos novos regimes de concessão implantados pela Lei n. 11.079/04 (posteriormente analisada):

É que o mecanismo clássico de concessão tinha a ver somente com obras ou serviços onerosos (ou seja, pagos pelos utentes mediante taxas ou tarifas de utilização), sendo o investimento do concessionário amortizado e remunerado pelos rendimentos da sua exploração. Mediante a concessão o Poder Público dispensava-se de qualquer envolvimento financeiro, recebendo no final da concessão a obra ou serviço em funcionamento, livre de encargos (em princípio). $\mathrm{O}$ mecanismo da concessão não era por isso aplicável às obras e serviços públicos gratuitos (ou quase gratuitos) para os utentes, como hospitais e escolas. ${ }^{327}$

O conceito de concessão proposto por Celso Antônio Bandeira de Mello, já transcrito, deixa clara a idéia de que seria pressuposto deste instituto a remuneração pela própria exploração do serviço, em geral mediante tarifas cobradas diretamente dos usuários do serviço. O autor é enfático em dizer que

é indispensável - sem o quê não se caracterizaria a concessão de serviço público - que o concessionário se remunere pela "exploração" do próprio serviço concedido. Isto, de regra, se faz, como indicado, "em geral" e "basicamente" pela percepção de tarifas cobradas dos usuários. (...) Se, entretanto, o serviço fosse remunerado apenas por fontes estranhas à

\footnotetext{
${ }^{326}$ Cf. MARQUES NETO, Floriano de Azevedo. Concessão de serviço público sem ônus para o usuário. In: WAGNER JUNIOR, Luiz Guilherme Costa (coord.). Direito público: estudos em homenagem ao Professor Adilson Abreu Dallari. Belo Horizonte : Del Rey, 2004, pp. 331-351. O autor, aliás, faz expressa menção ao desenvolvimento destas atividades por entidade do Terceiro Setor concessionária, nos seguintes termos: "O sistema estatal é aquele voltado à informação institucional do Estado (por exemplo o que ocorre nas TVs legislativas, na TV Justiça ou nos horários dedicados a informações institucionais - horário eleitoral ou Hora do Brasil); o sistema público é aquele voltado às finalidades de interesse público, educativas e culturais, desvestidas das finalidades econômicas, mercantis, como ocorre com as TVs educativas ou as TVs organizadas por OSCIPs; e por fim o sistema privado é aquele onde se alocam as empresas de radiodifusão que, malgrado servirem muito bem para a pluralidade na comunicação social, exploram os serviços com vistas aos interesses privados, de natureza econômica" (Ibidem, p. 336). Cf. DALLARI, Adilson de Abreu. Cobrança de taxa para custeio da TV educativa. Revista de Informação Legislativa, Brasília : Senado Federal, ano 35, n. 138, abr.-jun. 1998, pp. 113-125.

327 ARAGÃO, Alexandre. As parcerias público-privadas - PPP's no direito positivo brasileiro. Revista Eletrônica de Direito Administrativo Econômico, Salvador : IDPB, n. 2, mai.-jun.-jul. 2005, p. 4. Disponível na Internet: <http://www.direitodoestado.com.br>. Acesso em: 19 mar. 2007.
} 
exploração do serviço, não existiria concessão de serviço público, mas modalidade contratual diversa. ${ }^{328}$

Maria Sylvia Zanella Di Pietro também adverte que

No caso dos serviços sociais do Estado, como o ensino e a saúde, quando prestados pelo Estado, devem, obrigatoriamente, ser gratuitos. Por isso, não podem ser objeto de qualquer tipo de concessão que implique cobrança de tarifa, o que exclui a concessão de serviço público tradicional e a concessão patrocinada. ${ }^{329}$

Tarso Cabral Violin, analisando a questão das creches municipais, também se manifesta neste sentido:

O meio adequado para o repasse seria a concessão de serviços públicos, o que entendemos também não é compatível no caso das creches. Se os serviços de gestão das creches pudessem ser repassados a particulares, por meio de concessão de serviços públicos, o prestador destes serviços seria pago pelo próprio Município, e não pelos usuários das creches. ${ }^{330}$

Não nos parece, no entanto, que o nosso ordenamento jurídico exija esta limitação relativa à remuneração do concessionário para fins de permitir a implementação de determinada concessão de serviço público, permitindo arranjos que viabilizam a concessão de serviços públicos gratuitos para os usuários, como alguns serviços públicos sociais (saúde e educação, por exemplo).

Em primeiro lugar porque a Constituição Federal, em seu artigo 175, não estabelece qualquer espécie de limite à forma de remuneração do concessionário no conceito de concessão de serviço público. Em segundo lugar porque a Lei de Concessões (Lei n. 8.987/95), em especial em seu artigo $2^{\circ}$, também não estabelece este tipo de limitação, quedando silente quanto à forma de remuneração do serviço para que seja considerado concessão.

${ }^{328}$ MELLO, Celso Antônio Bandeira de. Curso de direito administrativo. $18^{a}$ ed. São Paulo : Malheiros, 2005, pp. 659-660, destaques no original.

329 DI PIETRO, Maria Sylvia Zanella. Parcerias na Administração Pública: concessão, permissão, franquia, terceirização, parceria público-privada e outras formas. $5^{\text {a }}$ ed. São Paulo : Atlas, 2006, p. 56. Em outra passagem a autora confirma seu entendimento, abordando especificamente os serviços de saúde: "Conforme assinalado, a descentralização por colaboração, mediante concessão ou permissão, é inadequada para esse tipo de atividade, uma vez que, em ambas as modalidades, o concessionário e o permissionário são remunerados não pelo poder concedente, mas pelos usuários do serviço; sendo a saúde prestada gratuitamente, não há como utilizar esses institutos" (ibidem, p. 243, destaque no original).

${ }^{330}$ VIOLIN, Tarso Cabral. A terceirização ou concessão de serviços públicos sociais. A privatização de creches municipais. Jus Navigandi. Disponível na Internet: $<$ http://jus2.uol.com.br/doutrina/texto.asp?id=3515>. Acesso em: 06 abr. 2010. 
Bem se vê, porém, que, nem na Constituição, nem na Lei, há referência que autorize dizer que a forma de remuneração ou investimento seja elemento intrínseco ao regime de concessão. Tampouco das definições constantes do direito positivo pode-se extrair a conclusão ora e vez abraçada pela doutrina de que seja essencial para termos uma concessão que a remuneração do concessionário esteja ligada à exploração do serviço mediante cobrança de tarifa. ${ }^{331}$

Os argumentos da doutrina para sustentar esta necessidade de cobrança de tarifa pelo concessionário se resumem, conforme Floriano de Azevedo Marques Neto, em três linhas:

i) primeira que a cobrança de tarifa do usuário seria intrínseca ao regime de concessão; ii) segunda que a não oneração do usuário e conseqüente assunção do pagamento pelo poder público elidiria a margem de risco inerente ao instituto; iii) terceira que a não cobrança desnaturaria o caráter de exploração do serviço. ${ }^{332}$

Quanto ao primeiro argumento, no sentido de que a tarifa seria intrínseca ao regime de concessão, como dissemos anteriormente nem a Constituição Federal nem a Lei de Concessões exige a cobrança de tarifa diretamente do usuário. Além disso, o já citado exemplo dos serviços de radiodifusão sonora e de sons e imagens, previstos no artigo 223 da Constituição Federal, auxilia na derrocada desta idéia. Se a própria Constituição prevê hipótese de concessão sem cobrança de tarifa dos usuários, como é o caso da radiodifusão, dizer que a tarifa é pressuposto da concessão seria excetuar este dispositivo constitucional. Além disso, o artigo 11, da Lei n. 8.987/95, é expresso em permitir a existência de outras fontes de receita, para além das tarifas, no regime de concessões. Vem assim o dispositivo:

Art. 11. No atendimento às peculiaridades de cada serviço público, poderá o poder concedente prever, em favor da concessionária, no edital de licitação, a possibilidade de outras fontes provenientes de receitas alternativas, complementares, acessórias ou de projetos associados, com ou sem exclusividade, com vistas a favorecer a modicidade das tarifas, observado o disposto no art. 17 desta Lei.

\footnotetext{
${ }^{331}$ MARQUES NETO, Floriano de Azevedo. Concessão de serviço público sem ônus para o usuário. In: WAGNER JUNIOR, Luiz Guilherme Costa (coord.). Direito público: estudos em homenagem ao Professor Adilson Abreu Dallari. Belo Horizonte : Del Rey, 2004, p. 345. Ainda neste sentido: "o facto de a remuneração pelos utentes ou da assunção de um risco pelo concessionário serem eventualmente normais no regime da concessão não exclui a natureza concessória do contrato em que a Administração assume o dever de remunerar, total ou parcialmente, o concessionário, nem mesmo o contrato em que ela assume a álea econômico-financeira inerente à gestão do serviço; para que possa falar-se de 'concessão de um serviço público', essencial é que a gestão (autônoma) do serviço seja transferida para o concessionário por um acto constitutivo de uma relação jurídica administrativa" (GONÇALVES, Pedro. A concessão de serviços públicos. Coimbra : Almedina, 1999, pp. 145-146).

${ }_{332}$ MARQUES NETO, Floriano de Azevedo. Ibidem, p. 344.
} 
A própria justificativa da norma é assaz esclarecedora: no atendimento às peculiaridades de cada serviço público. Ora, a lei reconhece que há serviços públicos em que a tarifa é essencial e outros em que a tarifa se torna um empecilho. Para estes casos existe a autorização legal da criação de arranjos contratuais - autorizados por lei - que prevejam outras hipóteses de remuneração do serviço concedido. E não há óbice legal algum a que estas outras fontes de receita acabem por excluir o regime de pagamento de tarifas pelos usuários. ${ }^{333}$ Há serviços públicos em que, por expressa determinação legal ou por características próprias, não admitem a cobrança de tarifas. Nestes casos o concessionário será remunerado por outras fontes. Voltamos à carga com os serviços públicos de radiodifusão, em que os concessionários são remunerados pela publicidade que divulgam, sem a cobrança de tarifa.

E desta exposição se observa que o terceiro argumento citado, de que a não cobrança de tarifa descaracterizaria a natureza de exploração do serviço, não se sustenta. $O$ simples fato de, por exemplo, os concessionários de serviço de radiodifusão explorarem a atividade sem a cobrança de tarifa, confirma o raciocínio. $\mathrm{O}$ elemento inerente à concessão não é o pagamento de tarifa pelo usuário, mas a prestação do serviço público ao usuário e o componente negocial ínsito ao serviço público delegado, como quer que ele se concretize.

E o argumento de que a não cobrança de tarifa do usuário afastaria o risco inerente à atividade, beneficiando o concessionário, é de se dizer que o risco da atividade que caracteriza a concessão não se resume à inadimplência tarifária. Pelo contrário, talvez o menos dos riscos em algumas atividades seja a inadimplência tarifária, próxima de zero em atividades como a dos pedágios, por exemplo. Ocorre que os concessionários assumem todos os riscos do negócio, como a manutenção do patrimônio envolvido, a elevação de custos de atividade, etc.

Pelo tudo que acima expus, não me parece existir argumento suficientemente forte para impedir que o poder público, no exercício de suas competências materiais, formule um modelo de concessão pelo qual o concessionário seja encarregado de prestar um serviço público, oferecendo-o diretamente aos indivíduos, mas remunerando-se não mediante a cobrança de tarifas diretamente destes usuários, mas por fontes alternativas. Dentre estas fontes alternativas pode, sim, estar o pagamento pelo Estado de um valor (inclusive com

\footnotetext{
333 "O argumento de que a cobrança de tarifa haverá de ser obrigatória, pois as fontes alternativas de receita estão vinculadas à modicidade tarifária mostra-se frágil porquanto a mais módica das tarifas é exatamente aquela igual a zero. Exigir a cobrança simbólica apenas para dizer que a tarifa há de ser módica seria ferir o princípio da razoabilidade" (Ibidem, p. 347).
} 
natureza tarifária) definido em lei, no edital ou no contrato por unidade de serviço utilizado. ${ }^{334}$

Temos, assim, que os serviços públicos sociais, mesmo aqueles cuja prestação deva se dar de forma integralmente gratuita como a saúde e a educação, podem ser objeto de concessão de serviço público, e o concessionário pode ser uma instituição sem fins lucrativos pertencente ao Terceiro Setor.

Os arranjos institucionais para isto devem encontrar soluções criativas com respaldo legal, que vão, em hipótese, desde a remuneração do concessionário pelo Poder Público $^{335}$ até a criação de dispositivo legal que atribua benefício tributário à entidade concessionária. $^{336}$

As mesmas considerações aqui expendidas para as concessões de serviço público servem para as concessões de serviço público precedida de obra pública e para as permissões de serviço público, previstas respectivamente nos artigos $2^{\circ}$, III e IV, da Lei n. 8.987/95, embora sejam situações mais específicas que limitam - mas não impedem - a delegação a entidades do Terceiro Setor.

\subsubsection{Parcerias público-privadas}

\footnotetext{
${ }^{334}$ Ibidem, p. 349. Também neste sentido: “A Administração pode transferir a prestação de serviço público a terceiro, sob o mesmo regime jurídico da concessão, sem que sua remuneração guarde relação com o resultado da exploração do serviço" (PORTO NETO, Benedicto. Concessão de serviço público no regime da Lei n. 8.987/95: conceitos e princípios. São Paulo : Malheiros, 1998, p. 76).

335 "A solução para o fornecimento de utilidades aos carentes, em hipóteses de serviços públicos concedidos, consiste na assunção pelo Estado da contribuição correspondente. Incumbirá ao Estado realizar a mediação entre a apropriação da riqueza dos que são titulares de capacidade contributiva e o pagamento ao concessionário da remuneração correspondente aos serviços ofertados aos destituídos de recursos. Tal poderá produzir-se diretamente, por meio da assunção por parte do Estado de subvenções destinadas a assegurar a viabilidade econômica da prestação do serviço público aos carentes. Mas também poderá dar-se de modo indireto, por meio de tarifas proporcionadas à capacidade contributiva, de modo que os titulares de maior riqueza arquem com parcela mais substancial dos custos necessários à manutenção de um serviço de abrangência universal" (JUSTEN FILHO, Marçal. As diversas configurações da concessão de serviço público. Revista de Direito Público da Economia - RDPE, Belo Horizonte : Fórum, ano 1, n. 1, 2003, p. 132). Mario Engler Pinto Junior, embora concorde que a caracterização da concessão comum não exige a cobrança de tarifas dos usuários, entende pela impossibilidade de contrapartida pelo poder concedente: "É certo que a concessão comum não exige a cobrança de tarifa dos usuários, uma vez que toda a receita necessária para assegurar a viabilidade econômica do empreendimento pode ter origem em outras fontes privadas. Esse é justamente o caso da concessão de radiodifusão, em que o exercício da atividade é sustentado inteiramente por receitas de publicidade e propaganda. $\mathrm{O}$ fundamental para a caracterização da concessão comum é a ausência de contrapartida pecuniária por parte do poder concedente" (PINTO JUNIOR, Mario Engler. Parceria público-privada: antigas e novas modalidades contratuais. In: PAVANI, Sérgio Augusto Zampol; ANDRADE, Rogério Emílio de (coord.). Parcerias público-privadas. São Paulo : MP Editora, 2006, p. 65).

${ }^{336}$ Imagine-se, por exemplo, a concessão de serviço público que envolva a gestão de uma escola técnica federal, antecedida de lei autorizativa que exija que os concorrentes disponham de condições para, assumindo esta função educacional pública, preencher os requisitos para a obtenção do Certificado Ministerial previsto na Lei n. 12.101, de 27 de novembro de 2009.
} 
Ainda na esteira das concessões - portanto dos contratos da Administração Pública -, mas tratadas de forma apartada em virtude de sua instituição posterior por Lei específica (Lei n. 11.079/2004), mister a análise do regime aplicável às chamadas parcerias públicoprivadas e a sua aproximação das atividades desenvolvidas pelo Terceiro Setor, com vistas a verificar a pertinência de sua utilização como instrumento de parceria com a Administração Pública.

Referida Lei n. 11.079/2004, nos termos do seu artigo $1^{\circ}$, institui normas gerais para licitação e contratação de parceria público-privada no âmbito da administração pública $^{337}$, apresentando definição para o termo parcerias público-privadas em seu artigo 20: "Parceria público-privada é o contrato administrativo de concessão, na modalidade patrocinada ou administrativa".

Instituiu, portanto, duas novas modalidades de concessão de serviços públicos, a concessão patrocinada e a concessão administrativa, diversas daquelas concessões de serviço público ordinárias, comuns ou tradicionais ${ }^{338}$ regulamentadas pela analisada Lei n. $8.987 / 95^{339}$.

\section{a) Concessão patrocinada}

Nos termos do artigo $2^{\circ}, \S 1^{\circ}$, da Lei n. 11.079/2004, “concessão patrocinada é a concessão de serviços públicos ou de obras públicas de que trata a Lei n ${ }^{0} 8.987$, de 13 de fevereiro de 1995, quando envolver, adicionalmente à tarifa cobrada dos usuários contraprestação pecuniária do parceiro público ao parceiro privado".

Afirma-se, por conta desta definição legal, que em relação às concessões patrocinadas

\footnotetext{
337 “Art. $1^{\circ}$ Esta Lei institui normas gerais para licitação e contratação de parceria público-privada no âmbito dos Poderes da União, dos Estados, do Distrito Federal e dos Municípios. Parágrafo único. Esta Lei se aplica aos órgãos da Administração Pública direta, aos fundos especiais, às autarquias, às fundações públicas, às empresas públicas, às sociedades de economia mista e às demais entidades controladas direta ou indiretamente pela União, Estados, Distrito Federal e Municípios".

${ }^{338}$ Expressões apontadas por Maria Sylvia Zanella Di Pietro (DI PIETRO, Maria Sylvia Zanella. Parcerias na Administração Pública: concessão, permissão, franquia, terceirização, parceria público-privada e outras formas. $5^{\text {a }}$ ed. São Paulo : Atlas, 2006, p. 82) como utilizadas para diferenciar os novos institutos daqueles tradicionais. Encontra-se, ainda, remissão ao termo concessões típicas para as concessões comuns: cf. MARQUES NETO, Floriano de Azevedo. As parcerias público-privadas no saneamento ambiental. Revista Eletrônica de Direito Administrativo Econômico, Salvador : IBPB, n. 2, mai.-jun.-jul. 2005, p. 3. Disponível na Internet: $<$ http://www.direitodoestado.com.br>. Acesso em: 19 mar. 2007.

${ }^{339} \mathrm{O}$ artigo $2^{\circ}, \S 3^{\circ}$, da Lei n. 11.079/2004, aliás, é expresso em diferençar os institutos: "Não constitui parceria público-privada a concessão comum, assim entendida a concessão de serviços públicos ou de obras públicas de que trata a Lei $\mathrm{n}^{\circ} 8.987$, de 13 de fevereiro de 1995 , quando não envolver contraprestação pecuniária do parceiro público ao parceiro privado".
} 
a sua única diferença para as concessões comuns é, portanto, que nessa a amortização dos investimentos privados é feita, ao menos em linha de princípio, integralmente pelas tarifas pagas pelos usuários, enquanto na concessão patrocinada a amortização é feita ao mesmo tempo com tarifas e verbas do próprio Erário. ${ }^{340}$

No entanto, como dissemos no tópico anterior o regime jurídico da concessão comum previsto na Lei n. 8.987/95 já permite a formulação de arranjos concessórios em que a tarifa não é elemento essencial, donde se conclui que a diferenciação entre o regime da concessão comum e o regime da concessão patrocinada não pode se dar pela forma da remuneração. ${ }^{341}$ Dizer que se configura a concessão patrocinada pela remuneração do concessionário não somente pela tarifa paga pelo usuário mas com subsídios do concedente seria desconsiderar esta hipótese no regime da concessão comum, com o que não concordamos.

Como bem observa Marçal Justen Filho sobre o tema,

a Lei n. 8.987 não pretendia impedir a realização de valores consagrados constitucionalmente. A temática da colaboração estatal para a remuneração do concessionário tem de ser interpretada em face desses princípios constitucionais fundamentais. Bem por isso, será vedada a subvenção quando configurara uma forma de benefício injustificado para o concessionário. Não se admite, em face da própria Constituição, é o concessionário receber benesses do poder concedente, com pagamentos destinados a eliminar de modo absoluto o risco intrínseco e inafastável. Mas não haverá inconstitucionalidade quando a contribuição estatal for instrumento para assegurar a

340 ARAGÃO, Alexandre. As parcerias público-privadas - PPP's no direito positivo brasileiro. Revista Eletrônica de Direito Administrativo Econômico, Salvador : IDPB, n. 2, mai.-jun.-jul. 2005, p. 6. Disponível na Internet: <http://www.direitodoestado.com.br>. Acesso em: 19 mar. 2007.

341 "Uma segunda acepção aproximaria a parceria público-privada do ajuste entre Administração e particular, com vistas à consecução de um empreendimento (bem, atividade ou utilidade) de interesse público que não fosse remunerado, de forma integral, nem pelos usuários, nem pelos recursos orçamentários. Seriam, neste sentido, as parcerias, espécies de contratações que envolvessem modelos de remuneração distintos dos modelos 'puros' da empreitada e da concessão de serviços públicos. Neste sentido, o traço essencial das parcerias seria a sua estrutura em torno de um mix de recursos para a remuneração do parceiro privado. Dentro das parcerias estariam todos os empreendimentos cometidos à iniciativa privada que não fossem remunerados com recursos advindos de investimentos públicos puros (ou seja, aqueles que são remunerados à conta de verbas de investimento previstas no orçamento), nem que fossem objeto de remuneração integral à conta de tarifa paga diretamente pelos usuários do bem ou serviço. Embora essa acepção pudesse servir para abranger parte das aplicações de parcerias que se tem em vista, ela se mostra conceitualmente falha. Modelos de remuneração mista (não exclusivamente tarifário) já se encontram previstos - como hipótese - na Lei de Concessões (Lei Federal n. 8.987/95). De fato, o artigo 11 da lei prevê a hipótese de, dentro das receitas ancilares, estarem previstas - para atingir a modicidade tarifária (v.g. menor carga sobre o usuário do serviço) - receitas acessórias, alternativas de projetos associados ou complementares (o que, a meu ver, autorizaria o arranjo de estruturas tarifárias com pagamento integral ou parcial, alternativo ou complementar, pelo poder público, do valor de tarifa que deixaria de ser cobrado diretamente do usuário). Segue daí que, conceituar parceria público-privado pelo arranjo da remuneração do particular, também não se mostra útil" (MARQUES NETO, Floriano de Azevedo. As parcerias público-privadas no saneamento ambiental. Revista Eletrônica de Direito Administrativo Econômico, Salvador : IDPB, n. 2, mai.-jun.-jul. 2005, p. 5. Disponível na Internet: <http://www.direitodoestado.com.br>. Acesso em: 19 de março de 2007). 
modicidade da tarifa, valor fundamental para o cumprimento das destinações do serviço público, ou a realização das funções estatais inerentes à persecução do interesse coletivo. ${ }^{342}$

Pode-se dizer, portanto, que a criação das concessões patrocinadas pela Lei $\mathrm{n}$. 11.079, em princípio, não se justifica pelo só fato de esta espécie de arranjo permitir a remuneração do concessionário para além do regime tarifário. Diz-se em princípio porque embora esta possibilidade, como dito, existisse no regime das concessões comuns, "as discussões eram tantas que muitos agentes públicos e privados não tinham segurança suficiente para celebrar delegações de serviços públicos com essa modelagem mais 'criativa', com alguma espécie de apoio financeiro direto do Poder Público". ${ }^{343}$

Efetivamente os instrumentos da concessão comum e da concessão patrocinada são bastante parecidos, sendo conceitualmente instrumentos contratuais postos à disposição da Administração Pública para que delegue a execução de serviços públicos à iniciativa privada, em nome próprio, mediante remuneração. Tanto é assim que o artigo $3^{\circ}, \S 1^{\circ}$, da Lei n. 11.079/2004, é expresso em fazer aplicar a Lei das Concessões subsidiariamente às concessões patrocinadas. ${ }^{344}$

Os pontos comuns entre a concessão comum e a concessão patrocinada são muitos, a justificar o regime híbrido aplicado a esta (conjugação da Lei n. 11.079/2004 com a Lei n. 8.987/95). Maria Sylvia Zanella Di Pietro aponta estas convergências, apresentando elenco específico e dizendo que,

mencionando especificamente a Lei n. 8.987/95, aplicam-se à concessão patrocinada as normas referentes a:

a. direitos e obrigações dos usuários (art. $7^{\circ}$ );

b. política tarifária (arts. $9^{\circ}$ a 13 ), no que couber;

c. cláusulas essenciais dos contrato (art. 23), o que não contrariarem os incisos do artigo $5^{\circ}$ da Lei n. 11.079;

d. encargos do poder concedente (art. 29);

e. encargos do concessionário (art. 31);

f. intervenção (arts. 32 a 34);

g. responsabilidade por prejuízos causados ao poder concedente e a terceiros (art. 25, caput);

h. subcontratação $\left(\operatorname{art.~} 25, \S \S 1^{\circ}\right.$ a $3^{\circ}$ );

\footnotetext{
342 JUSTEN FILHO, Marçal. Teoria geral das concessões de serviço público. São Paulo : Dialética, 2003, p. 93.

343 ARAGÃO, Alexandre. As parcerias público-privadas - PPP's no direito positivo brasileiro. Revista Eletrônica de Direito Administrativo Econômico, Salvador : IDPB, n. 2, mai.-jun.-jul. 2005, pp. 8-9. Disponível na Internet: $<$ http://www.direitodoestado.com.br>. Acesso em: 19 mar. 2007.

344 "Art. $3^{\circ}$ As concessões administrativas regem-se por esta Lei, aplicando-se-lhes adicionalmente o disposto nos arts. 21, 23, 25 e 27 a 39 da Lei ${ }^{\circ} 8.987$, de 13 de fevereiro de 1995, e no art. 31 da Lei ${ }^{\circ} 9.074$, de 7 de julho de 1995. $\S 1^{\circ}$ As concessões patrocinadas regem-se por esta Lei, aplicando-se-lhes subsidiariamente o disposto na Lei $\mathrm{n}^{\mathrm{o}}$ 8.987, de 13 de fevereiro de 1995, e nas leis que lhe são correlatas".
} 


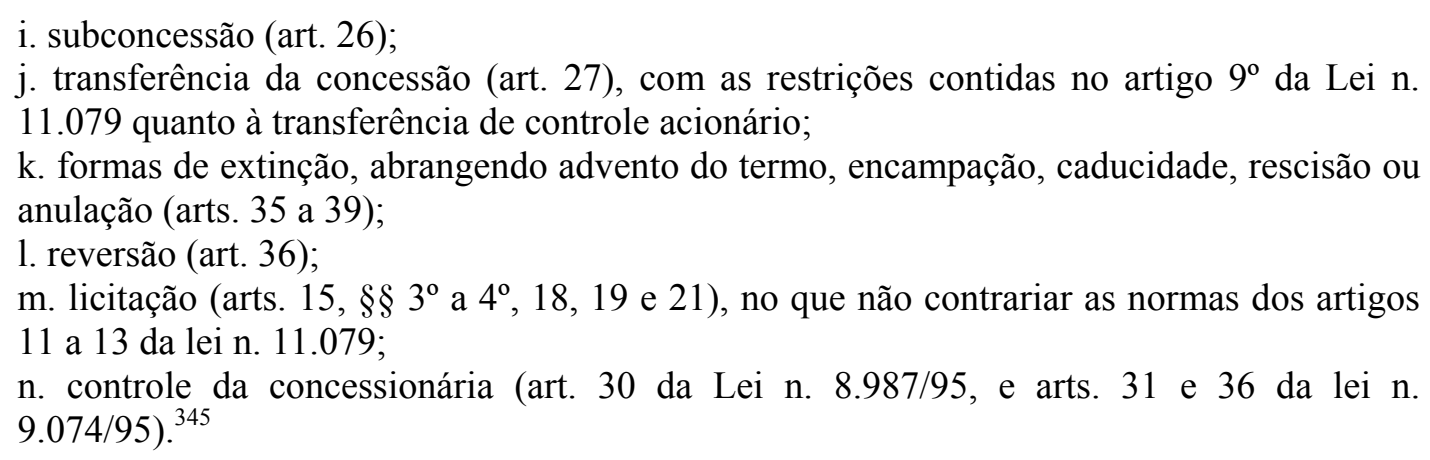

Prestam-se a finalidades bastante similares e são regidas por regimes jurídicos muito parecidos, sobretudo pela apropriação parcial das normas da Lei de Concessões pelas concessões patrocinadas. Porém, os regimes jurídicos são diversos, o que implica dizer que são institutos diversos. É o que se extrai do mesmo artigo $3^{\circ}$, da Lei n. $11.079 / 2004$, desta feita em seu $\S 2^{\circ}$ : “ $§ 2^{\circ}$ As concessões comuns continuam regidas pela Lei $n^{\circ} 8.987$, de 13 de fevereiro de 1995 , e pelas leis que lhe são correlatas, não se lhes aplicando o disposto nesta Lei". As concessões comuns, ao contrário das concessões patrocinadas, não são regidas por regime jurídico híbrido; continuam sob a égide exclusivamente da Lei n. 8.987/95, o que determina distinções bastante importantes entre os institutos.

Estas diferenças existem em diversos pontos capitais, que novamente com base na doutrina de Maria Sylvia Zanella Di Pietro ${ }^{346}$ trazemos à colação:

a) remuneração: como já dissemos, a doutrina costuma defender que uma das distinções entre o regime de concessão comum e o regime de concessão patrocinada seria a possibilidade, nesta, de conjugar a cobrança de tarifas dos usuários com a contraprestação do parceiro público ao privado. Já dissemos que não consideramos esta hipótese uma diferença, haja vista a concessão comum, em casos especiais, permitir este arranjo. Mas pode-se dizer que o regime da concessão patrocinada trouxe maior liberdade à utilização desta possibilidade, que em determinados casos pode ser o diferencial entre a Administração Pública optar pelo regime jurídico da concessão patrocinada ao invés do regime jurídico da concessão comum.

b) sociedade de propósitos específicos: o regime de concessão patrocinada (artigo $9^{\circ}$ da lei) exige a constituição de sociedade de propósitos específicos para gerir o projeto de parceria.

345 DI PIETRO, Maria Sylvia Zanella. Parcerias na Administração Pública: concessão, permissão, franquia, terceirização, parceria público-privada e outras formas. $5^{\mathrm{a}}$ ed. São Paulo : Atlas, 2006, pp. 163-164. ${ }^{346}$ Ibidem, p. 164. 
c) garantias: a lei das PPP prevê a possibilidade de a Administração Pública prestar garantias (artigos $5^{\circ}, \mathrm{VI}$, e $8^{\circ}$ ), ao parceiro privado, do cumprimento de suas obrigações assumidas na parceria.

d) riscos e ganhos compartilhados: o contrato deve prever a divisão de riscos entre os parceiros público e privado (artigo $5^{\circ}$, III), assim como dos ganhos econômicos decorrentes da redução do risco de créditos dos financiamentos utilizados pelo parceiro privado (artigo $5^{\circ}$, IX).

e) normas de licitação: as concessões patrocinadas estão sujeitas a normas específicas de licitação (artigos 11 a 13), que derrogam parcialmente as normas das Leis n. $8.987 / 95$ e $8.666 / 93$.

f) aplicação de penalidades à Administração Pública: a Lei n. 11.079/2004 prevê a possibilidade de penalizar a Administração Pública em caso de inadimplemento contratual (artigo $5^{\circ}$, II), fixadas em contrato e proporcionalmente ao gravame.

g) limite de prazo da concessão: os contratos de concessão patrocinada não poderão ser fixados por prazo inferior a 5 (cinco) e superior a 35 (trinta e cinco) anos (artigo $\left.5^{\circ}, \mathrm{I}\right)$.

h) limite de despesa: a Lei n. 11.079/2004 prevê limitação de despesas da União, Estados, Distrito Federal e Municípios com contratos de parcerias público-privadas (artigos 22 e 28).

i) valor mínimo do contrato: só será admitida a assinatura de contrato de concessão patrocinada se o seu valor for superior a $\mathrm{R} \$ 20.000 .000,00$ (vinte milhões de reais), conforme artigo $2^{\circ}, \S 4^{\circ}$, I, da Lei n. 11.079/2004.

Estas, entre outras porventura existentes, são diferenças entre os regimes jurídicos que se tornam cruciais quando da opção da Administração Pública por uma ou outra forma de delegação.

Determinadas situações não permitirão a contratação pelo regime jurídico da concessão patrocinada em virtude de o valor do contrato ser inferior ao mínimo legal; em outros casos, o prazo da concessão pretendido será inferior a 5 (cinco) anos ou superior a 35 (trinta e cinco), impedindo a concessão patrocinada. Em hipóteses como estas, à Administração Pública ainda haverá a possibilidade de invocação do regime da concessão comum, regulada pela Lei n. 8.987/95, se for de seu interesse.

Por outro lado, é possível que determinados serviços exijam a formatação de arranjo institucional bastante flexível quanto à remuneração do concessionário, sendo 
preferível a aplicação do regime de concessão patrocinada. Enfim, são regimes jurídicos distintos a serem aplicados caso a caso. ${ }^{347}$

\section{b) Concessão administrativa}

Nos termos do artigo $2^{\circ}, \S 2^{\circ}$, da Lei n. 11.079/2004, “concessão administrativa é o contrato de prestação de serviços de que a Administração Pública seja a usuária direta ou indireta, ainda que envolva execução de obra ou fornecimento e instalação de bens", donde se extrai a existência de dois tipos de concessão administrativa: i) a concessão administrativa de serviço público, em que o concessionário prestará serviço público aos usuários sem a cobrança de tarifa, sendo remunerado exclusivamente pela Administração Pública, usuária indireta dos serviços; e ii) a concessão administrativa de serviços ao Estado, em que o concessionário prestará serviços diretamente à Administração Pública. ${ }^{348}$

Observa-se que, fundamentalmente, as concessões administrativas de serviços públicos diferem das concessões patrocinadas pelo fato de nestas haver parcela de remuneração por tarifa necessariamente; as concessões administrativas de serviços ao Estado, por sua vez, diferem das concessões patrocinadas quanto ao objeto e quanto à remuneração tarifária nestas existente.

Característica inerente às concessões administrativas, portanto, é a ausência de remuneração tarifária do concessionário, que será remunerado pela Administração Pública; como define Paulo Modesto, é "uma espécie de contrato de risco de que a Administração Pública seja a 'usuária direta ou indireta', cumulado ou não com contrato de concessão de uso de bem público ou de obra pública". 349

\footnotetext{
347 "Conforme se verá, essas características nem sempre servem para distinguir, de forma absoluta, a concessão de serviços públicos tradicional e a concessão patrocinada. Por isso, é possível afirmar que a distinção não é propriamente conceitual, mas de regime jurídico, que parcialmente diverso" (DI PIETRO, Maria Sylvia Zanella. Parcerias na Administração Pública: concessão, permissão, franquia, terceirização, parceria público-privada e outras formas. $5^{\mathrm{a}}$ ed. São Paulo : Atlas, 2006, p. 164).

${ }^{348}$ Cf. SUNDFELD, Carlos Ari. Guia jurídico das parcerias público-privadas. In: Parcerias públicoprivadas. São Paulo : Malheiros, 2005, pp. 29-30. Gustavo Binenbojm adota esta classificação em BINENBOJM, Gustavo. As parcerias público-privadas (PPPs) e a Constituição. Revista Eletrônica de Direito Administrativo Econômico, Salvador : IDPB, n. 2, mai.-jun.-jul. 2005, p. 4. Disponível na Internet: $<\mathrm{http}: / /$ www.direitodoestado.com.br $>$. Acesso em: 19 mar. 2007. Maria Sylvia Zanella Di Pietro apresenta objetos diferentes para as concessões administrativas: execução material de atividade ou gestão de serviço público (DI PIETRO, Maria Sylvia Zanella. Ibidem, p. 168).

${ }^{349}$ MODESTO, Paulo. Reforma do Estado, formas de prestação de serviços ao público e parcerias públicoprivadas: demarcando as fronteiras dos conceitos de serviço público, serviços de relevância pública e serviços de exploração econômica para as parcerias público-privadas. Revista Eletrônica de Direito Administrativo Econômico, Salvador : Instituto de Direito Público da Bahia, n. 2, mai.-jun.-jul. 2005, p. 34. Disponível na Internet: <http://www.direitodoestado.com.br>. Acesso em: 08 mar. 2010.
} 
Destina-se exatamente aos casos em que não seja possível ou conveniente a cobrança de tarifas, o que ocorre em diversas situações.

Nos serviços prestados pelo Estado não é possível, frequentemente, reclamar contrapartidas dos usuários. Em algumas hipóteses, há previsão constitucional de gratuidade na prestação dos serviços, como ocorre na prestação de serviços de saúde (art. 198, § $1^{\circ}, \mathrm{CF}$ ) e de ensino (art. 206, IV , CF). Em outras situações, há decisão política de não onerar os usuários do seviço ou da obra pública (por exemplo, as concessões de rodovias com 'pedágio-sombra', mecanismo pelo qual o Poder Público remunera o concessionário segundo uma estimativa de utilização, não havendo pagamento de pedágio pelo usuário direto do serviço) ${ }^{350}$

Materialmente, a lei impede a formatação de concessão administrativa que tenha "como objeto único o fornecimento de mão-de-obra, o fornecimento e instalação de equipamentos ou a execução de obra pública" (artigo $2^{\circ}, \S 4^{\circ}$, III), hipóteses que estariam sujeitas ao regime da Lei n. 8.666/93. Seu objeto, em verdade, "é a terceirização da gestão do serviço, podendo ou não envolver obra, fornecimento e instalação de bens". ${ }^{351}$ Pressuposto necessário à concessão administrativa, portanto, é a autonomia empresarial ${ }^{352}$, uma das características que a afasta do regime de mera empreitada de obra ou serviço.

\section{c) As parcerias público-privadas e o Terceiro Setor}

\footnotetext{
${ }^{350}$ Ibidem, p. 38. Para outros exemplos: “Assim podemos enumerar, sem pretensão exauriente, as seguintes espécies de atividades que podem ser objeto da concessão administrativa: (1) serviços públicos econômicos em relação aos quais o Estado decida não cobrar tarifa alguma dos usuários (ex., rodovia em uma região muito pobre); (2) serviços públicos sociais, como a educação, a saúde e a cultura e o lazer em geral, que também podem ser prestados livremente pela iniciativa privada. Lembremos, por exemplo, de algumas experiências já vividas em algumas entidades da federação de 'terceirização' da administração de hospitais públicos; (3) atividades preparatórias ou de apoio ao exercício do poder de polícia, que, em si, é indelegável à iniciativa privada, nos termos aliás também expressamente estabelecidos no art. $4^{\circ}$, III, da Lei n. 11.079/04. Seriam os casos da hotelaria em presídios, da colocação de pardais eletrônicos em vias públicas, prestação de serviços de reboque para remoção de veículos estacionados irregularmente, etc.; (4) Atividades internas da Administração Pública, em que o próprio EStado, aí incluindo os seus servidores, é o único beneficiário do serviço (ex., construção e operação de uma rede de creches ou restaurantes para os servidores públicos, construção e operação de um centro de estudos sobre a gestão administrativa para elaboração de projetos para a maior eficiência do Estado, etc.)". (ARAGÃO, Alexandre. As parcerias público-privadas - PPP's no direito positivo brasileiro. Revista Eletrônica de Direito Administrativo Econômico, Salvador : IDPB, n. 2, mai.jun.-jul. 2005, p. 14. Disponível na Internet: <http://www.direitodoestado.com.br>. Acesso em: 19 mar. 2007).

351 DI PIETRO, Maria Sylvia Zanella. Parcerias na Administração Pública: concessão, permissão, franquia, terceirização, parceria público-privada e outras formas. $5^{\text {a }}$ ed. São Paulo : Atlas, 2006, p. 169.

352 “A concessão administrativa, enquanto delegação da gestão de determinada infra-estrutura administrativa deve, em primeiro lugar, assegurar ao concessionário autonomia empresarial no desenvolvimento da atividade, podendo definir a maior parte dos meios que julga aptos a alcançar os objetivos estabelecidos contratualmente. Essa autonomia de gestão decorre inclusive da vedação de as parcerias público-privadas se dirigirem unicamente ao fornecimento de mão-de-obra, ao fornecimento e instalação de equipamentos ou à execução de obra pública (art. 2º $§ 4^{\circ}$, III, Lei n. 11.079/2004)” (ARAGÃO, Alexandre. Op. cit., p. 16).
} 
Do quanto exposto brevemente sobre as formas possíveis de parcerias públicoprivadas previstas na Lei n. 11.079/2004, pode-se afirmar sem medo de errar que a concessão administrativa, pela característica específica da ausência de tarifa, tem aplicação inconteste às atividades relacionadas ao Terceiro Setor. Aliás, a doutrina enfatiza bastante esta característica.

Alexandre Aragão aponta que "especialmente em relação aos serviços públicos sociais ou culturais, as concessões administrativas revelam um grande espaço por elas deixado para a cooperação entre o Poder Público e as entidades privadas, inclusive sem fins lucrativos - o chamado terceiro setor". ${ }^{353}$ Maria Sylvia Zanella Di Pietro, ao analisar o objeto possível das concessões administrativas, entende que "só poderá ser serviço administrativo (atividade-meio) ou serviço social não exclusivo do Estado"354, demonstrando o vasto âmbito de aplicação às atividades do Terceiro Setor.

Bons exemplos de aplicação da concessão administrativa em áreas afetas à atividade do Terceiro Setor vêm da saúde e da educação, haja vista a previsão constitucional de gratuidade destes serviços quando prestados pelo Estado (artigos 198, § $1^{\text {o }}$, e 206, IV, da Constituição Federal, respectivamente). Esta exigência de gratuidade repercute na impossibilidade de cobrança de tarifa pelo delegatário, aproximando o conceito de concessão administrativa.

Embora as parcerias público-privadas se destinem à formação de contratos materialmente complexos, especialmente pela limitação de valor mínimo ser bastante expressiva, não se afasta a possibilidade de sua utilização para a formação de parcerias entre a Administração Pública e o Terceiro Setor.

Pode-se imaginar, por exemplo, um contrato de concessão administrativa entre a União Federal e entidade educacional sem fins lucrativos, tendo por objeto a reforma de complexo de escola técnica federal que inclui laboratórios, salas de aula, complexo administrativo, etc., e a posterior gestão desta escola técnica por esta entidade pelo prazo de 10 (dez) anos, variando a sua remuneração de acordo com a diminuição dos índices de evasão, com o aumento do índice de aprovação dos alunos nos vestibulares de faculdades públicas, com o aumento dos índices de concorrência para ingresso na escola técnica, etc. Poderia se inserir no contrato contrapartida relacionada a benefícios tributários, como a permissão expressa de contabilizar os alunos atendidos na escola técnica federal como bolsas de estudo para fins de gratuidade, de modo a utilizar esta atuação em seu índice de

\footnotetext{
${ }^{353}$ Ibidem, p. 14.

${ }^{354}$ DI PIETRO, Maria Sylvia Zanella. Op. cit., p. 169.
} 
obtenção do Certificado do Ministério da Educação previsto na Lei n. 12.101/2009, requisito para a fruição da "isenção" 355 a contribuição para a seguridade social.

$\mathrm{Na}$ área da saúde, Paulo Modesto apresenta exemplo que considera

a hipótese da União Federal pretender a instalação de um hospital para atendimento gratuito e especializado a portadores de cardiopatias em um Município carente. Não dispondo a União de recursos orçamentários para a construção e operação de um novo hospital no referido município, nem havendo auto sustentabilidade econômica do projeto, pela incerteza da demanda e pelo caráter gratuito do atendimento, nem sendo possível a aquisição direta do serviço através de hospital privados, por ausência de prestadores locais, pode-se cogitar a utilização do modelo da "concessão administrativa", remunerando-se o concessionário que assuma a construção e operação do novo hospital mediante a previsão contratual de um percentual de acréscimo aplicável sobre a tabela geral de procedimentos do SUS ou de uma estimativa de utilização mínima de procedimentos médicos. Em contrapartida aos investimentos e obras exigidas para a construção do hospital, para aquisição das instalações e manutenção dos serviços, além da remuneração paga a todo empreendedor proprietário de hospital credenciado junto ao SUS, o Poder Público asseguraria ao concessionário uma remuneração estimada (de forma semelhante ao pedágio-sombra) ou aplicaria sobre a efetiva utilização de usuários um percentual adicional sobre a tabela de procedimentos padrões do sistema único de saúde, com vistas à formação da parceria público-privada. O usuário não seria onerado com o custo de procedimentos médicos, o Estado não precisaria arcar imediatamente com o investimento de implantação do serviço e a amortização do capital privado investido ocorreria ao longo do tempo, assumindo o parceiro privado os riscos econômicos de demanda (maior ou menor quantidade de usuários) e outros que lhe sejam assinalados no vínculo que firmar com a Administração. ${ }^{356}$

\footnotetext{
${ }^{355}$ Sobre este tema polêmico, cf. SOUZA, Leandro Marins de. Tributação do terceiro setor no Brasil. São Paulo : Dialética, 2004.

${ }^{356}$ MODESTO, Paulo. Reforma do Estado, formas de prestação de serviços ao público e parcerias públicoprivadas: demarcando as fronteiras dos conceitos de serviço público, serviços de relevância pública e serviços de exploração econômica para as parcerias público-privadas. Revista Eletrônica de Direito Administrativo Econômico, Salvador : Instituto de Direito Público da Bahia, n. 2, mai.-jun.-jul. 2005, pp. 38-39. Disponível na Internet: <http://www.direitodoestado.com.br >. Acesso em: 08 mar. 2010. Este exemplo da utilização de concessões administrativas na área da saúde, aliás, já se transforma em realidade: "Está em fase final a licitação para operação via parceria público-privada do Hospital do Subúrbio, em Salvador. Trata-se do primeiro projeto já modelado do país a propor a delegação, em regime de concessão, da gestão de hospitais públicos ao setor privado. Essa iniciativa demonstra que as opções para o poder público na prestação de serviços de atenção à saúde, anteriormente restritas à assunção direta e à gestão por meio de Organizações Sociais (OS's), ampliaram-se de forma significativa. O projeto prevê a responsabilidade integral do concessionário, pelo prazo de dez anos, da gestão e operação da unidade hospitalar, inclusive quanto à prestação de serviços clínicos, aquisição, manutenção e reposição de equipamentos médicohospitalares, prestação de serviços de apoio (limpeza, segurança, lavanderia, catering, dentre outros), bem como, pela contratação e remuneração de pessoal. Há, ainda, a obrigação de atendimento aos parâmetros e diretrizes da Política Nacional de Humanização (HUMANIZASUS), presentes nas obrigações do concessionário e nos indicadores de seu desempenho. Busca-se, assim, maior eficiência na concretização desta Política, ainda incipiente na maioria das unidades hospitalares do país" (CYMBALISTA, Tatiana Matiello; LOUREIRO, Caio de Souza; NASCIMENTO, Mariana Chiesa Gouveia. A operação de hospitais por meio de PPP's: nova fronteira na prestação dos serviços de atenção à saúde. Disponível na Internet: <http://www.manesco.com.br/website/portugues/litteraExpress/default.asp?ltxCode=D51237EA-2B18-

4DAE-B2B5-8DCD7F9CD704>. Acesso em: 20 de março de 2010). Oportuno esclarecer que, ao que tudo indica, a concessão será executada por um consórcio de empresas, portanto não por entidades do Terceiro Setor.
} 
Observa-se que a área de atuação do Terceiro Setor é propícia a este tipo de arranjo. $\mathrm{Na}$ área cultural, por exemplo, é possível a concessão administrativa para a reforma do centro histórico de determinada cidade, tombado pelo patrimônio histórico, com a previsão de instalação de um museu e um teatro municipal em seus prédios, que ficariam sob administração da entidade cultural executante das reformas por determinado prazo. Sem prejuízo, aliás, neste como nos outros exemplos, de "receitas complementares, acessórias, alternativas ou decorrentes de projetos associados, até porque o inciso $\mathrm{V}$ do artigo $6^{\circ}$, ao falar em 'outros meios admitidos em lei', deixa claro que a indicação das formas de contraprestação não é taxativa". ${ }^{357}$ Trazendo a idéia para este exemplo, a entidade executora do projeto poderia buscar patrocínio de parceiros privados que dessem nome à sala do teatro, ou mesmo explorar a loja do museu...

Migrando da concessão administrativa para aproveitarmos o ensejo do exemplo na área cultural, insta dizer que mesmo concessões patrocinadas são possíveis entre a Administração Pública e o Terceiro Setor. A gestão de um museu municipal, inserida nos serviços públicos sociais quando prestada pelo Estado, é exemplo disso. Não há obrigatoriedade de gratuidade na administração de um museu público, podendo o próprio Poder Público - e o faz - cobrar ingresso dos visitantes. Permite-se, assim a configuração de uma concessão patrocinada em que o parceiro privado será remunerado pela tarifa de visitação do museu, pela contraprestação estatal e por receitas acessórias.

Pode-se dizer, portanto, que "o regime jurídico das PPPs não limita de plano a eventual participação das figuras amplamente incluídas no espectro das pessoas jurídicas de direito privado, como as organizações do terceiro setor". 358

\subsubsection{Licitação pública}

Embora não se inclua em uma das espécies de contratos da Administração Pública, justifica-se a inclusão deste tópico na medida em que o procedimento licitatório é exigido como regra geral a todas as contratações da Administração Pública Direta, Indireta, Fundos Especiais e entidades controladas pelas pessoas políticas em todos os níveis.

Esta exigência de fundamento constitucional se aplica tanto à contratação de obras, serviços, compras e alienações ${ }^{359}$, como às concessões e permissões de serviço público ${ }^{360}$,

357 DI PIETRO, Maria Sylvia Zanella. Parcerias na Administração Pública: concessão, permissão, franquia, terceirização, parceria público-privada e outras formas. $5^{\mathrm{a}}$ ed. São Paulo : Atlas, 2006, p. 169.

${ }^{358}$ REGULES, Luis Eduardo Patrone. Terceiro setor: regime jurídico das OSCIPs. São Paulo : Método, 2006, p. 135. 
tendo sido regulamentada pela Lei n. 8.666/93, que em seus dispositivos iniciais estabelece o seguinte:

Art. $1^{0}$ Esta Lei estabelece normas gerais sobre licitações e contratos administrativos pertinentes a obras, serviços, inclusive de publicidade, compras, alienações e locações no âmbito dos Poderes da União, dos Estados, do Distrito Federal e dos Municípios. Parágrafo único. Subordinam-se ao regime desta Lei, além dos órgãos da administração direta, os fundos especiais, as autarquias, as fundações públicas, as empresas públicas, as sociedades de economia mista e demais entidades controladas direta ou indiretamente pela União, Estados, Distrito Federal e Municípios.

Art. $2^{\underline{0}}$ As obras, serviços, inclusive de publicidade, compras, alienações, concessões, permissões e locações da Administração Pública, quando contratadas com terceiros, serão necessariamente precedidas de licitação, ressalvadas as hipóteses previstas nesta Lei.

Em especial para as concessões e permissões de serviço público, a Lei n. 8.987/95 que as regulamenta é expressa em exigir a licitação, em seu artigo 14 fazendo expressa menção de que será realizada nos termos da legislação própria, ou seja, pelo regime da Lei n. 8.666/93. ${ }^{361} \mathrm{O}$ artigo $2^{\circ}$, incisos II e III, porém, específica a modalidade da concorrência para as concessões e, somado ao artigo 40 , às permissões. ${ }^{362}$

Além disso, a Lei n. 11.079/2004, que instituiu as parcerias público-privadas, também prevê a aplicação da licitação na modalidade da concorrência para as concessões patrocinada e administrativa, nos seguintes termos: "Art. 10. A contratação de parceria

${ }^{359}$ Constituição Federal de 1988: “Art. 37. A administração pública direta e indireta de qualquer dos Poderes da União, dos Estados, do Distrito Federal e dos Municípios obedecerá aos princípios de legalidade, impessoalidade, moralidade, publicidade e eficiência e, também, ao seguinte: (...) XXI - ressalvados os casos especificados na legislação, as obras, serviços, compras e alienações serão contratados mediante processo de licitação pública que assegure igualdade de condições a todos os concorrentes, com cláusulas que estabeleçam obrigações de pagamento, mantidas as condições efetivas da proposta, nos termos da lei, o qual somente permitirá as exigências de qualificação técnica e econômica indispensáveis à garantia do cumprimento das obrigações".

${ }^{360}$ Constituição Federal de 1988: "Art. 175. Incumbe ao Poder Público, na forma da lei, diretamente ou sob regime de concessão ou permissão, sempre através de licitação, a prestação de serviços públicos".

${ }^{361}$ Lei n. 8.987/95: "Art. 14. Toda concessão de serviço público, precedida ou não da execução de obra pública, será objeto de prévia licitação, nos termos da legislação própria e com observância dos princípios da legalidade, moralidade, publicidade, igualdade, do julgamento por critérios objetivos e da vinculação ao instrumento convocatório".

${ }^{362}$ Lei n. 8.987/95: "Art. $2^{\circ}$. Para os fins do disposto nesta Lei, considera-se: (...) II - concessão de serviço público: a delegação de sua prestação, feita pelo poder concedente, mediante licitação, na modalidade de concorrência, à pessoa jurídica ou consórcio de empresas que demonstre capacidade para seu desempenho, por sua conta e risco e por prazo determinado; III - concessão de serviço público precedida da execução de obra pública: a construção, total ou parcial, conservação, reforma, ampliação ou melhoramento de quaisquer obras de interesse público, delegada pelo poder concedente, mediante licitação, na modalidade de concorrência, à pessoa jurídica ou consórcio de empresas que demonstre capacidade para a sua realização, por sua conta e risco, de forma que o investimento da concessionária seja remunerado e amortizado mediante a exploração do serviço ou da obra por prazo determinado. (...) Art. 40. A permissão de serviço público será formalizada mediante contrato de adesão, que observará os termos desta Lei, das demais normas pertinentes e do edital de licitação, inclusive quanto à precariedade e à revogabilidade unilateral do contrato pelo poder concedente. Parágrafo único. Aplica-se às permissões o disposto nesta Lei”. Sobre outras hipóteses específicas de licitação para concessão, cf. Leis n. 9.074/95, 9.427/96 e 9.472/96. 
público-privada será precedida de licitação na modalidade de concorrência, estando a abertura do processo licitatório condicionada a: (...)". Prevê procedimento licitatório específico mas que não afasta a aplicação do regime da Lei n. $8666 / 93^{363}$, inclusive porque o artigo 12 prevê a aplicação do procedimento vigente sobre licitações e contratos administrativos. $^{364}$

Regra geral, portanto, para os contratos da Administração Pública abordados, é a exigência de a escolha do contratado se submeter ao processo licitatório, cada qual com sua especificidade mas todos os casos sujeitos ao regime geral da Lei n. 8.666/93. Sujeitos, inclusive, às hipóteses de contratação direta, em que "a licitação é impossível ou em que sua realização seria incompatível com a satisfação das necessidades coletivas". 365

Não é diferente com as hipóteses de contratação entre a Administração Pública e o Terceiro Setor: a regra geral, nestes casos, é a submissão ao regime de seleção por licitação pública, salvo as hipóteses de contratação direta, como a dispensa e a inexigibilidade de licitação. $^{366}$

Interessa, neste ponto, identificar na Lei de Licitações as hipóteses de dispensa e inexigibilidade de licitação relacionadas a atividades próprias de entidades do Terceiro Setor, o que não significa dizer absolutamente que as demais hipóteses não se aplicam a eventual contratação da Administração Pública com o Terceiro Setor ${ }^{367}$. Mas não sendo especificamente vinculadas às atividades destas entidades, deixaremos de abordá-las.

\footnotetext{
363 "Além disso, aplica-se também subsidiariamente, em tudo o que não contraria suas leis de regência, a Lei n. 8.666, de 21-6-93, por força do que dispõe seu artigo 124. Assim, os casos omissos na legislação específica podem ser resolvidos, no que for compatível, pela aplicação da lei de licitações, com as alterações decorrentes das Leis n. 8.883, de 6-7-94, e 9.648, de 7-7-95. Em matéria de licitação, o artigo 12 da Lei n. 11.079 expressamente estabelece que o certame obedecerá ao procedimento previsto na legislação vigente sobre licitações e contratos administrativos" (DI PIETRO, Maria Sylvia Zanella. Parcerias na Administração Pública: concessão, permissão, franquia, terceirização, parceria público-privada e outras formas. $5^{\text {a }}$ ed. São Paulo : Atlas, 2006, p. 87).

364 “Art. 12. O certame para a contratação de parcerias público-privadas obedecerá ao procedimento previsto na legislação vigente sobre licitações e contratos administrativos e também ao seguinte."

365 JUSTEN FILHO, Marçal. Curso de direito administrativo. $2^{\mathrm{a}}$ ed. São Paulo : Saraiva, 2006, p. 351. Sobre as contratações diretas afirma o autor: "A Constituição acolheu a presunção de que prévia licitação produz a melhor contratação - entendida como aquela que assegura a maior vantagem possível à Administração Pública, com observância do princípio da isonomia. Mas a própria Constituição se encarregou de limitar tal presunção, facultando contratação direta (sem licitação) nos casos previstos em lei” (Ibidem, p. $350)$.

366 “A chamada 'contratação direta' - aquela não precedida de um procedimento licitatório formal - não significa ausência de respeito aos princípios básicos que orientam a atuação administrativa. Permanece o dever de realizar a melhor contratação possível, dando tratamento igualitário a todos os possíveis contratantes" (Ibidem, p. 351).

${ }^{367}$ Podemos imaginar uma hipótese com fundamento no artigo 24, IV, da Lei n. 8.666/93, que prevê dispensa de licitação em casos de emergência ou calamidade pública. Neste caso, a Administração Pública poderá contratar com fundamento em dispensa de licitação uma entidade sem fins lucrativos ou uma empresa, devidamente justificado. Mas só indiretamente se conclui pela possibilidade de participação de entidade do
} 
Há casos de dispensa e inexigibilidade de licitação relacionados diretamente com atividades desenvolvidas por entidades privadas sem fins lucrativos no chamado espaço de participação do Terceiro Setor.

É de se lembrar, no entanto, que as situações de dispensa e de inexigibilidade de licitação são exceções de cuja regra é a realização de licitação. Isto significa dizer que tais hipóteses não estão no campo da discricionariedade administrativa, mas sujeitas ao enquadramento legal apropriado e ao procedimento próprio destinado a estas situações.

A contratação direta não significa que são inaplicáveis os princípios básicos que orientam a atuação administrativa. Nem se caracteriza uma livre atuação administrativa. Nem se caracteriza uma livre atuação administrativa. $\mathrm{O}$ administrador está obrigado a seguir um procedimento administrativo determinado, destinado a assegurar (ainda nesses casos) a prevalência dos princípios jurídicos fundamentais. Permanece o dever de realizar a melhor contratação possível, dando tratamento igualitário a todos os possíveis contratantes. ${ }^{368}$

A conclusão pela dispensa ou pela inexigibilidade de licitação - salvo casos em que a urgência não permita realmente ${ }^{369}$ - deve ser precedida dos procedimentos iniciais normalmente adotados nos casos de licitação. Desde a definição da necessidade que dá ensejo à contratação, passando pela elaboração de $\operatorname{projetos}^{370}$, análise orçamentária, etc., somente no momento da realização da contratação é que a Administração Pública, verificando a hipótese legal de dispensa ou inexigibilidade, invocará a exceção para não levar a cabo o procedimento licitatório. Mesmo assim deverá justificar a opção e dar continuidade a procedimento próprio aplicável a casos de dispensa e inexigibilidade.

Exige-se, por exemplo, em determinadas hipóteses, ratificação da autoridade superior e publicação em prazo determinado como condição de sua eficácia, além de instrução processual com elementos de motivação do ato administrativo pela escolha da "modalidade" de contratação direta:

Terceiro Setor nesta contratação, imaginando, por exemplo, uma necessidade ambulatorial emergencial que possa ser sanada por este tipo de entidade.

368 JUSTEN FILHO, Marçal. Comentários à lei de licitações e contratos administrativos. 14a ed. São Paulo : Dialética, 2010, p. 295.

369 "Somente em hipóteses-limite é que a Administração estaria autorizada a contratar sem o cumprimento dessas formalidades. Seriam aqueles casos de emergência tão grave que a demora, embora mínima, pusesse em risco a satisfação dos valores a cuja realização se orienta a atividade administrativa" (ibidem, p. 295).

${ }^{370}$ Veja-se, por exemplo, o conteúdo do artigo $7^{\circ}$, da Lei n. 8.666/93, em especial seu $\S 9^{\circ}$, que exige a elaboração de projetos mesmo nos casos de dispensa e inexigibilidade de licitação: "Art. $7^{0}$ As licitações para a execução de obras e para a prestação de serviços obedecerão ao disposto neste artigo e, em particular, à seguinte seqüência: I - projeto básico; II - projeto executivo; III - execução das obras e serviços. (...) $\S 9^{0} \mathrm{O}$ disposto neste artigo aplica-se também, no que couber, aos casos de dispensa e de inexigibilidade de licitação". 
Art. 26. As dispensas previstas nos $\S \S 2^{\circ}$ e $4^{\circ}$ do art. 17 e no inciso III e seguintes do art. 24 , as situações de inexigibilidade referidas no art. 25 , necessariamente justificadas, e o retardamento previsto no final do parágrafo único do art. $8^{\circ}$ desta Lei deverão ser comunicados, dentro de 3 (três) dias, à autoridade superior, para ratificação e publicação na imprensa oficial, no prazo de 5 (cinco) dias, como condição para a eficácia dos atos. Parágrafo único. O processo de dispensa, de inexigibilidade ou de retardamento, previsto neste artigo, será instruído, no que couber, com os seguintes elementos:

I - caracterização da situação emergencial ou calamitosa que justifique a dispensa, quando for o caso;

II - razão da escolha do fornecedor ou executante;

III - justificativa do preço.

IV - documento de aprovação dos projetos de pesquisa aos quais os bens serão alocados.

As hipóteses de contratação direta também buscam a satisfação do interesse público, não se afastando dos postulados que orientam a realização das licitações. Diga-se, aliás, que salvo as hipóteses específicas de ausência de competição, mesmo as hipóteses de dispensa e inexigibilidade de licitação estão sujeitas ao princípio da isonomia, o que significa dizer que em havendo possibilidade de competição para o objeto da contratação a Administração deverá levar isto em conta. ${ }^{371}$ Vejamos, então, as hipóteses de dispensa e de inexigibilidade de licitação que aproveitam diretamente ao Terceiro Setor. ${ }^{372}$

\section{a) Dispensas de licitação e o Terceiro Setor}

As dispensas de licitação estão previstas nos artigos 17 e 24 , da Lei n. 8.666/93 ${ }^{373}$. São hipóteses em que o legislador entendeu pela inconveniência do procedimento

${ }^{371}$ Cf. JUSTEN FILHO, Marçal. Comentários à lei de licitações e contratos administrativos. $14^{\mathrm{a}}$ ed. São Paulo : Dialética, 2010, p. 298.

${ }_{372}$ Paolo Michiara, analisando o regime jurídico italiano, entende que as entidades de natureza voluntária como as do Terceiro Setor não deveriam ser habilitadas a contratar com a Administração Pública para a prestação de serviços, por entender que desnaturaria a natureza voluntária da atividade: "O acordo deveria ser considerado, como acenado nos parágrafos concernentes à natureza jurídica dos acordos com o voluntariado, um instrumento de incentivo (a disciplina de um financiamento) e não um contrato de serviço. Em outro sentido estaria desnaturada a própria natureza do voluntariado (se deveria tratar de atividade espontânea e gratuita, não de uma prestação de serviços do tipo empresarial, objeto de contrato de serviço). Nesta perspectiva o voluntariado não deveria poder participar de concorrências relativas a contratos de serviço" (MICHIARA, Paolo. Le convenzioni tra pubblica amministrazione e terzo settore: considerazione sulle procedure selettive a concorrenza limitata nell'ambito dei rapporti a collaborazione necessaria. Roma : Istituto Editoriale Regione Italiane S.R.L., 2005, p. 404). No original: "La convenzione dovrebbe essere considerata, come accenato nei paragrafi concernenti la natura giuridica delle convenzioni con il volontariato, uno strumento di incentivazione (il disciplinare di un finanziamento) e non un appalto di servizi. Diversamente argomentando verrebbe snaturata la natura stessa del volontariato (si dovrebbe trattare cioè di attività spontanea e gratuita, non di una prestazione di servizi di tipo imprenditoriale, oggetto appunto invece dell'appalto di servizi). In tale prospettiva il volontariato non dovrebbe poter partecipare a gare relative appunto a appalti di servizi".

${ }^{373}$ "Não há diferença real entre dispensada e dispensável. A diferença é a propósitos das hipóteses dos arts. 17 e 24, respectivamente, da Lei n. 8.666/93. Em ambos os casos, o legislador autoriza a contratação direta" (JUSTEN FILHO, Marçal. Curso de direito administrativo. $2^{\mathrm{a}}$ ed. São Paulo : Saraiva, 2006, p. 354). Hely Lopes Meirelles prefere diferenciar as hipóteses: "A Lei 8.666, de 1993, assim como o Estatuto anterior, 
licitatório em uma análise que sopesa as vantagens que traria ao Poder Público, verdadeira expressão do princípio da proporcionalidade. ${ }^{374}$

São situações em que, embora haja possibilidade de competição, a legislação optou por permitir à Administração Pública que não leve a efeito o procedimento licitatório, sob justificativas que podem ser denominadas
a) em razão do pequeno valor;
b) em razão de situações excepcionais;
c) em razão do objeto;
d) em razão da pessoa. ${ }^{375}$

Interessam para o presente trabalho, especialmente, as hipóteses de dispensa de licitação em razão do objeto e em razão da pessoa, haja vista permitirem a contratação direta de entidades do Terceiro Setor (seja em razão do seu objeto de atividade, seja em razão de sua personalidade jurídica), sempre que os requisitos para tanto permitirem.

\section{a.1) Contratação de instituição brasileira de pesquisa, ensino, desenvolvimento institucional ou dedicada à recuperação social do preso (art. 24, XIII)}

Em razão da pessoa é dispensável a licitação, conforme artigo 24, XIII,

na contratação de instituição brasileira incumbida regimental ou estatutariamente da pesquisa, do ensino ou do desenvolvimento institucional, ou de instituição dedicada à recuperação social do preso, desde que a contratada detenha inquestionável reputação ético-profissional e não tenha fins lucrativos.

Segundo Evandro José da Silva Prado

estabeleceu nítida distinção entre licitação dispensada (art. 17, I e II), licitação dispensável (art. 24, I a XXIV) e licitação inexigível (art. 25, I a III)" (MEIRELLES, Hely Lopes. Licitação e contrato administrativo. $15^{\text {a }}$ ed. São Paulo : Malheiros, 2010, p. 141).

${ }^{374}$ Cf. JUSTEN FILHO, Marçal. Curso de direito administrativo. $2^{\mathrm{a}}$ ed. São Paulo : Saraiva, 2006, p. 351.

375 DI PIETRO, Maria Sylvia Zanella. Direito administrativo. $19^{\mathrm{a}}$ ed. São Paulo : Atlas, 2006, p. 363. Marçal Justen Filho apresenta classificação diversa: “As diversas hipóteses previstas no art. 24 podem ser sistematizadas segundo o ângulo de manifestação de desequilíbrio na relação custo/benefício: a) custo econômico da licitação: quando o custo econômico da licitação for superior ao benefício dela extraível (incs. I e II); b) custo temporal da licitação: quando a demora na realização da licitação puder acarretar a ineficácia da contratação (incs. III e IV); c) ausência de potencialidade de benefício: quando inexistir potencialidade de benefício em decorrência da licitação (incs. V, VII, VIII, XI, XIV, XXIII e XXVI); d) destinação da contratação: quando a contratação não for norteada pelo critério da vantagem econômica, porque o Estado busca realizar outros fins (incs. VI, IX, XIII, XVI, XX, XXI, XXIV, XXV e XXVII)" (JUSTEN FILHO, Marçal. Ibidem, p. 357). 
inserem-se, dessa forma, como potenciais entidades aptas a esse tipo de contratação, as instituições e centros de pesquisa, universidades públicas, fundações universitárias, associações civis, organizações não-governamentais (ONGs) e outras sem finalidades lucrativas e que possuam objetivos estatuários condizentes com o que exige a legislação competente. ${ }^{376}$

Instituições privadas de pesquisa, instituições privadas de ensino e instituições privadas de desenvolvimento institucional, além de instituições dedicadas à recuperação social do preso, desde que tenham inquestionável reputação ético-profissional e não tenham fins lucrativos, podem ser contratadas pelo Poder Público sem a necessidade de licitação. É tema que aparenta tranqüilidade, mas que em verdade está rodeado de diversos debates e discussões conceituais.

A começar com a locução instituição brasileira, que embora aparente não ter qualquer significado técnico deve ser interpretada de modo a limitar a contratação direta a pessoas jurídicas formalmente instituídas, excluindo os movimentos e grupos sociais não constituídos como pessoa jurídica na forma da lei civil brasileira. ${ }^{377}$ Preenchido este requisito, deve-se passar à análise do conteúdo material da atuação da instituição: pesquisa, ensino, desenvolvimento institucional e recuperação social do preso.

A atividade de pesquisa que permite a contratação direta tem sido compreendida pela doutrina de forma restritiva, tanto para evitar que qualquer atividade se enquadre na vaga locução quanto para excluir da possibilidade de contratação direta atividades de vaga delimitação. ${ }^{378}$

\footnotetext{
${ }^{376}$ PRADO, Evandro José da Silva. Dispensa de licitação para contratação de instituição sem fins lucrativos. Revista do Tribunal de Contas de Santa Catarina, Florianópolis, ano 2, v. 3, 2004, p. 63. Disponível na Internet: <http://www.tce.sc.gov.br/site/publicacoes/livros/pdf/revista_tce_03.zip >. Acesso em: 12 abr. 2010. ${ }^{377}$ Marçal Justen Filho afirma que “a expressão 'instituição' exclui pessoas físicas. Ainda que o vocábulo permita severas disputas semânticas, a ideia de 'instituição' está vinculada a uma estrutura organizacional que transcende a participação e a identidade do ser humano. Na acepção aplicável ao caso, uma instituição é uma pessoa jurídica peculiarizada pela vinculação à realização de certos fins que transcendem os interesses dos seus associados, com as características da permanência ao longo do tempo e estabilidade de atuação. Ou seja, todas as instituições em sentido subjetivo são pessoas jurídicas, mas nem todas as pessoas jurídicas são instituições. A pessoa jurídica destituída de vinculação concreta e efetiva a uma atividade relacionada com a realização de idéias e objetivos que transcendem as pessoas físicas não é uma instituição. A instituição corresponde a uma organização de recursos materiais e de esforços humanos que se autonomiza em face dos seus próprios fundadores, passando a gozar de um acentuado grau de independência. São exemplos clássicos de instituição o Estado, a Igreja, algumas entidades de benemerência (Cruz Vermelha, Santas Casas de Misericórdia), fundações e assim por diante" (JUSTEN FILHO, Marçal. Comentários à lei de licitações e contratos administrativos. $14^{\mathrm{a}}$ ed. São Paulo : Dialética, 2010, p. 326). O autor, portanto, exige que além da constituição da entidade como pessoa jurídica, sua atuação social seja dotada das características da permanência e estabilidade.

${ }^{378}$ Cf. sobre o tema PRADO, Evandro José da Silva. Op. cit., pp. 61-82.
} 
Entendemos, com Marçal Justen Filho, que a priori o conceito do vocábulo pesquisa merece interpretação ampla. ${ }^{379}$ Quisesse a lei especificar a qual pesquisa estaria se referindo e o dispositivo seria mais claro. Mas a toda evidência, materialmente a pesquisa objeto de contratação pela Administração Pública deverá, além de se enquadrar nos requisitos necessários às hipóteses de dispensa (como a ausência de competição, por exemplo), guardar consonância com determinados contornos que limitam a subjetividade da escolha.

Em primeiro lugar pela necessidade de a pesquisa contratada ser específica, enquadrável no contexto conceitual do contrato administrativo. "Objetos vagos, para os fins da Lei n. 8.666/93, como, por exemplo, pesquisar a cura da AIDS, são ilegais, dispondo o Estado de outros meios para realizar tais atividades, inclusive mediante subvenção". ${ }^{380}$ Esta especificidade do objeto, aliás, auxilia na justificativa para a opção de contratação direta sem licitação, haja vista limitar a possibilidade de concorrência àquelas instituições que atuam especificamente no objeto da pesquisa.

É justamente o tópico objeto das maiores controvérsias quanto a este tema: o nexo entre o objeto específico da instituição e o objeto da pesquisa contratada. Verdadeiramente, não basta a instituição ser instituição de pesquisa para ser contratada para a elaboração de pesquisa específica. ${ }^{381}$ É necessário que seja instituição de pesquisa em área conexa à da pesquisa contratada.

Percebe-se, dessa forma, que a existência de nexo entre o objeto do contrato e a instituição contratada é condição essencial à validade da dispensa de licitação, pois uma interpretação lógica do dispositivo em questão conduz inexoravelmente à idéia de que não basta que a entidade contratada seja incumbida regimentalmente de pesquisa, ensino e desenvolvimento institucional, mas sim que o objeto a ser contratado tenha também a ver

\footnotetext{
379 "Em princípio, o conceito de pesquisa deve ser interpretado amplamente, evitando preconceitos quanto ao objeto da atuação desenvolvida" (JUSTEN FILHO, Marçal. Op. cit., p. 326).

${ }^{380}$ FERNANDES, Jorge Ulisses Jacoby. Contratação direta sem licitação. $4^{\text {a }}$ ed., Brasília : Brasília Jurídica, 1999, p. 316. No mesmo sentido: “A Administração Pública deve certificar-se de que a execução dos referidos projetos são viáveis dentro de um prazo determinado e que a instituição contratada possui, de fato, os requisitos e as competências necessárias para tal. Deve-se, ainda, levar em conta a possibilidade de estabelecer um planejamento para definir etapas e objetivos específicos inerentes à execução dos projetos, estimando, inclusive, um custo para cada fase do seu desenvolvimento" (PRADO, Evandro José da Silva. Op. cit., p. 73).

${ }^{381}$ Vale aqui a ressalva: "Reitera-se que a possibilidade de dispensa de licitação é instrumento absolutamente excepcional, colocado à disposição do administrador em numerus clausus. Caso contrário, bastaria a qualquer entidade incluir em seus estatutos que se dedica à pesquisa, ensino ou desenvolvimento institucional e poderia ser contratada aleatoriamente pela Administração Pública, sem licitação e para prestar todo e qualquer tipo de serviço" (ZUQUIM, Sávio de Faria Caram. Impossibilidade de dispensa de licitação para a contratação de entidades de ensino visando à realização de concursos públicos. Revista do Tribunal Regional Federal da $1^{a}$ Região, Brasília, v. 11, n. 2, abr.-jun. 1999, p. 51. Disponível na Internet: $<$ http://bdjur.stj.gov.br/xmlui/bistream/handle/2011/21895/impossibilidade_dispensa_licitacao_contratacao.p df? sequence=1>. Acesso em: 12 abr. 2010.
} 
com essas atividades. Interpretação diferente dá margem para que as instituição privilegiadas pela legislação criem estrutura específica para atender qualquer demanda de serviços requerida pelos agentes públicos, maculando o instituto do concurso público e da licitação. ${ }^{382}$

É o que Marçal Justen Filho chama de "vínculo de pertinência entre o fím da instituição e o objeto do contrato", pelo qual "somente se configuram os pressupostos do dispositivo quando o objeto da contratação inserir-se no âmbito de atividade inerente e próprio da instituição".383

Temos, assim, que uma instituição sem fins lucrativos que se dedique ao acompanhamento das condições de vida da população indígena de determinada região pode ser contratada com dispensa de licitação pelo Poder Público para a elaboração de um censo populacional de determinada tribo, incluído no conceito de pesquisa.

Da mesma forma uma instituição sem fins lucrativos cujo objeto seja o estudo e a pesquisa da aranha marrom pode ser contratada sem licitação para a elaboração de pesquisa sobre a incidência de picadas em certa região. ${ }^{384}$

Estes, entre outros exemplos inseridos no espaço de participação do Terceiro Setor anteriormente definido, se enquadram na idéia de contratação direta de entidades do Terceiro Setor para atividades de pesquisa.

Mas os requisitos acima analisados também servem para a hipótese da contratação por dispensa de licitação para atividade de ensino, desenvolvimento institucional e de recuperação social do preso

\footnotetext{
382 PRADO, Evandro José da Silva. Op. cit., pp. 68-69. Interessante citar o seguinte precedente jurisprudencial do Tribunal de Justiça do Estado de São Paulo sobre o tema: "CONTRATO ADMINISTRA TIVO - LF $n^{\circ}$ 8.666/93, art. 24, XIII - Dispensa de licitação - Serviços de aprimoramento e melhoria da produtividade e qualidade e controle orçamentário e financeiro dos valores disponibilizados aos módulos do PAS (Plano de Atendimento à Saúde) - Entidade brasileira voltada è pesquisa, ao ensino ou ao desenvolvimento institucional, sem fins lucrativos e de ilibada reputação. 1. O art. 24, XIII da LF nº 8.666/93 exige que a instituição nela mencionada tenha reconhecida reputação ético-profissional na área objeto do contrato. A ré FESPSP não prevê em seus estatutos a elaboração de projetos de controladoria e recursos financeiros, nem demonstrou ela ter especialidade ou renome nessa área. Trata-se de entidade voltada ao ensino e à pesquisa na área de sociologia, dedicada também ã formação e qualificação de pessoal para a administração pública, algo diverso do objeto do contrato. Não atende ela os requisitos do art. 24, XIII da Lei Federal de Licitações" (Tribunal de Justiça do Estado de São Paulo, $7^{\mathrm{a}}$ Câmara de Direito Público, Apelação cível n. 115.165-5/4-00, Rel. Des. Torres de Carvalho, 11/09/2000).

383 JUSTEN FILHO, Marçal. Comentários à lei de licitações e contratos administrativos. $14^{\mathrm{a}}$ ed. São Paulo : Dialética, 2010, pp. 327-328. Vide a respeito as decisões do Tribunal de Contas da União: Acórdãos $1616 / 2003,50 / 2007$ e 1614/2003.

${ }^{384}$ Segundo Jorge Ulisses Jacoby Fernades: “A atividade poderá, inclusive, nem ser a pesquisa, embora firmada com uma entidade dedicada à pesquisa, havendo compatibilidade com o objeto. Tal ocorreria, por exemplo, se uma Prefeitura firmasse um contrato de treinamento do pessoal acerca de agressões de cobras e aracnídeos e de fornecimento de vacinas com a Fundação Osvaldo Cruz" (FERNANDES, Jorge Ulisses Jacoby. Contratação direta sem licitação. $4^{\text {a }}$ ed. Brasília : Brasília Jurídica, 1999, p. 316).
} 
O ensino é conceito amplo que permite a inserção de diversas atividades desempenhadas também por uma diversidade grande de instituições e empresas, hipóteses nas quais o Poder Público deverá ser bastante criterioso no momento de selecionar o procedimento de contratação a ser levado em consideração. Como visto, sendo a dispensa de licitação exceção para os casos em que não haja competição, resta espaço a casos bastante específicos.

Quando estiver convicta que determinado curso ou treinamento é ministrado por apenas uma instituição sem fins lucrativos e que o setor privado também não disponha dessa atribuição, a entidade pública deve justificar a dispensa de licitação de forma detalhada, dando ênfase ao seu grau de necessidade e aos respectivos benefícios advindos com a contratação da entidade envolvida, destacando também os objetivos e resultados esperados. ${ }^{385}$

Um bom exemplo de atividade de ensino desenvolvida pelo Terceiro Setor e abrangida pelo dispositivo, embora aplicado pelo autor para o conceito de atividade de desenvolvimento institucional, seria a contratação de associação civil de amparo e inclusão dos portadores do vírus HIV nos seguintes termos:

Uma associação sem fins lucrativos que ampara os aidéticos, por exemplo, poderia ser contratada para auxiliar o órgão governamental no desempenho desse trabalho, realizando palestras e treinamento com todos os funcionários, destacando a importância e a necessidade de o indivíduo soropositivo adequar-se às condições de trabalho da entidade. ${ }^{386}$

O conceito de desenvolvimento institucional é ainda mais desafiador para fins de enquadramento nas hipóteses de dispensa de licitação ${ }^{387}$. O Tribunal de Contas da União já entendeu que seu conceito não pode ser considerado de forma abrangente, "a fim de evitar a contratação, sem maiores critérios, desses órgãos/entidades mediante dispensa de licitação". 388

A compreensão ampla deste conceito tem permitido a assinatura de diversos contratos com os mais variados objetos pela Administração Pública, sem licitação, sob o fundamento de que objetivam o crescimento da instituição, portanto buscariam o

\footnotetext{
${ }^{385}$ PRADO, Evandro José da Silva. Op. cit., p. 72.

${ }^{386}$ Ibidem, pp. 77-78.

387 "Existe maior dificuldade no tocante ao conceito de 'desenvolvimento institucional', inclusive por efeito de uma espécie de autorreferibilidade do dispositivo" (JUSTEN FILHO, Marçal. Comentários à lei de licitações e contratos administrativos. $14^{\mathrm{a}}$ ed. São Paulo : Dialética, 2010, p. 327). "Talvez a maior dificuldade encontrada pela doutrina especializada e pelos tribunais de contas para esclarecer o inciso em pauta é referente ao sentido exato da expressão 'desenvolvimento institucional"' (PRADO, Evandro José da Silva. Ibidem, p. 74.).

${ }^{388}$ Tribunal de Contas da União, Acórdão n. 3564/2006, Plenário, Rel. Min. Marcos Bemquerer.
} 
desenvolvimento institucional. São, no mais das vezes, serviços técnicos e fornecimento de mão-de-obra.

Uma das maiores irregularidades apontadas nestes relatórios diz respeito a contratos de parceria que visam ao fornecimento de ampla gama de serviços técnicos/administrativos e de assessoramento por parte das instituições destacadas, tais como: informática, assessoria jurídica e contábil, consultoria técnica e organizacional, apoio operacional, fornecimento de mão-de-obra etc. Ao ampararem a contratação desses serviços no dispositivo em pauta, as entidades estatais estão, na verdade, desvirtuando o objetivo de sua aplicação prática, produzindo vícios administrativos que fogem à regra estabelecida pelo legislador, pois esse procedimento não passa de uma forma de burlar o dispositivo constitucional (art. 37, inciso II) que exige a realização de concurso público para provimento de cargos públicos e do próprio certame licitatório. ${ }^{389}$

O Tribunal de Contas da União já se manifestou quanto à necessidade de limitar o conceito de desenvolvimento institucional, afastando a idéia de que compreenderia o aperfeiçoamento das instituições:

Uma interpretação apressada da Lei poderia conduzir à ilação de que desenvolvimento institucional seria qualquer ato voltado para o aperfeiçoamento das instituições, para a melhoria do desempenho das organizações. Nesse sentido, contudo, a simples automatização de procedimentos, a aquisição de equipamentos mais eficientes, a reforma das instalações de uma unidade, a ampliação das opções de atendimento aos clientes, o treinamento de servidores, a reestruturação organizacional e um sem-número de outras ações que significassem algum plus no relacionamento entre a Administração e a Sociedade poderiam ser entendidas como tal. ${ }^{390}$

A doutrina tenta apontar conceito para o instituto, mas não especifica o seu conteúdo com clareza:

Existe maior dificuldade no tocante ao conceito de "desenvolvimento institucional", inclusive por efeito de uma espécie de autorreferibilidade do dispositivo. Ali se indicam as instituições que promovem o desenvolvimento de outras instituições. Deve-se reputar que o dispositivo alude às instituições sociais e políticas. ${ }^{391}$

De todas as expressões utilizadas pelo legislador no inciso, o "desenvolvimento institucional" foi a mais ampla. Se a doutrina até agora debate-se por açambarcar e analisar as acepções da palavra instituição, a rigor, "desenvolvimento institucional" compreenderia crescimento, progresso, de qualquer coisa que possa estar compreendida no termo instituição. Cuida do desenvolvimento institucional tanto uma empresa que possui um centro de controle de qualidade, como uma faculdade, como um sindicato, como uma associação de moradores, enfim, qualquer "instituição" que se dedique a um fim. Por

\footnotetext{
${ }^{389}$ PRADO, Evandro José da Silva. Op. cit., pp. 63-64.

${ }^{390}$ Tribunal de Contas da União, Plenário, Decisão n. 30/2000, Rel. Min. Guilherme Palmeira.

391 JUSTEN FILHO, Marçal. Comentários à lei de licitações e contratos administrativos. $14^{\mathrm{a}}$ ed. São Paulo : Dialética, 2010, p. 327.
} 
óbvio, impõe o interesse público a restrição do termo a fim de que o mesmo se harmonize com o ordenamento jurídico. ${ }^{392}$

O Tribunal de Contas da União, na decisão antes citada, com apoio na doutrina de Marçal Justen Filho e Jorge Ulisses Jacoby Fernandes e no intuito de efetivar o seu intuito de limitar a aplicação do dispositivo de modo a impedir a utilização da dispensa de licitação desmedidamente, expressou entendimento de flagrante aproximação do conteúdo de desenvolvimento institucional às atividades que entendemos pertencentes ao espaço de participação do Terceiro Setor. Seria atividade considerada como de desenvolvimento institucional aquela vinculada a ação social constitucionalmente especificada como de interesse do Estado, fazendo menção expressa a alguns dispositivos que arrolam direitos sociais. Veja-se a seguinte passagem:

Logo, desenvolvimento institucional não pode significar, simplesmente, ao menos no contexto do inciso XIII, melhoria ou aperfeiçoamento das organizações públicas.

Os autores citados, em que pese às variações de abrangência admitidas, associam a expressão a alguma forma de ação social que tenha sido constitucionalmente especificada como de interesse do Estado. Nesse sentido, seriam entidades dedicadas ao desenvolvimento institucional, por exemplo, aquelas voltadas para a proteção à infância (arts. 203, I, e 204, I, da C.F.), ao deficiente (arts. 203, IV, e 204, I), à saúde (arts. 196, 197 e 200, V), para o desenvolvimento do ensino (arts. 205, 213 e 214), para o desporto (art. 217), entre outras. Nesse rol, entrariam as APAEs, as Sociedades Pestalozzi, a CNEC, a Associação das Pioneiras Sociais, as associações esportivas, etc. ${ }^{393}$

Interpretando a manifestação do Tribunal de Contas da União, Evandro José da Silva Prado propõe que

sob esta ótica, o significado da referida expressão parece estar relacionado a algum tipo de trabalho que a Administração Pública julgue importante para o seu fortalecimento institucional perante a sociedade e para o ambiente laboral em que se encontra inserida, como o de aprimorar o relacionamento e o desenvolvimento social de parte ou do total das pessoas que a compõem. Isso poderá ser viabilizado com a realização de palestras, treinamentos, reuniões e consultorias prestadas pelas instituições aqui destacadas. ${ }^{394}$

Embora não exatamente conclusivas, estas considerações auxiliam na compreensão das possibilidades de contratação direta de entidades do Terceiro Setor que desempenhem

\footnotetext{
392 FERNANDES, Jorge Ulisses Jacoby. Contratação direta sem licitação. $4^{\mathrm{a}}$ ed. Brasília : Brasília Jurídica, 1995, p. 225.

393 Tribunal de Contas da União, Plenário, Decisão n. 30/2000, Rel. Min. Guilherme Palmeira.

${ }^{394}$ PRADO, Evandro José da Silva. Op. cit., p. 77. O autor entende, ainda, que "devem os tribunais de contas dar uma explicação mais concreta sobre o significado da matéria em estudo, exemplificando, inclusive, alguns tipos de serviços prestados pelas entidades mencionadas que poderão ser contratados sem licitação, com fulcro no inciso XIII" (ibidem, p. 78).
} 
atividades que possam ser consideradas como de desenvolvimento institucional. Novamente Evandro Silva Prado nos auxilia afirmando que

o TCU, através das decisões 657/97 e 39/00, entende que a expressão "desenvolvimento institucional" esteja associada a alguma ação de "desenvolvimento social" promovida pelas instituições que lutam por uma causa específica, tais como: deficientes físicos, aidéticos, meio ambiente, hemofílicos, infância, desporto, ensino etc. No entanto, a contratação direta dessas instituições nem sempre é conveniente a todos os órgãos e empresas estatais, pelo fato de os serviços por elas prestados não se mostrarem úteis a todos os objetivos estratégicos e estatutários das entidades contratantes. ${ }^{395}$

É tema que realmente merece maiores considerações, quiçá alteração legislativa no intuito de esclarecer o seu conteúdo. ${ }^{396}$ Sabe-se, todavia, que a utilização do dispositivo é bastante freqüente, especialmente para a contratação das chamadas fundações de apoio às universidades públicas, no mais das vezes de forma indevida. ${ }^{397}$

\section{a.2) Aquisição ou restauração de obras de arte e objetos históricos, de autenticidade certificada, desde que compatíveis ou inerentes às finalidades do órgão ou entidade} (art. 24, XV)

Outra hipótese de dispensa de licitação que materialmente se aproxima bastante do espaço de participação do Terceiro Setor, desta feita em razão do objeto, está prevista no artigo 24, XV, da Lei n. 8666/93, in verbis:

para a aquisição ou restauração de obras de arte e objetos históricos, de autenticidade certificada, desde que compatíveis ou inerentes às finalidades do órgão ou entidade.

Observa-se que o dispositivo prevê duas hipóteses distintas: i) aquisição de obras de arte e objetos históricos; e b) restauração de obras de arte de objetos históricos. Ambos se justificam no preceito constitucional contido no artigo $216, \S 1^{\mathrm{o}}$, que dispõe: "§ $1^{\mathrm{o}}-\mathrm{O}$

\footnotetext{
395 Ibidem, p. 80.

396 Há poucos julgados esclarecedores sobre o tema, e mesmo o Supremo Tribunal Federal, quando se manifestou, não enfrentou o mérito conceitual. Cf. Supremo Tribunal Federal, Inquérito n. 1957-7/PR, Pleno, Rel. Min. Carlos Velloso, 11/05/2005.

397 Sobre o tema: DI PIETRO, Maria Sylvia Zanella. Parcerias na Administração Pública: concessão, permissão, franquia, terceirização, parceria público-privada e outras formas. $5^{\text {a }}$ ed. São Paulo : Atlas, 2006, pp. 281 e ss. Veja-se, também, hipótese específica de dispensa de licitação criada pela Lei n. 8.958/94: “Art. $1^{\circ}$ As instituições federais de ensino superior e de pesquisa científica e tecnológica poderão contratar, nos termos do inciso XIII do art. 24 da Lei $\mathrm{n}^{\circ}$ 8.666, de 21 de junho de 1993, e por prazo determinado, instituições criadas com a finalidade de dar apoio a projetos de pesquisa, ensino e extensão e de desenvolvimento institucional, científico e tecnológico de interesse das instituições federais contratantes".
} 
Poder Público, com a colaboração da comunidade, promoverá e protegerá o patrimônio cultural brasileiro, por meio de inventários, registros, vigilância, tombamento e desapropriação, e de outras formas de acautelamento e preservação".

Neste mister constitucional, em determinadas hipóteses o Poder Público se verá diante da necessidade de adquirir obras de arte ou objetos históricos. Imagina-se, assim, a hipótese de importante documento histórico ser descoberto no acervo de um museu privado. Dada a singularidade da obra, o Poder Público dispensará licitação para a sua aquisição, para que figure no acervo público e seja destinado ao conhecimento de toda a população. Também na hipótese de acervo de importante artista nacional, sob a guarda de instituição privada sem fins lucrativos em dificuldades para mantê-lo, poderá o Poder Público intervir fazendo a aquisição sem licitação. Como ensina Marçal Justen Filho,

deverá ser justificado o interesse estatal na aquisição do bem. Usualmente, isso se passa quando os custos de conservação sejam insuportáveis para o proprietário, quando se pretenda assegurar o amplo acesso da população ao bem, quando se tratar de evitar o deslocamento do bem para o estrangeiro etc. ${ }^{398}$

Considerando que há grande número de museus privados sem fins lucrativos, e mesmo instituições sem fins lucrativos criadas para a guarda do acervo de documentos históricos e obras de arte de personalidades, justifica-se a possibilidade de contratação nestes moldes entre a Administração Pública e o Terceiro Setor.

Em outras hipóteses, o Poder Público poderá se ver compelido a contratar serviços de restauração de documentos históricos e obras de arte, segunda situação prevista no dispositivo em análise. Esta restauração, como a própria lei reconhece em seu artigo $13^{399}$, é serviço técnico profissional especializado, gerando no mais das vezes hipóteses de contratação por inexigibilidade de licitação com fundamento na inexistência de competição $^{400}$, conforme artigo 25 , II, adiante analisado. ${ }^{401}$ Haverá casos entretanto que,

\footnotetext{
398 JUSTEN FILHO, Marçal. Comentários à lei de licitações e contratos administrativos. $14^{\mathrm{a}}$ ed. São Paulo : Dialética, 2010, p. 332.

399 “Art. 13. Para os fins desta Lei, consideram-se serviços técnicos profissionais especializados os trabalhos relativos a: (...) VII - restauração de obras de arte e bens de valor histórico. § 1 ${ }^{\circ}$ Ressalvados os casos de inexigibilidade de licitação, os contratos para a prestação de serviços técnicos profissionais especializados deverão, preferencialmente, ser celebrados mediante a realização de concurso, com estipulação prévia de prêmio ou remuneração".

400 "A hipótese se enquadra, teoricamente, como impossibilidade de competição e seria mais apropriado reconhecer a ocorrência de inexigibilidade de licitação (tal como o fazia a lei anterior). Aliás, isto está implicitamente reconhecido no próprio art. 13, VII, que trata a restauração de obras de arte como serviço técnico profissional especializado (cuja contratação se submete ao disposto no art. 25, II)" (JUSTEN FILHO, Marçal. Op. cit., p. 332). No mesmo sentido: DI PIETRO, Maria Sylvia Zanella. Op. cit., p. 367.
} 
pelo contrário, sugerirão a realização de seleção técnica pelo Poder Público em virtude da existência de diversos profissionais habilitados à execução da restauração.

Em qualquer caso, no entanto, a possibilidade de contratação com entidade sem fins lucrativos da área da cultura é evidente, justificando a interface do tema com o Terceiro Setor.

\section{a.3) Contratação de associação de portadores de deficiência física, sem fins lucrativos e de comprovada idoneidade, por órgãos ou entidades da Admininistração Pública, para a prestação de serviços ou fornecimento de mão-de-obra, desde que o preço contratado seja compatível com o praticado no mercado (art. 24, XX)}

Ainda outra hipótese de dispensa de licitação relacionada a atividades desenvolvidas pelo Terceiro Setor é encontrada na Lei n. 8666/93, especificamente em seu artigo 24, XX, que estabelece a dispensa

na contratação de associação de portadores de deficiência física, sem fins lucrativos e de comprovada idoneidade, por órgãos ou entidades da Admininistração Pública, para a prestação de serviços ou fornecimento de mão-de-obra, desde que o preço contratado seja compatível com o praticado no mercado.

Classificada como dispensa em razão da pessoa, a norma tem conteúdo social dúplice; em primeiro lugar de conscientização quanto às potencialidades das pessoas portadoras de necessidades especiais no mercado de trabalho e em segundo lugar inclusivo das pessoas portadoras de deficiência.

Neste sentido que se observa no conteúdo da norma a dispensa de licitação para a contratação de entidade sem fins lucrativos com o objeto descrito no dispositivo para promover palestras aos funcionários públicos quanto à realidade dos seus colegas portadores de necessidades especiais. Da mesma forma, permite compreender a possibilidade de contratação de entidade para prestar consultoria específica na adaptação de determinada repartição pública às necessidades especiais. ${ }^{402}$ Seriam expressões da

401 Esta hipótese, aliás, era considerada hipótese de inexigibilidade no regime anterior do Decreto-lei $\mathrm{n}$. 2300/86 (art. 23, V).

402 "Quanto ao objeto, adota-se parcimônia e a mesma inteligência doutrinária e jurisprudencial utilizada para o inciso XIII do artigo 24, isto é, o objeto do contrato e suas atividades devem possuir compatibilidade com os fins da entidade e, no caso, com o tipo de deficiência. Notadamente, o serviço deve ter adequação com a expertise da instituição. Não seria, por exemplo, ilegal a contratação de uma Associação de Arquitetos e Amigos do Deficiente Físico, para auxiliar na elaboração de projetos de urbanismo" (FARIA, Juliana Campos de. Contratação de entidades de portadores de deficiência física: releitura da dispensa de licitação à 
primeira possibilidade prevista no inciso, a da contratação de entidade para a prestação de serviços. Sempre, claro, desde que preenchidos os requisitos da dispensa anteriormente analisados, inclusive aqueles relacionados à pertinência temática debatidos quando da análise do inciso XIII. ${ }^{403}$ Não faria sentido, por exemplo, “o Clube de Basquete de Deficientes Físicos ser dispensado de licitação para pintar as quadras de basquete das escolas públicas, sendo que, efetivamente quem realizaria o serviço seria uma empresa de engenharia terceirizada. Tal situação configura burla à licitação"404.

Em sua vertente inclusiva, o dispositivo permite a contratação com dispensa de licitação de entidade para o fornecimento de mão-de-obra. É medida que, reconhecendo a vulnerabilidade social da pessoa com necessidades especiais ${ }^{405}$ que repercute na dificuldade em obter colocação no mercado de trabalho, incentiva organizações a intermediarem esta inserção dispensada de licitação. ${ }^{406}$ Ocorre que esta disposição acaba por levantar preocupação, "uma vez que toda a contratação de mão-de-obra, na Administração Direta ou Indireta, está sujeita a concurso público, nos termos do artigo 37, inciso II, da Constituição Federal, ressalvada a hipótese de contratação temporária prevista no inciso IX do mesmo dispositivo" ${ }^{\text {407 }}$. O dispositivo, portanto, não pode conflitar com a norma constitucional que rege a contratação na Administração Pública. Veja-se, aliás, que o mesmo artigo 37, em seu inciso VIII, determina a reserva de vagas em concursos públicos para deficientes:

Luz da função social do contrato administrativo, do direito à educação especial e conforme $\operatorname{ADPF} \mathrm{n}^{\circ} 45$. Boletim Jurídico, n. 188, 28/07/2006. Disponível na Internet: < http://www.boletimjuridico.com.br/doutrina/texto.asp?id=1445>. Acesso em: 13 abr. 2010).

403 "O dispositivo relaciona-se diretamente com o previsto no inc. XIII. A proximidade entre as disposições dos dois incisos é evidente. (...) Aplicam-se ao caso as mesmas considerações realizadas sobre o objeto das contratações realizadas com base no inc. XIII. Trata-se da questão da pertinência absoluta, da pertinência relativa e da vedação à intermediação" (JUSTEN FILHO, Marçal. Comentários à lei de licitações e contratos administrativos. $14^{\mathrm{a}}$ ed. São Paulo : Dialética, 2010, p. 336).

${ }^{404}$ FARIA, Juliana Campos de. Op. cit..

405 Entendemos que a norma deve ser interpretada de forma a incluir outros tipos de deficiência que não a conhecida como física. Neste sentido entende-se que "a Lei alude apenas a defíciência física, mas é evidente que toda e qualquer associação que congregue portadores de alguma necessidade especial poderá ser contratada diretamente. Portanto, podem ser contratadas diretamente entidades que congreguem portadores de Síndrome de Down, por exemplo" (JUSTEN FILHO, Marçal. Op. cit., p. 336).

406 "Trata-se de uma modalidade indireta de fomento. Os recursos públicos são aplicados de modo a produzir efeitos indiretos relevante. O objetivo imediato reside na satisfação de uma necessidade pública, objeto da contratação. No entanto e conjuntamente, há outro intento. Trata-se de incentivar a atividade de certas entidades privadas, não integrantes da Administração Pública, mas cuja atuação relaciona-se com o bem comum. Produz-se uma espécie de 'função social do contrato administrativo', no sentido de que a contratação é instrumento de realização de outros valores sociais que não a mera obtenção pela Administração dos bens e serviços de que necessita" (ibidem, p. 335).

${ }^{407}$ DI PIETRO, Maria Sylvia Zanella. Direito administrativo. $19^{a}$ ed. São Paulo : Atlas, 2006, p. 369. 
Art. 37. A administração pública direta e indireta de qualquer dos Poderes da União, dos Estados, do Distrito Federal e dos Municípios obedecerá aos princípios de legalidade, impessoalidade, moralidade, publicidade e eficiência e, também, ao seguinte: (...)

VIII - a lei reservará percentual dos cargos e empregos públicos para as pessoas portadoras de deficiência e definirá os critérios de sua admissão.

Desta forma, deve-se concluir que o disposto no artigo 24, XX, da Lei n. 8666/93, não se confunde com a colocação dos portadores de necessidades especiais em cargos ou empregos públicos, que deverão ser preenchidos por concurso e levar em conta a reserva de vagas a deficientes. O fornecimento de mão-de-obra a que se refere a norma está relacionado aos serviços prestados pela entidade contratada, especificamente aqueles que podem ser objeto de contrato administrativo. E neste caso de fornecimento de mão-deobra, quer nos parecer que a norma exija, diferentemente da prestação de serviços pura e simples antes explicitada, que as pessoas que executarão os trabalhos serão propriamente aquelas portadoras de deficiência. O contrato é firmado com a associação, que se incumbirá de promover a colocação de deficiente auditivo no serviço de reprografia de determinado órgão, do portador de síndrome de Down no serviço de entrega de malotes, do cadeirante na recepção, etc.

Valem, ainda, duas ressalvas importantes. Em primeiro lugar, entende-se afastada a discussão sobre a isonomia com outras empresas dos setores em que sejam colocados os portadores de necessidades especiais, com fundamento na já abordada função social do contrato administrativo, já que "os portadores de necessidades especiais encontram-se em situação material peculiar, inconfundível com as pessoas que não apresentam limitações similares". ${ }^{408}$ Em segundo, dada a natureza social da norma, entende-se que não somente as figuras associativas podem ser contratadas nestes termos, mas também as fundacionais e as cooperativas sociais (estas, inclusive, exatamente com este objeto).

É, portanto, hipótese de dispensa exclusivamente destinada a entidades do Terceiro Setor, seja por considerá-las promotoras do direito social à integração no mercado de trabalho (art. 203, III, da Constituição Federal), seja por considerá-las promotoras do direito social à integração das pessoas portadores de deficiência à vida comunitária (artigo 203, IV, da Constituição Federal).

\section{a.4) Contratação da coleta, processamento e comercialização de resíduos sólidos urbanos recicláveis ou reutilizáveis, em áreas com sistema de coleta seletiva de lixo,}

${ }^{408}$ JUSTEN FILHO, Marçal. Op. cit., p. 336. 


\section{efetuados por associações ou cooperativas formadas exclusivamente por pessoas} físicas de baixa renda reconhecidas pelo poder público como catadores de materiais recicláveis, com o uso de equipamentos compatíveis com as normas técnicas, ambientais e de saúde pública (art. 24, XXVII) ${ }^{409}$

Outra hipótese de dispensa de licitação diretamente ligada ao Terceiro Setor e repleta de conteúdo social foi incluída pela Lei n. 11.445/2007 no artigo 24, da Lei n. 8666/93, mais especificamente em seu inciso XXVII, nos seguintes termos:

na contratação da coleta, processamento e comercialização de resíduos sólidos urbanos recicláveis ou reutilizáveis, em áreas com sistema de coleta seletiva de lixo, efetuados por associações ou cooperativas formadas exclusivamente por pessoas físicas de baixa renda reconhecidas pelo poder público como catadores de materiais recicláveis, com o uso de equipamentos compatíveis com as normas técnicas, ambientais e de saúde pública.

O evidente conteúdo social é múltiplo ${ }^{410}$. É norma pautada por preocupações de saúde pública, ambientais e, principalmente, sociais no sentido estrito do termo, ao incentivar a organização de pessoas de baixa renda para o desenvolvimento de uma atividade econômica.

A norma prevê duas hipóteses a nosso ver distintas de organização da atividade que se pretende incentivar.

A primeira delas através da contratação de associação sem fins lucrativos, hipótese em que as pessoas físicas de baixa renda a que se dirige a norma não poderiam ser associados para receber os frutos da contratação, mas sim contratados pelo regime da Consolidação das Leis do Trabalho. Isto porque as associações civis sem fins lucrativos, para se caracterizarem como tal, não podem efetuar distribuição de lucros. Assim, a

\footnotetext{
${ }^{409}$ A título de informação, o artigo 24, XXIV prevê dispensa de licitação na "celebração de contratos de prestação de serviços com as organizações sociais, qualificadas no âmbito das respectivas esferas de governo, para atividades contempladas no contrato de gestão". Entendemos, no entanto, que as organizações sociais (qualificação criada pela Lei n. 9.637/90) não fazem parte do Terceiro Setor, haja vista a obrigatoriedade prevista em lei de participação de servidores públicos em seus Conselhos de Administração, retirando a natureza puramente privada da instituição (embora não afaste a sua natureza jurídica privada). Para uma análise aprofundada das características e do papel das organizações sociais, cf. OLIVEIRA, Gustavo Justino de. Contrato de gestão. São Paulo : RT, 2008.

410 "Logo, existem razões de diversa ordem no sentido do incentivo e fomento à atividade dos catadores de papel. Trata-se não apenas de assegurar a eles a elevação da condição de vida digna, mas também promover a sua integração à atividade econômica formal - inclusive para o efeito de garantir o acesso à seguridade social. Também se busca incentivar uma atividade econômica de grande relevância para a vida comunitária. Mais ainda, pretende-se proteger o meio ambiente e evitar a elevação dos índices de poluição e de destruição da natureza" (JUSTEN FILHO, Marçal. Ob. cit., p. 352).
} 
associação seria contratada pela Administração Pública, havendo no contrato a forma de sua remuneração, e promoveria o pagamento do salário dos catadores.

Este, no entanto, não é o sistema previsto no Decreto n. 5.940/2006, que "institui a separação dos resíduos recicláveis descartados pelos órgãos e entidades da administração pública federal direta e indireta, na fonte geradora, e a sua destinação às associações e cooperativas dos catadores de materiais recicláveis, e dá outras providências". Este Decreto regula "a separação dos resíduos recicláveis descartados pelos órgãos e entidades da administração pública federal direta e indireta, na fonte geradora, e a sua destinação às associações e cooperativas dos catadores" (artigo $1^{\circ}$ ). É no artigo $3^{\circ}$, IV, do referido Decreto, que se encontra o dispositivo que causa espécie:

Art. $3^{\circ}$ Estarão habilitadas a coletar os resíduos recicláveis descartados pelos órgãos e entidades da administração pública federal direita e indireta as associações e cooperativas de catadores de materiais recicláveis que atenderem aos seguintes requisitos:

I - estejam formal e exclusivamente constituídas por catadores de materiais recicláveis que tenham a catação como única fonte de renda;

II - não possuam fins lucrativos;

III - possuam infra-estrutura para realizar a triagem e a classificação dos resíduos recicláveis descartados; e

IV - apresentem o sistema de rateio entre os associados e cooperados.

O regime jurídico das associações civis sem fins lucrativos não é compatível com a previsão de rateio das receitas entre os seus associados. Ao contrário das cooperativas, que desenvolvem atividades de fins econômicos e, portanto, com previsão de partilha de resultados, a ausência de lucro é pressuposto do regime das associações. Por conta disso entendemos que o único arranjo possível para a contratação de associações civis para a promoção de coleta de resíduos sólidos é aquela em que os catadores são funcionários da associação, remunerados por esta função de acordo com as normas da CLT.

A segunda hipótese de organização da atividade passível de ser contratada com dispensa de licitação é através da organização de cooperativas de catadores, estas sim compatíveis com a idéia de rateio das receitas. Nesta hipótese os catadores seriam cooperados e receberiam proventos de acordo com as normas da cooperativa contratada, a depender dos termos da contratação com o Poder Público. ${ }^{411}$

${ }^{411}$ Esta hipótese, em nosso sentir, salvo se a cooperativa contratada se enquadrar no conceito de cooperativa social, não está enquadrada na idéia de Terceiro Setor. 
a.5) Contratação de instituição ou organização, pública ou privada, com ou sem fins lucrativos, para a prestação de serviços de assistência técnica e extensão rural no âmbito do Programa Nacional de Assistência Técnica e Extensão Rural na Agricultura Familiar e na Reforma Agrária, instituído por lei federal (art. 24, XXX)

Por fim, encerrando as hipóteses de dispensa de licitação que podem ser consideradas materialmente vinculadas de forma direta às atividades do Terceiro Setor, a Lei n. 12.188, de 11 de janeiro de 2010, que "institui a Política Nacional de Assistência Técnica e Extensão Rural para a Agricultura Familiar e Reforma Agrária - PNATER e o Programa Nacional de Assistência Técnica e Extensão Rural na Agricultura Familiar e na Reforma Agrária - PRONATER”, também promove alteração na Lei n. 8666/93 para incluir o inciso XXX, no artigo 24, dispondo que é dispensável a licitação

na contratação de instituição ou organização, pública ou privada, com ou sem fins lucrativos, para a prestação de serviços de assistência técnica e extensão rural no âmbito do Programa Nacional de Assistência Técnica e Extensão Rural na Agricultura Familiar e na Reforma Agrária, instituído por lei federal.

A Lei n. 12.188/2010, trata de especificar o que vêm a ser os serviços de assistência técnica e extensão rural, quando em seu artigo $2^{\circ}$, I, assevera:

Art. $2^{\circ}$ Para os fins desta Lei, entende-se por:

I - Assistência Técnica e Extensão Rural - ATER: serviço de educação não formal, de caráter continuado, no meio rural, que promove processos de gestão, produção, beneficiamento e comercialização das atividades e dos serviços agropecuários e não agropecuários, inclusive das atividades agroextrativistas, florestais e artesanais;

Referidos serviços são espécie do gênero educação, voltados à orientação do homem do campo com vistas à melhoria da qualidade e da quantidade de sua produção, conseqüentemente de sua qualidade de vida. E as organizações privadas sem fins lucrativos cujo objeto específico seja a prestação de serviços de assistência técnica e extensão rural, em atividade há no mínimo 5 anos e que preencha os demais requisitos da Lei n. 12.188/2010 (artigo 15), poderá ser selecionada por chamada pública (artigo 19) e contratada pelo Ministério do Desenvolvimento Agrário ou pelo INCRA (artigo 18).

\section{b) Inexigibilidades de licitação e o Terceiro Setor}


As inexigibilidades de licitação estão previstas no artigo 25, da Lei n. 8.666/93, e são vinculadas à idéia matriz de inviabilidade de competição. Diferente da dispensa, em que pode haver competição de concorrentes mas a lei autoriza a Administração Pública a abrir mão da licitação justificadamente, na inexigibilidade a competição é inviável "porque só existe um objeto ou uma pessoa que atenda às necessidades da Administração". 412

São, genericamente, os seguintes casos:

Art. 25. É inexigível a licitação quando houver inviabilidade de competição, em especial: I - para aquisição de materiais, equipamentos, ou gêneros que só possam ser fornecidos por produtor, empresa ou representante comercial exclusivo, vedada a preferência de marca, devendo a comprovação de exclusividade ser feita através de atestado fornecido pelo órgão de registro do comércio do local em que se realizaria a licitação ou a obra ou o serviço, pelo Sindicato, Federação ou Confederação Patronal, ou, ainda, pelas entidades equivalentes;

II - para a contratação de serviços técnicos enumerados no art. 13 desta Lei, de natureza singular, com profissionais ou empresas de notória especialização, vedada a inexigibilidade para serviços de publicidade e divulgação;

III - para contratação de profissional de qualquer setor artístico, diretamente ou através de empresário exclusivo, desde que consagrado pela crítica especializada ou pela opinião pública.

Diz-se genericamente porque na prática podem ocorrer outros casos de inviabilidade de competição não previstos no referido dispositivo, que não é exaustivo. ${ }^{413}$

Não há, diferente dos casos de dispensa, hipóteses especificamente destinadas a atividades desenvolvidas por entidades do Terceiro Setor, o que não significa dizer que tais entidades não possam ser contratadas por inexigibilidade de licitação. Regra geral, basta que a entidade desenvolva atividade em que a competição seja inviável e, em havendo necessidade da Administração Pública quanto a esta atividade, estará justificada a inexigibilidade.

Em linhas gerais, a lei prevê a justificativa da inexigibilidade em três situações, brevemente analisadas a seguir em cotejo com as atividades do Terceiro Setor.

\section{b.1) Fornecedor único na aquisição de determinado bem específico (inciso I)}

412 DI PIETRO, Maria Sylvia Zanella. Direito administrativo. 19a ed. São Paulo : Atlas, 2006, p. 361, destaques no original.

413 “Com efeito, a inexigibilidade é decorrência da inviabilidade de competição; o próprio dispositivo prevê algumas hipóteses, o que não impede que outras surjam na prática. Se a competição inexiste, não há que se falar em licitação. A inviabilidade deve ficar adequadamente demonstrada" (DI PIETRO, Maria Sylvia Zanella. Op. cit., p. 363). 
É o que Marçal Justen Filho chama de "ausência de alternativas""414 que leva à inviabilidade de competição. Neste caso, a Administração Pública necessita adquirir bem específico, cuja peculiaridade leva a somente uma opção de contratação. A singularidade do objeto não deixa escolhas ao Poder Público e a lei soluciona o problema permitindo a contratação da única opção sem que seja levado a efeito o procedimento licitatório. Em linhas gerais a hipótese trazida pelo inciso em comento é esta. ${ }^{415}$

Seria o caso de inexigibilidade, por exemplo, se um laboratório administrado por entidade privada sem fins lucrativos especializada no diagnóstico precoce de determinada doença desenvolvesse equipamento inédito para o auxílio na elaboração deste exame.

São situações difíceis de exemplificar, mas que podem acontecer na prática e dispõem de justificativa legal para a inexigibilidade.

\section{b.2) Contratação de singulares serviços técnicos profissionais especializados, com profissionais ou empresas de notória especialização (inciso II)}

Nestas situações, como já decidiu o Superior Tribunal de Justiça, é imprescindível a a caracterização de três requisitos para permitir a inexigibilidade da licitação: “a) serviço técnico listado no art. 13; b) profissional (pessoa física) ou empresa de notória especialização; c) natureza singular do serviço a ser prestado". ${ }^{416}$

O já transcrito artigo 13 especifica os seguintes serviços técnicos profissionais especializados:

Art. 13. Para os fins desta Lei, consideram-se serviços técnicos profissionais especializados os trabalhos relativos a:

I - estudos técnicos, planejamentos e projetos básicos ou executivos;

II - pareceres, perícias e avaliações em geral;

III - assessorias ou consultorias técnicas e auditorias financeiras ou tributárias;

IV - fiscalização, supervisão ou gerenciamento de obras ou serviços;

$\mathrm{V}$ - patrocínio ou defesa de causas judiciais ou administrativas;

VI - treinamento e aperfeiçoamento de pessoal;

VII - restauração de obras de arte e bens de valor histórico.

\footnotetext{
${ }^{414}$ JUSTEN FILHO, Marçal. Comentários à lei de licitações e contratos administrativos. $14^{\mathrm{a}}$ ed. São Paulo : Dialética, 2010, p. 358.

${ }^{415}$ Para peculiaridades sobre o caso, cf. JUSTEN FILHO, Marçal. Op. cit., pp. 358 e ss.

${ }^{416}$ SUPERIOR TRIBUNAL DE JUSTIÇA, RESP n. 942.412/SP, $2^{\text {a }}$ Turma, Rel. Min. Herman Benjamin, DJe de 09/03/2009.
} 
Não basta, para fins de inexigibilidade, constarem desta lista. Devem ser realizados por profissional ou empresa de notória especialização. O próprio artigo $25, \S 1^{\circ}$, dá a nota do que venha a ser este requisito:

$\S 1^{0}$ Considera-se de notória especialização o profissional ou empresa cujo conceito no campo de sua especialidade, decorrente de desempenho anterior, estudos, experiências, publicações, organização, aparelhamento, equipe técnica, ou de outros requisitos relacionados com suas atividades, permita inferir que o seu trabalho é essencial e indiscutivelmente o mais adequado à plena satisfação do objeto do contrato.

E para completar os requisitos e permitir a contratação sob a justificativa de inexigibilidade, deve-se comprovar a natureza singular dos serviços prestados, o que pode ser compreendido, numa acepção singela, como aquelas hipóteses específicas em que tais serviços sejam necessários em virtude de situação que foge à normalidade. ${ }^{417}$

Fazendo a diferenciação entre uma situação normal e uma situação anormal, já derivando para a análise da viabilidade de contratação de entidade do Terceiro Setor nesta hipótese, voltamos à carga com o conteúdo do inciso VII, do artigo 13, que trata da restauração de obras de arte e bens de valor histórico. Naturalmente, a restauração de determinado prédio histórico, compreendendo a pintura de sua fachada, revisão das instalações elétricas, etc., é hipótese que pode ser considerada dentro dos padrões de normalidade, não se compreendendo como serviços de natureza singular. A restauração deste mesmo prédio histórico, que tenha passado por um incêndio de grandes proporções que afetou afrescos de importante artista existentes em suas paredes internas, que além de terem recebido rachaduras ficaram plenas de fuligens, comprometendo a obra de arte, se insere naquelas hipóteses em que a situação pode ser considerada anômala. Exigirá a contratação de profissional ou empresa de notória especialização em restauros e, num ponto ótimo, profunda conhecedora das obras do artista a serem restauradas. Neste caso, pode ser que um instituto cultural de estudo e preservação da obra deste autor seja a hipótese mais adequada - senão única - com estes requisitos, motivo que justificaria a inexigibilidade de licitação.

Outras situações, sem dúvida, podem gerar a contratação de entidade do Terceiro Setor sob o pálio da inexigibilidade de licitação, mas devido à diversidade das atividades

417 “Cada espécie de atividade referida no art. 13 pode envolver situações-padrão e casos anômalos. Apenas esses últimos comportam contratação direta, tal como determinado no art. 25, inc. II” (JUSTEN FILHO, Marçal. Op. cit., p. 369). 
previstas no artigo 13 é difícil imaginar outros exemplos que não advenham de uma situação prática específica.

\section{b.3) Contratação de profissional do setor artístico (inciso III)}

Baseada na natureza personalíssima do serviço, embora não pareça situação corriqueira a contratação de profissional do setor artístico pela Administração Pública, a lei prevê a hipótese de inexigibilidade em se tratando de artistas consagrados pela crítica ou pela opinião pública.

Há, no entanto, hipóteses em que se justificam as contratações neste sentido. A contratação de cantores para animar as festividades cívicas, a contratação de renomado pintor para a decoração de parede de prédio público, a contratação de escultor para a confecção de busto de personagem histórico celebre para colocação em determinada praça pública, a contratação de respeitado ator para campanha televisiva de certo programa de ação pública, etc. Todas estas situações, é claro, permeadas pela análise do interesse público envolvido e da real aplicação da inexigibilidade de licitação.

Uma possibilidade vinculada diretamente à atuação do Terceiro Setor é a contratação de um coral infantil de renomes nacional e internacional, coordenado por entidade sem fins lucrativos, para as festividades oficiais de fim de ano do Município em que se situa a instituição. Outra hipótese é a contratação de famosa equipe de basquetebol de exibição, criada por entidade sem fins lucrativos, para evento beneficente de lançamento da quadra pública de esportes construída pelo Poder Público.

Enfim, mais uma vez estamos diante de situações específicas que tornam difícil a empreitada de buscar exemplos sem o devido referencial prático.

\subsection{Repasses financeiros para entidades do Terceiro Setor}

Além dos contratos administrativos, há outras formas de parceria possíveis entre a Administração Pública e o Terceiro Setor que envolvem repasses financeiros.

Estes repasses financeiros são feitos através das transferências voluntárias, assim chamadas por não se constituírem em transferências obrigatórias (constitucionais ou legais).

A Lei de Responsabilidade Fiscal (Lei Complementar n. 101/2000), em seu artigo 25 , conceitua transferência voluntária como "a entrega de recursos correntes ou de capital a 
outro ente da Federação, a título de cooperação, auxílio ou assistência financeira, que não decorra de determinação constitucional ou legal ou se destine ao Sistema Único de Saúde”.

Embora este conceito legal não englobe as transferências a entidades privadas, é certo que estes repasses se enquadram como tal no plano orçamentário. É como ensina Natasha Schmitt Caccia Salinas: "O repasse de recursos da União às entidades privadas sem fins lucrativos a título de cooperação, auxílio ou assistência financeira que não decorra de determinação legal ou se destine ao Sistema Único de Saúde- SUS é denominado transferência voluntária". 418 Veja-se a interessante passagem em que a autora explica o funcionamento da definição orçamentária do que sejam as transferências voluntárias:

O Orçamento Geral da União ("OGU") disciplina ano a ano as receitas livres de alocação, ou seja, aquelas que não custearão despesas de caráter não discricionário, tais como transferências constitucionais e legais aos Estados e Municípios, despesas com pessoal e encargos sociais, benefícios previdenciários, custeio obrigatório da saúde e da educação, dentre outros. Subtraídas todas as despesas não discricionárias do orçamento, resta apenas $11 \%$ da totalidade dos recursos previstos no OGU para serem destinados às transferências voluntárias, equivalentes a quantia que varia entre $\mathrm{R} \$ 50$ bilhões e $\mathrm{R} \$ 60$ bilhões de reais por ano. Essa quantia destinada às transferências voluntárias, no entanto, é distribuída entre Estados, Municípios e entidades do terceiro setor, sendo destinados a estas últimas um montante que varia entre $\mathrm{R} \$ 2$ e R $\$ 3$ bilhões. ${ }^{419}$

A alocação dos recursos destinados a transferências voluntárias deve observar os critérios definidos na programação orçamentária, atribuição que é dada ao Plano Plurianual pelo artigo 165, $\S 1^{\circ}$, da Constituição Federal, que define a sua abrangência:

Art. 165. Leis de iniciativa do Poder Executivo estabelecerão:

I - o plano plurianual;

(...)

$\S 1^{\circ}$ - A lei que instituir o plano plurianual estabelecerá, de forma regionalizada, as diretrizes, objetivos e metas da administração pública federal para as despesas de capital e outras delas decorrentes e para as relativas aos programas de duração continuada.

O Plano Plurianual em vigor (2008/2011) foi estabelecido pela Lei n. 11.653/2008 e estabelece os programas a serem realizados neste período. Importante papel assume a Lei de Diretrizes Orçamentárias, também prevista no artigo 165, da Constituição Federal:

Art. 165. Leis de iniciativa do Poder Executivo estabelecerão:

\footnotetext{
418 SALINAS, Natasha Schmitt Caccia. Avaliação legislativa no Brasil: um estudo de caso sobre as normas de controle das transferências voluntárias de recursos públicos para entidades do terceiro setor. Dissertação de mestrado. São Paulo, Faculdade de Direito da USP, 2008, p. 77.

${ }^{419}$ Ibidem, p. 77.
} 


\begin{abstract}
(...)
II - as diretrizes orçamentárias;

(...)

$\S 2^{\circ}$ - A lei de diretrizes orçamentárias compreenderá as metas e prioridades da administração pública federal, incluindo as despesas de capital para o exercício financeiro subseqüente, orientará a elaboração da lei orçamentária anual, disporá sobre as alterações na legislação tributária e estabelecerá a política de aplicação das agências financeiras oficiais de fomento.
\end{abstract}

Na Lei de Diretrizes Orçamentárias para o exercício de 2010, Lei n. 12017/2009, existe uma seção específica sobre as transferências (voluntárias) para o setor privado. Embora chamadas de transferências - setor privado, não perdem a característica de transferências voluntárias pelo fato de não serem transferências obrigatórias, e têm as características que passamos a demonstrar.

\title{
4.2.1 Subvenções sociais
}

O artigo 32 da Lei n. 12017/2009 trata especificamente das transferências chamadas de subvenções sociais, que se destinam à "prestação de serviços essenciais de assistência social, médica e educacional, sempre que a suplementação de recursos de origem privada aplicados a esses objetivos, revelar-se mais econômica"420. O dispositivo vem nos seguintes termos:

Art. 32. A transferência de recursos a título de subvenções sociais, nos termos do art. 16 da Lei $\mathrm{n}^{\mathrm{0}}$ 4.320, de 1964, atenderá as entidades privadas sem fins lucrativos que exerçam atividades de natureza continuada nas áreas de cultura, assistência social, saúde e educação e preencham uma das seguintes condições:

I - sejam de atendimento direto ao público, de forma gratuita, e tenham certificação de entidade beneficente de assistência social nas áreas de saúde, educação ou assistência social, expedida pelo Conselho Nacional de Assistência Social - CNAS ou por outro órgão competente das demais áreas de atuação governamental, de acordo com lei superveniente;

II - sejam formalmente vinculadas a organismo internacional do qual o Brasil participe, tenham natureza filantrópica ou assistencial e estejam registradas nos termos do inciso I do caput deste artigo;

III - atendam ao disposto no art. 204 da Constituição, no art. 61 do ADCT, bem como na Lei no 8.742, de 7 de dezembro de 1993; ou

IV - sejam qualificadas como Organização da Sociedade Civil de Interesse Público OSCIP, com termo de parceria firmado com o Poder Público Federal, de acordo com a Lei no 9.790 , de 23 de março de 1999.

Parágrafo único. O disposto no caput também se aplica:

I - às entidades de assistência social voltadas ao atendimento direto e gratuito de pessoas deficientes, crianças e idosos detentoras de registro ou certificação de entidade beneficente de assistência social, expedida pelo Conselho Nacional de Assistência Social - CNAS ou

${ }^{420}$ Artigo 16, da Lei n. 4320/1964. 
por outro órgão competente das demais áreas de atuação governamental, de acordo com lei superveniente; e

II - às entidades de educação extraescolar de atendimento direto e gratuito detentoras de certificação de entidade beneficente de assistência social na área de educação, expedida pelo Conselho Nacional de Assistência Social - CNAS ou por outro órgão competente das demais áreas de atuação governamental, de acordo com lei superveniente.

Segundo a Lei n. 4320/64, artigo 12, $\S 3^{\circ}$, I, as subvenções sociais são transferências destinadas a cobrir despesas de custeio das instituições públicas ou privadas de caráter assistencial ou cultural, sem finalidade lucrativa. ${ }^{421}$

\subsubsection{Contribuições correntes}

O artigo 33, da Lei n. 12017/2009, por sua vez, regulamenta os repasses de recursos a título de contribuição corrente, nos seguintes termos:

Art. 33. A transferência de recursos a título de contribuição corrente somente será destinada a entidades sem fins lucrativos e que preencham uma das seguintes condições:

I - estejam autorizadas em lei específica;

II - estejam, dadas suas peculiaridades, nominalmente identificadas no projeto de lei enviado pelo Poder Executivo e na respectiva lei; ou

III - sejam selecionadas para execução, em parceria com a Administração Pública Federal, de programas e ações que contribuam diretamente para o alcance de diretrizes, objetivos e metas previstas no plano plurianual, sendo vedada sua concessão para as áreas de que trata o art. 32, desta lei.

$\S 1^{\mathrm{o}}$ A transferência de recursos a título de contribuição corrente não autorizada em lei específica dependerá de publicação, para cada entidade beneficiada, de ato de autorização da unidade orçamentária transferidora, o qual conterá o critério de seleção, o objeto, o prazo do convênio ou instrumento congênere e a justificativa para a escolha da entidade.

$\S 2^{\mathrm{o}} \mathrm{O}$ disposto no caput deste artigo e em seu $\S 1^{\circ}$ aplica-se aos casos de prorrogação ou renovação de convênio ou instrumento congênere ou aos casos em que, já havendo sido firmado o instrumento, devam as despesas dele decorrentes correr à conta de dotações consignadas na Lei Orçamentária de 2010.

As transferências a título de contribuições correntes são tidas pela Lei n. 4320/64, artigo 12, $\S 6^{\circ}$, como transferências de capital, assim consideradas as "dotações para investimentos ou inversões financeiras que outras pessoas de direito público ou privado devam realizar", 422

421 " $\S 3^{\circ}$ Consideram-se subvenções, para os efeitos desta lei, as transferências destinadas a cobrir despesas de custeio das entidades beneficiadas, distinguindo-se como: I - subvenções sociais, as que se destinem a instituições públicas ou privadas de caráter assistencial ou cultural, sem finalidade lucrativa".

422 " $\S 6^{\circ}$ São Transferências de Capital as dotações para investimentos ou inversões financeiras que outras pessoas de direito público ou privado devam realizar, independentemente de contraprestação direta em bens ou serviços, constituindo essas transferências auxílios ou contribuições, segundo derivem diretamente da Lei de Orçamento ou de lei especialmente anterior, bem como as dotações para amortização da dívida pública". 
Conforme observa Gustavo Justino de Oliveira, analisando a Lei de Diretrizes Orçamentárias para 2006,

ainda que haja uma definição relativamente distinta na Instrução Normativa n. 01/97-STN, art. $1^{\circ}$, par. $1^{\circ}$, inc. VI, é a Lei federal n. 11.178/05 (LDO) que veicula uma regulamentação mais clara desta espécie de repasse público, estabelecendo em seu art. 32, caput, que "é vedada a destinação de recursos a entidade privada a título de contribuição corrente, ressalvada a autorizada em lei específica ou destinada à entidade sem fins lucrativos selecionada para execução, em parceria com a administração pública federal, de programas e ações que contribuam diretamente para o alcance de diretrizes, objetivos $e$ metas previstas no plano plurianual"'.[sem grifo no original]

Ou seja, se antes havia a obrigatoriedade de destinação de contribuições unicamente se houvesse lei anterior que a autorizasse, agora, em face do citado artigo, existe a possibilidade de que isso decorra diretamente de parceria efetivada pelo Poder Público concedente. $^{423}$

Isto significa dizer que além das hipóteses de específica previsão legal, as contribuições podem ser destinadas a projetos de parceria com a Administração Pública Federal que tenham por objeto programas e ações vinculados ao plano plurianual, desde que em área não abrangida pelas subvenções sociais (cultura, assistência social, saúde e educação), desde que observado o requisito do $\S 1^{\mathrm{o}}$.

\subsubsection{Auxílios}

A exemplo das contribuições, os auxílios são considerados como transferências de capital destinados para investimentos ou inversões financeiras, com a diferença de que os auxílios, ao invés de lei específica, encontram fundamento na Lei de Orçamento, conforme explicita o já transcrito artigo $12, \S 6^{\circ}$, da Lei n. $4320 / 64 .^{424}$

O artigo 34, da atual Lei de Diretrizes Orçamentárias, delimita as possibilidades de concessão de auxílios nos seguintes termos:

Art. 34. A transferência de recursos a título de auxílios, previstos no art. $12, \S 6^{\circ}$, da Lei $n^{\circ}$ 4.320, de 1964, somente poderá ser realizada para entidades privadas sem fins lucrativos e desde que sejam:

${ }^{423}$ OLIVEIRA, Gustavo Justino de. Gestão privada de recursos públicos para fins públicos: o modelo das OSCIP. In: __ (coord.). Terceiro Setor, empresas e Estado: novas fronteiras entre o público e o privado. Belo Horizonte : Fórum, 2007, pp. 240-241, destaques no original.

424 “A Lei federal n. 4.320/64, em seu art. 12 , par. $6^{\circ}$, qualifica o auxílio como uma espécie de transferência de capital, derivada diretamente da Lei de Orçamento, e destina-se a investimentos ou inversões financeiras que entidades públicas ou privadas sem fins lucrativos devam realizar, independentemente de contraprestação direta em bens ou serviços" (ibidem, p. 239). 
I - de atendimento direto e gratuito ao público e voltadas para a educação especial, ou representativas da comunidade escolar das escolas públicas estaduais e municipais da educação básica ou, ainda, unidades mantidas pela Campanha Nacional de Escolas da Comunidade - CNEC;

II - cadastradas junto ao Ministério do Meio Ambiente para recebimento de recursos oriundos de programas ambientais, doados por organismos internacionais ou agências governamentais estrangeiras;

III - voltadas a ações de saúde e de atendimento direto e gratuito ao público, inclusive à assistência a portadores de DST/AIDS, prestadas pelas Santas Casas de Misericórdia e por outras entidades sem fins lucrativos que sejam certificadas como entidades beneficentes de assistência social expedida pelo Conselho Nacional de Assistência Social - CNAS, ou por órgão governamental na área de saúde de acordo com lei superveniente;

IV - signatárias de contrato de gestão com a Administração Pública Federal, não qualificadas como organizações sociais nos termos da Lei no 9.637, de 15 de maio de 1998; V - qualificadas como Organização da Sociedade Civil de Interesse Público - OSCIP, com termo de parceria firmado com o Poder Público Federal, de acordo com a Lei $\mathrm{n}^{\mathbf{0}}$ 9.790, de 1999, e que participem da execução de programas constantes do plano plurianual, devendo a destinação de recursos guardar conformidade com os objetivos sociais da entidade;

VI - qualificadas ou registradas e credenciadas como instituições de apoio ao desenvolvimento da pesquisa científica e tecnológica com contrato de gestão firmado com órgãos públicos;

VII - qualificadas para o desenvolvimento de atividades esportivas que contribuam para a capacitação de atletas de alto rendimento nas modalidades olímpicas e paraolímpicas, desde que formalizado instrumento jurídico adequado que garanta a disponibilização do espaço esportivo implantado para o desenvolvimento de programas governamentais, e demonstrada, pelo órgão concedente, a necessidade de tal destinação e sua imprescindibilidade, oportunidade e importância para o setor público;

VIII - voltadas, na área de assistência social, ao atendimento direto e gratuito de pessoas portadoras de deficiência;

IX - voltadas diretamente às atividades de coleta e processamento de material reciclável, desde que constituídas sob a forma de associações ou cooperativas integradas por pessoas em situação de risco social, na forma prevista em regulamento do Poder Executivo, cabendo ao órgão concedente aprovar as condições para a aplicação dos recursos;

$\mathrm{X}$ - voltadas ao atendimento de pessoas carentes em situação de risco social ou diretamente alcançadas por programas e ações de combate à pobreza e geração de trabalho e renda, nos casos em que ficar demonstrado que a entidade privada tem melhores condições que o Poder Público local para o desenvolvimento das ações pretendidas, devidamente justificado pelo órgão concedente responsável; e

XI - de atendimento direto e gratuito de crianças e idosos, detentoras de registro ou certificação de entidade beneficente de assistência social, expedida pelo Conselho Nacional de Assistência Social - CNAS ou por outro órgão competente das demais áreas de atuação governamental, de acordo com lei superveniente.

Observa-se que o referido dispositivo apresenta requisitos à concessão de auxílios para pessoas jurídicas sem fins lucrativos, especificando aquelas que fazem jus a esta transferência. As limitações materiais são das mais diversas, chamando atenção a impossibilidade de concessão de auxílios para as entidades qualificadas como Organização Social e a possibilidade para as que tenham a qualificação como Organização da Sociedade Civil de Interesse Público. 
Frise-se, valendo para as contribuições e para os auxílios, que o artigo 12, da Lei n. 4320/64, classifica como investimentos e inversões financeiras, objeto de suas concessões, o seguinte:

$\S 4^{\circ}$ Classificam-se como investimentos as dotações para o planejamento e a execução de obras, inclusive as destinadas à aquisição de imóveis considerados necessários à realização destas últimas, bem como para os programas especiais de trabalho, aquisição de instalações, equipamentos e material permanente e constituição ou aumento do capital de empresas que não sejam de caráter comercial ou financeiro.

$\S 5^{\circ}$ Classificam-se como Inversões Financeiras as dotações destinadas a:

I - aquisição de imóveis, ou de bens de capital já em utilização;

II - aquisição de títulos representativos do capital de empresas ou entidades de qualquer espécie, já constituídas, quando a operação não importe aumento do capital;

III - constituição ou aumento do capital de entidades ou empresas que visem a objetivos comerciais ou financeiros, inclusive operações bancárias ou de seguros.

Estas são, em largas passadas, as hipóteses existentes de transferência voluntária de recursos para entidades privadas sem fins lucrativos, cuja seleção pode se dar de três maneiras:

a) Apresentação de emenda ao OGU por deputado federal ou senador. Neste caso, o nome da entidade e do respectivo projeto a ser custeado com transferências voluntárias já está contemplado no próprio OGU, cabendo ao órgão gestor dos recursos do programa efetuar as referidas análises técnicas em total ausência de competição.

b) Demanda espontânea da entidade privada sem fins lucrativos, que formula um projeto por livre iniciativa ao órgão que disponha de recursos para a execução de um programa orçamentário;

c) Demanda induzida pelos ministérios, em que estes escolherão, mediante procedimento seletivo, os projetos que se adequem às suas necessidades. A seleção de projetos poderá ser regionalizada, situação em que somente entidades com sede na referida região escolhida pelo ministério poderão concorrer ao financiamento de projetos. ${ }^{425}$

Estas hipóteses de transferência voluntária, no entanto, carecem de formalização através de instrumentos jurídicos próprios, cujos principais são os convênios e os termos de

${ }^{425}$ SALINAS, Natasha Schmitt Caccia. Avaliação legislativa no Brasil: um estudo de caso sobre as normas de controle das transferências voluntárias de recursos públicos para entidades do terceiro setor. Dissertação de mestrado. São Paulo, Faculdade de Direito da USP, 2008, pp. 78-79. 
parceria, além da figura menos usual dos contratos de repasse. ${ }^{426}$ Passa-se, então, à abordagem sucinta destas três figuras. ${ }^{427}$

\subsection{Convênios}

Saindo, portanto, da parceria de natureza contratual, outro instrumento de formalização de parceria possível de ser utilizado pela Administração Pública com o Terceiro Setor é o convênio. Embora em sua origem não tivesse esta função, hoje a figura do convênio é das mais utilizadas para formalizar relações de colaboração públicoprivadas.

Em sua origem no ordenamento jurídico brasileiro, os convênios tinham por função instrumentalizar o relacionamento entre entidades públicas, com vistas a facilitar a execução de seus serviços por meio da descentralização; pretendia o intercâmbio de funcionários e estrutura entre os poderes públicos nos mais diversos níveis. Pode-se dizer que os convênios foram "instituídos no ordenamento jurídico brasileiro para instrumentalizar a descentralização de programas governamentais para entidades públicas que já detivessem capacidade instalada para realizar as ações previstas no objeto do ajuste". 428

É o que se extrai, aliás, do contido no artigo $13, \S 3^{\circ}$, da Constituição de 1967 , que estabelecia que "a União, os Estados e os Municípios poderão celebrar convênios para execução de suas leis, serviços ou decisões, por intermédio de funcionários federais, estaduais ou municipais". O dispositivo constitucional era expresso em configurar os convênios como normas de colaboração entre entes públicos, reforçado pelas normas de descentralização administrativa contidas no Decreto-lei n. 200/67. Mais do que isso, o artigo 10 do referido Decreto-lei não deixa dúvidas de que os convênios eram instrumentos exclusivamente para efetivar a descentralização da Administração Federal para as unidades

\footnotetext{
426 “A legislação sobre transferência de recursos públicos a entidades privadas sem fins lucrativos concentrase sobretudo em atos administrativos de natureza infra-legal. Tais repasses de recursos podem ser efetivados mediante a celebração de dois instrumentos jurídicos principais: os convênios e os termos de parceria. (...) Há que se ressaltar também a presença de um terceiro instrumento de transferências voluntárias - o contrato de repasse - cuja incidência sobre as entidades sem fins lucrativos passou a ser admitida apenas recentemente" (ibidem, pp. 70-71).

427 “Já foi visto, por exemplo, em relação à saúde, que ela pode ser prestada pelo Estado como serviço público próprio, ou pelo particular, como serviço público impróprio. Quando prestada pelo particular, o Estado pode fomentar, pela outorga de auxílios ou subvenções, que se formaliza mediante convênio" (DI PIETRO, Maria Sylvia Zanella. Parcerias na Administração Pública: concessão, permissão, franquia, terceirização, parceria público-privada e outras formas. $5^{\mathrm{a}}$ ed. São Paulo : Atlas, 2006, p. 250).

${ }^{428}$ SALINAS, Natasha Schmitt Caccia. Op. cit., p. 83.
} 
federadas, especialmente quando, além de em seu $\S 1^{\circ}$, “ $b$ ”, fazer esta expressa menção, em sua alínea "c" reservar os contratos e as concessões para as descentralizações da Administração Federal para a órbita privada, nos seguintes termos:

Art. 10. A execução das atividades da Administração Federal deverá ser amplamente descentralizada.

$\S 1^{\circ} \mathrm{A}$ descentralização será posta em prática em três planos principais:

a) dentro dos quadros da Administração Federal, distinguindo-se claramente o nível de direção do de execução;

b) da Administração Federal para a das unidades federadas, quando estejam devidamente aparelhadas e mediante convênio;

c) da Administração Federal para a órbita privada, mediante contratos ou concessões.

Através do Decreto Federal n. 93.872/86, artigo 48, abriu-se a possibilidade de os órgãos e entidades da administração federal firmarem convênios, acordo ou ajuste com organizações particulares para a execução cooperada de serviços de interesse recíproco, ficando claro em seu $\S 1^{\circ}$ que em não se tratando de interesse recíproco estaria desfigurado o instituto do convênio, acordo ou ajuste, para a figura do contrato. ${ }^{429}$

A partir deste momento, portanto, instituiu-se a possibilidade da assinatura de convênios entre os entes da Administração Pública e organizações particulares - dentre as quais aquelas inseridas no conceito de Terceiro Setor - com vistas à execução cooperada de serviços de interesse recíproco.

Os convênios entre entes públicos e organizações privadas inserem-se no contexto das atividades de fomento de parte do Estado, ou seja, aquelas atividades destinadas a incentivar a atuação da iniciativa privada em temas de relevante interesse público. Em áreas em que o Estado está incumbido de desenvolver atividades prestacionais de interesse público, mas que a iniciativa privada também detém titularidade (serviços públicos impróprios), o Estado fomenta a participação privada através de ferramentas financeiras, tributárias, etc. No caso dos convênios, o Estado destina verbas à atividade privada de interesse público, considerando que o resultado desta atividade é de interesse comum entre os convenentes.

Embora a Constituição Federal de 1988 não preveja expressamente a possibilidade de convênios firmados entre a Administração Pública e organizações privadas num âmbito

\footnotetext{
429 “Art . 48. Os serviços de interesse recíproco dos órgãos e entidades de administração federal e de outras entidades públicas ou organizações particulares, poderão ser executados sob regime de mútua cooperação, mediante convênio, acordo ou ajuste. $\S 1^{\circ}$ Quando os participantes tenham interesses diversos e opostos, isto é, quando se desejar, de um lado, o objeto do acordo ou ajuste, e de outro lado a contraprestação correspondente, ou seja, o preço, o acordo ou ajuste constitui contrato".
} 
geral, a doutrina encontra fundamento para a sua recepção no seu artigo 23, parágrafo único $^{430}$, "como instrumento de cooperação associativa" ${ }^{331}$. Como ressalta Hely Lopes Meirelles,

pela interpretação do texto constitucional e pela defeituosa redação da norma federal ordinária [Dec.-lei 200/67], tem-se a impressão de que o convênio só é admissível entre entidades estatais, para execução por seus agentes, quando, na realidade, a possibilidade de tais acordos é ampla, entre quaisquer pessoas ou organizações públicas ou particulares que disponham de meios para realizar os objetivos comuns, de interesse recíproco dos partícipes. $^{432}$

Também o artigo 199, § $1^{\mathrm{o}}$, embora em âmbito especificamente relacionado à saúde, prevê a possibilidade de convênio entre a Administração Pública e instituições privadas

Art. 199. A assistência à saúde é livre à iniciativa privada.

$\S 1^{\circ}$ - As instituições privadas poderão participar de forma complementar do sistema único de saúde, segundo diretrizes deste, mediante contrato de direito público ou convênio, tendo preferência as entidades filantrópicas e as sem fins lucrativos.

No entanto, mesmo que de forma tímida e não muito clara, alguns importantes diplomas legais trataram de inserir estes convênios em nosso mundo jurídico, embora de forma tão sutil que cause interpretações diversas. ${ }^{433}$

Veja-se que após a legislação antes citada há menção à figura dos convênios em alguns diplomas legais, no mais das vezes sutis quanto aos convênios entre órgãos públicos e entidade privadas.

A Lei n. 8.666/93, por exemplo, em seu artigo 116, assim dispõe: “Art. 116. Aplicam-se as disposições desta Lei, no que couber, aos convênios, acordos, ajustes e outros instrumentos congêneres celebrados por órgãos e entidades da Administração". Considerando que esta lei estabelece normas gerais sobre contratos administrativos e considera "contrato todo e qualquer ajuste entre órgãos ou entidades da

430 "Parágrafo único. Leis complementares fixarão normas para a cooperação entre a União e os Estados, o Distrito Federal e os Municípios, tendo em vista o equilíbrio do desenvolvimento e do bem-estar em âmbito nacional". (Redação dada pela Emenda Constitucional nº 53, de 2006)

${ }^{431}$ MEIRELLES, Hely Lopes. Direito administrativo brasileiro. 26 a ed. São Paulo : Malheiros, 2001 , p. 378 , destaque no original.

432 Ibidem, p. 378.

433 "No que diz respeito ao impulso legislativo que motivou a edição das normas disciplinadoras dos convênios, tem-se a impressão, da leitura de seus dispositivos, que a atenção do legislador estava exclusivamente voltada para as verbas a serem repassadas pela União aos Estados e Municípios, "esquecendo-se" o formulador dos atos normativos abaixo indicados de mencionar as entidades privadas nas definições dos referidos ajustes." (SALINAS, Natasha Schmitt Caccia. Op. cit., p. 83). 
Administração Pública e particulares, em que haja um acordo de vontades para a formação de vínculo e a estipulação de obrigações recíprocas, seja qual for a denominação utilizada" (artigo $2^{\circ}$, parágrafo único), imperativo reconhecer que a lei faz menção subliminar aos convênios público-privados. Afinal de contas, tais convênios são acordos de vontade celebrados por órgãos ou entidades da Administração com particulares. ${ }^{434}$

Da mesma forma a Instrução Normativa n. 01/1997, da Secretária do Tesouro Nacional, que embora atue no plano infralegal é um dos principais diplomas norteadores da disciplina dos convênios em nosso país, parece não abranger os convênios públicoprivados, mas sutilmente o faz. Veja-se o seu artigo $1^{\mathrm{o}}$ :

Art. $1^{\circ}$ A celebração (assinatura de termo de convênio) e a execução de convênio de natureza financeira, para fins de execução descentralizada de Programa de Trabalho de responsabilidade de órgão ou entidade da Administração Pública Federal, direta ou indireta, serão efetivadas nos termos desta Instrução Normativa.

$\S 1^{\circ}$ Para fins desta Instrução Normativa, considera-se:

I - convênio - instrumento qualquer que discipline a transferência de recursos públicos e tenha como partícipe órgão da administração pública federal direta, autárquica ou fundacional, empresa pública ou sociedade de economia mista que estejam gerindo recursos dos orçamentos da União, visando à execução de programas de trabalho, projeto/atividade ou evento de interesse recíproco, em regime de mútua cooperação;

II - concedente - órgão da administração pública federal direta, autárquica ou fundacional, empresa pública ou sociedade de economia mista, responsável pela transferência dos recursos financeiros ou pela descentralização dos créditos orçamentários destinados à execução do objeto do convênio;

III - convenente - órgão da administração pública direta, autárquica ou fundacional, empresa pública ou sociedade de economia mista, de qualquer esfera de governo, ou organização particular com a qual a administração federal pactua a execução de programa, projeto/atividade ou evento mediante a celebração de convênio.

Resumindo a análise deste dispositivo, o caput e o $\S 1^{\circ}$, I e II, tratam de definir o pólo ativo do repasse financeiro: necessariamente órgão da administração pública federal direta ou indireta. E o inciso III define os possíveis integrantes do pólo passivo do convênio, dentre os quais inclui o vocábulo organização particular.

Mais recentemente foi aprovado o Decreto n. 6.170/2007, que "dispõe sobre as normas relativas às transferências de recursos da União mediante convênios e contratos de repasse, e dá outras providências". Regulamentando o artigo 10, do Decreto-lei n. 200/67 (que como visto não faz menção aos convênios público-privados), o artigo 116, da Lei n. 8666/93 (que pode ser interpretado como abrangendo esta figura) e o artigo 25, da Lei n. 101/2000 (que também não faz menção à forma conveniada entre o Poder Público e

\footnotetext{
${ }^{434}$ Não queremos significar, com isso, que se aplica o regime das licitações aos convênios, como será tratado posteriormente.
} 
entidades privadas $)^{435}$, referido Decreto é expresso em regulamentar os convênios públicoprivados em seu artigo $1^{\mathrm{o}}$ :

Art. $1^{0}$ Este Decreto regulamenta os convênios, contratos de repasse e termos de cooperação celebrados pelos órgãos e entidades da administração pública federal com órgãos ou entidades públicas ou privadas sem fins lucrativos, para a execução de programas, projetos e atividades de interesse recíproco que envolvam a transferência de recursos oriundos do Orçamento Fiscal e da Seguridade Social da União.

Importante definição é trazida pelo $\S 1^{\circ}$, I, deste Decreto, ao dispor:

$\S 1^{\circ}$ Para os efeitos deste Decreto, considera-se:

I - convênio - acordo, ajuste ou qualquer outro instrumento que discipline a transferência de recursos financeiros de dotações consignadas nos Orçamentos Fiscal e da Seguridade Social da União e tenha como partícipe, de um lado, órgão ou entidade da administração pública federal, direta ou indireta, e, de outro lado, órgão ou entidade da administração pública estadual, distrital ou municipal, direta ou indireta, ou ainda, entidades privadas sem fins lucrativos, visando a execução de programa de governo, envolvendo a realização de projeto, atividade, serviço, aquisição de bens ou evento de interesse recíproco, em regime de mútua cooperação;

Assim como no Decreto n. 93.872/1986, o conceito trazido por este dispositivo traz a nota principal de distinção entre os convênios e os contratos: o interesse recíproco e a mútua cooperação.

E é exatamente aí que diferem, no ponto nodal, os convênios dos contratos. Embora ambos possam ser considerados como acordos de vontades, fato é que o convênio e o contrato são figuras distintas e de características próprias. ${ }^{436}$

Consoante a clássica lição de Hely Lopes Meirelles, "convênios administrativos são acordos firmados por entidades públicas de qualquer espécie, ou entre estas e organizações particulares, para realização de objetivos de interesse comum dos partícipes". ${ }^{437}$ Diferem os institutos, assim, principalmente, em razão dos interesses envolvidos em cada qual;

435 “Art. 25. Para efeito desta Lei Complementar, entende-se por transferência voluntária a entrega de recursos correntes ou de capital a outro ente da Federação, a título de cooperação, auxílio ou assistência financeira, que não decorra de determinação constitucional, legal ou os destinados ao Sistema Único de Saúde".

436 "O convênio tem em comum com o contrato o fato de ser um acordo de vontades. Mas é um acordo de vontades com características próprias” (DI PIETRO, Maria Sylvia Zanella. Parcerias na Administração Pública: concessão, permissão, franquia, terceirização, parceria público-privada e outras formas. $5^{\mathrm{a}}$ ed. São Paulo : Atlas, 2006, p. 246).

${ }^{437}$ MEIRELLES, Hely Lopes. Direito administrativo brasileiro. 26a ed. São Paulo : Malheiros, 2001, p. 377. 
enquanto no contrato os interesses são "opostos e contraditórios",438, no convênio os interesses são recíprocos. ${ }^{439}$

Além deste ponto de distinção entre os convênios e os contratos, podem ainda ser apontados outros critérios que auxiliam na diferenciação, de modo a fazer aplicação do correto regime jurídico ao caso concreto. ${ }^{440}$ "Nossas Administrações, entretanto, têm confundido, em muitos casos, o convênio com o contrato administrativo, realizando este em lugar e com a denominação daquele, o que dificulta sua interpretação e execução". ${ }^{41}$

São figuras juridicamente distintas e sujeitas a regimes jurídicos próprios, portanto devem ser aplicadas adequadamente sob pena de desvirtuamento. Ocorre com bastante freqüência a utilização pela Administração Pública de instrumentos conveniais para relações de nítida natureza contratual, mormente com vistas a escapar dos rígidos procedimentos de escolha dos contratados, de utilização das verbas repassadas, etc..

Uma das características marcantes dos convênios, que decorre justamente do fato de serem firmados para fins de mútua colaboração, é a impossibilidade de se falar em

${ }^{438}$ DI PIETRO, Maria Sylvia Zanella. Op. cit., p. 246.

439 "Convênio é acordo, mas não é contrato. No contrato as partes têm interesses diversos e opostos; no convênio os partícipes têm interesses comuns e coincidentes. Por outras palavras: no contrato há sempre duas partes (podendo ter mais de dois signatários), uma que pretende o objeto do ajuste (a obra, o serviço etc.), outra que pretende a contraprestação correspondente (o preço, ou qualquer outra vantagem), diversamente do que ocorre no convênio, em que não há partes, mas unicamente partícipes com as mesmas pretensões. Por essa razão, no convênio a posição jurídica dos signatários é uma só, idêntica para todos, podendo haver apenas diversificação na cooperação de cada um, segundo suas possibilidades, para a consecução do objetivo comum, desejado por todos" (MEIRELLES, Hely Lopes. Op. cit., p. 377, destaques no original). "O convênio é um instrumento largamente utilizado pelo Poder Público quando se une a outros entes, públicos ou privados, em regime de colaboração, almejando objetivos comuns, ainda que cada partícipe possua obrigações distintas de acordo com suas possibilidades, segundo partilha definida no instrumento convenial. Há, pois, no convênio, efetiva cooperação entre os partícipes, não sendo caracterizado pela comutatividade, típica dos contratos, quando o interesse dos contratantes se revela contraposto, ou seja, cada parte tem objetivos e finalidades distintos (embora, nem por isso se autorize o afastamento da noção de parceria)" (SOUTO, Marcos Juruena Villela. Parceria para divulgação do desporto. In:

Direito administrativo das parcerias. Rio de Janeiro : Lumen Juris, 2005, p. 165, destaques no original). "O convênio consiste numa avença em que dois ou mais sujeitos, sendo ao menos um deles integrante da Adminsitração Pública, comprometem-se a atuar de modo conjugado para a satisfação de necessidades de interesse coletivo, sem intento de cunho lucrativo" (JUSTEN FILHO, Marçal. Curso de direito administrativo. $2^{\mathrm{a}}$ ed. São Paulo : Saraiva, 2006, p. 293)."Diz-se que as vontades das partes no contrato são contrapostas, de modo que o resultado de sua conjugação forma uma terceira vontade, a vontade contratual. Já nos convênios há homogeneidade de interesses, de modo que um único objetivo passa a ser buscado por meio da soma de esforços" (MÂNICA, Fernando Borges. Negócio jurídico para a prestação de serviços por entidade do terceiro setor: natureza jurídica, requisitos, critérios e procedimento para a celebração do ajuste. Revista de Direito do Terceiro Setor - RDTS, Belo Horizonte : Fórum, ano 1, n. 2, jul.-dez. 2007, p. 145).

${ }^{440}$ Cf. DI PIETRO, Maria Sylvia Zanella. Op. cit., pp. 247-248.

${ }^{441}$ MEIRELLES, Hely Lopes. Op. cit., p. 378, destaques no original. "Há de se ressaltar que têm sido, equivocadamente, firmados convênios em vez de contratos, com o simples intuito de fuga do procedimento licitatório, ou mesmo por desconhecimento das reais possibilidades de uso de cada instituto" (VIOLIN, Tarso Cabral. Terceiro setor e as parcerias com a Administração Pública: uma análise crítica. Belo Horizonte : Fórum, 2006, p. 237). "Entretanto, é de se reconhecer que a questão é complexa e grande parte da doutrina adota entendimento ampliativo do convênio. Daí a utilização muitas vezes indevida de tal figura, em substituição ao contrato, como tentativa de fuga aos ditames que regem a contratualização administrativa" (MÂNICA, Fernando Borges. Op. cit., p. 147). 
remuneração ou preço. O Estado não remunera o particular para o desempenho de uma atividade de seu interesse, justamente porque o convênio se presta a formalizar um regime de cooperação entre Estado e particular na busca de um interesse comum. Embora seja comum o repasse de verbas do Poder Público para a entidade convenente, este repasse não se caracteriza como contraprestação ou preço de serviços prestados, mas uma das formas de expressão da mútua cooperação compreendida no convênio.

No caso do convênio, se o conveniado recebe determinado valor, este fica vinculado ao objeto do convênio durante toda sua execução, razão pela qual o executor deverá demonstrar que referido valor está sendo utilizado em consonância com os objetivos estipulados. Como não há comutatividade de valores, não basta demonstrar o resultado final obtido; é necessário demonstrar que todo o valor repassado foi utilizado na consecução daquele resultado. Vale dizer que o dinheiro assim repassado não muda sua natureza por força do convênio; ele é transferido e utilizado pelo executor do convênio, mantida sua natureza de dinheiro público (no sentido de que está destinado a fim público). ${ }^{442}$

Diferentemente do contrato, em que a Administração paga ao contratado o preço dos serviços prestados e àquela não importa a que título o dinheiro foi utilizado pelo particular, no convênio o repasse financeiro é feito estritamente para a utilização no objeto do convênio de acordo com os pactos celebrados. ${ }^{443}$

Aliás, a vedação à remuneração através dos convênios está prevista expressamente na Portaria Interministerial MP/MF/CGU n. 127/08, que regulamenta o Decreto n. 6.170/70, quando impede a inclusão de cláusula convenial relativa ao pagamento de taxa de administração ${ }^{444}$, de gerência ou similar, nos seguintes termos:

Art. 39. O convênio ou contrato de repasse deverá ser executado em estrita observância às cláusulas avençadas e às normas pertinentes, inclusive esta Portaria, sendo vedado:

I - realizar despesas a título de taxa de administração, de gerência ou similar.

\footnotetext{
${ }^{442}$ DI PIETRO, Maria Sylvia Zanella. Op. cit., p. 251.

443 "Essa necessidade de controle se justifica em relação aos convênios precisamente por não existir neles a reciprocidade de obrigações presente nos contratos; as verbas repassadas não têm a natureza de preço ou remuneração que uma das partes paga à outra em troca de benefício recebido. Dessa distinção resulta uma conseqüência: no contrato, a Administração paga uma remuneração em troca de uma obra, um serviço, um projeto, um bem, de que necessita; essa obra, serviço, projeto ou bem entra para o patrimônio público e o valor pago pela Administração entra para o patrimônio do contratado; a forma como este vai utilizar esse valor deixa de interessar ao Poder Público; aquele valor deixou de ser dinheiro público no momento em que entrou para o patrimônio privado; vale dizer que o interesse do Poder Público se exaure com a entrega definitiva do objeto do contrato nas condições estipuladas" (ibidem, p. 251).

${ }^{444}$ Cf. sobre o tema OLIVEIRA, Gustavo Justino de. Taxa de administração prevista em contratos de gestão firmados com organizações sociais: típicos instrumentos de fomento público para entidades do terceiro setor. Revista de Direito do Terceiro Setor - RDTS, Belo Horizonte : Fórum, ano 3, n. 5, jan.-jun. 2009, pp. 117141.
} 
O conceito de taxa de administração, que não consta da legislação regente da matéria, pode ser apropriado da interpretação do Tribunal de Contas da União, que a entende como "a remuneração supostamente devida à entidade conveniada pelo gerenciamento das atividades previstas no convênio, calculada na forma de um percentual sobre o total do montante de recursos públicos repassado" "445. A taxa de administração, que teria conteúdo remuneratório ou contraprestacional da atividade assumida pelo particular no convênio é expressamente rechaçada pela legislação que regula a matéria.

Além disso, o próprio custeio das atividades desenvolvidas pela entidade privada convenente está limitado pela legislação. Dos repasses públicos feitos com justificativa no convênio firmado, embora instituída de forma discutível, somente $15 \%$ do valor pode ser gasto com despesas administrativas da entidade, o que envolve a remuneração dos funcionários vinculados diretamente às atividades do convênio (previstas no plano de trabalho inclusive). ${ }^{446}$ É o que dispõe o parágrafo único, do artigo 39, da mesma Portaria Interministerial: "Parágrafo único. Os convênios ou contratos de repasse celebrados com entidades privadas sem fins lucrativos, poderão acolher despesas administrativas até o limite de quinze por cento do valor do objeto, desde que expressamente autorizadas e demonstradas no respectivo instrumento e no plano de trabalho".

Outra conseqüência da natureza própria dos convênios como acordo de vontades em que as partes buscam um resultado comum, com interesses próprios e mútua colaboração, é o fato de que "não há vinculação contratual ou cláusula de permanência obrigatória", ${ }^{447}$ Neste sentido,

as relações formalizadas pela via do convênio são dotadas de relativa instabilidade e em regra não geram efeitos vinculantes para as partes, uma vez que a qualquer momento qualquer dos partícipes pode denunciá-lo, ficando os convenentes responsáveis somente pelas obrigações e auferindo as vantagens do tempo em que dele participaram voluntariamente, não sendo admissível cláusula obrigatória de permanência ou sancionadora dos denunciantes, nos termos do revogado art. 57 do Decreto n. 93.872/86. ${ }^{448}$

\footnotetext{
${ }^{445}$ Cf. Acórdãos 235/03, 1146/03, 191/99, 1542/08.

446 A Comissão Gestora do SICONV, em reunião ocorrida em 27/03/2009, aprovou Nota Técnica esclarecendo a limitação de $15 \%$ para despesas administrativas. Disponível em: $<$ https://www.convenios.gov.br/portal/arquivos/Orientacoes_Normativas_sobre_Despesas_Administrativas.p df>. Acesso em: 16 abr. 2010.

${ }^{447}$ MÂNICA, Fernando Borges. Negócio jurídico para a prestação de serviços por entidade do terceiro setor: natureza jurídica, requisitos, critérios e procedimento para a celebração do ajuste. Revista de Direito do Terceiro Setor - RDTS, Belo Horizonte : Fórum, ano 1, n. 2, jul.-dez. 2007, p. 146.

448 OLIVEIRA, Gustavo Justino de. Taxa de administração prevista em contratos de gestão firmados com organizações sociais: típicos instrumentos de fomento público para entidades do terceiro setor. Revista de Direito do Terceiro Setor - RDTS, Belo Horizonte : Fórum, ano 3, n. 5, jan.-jun. 2009, p. 138.
} 
É, aliás, o texto do artigo 12 do Decreto n. 6.170/2007:

Art. 12. O convênio poderá ser denunciado a qualquer tempo, ficando os partícipes responsáveis somente pelas obrigações e auferindo as vantagens do tempo em que participaram voluntariamente do acordo, não sendo admissível cláusula obrigatória de permanência ou sancionadora dos denunciantes.

Outra conseqüência importante decorrente da característica dos convênios advém da desnecessidade de licitação para a sua assinatura. Isto porque "o convênio envolve uma cooperação de esforços, de livre adesão, para a consecução de objetivos comuns, que singulariza o objeto e torna desnecessária a licitação na eleição do parceiro privado". ${ }^{449} \mathrm{De}$ fato, os convênios se enquadram no antes analisado conceito de inviabilidade de competição, uma vez que nele não há proveito econômico (remuneração ou preço).

Mais do que isso, quer nos parecer que a própria Lei n. 8.666/93 não tem a intenção de aplicar as exigências do procedimento licitatório aos convênios. A análise vem da leitura conjugada do artigo $2^{\circ}$, que em seu parágrafo único define a figura dos contratos sujeitos à licitação, com a análise do artigo 116 , que ressalva a aplicação da lei no que couber aos convênios.

Sendo mais específico, o artigo $2^{\circ}$ é expresso em dizer que os contratos da Administração Pública com terceiros serão precedidos de licitação, seja qual for a denominação utilizada, o que significa dizer que todo acordo de vontades da Administração Pública que tenha conteúdo contratual está sujeito a licitação. Também implica dizer que todo acordo de vontade da Administração Pública que não tenha conteúdo contratual não está sujeito a licitação. Desta forma, não precisaria outro dispositivo para dizer que para os convênios e outros instrumentos de natureza não contratual não estariam sujeitos à licitação. No entanto, veio o artigo $116 \mathrm{e}$ fez a ressalva de que a lei só se aplica aos convênios, acordos, ajustes e outros instrumentos congêneres, todos eles de natureza não contratual, no que couber. Conclusão é que o artigo $2^{\circ}$ não se aplica aos instrumentos citados no artigo 116 por não terem natureza contratual e, ressalvese, quando não tenham natureza contratual. A ressalva é importante porque "não obstante a denominação de 'convênio', ou 'protocolo de intenções', ou 'termo de compromisso', ou

${ }^{449}$ SOUTO, Marcos Juruena Villela. Direito administrativo das parcerias. Rio de Janeiro : Lumen Juris, 2005, p. 167. "Enquanto os contratos abrangidos pela Lei n. 8.666 são necessariamente precedidos de licitação - com as ressalvas legais - no convênio não se cogita de licitação, pois não há viabilidade de competição quando não se trata de mútua colaboração, sob variadas formas, como repasse de verbas, uso de equipamentos, de recursos humanos, de imóveis, de know-how. Não se cogita de remuneração que admita competição" (DI PIETRO, Maria Sylvia Zanella. Temas polêmicos sobre licitações e contratos. $4^{a}$ ed. São Paulo : Malheiros, 2000, p. 310). 
outra qualquer semelhante, se do ajuste resultarem obrigações recíprocas, com formação de vínculo contratual, a licitação será necessária, sob pena de ilegalidade". ${ }^{450}$

Oportuna a citação de decisões proferida pelo Tribunal de Contas da União a este respeito:

Em se tratando de convênio, por razões de ordem lógica, seria inexigível o procedimento licitatório, não pelos motivos do art. 24, inciso XIII, da Lei 8.666/93 (dispensa), mas pelo fato da inviabilidade de competição. Seria um caso de mútua colaboração ou da própria política de fomento, como ressaltado doutrinariamente pela administrativista Maria Sylvia Zanella Di Pietro, na obra Direito Administrativo, $12^{\mathrm{a}}$ ed., SP, Atlas, 2000, p.287. ${ }^{451}$

Para aquisição de medicamentos fabricados pelos Laboratórios Oficiais, bem como dos demais produtos por eles processados, a existência de interesses recíprocos entre as partes que podem ser alcançados em regime de mútua cooperação viabiliza a utilização de convênio, descartada a necessidade de licitação, porque não existe na Lei n. 8.666/93 qualquer dispositivo que coloque o procedimento licitatório como antecedente necessário ao convênio. ${ }^{452}$

No entanto, oportuno salientar que o afastamento da exigência de submissão ao procedimento licitatório não significa a desnecessidade de a Administração Pública pautar a escolha do parceiro privado com base nos princípios da impessoalidade, da moralidade, isonomia, publicidade, a que está sujeita.E assim expomos para defender a necessidade de a Administração Pública levar a cabo, quando o objeto do convênio permitir que mais de um interessado se habilite, processo de seleção que identifique o projeto mais adequado aos interesses comuns buscados.

Embora em relação aos convênios seja usual defender que a inviabilidade de competição decorrente da reciprocidade de interesses afasta o regime licitatório, temos para nós que a pluralidade de entidades capacitadas a realizar o interesse público objeto do convênio leva à pluralidade de projetos para alcançar o fím almejado, exigindo que a Administração Pública realize procedimento de seleção do projeto mais adequado. ${ }^{453}$

\footnotetext{
${ }^{450}$ DI PIETRO, Maria Sylvia Zanella. Ibidem, p. 310. Como denuncia Odete Medauar, "alguns casos ocorrem na prática, nos quais, a título de convênio, obras são contratadas sem licitação e pessoas são investidas em funções e empregos públicos sem concurso ou seleção" (MEDAUAR, Odete. Direito administrativo moderno. $10^{\mathrm{a}}$ ed. São Paulo : RT, 2006, p. 228).

${ }^{451}$ Tribunal de Contas da União, Acórdão n. 10/2002, Processo 010.518/2001-4, DOU 27/02/2002.

${ }^{452}$ Tribunal de Contas da União, Decisão n. 287/96, Processo 020.069/93-6, Relator Min. Iram Saraiva, DOU 17/06/1996.

${ }^{453}$ É, em certa medida, o entendimento de Odete Medauar, embora entenda pela aplicação da licitação nestes casos: "No entanto, se a Administração pretender realizar convênio para resultado e finalidade que poderão ser alcançados por muitos, deverá ser realizada licitação ou se abrir a possibilidade de conveniar sem limitação, atendidas as condições fixadas genericamente; se assim não for, haverá ensejo para burla, acobertada pela acepção muito ampla que se queira dar aos convênios" (MEDAUAR, Odete. Op. cit., p. 228). Marcos Juruena Villela Souto sugere a adoção de um procedimento simplificado para evitar o risco de
} 
Há que se convir, no entanto, que em determinadas hipóteses a especificidade do objeto do convênio realmente o insere na hipótese de inviabilidade de competição, especialmente quando não envolve repasse de recursos. Um exemplo seria a assinatura de convênio entre Escola Pública Municipal e entidade sem fins lucrativos da região, para a utilização, por esta, da quadra de esportes da escola no período de contraturno para o desenvolvimento de atividades esportivas para os seus atendidos. Ou mesmo convênio que envolva repasse de recursos para a aquisição de computadores, por esta mesma entidade, para aparelhar uma sala de informática para uso de seus assistidos. Concordamos parcialmente, neste ponto, com Odete Medauar quando ensina que "no tocante aos convênios entre órgãos e entes estatais e entidades particulares, o que, sobretudo, fundamenta a desobrigação de licitação é a especificidade do objeto e da finalidade"454, com a ressalva de que entendemos suficiente processo de seleção da entidade parceira não necessariamente conforme a Lei n. 8.666/93.

Outro tema que envolve os convênios e as licitações diz respeito à exigência contida no artigo 27, da Instrução Normativa STN n. 01/1997, com a redação dada pela Instrução Normativa STN n. 03/2003 por sugestão do Acórdão n. 1070/2003, do Tribunal de Contas da União ${ }^{455}$. O dispositivo vem no seguinte sentido:

Art. 27. O convenente, ainda que entidade privada, sujeita-se, quando da execução de despesas com os recursos transferidos, às disposições da Lei ${ }^{0} 8.666$, de 21 de junho de 1993, especialmente em relação a licitação e contrato, admitida a modalidade de licitação prevista na Lei $n^{\circ} 10.520$, de 17 de julho de 2002, nos casos em que especifica. ${ }^{456}$

argüição de fuga ao regime publicístico: "Nessa linha, não haveria impedimento de se adotar um procedimento simplificado, porém aberto e transparente para a escolha de parceiros, sem, contudo, se submeter aos formalismos da Lei n. 8.666/93" (SOUTO, Marcos Juruena Villela. Parceria para divulgação do desporto. In: _. Direito administrativo das parcerias. Rio de Janeiro : Lumen Juris, 2005, p. 194). Tarso Cabral Violin também segue neste sentido: "Além disso, concordamos que existindo mais de um interessado em situação de igualdade, com interesse em firmar convênio com a Administração Pública, não poderá o administrador, sem qualquer motivação, escolher sua entidade 'preferida'. Nessa situação, para o melhor atendimento do interesse público e princípios como o da moralidade, isonomia, publicidade, a Administração está vinculada a realizar processo de escolha, com divulgação da intenção de firmar o convênio, e seleção por meio de critérios pré-definidos" (VIOLIN, Tarso Cabral. Terceiro setor e as parcerias com a Administração Pública: uma análise crítica. Belo Horizonte : Fórum, 2006, p. 249).

${ }^{454}$ MEDAUAR, Odete. Direito administrativo moderno. $10^{\mathrm{a}}$ ed. São Paulo : RT, 2006, p. 228.

455 Tribunal de Contas da União, Plenário, Processo n. 003.361/2002-2, Acórdão n. 1.070/2003, Rel. Min. Ubiratan Aguiar, DOU 18/08/2003.

${ }^{456}$ A redação anterior do dispositivo era a seguinte: “Art. 27 - Quando o convenente integrar a administração pública, de qualquer esfera do governo, deverá, obrigatoriamente sujeitar-se às disposições da Lei $n^{\circ}$ 8666/93, especialmente naquilo que se refira a licitação e contrato. Parágrafo único - o convenente entidade privada não sujeita a Lei $\mathrm{n}^{\circ}$ 8.666/93, deverá , na execução das despesas com recursos recebidos em transferências, adotar procedimentos análogos aos estabelecidos pela referida lei." 
No mesmo sentido, desta feita se apropriando de sugestão do Acórdão n. 353/05, do Tribunal de Contas da União, foi aprovado o Decreto n. 5.504/2005, que sob o fundamento de regulamentar o artigo 116, da Lei n. 8.666/93, exige a inserção de cláusula obrigando a sujeição da utilização de verbas públicas repassadas ao parceiro privado ao processo de licitação pública, especificamente o pregão, de preferência eletrônico (próprio ou de terceiros). ${ }^{457}$

Posteriormente, no entanto, o Decreto n. 6.170/2007, em seu artigo 11, simplificou esta exigência ao prever a suficiência de cotação prévia de preços no mercado, nos seguintes termos:

Art. 11. Para efeito do disposto no art. 116 da Lei $n^{\circ} 8.666$, de 21 de junho de 1993, a aquisição de produtos e a contratação de serviços com recursos da União transferidos a entidades privadas sem fins lucrativos deverão observar os princípios da impessoalidade, moralidade e economicidade, sendo necessária, no mínimo, a realização de cotação prévia de preços no mercado antes da celebração do contrato.

Embora do Decreto n. 6.170/2007 não conste revogação expressa do Decreto n. $5.504 / 2005$, por ser aquela norma posterior e de igual hierarquia, tratando do mesmo tema, podemos considerar revogado este Decreto quanto a este assunto.

Em largas passadas, este é o regime aplicável aos convênios firmados pela Administração Pública, cujas características, indene de dúvidas, fazem com que se configurem como importantes ferramentas de fomento às atividades desenvolvidas pelo Terceiro Setor.

\subsection{Contratos de Repasse}

457 “Art. $1^{\circ}$ Os instrumentos de formalização, renovação ou aditamento de convênios, instrumentos congêneres ou de consórcios públicos que envolvam repasse voluntário de recursos públicos da União deverão conter cláusula que determine que as obras, compras, serviços e alienações a serem realizadas por entes públicos ou privados, com os recursos ou bens repassados voluntariamente pela União, sejam contratadas mediante processo de licitação pública, de acordo com o estabelecido na legislação federal pertinente. $\S 1^{\circ}$ Nas licitações realizadas com a utilização de recursos repassados nos termos do caput, para aquisição de bens e serviços comuns, será obrigatório o emprego da modalidade pregão, nos termos da Lei $\mathrm{n}^{\circ}$ 10.520, de 17 de julho de 2002, e do regulamento previsto no Decreto $\mathrm{n}^{0} 5.450$, de 31 de maio de 2005, sendo preferencial a utilização de sua forma eletrônica, de acordo com cronograma a ser definido em instrução complementar. $\S 2^{\circ} \mathrm{A}$ inviabilidade da utilização do pregão na forma eletrônica deverá ser devidamente justificada pelo dirigente ou autoridade competente. $\S 3^{\circ}$ Os órgãos, entes e entidades privadas sem fins lucrativos, convenentes ou consorciadas com a União, poderão utilizar sistemas de pregão eletrônico próprios ou de terceiros. $\S 4^{\circ}$ Nas situações de dispensa ou inexigibilidade de licitação, as entidades privadas sem fins lucrativos, observarão o disposto no art. 26 da Lei $\mathrm{n}^{\circ}$ 8.666, de 21 de junho de 1993, devendo a ratificação ser procedida pela instância máxima de deliberação da entidade, sob pena de nulidade". 
Outra ferramenta possível para instrumentalizar as chamadas transferências voluntárias para o Terceiro Setor é a utilização dos contratos de repasse, através do qual os recursos da União são transferidos para as demais pessoas políticas e entidade privadas por intermédio de instituições ou agências financeiras oficiais federais, destinados à execução de programas governamentais. ${ }^{458}$ As agências financeiras oficiais atuam como mandatárias da União para fiscalização e execução das transferências de recursos da União.

Conforme nos dá conta Natasha Schmitt Caccia Salinas, o

contrato de repasse aplicável às entidades sem fins lucrativos surgiu com o advento da LDO para o exercício de 2006, que introduziu uma sistemática na qual a União passou a transferir voluntariamente recursos a entes privados por intermédio de instituição financeira oficial. $^{459}$

Foi, portanto, a Lei n. 11.178/2005 que estendeu a possibilidade de utilização dos contratos de repasse para as transferências financeiras para entidades privadas, especificamente em seu artigo 111 que estabelece:

Art. 111. As transferências financeiras para órgãos públicos e entidades públicas e privadas poderão ser feitas por intermédio de instituições e agências financeiras oficiais, que atuarão como mandatárias da União para execução e fiscalização, devendo a nota de empenho ser emitida até a data da assinatura do respectivo acordo, convênio, ajuste ou instrumento congênere.

A partir de então, o instrumento criado pela Lei n. $9.082 / 95^{460}$ e regulamentado pelo Decreto n. $1.819 / 96^{461}$ exclusivamente para as transferências entre a União e as demais

\footnotetext{
${ }^{458}$ Decreto n. 6.170/2007: “§ $1^{\circ}$ Para os efeitos deste Decreto, considera-se: (...) II - contrato de repasse instrumento administrativo por meio do qual a transferência dos recursos financeiros se processa por intermédio de instituição ou agente financeiro público federal, atuando como mandatário da União". "Como decorrência da celebração do contrato de repasse entre União e instituição financeira, esta passou a atuar como mandatária daquela, tornando-se responsável pelo acompanhamento da execução e fiscalização dos programas ou projetos vinculados à realização de programas governamentais não decorrentes de determinação constitucional ou legal nem destinados ao SUS ('Sistema Único de Saúde')" (SALINAS, Natasha Schmitt Caccia. Avaliação legislativa no Brasil: um estudo de caso sobre as normas de controle das transferências voluntárias de recursos públicos para entidades do terceiro setor. Dissertação de mestrado. São Paulo, Faculdade de Direito da USP, 2008, p. 87).

${ }^{459}$ SALINAS, Natasha Schmitt Caccia. Ibidem, p. 87. Continua a autora: "O contrato de repasse vinha sendo aplicado a entes públicos, no entanto, desde sua criação, com a edição da LDO para o exercício de 1996 e a publicação do Decreto n. 1.819, de 16 de fevereiro de 1996, que a regulamentou" (ibidem, p. 87).

460 "Art. 18. As transferências de recursos da União, consignadas na lei orçamentária anual, para Estados, Distrito Federal ou Municípios, a qualquer título, inclusive auxílios financeiros e contribuições, serão realizadas exclusivamente mediante convênio, acordo, ajuste ou outros instrumentos congêneres, na forma da legislação vigente, ressalvadas aquelas decorrentes de recursos originários da repartição de receitas previstas em legislação específica e as repartições de receitas tributárias e as destinadas a atender a estado de calamidade pública legalmente reconhecido mediante ato ministerial, e dependerão da unidade beneficiada comprovar, no ato da assinatura do instrumento original que:(Redação dada pela Lei ${ }^{\circ} 10.210$, de 23.3.2001)
} 
pessoas políticas passou a ser admitido para os repasses para as entidades privadas, através das instituições financeiras como mandatárias da União.

De acordo com a regulamentação, o Ministério responsável pela execução do programa ou projeto objeto do repasse deve firmar termo de cooperação com instituição ou agência financeira oficial federal, que atuará como sua mandatária, efetuando o repasse para a entidade privada.

A Instrução Normativa n. 01/97 já previa que os contratos de repasse estavam sujeitos à mesma regulamentação dos convênios, quando o parágrafo único do seu artigo 39 estabelecia o seguinte: "Parágrafo único. As disposições desta Instrução Normativa aplicam-se no que couber ao 'contrato de repasse' a que se refere o Decreto $\mathrm{n}^{\mathrm{o}} 1.819$, de 16.02.96, que se equipara à figura do convênio, conceituada no inciso $\mathrm{I}$, do art. $1^{\circ}$ ". O Decreto n. 6.170/2007 confirmou este fato ao dispor que:

Art. $1^{\circ}$ Este Decreto regulamenta os convênios, contratos de repasse e termos de cooperação celebrados pelos órgãos e entidades da administração pública federal com órgãos ou entidades públicas ou privadas sem fins lucrativos, para a execução de programas, projetos e atividades de interesse recíproco que envolvam a transferência de recursos oriundos do Orçamento Fiscal e da Seguridade Social da União.

Salvo algumas regras específicas destinadas aos contratos de repasse constantes deste Decreto, a regulamentação é a mesma dos convênios e os comentários feitos no tópico anterior servem para o presente instrumento.

\subsection{Termos de Parceria}

Saindo da esfera dos instrumentos tradicionalmente considerados como aptos a efetivar as parcerias da Administração Pública (contratos e convênios) e que se aplicam à atividade do Terceiro Setor por empréstimo, insta conhecer a única ferramenta criada especificamente para estabelecer relações de parceria entre a Administração Pública e o Terceiro Setor.

$\S 4^{\circ}$ As transferências previstas neste artigo poderão ser feitas por intermédio de instituições e agências financeiras oficiais, que atuarão como mandatárias da União para execução e fiscalização".

461 "Art. $2^{\circ}$ As transferências de que trata o artigo anterior poderão ser feitas por intermédio de instituições ou agências financeiras oficiais federais, que atuarão como mandatárias da União. Parágrafo único. Na hipótese deste artigo o Ministério competente para a execução do programa ou projeto deverá firmar, com a instituição ou agência financeira escolhida, o respectivo instrumento de cooperação, em que serão fixados, dentre outros, os limites de poderes outorgados. Art. $3^{\circ} \mathrm{A}$ transferência dos recursos pelos mandatários será efetuada mediante contrato de repasse, do qual constarão os direitos e obrigações das partes, inclusive quanto à obrigatoriedade de prestação de contas perante o Ministério competente para a execução do programa ou projeto". 
Inserida no contexto da chamada reforma do marco legal do Terceiro Setor ${ }^{462}$, através da Lei n. ${ }^{\circ} 9.790$, de 23 de março de $1999^{463}$, foi instituída qualificação destinada às pessoas jurídicas de direito privado intitulada com o acrônimo Oscip, ou seja, organização da sociedade civil de interesse público.

Conforme dispõe o art. $1^{\mathrm{o}}$ da referida lei, "podem qualificar-se como Organizações da Sociedade Civil de Interesse Público as pessoas jurídicas de direito privado, sem fins lucrativos, desde que os respectivos objetivos sociais e normas estatutárias atendam aos requisitos instituídos por esta Lei". 464

Esta Lei n. ${ }^{\circ}$ 9.790/99 (organizações da sociedade civil de interesse público) foi instituída com o fim de possibilitar o desenvolvimento de setores considerados de interesse público, com a atuação direta da iniciativa privada mediante termo de parceria com o Poder Público, conforme estabelece seu artigo $9^{\circ} .^{465}$

A técnica legislativa adotada foi a de anteriormente excepcionar as pessoas jurídicas que não podem se enquadrar como OSCIP, através de seu artigo $2^{\circ}$ que ora se transcreve por imprescindível:

Art. $2^{\circ}$ Não são passíveis de qualificação como Organizações da Sociedade Civil de Interesse Público, ainda que se dediquem de qualquer forma às atividades descritas no art. $3^{\circ}$ desta Lei:

I - as sociedades comerciais;

II - os sindicatos, as associações de classe ou de representação de categoria profissional;

III - as instituições religiosas ou voltadas para a disseminação de credos, cultos, práticas e visões devocionais e confessionais;

IV - as organizações partidárias e assemelhadas, inclusive suas fundações;

$\mathrm{V}$ - as entidades de benefício mútuo destinadas a proporcionar bens ou serviços a um círculo restrito de associados ou sócios;

VI - as entidades e empresas que comercializam planos de saúde e assemelhados;

VII - as instituições hospitalares privadas não gratuitas e suas mantenedoras;

VIII - as escolas privadas dedicadas ao ensino formal não gratuito e suas mantenedoras;

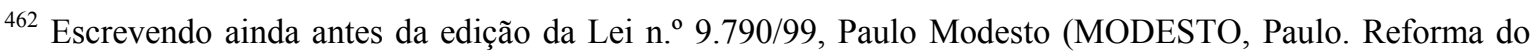
marco legal do terceiro setor no Brasil. In: FALCÃO, Joaquim; CUENCA, Carlos (org.). Mudança social e reforma legal: estudos para uma nova legislação do Terceiro Setor. Brasília : Conselho da Comunidade Solidária : UNESCO : BID : FBB, 1999, p. 150) assim se manifestou: “A mais nova proposta de alteração do marco legal das organizações do Terceiro Setor no Brasil é o recentíssimo projeto de lei sobre organizações da sociedade civil de caráter público, que tenta também esvaziar na prática o título de utilidade pública".

${ }^{463}$ Regulamentada pelo Decreto n. ${ }^{\circ} 3.100$, de 30 de junho de 1999.

${ }^{464} \mathrm{O}$ conceito de sem fins lucrativos é trazido pelo próprio artigo $1^{\mathrm{o}}$ : "§ $1^{\mathrm{o}}$ Para os efeitos desta Lei, considera-se sem fins lucrativos a pessoa jurídica de direito privado que não distribui, entre os seus sócios ou associados, conselheiros, diretores, empregados ou doadores, eventuais excedentes operacionais, brutos ou líquidos, dividendos, bonificações, participações, ou parcelas do seu patrimônio, auferidos mediante o exercício de suas atividades, e que os aplica integralmente na consecução do respectivo objeto social".

${ }^{465}$ Lei n. ${ }^{\circ}$ 9.790/99: “Art. 9'. Fica instituído o Termo de Parceria, assim considerado o instrumento passível de ser firmado entre o Poder Público e as entidades qualificadas como Organizações da Sociedade Civil de Interesse Público destinado à formação de vínculo de cooperação entre as partes, para o fomento e a execução das atividades de interesse público previstas no artigo $3^{\circ}$ desta lei”. 
IX - as organizações sociais;

$\mathrm{X}$ - as cooperativas;

XI - as fundações públicas;

XII - as fundações, sociedades civis ou associações de direito privado criadas por órgão público ou por fundações públicas;

XIII - as organizações creditícias que tenham quaisquer tipo de vinculação com o sistema financeiro nacional a que se refere o art. 192 da Constituição Federal.

Estas são as pessoas jurídicas impedidas de serem qualificadas como Oscip, não se lhes afastando, no entanto, no que couber, as outras titulações existentes. Ressalte-se: no que couber. A lei tem a clara intenção de proceder à categorização das organizações do Terceiro Setor, destinando-se tão-somente a parte delas por considerá-las as únicas merecedoras dos incentivos previstos na legislação, a exemplo de ordenamentos jurídicos estrangeiros. $^{466}$

Nos Estados Unidos, por exemplo, há distinção entre espécies de atividades desenvolvidas por entidades sem fins lucrativos, destinando-se os benefícios fiscais de forma diferenciada de acordo com sua característica. O Código Tributário norte-americano (tax code) divide estas entidades em duas seções diferentes, 501 (c) (3) e 501 (c) (4), e uma das diferenças é o fato de as doações feitas às organizações enquadradas nesta seção não serem dedutíveis do imposto de renda. ${ }^{467}$

${ }^{466}$ José Eduardo Sabo Paes (PAES, José Eduardo Sabo. Fundações e entidades de interesse social: aspectos jurídicos, administrativos, contábeis e tributários. Brasília : Brasília Jurídica, 2003, p. 90) exemplifica: "E, nesse campo, os países anglo-saxônicos dispõem de uma das tradições mais ricas, sendo deles a disseminação comum dos termos non profit sector, independent sector ou voluntary sector para se referir ao que atualmente vem sendo chamado de Terceiro Setor, cuja legislação é o resultado de séculos de experiência social e jurídica, tendo eles já desenvolvido um marco legal do Terceiro Setor, onde, em linhas gerais, optou-se por distinguir em duas categorias as organizações do referido setor, tendo como parâmetro as suas finalidades. A primeira categoria é formada pelas organizações de interesse (ou caráter) público - que são aquelas voltadas para a defesa do interesse mais amplo da sociedade ou para o desenvolvimento de uma atividade que traz benefícios para a sociedade como um todo, mesmo que, aparentemente, ela se dedique apenas a beneficiar agrupamentos específicos (como, por exemplo, os aidéticos ou as populações mais carentes). A segunda é integrada pelas organizações de ajuda mútua ou de auto-ajuda - que são as organizações ou agrupamentos que se formam para defender interesses coletivos, mas de um círculo restrito, específico, de pessoas, como, por exemplo, uma associação de classe, um clube social ou uma associação de moradores de uma determinada zona da cidade ou de funcionários de uma determinada empresa".

467 "Mais formalmente, focamos aqui nas organizações que são elegíveis para a isenção do imposto de renda pela Seção 501 (c) (3) do Código Tributário, e as que se aproximam mais do conceito de 'organizações de bem estar social' elegíveis para a isenção pela Seção 501 (c) (4) deste Código. Incluídas aqui estão organizações que operam 'exclusivamente por propósitos religiosos, caritativos, científicos ou educacionais' e que não distribuem qualquer renda que gerem para qualquer sócio ou outra pessoa. Sozinhas entre os vinte e seis tipos de organizações isentas do imposto de renda, as organizações da Seção 501 (c) (3) também são elegíveis a receber dedução fiscal das doações feitas por pessoas físicas ou jurídicas, reflexo do fato de que se espera que elas sirvam os interesses do público em geral ao invés dos interesses e necessidades tão-somente dos membros da organização" (SALAMON, Lester. The resilient sector: the State of nonprofit America. In: (coord.). The State of nonprofit America. Washington, D.C. : Brooking Institution Press, 2003, p. 7 , tradução nossa). No original: "More formally, we focus here on organizations that are eligible for exemption from federal income taxation under Section 501 (c) (3) of the tax code, plus the closely related 'social welfare organizations' eligible for exemption under Section 501 (c) (4) of this code. Included here are 
Resta conhecer, portanto, o rol de atividades consideradas por esta lei como merecedoras da qualificação como Oscip. Como se vê, as atividades previstas se identificam com aquelas anteriormente apresentadas como fazendo parte do espaço de participação do Terceiro Setor. São elas, de acordo com o artigo $3^{\circ}$ do referido diploma legal:

I - promoção da assistência social;

II - promoção da cultura, defesa e conservação do patrimônio histórico e artístico;

III - promoção gratuita da educação, observando-se a forma complementar de participação das organizações de que trata esta Lei;

IV - promoção gratuita da saúde, observando-se a forma complementar de participação das organizações de que trata esta Lei;

$\mathrm{V}$ - promoção da segurança alimentar e nutricional;

VI - defesa, preservação e conservação do meio ambiente e promoção do desenvolvimento sustentável;

VII - promoção do voluntariado;

VIII - promoção do desenvolvimento econômico e social e combate à pobreza;

IX - experimentação, não-lucrativa, de novos modelos sócio-produtivos e de sistemas alternativos de produção, comércio, emprego e crédito;

$\mathrm{X}$ - promoção de direitos estabelecidos, construção de novos direitos e assessoria jurídica gratuita de interesse suplementar;

XI - promoção da ética, da paz, da cidadania, dos direitos humanos, da democracia e de outros valores universais;

XII - estudos e pesquisas, desenvolvimento de tecnologias alternativas, produção e divulgação de informações e conhecimentos técnicos e científicos que digam respeito às atividades mencionadas neste artigo.

Desta forma, exercendo a pessoa jurídica de direito privado ao menos uma destas atividades enumeradas, bem como observando os demais requisitos legais para tanto, poderá ser qualificada como Oscip. E estes demais requisitos legais, que se dirigem ao estatuto da entidade, estão previstos no artigo $4^{\circ}$ da mesma lei. ${ }^{468}$

organizations that operate 'exclusively for religious, charitable, scientific, or educational purposes' and that do not distribute any profits they may generate to any private shareholder or individual. Alone among the twenty-six types of organizations exempted from federal income taxation, the 501 (c) (3) organizations are also eligible to receive tax-deductible contributions from individuals and businesses, a reflection of the fact that they are expected to serve broad public purposes as opposed to the interests and needs of the members of the organizations alone".

468 "Art. $4^{\circ}$. Atendido o disposto no artigo $3^{\circ}$, exige-se ainda, para qualificarem-se como Organizações da Sociedade Civil de Interesse Público, que as pessoas jurídicas interessadas sejam regidas por estatutos cujas normas expressamente disponham sobre: I - a observância dos princípios da legalidade, impessoalidade, moralidade, publicidade, economicidade e da eficiência; II - a adoção de práticas de gestão administrativa, necessárias e suficientes a coibir a obtenção, de forma individual ou coletiva, de benefícios ou vantagens pessoais, em decorrência da participação no respectivo processo decisório; III - a constituição de conselho fiscal ou órgão equivalente, dotado de competência para opinar sobre os relatórios de desempenho financeiro e contábil, e sobre as operações patrimoniais realizadas, emitindo pareceres para os organismos superiores da entidade; IV - a previsão de que, em caso de dissolução da entidade, o respectivo patrimônio líquido será transferido a outra pessoa jurídica qualificada nos termos desta Lei, preferencialmente que tenha o mesmo objeto social da extinta; V - a previsão de que, na hipótese de a pessoa jurídica perder a qualificação 
Qualificada como Oscip, a pessoa jurídica de direito privado sem fins lucrativos poderá firmar termo de parceria com o Poder Público, com vistas a dar execução às atividades sociais da entidade mediante determinados rigores exigidos nos artigos $9^{\circ}$ a 15 da lei. Esta foi a grande novidade da referida legislação: criar nova e específica ferramenta de formalização de parceria entre a Administração Pública e o Terceiro Setor. O termo de parceria, portanto, se insere na esfera das atividades de fomento do Estado.

É importante ressaltar que os termos de parceria celebrados com entidades privadas qualificadas como OSCIP são acordos administrativos colaborativos, ajustados entre o Poder Público e entidades privadas sem fins lucrativos. São acordos utilizados para viabilizar a concertação administrativa, e têm por função principal instituir e disciplinar vínculos de colaboração entre o Estado e a sociedade civil, estando presente em ambos os casos a atividade de fomento por parte do Estado. ${ }^{469}$

O próprio artigo $9^{\circ}$ da Lei apresenta definição do termo de parceria, ressaltando a intenção da lei em criar instrumento representativo da colaboração entre o Poder Público e a sociedade civil:

Art. 9ํㅜㄹ instituído o Termo de Parceria, assim considerado o instrumento passível de ser firmado entre o Poder Público e as entidades qualificadas como Organizações da Sociedade Civil de Interesse Público destinado à formação de vínculo de cooperação entre as partes, para o fomento e a execução das atividades de interesse público previstas no art. $3^{-}$desta Lei.

Importantes elementos são extraídos deste conceito legal, mormente indicadores da finalidade atribuída ao instrumento criado. A começar com a definição da relação entre a

instituída por esta Lei, o respectivo acervo patrimonial disponível, adquirido com recursos públicos durante o período em que perdurou aquela qualificação, será transferido a outra pessoa jurídica qualificada nos termos desta Lei, preferencialmente que tenha o mesmo objeto social; VI - a possibilidade de se instituir remuneração para os dirigentes da entidade que atuem efetivamente na gestão executiva a para aqueles que a ela prestam serviços específicos, respeitados, em ambos os casos, os valores praticados pelo mercado, na região correspondente a sua área de atuação; VII - as normas de prestação de contas a serem observadas pela entidade, que determinarão, no mínimo: a) a observância dos princípios fundamentais de contabilidade e das Normas Brasileiras de Contabilidade; b) que se dê publicidade por qualquer meio eficaz, no encerramento do exercício fiscal, ao relatório de atividades e das demonstrações financeiras da entidade, incluindo-se as certidões negativas de débitos junto ao INSS e ao FGTS, colocando-os à disposição para exame de qualquer cidadão; c) a realização de auditoria, inclusive por auditores externos independentes se for o caso, da aplicação dos eventuais recursos objeto do termo de parceria conforme previsto em regulamento; d) a prestação de contas de todos os recursos e bens de origem pública recebidos pelas Organizações da Sociedade Civil de Interesse Público será feita conforme determina o parágrafo único do artigo 70 da Constituição Federal".

469 OLIVEIRA, Gustavo Justino de; MÂNICA, Fernando Borges. Organizações da Sociedade Civil de Interesse Público: termo de parceria e licitação. Boletim de Direito Administrativo, São Paulo : NDJ, ano XXI, n. 9, setembro de 2005, p. 1019. Também sobre os termos de parceria, cf. BARBOSA, Maria Nazaré Lins. Os termos de parceria como alternativa aos convênios - aspectos jurídicos. In: SZAZI, Eduardo (org.).

Terceiro setor: temas polêmicos 1. São Paulo : Peirópolis, 2004, pp. 25-44. 
Administração Pública e a entidade parceria: vínculo de cooperação. Afasta-se, portanto, a natureza contratual do instrumento ${ }^{470}$, aproximando-se da natureza jurídica dos convênios. $^{471}$

Temos para nós que, com Gustavo Justino de Oliveira e Fernando Borges Mânica, o termo de parceria é "nova forma jurídica de ajuste, a qual formaliza parcerias entre o

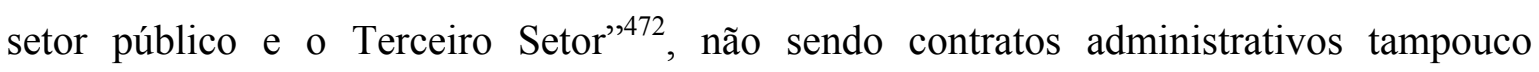
convênios, embora tenham algumas semelhanças com estes. São, verdadeiramente, novas formas de ajuste sujeitas a regime jurídico próprio.

Quanto à finalidade, importante o conteúdo do citado artigo $9^{\circ}$ ao fazer menção à atividade de fomento, demonstrando que os termos de parceria não se prestam a delegar serviços públicos à iniciativa privada, mas sim a fomentar as atividades de interesse público eleitas pela lei e desempenhadas pelas entidades sem fins lucrativos por ela abrangidas $^{473}$.

${ }^{470}$ Em sentido diverso entende Tarso Cabral Violin: "Sobre os termos de parceria temos o mesmo posicionamento quanto aos contratos de gestão. Ou seja, entendemos que os termos de parceria firmados entre a Administração Pública e as OSCIPs têm a mesma natureza jurídica dos contratos administrativos, com algumas peculiaridades próprias (VIOLIN, Tarso Cabral. Terceiro setor e as parcerias com a Administração Pública: uma análise crítica. Belo Horizonte : Fórum, 2006, p. 268). Marçal Justen Filho prefere não definir uma única natureza jurídica aos termos de parceria: "É problemático definir, examinando a questão em tese, a natureza jurídica de um contrato de gestão. Até se poderia reconhecer figura similar ao 'convênio'. É que as partes, no contrato de gestão, não têm interesses contrapostos. Não se trata de submeter parcialmente o interesse próprio a um sacrifício para obter benefícios egoísticos ou vantagens consistentes na redução do patrimônio alheio. Trata-se, muito mais, de contratos organizacionais ou associativos, pelos quais diversos sujeitos estruturam deveres e direitos em face de interesses comuns. Mas, no caso concreto, a expressão 'contrato de gestão' pode comportar inúmeras figuras jurídicas, da mais diversa natureza. Caberá examinar a situação concreta para atingir uma conclusão. O regime jurídico aplicável dependerá da identificação do substrato da relação jurídica pactuada. (...) A Lei n. 9.790 denomina 'termo de parceria' a essa contratação entre o Estado e a OSCIP. O conteúdo da figura não difere daquele denominado 'contrato de gestão’ pela Lei n. 9.637. Não há dúvida acerca da idêntica natureza jurídica de ambas as figuras, inclusive no tocante a limites e impedimentos. Aplicam-se aqui os comentários expendidos a propósito de tema similar quanto às organizações sociais" (JUSTEN FILHO, Marçal. Curso de direito administrativo. $2^{\mathrm{a}}$ ed. São Paulo : Saraiva, 2006, pp. 141-142). Egon Bockmann Moreira afasta expressamente a natureza contratual dos termos de parceria: "Para a implementação dessa metamorfose foram criadas novas figuras jurídicas, de difícil adaptação aos modelos antigos, que implementaram um outro tipo de convivência entre o público e o privado em setores essenciais às políticas públicas. Os exemplos mais próximos são os 'contratos de gestão' e os 'termos de parceria', nenhum dos quais se encaixa no conceito tradicional dos contratos administrativos" (MOREIRA, Egon Bockmann. Desenvolvimento econômico, políticas públicas e pessoas privadas (passado, presente e futuro de uma perene transformação). Revista de Direito do Estado - RDE, ano 3, n. 10, abr.-jun 2008, p. 215).

471 "Quanto ao vínculo com a Administração Pública, é estabelecido, conforme visto, por meio de termo de parceria, em tudo semelhante ao contrato de gestão previsto em lei para as organizações sociais. Não tem, como esse último, natureza contratual, assemelhando-se muito mais aos convênios tradicionalmente celebrados entre o Poder Público e entidades privadas para formalizar o fomento" (DI PIETRO, Maria Sylvia Zanella. Parcerias na Administração Pública: concessão, permissão, franquia, terceirização, parceria público-privada e outras formas. $5^{\text {a }}$ ed. São Paulo : Atlas, 2006, p. 273, destaque no original).

${ }_{472}$ OLIVEIRA, Gustavo Justino de; MÂNICA, Fernando Borges. Op. cit., p. 1022.

${ }^{473}$ Com a ressalva de que não incluímos as Organizações Sociais no conceito de Terceiro Setor: "À semelhança dos convênios, os contratos de gestão e os termos de parceria têm como objetivo instrumentalizar o fomento estatal a atividades de interesse público desenvolvidas por entidades do terceiro setor" (MÂNICA, 
E estas atividades, além de materialmente deverem observância ao disposto no artigo $3^{\circ}$, formalmente devem ser realizadas sob uma das duas formas previstas em seu parágrafo único $^{474}$, que a nosso ver contempla, resumidamente: i) a execução direta de projetos, programas e planos de ações correlatas às atividades previstas no artigo $3^{\circ}$, mediante a doação - no sentido de destinação - de recursos físicos, humanos e financeiros; e ii) a execução indireta destes projetos, programas e planos de ações correlatas, através da prestação de serviços intermediários de apoio a outras organizações sem fins lucrativos ou órgãos públicos. ${ }^{475}$

Um exemplo de execução direta das atividades por meio de termo de parceria pode ser o da colaboração mútua entre o Poder Público e uma entidade sem fins lucrativos com vistas a desenvolver projeto de desenvolvimento sustentável em determinada região e em favor de população ribeirinha, promovendo ações de detecção dos problemas por ela enfrentados, das suas habilidades e necessidades, de modo a dotá-la de recursos materiais e imateriais para uma existência digna.

Exemplo de execução indireta das atividades seria o vínculo de cooperação entre o Poder Público e entidade sem fins lucrativos para a capacitação de associações e cooperativas de catadores de recicláveis em áreas como empreendedorismo, finanças, plano de negócios, etc., com vistas a dotá-las de auto-sustentabilidade.

Há, no entanto, outros requisitos a serem observados que em um primeiro momento são formais mas após a qualificação da entidade passam a orientar as suas atividades com vistas especialmente ao controle de repasses de verbas públicas. São as seguintes cláusulas estatutárias obrigatórias previstas no artigo $4^{\circ}$ :

I - a observância dos princípios da legalidade, impessoalidade, moralidade, publicidade, economicidade e da eficiência: esta cláusula estatutária obrigatória tem a

Fernando Borges. Negócio jurídico para a prestação de serviços por entidade do terceiro setor: natureza jurídica, requisitos, critérios e procedimento para a celebração do ajuste. Revista de Direito do Terceiro Setor - RDTS, Belo Horizonte : Fórum, ano 1, n. 2, jul.-dez. 2007, p. 148).

474 "Parágrafo único. Para os fins deste artigo, a dedicação às atividades nele previstas configura-se mediante a execução direta de projetos, programas, planos de ações correlatas, por meio da doação de recursos físicos, humanos e financeiros, ou ainda pela prestação de serviços intermediários de apoio a outras organizações sem fins lucrativos e a órgãos do setor público que atuem em áreas afins".

${ }^{475}$ Gustavo Justino de Oliveira e Fernando Borges Mânica entendem de forma diferente as possibilidades de atuação das entidades que pretendem a qualificação como Oscip: "De acordo com a Lei das OSCIPs, a entidade assim qualificada há de expressar sua dedicação às atividades enumeradas no parágrafo único do art. $3^{\circ}$ da Lei federal n. 9.790/99 por intermédio (i) da realização de projetos, programas e planos de ações correlatas, (ii) da doação de recursos físicos, humanos e financeiros, ou ainda (iii) através da prestação de serviços intermediários de apoio a outras organizações sem fins lucrativos e órgãos do setor público que atuem em áreas afins" (OLIVEIRA, Gustavo Justino de; MÂNICA, Fernando Borges. Op. cit., p. 1020). Entendemos que a doação de recursos físicos, humanos e financeiros prevista na lei é instrumental à execução direta das atividades, e no mais das vezes será instrumental à execução indireta também, não fazendo sentido considerá-la apartadamente. 
função de aproximar os termos de parceria, sujeitos ao regime jurídico de direito privado, de limitações impostas pelo regime jurídico de direito público, tendo em vista o repasse de verbas públicas envolvido nos termos de parceria;

II - a adoção de práticas de gestão administrativa, necessárias e suficientes a coibir a obtenção, de forma individual ou coletiva, de benefícios ou vantagens pessoais, em decorrência da participação no respectivo processo decisório: o dispositivo tem como função coibir o desvio da finalidade não lucrativa pela entidade parceira, impedindo além da distribuição de lucros a obtenção de outras vantagens pessoais àqueles que dela participam. ${ }^{476}$ Impede-se, assim, a apropriação privada dos frutos da atividade de interesse público desenvolvida pela entidade.

III - a constituição de conselho fiscal ou órgão equivalente, dotado de competência para opinar sobre os relatórios de desempenho financeiro e contábil, e sobre as operações patrimoniais realizadas, emitindo pareceres para os organismos superiores da entidade: exige-se, assim, importante forma de controle interno sobre as atividades da entidade, mediante a instalação obrigatória de Conselho Fiscal;

IV - a previsão de que, em caso de dissolução da entidade, o respectivo patrimônio líquido será transferido a outra pessoa jurídica qualificada nos termos desta Lei, preferencialmente que tenha o mesmo objeto social da extinta: é dispositivo que, a exemplo do previsto no inciso II, tem por função impedir a apropriação indevida dos frutos da atuação da entidade particularmente, garantindo a continuidade do patrimônio amealhado pela entidade no desempenho de atividades de interesse público; ${ }^{477}$

$V$ - a previsão de que, na hipótese de a pessoa jurídica perder a qualificação instituída por esta Lei, o respectivo acervo patrimonial disponível, adquirido com recursos públicos durante o periodo em que perdurou aquela qualificação, será transferido a outra pessoa jurídica qualificada nos termos desta Lei, preferencialmente que tenha o mesmo objeto social: a exemplo do dispositivo anterior, tem por finalidade impedir a apropriação privada do patrimônio da entidade; além disso, tem como conteúdo a preservação do patrimônio público afetado à atividade desenvolvida pela entidade, mormente a

\footnotetext{
${ }^{476}$ O Decreto n. 3.100/99, que regulamenta a Lei n. 9.790/99, assim define a abrangência das vantagens pessoais impedidas pelo dispositivo legal: "Art. $7^{\circ}$ Entende-se como benefícios ou vantagens pessoais, nos termos do inciso II do art. $4^{\circ}$ da Lei $\mathrm{n}^{\circ}$ 9.790, de 1999, os obtidos: I - pelos dirigentes da entidade e seus cônjuges, companheiros e parentes colaterais ou afins até o terceiro grau; II - pelas pessoas jurídicas das quais os mencionados acima sejam controladores ou detenham mais de dez por cento das participações societárias".

${ }^{477}$ É dispositivo cuja previsão legal já existia para as associações (Código Civil, artigo 61) e para as fundações (Código Civil, artigo 69).
} 
desqualificação pressupõe que a entidade não alcançou a finalidade pública a que se prestava o termo de parceria assinado;

$V I$ - a possibilidade de se instituir remuneração para os dirigentes da entidade que atuem efetivamente na gestão executiva e para aqueles que a ela prestam serviços específicos, respeitados, em ambos os casos, os valores praticados pelo mercado, na região correspondente a sua área de atuação: uma das inovações desta qualificação é a possibilidade, não encontrada em outros títulos até então existentes ${ }^{478}$, de remuneração com limites - de seus dirigentes pelo exercício do cargo ou pela prestação de serviços específicos à entidade. É medida de profissionalização das entidades do Terceiro Setor, fundada na correta premissa de que permite que pessoas qualificadas para o exercício de funções administrativas auxiliem no crescimento do setor, acabando com a dependência das entidades de benfeitores dispostos a doar seu tempo para um trabalho não remunerado;

$V I I$ - as normas de prestação de contas a serem observadas pela entidade, que determinarão, no mínimo: a) a observância dos princípios fundamentais de contabilidade e das Normas Brasileiras de Contabilidade; b) que se dê publicidade por qualquer meio eficaz, no encerramento do exercício fiscal, ao relatório de atividades e das demonstrações financeiras da entidade, incluindo-se as certidões negativas de débitos junto ao INSS e ao FGTS, colocando-os à disposição para exame de qualquer cidadão; c) a realização de auditoria, inclusive por auditores externos independentes se for o caso, da aplicação dos eventuais recursos objeto do termo de parceria conforme previsto em regulamento; d) a prestação de contas de todos os recursos e bens de origem pública recebidos pelas Organizações da Sociedade Civil de Interesse Público será feita conforme determina o parágrafo único do art. 70 da Constituição Federal: é norma que confere padrão de publicidade às contas das entidades qualificadas como Oscip, além de instituir controles social e externo importantes para o acompanhamento da lisura das atividades desenvolvidas. A começar com a exigência de observância às Normas Brasileiras de Contabilidade, o que significa a manutenção de obrigações acessórias de natureza financeira e tributária para permitir, além da qualidade documental, adequada fiscalização das pessoas competentes, inclusive sob pena de perda da qualificação. Além disso, como ferramenta de controle social a entidade deve publicar anualmente seu relatório de

${ }^{478}$ Cf. Lei n. 91/35 e Decreto n. 50.517/61 (Título de Utilidade Pública Federal); Lei n. 8.742/93 e Decreto n. 2.536/98 (Certificado de Entidade Beneficente de Assistência Social). 
atividades e suas demonstrações financeiras, inclusive as certidões negativas ${ }^{479}$. Outras ferramentas de controle externo criadas pelo dispositivo dizem respeito à realização de auditoria (alínea “c") e à sujeição ao Tribunal de Contas (alínea “d”), cujo conteúdo e extensão são extraídos do Decreto n. 3.100/99.

Assim, estando as atividades formalmente e materialmente aptas a ensejar a qualificação da entidade como Oscip, esta estará habilitada a firmar termo de parceria com o Poder Público para a mútua colaboração na execução de tais atividades. Este termo de parceria, firmado de comum acordo entre o Poder Público e as OSCIPs, discriminará direitos, responsabilidades e obrigações (Lei n. 9.790/99, artigo 10), devendo conter obrigatoriamente as seguintes cláusulas (Lei n. 9.790/99, artigo 10, § $2^{\circ}$ ):

I - a do objeto, que conterá a especificação do programa de trabalho proposto pela Organização da Sociedade Civil de Interesse Público: o objeto, envolvendo a execução direta ou indireta de uma das atividades permitidas pelo artigo $3^{\circ}$, deverá estar especificado em programa de trabalho;

II - a de estipulação das metas e dos resultados a serem atingidos e os respectivos prazos de execução ou cronograma: o programa de trabalho deverá ter pertinência com metas e resultados a serem atingidos, bem como com o cronograma de execução, que auxiliarão no controle de resultados a que está submetido o termo de parceria;

III - a de previsão expressa dos critérios objetivos de avaliação de desempenho a serem utilizados, mediante indicadores de resultado: devem ser definidos os critérios de avaliação que permitirão avaliar se as metas e resultados foram atingidos, comparando-os com os indicadores apontados contratualmente;

IV - a de previsão de receitas e despesas a serem realizadas em seu cumprimento, estipulando item por item as categorias contábeis usadas pela organização e o detalhamento das remunerações e beneficios de pessoal a serem pagos, com recursos oriundos ou vinculados ao Termo de Parceria, a seus diretores, empregados e consultores:

\footnotetext{
${ }^{479}$ A propósito do controle social, vide os artigos $7^{\circ}$ e $8^{\circ}$, da Lei n. 9.790/99 e o artigo $4^{\circ}$, do Decreto $n$. 3.100/99: "Art. $7^{0}$ Perde-se a qualificação de Organização da Sociedade Civil de Interesse Público, a pedido ou mediante decisão proferida em processo administrativo ou judicial, de iniciativa popular ou do Ministério Público, no qual serão assegurados, ampla defesa e o devido contraditório. Art. $8^{\circ}$ Vedado o anonimato, e desde que amparado por fundadas evidências de erro ou fraude, qualquer cidadão, respeitadas as prerrogativas do Ministério Público, é parte legítima para requerer, judicial ou administrativamente, a perda da qualificação instituída por esta Lei"; "Art. $4^{\circ}$ Qualquer cidadão, vedado o anonimato e respeitadas as prerrogativas do Ministério Público, desde que amparado por evidências de erro ou fraude, é parte legítima para requerer, judicial ou administrativamente, a perda da qualificação como Organização da Sociedade Civil de Interesse Público. Parágrafo único. A perda da qualificação dar-se-á mediante decisão proferida em processo administrativo, instaurado no Ministério da Justiça, de ofício ou a pedido do interessado, ou judicial, de iniciativa popular ou do Ministério Público, nos quais serão assegurados a ampla defesa e o contraditório".
} 
especificação das receitas e despesas vinculadas ao objeto do Termo de Parceria, com o objetivo de fazer o controle da correta aplicação dos recursos envolvidos em comparação com os critérios de avaliação de desempenho;

$V$ - a que estabelece as obrigações da Sociedade Civil de Interesse Público, entre as quais a de apresentar ao Poder Público, ao término de cada exercício, relatório sobre a execução do objeto do Termo de Parceria, contendo comparativo específico das metas propostas com os resultados alcançados, acompanhado de prestação de contas dos gastos e receitas efetivamente realizados, independente das previsões mencionadas no inciso $I V$ : a obrigação de apresentação anual do relatório de cumprimento de metas pelo parceiro privado, além de relatório financeiro;

VI - a de publicação, na imprensa oficial do Município, do Estado ou da União, conforme o alcance das atividades celebradas entre o órgão parceiro e a Organização da Sociedade Civil de Interesse Público, de extrato do Termo de Parceria e de demonstrativo da sua execução física e financeira, conforme modelo simplificado estabelecido no regulamento desta Lei, contendo os dados principais da documentação obrigatória do inciso $V$, sob pena de não liberação dos recursos previstos no Termo de Parceria: a obrigatoriedade de publicação de extrato do termo de parceria na imprensa oficial antes da liberação dos recursos.

Destes dispositivos chama a atenção, além das novas previsões relativas às ferramentas de controle externo, a ênfase ao controle de resultados dada pela legislação no cumprimento dos termos de parceria, confirmada pela previsão do artigo 11 da mesma lei:

Art. 11. A execução do objeto do Termo de Parceria será acompanhada e fiscalizada por órgão do Poder Público da área de atuação correspondente à atividade fomentada, e pelos Conselhos de Políticas Públicas das áreas correspondentes de atuação existentes, em cada nível de governo.

$\S 1^{\circ}$ Os resultados atingidos com a execução do Termo de Parceria devem ser analisados por comissão de avaliação, composta de comum acordo entre o órgão parceiro e a Organização da Sociedade Civil de Interesse Público.

$\S 2^{\underline{o}} \mathrm{~A}$ comissão encaminhará à autoridade competente relatório conclusivo sobre a avaliação procedida.

O Decreto n. 3.100/99 (artigo 12) especifica o conteúdo da prestação de contas exigida no artigo $10, \S 2^{\circ}, \mathrm{V}$, da Lei n. 9.790/99, esclarecendo o evidente intuito de controle de resultados contido na norma:

Art. 12. Para efeito do disposto no $\S 2^{\circ}$, inciso V, do art. 10 da Lei $\mathrm{n}^{0} 9.790$, de 1999, entende-se por prestação de contas relativa à execução do Termo de Parceria a 
comprovação, perante o órgão estatal parceiro, da correta aplicação dos recursos públicos recebidos e do adimplemento do objeto do Termo de Parceria, mediante a apresentação dos seguintes documentos: I - relatório sobre a execução do objeto do Termo de Parceria, contendo comparativo entre as metas propostas e os resultados alcançados; II demonstrativo integral da receita e despesa realizadas na execução; III - parecer e relatório de auditoria, nos casos previstos no art. 20; e IV - entrega do extrato da execução física e financeira estabelecido no art. 19.

Ponto que envolve alguma polêmica na legislação dos termos de parceria diz respeito à sua submissão ou não às normas de licitação previstas na Lei n. 8.666/93. Questiona-se se a Administração Pública está sujeita ao procedimento licitatório para a escolha da entidade parceira a fim de firmar termo de parceria nos termos da Lei $\mathrm{n}$. 9.790/99 e seu Decreto regulamentar n. 3.100/99.

Há quem entenda que a assinatura de termo de parceria deve ser precedida de licitação. Neste sentido é a lição de Marçal Justen Filho, para quem

é obrigatória a adoção de procedimento licitatório para realização tanto do contrato de gestão como do termo de parceria. Não é facultado à Administração escolher, sem prévio procedimento licitatório, uma determinada organização da sociedade civil para realizar um "termo de parceria" e, a partir daí, atribuir-lhe recursos para contratações as mais diversas não subordinadas a licitação. Isso seria a porta aberta para a fraude e a destruição da regra constitucional da obrigatoriedade da licitação. ${ }^{480}$

Também é o entendimento de José Anacleto Abduch Santos, que afirma que "quanto à escolha das entidades do Terceiro Setor pela Administração Pública, para com elas firmar contrato de gestão ou termo de parceria, deve prevalecer a regra geral prevista na Constituição que obriga licitar, salvo hipótese de dispensa ou inexigibilidade" ${ }^{„ 481}$. Ainda neste sentido se manifesta Tarso Cabral Violin, defendendo que "a Administração Pública deverá realizar licitação que assegure o atendimento dos princípios da igualdade, moralidade, economicidade, publicidade, dentre outros, para a escolha da entidade celebrante do termo de parceria" 482 .

Entendemos, no entanto, em sentido diverso. Inicialmente, voltamos à carga com o quanto dito em relação à natureza jurídica dos termos de parceria: são novas formas de

\footnotetext{
480 JUSTEN FILHO, Marçal. Comentários à lei de licitações e contratos administrativos. $14^{\mathrm{a}}$ ed. São Paulo : Dialética, 2010, pp. 40-41.

${ }^{481}$ SANTOS, José Anacleto Abduch. Licitação e terceiro setor. In: OLIVEIRA, Gustavo Justino de (coord.). Terceiro setor, empresas e Estado: novas fronteiras entre o público e o privado. Belo Horizonte : Fórum, 2007, p. 300.

${ }^{482}$ VIOLIN, Tarso Cabral. Terceiro setor e as parcerias com a Administração Pública: uma análise crítica. Belo Horizonte : Fórum, 2006, p. 270.
} 
colaboração entre o Poder Público e o Terceiro Setor, não se sujeitando às regras relativas aos contratos administrativos e aos convênios.

Como já visto, a Constituição Federal de 1988, em seu artigo 37, XXI, estabelece a exigência de processo de licitação pública para as contratações feitas pela Administração Pública, tendo ficado a cargo ficou a cargo da Lei n. 8.666/93 a sua regulamentação.

A exemplo do quanto argumentamos em relação aos convênios, a relação entabulada através dos termos de parceria não admite a extensão das normas licitatórias a este novo arranjo colaborativo. $\mathrm{O}$ fato de o Poder Público e a entidade almejarem o mesmo objetivo através da assinatura de termo de parceria afasta a fundamentação de exigência da licitação, pois o que se busca não é a contratação de serviços para solucionar interesse da Administração. Busca-se, através de acordo de colaboração, a união de esforços para o desempenho de ação de interesse público, mútuo entre as partes.

Nos termos do que foi acima delineado, os Termos de Parceria celebrados entre o Poder Público e a OSCIP consistem em acordos colaborativos que viabilizam a concertação administrativa. Nesse sentido, entende-se, portanto, lícito sustentar que tal mecanismo constitui um novo modelo de gestão de serviços públicos. Optando, pois, o Poder Público pela parceria com a iniciativa privada para a promoção do desenvolvimento nacional, resta claro que o parceiro privado estará em uma posição distinta das situações ocupadas pelo particular enquanto mero fornecedor de bens e serviços, ou mesmo delegatário para a execução de serviços públicos nos termos e na forma em que a Administração determinar. Além disso, o objeto do Termo de Parceria refere-se necessariamente a uma das finalidades constantes do já mencionado art. $3^{\circ}$ da Lei das OSCIPs, cujo rol exemplifica uma série de serviços públicos sociais e promoção dos direitos fundamentais. A atuação das OSCIPs, portanto, dirige-se diretamente ao atendimento do interesse público e não ao atendimento de uma necessidade da Administração Pública. Assim, o Termo de Parceria configura nova forma jurídica de ajuste, a qual formaliza parcerias entre o setor público e o Terceiro Setor, visando promover o desenvolvimento dos indivíduos, da sociedade e do País. Nesse sentido, fica evidente a inaplicabilidade da Lei de Licitações para a celebração de Termo de Parceria. Afinal, não se trata de contratação administrativa, mas de uma nova modalidade de acordo administrativo, cujo objetivo consiste em fomentar a prestação de serviços públicos sociais e a promoção de direitos fundamentais por entidades privadas não lucrativas qualificadas como OSCIP. ${ }^{483}$

Além disso, a Lei n. 9.790/99 não faz menção à sujeição da escolha do parceiro privado por meio de licitação pública; pelo contrário, a legislação define método de seleção próprio para este fím denominado concurso de projetos. É o que dispõe o artigo 23 , do Decreto n. 3.100/99:

483 OLIVEIRA, Gustavo Justino de; MÂNICA, Fernando Borges. Organizações da Sociedade Civil de Interesse Público: termo de parceria e licitação. Boletim de Direito Administrativo, São Paulo : NDJ, ano XXI, n. 9, set. 2005, pp. 1021-1022. 
Art. 23. A escolha da Organização da Sociedade Civil de Interesse Público, para a celebração do Termo de Parceria, poderá ser feita por meio de publicação de edital de concursos de projetos pelo órgão estatal parceiro para obtenção de bens e serviços e para a realização de atividades, eventos, consultorias, cooperação técnica e assessoria.

Parágrafo único. Instaurado o processo de seleção por concurso, é vedado ao Poder Público celebrar Termo de Parceria para o mesmo objeto, fora do concurso iniciado.

O concurso de projetos de que trata o Decreto é regulamento por ele próprio, que estabelece requisitos a serem observados para esta seleção em quatro fases que podem ser assim especificadas: i) convocação dos interessados; ii) apresentação do projeto; iii) seleção do projeto; iv) assinatura do Termo de Parceria.

A convocação deverá ser feita por edital (artigo 25) em que constem todas as informações objetivas e detalhadas sobre o objeto do termo de parceria (artigo 24 e 25, II), bem como informações formais sobre o concurso, como prazo, local, condições e forma da apresentação das propostas (artigo 25, I, IV e V), critérios para seleção da proposta vencedora (artigo 25, III), data do julgamento e da provável celebração do termo de parceria (artigo 25, VI) e o valor máximo a ser desembolsado (artigo 25, VII).

A apresentação do projeto pela potencial entidade parceira ao órgão estatal parceiro responsável pela seleção, nos termos e prazo definidos no edital conforme os artigos 24 e 25 , deverá ser feita de forma a detalhar o seu conteúdo técnico e os custos de implementação (artigo 26).

A fase de seleção do projeto, o órgão público parceiro deve observância a critérios legais pré-estabelecidos no artigo 27. Deverá em primeiro lugar analisar se o projeto apresentado se adequa ao edital, ou seja, se a entidade proponente logrou alcançar o mérito pretendido pelo órgão público ao abrir a seleção (artigo 27, I). Além disso, deverá se certificar da capacidade técnica e operacional da entidade proponente (artigo 27, II) e se a mesma está juridicamente e financeiramente regular (artigo $27, \mathrm{~V}$ e $\mathrm{VI}^{484}$ ), evitando assim a assinatura de termo de parceria com entidade desqualificada para o desenvolvimento das atividades envolvidas no projeto, ou ainda cujas demonstrações financeiras demonstrem má administração. Será levado em conta também se a proposta apresentada se ajusta às especificações técnicas apresentadas no edital (artigo 27, IV). Não só tecnicamente, mas

\footnotetext{
${ }^{484}$ Este dispositivo faz menção à análise, no momento da seleção das propostas, dos documentos exigidos no artigo $11, \S 2^{\circ}$, que dispõe: " $\S 2^{\circ}$ A prestação de contas será instruída com os seguintes documentos: I relatório anual de execução de atividades; II - demonstração de resultados do exercício; III - balanço patrimonial; IV - demonstração das origens e aplicações de recursos; V - demonstração das mutações do patrimônio social; VI - notas explicativas das demonstrações contábeis, caso necessário; e VII - parecer e relatório de auditoria nos termos do art. 19 deste Decreto, se for o caso".
} 
também a forma de alcançar o resultado, os custos, o cronograma e quais os resultados pretendidos serão avaliados na seleção do melhor projeto (artigo $27, \mathrm{III}){ }^{485}$

Avaliados os projetos apresentados com base nestes critérios, que deverão constar do edital (artigo 29) ${ }^{486}$, uma comissão julgadora não remunerada (artigo 30, $\S 1^{\circ}$ ) designada pelo órgão estatal parceiro e composta no mínimo "por um membro do Poder Executivo, um especialista no tema do concurso e um membro do Conselho de Política Pública da área de competência" (artigo 30, caput), apresentará o resultado dos trabalhos indicando os aprovados e o habilitado a firmar o termo de parceria (artigo 31). ${ }^{487}$

Este, e nenhum outro, é o procedimento previsto na legislação para a seleção do parceiro privado apto à assinatura de termo de parceria com o Poder Público, com a ressalva, aliás, de este procedimento é opcional ao órgão público parceiro. Como visto, o artigo 23, do Decreto n. 3.100/99, prevê que a escolha da Oscip pelo parceiro público poderá ser feita por meio de concurso de projetos, o que implica concluir que ficará a cargo do órgão público a definição quanto à aplicação ou não do procedimento de concurso de projetos.

Nos termos da lei, portanto, entendendo o órgão público parceiro que não é o caso de realização de concurso de projetos, poderá levar a efeito a assinatura do termo de parceria com entidade qualificada como Oscip diretamente, claro que observadas as demais exigências legais para tanto (artigos $9^{\circ}$ a 15, da Lei n. 9.790/99, e artigos $9^{\circ}$ a 22, do Decreto n. 3.100/99). Embora esta seja a realidade legislativa, não podemos deixar de criticar a assinatura de termo de parceria, cujo objeto é o estabelecimento de vínculo de cooperação entre parceiros público e privado para a realização de atividade de interesse público mútuo, sem a elaboração de um concurso de projetos. Não se está, aqui, defendendo a aplicação da Lei de Licitações; pelo contrário, entende-se pela sua

485 O artigo 28 do Decreto traz importante balizamento para a etapa de seleção dos projetos: “Art. 28. Obedecidos aos princípios da administração pública, são inaceitáveis como critério de seleção, de desqualificação ou pontuação: I - o local do domicílio da Organização da Sociedade Civil de Interesse Público ou a exigência de experiência de trabalho da organização no local de domicílio do órgão parceiro estatal; II - a obrigatoriedade de consórcio ou associação com entidades sediadas na localidade onde deverá ser celebrado o Termo de Parceria; III - o volume de contrapartida ou qualquer outro benefício oferecido pela Organização da Sociedade Civil de Interesse Público".

486 "Art. 29. O julgamento será realizado sobre o conjunto das propostas das Organizações da Sociedade Civil de Interesse Público, não sendo aceitos como critérios de julgamento os aspectos jurídicos, administrativos, técnicos ou operacionais não estipulados no edital do concurso".

487 “Art. 31. Após o julgamento definitivo das propostas, a comissão apresentará, na presença dos concorrentes, os resultados de seu trabalho, indicando os aprovados. $\S 1^{\circ} \mathrm{O}$ órgão estatal parceiro: I - não examinará recursos administrativos contra as decisões da comissão julgadora; II - não poderá anular ou suspender administrativamente o resultado do concurso nem celebrar outros Termos de Parceria, com o mesmo objeto, sem antes finalizar o processo iniciado pelo concurso. $\S 2^{\circ}$ Após o anúncio público do resultado do concurso, o órgão estatal parceiro o homologará, sendo imediata a celebração dos Termos de Parceria pela ordem de classificação dos aprovados". 
inaplicabilidade inclusive conceitual aos termos de parceria. Mas a elaboração de análise comparativa entre várias possibilidades de execução de determinada atividade para se alcançar tais e quais finalidades é medida que se deveria impor, mormente em se tratando de vínculos que envolvem repasse de verbas públicas. ${ }^{488}$

Outra polêmica existente no ambiente dos termos de parceria diz respeito à necessidade ou não de as entidades parcerias privadas fazerem aplicar a Lei de Licitações para as aquisições de bens e serviços feitas com verbas públicas repassadas pelo parceiro público no âmbito de termo de parceria. Mais uma vez lembrando que entendemos o termo de parceria como nova forma de arranjo institucional entre a Administração Pública e entidades privadas, diversa dos contratos administrativos e dos convênios, vale frisar que a legislação específica dos termos de parceria não faz esta exigência.

Diferente da antes analisada legislação dos convênios (IN STN n. 01/1997, artigo 27, e Decreto n. 5.504/2005, artigo $1^{\circ}$ ), que exige que a entidade privada convenente que receba verbas públicas realize licitação pública, de preferência o pregão eletrônico, a legislação regente dos termos de parceria não prevê esta necessidade. Pelo contrário, o artigo 14, da Lei n. 9.790/99, é claro ao estabelecer que competirá à entidade privada parceira a edição de "regulamento próprio contendo os procedimentos que adotará para a contratação de obras e serviços, bem como para compras", devendo observância aos princípios da legalidade, impessoalidade, moralidade, publicidade, economicidade e da eficiência (artigo $\left.4^{\circ}, \mathrm{I}\right)$.

Isto não impede, é claro, que a entidade parceira se utilize do procedimento do pregão eletrônico ou mesmo dos procedimentos licitatórios, embora, em especial quanto à licitação, no mais das vezes seja impossível a aplicação de suas exigências procedimentais, o que gera regulamentos de compras bastante mais simplificados. Ou mesmo, nada impede que o edital de concurso de projetos exija a aplicação do procedimento licitatório, embora não seja obrigado. O fato é que basta, para os fins da legislação regente dos termos de parceria, que a entidade privada esteja adstrita a regulamento próprio que definirá os critérios de seleção para o gasto das verbas públicas que receberá do parceiro público.

Ocorre que o antes citado Decreto n. 5.504/2005, que rege os convênios e exige o pregão eletrônico para as compras feitas pelas entidades privadas convenentes com dinheiro público, faz expressa menção da sua aplicação às Oscips em seu artigo $1^{\circ}, \S 5^{\circ}$ :

\footnotetext{
488 Sobre esta polêmica na realidade italiana, cf. GAGLIARDUCCI, Francesca et al. Pubblica amministrazione, acquisti etici e terzo settore. In: CITTADINO, Caterina (org.). Dove lo Stato non arriva: pubblica amministrazione e terzo settore. Firenze : Passigli, 2008, pp. 199-270.
} 
$\S 5^{\circ}$ Aplica-se o disposto neste artigo às entidades qualificadas como Organizações Sociais, na forma da Lei ${ }^{\circ}$ 9.637, de 15 de maio de 1998, e às entidades qualificadas como Organizações da Sociedade Civil de Interesse Público, na forma da Lei ${ }^{\circ}$ 9.790, de 23 de março de 1999, relativamente aos recursos por elas administrados oriundos de repasses da União, em face dos respectivos contratos de gestão ou termos de parceria.

Este Decreto gera inúmeras críticas doutrinárias, inclusive propondo a sua inconstitucionalidade, a exemplo do entendimento de Gustavo Justino de Oliveira no sentido de que

o Decreto n. 5.504/05 afronta o inc. XXVII do art. 22 e o inc. XXI do art. 37, ambos da Constituição da República. Os dois preceitos constitucionais são de clareza solar quando estipulam como destinatários da obrigatoriedade de licitar os órgãos e entidades da Administração Pública direta e indireta. ${ }^{489}$

Realmente, pelo fato de as entidades qualificadas como Oscip e os termos de parceria possíveis de serem por ela firmados com entes públicos estarem sujeitos a regime jurídico especial, notadamente no que tange à utilização dos recursos públicos a elas destinados constante do artigo 14, da Lei n. 9.790/99, a previsão do Decreto que exige a utilização do procedimento licitatório para estas compras deve ser considerada ilegal. "As disposições do Decreto n. 5.504/05 colidem com a disciplina especial das OSCIPs, notadamente com o que estabelece o art. 14 da Lei federal n. 9.790/99". 490

Como dissemos no tópico dos convênios, no entanto, podemos considerar que o artigo 11, do Decreto n. 6.170/2007, revogou o artigo $1^{\circ}$, $\S 5^{\circ}$, do Decreto n. 5.504/05, no que tange à exigência de pregão para as aquisições feitas com verbas públicas repassadas às Oscips. É suficiente, portanto, a realização de cotação prévia de preços no mercado, que deverá ser objeto de regulamento específico da entidade.

Tem-se, assim, em largas passadas o regime jurídico aplicável às parcerias entre a Administração Pública e o Terceiro Setor através desta nova modalidade de arranjo colaborativo instituída pela Lei n. 9.790/99 e regulamentada pela Lei n. 3.100/99.

489 OLIVEIRA, Gustavo Justino de. OSCIPS e licitação: ilegalidade do Decreto n. 5.504, de 05.08.05. Revista Eletrônica sobre a Reforma do Estado - RERE, Salvaldor : IBDP, n. 12, dez.-jan.-fev. 2008, p. 36. Disponível na Internet: <http://www.direitodoestado.com/revista/RERE-12-DEZEMBRO-2007GUSTAVO\%20JUSTINO.pdf $>$. Acesso em: 20 abr. 2010. O autor vai além entendendo que "ao exigir a realização de processo licitatório, mesmo que a via eleita fosse a lei, e não o inválido decreto, haveria uma flagrante ofensa ao inc. XVIII do art. $5^{\circ}$ da Constituição da República, o qual veda toda sorte de interferência estatal no funcionamento das associações" (ibidem, p. 36).

${ }^{490}$ Ibidem, p. 36. 


\section{CAPÍtUlO 5. PARCERIAS ENTRE A ADMINISTRAÇÃO PÚBLICA E O TERCEIRO SETOR: EM DIREÇÃO A UMA PROPOSTA}

Tendo sido fixadas as premissas iniciais de trabalho, tanto em relação aos motivos que determinam o atual reposicionamento do Direito Administrativo e de suas ferramentas clássicas quanto em relação ao fortalecimento do Terceiro Setor como partícipe no desenvolvimento de ações voltadas aos direitos fundamentais e ao conteúdo constitucional, resta fazer a conexão entre as premissas e a apresentação de proposta legislativa concernente às relações de parceria entre a Administração Pública o Terceiro Setor.

Esta conexão entre as premissas pode ser sugerida em função de duas constatações distintas possíveis de serem feitas do quanto foi analisado até o presente momento e que serão objeto de aprofundamento neste tópico, quais sejam: i) a necessidade de adaptação dos institutos do Direito Administrativo ao novo momento da Administração Pública, que propõe o consensualismo e a formação de redes para o desempenho da ação pública e o alcance dos seus objetivos sociais, legitimando a formação de acordos colaborativos com o Terceiro Setor; e ii) a obsolescência do atual modelo regulatório de parcerias entre a Administração Pública e o Terceiro Setor. Passa-se, assim, à análise destes tópicos.

\subsection{Do reposicionamento das relações entre Administração Pública e Terceiro Setor}

Como visto no Capítulo 2, diversos fatores têm fomentado debates em torno de um reposicionamento do papel do Estado, em especial em suas relações com a sociedade civil, de modo a encontrar modelo substitutivo ao então vigente. A emergência de novos conceitos ou mesmo a remodelação de conceitos nem tão novos assim têm exigido um repensar na atuação estatal sobretudo de modo a propiciar a atuação da própria sociedade civil em temas de seu interesse.

Demonstramos em passagens anteriores que em outros países esta idéia de participação da sociedade civil é alçada a tema constitucional, posicionando o cidadão como protagonista no desenvolvimento de determinadas ações de interesse geral. Estamos falando novamente da Constituição italiana de 1947, que recebeu alteração em 2001 para, com base no princípio da subsidiariedade, outorgar ao cidadão a primazia de atuação naquelas ações em que logre solucionar as suas necessidades. Inclua-se, neste conceito, a 
atuação associada de cidadãos, bem como não se afaste a possibilidade de parcerias entre a sociedade civil e a Administração Pública no intento de alcançar estes fins almejados. ${ }^{491}$

Valem, neste momento, duas ressalvas: i) esta outorga de primazia da sociedade civil a temas de interesse geral, sem os devidos cuidados, não está livre de críticas; e ii) o ordenamento jurídico brasileiro não acolhe o princípio da subsidiariedade nestes termos ${ }^{492}$.

A primeira ressalva é confirmada pelas críticas de Paolo Michiara, ao dispor que

ao público deveria remanescer, além da faculdade reguladora, a possibilidade (o dever em alguns casos) de intervir diretamente para assegurar os direitos sociais essenciais dos cidadãos, removendo assim do privado social a preocupação de ter que desenvolver, às vezes certamente sem adequada remuneração, obrigações de mera substituição. Argumentando de outra forma, se institucionalizaria a cooperação social, com perda de eficiência e de liberdade para a própria cooperação e para todo o sistema de serviços à pessoa. ${ }^{493}$

A segunda ressalva é extraída do nosso próprio ordenamento jurídico, que não mais prevê este princípio expressamente, embora o princípio seja inspirador de nossas reformas administrativas ${ }^{494}$ e um dos responsáveis pela “ampliação das atividades administrativa de

${ }^{491}$ Cf. MICHIARA, Paolo. Le convenzioni tra pubblica amministrazione e terzo settore: considerazioni sulle procedure selettive a concorrenza limitata nell'ambito dei rapporti a collaborazione necessária. Roma : Istituto Editoriale Regioni Italiane S.R.L., 2005; FICI, Antonio. I contratti tra pubblica amministrazione ed enti non profit nel settore dei servizi alla persona. In: CAFAGGI, Fabrizio (org.). Modelli di governo, riforma dello stato sociale e ruolo del terzo settore. Bologna : Il Mulino, 2002, pp. 137-178; DALLA MURA, Franco. Pubblica amministrazione e non profit: guida ai rapporti innovativi nel quadro della legge 328/2000. Roma : Carocci Faber, 2003.

${ }^{492}$ Conclusão também apresentada em aula proferida por Gustavo Justino de Oliveira na disciplina "Parcerias do Estado com o Terceiro Setor", no Programa de Pós-graduação Stricto Senso em Direito, da Universidade de São Paulo, no primeiro semestre de 2009.

493 MICHIARA, Paolo. Op. cit., p. 405, tradução nossa. No original: “Al pubblico dovrebbe insomma rimanere, oltre allá facoltà regolatrice, anche la possibilita (il dovere in alcuni casi) di intervenire direttamente per assicurare i diritti sociali essenziali dei cittadini, togliendo in questo modo al privato sociale l'assillo di dover svolgere, a volte addirittura senza adeguata remunerazione, compiti di mera supplenza. Diversamente argomentando si istituzionalizzerebbe la cooperazione sociale, con perdita di efficienza e di libertà per la cooperazione stessa e per l'intero sistema dei servizi alla persona”. O autor confirma esta preocupação em nota de rodapé, afirmando que "deve ser considerado, aliás, que não seja (provavelmente) conforme a constituição uma total transferência dos serviços à pessoa. Em alguns setores, diretamente ou indiretamente, se assiste no entanto a um total 'abandono' por parte do público (diferentemente do que ocorre em outros campos como, por exemplo, a saúde)" (Ibidem, p. 405, n.r. 10, tradução nossa). No original: "Bisogna ritenere del resto che non sia (probabilmente) conforme a costituzione una totale esternalizzazione dei servizi alla persona. In alcuni settori, direttamente o indirettamente, si assiste invece ad un totale 'abbandono' da parte del pubblico (diversamente da quello che avviene in altri campi quale ad esempio la sanità)". Ainda sobre o tema, importante a contribuição de Gregorio Arena sobre a relevância da atuação do Poder Público nos temas de interesse geral, considerando o princípio da subsidiariedade: "O papel dos sujeitos públicos em garantir os direitos civis e sociais reconhecidos pela Constituição remanesce essencial" (ARENA, Gregorio. Cittadini attivi: un altro modo di pensare all'Italia. Roma-Bari : Laterza, 2006, p. VIII, tradução nossa).

494 “O princípio da subsidiariedade, embora bem anterior à nova concepção do Estado de Direito Democrático, assume agora importância fundamental na definição do papel do Estado (DI PIETRO, Maria Sylvia Zanella. Parcerias na Administração Pública: concessão, permissão, franquia, terceirização, parceria público-privada e outras formas. $5^{\text {a }}$ ed. São Paulo : Atlas, 2006, p. 33, destaque no original). 
fomento" "495 e pelo crescimento "dos inúmeros instrumentos de parceria do setor público com o privado" $" 496$.

Ambas as ressalvas servem para demonstrar que, de uma forma ou de outra, a inspiração da idéia de subsidiariedade auxilia na compreensão quanto à necessidade de se repensar a atuação estatal. Fortalecendo a importância da função estatal de fomento à iniciativa privada pelo reconhecimento de seu relevante papel desempenhado à sociedade, abre-se espaço de debate e amadurecimento dos conceitos de atuação concertada da Administração Pública com a sociedade civil, mediante parcerias.

No Brasil, revitalizam-se dispositivos constitucionais que propõem a coparticipação entre o Estado e a sociedade civil nos setores afetos aos direitos fundamentais, especialmente aqueles incluídos no capítulo da Ordem Social: artigos 197 e 198, IIII (saúde); artigo 204, I (assistência social); artigos 205, 206, IV, 209, 213 e 227 (educação); artigo 216, $\S 1^{\circ}$ (cultura); artigo 225 (meio ambiente); entre outros. Embora não fundamentado expressamente no princípio da subsidiariedade, o ordenamento constitucional brasileiro adota formatação que atribui titularidade concorrente ao Estado e à sociedade civil em determinadas matérias de interesse público. Extrai-se desta realidade ser imperativo constitucional a ação conjunta do Estado e da sociedade civil nestas matérias; o Estado, que continua como responsável principal no suprimento destas necessidades sociais, não pode monopolizar a ação pública tampouco se ausentar da atuação direta.

Defende-se, não somente no campo social mas como realidade própria de todas as relações entre o Estado e o cidadão, a superação do paradigma bipolar ${ }^{497}$ no qual o Estado é posto em posição de superioridade perante os outros sujeitos e esta relação se funda na contraposição Estado-cidadão. A superação deste paradigma bipolar se desenvolve em torno de um "espaço no qual se desenvolve a atividade pública e o intercâmbio Estadosociedade", denominado de arena pública ${ }^{498}$, marcada entre outras coisas pelo fim do bipolarismo. $^{499}$

\footnotetext{
${ }^{495}$ Ibidem, p. 37, destaque no original.

496 Ibidem, p. 38, destaque no original).

${ }^{497}$ Cf. CASSESE, Sabino. L'arena pubblica: nuovi paradigmi per lo Stato. Rivista trimestrale di diritto pubblico, Roma : Giuffrè, n. 3, 2001, pp. 601-650.

498 "Al nuovo paradigma (o, forse, meglio, ai nuovi paradigmi) si à assegnato uma denominazione provvisoria, quella di 'arena pubblica'. Questa espressione è adoperata in un significato genérico dalla scienza política anglosassone, per la quale essa è lo spazio nel quale si svolge l'attività pubblica e l'intercambio Stato-società" (ibidem, p. 607).

499 "Em conclusão, Estado e mercado, público e privado, onde eram considerados mundos separados e em oposição, se apresentam como entidades interpenetrantes" (ibidem, p. 649, tradução nossa).
} 
No momento próprio em que, graças à subsidiariedade, se reconhece que os cidadãos podem assumir autonomamente o papel de sujeitos ativos na persecução do interesse geral, encerra-se uma das razões principais da posição de superioridade atribuída à Administração Pública nos confrontos dos cidadãos entendidos como administrados. ${ }^{500}$

Torna-se possível, assim, a assunção de um novo paradigma baseado no pluralismo social que reconhece a função paritária da Administração Pública e da sociedade na resposta a determinadas demandas sociais, assumindo-se, via de conseqüência, a inexistência de monopólio estatal sobre as questões sociais. ${ }^{501}$

É claro que esta nova realidade de participação social pode se expressar de diversas formas, como a atuação voluntária de determinado cidadão em uma causa social, ou através do desenvolvimento de atividade social por determinada empresa, ou pela atuação direta de entidade sem fins lucrativos na prestação de serviços sociais. Aliás, engloba não somente a etapa de execução das ações relacionadas a direitos fundamentais, mas a sua programação $^{502}$ e controle. De qualquer forma, para o que importa ao presente trabalho cumpre afirmar que uma das formas possíveis de realização deste novo paradigma plural ${ }^{503}$ contido na idéia de arena pública é a realização de parcerias entre a Administração Pública e a sociedade civil em áreas cujas titularidades sejam concorrentes.

\footnotetext{
${ }^{500}$ ARENA, Gregorio. Cittadini attivi: un altro modo di pensare all'Italia. Roma-Bari : Laterza, 2006, p. 6, tradução nossa. No original: "Nel momento stesso in cui, grazie alla sussidiarietà, si riconosce che i cittadini possono assumere autonomamente il ruolo di soggetti attivi nel persguimento dell'interesse generale, viene infatti meno uma delle ragioni principali della posizione di superiorità attribuita alla pubblica amministrazione nei confronti dei cittadini intesi come amministrati”.

${ }^{501}$ Esta constatação é feita por Gregorio Arena com fundamento no princípio da subsidiariedade incluído na Constituição italiana: "A Constituição reconhece de fato pela primeira vez, mesmo que implicitamente, que as administrações não têm mais o 'monopólio' da tutela do interesse público" (ibidem, p. IX, tradução nossa). No original: "La Costituzione riconosce infatti per la prima volta, sia pure implicitamente, che le amministrazioni non hanno più il 'monopolio' della tutela dell'interesse pubblico".

502 "Qual deve ser o modelo de representação do Terceiro setor? Certamente não aquele da representação política e ainda menos a sindical. Mais do que isso, o modelo que reputo mais consoante às especificidades próprias dos sujeitos do Terceiro setor é aquele deliberativo, segundo o qual o modo pelo qual as várias expressões do Terceiro setor se inserem na decisão coletiva é o mesmo o da deliberação, vale dizer 'do processo dialógico no qual se trocam argumentações, com a finalidade de resolução de situações problemáticas que não seriam resolvíveis sem a coordenação interpessoal e a cooperação" (ZAMAGNI, Stefano. Introduzione. In: CITTADINO, Caterina (org.). Dove lo Stato non arriva: pubblica amministrazione e terzo settore. Firenze : Passigli, 2008, p. 11, tradução nossa). No original: "Quale ha da essere il modello di rappresentanza del Terzo settore? Certamente non quello della rappresentanza politica e ancor meno sindacale. Piuttosto, il modello che reputo più consono alle specificità proprie dei soggetti del Terzo settore è quello deliberativo, secondo cui il modo nel quale le varie espressioni del Terzo settore giungono alla decisione collettiva è qullo proprio della deliberazione, vale a dire 'del processo dialogico in cui ci si scambia argomentazioni, finalizzato alla risoluzione di situazioni problematiche che non sarebberto risolvibili senza il coordinamento interpersonale e la cooperazione"”. Cf. CITTADINO, Caterina et. al. La partecipazione alle attività di pianificazione e programmazione delle politiche di settore. In: CITTADINO, Caterina (org.). Dove lo Stato non arriva: pubblica amministrazione e terzo settore. Firenze : Passigli, 2008, pp. 155-198.

${ }_{503}$ Paradigma subsidiário, na expressão de Arena (ARENA, Gregorio. Op. cit., p. 6, tradução nossa).
} 
"Por último, se notou uma forma diferente de se estabelecerem as relações entre público e privado. Estas não são só bipolares. São também multipolares". ${ }^{504}$ Passa-se a entender o interesse público como tema afeto a uma multiplicidade de atores, não mais como monopólio estatal, exigindo a instituição de novos arranjos institucionais entre o Estado e a sociedade civil com vistas à efetivação deste interesse público. Estes novos arranjos pressupõem o reconhecimento, pelo setor público, da importância do setor privado nas respostas às demandas sociais, chamando-o a participar e a assumir tarefas públicas sob o influxo da vertente colaborativa.

Ao invés de o interesse público ser imposto de cima para baixo, como expressão da autoridade pública, passa a ser negociado entre os diversos atores envolvidos no seu cumprimento. A desmonopolização deste interesse público sob a inspiração das idéias de governança e consensualismo gera alterações substanciais na forma de relacionamento entre a Administração Pública e a sociedade civil. É um dos novos paradigmas do Estado apontado por Cassese, ao dispor que

onde tradicionalmente o modo de decidir era determinado pela forma seqüencial (o procedimento) e da ponderação (a discricionariedade da decisão), nos casos analisados as coisas são diferentes. Não é o procedimento que modula a negociação, mas a negociação que plasma o procedimento. A série ou seqüência se adapta à necessidade do acordo. A liberdade das formas própria do direito privado penetra no direito público. (...) Vêm em primeiro plano a negociação no lugar do procedimento, a liberdade das formas no lugar da tipicidade, a troca no lugar da ponderação. Daí derivam práticas jurídicas mais eficazes, mas também mais flexíveis, que não seriam aceitáveis se não valesse também para elas o postulado segundo o qual a decisão segundo o direito não é menos discricionária ou política que outras decisões públicas, exceto pelo fato de ser controlada por critérios ou princípio de segundo grau como a consulta recíproca, o consenso das partes, a motivação, etc. $^{505}$

Fortalece-se a idéia do consensualismo nas ações estatais, fruto da influência dos conceitos trazidos pela idéia de governança, apropriada do setor privado pelo setor público e que é marcada pela consulta, concertação, coordenação, parcerias, diálogo social,

\footnotetext{
${ }^{504}$ CASSESE, Sabino. Op. cit., p. 649, tradução nossa. No original: "Da ultimo, si è notato um diverso modo di stabilire le relazioni tra pubblico e privato. Queste non sono solo bipolari. Sono anche multipolari".

${ }^{505}$ Ibidem, pp. 647-648, tradução nossa. No original: "Ove tradizionalmente il modo di decidere era determinato nella forma sequenziale (il procedimento) e della ponderazione (la discrezionalità della deciosione), nei casi presi in esame le cose vanno diversamente. Non è il procedimento che modula il negoziato, ma il negoziato che plasma il procedimento. La serie o sequenza si adatta allá necessita dell'accordo. La liberta delle forme propria del diritto privato penetra nel diritto pubblico. (...) Vengono in primo piano il negoziato al posto del procedimento, la libertà delle forme in luogo della tipicità, lo scambio in luogo della ponderazione. Ne derivano pratiche giuridiche più efficaci, ma anche più molli, che non sarebbero accettabili se non valesse anche per esse il postulato per cui la decisione secondo il diritto non è meno discrezionale o política di altre deciosioni pubbliche, salvo che è controllata da criteri o principi di secondo grado quali la consultazione recíproca, il consenso delle parti, la motivazione, ecc.”.
} 
recomendação, programação, avaliação, operação em redes, todo instrumentos dotados de inequívoca flexibilidade. ${ }^{506}$

Este contexto de repensamento das ações do Estado aponta para o que se pode denominar de Estado contratual, na acepção criada por Gaspar Ariño Ortiz, para quem

Do ponto de vista organizativo e institucional isso significa a substituição do antigo modelo de Estado administrativo-burocrático, hierárquico, unitário, centralizado e gestor direto, por um novo tipo de Administração em que uma multiplicidade de organizações, governamentais, privadas e o que vem sendo denominado "terceiro setor" (públicoprivado), assumiriam a gestão de serviços com financiamento e controle do Estado. Isso não é uma invenção, é simplesmente a volta do antigo sistema da "concessão", do "concerto" ou da "empresa mista" como forma de realizar a gestão privada das atividades públicas. É também a volta do princípio da subsidiariedade, o qual recebe atualmente novas formulações. Assim, fala-se de uma das características mais importantes do Estado atual: sua condição de "Estado contratual", apontando a utilização pelo Estado de organizações privadas, com ou sem fins lucrativos, para alcançar os seus fins públicos. ${ }^{507}$

Nesta modelagem, o Estado deixa de ser o responsável único pela busca do bem comum, compartilhando responsabilidades e ações com a sociedade para esta finalidade através de arranjos consensuais como ferramentas multilaterais de promoção do interesse público. Compartilha-se a ação pública entre o Estado e a sociedade civil, através de ferramentas consensuais, sempre tendo por finalidade maior o alcance do bem comum que é objeto de ambos. ${ }^{508}$

506 Cf. QUERMONNE, Jean-Louis. Gouvernance et gouvernment: deux lectures d'une politique institutionnelle européenne. In: IHL, Olivier (coord.). Les "sciences" de l'action publique. Grenoble : Presses universitaires de Grenoble, 2006, p. 122.

${ }^{507}$ ARIÑO ORTIZ, Gaspar. El retorno a lo privado: ante uma nueva encrucijada histórica. In: (org.). Privatización y liberalización de servicios. Madrid : Universidad Autônoma de Madrid, 1999, p. 26, apud OLIVEIRA, Gustavo Justino. Parceria público-privada e direito ao desenvolvimento: uma abordagem necessária. Revista Eletrônica de Direito Administrativo Econômico - REDAE, Salvador : IDPB, n. 3, ago.-set.-out. 2005, p. 8. Disponível na Internet: <http://www.direitodoestado.com/revista/REDAE-3AGOSTO-2005-GUSTAVO\%20JUSTINO.pdf $>$. Acesso em: 22 abr. 2010. Cf. CAFAGGI, Fabrizio. Governare per contratto o per organizzazione? Alternative istituzionali nella riforma dello stato sociale. In: (org.). Modelli di governo, riforma dello stato sociale e ruolo del terzo settore. Bologna : Il Mulino, 2002, pp. 75-135; GAUDIN, Jean-Pierre. Gouverner par contrat. Paris : Presses de Sciences PO, 1999.

508 "Ao que parece, o fim do Estado contemporâneo é o de constituir-se em canal e instrumento indispensável para a promoção do desenvolvimento dos indivíduos e da própria sociedade. Eis uma leitura atualizada da consagrada expressão bem comum, entendida pela doutrina clássica como a finalidade a ser perseguida pelo Estado. Assim, afloram novos modelos consensuais e novas formas contratuais, especificamente formatados para serem utilizados pelo Estado para promover o desenvolvimento. Essa nova dinâmica contratual no setor público possui bases distintas da tradicional modelagem do contrato administrativo, evidenciando linhas de transformação do contratualismo administrativo clássico" (OLIVEIRA, Gustavo Justino. Parceria público-privada e direito ao desenvolvimento: uma abordagem necessária. Revista Eletrônica de Direito Administrativo Econômico - REDAE, Salvador : IDPB, n. 3, ago.-set.-out. 2005, p. 8. Disponível na Internet: <http://www.direitodoestado.com/revista/REDAE-3AGOSTO-2005-GUSTAVO\%20JUSTINO.pdf >. Acesso em: 22 abr. 2010). 
Emergem as parcerias neste contexto de contratualização da ação administrativa ${ }^{509}$, de busca de instrumentos consensuais pela Administração Pública para "concertar" a busca pelo bem comum, de co-administração entre a Administração Pública e a sociedade civil em matérias de titularidade compartida. É o que Gregorio Arena chama de administração compartilhada, na qual "política, administração e cidadãos convergem na persecução do interesse geral". 510

Este novo modelo foi denominado "administração compartilhada" para indicar que cidadãos e administrações não se limitam a administrar juntos, mas o fazem aliando-se contra um adversário comum representado pela complexidade das sociedades modernas e compartilhando tanto o objetivo, que consiste na satisfação de um interesse geral, como os recursos que ambos os sujeitos da relação poder colocar em campo. ${ }^{511}$

Como dito, uma das formas de expressão desta nova modelagem chamada de Estado contratual é a das parcerias entre a Administração Pública e o Terceiro Setor. Desenvolvem-se na medida em que a Administração Pública, em temas de interesse público cuja titularidade não lhe é exclusiva, se utiliza da ferramenta do fomento para alcançar a finalidade desejada. Sendo função administrativa a prestação de serviços públicos e $\mathrm{O}$ fomento, ambos com o intuito de atender concretamente às necessidades coletivas, a Administração Pública opta em desenvolver certas atividades indiretamente através do fomento à iniciativa privada de utilidade pública. ${ }^{512}$ "Ao invés de o Estado

509 “O novo modelo do Estado Democrático de Direito estimula a harmonia entre a atividade estatal e a ação privada, valorizando os entes de cooperação e fortalecendo o desenvolvimento da comunidade mediante os instrumentos de garantia e de proteção de direitos coletivos e difusos. A associação entre o serviço público e a atividade privada acrescenta ao instrumento tradicional da concessão ou permissão os novos parâmetros de consórcio e de parceria (...). Em figurinos atuais, a legislação federal adiciona novas técnicas de cooperação entre o Estado e a atividade privada, delegando-se a esta última a execução de serviços públicos, mediante contratos de gestão ou esquemas de terceirização" (TÁCITO, Caio. Direito administrativo de amanhã. In:

Temas de direito público (estudos e pareceres). Rio de Janeiro : Renovar, 2002, $3^{\circ}$ vol., p. 30).

${ }^{510}$ ARENA, Gregorio. Cittadini attivi: un altro modo di pensare all'Italia. Roma-Bari : Laterza, 2006, p. 29, tradução nossa. O autor justifica a administração compartilhada sob o argumento de que "as instituições se deram conta de que hoje, em muitos setores da vida coletiva, sem a participação ativa e responsável dos cidadãos elas não têm condições de realizar sozinhas o interesse geral". No original: "Nel caso dell'amministrazione condivisa, invece, politica, amministrazione e cittadini convergono nel perseguimento dell'interesse generale perchè le istituzioni si sono rese conto che oggi, in molti settori della vita collettiva, senza la partecipazione attiva e responsabile dei cittadini esse non sono in grado di realizzare da sole l'interesse generale".

511 Ibidem, pp. 29-30, tradução nossa. No original: "Questo nuovo modello è stato denominato 'amministrazione condivisa' per indicare che cittadini e amministrazioni non si limitano ad amministrare insieme, ma lo fanno alleandosi contro un avversario comune rappresentato dalla complessità delle società moderne e condividendo sia l'obiettivo, che consiste nel soddisfacimento di un interesse generale, sia le risorse che entrambi i soggetti del rapporto possono mettere in campo".

512 "Em sentido objetivo, a Administração Pública abrange as atividades exercidas pelas pessoas jurídicas, órgãos e agentes incumbidos de atender concretamente às necessidades coletivas; corresponde à função administrativa, atribuída preferencialmente aos órgãos do Poder Executivo. Nesse sentido, a Administração Pública abrange o fomento, a polícia administrativa, e o serviço público. Alguns autores falam em 
desempenhar, ele mesmo, determinada atividade, opta por incentivar ou auxiliar o particular que queira fazê-lo, por meio de auxílios financeiros ou subvenções, financiamentos, favores fiscais etc." $" 513$.

Este movimento de contratualização da Administração Pública se converteu em legislação efetiva em nosso ordenamento jurídico, no âmbito da chamada Reforma do Aparelho do Estado brasileiro ocorrida na década de 90 do século passado. ${ }^{514}$

Nos termos do chamado Plano Direito da Reforma do Aparelho do Estado, desenvolvido no âmbito do então Ministério da Administração Federal e Reforma do Estado - MARE e capitaneado pelo Ministro da pasta, Luiz Carlos Bresser Pereira, a reforma veio

no sentido de uma administração pública que chamaria de "gerencial", baseada em conceitos atuais de administração e eficiência, voltada para o controle dos resultados e descentralizada para poder chegar ao cidadão, que, numa sociedade democrática, é quem

intervenção como quarta modalidade, enquanto outros a consideram como espécie de fomento. O fomento abrange a atividade administrativa de incentivo à iniciativa privada de utilidade pública" (DI PIETRO, Maria Sylvia Zanella. Direito Administrativo. 19a ed. São Paulo: Atlas, 2006, p. 73, destaques no original).

${ }_{513}$ Ibidem, p. 339. Para uma constatação crítica, porém otimista, deste movimento de parcerias no Reino Unido, cf. MORISON, John. The Government-voluntary sector compacts: governance, governmentality, and civil society. Journal of law and society, Oxford : Blackwell Publishers, vol. 27, n. 1, mar. 2000, pp. 98132.

${ }^{514} \mathrm{Na}$ Itália: “A vigente legislação em matéria de assistência e saúde consente à administração pública 'confiar' determinados serviços a entes sem fins lucrativos, ou de 'valer-se' destes mediante a estipulação de 'convênios' ou de 'acordos contratuais'. Genericamente, o texto único sobre a ordenação dos entes locais, como recentemente modificado e complementado pela lei financeira 2002, prevê que os serviços públicos locais sem relevância industrial possam, na presença de determinadas circunstâncias, ser confiados a terceiros, precisando também que a relação entre os entes locais e os sujeitos operadores de serviços são regulados por 'contratos de serviço' (art. 113-bis, parágrafos 4 e 5). Por força de tais previsões normativas, a administração pública é portanto autorizada a envolver terceiros na gestão de serviços à pessoa. $\mathrm{O}$ reconhecimento desta possibilidade, naturalmente, não constitui uma novidade no quadro das modalidades operativas geralmente concedidas à administração titular de funções, mas se caracteriza, todavia, sobretudo pelo referimento - em alguns casos - aos 'convênios' como forma jurídica de interação com os terceiros, e em segundo lugar pela clara individualização dos terceiros a serem envolvidos às vezes (mas não sempre) em via absolutamente prefernecial, quais sejam os entes normalmente inscritos na categoria do non profit ou do assim chamado terceiro setor" (FICI, Antonio. I contratti tra pubblica amministrazione ed enti non profit. In: CAFAGGI, Fabrizio (org.). Modelli di governo, riforma dello stato sociale e ruolo del terzo settore. Bologna : Il Mulino, 2002, pp. 137-139, tradução nossa). No original: "La vigente legislazione in materia di assistenza e sanità consente alla pubblica amministrazione di 'affidare' determinati servizi ad enti non profit, ovvero di 'avvalersi' di questi ultimi mediante la stipula di 'convenzioni' o di 'accordi contrattuali'. Più in generale, il testo unico sull'ordinamento degli enti locali, come recentemente modificato ed integrato dalla legge finanziaria 2002, prevede che i servizi pubblici locali privi di rilevanza industriale possano, in presenza di determinate circostanze, essere affidati a terzi, precisando altresì che i rapporti tra gli enti locali e i soggetti erogatori di servizi sono regolati da 'contratti di servizio' (art. 113-bis, commi 4 e 5). In forza di tali previsioni normative, la pubblica amministrazione è dunque autorizzata a coinvolgere soggetti terzi nella gestione di servizi alla persona. Il riconoscimento di questa possibilità, naturalmente, non costituisce una novità nel quadro delle modalità operative generalmente concesse all 'amministrazione titolare di funzioni, ma si caratterizza, tuttavia, innanzitutto per il riferimento - in alcuni casi - alle 'convenzioni' quale forma giuridica dell'interazione con i terzi, e in secondo luogo per la chiara individuazione dei terzi da coinvolgere talvolta (ma non sempre) in via assolutamente preferenziale, e cioè enti normalmente ascritti alla categoria del non profit o del c.d. terzo settore". 
dá legitimidade às instituições e que, portanto, se torna "cliente privilegiado" dos serviços prestados pelo Estado. ${ }^{515}$

Fundado na crise fiscal do Estado brasileiro decorrente de uma estratégia estatizante, gerando a superação da forma de administrar o Estado, a Reforma do Aparelho do Estado brasileiro surge em meados dos anos 90 do século passado com o expresso intuito de "resgatar sua autonomia financeira e sua capacidade de implementar políticas públicas". ${ }^{516}$ Referido plano de reforma apontava como inadiáveis:

(1) o ajustamento fiscal duradouro; (2) reformas econômicas orientadas para o mercado, que, acompanhadas de uma política industrial e tecnológica, garantam a concorrência interna e criem as condições para o enfrentamento da competição internacional; (3) a reforma da previdência social; (4) a inovação dos instrumentos de política social, proporcionando maior abrangência e promovendo melhor qualidade para os serviços sociais; e (5) a reforma do aparelho do Estado, com vistas a aumentar sua "governança", ou seja, sua capacidade de implementar de forma eficiente políticas públicas. ${ }^{517}$

Chamam a atenção a necessidade apontada de inovação dos instrumentos de política social e de implementação eficiente de políticas públicas fundadas na governança. A Reforma, portanto, expressamente assumia os conceitos trazidos pela governança pública, dentre os principais o consensualismo, o contratualismo, a concertação, a administração em redes, etc.

O Plano Diretor da Reforma do Aparelho do Estado optou por dividir o seu objeto em quatro setores, a saber: i) núcleo estratégico: é a Administração Pública em sentido amplo (Poderes Executivo, Legislativo e Judiciário, Ministério Público e demais funcionários públicos responsáveis diretos pelas políticas públicas); ii) atividades exclusivas do Estado: aqueles setores em que só o Estado pode atuar (poder de polícia, fomento público, etc.); iii) serviços não exclusivos do Estado: atividades de titularidade compartida entre o Estado e as organizações públicas não-estatais e privadas (educação, saúde, museus, etc.); iv) produção de bens e serviços para o mercado: área de atuação das empresas.

Ecos deste Plano Diretor da Reforma do Aparelho do Estado foram sentidos na prática, especialmente nos setores relacionados às atividades desenvolvidas no âmbito do

\footnotetext{
515 PLANO DIRETOR DA REFORMA DO APARELHO DO ESTADO. MINISTÉRIO DA ADMINISTRAÇÃO FEDERAL E DA REFORMA DO ESTADO, 1995, p. 7.

516 PLANO DIRETOR DA REFORMA DO APARELHO DO ESTADO. MINISTÉRIO DA ADMINISTRAÇÃO FEDERAL E DA REFORMA DO ESTADO, 1995, p. 11.

517 PLANO DIRETOR DA REFORMA DO APARELHO DO ESTADO. MINISTÉRIO DA ADMINISTRAÇÃO FEDERAL E DA REFORMA DO ESTADO, 1995, p. 11.
} 
mercado, na área de atuação das empresas para utilizar a expressão reformista. Basta compararmos os objetivos específicos determinados no Programa com a produção legislativa em cada tema para constatarmos isto. Especificamente, para se ter um exemplo, quanto ao setor da produção de bens e serviços para o mercado, os objetivos específicos eram os seguintes: "1 - Dar continuidade ao processo de privatização através do Conselho de Desestatização. 2 - Reorganizar e fortalecer os órgãos de regulação dos monopólios naturais que forem privatizados. 3 - Implantar contratos de gestão nas empresas que não puderem ser privatizadas". 518

No decorrer da década de 90, mesmo anteriormente ao Plano Diretor de Reforma do Aparelho do Estado, e início da década de 2000 o processo de desestatização foi intenso no Brasil. Além disso, para alcançar os objetivos propostos pela reforma foram editadas as Leis n. $8.987 / 95$ e 9.074/95 (concessão e permissão de serviço público) e, em outro momento, a Lei n. 11.079/2004 (Parcerias Público-privadas). No âmbito da regulação foi promulgada a Lei n. 9.986/2000 (Agências Reguladoras). ${ }^{519}$ Criou-se, assim, um aparato legislativo respeitável com vistas a dar efetividade ao objetivo global relativo à produção de bens e serviços para o mercado, qual seja o de limitar a ação do Estado e reservar a produção de bens e serviços para o mercado para a iniciativa privada. ${ }^{520}$

Quanto aos reflexos práticos da Reforma no contexto dos serviços não exclusivos do Estado em que se inserem as atividades do Terceiro Setor, estamos certos de que os objetivos pretendidos estão longe de serem alcançados. A grande proposta da Reforma neste campo ficou por conta da criação das organizações sociais, instrumento de "publicização" das atividades públicas não-estatais. Vinha assim um dos objetivos específicos do Plano de Reforma nesta área:

Transferir para o setor público não-estatal estes serviços, através de um programa de "publicização", transformando as atuais fundações públicas em organizações sociais, ou

\footnotetext{
518 PLANO DIRETOR DA REFORMA DO APARELHO DO ESTADO. MINISTÉRIO DA ADMINISTRAÇÃO FEDERAL E DA REFORMA DO ESTADO, 1995, p. 47.

${ }^{519}$ Neste meio tempo foram instituídas 10 agências reguladoras, tidas como autarquias especiais, somente no âmbito federal, a saber: Agência Nacional de Energia Elétrica (ANEEL): Lei n. 9.427/96; Agência Nacional de Telecomunicações (ANATEL): Lei n. 9.472/97; Agência Nacional do Petróleo, Gás Natural e Biocombustíveis (ANP): Lei n. 9.478/97; Agência Nacional de Vigilância Sanitária (ANVISA): Lei n. 9.782/99; Agência Nacional de Saúde Suplementar (ANS): Lei n. 9.961/00; Agência Nacional de Águas (ANA): Lei n. 9.984/00; Agência Nacional de Transportes Terrestres (ANTT): Lei n. 10.233/01; Agência Nacional de Transportes Aquaviários (ANTAQ): Lei n. 10.233/01; Agência Nacional do Cinema (ANCINE): MP n. 2228-1/01; Agência Nacional de Aviação Civil (ANAC): Lei n. 11.182 de 27 de setembro de 2005.

520 “O objetivo último [do Plano Diretor da Reforma do Aparelho do Estado] - o da privatização em sentido amplo - continua sendo buscado por outros instrumentos, em especial com as parcerias público-privadas" (DI PIETRO, Maria Sylvia Zanella. Parcerias na Administração Pública: concessão, permissão, franquia, terceirização, parceria público-privada e outras formas. $5^{\mathrm{a}}$ ed. São Paulo : Atlas, 2006, p. 54).
} 
seja, em entidades de direito privado, sem fins lucrativos, que tenham autorização específica do poder legislativo para celebrar contrato de gestão com o poder executivo e assim ter direito a dotação orçamentária. ${ }^{521}$

Este objetivo repercutiu na edição da Lei n. ${ }^{0}$ 9.637, de 15 de maio de 1998, que criou a qualificação de entidades como organizações sociais ${ }^{522}$, cuja finalidade era proporcionar o desenvolvimento, através de contrato de gestão ${ }^{523}$ firmado entre a entidade e o Poder Público, de atividades praticadas pelas organizações sociais por serem reconhecidamente de jaez social, complementares, então, à atividade estatal. Sobretudo em face dos temas abarcados pela legislação das organizações sociais, quais sejam o ensino, $a$ pesquisa científica, o desenvolvimento tecnológico, a proteção e preservação do meio ambiente, a cultura e a saúde. ${ }^{524}$

Através da observância de determinados requisitos legais, portanto, a Lei n. ${ }^{o}$ 9.637/98 permite que pessoas jurídicas de direito privado sejam qualificadas como organizações sociais e, através de contratos de gestão firmados com o Poder Público, desenvolvam atividades relacionadas ao desenvolvimento educacional e assistencial, sendo então declaradas entidades de interesse social e utilidade pública $^{525}$, recebendo, inclusive, incentivo do Poder Público para o fomento das atividades sociais, conforme preceitua o artigo 12 da lei.

Trata-se, efetivamente, a qualificação das entidades como organizações sociais, de instrumento criado no bojo do Plano Diretor da Reforma do Aparelho do Estado com vistas

521 PLANO DIRETOR DA REFORMA DO APARELHO DO ESTADO. MINISTÉRIO DA ADMINISTRAÇÃO FEDERAL E DA REFORMA DO ESTADO, 1995, pp. 46-47. Os demais objetivos neste campo eram os seguintes: "Lograr, assim, uma maior autonomia e uma conseqüente maior responsabilidade para os dirigentes desses serviços; Lograr adicionalmente um controle social direto desses serviços por parte da sociedade através dos seus conselhos de administração. Mais amplamente, fortalecer práticas de adoção de mecanismos que privilegiem a participação da sociedade tanto na formulação quanto na avaliação do desempenho da organização social, viabilizando o controle social. Lograr, finalmente, uma maior parceria entre o Estado, que continuará a financiar a instituição, a própria organização social, e a sociedade a que serve e que deverá também participar minoritariamente de seu financiamento via compra de serviços e doações. Aumentar, assim, a eficiência e a qualidade dos serviços, atendendo melhor o cidadãocliente a um custo menor".

522 "Com efeito, não há como negar que a criação da organização social foi um dos frutos produzidos pela Reforma do Estado" (ROCHA, Sílvio Luís Ferreira da. Terceiro Setor. São Paulo : Malheiros, 2003, p. 81).

${ }^{523}$ Sobre o tema dos contratos de gestão, cf. por todos OLIVEIRA, Gustavo Justino. Contrato de gestão. São Paulo : RT, 2008.

${ }^{524}$ Lei n. ${ }^{\circ}$ 9.637/98: “Art. 1 ${ }^{\circ}$. O Poder Executivo poderá qualificar como organizações sociais pessoas jurídicas de direito privado, sem fins lucrativos, cujas atividades sejam dirigidas ao ensino, à pesquisa científica, ao desenvolvimento tecnológico, à proteção e preservação do meio ambiente, à cultura e à saúde, atendidos os requisitos previstos nesta Lei".

${ }^{525}$ Lei n. ${ }^{\circ}$ 9.637/98: "Art. 11. As entidades qualificadas como organizações sociais são declaradas como entidades de interesse social e utilidade pública, para todos os efeitos legais". 
a dotar a prestação dos serviços sociais de maior flexibilidade, através da interposição destas entidades entre o Estado e a sociedade receptora dos serviços.

Nos dias atuais, está presente o Plano Diretor da Reforma do Aparelho do Estado, o qual apresenta um novo modelo de instituição: as organizações sociais. No dizer dos idealizadores dessa nova reforma, as organizações sociais não são uma nova espécie de pessoa jurídica privada. Tampouco se tratam de entidades criadas por lei e encartadas na estrutura da administração pública. São pessoas jurídicas organizadas sob a forma de fundação privada ou associação sem fins lucrativos, que recebem o 'título jurídico especial' de organização social, conferido pelo Poder Público, mediante atendimento dos requisitos previstos expressamente em lei. A inovação, portanto, não está na estrutura da pessoa jurídica, mas, sim, na nova forma de parceria entre o ente privado e o Poder Público. ${ }^{26}$

Os contratos de gestão criados pela legislação por provocação do Plano Diretor da Reforma do Aparelho do Estado são importantes instrumentos de realização do interesse público no campo social, mormente por significarem moderna ferramenta que se insere no contexto da Administração Pública Consensual e da nova contratualização administrativa ${ }^{527}$, o que verdadeiramente "marca (ou ao menos sinaliza) a evolução de um modelo de gestão pública centrado no ato administrativo para um modelo baseado também nos acordos administrativos $" 528$.

Há uma exigência legal específica, no entanto, que merece destaque para os fins do presente trabalho por nos autorizar concluir que as Organizações Sociais não fazem parte do Terceiro Setor. Esta exigência diz respeito à participação obrigatória ${ }^{529}$ de

\footnotetext{
${ }^{526}$ ALVES, Francisco de Assis. Fundações, organizações sociais e agências executivas: organizações da sociedade civil de interesse público e outras modalidades de prestação de serviços públicos. São Paulo : LTr, 2000, p. 183 e ss. E continua, fazendo expressa menção à inflexibilidade do aparato estatal: “O projeto de reforma centra-se num dos principais problemas enfrentados pela administração pública: a rigidez resultante da aplicação de normas burocráticas, mesmo para os setores onde estas não são consideradas necessárias, como é o caso do setor compreendido pelos serviços não-exclusivos do Estado, que se caracteriza pela prestação de serviços sociais. Por isso mesmo, o Plano Diretor, um dos esteios da Reforma Administrativa, indica a prestação desses serviços, como o setor apropriado a ser desenvolvido pelas organizações sociais. Os serviços a que alude o referido Plano são aqueles relacionados fundamentalmente às áreas da saúde e da educação, hoje mantidas pelo Estado através de autarquias e fundações. A flexibilidade é fator determinante para a eficiência na prestação desses serviços. (...) Com as organizações sociais, o que se pretende é criar uma parceria entre o Estado e instituições privadas de fins públicos. Com essa modalidade de parceria da Administração Pública, objetiva-se implantar uma nova forma de participação popular na gestão administrativa" (ibidem, p. 185).

${ }^{527}$ Sobre estes temas cf. OLIVEIRA, Gustavo Justino. Contrato de gestão. São Paulo : RT, 2008.

528 Ibidem, p. 262, destaques no original. "Os contratos de gestão têm natureza jurídica que poderia ser qualificada de 'acordos cooperativos funcionalizados': manifestações plurilaterais de compromisso, cujos objetivos devem ir além dos limites dos interesses íntimos dos participantes" (MOREIRA, Egon Bockmann. Organizações Sociais, Organizações da Sociedade Civil de Interesse Público e seus "Vínculos Contratuais" com o Estado. In: MOREIRA, Egon Bockmann; CUÉLLAR, Leila. Estudos de Direito Econômico. Belo Horizonte : Fórum, 2004, p. 274).

${ }^{529}$ Lei n. 9.637/98: “Art. $2^{\circ}$ São requisitos específicos para que as entidades privadas referidas no artigo anterior habilitem-se à qualificação como organização social: I - comprovar o registro de seu ato constitutivo, dispondo sobre: (...) c) previsão expressa de a entidade ter, como órgãos de deliberação superior e de direção,
} 
representantes do Poder Público no Conselho de Administração da entidade (de $20 \%$ a $40 \%$ dos componentes) ${ }^{530}$, órgão colegiado de deliberação superior com importantes atribuições legais como fixar o objeto de atuação da entidade, designar e dispensar os membros da diretoria e definir a sua remuneração, entre outras.

Esta exigência, embora não descaracterize a natureza privada das entidades qualificadas como Organizações Sociais, interfere sobremaneira na sua autonomia ao permitir a imiscuição do Poder Público em suas deliberações. Mais do que isso, a inserção de representantes do Poder Público no Conselho de Administração com a evidente função de controle das atividades da entidade, seja aquela pública transformada em privada seja a originalmente privada que obtém a qualificação, afeta a composição social da entidade hialinamente: passa de entidade constituída pela iniciativa privada para entidade constituída pela iniciativa privada e pelo Poder Público. Esta natureza mista ${ }^{531}$ da entidade permite afastá-la do conceito proposto de Terceiro Setor, especialmente considerando que a origem deste conceito é justamente a mobilização da sociedade civil voluntariamente em torno das causas sociais, como expressão de sua participação constitucionalmente consagrada. Permitir a ingerência pública direta em órgão deliberativo de entidade privada é desvirtuar a voluntariedade da atividade social desenvolvida, donde se extrai que "a rigor, as organizações sociais não podem ser entendidas como entidades nãogovernamentais ou integrantes do denominado Terceiro Setor. (...) Com efeito, as organizações sociais são espécie do gênero entidade paraestatal”. ${ }^{532}$

um conselho de administração e uma diretoria definidos nos termos do estatuto, asseguradas àquele composição e atribuições normativas e de controle básicas previstas nesta Lei; d) previsão de participação, no órgão colegiado de deliberação superior, de representantes do Poder Público e de membros da comunidade, de notória capacidade profissional e idoneidade moral."

${ }^{530}$ Lei n. 9.637/98: “Art. $3^{\circ} \mathrm{O}$ conselho de administração deve estar estruturado nos termos que dispuser o respectivo estatuto, observados, para os fins de atendimento dos requisitos de qualificação, os seguintes critérios básicos: I - ser composto por: a) 20 a $40 \%$ (vinte a quarenta por cento) de membros natos representantes do Poder Público, definidos pelo estatuto da entidade; b) 20 a 30\% (vinte a trinta por cento) de membros natos representantes de entidades da sociedade civil, definidos pelo estatuto; c) até $10 \%$ (dez por cento), no caso de associação civil, de membros eleitos dentre os membros ou os associados; d) 10 a $30 \%$ (dez a trinta por cento) de membros eleitos pelos demais integrantes do conselho, dentre pessoas de notória capacidade profissional e reconhecida idoneidade moral; e) até 10\% (dez por cento) de membros indicados ou eleitos na forma estabelecida pelo estatuto".

${ }^{531}$ Sobre entidades mistas que desenvolvem atividades de interesse social, cf.: IAMICELI, Paola. Servizi alla persona e forme privatistiche di gestione: il modello delle organizzazioni miste. In: CAFAGGI, Fabrizio. Modelli di governo, riforma dello stato sociale e ruolo del terzo settore. Bologna : Il Mulino, 2002, pp. 179-253.

532 OLIVEIRA, Gustavo Justino. Op. cit., pp. 278-280, destaque no original. Também neste sentido: “Observa-se, no entanto, que um outro instrumento destinado a regular as transferências voluntárias a entidades sem fins lucrativos para entidades que assumem a qualificação de Organização Social ('OS'), não será contemplado neste trabalho. Optou-se por excluir do presente estudo de caso as normas que disciplinam este instrumento jurídico - o contrato de gestão - em razão do regime jurídico diferenciado a que este se submete. As OS, além de receberem créditos orçamentários específicos, bens e serviços públicos cedidos, 
Outro fator que aproxima as Organizações Sociais do setor público é o fato de que a lei atribui ao administrador discricionariedade no deferimento do pedido de qualificação da entidade, transformando-a em uma opção política. Na lição de Sílvio Luís Ferreira da Rocha, "a atividade do administrador em conceder ou não conceder dita qualificação encontra-se no campo da discricionariedade, pois o legislador conferiu-lhe liberdade decisória quanto à conveniência de conceder a qualificação e à oportunidade de fazê-lo".533 Este dispositivo é criticado pela doutrina, como são exemplos o próprio autor citado ${ }^{534}$, Francisco de Assis Alves ${ }^{535}$ e José Eduardo Sabo Paes ${ }^{536}$, entre outros.

Estas críticas, somadas a outros fatores, justificam o fato de os contratos de gestão não terem alcançado plena aplicação em nosso país. Como observa Maria Sylvia Zanella Di Pietro

na realidade, a extinção do Ministério da Administração e Reforma do Estado (Mare) e a oposição doutrinária a algumas das inovações (em especial às organizações sociais e aos contratos de gestão) acabaram por deter a implantação e o avanço de muitos dos instrumentos previstos no Plano Diretor. ${ }^{537}$

Além disso, a própria cultura da Administração Pública brasileira, arraigada das técnicas tradicionais fundadas no paradigma bipolar Estado-cidadão, não absorveu as técnicas consensuais satisfatoriamente.

Se os contratos de gestão não alcançaram ainda o prestígio e a projeção esperados em nosso sistema, isto não se deve à ausência de uma legislação de referência. Ela existe e está afinada com as mais recentes experiências internacionais. No entanto, essa legislação de

devem possuir servidores públicos em seus Conselhos de Administração, fazendo com que estas operem numa lógica 'quase-governamental'. Ademais, a vinculação estreita entre estas entidades e a Administração Pública decorre da própria origem dessas organizações que, normalmente, originam-se de serviços públicos prestados por esta. O vínculo mais estreito entre essas entidades e a Administração Pública não se enquadraria na hipótese a ser testada ao longo deste trabalho, qual seja, a de que a ineficácia e ineficiência dos instrumentos jurídicos de transferências voluntárias decorreria, em certa medida, das dificuldades que possui o setor privado sem fins lucrativos em se amoldar estritamente ao regime jurídico de direito público vigente. Por essa razão, o estudo das normas que disciplinam o contrato de gestão foi excluído da análise desta dissertação" (SALINAS, Natasha Schmitt Caccia. Avaliação legislativa no Brasil: um estudo de caso sobre as normas de controle das transferências voluntárias de recursos públicos para entidades do terceiro setor. Dissertação de mestrado. São Paulo, Faculdade de Direito da USP, 2008, p. 79, destaques no original).

${ }^{533}$ ROCHA, Sílvio Luís Ferreira da. Terceiro Setor. São Paulo : Malheiros, 2003, p. 103.

${ }^{534}$ Ibidem, pp. 103-106.

535 ALVES, Francisco de Assis. Fundações, organizações sociais e agências executivas: organizações da sociedade civil de interesse público e outras modalidades de prestação de serviços públicos. São Paulo : LTr, 2000, p. 194.

536 PAES, José Eduardo Sabo. Fundações e entidades de interesse social: aspectos jurídicos, administrativos, contábeis e tributários. $4^{\mathrm{a}}$ ed. Brasília : Brasília Jurídica, 2003, p. 103.

537 DI PIETRO, Maria Sylvia Zanella. Parcerias na Administração Pública: concessão, permissão, franquia, terceirização, parceria público-privada e outras formas. $5^{\text {a }}$ ed. São Paulo : Atlas, 2006, p. 53. 
ponta encontra-se em total descompasso com a cultura organizacional da Administração Pública brasileira, arraigada em práticas de gestão ultrapassadas e refratária a processos comunicacionais e de contínua programação concertada com a população. ${ }^{538}$

Embora entendamos que as Organizações Sociais não se enquadram no conceito de Terceiro Setor pelos motivos expostos ${ }^{539}$, estas considerações servem para contextualizar o surgimento de outra qualificação jurídica destinada a pessoas jurídicas de direito privado sem fins lucrativos que, esta sim destinada ao Terceiro Setor, padece dos mesmos problemas.

A já analisada Lei n. 9.790/99 instituiu a qualificação das Organizações da Sociedade Civil de Interesse Público, as Oscips, cuja função principal é a possibilidade de tais entidades firmarem termos de parceria com o Poder Público.

$\mathrm{Na}$ esteira da visibilidade crescente das atividades desempenhadas pelas entidades do Terceiro Setor sobretudo nos anos 90, "resultado do trabalho de dezenas de organizações da sociedade civil, em parceria com o Governo Federal e o Congresso Nacional, articulado pelo Conselho da Comunidade Solidária"540, iniciaram-se debates para a propositura de uma Reforma do Marco Legal do Terceiro Setor.

Foram editadas, neste contexto, a Lei n. ${ }^{\circ}$ 9.637, de 15 de maio de $1998^{541}$, e a Lei n. ${ }^{\circ}$ 9.790, de 23 de março de 1999. Esta última é conhecida como a Lei das Oscip, a nova lei do Terceiro Setor ou Regulamento do Terceiro Setor. Não obstante ser marco legal deveras importante para o Terceiro Setor, a Lei das Oscip não ganha conotação de regulamento.

\footnotetext{
${ }^{538}$ OLIVEIRA, Gustavo Justino. Contrato de gestão. São Paulo : RT, 2008, p. 291. O autor continua: “As dificuldades apontadas não têm nem poderiam ter por fim eclipsar a importância do contrato de gestão para a evolução da Administração Pública e do direito administrativo brasileiros" (ibidem, p. 291).

539 "Conseguintemente, as organizações sociais, como nascidas, negam duas vezes as ideias que, em tese, as sustentariam - de parceria e de terceiro setor. Não é possível mencionar terceiro setor, como abrangente da sociedade, se as organizações sociais são representadas por instituições criadas pelo próprio Estado, com esse guardando laços estreitos, desse recebendo os valores que aplica, os bens de que se utiliza e os servidores que executam suas atividades" (FERNANDES, Luciana de Medeiros. Reforma do Estado e Terceiro Setor. Curitiba : Juruá, 2009, pp. 458-459).

${ }^{540}$ FERRAREZI, Elisabete e REZENDE, Valéria. OSCIP - Organização da sociedade civil de interesse público: a Lei . $^{\circ}$ 9.790/99 como alternativa para o terceiro setor. $2^{\mathrm{a}}$ ed. Brasília : Comunidade Solidária, 2002, p. 27. Disponível na Internet: <http://www.comunidadesolidaria.org.br>. Acesso em: 29 jan. 2003.

${ }^{541}$ A lei que criou a qualificação das organizações sociais, embora inegavelmente inspirada no Plano de Reforma do Aparelho do Estado brasileiro, também costuma ser relacionada com a chamada Reforma do Marco Legal do Terceiro Setor. Sobre esta última vinculação, cf. MODESTO, Paulo. Reforma do marco legal do Terceiro Setor no Brasil. In: FALCÃO, Joaquim; CUENCA, Carlos (org.). Mudança social e reforma legal: estudos para uma nova legislação do Terceiro Setor. Brasília : Conselho da Comunidade Solidária : UNESCO : BID : FBB, 1999, p. 145 e ss.
} 
Foi um passo que deve ser engrandecido, não só por ter ocorrido em reconhecimento ao já existente crescimento do Terceiro Setor, mas sobretudo por ter a exata intenção de promover ainda mais este aumento.

Inicia-se, com esta nova legislação, nova etapa de discussões sobre o Terceiro Setor e sobre as suas relações com o Poder Público, tendo na ferramenta do termo de parceria a inovação que permite inserir esta qualificação ao lado das organizações sociais como um marco em direção à consolidação da Administração Pública consensual.

Considerando que as organizações sociais devem ser tidas como entidades paraestatais em virtude de sua natureza quase pública, é de se ressaltar que a criação da qualificação como Organização da Sociedade Civil de Interesse Público e da ferramenta do termo de parceria deve ser tida como pioneira no reposicionamento da relação do Estado com o Terceiro Setor no bojo de uma Administração Pública Consensual. Inaugurou importante instrumento de diálogo entre o Estado e a sociedade civil, abrindo vasto campo de participação cidadã no âmbito dos serviços sociais em que se insere, sendo verdadeiro reflexo de uma democracia participativa numa acepção mais material do termo.

Ocorre que por motivos diversos, que vão desde a insegurança jurídica com que devem conviver as entidades que buscam parcerias com o Poder Público até o próprio preconceito da Administração Pública com instrumentos inovadores como os termos de parceria, a Lei n. 9.790/99 tem produzido muito poucos efeitos se comparada com o seu potencial. Uma lei aprovada há mais de 10 anos, tida como um marco referencial na regulamentação das relações entre a Administração Pública e as entidades sem fins lucrativos, que até então padeciam da quase completa impossibilidade de relacionamento com o Estado por ausência de ferramentas - sabe-se que os convênios são regidos por um componente político incontestável -, gerou a pífia marca de 168 termos de parceria firmados entre a sua edição e 31 de dezembro de 2007, consolidando a quantia total de $\mathrm{R} \$$ 553.426.234,48 (quinhentos e cinqüenta e três milhões, quatrocentos e vinte e seis mil, duzentos e trinta e quatro reais e quarenta e oito centavos) em repasses financeiros. ${ }^{542}$

Para fins comparativos, conforme esta pesquisa levando em conta os exercícios de 2004 a 2007 o volume total de transferência de recursos de entes federais para entidades qualificadas como Oscip através de termos de parceria foi de $\mathrm{R} \$ 252.829 .930,06$ (duzentos e cinqüenta e dois milhões, oitocentos e vinte e nove mil, novecentos e trinta reais e seis

542 SOARES, Laura Letsch. Oscip's - Organizações sociais da sociedade civil de interesse público: resultados práticos alcançados após a promulgação da Lei 9.790/99. In: $18^{\circ}$ CONGRESSO BRASILEIRO DE CONTABILIDADE, Gramado, 24-28/2008, p. 7. Trabalhos. Disponível na Internet: <www.congressofc.org.br/hotsite/trabalhos_11449.pdf>. Acesso em: 22 abr. 2010. 
centavos). Enquanto isso, a totalidade dos recursos transferidos a pessoas jurídicas sem fins lucrativos no mesmo período, conforme informação do Portal Transparência Brasil do Governo Federal ${ }^{543}$, foi de R\$ 10.632.041.935,82 (dez bilhões, seiscentos e trinta e dois milhões, quarenta e um mil, novecentos e trinta e cinco reais e oitenta e dois centavos).

O número de termos de parceria celebrados com a União, no entanto, é inexpressivo se comparado com o de convênios, razão pela qual os atos administrativos emanados do poder executivo assumem papel principal na presente análise, pois são eles que "de fato" instrumentalizam a maior parte dos ajustes entre governo federal e terceiro setor no Brasil. $^{544}$

Constata-se, assim, que na área social o movimento de Reforma do Aparelho do Estado brasileiro, fortalecido pela Reforma do Marco Legal do Terceiro Setor, ainda não logrou instalar nova mentalidade de consenso. As atividades prestacionais vinculadas a direitos fundamentais e a garantia do conteúdo constitucional, foco da atuação do Terceiro Setor, continuam regidas pela ótica burocrática quando desenvolvidas em regime de coparticipação público-privada, especialmente em virtude de resistência da Administração Pública em adotar o novo mecanismo legal dos termos de parceria. Como adverte Natasha Schmitt Caccia Salinas, o tímido crescimento da celebração de termos de parceria tem como um fator específico fundamental a "resistência do poder público em se adaptar ao novo instrumento, devido à costumes organizacionais ou falta de capacitação". 545

De fato, a busca por ferramentas modernas de relacionamento consensual entre a Administração Pública e o Terceiro Setor para o desempenho de atividades de interesse social deu grande passo com a edição da Lei n. 9.790/99, mas passados mais de dez anos ela carece de reforço legislativo para alcançar os resultados pretendidos.

Como já apontava Augusto de Franco

a Lei 9790/99 - mais conhecida como 'a nova lei do Terceiro Setor' - representa apenas um passo, um primeiro e pequeno passo, na direção da reforma do marco legal que regula as relações entre Estado e Sociedade Civil no Brasil. O sentido estratégico maior dessa reforma é o empoderamento das populações, para aumentar a sua possibilidade e a sua capacidade de influir nas decisões públicas e de aduzir e alavancar novos recursos ao processo de desenvolvimento do país. A Lei 9790/99 visa, no geral, a estimular o

\footnotetext{
${ }^{543}$ www.portaldatransparencia.gov.br.

544 SALINAS, Natasha Schmitt Caccia. Avaliação legislativa no Brasil: um estudo de caso sobre as normas de controle das transferências voluntárias de recursos públicos para entidades do terceiro setor. Dissertação de mestrado. São Paulo, Faculdade de Direito da USP, 2008, p. 70.

545 Ibidem, p. 70.
} 
crescimento do Terceiro Setor. (...) Para tanto, faz-se necessário construir um novo arcabouço legal. (...) Evidentemente ainda estamos longe de alcançar tal objetivo. ${ }^{546}$

Muitos destes problemas decorrem da convivência conflitiva entre os regimes jurídicos do criado termo de parceria com o consagrado convênio. Justamente esta diversidade de regimes, do burocrático e consagrado convênio ao consensual e inovador termo de parceria, gera dificuldades na opção do administrador público no momento de firmar o instrumento colaborativo com a entidade sem fins lucrativos. Não faltam menções à assinatura de convênios entre o Poder Público e Oscips ${ }^{547}$, assim como há informações de que alguns termos de parceria são firmados entre órgão público e Oscip sob a égide da legislação regente dos convênios. ${ }^{548}$

Mas esta resistência da Administração Pública pode ser creditada à ausência de um verdadeiro marco legal para as relações colaborativas com o Terceiro Setor. Embora a Lei das Oscip tenha inaugurado um modelo consensual de sumas importância e relevância, algumas indefinições da própria lei e de seu decreto regulamentar, somadas a um histórico legislativo absurdamente confuso e mantido pela reforma, assim como a criação de requisitos normativos posteriores incompatíveis com a idéia proposta pela lei, dificultam a sua aplicação pela Administração Pública.

São de suma importância as seguintes constatações efetuadas por Valéria Maria Trezza sobre o assunto, em pesquisa efetuada diretamente junto a entes públicos que firmaram termos de parceria com base na Lei n. 9.790/99:

\footnotetext{
${ }^{546}$ FRANCO, Augusto de. Prefácio à primeira edição: o que está por trás da nova lei do terceiro setor. In: FERRAREZI, Elisabete; REZENDE, Valéria. OSCIP - Organização da sociedade civil de interesse público: a Lei n. ${ }^{\circ}$ 9.790/99 como alternativa para o terceiro setor. $2^{\mathrm{a}}$ ed. Brasília : Comunidade Solidária, 2002, p. 7. Disponível na Internet: <http://www.comunidadesolidaria.org.br >. Acesso em: 29 jan. 2003.

547 "Além disso, é possível observar que em não raras situações a União repassa recursos para uma OSCIP por meio da celebração de um convênio, e não um termo de parceria, não sendo aplicável, para aquele ajuste, os dispositivos normativos da Lei que instituiu as OSCIPs, e sim os referidos atos normativos que tratam de convênios". (SALINAS, Natasha Schmitt Caccia. Op. cit., p. 70).

548 "Os sete Termos de Parceria firmados pelo FNMA foram tratados do mesmo modo que os convênios. Segundo a responsável pela Coordenadoria de Contratos e Convênios do FNMA esse procedimento foi adotado porque houve uma orientação da Consultoria Jurídica para se aplicar a IN/STN no 01/97 mesmo se tratando de Termo de Parceria. Assim, segundo ela, o instrumento virou um convênio com algumas características do Termo de Parceria, como a comissão de avaliação e algumas diferenças na prestação de contas. Alguns benefícios previstos na Lei $\mathrm{n}^{\circ} 9.790 / 99$ e no Decreto $\mathrm{n}^{\circ} 3.100 / 99$, como a possibilidade de remuneração de pessoal e a aquisição de bens com os recursos do Termo de Parceria, não foram permitidas. $\mathrm{O}$ tratamento que estava sendo dado ao instrumento, com a aplicação da IN/STN $n^{\circ}$ 01/97, e que acabou por não proporcionar muitas diferenças em relação ao convênio, levou o FNMA a não firmar outros Termos de Parceria a partir de 2003" (TREZZA, Valéria Maria. O termo de parceria como instrumento de relação público/privado sem fins lucrativos: o difícil equilíbrio entre flexibilidade e controle. Dissertação de mestrado. São Paulo, Escola de Administração de Empresas de São Paulo, Fundação Getúlio Vargas, 2007, pp. 94-95. Disponível na Internet: <http://www.dominiopublico.gov.br/download/texto/cp023498.pdf $>$. Acesso em: 24 abr. 2010).
} 
Um primeiro ponto que achamos importante ressaltar é o fato de que não parece existir nos órgãos públicos uma política de utilização do Termo de Parceria na relação com as OSCIPs: hora eles utilizam o convênio, hora o novo instrumento. Além disso, o levantamento dos Termos de Parceria apontou que grande parte das organizações tem somente um ou dois Termos firmados e a maioria órgãos públicos não tem mais do que três. Parece-nos que tal situação é decorrente do fato dos gestores públicos não terem internalizado na gestão dos projetos a prática de buscar eficiência e resultados, mas de ainda estarem presos apenas em seguir os procedimentos para que não haja, futuramente, nenhum questionamento por parte dos órgãos fiscalizadores. Além disso, vários exemplos que apresentamos demonstram a grande insegurança dos gestores que lidam com a celebração de parcerias com as OSCIPs. Eles gostariam que houvessem dispositivos expressos que pudessem embasar a aplicação das normas do Termo de Parceria e, sentindo falta desse detalhamento na legislação de OSCIP, os técnicos voltam-se para outras normas. No entanto, um dos motivos para a criação da legislação de OSCIP, como vimos, foi trazer mudanças nas regras que regulam a celebração de parcerias entre o Poder Público e as organizações sem fins lucrativos, considerada inadequada. De fato, muitos dispositivos da Lei $\mathrm{n}^{\circ}$ 9.790/99 e do Decreto $\mathrm{n}^{\circ} 3.100 / 99$ conflitam com a legislação anterior. No entanto, o objetivo não é que se aplique ambas as legislações, mas que a nova substitua a anterior. Tentar seguir os dois regulamentos acarreta, no mínimo, a anulação dos efeitos que se espera ter do Termo de Parceria. Não é de se estranhar, portanto, que vários gestores não vejam diferenças ou vantagens no novo instrumento. Mas como pudemos notar, não faltam dispositivos que direta e indiretamente regulam o instrumento, nem embasamento legal para os novos procedimentos. Parece-nos, portanto, que os empecilhos são muito mais em decorrência de insegurança em lidar com o novo instrumento, do que a falta de regulação. $O$ conflito entre os dispositivos da lei e a forma como o instrumento é aplicado talvez decorra do fato de que a proposta de se instituir novas formas de controle e de flexibilização de procedimentos é potencialmente boa, no entanto, ela esbarra na estrutura de funcionamento dos órgãos e, até mesmo, uma na outra, provocando a diminuição das vantagens na prática. Um bom exemplo é em relação à escolha das organizações sem fins lucrativos. A não realização do concurso de projetos indica que não se conseguiu implementar, plenamente, com o Termo de Parceria, um mecanismo que daria muito mais transparência e objetividade ao processo de repasse de recursos do Poder Público às OSCIPs. Em outras palavras, no quesito relativo à seleção de projetos, não se conseguiu romper com a prática antiga. Em resumo, a nossa percepção é a de que, teoricamente, o instrumento do Termo de Parceria apresenta um equilíbrio entre os dispositivos que tratam da flexibilização de procedimentos e os mecanismos de controle. No entanto, a aplicação prática do instrumento parece apontar como um fator que restringe e ocasiona o desequilíbrio entre os dois aspectos. Seria interessante que futuros estudos pudessem investigar a utilização do Termo de Parceria junto a mais órgãos. A falta de estudos e pesquisas sobre o novo instrumento (e também sobre o tradicional convênio) prejudica uma análise mais precisa do tema. $\mathrm{O}$ acesso a dados agregados sobre os Termos que estão sendo celebrados entre as diversas esferas de governo e as OSCIPs, que nos proporcionasse uma visão atual sobre a freqüência com que o instrumento está sendo utilizado, com quais órgãos, para quais objetivos e de que forma, permitiria a construção de um diagnóstico dos problemas enfrentados e a busca por soluções. Também ajudaria nesse sentido, pesquisas que cruzassem a visão das OSCIPs sobre a utilização do instrumento com a dos órgãos públicos. Talvez o Poder Público e o Terceiro Setor ainda careçam de uma legislação que contemple todas as necessidades que decorrem da relação entre eles. No entanto, como pudemos notar nessa análise, a questão da relação entre Poder Público e organizações sem fins lucrativos e os instrumentos que a oficializam está longe de ser apenas uma questão de criação de leis. Ela passa pela estrutura e cultura dos órgãos públicos, e até por questões políticas. É necessário vencer a resistência ao novo, a concentração geográfica peculiar à realidade brasileira e as dificuldades naturais decorrentes da utilização de qualquer novo mecanismo. Enquanto isso, é provável que 
os instrumentos existentes continuem a conviver juntos. $O$ Termo de Parceria só pode ser firmado com as OSCIPs e o Contrato de Gestão com as OSs, o que obriga a utilização do convênio com as organizações não qualificadas. Desta forma, mesmo não sendo o convênio um instrumento que atenda às necessidades geradas com a Reforma do Estado, parece que ainda não se criou substitutos adequados a ele. Talvez, a alternativa seja melhorar o mecanismo do convênio. Talvez, seja criar mais um mecanismo. $O$ fato é que a parceria entre o Estado e as organizações sem fins lucrativos na provisão de serviços deve permanecer e, provavelmente, até aumentar. Assim, permanece a necessidade de se elaborar um melhor instrumento de relação entre eles. $^{549}$

Passa-se, portanto, à análise dos conflitos que têm gerado a dificuldade de se estabilizar a opção por instrumento consensual de relacionamento entre a Administração Pública e o Terceiro Setor.

\subsection{Os conflitos legislativos que intimidam o desenvolvimento das parcerias e as necessárias alterações legislativas}

Antes de qualquer coisa, importa ressalvar que as ferramentas de mútua colaboração entre o Estado e o Terceiro Setor existentes atualmente na legislação brasileira são os convênios, os contratos de repasse e os termos de parceria. Embora os contratos administrativos se insiram no contexto das parcerias entre a Administração Pública e o Terceiro Setor de forma incidental, as suas características, suas funções, seus objetivos, etc., conforme já analisado anteriormente, não permitem considerá-los instrumentos de mútua colaboração entre as partes. Foram analisados em capítulo próprio num esforço de sistematização das formas de parceria entre a Administração Pública e o Terceiro Setor em um contexto geral.

A mútua colaboração, efetivamente, se dá através de convênios, contratos de repasse e termos de parceria. Os dois primeiros são instrumentos marcados pela vertente burocrática da Administração Pública, enquanto o último é a ferramenta criada para instalar uma nova formatação no relacionamento entre o Estado e as entidades sem fins lucrativos na área social.

Ocorre que as diferenças entre os institutos, sobretudo os diferenciais dos termos de parceria em relação aos convênios, acabam por serem eclipsadas pela insegurança jurídica decorrente da nossa confusa legislação sobre o tema das parcerias entre a Administração

\footnotetext{
${ }^{549}$ Ibidem, pp. 131-132, destaques nossos. Sobre a necessária regulação do Terceiro Setor, cf. NÓBREGA, Theresa Christine de Albuquerque. A regulação do Terceiro Setor no Brasil: uma reflexão sobre o regime jurídico dos termos de parceria. In: CARVALHO, Cristiano; PEIXOTO, Marcelo Magalhães (coord.). Aspectos jurídicos do Terceiro Setor. $2^{\mathrm{a}}$ ed., São Paulo : MP, pp. 403-430.
} 
Pública e o Terceiro Setor. Um emaranhado de leis difusas regula um sem número de temas que acabam por dificultar a compreensão dos limites de cada instrumento criado; títulos e qualificações antigos ainda convivem com outros mais modernos, a legislação tributária não auxilia na definição dos benefícios existentes a cada tipo de entidade, rígidas formas de controle ex ante competem atenção com uma diversidade de sobrepostos controles ex post, órgãos públicos diversos são chamados a fiscalizar este emaranhado... Enfim, a ausência de uma sistematização do setor tem gerado indefinição prejudicial à prestação de serviços de relevância social. Passemos a abordar sucintamente alguns destes problemas para, posteriormente, apontar sugestão de alteração legislativa com vistas a dar início a um clareamento na regulação das parcerias entre a Administração Pública e o Terceiro Setor.

\subsubsection{Convivência de títulos e qualificações: pela unificação do regime}

Sabe-se que a qualificação como Oscip foi instituída com pelo menos uma intenção evidente: a superação da chamada crise do título de utilidade pública. ${ }^{550}$ Conforme Joaquim Falcão e Carlos Cuenca à época, “o Terceiro Setor está incluído na pauta legislativa do Brasil de hoje porque a legislação está desatualizada. Defasada em relação à realidade. O setor mudou, cresceu, se fortaleceu; as leis, não". 551

Esta crise do título de utilidade pública ${ }^{552}$ a que se faz menção deve considerar não somente a legislação específica deste título, qual seja a Lei n. 91/35 e seu Decreto regulamentar n. 50.517/61, mas também a relativa ao então existente Certificado de

\footnotetext{
550 "A avaliação das propostas mais recentes de alteração do marco legal das entidades privadas de fins públicos no Brasil não pode prescindir de uma prévia consideração da crise do título de utilidade pública, qualificação tradicionalmente utilizada no país para as entidades do Terceiro Setor, bem como de uma análise das vantagens e desvantagens para as entidades do Terceiro Setor de receberem do Poder Público a concessão de títulos jurídicos especiais. A crise do título de utilidade pública federal explica uma parte expressiva das inovações contempladas no título de organização social e na proposta do título de organização da sociedade civil de caráter público" (MODESTO, Paulo. Reforma do marco legal do Terceiro Setor no Brasil. In: FALCÃO, Joaquim; CUENCA, Carlos (org.). Mudança social e reforma legal: estudos para uma nova legislação do Terceiro Setor. Brasília : Conselho da Comunidade Solidária : UNESCO : BID : FBB, 1999, p. 154). Em outra passagem: "Este caráter indiferenciado da referência às entidades do Terceiro Setor (qualificam-se do mesmo modo creches e clubes, escolas comunitárias e escolas privadas pagas etc.) e a debilidade do sistema de controle facilitaram a ocorrência de abusos importantes e fomentaram a desconfiança em atividades e relações de parceria em que confiança e probidade são valores fundamentais" (ibidem, p. 145).

${ }^{551}$ FALCÃO, Joaquim; CUENCA, Carlos. Diretrizes para nova legislação do terceiro setor. In: (org.). Mudança social e reforma legal: estudos para uma nova legislação do Terceiro Setor. Brasília : Conselho da Comunidade Solidária : UNESCO : BID : FBB, 1999, p. 22.

552 "A concessão de incentivos diretos ou indiretos e a legislação lacônica estimularam a proliferação de entidades de utilidade pública, muitas sem preencherem o fim exclusivo de servir desinteressadamente à coletividade" (ROCHA, Sílvio Luís Ferreira da. Terceiro setor. São Paulo : Malheiros, 2003, p. 60).
} 
Entidade Beneficente de Assistência Social (chamado $\mathrm{CEAS}^{553}$ ), qual seja a Lei n. 8.742/93 e seu Decreto regulamentar n. 2.536/98.

O título de utilidade pública federal é a mais antiga tentativa de distinção entre as atividades desenvolvidas desinteressadamente para a coletividade pelas sociedades civis, associações e fundações.

No que interessa ao presente trabalho, importa dizer que apesar da disposição expressa prevista no artigo $3^{\circ}$, da Lei n. ${ }^{\circ}$ 91/35, de que "nenhum favor do Estado decorrerá do título de utilidade pública, salvo a garantia de usa exclusivo, pela sociedade, associação ou fundação, de emblemas, flâmulas, bandeiras ou distintivos próprios, devidamente registrados no Ministério da Justiça", além, é claro, da menção ao título de utilidade pública federal, o que se observa é que ele vinha se prestando à concessão de alguns privilégios (em especial repasses financeiros), especialmente porque era requisito para o Registro no Conselho Nacional de Assistência Social e para a concessão do Certificado de Entidade Beneficente de Assistência Social, exigidos em algumas situações para a concessão de subvenções e auxílios.

O Certificado de Entidade Beneficente de Assistência Social - CEBAS tem origem na Lei n. ${ }^{o}$ 8.742, de 07 de dezembro de 1993, a Lei Orgânica da Assistência Social, que ao instituir a organização da assistência social atribuiu competência ao Conselho Nacional da Assistência Social para a concessão do Certificado. Regulamento pelo Decreto n. ${ }^{\circ}$ 2.536, de 6 de abril de 1998, o Certificado destinado às entidades beneficentes de assistência social que preenchessem exaustivos requisitos tinha as principais funções de possibilitar o recebimento de alguns repasses conforme a legislação financeira específica, firmar convênios na área da assistência social e permitir a isenção das contribuições para a seguridade social (cota patronal). Documento marcado por intensa insatisfação de todo o setor, notadamente por sua natureza absurdamente burocrática que dificultava tanto a sua obtenção quanto a sua manutenção, foi recentemente extinto para a criação de três outros títulos diversos que vêm sendo chamados Certificados Ministeriais.

Foi a Lei n. 12.101/2009 a incumbida destas alterações, convertendo o CEAS em três certificados distintos: i) Certificado de Entidade de Saúde, concedido pelo Ministério da Saúde; ii) Certificado de Entidade de Educação, concedido pelo Ministério da Educação; e iii) Certificado de Entidade de Assistência Social, concedido pelo Ministério do Desenvolvimento Social e Combate à Fome. Esta lei, ainda não regulamentada, pode

$\overline{{ }^{553} \text { Revogado pela Lei n. } 12.101 / 09 .}$ 
receber elogios na medida em que extinguiu um certificado cuja regulamentação trazia insegurança jurídica que passava do insustentável tanto para as entidades do Terceiro Setor como para os órgãos públicos envolvidos. No entanto, fomentada expressamente por motivos de natureza tributária ${ }^{554}$, uma crítica oportuna no que toca ao presente trabalho diz respeito à triplicação de Certificados.

Para resumir o quadro legal, especificamente comparando com o regime das parcerias entre a Administração Pública e o Terceiro Setor, temos a seguinte situação:

a) Entidades sem fins lucrativos sem titulação ou qualificação específica, que podem firmar convênios e contratos de repasse para receber subvenções, auxílios e contribuições, desde que desenvolvam determinadas atividades; ${ }^{555}$

b) Entidades sem fins lucrativos detentoras do Título de Utilidade Pública Federal, que embora em vigor não têm o condão de dotá-las de benefício específico, mas que podem firmar convênios e contratos de repasse para receber subvenções, auxílios e contribuições, desde que desenvolvam determinadas atividades;

c) Entidades sem fins lucrativos detentoras do Certificado de Entidade Beneficente de Assistência Social em vigor ${ }^{556}$, que podem firmar convênios e contratos de repasse para receber subvenções, auxílios e contribuições, desde que desenvolvam determinadas atividades; ${ }^{557}$

d) Entidades sem fins lucrativos qualificadas como Organizações da Sociedade Civil de Interesse Público - Oscips, que podem firmar termo de parceria com o Poder Público e/ou firmar convênios e contratos de repasse para receber subvenções, auxílios e contribuições.

Este quadro normativo de convivência de diversos instrumentos de titulação e qualificação das entidades do Terceiro Setor, notadamente por abranger uma quantidade enorme de dispositivos infra-legais de difíceis cumprimento e compreensão, acaba por

\footnotetext{
554 Mais precisamente para tentar clarear os requisitos para a fruição da isenção a contribuições para a seguridade social anteriormente previstos no revogado artigo 55, da Lei n. 8.212/91, embora entendamos que tenha perdido oportunidade de tratar o problema de forma ampla e adequada, criando ainda conflitos interpretativos em relação aos requisitos para a fruição da imunidade tributária prevista no artigo $195, \S 7^{\circ}$, da Constituição Federal.

555 “Observa-se, das disposições referidas da LDO, que os recursos sob a forma de contribuições, auxílios e subvenções sociais serão transferidos voluntariamente para entidades sem fins lucrativos conquanto estas possuam determinados títulos e/ou desenvolvam certas atividades" (SALINAS, Natasha Schmitt Caccia. Avaliação legislativa no Brasil: um estudo de caso sobre as normas de controle das transferências voluntárias de recursos públicos para entidades do terceiro setor. Dissertação de mestrado. São Paulo, Faculdade de Direito da USP, 2008, p. 117).

${ }^{556}$ Lei n. 12.101/09: “Art. 38. As entidades certificadas até o dia imediatamente anterior ao da publicação desta Lei poderão requerer a renovação do certificado até a data de sua validade".

${ }^{557}$ Como a Lei n. 12.101/09 ainda não foi regulamentada, as hipóteses de qualificação nela previstas ainda não ocorreram.
} 
tumultuar a tomada de decisões tanto do gestor da entidade sem fins lucrativos quanto do administrador público.

Não se está aqui a falar da confusão legislativa dos diplomas anteriores à Lei das Oscip, sobretudo porque esta seria a resposta legislativa apresentada a este problema. O que se está a advogar é que a Leis das Oscip - e, mais recentemente, a Lei n. 12.101/09perdeu oportunidade de unificar o regime de concessão de títulos que tanta confusão tem causado em nosso sistema.

No entanto, para dar o tom e justificar a nossa defesa de que a quantidade de títulos e qualificações existente em nada auxilia no aperfeiçoamento do regime jurídico do Terceiro Setor no país, trazemos à colação as constatações de Ferrarezi sobre os antigos regimes, nos quais inserimos o trazido pela Lei n. 12.101/09:

Embora tenha havido mudanças na concessão do certificado, tornando-o mais seletivo, há distorções nesse sistema antigo - que ainda vigora. A primeira é a crença de que as sucessivas barreiras burocráticas dificultariam a ocorrência de favoritismo, quando se sabe que quanto mais dificuldades burocráticas são acrescidas, mais riscos de tráfico de influências.(...)

A segunda trata do emaranhado de leis, decretos e resoluções internas que foram sendo criados e recriados, com vínculos entre as várias exigências - que se baseiam mais em "tradição" do que numa referência racional e justa para alocação de recursos públicos. (...) Terceiro: chama a atenção o anacronismo dessa legislação, com suas exigências vinculadas para as isenções face ao impacto efetivo sobre a sociedade vis a vis o custo de gerir e analisar processos com inúmeros documentos contábeis, os recursos em caso de indeferimentos, a atualização dos títulos vinculados, repetição de requisitos administrativos em diferentes órgãos públicos etc. Não há justificativa racional para essa organização de trabalho - sobreposto e de eficácia duvidosa. Nessa concepção de domínio burocrático, a efetividade, o valor que aporta para a sociedade, e os resultados não importam, o que importa é justificar os meios pelos quais a burocracia reproduz seu próprio domínio. Os órgãos responsáveis pela emissão desses títulos se tornaram analistas de documentos formais em detrimento da análise da relevância pública das ações dessas associações. ${ }^{558}$

Temos para nós, portanto, que este seja o primeiro dos problemas a serem enfrentados no presente momento em que se propõe um novo marco legal para as relações entre a Administração Pública e o Terceiro Setor, cristalizando o regime jurídico aplicável a estas situações.

\subsubsection{Seleção do parceiro privado: necessidade de previsão específica}

${ }^{558}$ FERRAREZI, Elisabete. O novo marco legal do terceiro setor no Brasil. 2001, p. 5. Disponível na Internet: < http://www.lasociedadcivil.org/docs/ciberteca/ferrarezi.pdf>. Acesso em: 24 abr. 2010. 
A regulamentação dos convênios ${ }^{559}$ e dos termos de parceria apresenta conflitos também quanto à seleção do parceiro privado, merecendo reformulação para um melhor aproveitamento das relações entre o Poder Público e o Terceiro Setor.

Como já visto em tópicos anteriores, para a celebração de convênio e termo de parceria não é necessário que o órgão público parceiro realize licitação. Por estarem no grupo dos instrumentos de mútua colaboração entre a Administração Pública e parceiros privados, considera-se incompatível a seleção através de procedimento licitatório.

Ficou a cargo de cada legislação estabelecer a forma de seleção do parceiro privado para cada tipo de relacionamento.

No que toca aos convênios, embora não sujeitos ao procedimento licitatório devem observância a procedimento específico de seleção previsto no artigo 116, da Lei n. 8.666/93, mediante a apresentação de minucioso plano de trabalho:

Art. 116. Aplicam-se as disposições desta Lei, no que couber, aos convênios, acordos, ajustes e outros instrumentos congêneres celebrados por órgãos e entidades da Administração.

$\S 1^{\underline{0}} \mathrm{~A}$ celebração de convênio, acordo ou ajuste pelos órgãos ou entidades da Administração Pública depende de prévia aprovação de competente plano de trabalho proposto pela organização interessada, o qual deverá conter, no mínimo, as seguintes informações:

I - identificação do objeto a ser executado;

II - metas a serem atingidas;

III - etapas ou fases de execução;

IV - plano de aplicação dos recursos financeiros;

$\mathrm{V}$ - cronograma de desembolso;

VI - previsão de início e fim da execução do objeto, bem assim da conclusão das etapas ou fases programadas;

VII - se o ajuste compreender obra ou serviço de engenharia, comprovação de que os recursos próprios para complementar a execução do objeto estão devidamente assegurados, salvo se o custo total do empreendimento recair sobre a entidade ou órgão descentralizador.

Além deste dispositivo, o artigo $2^{\circ}$, caput, da Instrução Normativa n. 01/97, com as alterações promovidas pela Instrução Normativa n. 04/07, estabelece que “o convênio será proposto pelo interessado ao titular do Ministério, órgão ou entidade responsável pelo programa, mediante a apresentação do Plano de Trabalho (Anexo I), que conterá, no mínimo, as seguintes informações". A ao caput segue uma lista de exigências que avança do rigorismo formal ao exagero. ${ }^{560}$ Fossem cumpridas todas as exigências, poderíamos

\footnotetext{
559 Quando tratamos dos convênios considere-se incluídos os contratos de repasse, salvo comentário específico em cada caso.

${ }^{560}$ A título de documentação, são as seguintes as informações exigidas pelo dispositivo: “I - razões que justifiquem a celebração do convênio; II - descrição completa do objeto a ser executado; III - descrição das
} 
metas a serem atingidas, qualitativa e quantitativamente; III-A - licença ambiental prévia, quando o convênio envolver obras, instalações ou serviços que exijam estudos ambientais, como previsto na Resolução no 001, de 23 de janeiro de 1986, do Conselho Nacional do Meio Ambiente (CONAMA), publicada no Diário Oficial da União de 17 de fevereiro daquele ano; IV - etapas ou fases da execução do objeto, com previsão de início e fim; V - plano de aplicação dos recursos a serem desembolsados pelo concedente e a contrapartida financeira do proponente, se for o caso, para cada projeto ou evento; VI - cronograma de desembolso; VII comprovação pelo convenente de que não se encontra em situação de mora ou inadimplência perante órgão ou entidade da Administração Pública Federal Direta e Indireta; VIII - comprovação do exercício pleno dos poderes inerentes à propriedade do imóvel, mediante certidão emitida pelo cartório de registro de imóveis competente, quando o convênio tiver por objeto a execução de obras ou benfeitorias no imóvel; e : IX admite-se, por interesse público ou social, condicionadas à garantia subjacente de uso pelo prazo mínimo de vinte anos, as seguintes hipóteses alternativas à comprovação do exercício pleno dos poderes inerentes à propriedade do imóvel, prevista no inciso VIII do "caput" deste artigo: a) posse de imóvel: a.1) em área desapropriada ou em desapropriação por Estado, por Município, pelo Distrito Federal ou pela União; a.2) em área devoluta; a.3) em territórios ocupados por comunidades quilombolas ou indígenas, devidamente certificadas por órgão ou entidade competente; b) imóvel recebido em doação: b.1) da União, do Estado, do Município ou do Distrito Federal, já aprovada em lei, conforme o caso e se necessária, inclusive quando o processo de registro de titularidade do imóvel ainda se encontrar em trâmite; b.2) de pessoa física ou jurídica, inclusive quando o processo de registro de titularidade do imóvel ainda se encontrar em trâmite, neste caso, com promessa formal de doação irretratável e irrevogável; c) imóvel que, embora ainda não haja sido devidamente consignado no cartório de registro de imóveis competente, pertence a Estado que se instalou em decorrência da transformação de Território Federal, ou mesmo a qualquer de seus Municípios, por força de mandamento constitucional ou legal; d) imóvel pertencente a outro ente público que não o proponente, desde que a intervenção esteja autorizada pelo proprietário, por meio de ato do chefe do poder executivo ou titular do órgão detentor de delegação para tanto; e) contrato ou compromisso irretratável e irrevogável de constituição de direito real sobre o imóvel, na forma de cessão de uso, concessão de direito real de uso, concessão de uso especial para fins de moradia, aforamento ou direito de superfície; f) imóvel ocupado que, independentemente da sua dominialidade, esteja inserido em Zona Especial de Interesse Social (Zeis), instituída na forma prevista na Lei $\mathrm{n}^{\circ}$ 10.257, de 10 de julho de 2001 (Estatuto da Cidade), devendo, neste caso, serem apresentados os seguintes documentos: f.1) cópia da publicação, em periódico da Imprensa Oficial, da lei estadual, municipal ou distrital federal instituidora da Zeis; f.2) demonstração de que o imóvel beneficiário do investimento encontra-se na Zeis instituída pela lei referida no item anterior; e f.3) declaração firmada pelo chefe do poder executivo (governador ou prefeito) do ente federativo a que o convenente seja vinculado de que os habitantes da Zeis serão beneficiários de ações visando à regularização fundiária da área habitada para salvaguardar seu direito à moradia; g) imóvel objeto de sentença favorável aos ocupantes, transitada em julgado, proferida em ação judicial de usucapião ou concessão de uso especial para fins de moradia, nos termos do art. 183 da Constituição Federal, da Lei n 10.257, de 2001, e da Medida Provisória $\mathrm{n}^{\mathbf{0}}$ 2.220, de 4 de setembro de 2001; h) imóvel tombado pelo Instituto do Patrimônio Histórico e Artístico Nacional (Iphan), desde que haja aquiescência do Instituto. $\S 1^{\circ}$ Integrará o Plano de Trabalho a especificação completa do bem a ser produzido ou adquirido e, no caso de obras, instalações ou serviços, o projeto básico, entendido como tal o conjunto de elementos necessários e suficientes para caracterizar, de modo preciso, a obra, instalação ou serviço objeto do convênio, ou nele envolvida, sua viabilidade técnica, custos, fases ou etapas, e prazos de execução, devendo, ainda, conter os elementos discriminados no inciso IX do art. $6^{\circ}$ da Lei no- 8.666 , de 21 de junho de 1993, inclusive os referentes à implementação das medidas sugeridas nos estudos ambientais eventualmente exigidos, conforme disposto no art. 12 da Lei $\mathrm{n}^{0} 6.938$, de 31 de agosto de 1981. § $2^{\circ}$ A contrapartida, de responsabilidade dos Estados, Municípios e do Distrito Federal, bem como das respectivas entidades autárquicas, fundacionais ou de direito privado (empresas públicas ou sociedades de economia mista), será estabelecida de modo compatível com a capacidade financeira do ente federativo beneficiado, observados os limites (percentuais) e as ressalvas estabelecidos na lei federal anual de diretrizes orçamentárias. $\S 3^{\circ} \mathrm{O}$ ente federativo beneficiado deverá comprovar que os recursos referentes à contrapartida para complementar a consecução do objeto do convênio estão devidamente assegurados, ressalvada a hipótese prevista no inciso VII do $\S 1^{\circ}$ do art. 116 da Lei $n^{\circ} 8.666$, de 1993. $\S 4^{\circ}$ Os beneficiários das transferências de que trata o art. $1^{\circ}$ desta Instrução Normativa, quando integrantes da Administração Pública de qualquer esfera de governo, deverão incluí-las em seus orçamentos. $\S 5^{\circ}$ A celebração de convênio visando à realização de serviços ou execução de obras a serem custeadas, ainda que apenas parcialmente, com recursos externos dependerá da prévia contratação da operação de crédito externo. $\S 6^{\circ} \mathrm{O}$ Estado, o Município ou Distrito Federal, bem como seus respectivos órgãos ou entidades, somente poderá figurar como convenente se atender a todas as exigências discriminadas na Constituição Federal, na Lei Complementar nº 101, de 4 de maio de 2000 (Lei de Responsabilidade Fiscal - 
criticar no sentido de serem demasiadamente formais e pouco voltadas ao controle dos resultados do convênio firmado. Ocorre que, como visto no caput, faz-se menção ao Anexo I da Instrução Normativa quanto ao plano de trabalho, e nele se encontra modelo que aparenta não compreender todas as exigências da lista do artigo $2^{\circ}$.

Como observa Natasha Schmitt Caccia Salinas,

embora estas informações constituam exigências previstas em atos normativos de natureza legal e também administrativa, a referida legislação não estabelece parâmetros precisos para que a administração pública avalie a adequação de cada um dos referidos itens do plano de trabalho. ${ }^{561}$

LRF), na lei federal anual de diretrizes orçamentárias (LDO), nesta Instrução Normativa e demais normas pertinentes. $\S 7^{\circ}$ Quando o convênio envolver montante igual ou inferior ao previsto na alínea 'a' do inciso II do "caput" do art. 23 da Lei $\mathrm{n}^{0}$ 8.666, de 1993, poderá integrar o Plano de Trabalho projeto básico simplificado, contendo especificações mínimas, desde que essa simplificação não comprometa o acompanhamento e controle da execução da obra ou instalação. $\S 8^{\circ}$ Para fins de celebração do convênio, admite-se projeto básico sob a forma de pré-projeto, desde que do termo de convênio conste cláusula específica suspensiva que condicione a liberação da parcela única ou da primeira das parcelas de recursos do convênio à prévia apresentação do projeto básico na forma prevista nos $\S \S 1^{\circ}$ ou 7 o- deste artigo, conforme o caso. $\S 9^{\circ} \mathrm{O}$ pré-projeto de que trata o $\S 8$ o- deste artigo deverá conter o cronograma de execução da obra ou serviço (metas, etapas ou fases), o plano de aplicação dos recursos envolvidos no convênio, discriminandose, inclusive, os valores que correrão à conta da contrapartida, e o cronograma de desembolso dos recursos, em quotas pelo menos trimestrais, permitida, na hipótese de o pré-projeto não ser aceito pelo concedente, a apresentação dos detalhes de engenharia no projeto básico. $\S 10$. Visando a evitar atraso na consecução do objeto do convênio, pelo descumprimento do cronograma de desembolso de recursos, o concedente deverá desenvolver sistemática específica de planejamento e controle dos convênios, de maneira a se garantir harmonia entre sua execução física e a financeira, esta subordinada aos decretos de programação financeira do Poder Executivo federal. § 11. Nas hipóteses previstas no item 'a.1' da alínea 'a' do inciso IX do "caput" deste artigo, quando o processo de desapropriação não estiver concluído, é permitida a comprovação do exercício pleno dos poderes inerentes à propriedade do imóvel via Termo de Imissão Provisória de Posse ou alvará do juízo da vara onde o processo estiver tramitando, admitindo-se, ainda, caso esses documentos não hajam sido emitidos, a apresentação, pelo proponente do convênio, de cópia da publicação, na Imprensa Oficial, do decreto de desapropriação e do Registro Geral de Imóveis (RGI) do imóvel, acompanhado do acordo extrajudicial firmado com o expropriado. $\S 12$. Na hipótese prevista na alínea ' $b$ ' do inciso IX do "caput" deste artigo, é imperativa a apresentação da promessa formal de doação (termo de doação), irretratável e irrevogável, caso o processo de registro da doação ainda não haja sido concluído. § 13. Quando o convênio tiver por objeto obras habitacionais ou urbanização de interesse público ou social, deverá constar no instrumento de autorização ou, se for o caso, no contrato ou compromisso, de que tratam as alíneas 'd' e 'e' do inciso IX do "caput" deste artigo, a obrigação de se realizar a regularização fundiária em favor das famílias moradoras ou a cessão do imóvel ao proponente do convênio a fim de que este possa promovê-la. $\S$ 14. Nas hipóteses previstas no item 'a.3' da alínea 'a' do inciso IX do "caput" deste artigo, a fim de assegurar o uso coletivo do bem, as obras e benfeitorias deverão ser realizadas nas áreas ocupadas pelas comunidades, o que deverá ser comprovado: I - quando se tratar de territórios ocupados por comunidades quilombolas, mediante: a) certidão de que trata o $\S 4^{\circ}$ do art. $3^{\circ}$ do Decreto $\mathrm{n}^{\circ} 4.887$, de 20 de novembro de 2003; e b) portaria de órgão da União, dos Estados, do Distrito Federal ou dos Municípios, responsável pela delimitação, demarcação e regularização das terras quilombolas nos entes federativos, reconhecendo e declarando os limites do território quilombola, conforme o art. $3^{\circ}$ do Decreto $\mathrm{n}^{\circ} 4.887$, de 2003 . II - quando se tratar de territórios tradicionalmente ocupados por comunidades indígenas, mediante documento expedido pela Fundação Nacional do Índio (Funai). § 15. Nas hipóteses previstas no item 'a.3' da alínea 'a' do inciso IX do caput deste artigo, quando se tratar de território ocupado por comunidade quilombola, a garantia será prestada mediante declaração do representante oficial da comunidade, registrada em cartório, sendo dispensável no caso de territórios tradicionalmente ocupados por indígenas".

${ }^{561}$ SALINAS, Natasha Schmitt Caccia. Op. cit., p. 118. 
A formalidade legal não repercute na prática dos convênios, cujos planos de trabalho são feitos de forma a não se prestarem efetivamente à seleção do parceiro privado, mas para preencher o requisito legal. Aliás, "a ausência de parâmetros de seleção de projetos a serem desenvolvidos por entidades do terceiro setor revela uma despreocupação (ou uma preocupação intencionalmente oculta) de que interesses particularísticos se apropriem de processos internos do Estado". 562

Esta preocupação é pertinente especialmente em virtude da possibilidade de entidades privadas firmarem convênios com o Poder Público para a efetivação de transferências voluntárias através do instrumento das emendas parlamentares ao orçamento $^{563}$, ferramentas que podem beneficiar nominalmente determinada entidade ou todas as entidades de uma região indistintamente. Mais uma prova de que a realização de plano de trabalho é instrumento que não se presta à seleção efetiva da entidade merecedora de recursos públicos, mas ao mero cumprimento formal da lei.

O resultado dessas lacunas legislativas propicia um cenário em que os planos de trabalho são mal elaborados, seus objetos são imprecisos, suas metas são insuficientemente descritas, sem uma coerente mensuração de suas unidades de produto e insumos, seus projetos básicos não são apresentados, ou o são de forma incompleta e com informações insuficientes etc. ${ }^{564}$

\footnotetext{
562 Ibidem, p. 111.

563 "Esta ausência de parâmetros de atuação para a discricionariedade administrativa no tocante à destinação de recursos públicos revela-se ainda mais complexa nos casos em que são contemplados nominalmente, por meio de emendas parlamentares ao orçamento, Estados, Municípios e entidades privadas que se beneficiarão das transferências voluntárias. Além das emendas propostas individualmente pelos parlamentares, as bancadas também podem propor alterações no orçamento, desde que estas se destinem indistintamente a todas as entidades sem fins lucrativos localizados em uma determinada região do país. Diante desse cenário, verifica-se que os parlamentares procuram beneficiar, por meio da proposição de emendas ao orçamento, entidades públicas e privadas localizadas em sua base de apoio, sem uma preocupação em alocar estrategicamente os recursos públicos de modo a atender às prioridades nacionais. Em decorrência dessas práticas, há quem afirme que o orçamento público não representa outra coisa que não uma 'colcha de retalhos', cujo conjunto não guarda nenhuma coerência ou unidade, havendo também quem conclua, de forma ainda mais extremada, que "não se fazem políticas públicas por intermédio de transferências voluntárias" (ibidem, p. 112).

${ }^{564}$ Ibidem, p. 119. Esta situação, aliás, é confirmada por auditoria elaborada a pedido do Tribunal de Contas da União em convênios celebrados entre órgãos federais e entidades sem fins lucrativos, divulgada através do Acórdão n. 2066/06, conforme o seguinte trecho: "10. Consolidando os trabalhos das fiscalizações realizadas nos 28 convênios auditados pelas Secretarias de Controle Externo nos Estados do Amazonas, Bahia, Ceará, Goiás, Pernambuco, Rio de Janeiro, Rondônia e Roraima, o Relatório ora em exame apresenta os principais achados de auditoria. Sobre o assunto, reproduzo, a seguir, excertos da análise feita pela Adfis, com o intuito de evitar a perda de informação. '3.1 Planos de trabalho mal elaborados. Objetos imprecisos. Metas insuficientemente descritas. Projetos básicos ausentes, incompletos ou com informações insuficientes. 3.1.1 A insuficiência e até mesmo a falta das informações exigidas pela IN-STN 01/97, que rege a celebração de convênios no âmbito federal é característica comum nos planos de trabalho dos convênios pactuados. 3.1.2 Os objetos não são definidos com precisão, faltam especificações completas de seus elementos característicos descritas de forma detalhada, objetiva e clara de modo a permitir a identificação exata do que se pretende realizar ou obter. 3.1.3 Em geral, as metas são descritas com insuficiência de informações qualitativas e quantitativas, muitas vezes de forma genérica, de difícil entendimento. Não trazem informações que
} 
O Decreto n. 6.170/07 prevê a possibilidade de o órgão público elaborar seleção de projetos através de chamamento público para a assinatura de convênios: "Art. $4^{\mathrm{o}} \mathrm{A}$ celebração de convênio com entidades privadas sem fins lucrativos poderá ser precedida de chamamento público, a critério do órgão ou entidade concedente, visando à seleção de projetos ou entidades que tornem mais eficaz o objeto do ajuste". No entanto, não resolve a situação em virtude de tal procedimento não interferir na sistemática do plano de trabalho existente e, principalmente, por ser opcional.

No que diz respeito aos termos de parceria, vimos que também não estão sujeitos ao procedimento licitatório e que a sua legislação específica estabelece a possibilidade de elaboração de concurso de projetos para a escolha do parceiro privado. Como já nos manifestamos, o fato de a legislação prever a possibilidade de termos de parceria serem firmados diretamente entre o Poder Público e a entidade do Terceiro Setor interessada na parceria é ponto fraco que deslegitima o instituto, por permitir que se incorra nos mesmos equívocos acompanhados na assinatura de convênios, notadamente no que diz respeito ao direcionamento dos recursos movido por interesses políticos.

Não à toa, como visto, o Tribunal de Contas da União sugeriu a alteração do dispositivo para exigir o concurso de projetos para termos de parceria que envolvessem valores superiores a um determinado patamar $^{565}$, e depois sugeriu a obrigatoriedade do concurso para todos os termos de parceria ${ }^{566}$.

permitam avaliar os objetivos que se pretende atingir, como serão realizadas as ações e o que se obterá concretamente em termos de produtos ou serviços a serem prestados à comunidade. 3.1.4 A falta de clareza nos desdobramentos das metas e das ações que efetivamente deverão ser implementadas, redundam em cronogramas de desembolso irreais, sem correlação entre as etapas de execução física e os aportes requeridos, de modo a quantificar realisticamente ao longo do tempo as parcelas de recursos necessárias, potencializando, assim, a liberação excessiva ou insuficiente de recursos em prejuízo da racionalidade administrativa e dos serviços que se pretende disponibilizar à população'. 11. O ACE Coordenador também relata a ausência de projeto básico em diversos convênios, dificultando a avaliação dos planos de trabalho, possibilitando o desvirtuamento do objeto e a ocorrência de outras irregularidades em fases posteriores. '3.2 Deficiências na avaliação técnica e apreciação jurídica dos planos de trabalho e termos de convênios. Inexistência de análises detalhadas de custo dos objetos propostos e da capacidade das entidades proponentes para executá-los. Aprovação de convênios na ausência ou à revelia de pareceres. Descentralização de execução a entidades que não dispõem de condições para consecução dos objetos ou atribuições estatutárias para executá-los. 3.2.1 De modo geral, as análises técnicas são caracterizadas pela superficialidade e insuficiência. Na totalidade dos casos, inexiste qualquer avaliação quanto a qualificação técnica e operacional da convenente para consecução dos objetos propostos. Em grande parte não se faz qualquer análise detalhada e documentada dos custos envolvidos. A ausência de restrições às deficiências dos planos de trabalho, descritas no achado anterior, associada às inconsistências entre os pareceres e os elementos constantes do processo sugerem um padrão de análise tão somente pro forma"” (TRIBUNAL DE CONTAS DA UNIÃO, Plenário, acórdão n. 2066/2006, Relator Min. Marcos Bemquerer, DOU 13 de novembro de 2006).

565 “Texto original: 'Art. 23. A escolha da Organização da Sociedade Civil de Interesse Público, para a celebração do Termo de Parceria, poderá ser feita por meio de edital de concursos de projetos pelo órgão estatal parceiro para obtenção de bens e serviços e para a realização de atividades, eventos, consultorias, 
E realmente merece revisão esta faculdade prevista na legislação para a assinatura de concurso de projetos. Justamente por esta indefinição legal, administradores públicos têm optado pela assinatura de convênios mesmo com entidades qualificadas como Oscip, como já apontado com base em pesquisa realizada por Valéria Maria Trezza. É constatação que exige a reformulação legal, pois aponta um looping legislativo preocupante: critica-se o sistema de seleção de projetos dos convênios, em virtude de sua marca burocratizante e política, criando-se legislação moderna e voltada ao consensualismo que, no entanto, apresenta falhas que estimulam a assinatura de convênios. ${ }^{567}$

\subsubsection{Incompatibilidades legislativas quanto ao destino dos recursos repassados}

cooperação técnica e assessoria.' Texto sugerido: 'Art. 23. A escolha da Organização da Sociedade Civil de Interesse Público, para a celebração do Termo de Parceria, deverá ser feita por meio de edital de concursos de projetos pelo órgão estatal parceiro, sempre que os valores a serem repassados pelo órgão estatal atinja o limite de R\$ ........................ C. Comentário: ‘A utilização da palavra 'poderá' torna o texto original meramente recomendatório, deixando à discricionariedade do administrador a decisão de optar ou não pelo concurso. Considerando que o concurso exige trâmites burocráticos que podem onerar a eficiência do processo de seleção para os Termos de Parceria, infere-se que a sua mera sugestão, no corpo do Decreto, será pouco efetiva. Cabe lembrar que a realização do concurso busca a isonomia no tratamento das OSCIPs e a melhor eficiência na realização do objeto pactuado. A título de racionalização, poderia ser estabelecido um limite de valor a partir do qual seria obrigatório o concurso. Tal valor seria calculado a partir da relação custo benefício para as OSCIP participarem do certame. Outra questão a destacar é que os tipos de objetos enumerados no texto original parecem confrontar-se com a finalidade legal dos Termos de Parceria. Segundo o art. $8^{\circ}$ do Decreto, a parceria deve objetivar o fomento e a execução das atividades de interesse público previstas no art. $3^{\circ}$, da Lei $\mathrm{n}^{\circ}$ 9.790/99. Aquele artigo enumera as finalidades precípuas das OSCIPs, não englobando, conforme parece, o fornecimento de bens ou serviços de assessoria, consultoria, promoção de eventos, nem atividades de cooperação técnica. A ocorrência comum desses objetos nos convênios atuais (cursos, seminários, aquisição de serviços etc.) suscita a questão do possível uso do convênio como fuga ao processo de licitação. Ainda nesse sentido, poderiam ser incluídas no Decreto as seguintes vedações aos Termos de Parceria e/ou às OSCIPs: terceirização de atividades meio no Setor Público; utilização de instalações públicas para realização dos serviços contratados; aquisição de bens e serviços para uso pela Administração Pública” (TRIBUNAL DE CONTAS DA UNIÃO, Decisão n. 931/1999, Plenário, Relator Min. Marcos Vilaça, BCTU 78/1999).

566 “80. Por fim, cabe assinalar a existência de previsão, no Decreto n. ${ }^{\circ} 3.100 / 99$, de escolha de Oscip por meio da publicação de edital de concursos de projetos. A previsão é uma faculdade conferida à Administração e não infirma a conclusão acerca da inaplicabilidade da Lei n. ${ }^{\circ}$ 8.666/93 para a escolha de Oscip para a celebração de Termo de Parceria. Ao contrário, o Decreto, de forma muito correta, estabeleceu um método objetivo de seleção de Oscip para a firmatura de Termo de Parceria. Lamento somente que esse método impessoal só se aplique aos casos em que a Administração eleger, com base em critérios de conveniência e oportunidade. Assim, penso que se possa determinar, como sugere o Ministro Ubiratan Aguiar, em lugar de apenas recomendar, como fiz constar de minha proposta original, ao Ministério do Planejamento e à Casa Civil da Presidência da República que examinem a possibilidade de incluir no Decreto dispositivo que determine a aplicação do critério de seleção de Oscip previsto no art.23 em toda e qualquer situação" (TRIBUNAL DE CONTAS DA UNIÃO, Acórdão 1777/2005, Plenário, Relator Min. Marcos Vilaça, DOU 20 de novembro de 2005).

567 Sobre a problemática da concorrência no âmbito dos convênios entre a Administração Pública e o Terceiro Setor na Itália, cf. PELLIZZER, Franco; SANTI, Giacomo. La “convenzione” con gli enti non profit fra sistema contrattualistico comunitário, normative nazionali ed intervento attuativo regionale. In: CARINCI, Franco (org.) Non profit e volontariado: profili giuridico istituzionali 1. Milano : IPSOA, 1999, pp. 139-173. 
Outro tema que gera controvérsias no âmbito do relacionamento entre a Administração Pública e o Terceiro Setor, mesmo no regime da Lei das Oscip, diz respeito às incompatibilidades legislativas quanto ao destino dos recursos repassados às entidades sem fins lucrativos.

No regime dos convênios estas limitações são bastante numerosas. Já tratamos sucintamente da impossibilidade de pagamento de taxa de administração, bem como da limitação à utilização dos recursos em despesas de custeio das entidades, mas há muitas outras limitações que têm o intuito de "garantir que os recursos transferidos não sejam desviados do objeto pactuado, uma vez que despesas gerais das entidades sem fins lucrativos, não decorrentes da realização do objeto do convênio, poderiam ser suportados por esses recursos". 568

Boa parte das limitações impostas pela legislação dos convênios "revela-se mais ajustável às parcerias público-públicas (entre União e Estados ou entre União e Municípios)". 569

Embora a Lei das Oscip, com o claro intuito de flexibilizar as normas previstas na regulamentação dos convênios, apresente poucas limitações à utilização dos recursos, dois fenômenos merecem ser citados quanto ao tema. O primeiro deles diz respeito aos reflexos das leis orçamentárias na destinação de recursos recebidos através de termos de parceria firmados entre entes públicos e Oscips e o segundo à utilização das normas limitadoras previstas para os convênios em termos de parceria firmados.

Em primeiro lugar, é de se dizer que a utilização de recursos públicos pelas Oscips encontra barreira na Lei de Diretrizes Orçamentárias, a exemplo do artigo 21, da Lei n. 12.017/2009 (LDO para exercício 2010). As leis orçamentárias, notadamente por sua precariedade, não têm acompanhado as diversas facetas do relacioamento entre a Administração Pública e o Terceiro Setor, merecendo reforma.

É necessário promover alterações na legislação do Direito Fianceiros referentes às normas para transferência de recursos da União para o setor privado. As atuais não parecem suficientemente adequadas para atender às diferentes situações permissivas e impeditivas das situações de fomento direto do Estado às entidades do terceiro setor. Isso porque as regras atuais têm vigência precária, uma vez que vêm sendo reproduzidas, recorrentemente, nas LDOs. Devem, portanto, tornarem-se permanentes, mediante apresentação e aprovação de proeto de lei com os aperfeiçoamentos que se fizerem necessários. O mesmo diga-se da

\footnotetext{
${ }^{568}$ SALINAS, Natasha Schmitt Caccia. Op. cit., p. 120.

${ }^{569}$ Ibidem, p. 121. Sobre as demais limitações existentes no regime dos convênios e seu desajustamento aos convênios público-privados, cf. a mesma obra, pp. 119-123.
} 
tramitação das leis orçamentárias e da apresentação de emendas parlamentares ao orçamento. ${ }^{570}$

Em segundo lugar, a instabilidade jurídica criada pelo conjunto desconcertado de leis acaba por incentivar a utilização das limitações impostas pela legislação dos convênios também aos termos de parceria. Não raro se encontram termos de parceria que contêm a previsão de impedir a utilização dos recursos públicos repassados para a remuneração do funcionário da entidade privada gestor do termo de parceria, ou expressamente impedindo a utilização das verbas para o pagamento de qualquer verba de custeio da entidade, mesmo que estritamente relacionada ao objeto do termo de parceria.

Por estes motivos, é tópico que merece revisão legislativa para esclarecer os limites de cada regime jurídico existente para a formalização de parcerias entre a Administração Pública e o Terceiro Setor.

\subsubsection{Pluralidade de órgãos certificadores: pela unificação da certificação}

Problema que não atinge a celebração de convênios em todas as situações mas que de forma no mínimo indireta interfere em todo o sistema de parcerias entre a Administração Pública e o Terceiro Setor, diz respeito à pluralidade de órgãos certificadores.

Como a assinatura de convênio não pressupõe que a entidade seja detentora de títulos, somente em alguns casos, esta pluralidade é mais grave para o sistema como um todo que propriamente para os convênios. Cabe a ressalva de que o título usualmente exigido para a assinatura de convênios é o Certificado de Entidade Beneficente de Assistência Social, que será substituído pelos Certificados Ministeriais.

Mas em decorrência da pluralidade de títulos e qualificações existentes em nosso ordenamento jurídico, existe também uma pluralidade de órgãos certificadores das entidades aptas a receberem esta outorga.

Atualmente, o Ministério da Justiça é responsável pela qualificação como Oscip e pela concessão do Título de Utilidade Pública Federal. O Conselho Nacional da Assistência Social, até então responsável pela concessão do CEAS, foi substituído pelos Ministérios da Saúde, da Educação e do Desenvolvimento Social e Combate à Fome, na função de certificação.

\footnotetext{
${ }^{570}$ DIAS, Maria Tereza Fonseca. Terceiro setor e Estado: legitimidade e regulação: por um novo marco jurídico. Belo Horizonte : Fórum, 2008, p. 345.
} 
A Lei n. 9.790/99 não auxiliou neste sentido; pelo contrário, ao criar mais um título também criou mais uma responsabilidade a ser destinada a um órgão público. O Ministério da Justiça, que já concedia o Título de Utilidade Pública federal, ficou incumbido desta certificação. Também não auxiliou em nada a referida Lei n. 12.101/2009, que sob o pretexto de descomplicar a concessão de títulos na esfera da assistência social, transformou um órgão certificador (CNAS) em três órgãos certificadores (Ministérios da Saúde, da Educação e do Desenvolvimento Social e Combate à Fome), portanto três regulmentações distintas, três procedimentos distintos, três estruturas distinas, três formas de certificação distintas. O benefício que se pode extrair desta lei é a intenção de tornar mais técnico o ato de certificação, aproximando-o da área de competência. No entanto, melhor seria que esta especialização fosse feita no bojo de um órgão somente, padronizando as certificações.

A descentralização da função certificadora em diversos órgãos distintos acaba por dificultar a compreensão das suas finalidades, rigores, procedimentos, etc., exigindo a reformulação do sistema. ${ }^{571}$

\subsubsection{Pluralidade de controles}

Um dos temas que mais preocupa na análise da legislação regente das parcerias entre a Administração Pública e o Terceiro Setor diz respeito às ferramentas de controle dos recursos públicos objeto de repasse ${ }^{572}$. É tema que se insere no âmbito da função reguladora do Estado, pois "quando se trata da transferência de atividade anteriormente desempenhadas diretamente pelo Estado, deve surgir, concomitantemente, um Estado regulador, com força coercitiva direcionada à plena consecução dos objetivos ora deferidos a entidades privadas sem fins lucrativos". 573

\footnotetext{
571 "Do ponto de vista administrativo, haveria apenas uma autoridade administrativa competente e responsável por efetuar o registro de todas as entidaes privadas sem fins lucrativos" (ibidem, p. 238).

${ }^{572} \mathrm{O}$ cotidiano nos mostra, sem necessidade de maiores delonas, que um dos temas mais complexos do repasse de verbas públicas para o Terceiro Setor é justamente o do controle e da fiscalização. "Ver-se-á, no capítulo em que serão apresentados os resultados da pesquisa empírica desenvolvida com entidade sem fins lucrativos, que diante de sucessivos episódios de irregularidades envolvendo transferências voluntárias para organizações não governamentais, uma parcela deste setor tem estabelecido como regra de política interna não buscar recursos que sejam objeto de emendas parlamentares. Embora haja um significativo segmento de entidades sérias que se beneficiam de emendas, sobretudo daquelas propostas por bancadas parlamentares, os episódios de irregularidades têm provocado uma perda de credibilidade do setor, bem como um arrefecimento ainda maior das normas de controle prévio à celebração de convênios" (SALINAS, Natasha Schmitt Caccia. Op. cit, p. 113). Sobre o controle, cf. FERRARI, Paola Nery; FERRARI, Regina Maria Macedo Nery. Controle das organizações sociais. Belo Horizonte : Fórum, 2007.

${ }^{573}$ DIAS, Maria Tereza Fonseca. Op. cit., p. 352.
} 
Sabe-se que no bojo das discussões da Administração Pública Consensual se insere relevante tópico que trata do controle de resultados, no qual se defende que aos métodos tradicionais de controle da legalidade utilizados pela Administração Pública devem ser agregados métodos de controle de resultados. Como nos ensina Gustavo Justino de Oliveira,

é evidente que a gestão pública há de ser permanentemente avaliada a partir de critérios que envolvam aspectos de legalidade, o que inclui o controle hierárquico. Todavia, os métodos e técnicas organizacionais de ponta, que eventualmente possibilitem mensurar o desempenho e os resultados conquistados pelo desenvolvimento da ação administrativa, devem ser igualmente implementados. ${ }^{574}$

$\mathrm{Na}$ esteira da vertente consensual da Administração Pública em que se inserem as suas parcerias com o Terceiro Setor, várias ferramentas de controle de resultados foram criadas especialmente pela Lei das Oscip, ladeadas de instrumentos de controle de legalidade. Veja-se, sucintamente:

a) Programa de trabalho e relatório anual de execução do termo de parceria (artigo 10, da Lei n. 9.790/99): como exigência prévia à assinatura do termo de parceria, melhor dizendo como cláusula obrigatória do termo de parceria, consta a necessidade de prever no seu objeto as metas e resultados propostos, bem como os prazos previstos e os critérios objetivos de avaliação de desempenho. Além disso, obriga-se a constar no termo de parceria a apresentação pela parceira privada de relatório anual da execução do termo de parceria ao parceiro público;

b) Comissão de avaliação e Conselhos de Políticas Públicas (artigo 11, da Lei 9.790/99): embora a lei não seja clara quanto a este controle, no decorrer do termo de parceria será constituída comissão de avaliação (“composta por dois membros do respectivo Poder Executivo, um da Organização da Sociedade Civil de Interesse Público e um membro indicado pelo Conselho de Política Pública da área de atuação correspondente, quando houver, ${ }^{575}$ ), que acompanhará a execução dos trabalhos e os resultados atingidos;

c) Relatório anual de auditoria independente (artigo 19, do Decreto n. 3.100/99): caso a Oscip receba recursos superiores a $\mathrm{R} \$ 600.000,00$ (seiscentos mil reais);

d) Publicidade anual do relatório de atividades e demonstrações financeiras (artigo $4^{\text {o }}$, VII, “c”, da Lei n. 9.790/99);

\footnotetext{
574 OLIVEIRA, Gustavo Justino. Contrato de gestão. São Paulo : RT, 2008, p. 182.

575 Artigo 20, do Decreto n. 3.100/99.
} 
e) Prestação de contas anual das atividades da Oscip ao parceiro público (artigos $4^{\circ}$, VII, “d”, da Lei n. 9.790/99, e 11, do Decreto n. 3.100/99): difere do relatório anual do termo de parceria, pois envolve todas as atividades da entidade.

Não são poucas as exigências legais de prestação de contas em relação às entidades que buscam a qualificação como Oscip e firma termo de parceria com o Poder Público. Mas não pára por aí.

O Ministério da Justiça, através da Portaria SNJ n. 24/2007, criou a obrigatoriedade de cadastramento das entidades portadoras do Título de Utilidade Pública Federal, da qualificação como Oscip e das organizações estrangeiras que funcionam no país, no chamado Cadastro Nacional de Entidades de Utilidade Pública - CNES, que permite a expedição de certidão de regularidade da entidade perante o Ministério da Justiça desde que preste contas anualmente.

Além disso, caso a entidade qualificada como Oscip seja constituída sob a forma de fundação, deverá prestar contas anualmente ao Ministério Público de seu Estado, em sua maioria através do complexo sistema denominado SICAP - Sistema de Cadastro e Prestação de Contas.

Afora o controle social e os controles internos da própria entidade, também ferramentas úteis à fiscalização das suas atividades.

O controle e a fiscalização são temas que repercutem sobremaneira da qualidade da regulação das atividades do Terceiro Setor, especialmente em sua interface com a Administração Pública, a merecer melhores cuidados. ${ }^{576}$

Temos para nós que embora tenha logrado revitalizar o sistema de controle das transferências públicas, focando em controles de resultado sem esquecer de controles formais, a Lei das Oscip merece alterações que centralizem este controle das transferências em órgão específico.

\footnotetext{
576 "Para melhorar a 'qualidade da regulação' da atividade de tutela promocional do Terceiro setor e da própria atividade administrativa quando se relacione com os entes do Terceiro setor deve contribuir também a concreta atuação da legislação sobre empresa social, na qual pela primeira vez se enfrenta outro ponto crítico para o mundo do Terceiro setor: a accountability, ou seja a prestação de contas aos terceiros dos resultados obtidos e do emprego mais ou menos eficiente dos recursos disponíveis" (TIBERI, Giulia. La dimensione costituzionale del Terzo settore. In: CITTADINO: Caterina (org.). Dove lo Stato non arriva: pubblica amministrazione e terzo settore. Firenze : Passigli, 2008, p. 73, tradução nossa). No original: "A migliore la 'qualità della regolazione' dell'attività di tutela promozionale del Terzo settore e la stesssa attività amministrativa allorché si interfaccia con gli enti del Terzo settore dovrebbe contribuir non poco anche la concreta attuazione della legislazione sulla impresa sociale, in cui per la prima volta si affronta un ulteriore nodo critico per il mondo del Terzo settore: la accountability, ossia il render conto ai terzi dei risultati ottenuti e dell'impiego più o meno efficiente delle risorse disponibili'. Sobre o controle, cf. VALLE, Vanice Lírio do. Terceiro Setor e parcerias com a Administração Pública: desafios ao controle das OS e OSCIPs. Revista de Direito do Terceiro Setor - RDTS, Belo Horizonte : Fórum, ano 2, n. 4, jul.-dez. 2008, pp. 4764.
} 


\subsubsection{Breve conclusão parcial}

Vários outros motivos poderiam ser invocados para demonstrar a instabilidade jurídica em que se encontram as parcerias firmadas entre a Administração Pública e o Terceiro Setor. Nosso atual ordenamento jurídico, embora tenha recebido importantes inovações com a edição da Lei n. 9.790/99, ainda é tumultuado pela profusão de leis desconexas, pela falta de sistematização das regras pertinentes a este setor, pela insegurança da Administração Pública em aplicar os novos instrumentos criados, pelo desconhecimento das ferramentas existentes, de seus limites, possibilidades, etc.

$\mathrm{O}$ atual modelo de gestão das questões sociais tem se mostrado insuficiente, perdendo assim a própria sociedade em duplo sentido: i) dificuldades em participar do processo de atendimento às demandas sociais; e ii) dificuldades em receber serviços sociais de qualidade. É com vistas a um reposicionamento do atual modelo de gestão administrativa do relacionamento entre a Administração Pública e o Terceiro Setor na importante função de dar resposta aos anseios sociais que ora se apresenta modelo legislativo com propostas de inovação.

\subsection{Propostas de alteração do atual modelo de relacionamento entre a Administração Pública e o Terceiro Setor: exposição de motivos}

Considerando o quanto exposto até o presente momento e outros conceitos que daí podem ser extraídos, entendemos possível dividir as propostas de alteração do atual modelo de relacionamento entre a Administração Pública e o Terceiro Setor em 4 vertentes principais, de certa forma bastante claras na formatação da proposta de anteprojeto de lei, a saber: i) Elementos conceituais; ii) Qualificação jurídica; iii) Parcerias; iv) Agência Reguladora.

Em primeiro lugar, optamos por efetuar conceituação dos termos Adminitração Pública e, especialmente, Terceiro Setor, com vistas a inserir o termo em nossa legislação e dotá-lo de juridicidade nos moldes da legislação de outros países. Exemplo disso é o sistema jurídico italiano, expresso em acolher o Terceiro Setor e legitimá-lo como conceito jurídico participante da promoção de serviços sociais. O termo Terceiro Setor foi expressamente incluído no ordenamento jurídico italiano através da "Legge quadro per la realizzazione del sistema integrato di interventi e servizi sociali”, cujo artigo $5^{\circ}$ define o 
papel do Terceiro Setor e estabelece que os entes políticos deverão promover ações de apoio e a qualificação das entidades que nele operam

Artigo 5. Papel do terceiro setor. 1. Para promover a implementação do princípio da subsidiariedade, os entes locais, as regiões e o Estado, no âmbito dos recursos disponíveis com base no plano de que tratam os artigos 18 e 19, promovem ações para o apoio e a qualificação dos sujeitos que operam no terceiro setor inclusive através de políticas formativas e interventias para o acesso facilitado ao crédito e aos fundos da União Européia. ${ }^{577}$

A inserção do termo no âmbito legislativo permite que os estudos sobre o tema tomem contorno de juridicidade efetiva, já que passa do mundo dos fatos ao mundo do direito e produz efeitos jurídicos. Além do que permite a sistematização do estudo ao permitir a fixação de premissa; a partir da inserção do termo na legislação, Terceiro Setor passa a ser aquilo que a lei diz que é.

A segunda vertente em que se investiu foi a da definição e unificação de qualificação jurídica para as entidades do Terceiro Setor, a depender de requisitos legalmente previstos para tanto

A concessão caso a caso de títulos jurídicos especiais a entidades do Terceiro Setor parece atender a pelo menos três propósitos. Em primeiro lugar, diferenciar as entidades qualificadas, beneficiadas com o título, relativamente às entidades comuns, destituídas dessa especial qualidade jurídica. Essa diferenciação permite inserir as entidades qualificadas em um regime jurídico específico. Em segundo lugar, a concessão do título permite padronizar o tratamento normativo de entidades que apresentem características comuns relevantes, evitando o tratamento legal casuístico dessas entidades. Em terceiro lugar, a outorga de títulos permite o estabelecimento de um mecanismo de controle de aspectos da atividade das entidades qualificadas, flexível por excelência, entre outras razões, porque o título funciona como um instrumento que admite não apenas concessão, mas também suspensão e cancelamento. ${ }^{578}$

\footnotetext{
577 No original e na íntegra: "Articolo 5. (Ruolo del terzo settore). 1. Per favorire l'attuazione del principio di sussidiarietà, gli enti locali, le regioni e lo Stato, nell'ambito delle risorse disponibili in base ai piani di cui agli articoli 18 e 19, promuovono azioni per il sostegno e la qualificazione dei soggetti operanti nel terzo settore anche attraverso politiche formative ed interventi per l'accesso agevolato al credito ed ai fondi dell'Unione europea. 2. Ai fini dell'affidamento dei servizi previsti dalla presente legge, gli enti pubblici, fermo restando quanto stabilito dall'articolo 11, promuovono azioni per favorire la trasparenza e la semplificazione amministrativa nonché il ricorso a forme di aggiudicazione o negoziali che consentano ai soggetti operanti nel terzo settore la piena espressione della propria progettualità, avvalendosi di analisi e di verifiche che tengano conto della qualità e delle caratteristiche delle prestazioni offerte e della qualificazione del personale. 3. Le regioni, secondo quanto previsto dall'articolo 3, comma 4, e sulla base di un atto di indirizzo e coordinamento del Governo, ai sensi dell'articolo 8 della legge 15 marzo 1997, n. 59, da emanare entro centoventi giorni dalla data di entrata in vigore della presente legge, con le modalità previste dall'articolo 8 , comma 2 , della presente legge, adottano specifici indirizzi per regolamentare i rapporti tra enti locali e terzo settore, con particolare riferimento ai sistemi di affidamento dei servizi alla persona. 4. Le regioni disciplinano altresì, sulla base dei principi della presente legge e degli indirizzi assunti con le modalità previste al comma 3 , le modalità per valorizzare l'apporto del volontariato nell'erogazione dei servizi”. Disponível na Internet: $<$ http://www.comune.roma.it/accacomune/Progetti/LeggeQuadro.asp>. Acesso em: 15 de agosto de 2003.

578 MODESTO, Paulo. Reforma do marco legal do terceiro setor no Brasil. In: FALCÃO, Joaquim; CUENCA, Carlos (org.). Mudança social e reforma legal: estudos para uma nova legislação do Terceiro Setor. Brasília : Conselho da Comunidade Solidária : UNESCO : BID : FBB, 1999, p. 141.
} 
Não que a qualificação para as entidades do Terceiro Setor não existisse, pois a Lei n. 9.790/99 já havia tratado disso. Simplesmente buscamos revigorar este título e adaptá-lo ao conceito de Terceiro Setor que propusemos, bem como à reformulação na competência quanto à concessão deste título. A importância deste tópico está, sobretudo, na exigência da qualificação para a candidatura das entidades às formas de parceria que são criadas posteriormente. É, aliás, preocupação já manifestada pelo Tribunal de Contas da União:

3.2.38 Outra questão que merece ser destacada é a ausência de critérios transparentes para a escolha das ONG que receberão recursos por meio de convênios e instrumentos similares. Não há publicação de edital para habilitação e seleção das entidades que prestarão serviços à comunidade, nem sequer a utilização dos títulos jurídicos atribuídos pelo Poder Público como critério avaliativo na escolha das entidades convenentes, embora, é bom que se destaque, a qualificação ou título jurídico, seja qual for, não elide a avaliação técnica das proposições e a aferição da legitimidade das parcerias e do interesse público recíproco nelas envolvido. ${ }^{579}$

E como a qualificação, por si só, não pode legitimar automaticamente as entidades à parcerização, enfoque especial foi destinado a estas possibilidades no âmbito do Anteprojeto. Foram criadas duas possibilidades com objetos distintos: i) o termo de fomento, cujo objetivo é o fomento a projeto específico de duração não continuada da entidade; e ii) o termo de parceria, basicamente no formato já previsto na Lei das Oscip. Proposta que consideramos importante é a de permitir que algumas entidades específicas não qualificadas por impedimento legal (chamadas entidade equiparadas) possam usufruir dos termos de fomento; somente as qualificadas podem usufruir das duas possibilidades de parceria. Além disso, no ensejo das parcerias foram extintos os demais títulos dentro de determinado período, bem como ficou prevista a impossibilidade de as Leis Orçamentárias criarem outras hipóteses de fomento para entidades privadas sem fins lucrativos que não as previstas no Anteprojeto. Buscou-se unificar as titulações e sistematizar as parcerias, centralizando-se em um documento legal específico.

Por fim, o Anteprojeto propõe a criação da Agência Reguladora do Terceiro Setor, cuja finalidade é o fomento das atividades do Terceiro Setor e a regulação e fiscalização do relacionamento entre a Administração Pública e as entidades qualificadas como Organizações do Terceiro Setor. A idéia de criar Agência Reguladora advém principalmente da necessidade de centralização das atividades fiscalizatórias relativas ao

579 TRIBUNAL DE CONTAS DA UNIÃO, Plenário, acórdão n. 2066/2006, Relator Min. Marcos Bemquerer, DOU 13 de novembro de 2006. 
relacionamento da Administração Pública com entidades sem fins lucrativos e de efetivação do controle da utilização dos recursos repassados, haja vista a enormidade de distorções e escândalos que acompanhamos todos os dias neste tema. A Agência seria responsável também pela própria qualificação das entidades como Organização do Terceiro Setor, entre outras atribuições de fomento e fiscalizatórias.

Não podemos deixar de registrar que a elaboração do presente trabalho e o conteúdo do Anteprojeto proposto tem inspirações importantes, sobre as quais falaremos sucintamente.

a) Agenzia per le ONLUS: o regime jurídico italiano relativo ao Terceiro Setor não apresenta diferenças significativas em relação ao sistema brasileiro. Como dão conta Barbetta e Maggio, "a legislação italiana sobre o setor non profit é de fato um aglomerado composto de leis crescidas de maneira desorgânica no curso do tempo e ainda privadas de uma adequada sistematicidade". ${ }^{580}$ Como se não bastasse,

todavia, especialmente nas últimas duas décadas, uma abundante produção de leis especiais contribuiu para complicar (e confundir) notavelmente as coisas, sem de resto dar à legislação aquelas características de modernidade invocadas pelo novo papel que o setor sem fins lucrativos italiano veio a cobrir no mercado dos serviços à pessoa e à comunidade no âmbito da reforma do nosso sistema de welfare. ${ }^{581}$

\footnotetext{
${ }^{580}$ BARBETTA, Gian Paolo e MAGGIO, Francesco. Nonprofit. $2^{\circ}$ ed. Bologna : Il Mulino, 2008, p. 32, tradução nossa. No original: "La legislazione italiana sul settore non profit è infatti un insieme composito di leggi cresciute in maniera disorganica nel corso del tempo e tuttora prive di un'adeguata sistematicità". Também neste sentido: "A emergência nos últimos anos do Terceiro setor como categoria relevante também sob o ponto de vista jurídico, (...) encontra até agora o inconveniente de uma legislação fragmentária e desorgânica. O legislador de fato preferiu intervir setorialmente e freqüentemente de maneira contingente para regular, em particular, o perfil fiscal dos sujeitos do Terceiro setor, criando categorias novas de entes privados beneficiados sob diversos perfis por não terem fins lucrativos. $O$ che, além da exigência de sistematização teórica das várias tipologias jurídicas - che teriam na verdade aconselhado uma intervenção orgânica no livro I do Código Civil - não deixou de gerar conseqüências no plano prático, porque não contribui na criação de um 'ambiente jurídico' favorável para o desenvolvimento do Terceiro setor" (TIBERI, Giulia. La dimensione costituzionale del Terzo settore. In: CITTADINO: Caterina (org.). Dove lo Stato non arriva: pubblica amministrazione e terzo settore. Firenze : Passigli, 2008, pp. 26-27, tradução nossa). No original: "L'emersione negli ultimi anni del Terzo settore come categoria rilevante anche sotto il profilo giuridico, (...) ha finora scontato l'inconveniente di una legislazione assai frammentaria e disorganica. Il legislatore ha infatti preferito intervenire settorialmente e spesso in maniera contingente per regolare, in particolare, il profilo fiscale del Terzo settore, creando categorie nuove di enti privati agevolate sotto diversi profili perchè privi di sopo di lucro. Il che, al di là delle esigenze di sistematizzazione teorica delle varie tipologie giuridiche - che avrebbero in verità consigliato un intervento organico all'interno del libro I del codice civile - non è stato privo di conseguenze sul piano pratico, perchè non ha contribuito a creare un ‘ambiente giuridico' favorevole per lo sviluppo del Terzo settore”.

${ }^{581}$ BARBETTA, Gian Paolo e MAGGIO, Francesco. Op. cit., p. 39, tradução nossa. No original: "Tuttavia, specie negli ultimi due decenni, un'abbondante produzione di legislazione speciale ha contribuito a complicare (e a confondere) notevolmente le cose, senza del resto dare alla legislazione quei caratteri di modernità richiesti dal nuovo ruolo che il settore nonprofit italiano è venuto a ricoprire entro i mercati dei servizi alla persona e alla comunità nell'ambito della riforma del nostro sistema di welfare".
} 
No entanto, embora a legislação italiana não tenha logrado, como a brasileira, alcançar sistematização suficiente sobre as atividades do Terceiro Setor, tem demonstrado a preocupração em buscar novidades. Podemos citar a criação da qualificação de empresas sociais $^{582}$, da qual não nos ocuparemos mas que merece estudos ${ }^{583}$, bem como a criação, já há mais tempo, da Agenzia per le ONLUS - Organizzazioni Non Lucrative di Utilità Sociale. $^{584}$

A Agenzia per le ONLUS está vinculada ao Presidente do Conselho de Ministros italiano e tem como função principal "o exercício dos poderes de direção, promoção, vigilância e inspeção para a uniforme e correta observância da disciplina legislativa e regulamentar no que concerne às organizações não lucrativas de utilidade social, ao

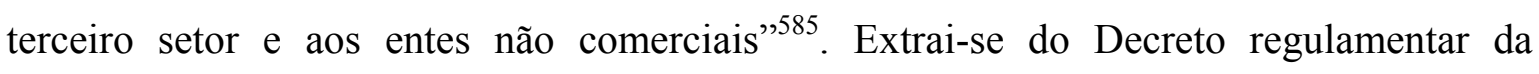
Agência que ela tem três funções principais: vigilância e controle, promoção, esclarecimentos aos órgãos de governo e ao Parlamento quanto ao tema. "È evidente então a ampla competência em matéria de direção e de controle atribuída à Autoridade do Terceiro Setor, a qual, ainda pode desenvolver atribuições de vigilância e inspeção, inclusive convidando representantes dos entes a fornecerem dados e informações" ${ }^{\text {"586 }}$.

\footnotetext{
${ }^{582}$ Decreto legislativo 155, 24 marzo 2006.

${ }^{583}$ Sobre o tema, cf. TOLEDO, Juliana Amaral; SILVA, Fernando Moraes Quintino da. A empresa social - o crescimento do empreendedorismo social e a retomada dos valores sociais no setor empresarial. Revista de Direito do Terceiro Setor - RDTS, Belo Horizonte : Fórum, ano 3, n. 6, jul.-dez. 2009, pp. 93-112.

${ }_{584}$ Instituída pelo Decreto del Presidente del Consiglio dei Ministri, 26 settembre 2000, regulamentada pelo Decreto del Presidente del Consiglio dei Ministri 329, 21 Marzo 2001, foi estabelecida em 8 de março de 2002.

${ }^{585}$ DPCM 329/2001: “Art. 3. Attribuzioni. 1 . Nell'esercizio delle attribuzioni di cui all'articolo 3, commi 191 e 192 della legge 23 dicembre 1996, n. 662, l'Agenzia: a) nell'ambito della normativa vigente, esercita i poteri di indirizzo, promozione, vigilanza e ispezione per la uniforme e corretta osservanza della disciplina legislativa e regolamentare per quanto concerne le organizzazioni non lucrative di utilità sociale, il terzo settore e gli enti non commerciali, di seguito denominati 'organizzazioni, terzo settore e enti'."

${ }^{586}$ GIACINTI, Roberto; NADDI, Donatella. Agenzia per Le Onlus e Agenzia delle Entrate si contendono l'attività ispettiva e di controllo. Terzo Settore. Milano : Il Sole 24 Ore, n. 10, out. 2005, p. 55, tradução nossa. No original: "È evidente quindi l'ampia competenza in materia sia di indirizzo che di controllo attribuita all'Authority del Terzo Settore, la quale, appunto può svolgere compiti di vigilanza e ispezione anche invitando i rappresentanti degli enti a comparire per fornire dati e notizie". "Importantes funções promocionais do setor non profit foram outorgadas à Agência para as organizações não lucrativas de utilidade social, à qual são atribuídas funções transversais de promoção e controle em relação a todos os sujeitos que compõem o Terceiro setor" (TIBERI, Giulia. La dimensione costituzionale del Terzo settore. In: CITTADINO: Caterina (org.). Dove lo Stato non arriva: pubblica amministrazione e terzo settore. Firenze : Passigli, 2008, p. 61, tradução nossa). No original: "Importanti compiti promozionali del settore del non profit sono stati infine previsti in capo all'Agenzia per le organizzazioni non lucrative di utilità sociale, alla quale significativamente sono assegnati compiti trasversali di promozione e controllo nei confronti di tutti i soggetti che compongono il Terzo settore". Cf. BRUSCUGLIA, Luciano; ROSSI, Emanuele (coord.). Terzo settore e nuove categorie giuridiche: le organizzazioni non lucrative di utilità sociale. Milano : Giuffrè, 2000.
} 
Embora o primeiro mandato da Agência italiana tenha se encerrado em 2007, especialmente por falta de regulamentação e de clareza em algumas atribuições, a sua função está bastante limitada. Tem atuado fundamentalmente na área fiscal, como fiscal dos requisitos para a obtenção da qualificação ONLUS pelas entidades, porém tem sofrido com a indefinição legal da competência para tanto, criando situação de conflito com órgão do Ministério das Finanças (Agenzia delle Entrate). ${ }^{587}$

Há, ainda, críticas à indefinição do papel da Agência, se de controle ou de promoção, defendendo-se que "não é fácil combinar dois objetivos substancialmente diversos $" 588$. Entendemos, no entanto, que a promoção do Terceiro Setor é compatível com a sua regulação, ambos voltados ao fortalecimento das relações com o Poder Público e a sociedade através da qualificação pessoal e normativa do setor. Promover o Terceiro Setor não significa defendê-lo; significa qualificá-lo e legitimá-lo. São atividades absolutamente compatíveis: quanto mais qualificadas as entidades do Terceiro Setor, menos problemas regulatórios existirão. A Charity Comission inglesa, por exemplo, tem esta característica dúplice.

\section{b) Charity Comission for England and Wales e Cabinet Office - The Office of the Third}

Sector: o regime jurídico da Inglaterra em relação às entidades do Terceiro Setor apresenta interessantes ferramentas de regulação e fomento, cuja aplicação fica a cargo da Charity Comission e do Cabinet Office.

\footnotetext{
587 "No estado atual é claro, no entanto, que existe um conflito de competência entre a Agenzia delle Entrate e a Agenzia per Le Onlus" (GIACINTI, Roberto; NADDI, Donatella. Agenzia per Le Onlus e Agenzia delle Entrate si contendono l'attività ispettiva e di controllo. Terzo Settore, Milano : Il Sole 24 Ore, n. 10, out. 2005 , p. 54, tradução nossa). No original: "Allo stato attuale è chiaro, invece, che esiste un contrasto di competenza fra l'Agenzia delle Entrate e l'Agenzia per le Onlus". Também sobre este conflito: RICCI, Sergio. Controlli e verifiche: stretta sulle Onlus. Terzo Settore, Milano : Il Sole 24 Ore, n. 3, mar. 2007, pp. 33-36. Conforme já apontava Marcella Gola a necessidade de "fortalecimento do órgão, orientado à transformação em uma verdadeira Authority" (GOLA, Marcella. L'organismo di controllo degli enti non commerciali e delle Onlus nella Legge n. 662/96. In: CARINCI, Franco (org.). Non profit e volontariado: profili giuridico istituzionali 1. Milano : IPSOA, 1999, pp. 91-105). Sobre as dificuldades enfrentadas pela Agência: ZAMAGNI, Stefano. L'Agenzia per le Onlus al sua secondo mandato. Terzo Settore, Milano : Il Sole 24 Ore, n. 3, mar. 2007, pp. I-VI.

${ }^{588}$ PASTORI, Giorgio. L'organismo di controllo delle ONLUS. In: Studi in onore di Umberto Pototsching. $2^{\circ}$ vol., Milano : Giuffrè, 2002, p. 91, tradução nossa. No original, na íntegra: "È questo allora il nodo problematico da sciogliere (che dovrà sciogliere il regolamento previsto). L'organismo di controllo è oggi potenzialmente qualcosa di intermedio fra l'autorità di garanzia e l'agenzia tecnica di indirizzo e promozione. E può essere che si voglia intenzionalmente far nascere l'organismo dall'intreccio dei due modelli. Non è facile tuttavia combinare due anime sostanzialmente diverse in un unica figura e una scelta in favore dell'una o dell'altra configurazione parrebbe invece imporsi".
} 
A Charity Comission ${ }^{589}$ é o órgão de registro e regulação das charities inglesas e do País de Gales, atualmente regulamentada pelo Charities Act de 2006. As charities são instituições dedicadas exclusivamente a propósitos de caridade e em benefício público. Os propósitos de caridade estão listados na Parte 1, Seção 2, do Charities Act, nos seguintes termos:

(a) a prevenção ou alívio da pobreza;

(b) o avanço da educação;

(c) o avanço da religião;

(d) o avanço da saúde ou o salvamento de vidas;

(e) o avanço da cidadania ou do desenvolvimento da comunidade;

(f) o avanço das artes, da cultura, do patrimônio ou das ciências;

(g) o avanço do esporte amador;

(h) o avanço dos direitos humanos, resolução de conflitos ou da reconciliação, ou a promoção da harmonia religiosa ou racial ou da igualdade e diversidade;

(i) o avanço da proteção ou melhoria ambiental;

(j) o auxílio aos necessidades por razões de juventude, idade, doença, deficiência,

dificuldades financeiras ou outras desvantagens;

(k) o avanço do bem-estar dos animais;

(1) a promoção da eficiência das forças armadas da Coroa, ou da eficiência da polícia, bombeiros e serviços de resgate e de ambulância;

(m) quaisquer outros propósitos de acordo com a subseção (4). ${ }^{590}$

Além de desenvolver uma das atividades acima listadas, deve fazê-lo em beneficio público, definido pela legislação regente das charities; isto significa dizer que o simples desenvolvimento destas atividades não presume o benefício público, devendo-se submeter a entidade ao chamado "teste do benefício público" (Charities Act 2006, Parte 1, Seção 3), feito através da comparação da atividade desenvolvida pela entidade na prática, em cotejo com a legislação regente das charities.

\footnotetext{
${ }^{589}$ Sobre a Charity Comission, cf. BRASIL. MINISTÉRIO DA JUSTIÇA. SECRETARIA DE ASSUNTOS LEGISLATIVOS. PNUD. INSTITUTO PRO BONO. OLIVEIRA, Gustavo Justino de (coord. acad.). Estado Democrático de Direito e Terceiro Setor. Série Pensando o Direito. Brasília, n. 16, 2009, pp. 23-27 e 55-60. Disponível na Internet: $<$ http://portal.mj.gov.br/main.asp?Team=\%7B7393FACA\%2DF9C1\%2D42B0\%2DBE43\%2D8F8756A587 C8\%7D>. Acesso em: 20 abr. 2010.

${ }^{590}$ INGLATERRA. CHARITIES ACT. 2006. PART 1. SECTION 2. SUBSECTION 2. Disponível na Internet: <http://www.opsi.gov.uk/acts/acts2006/ukpga_20060050_en_2\#pt1-11g1>. Acesso em 03 mai. 2010. No original: "(a) the prevention or relief of poverty; (b) the advancement of education; (c) the advancement of religion; (d) the advancement of health or the saving of lives; (e) the advancement of citizenship or community development; (f) the advancement of the arts, culture, heritage or science; (g) the advancement of amateur sport; (h) the advancement of human rights, conflict resolution or reconciliation or the promotion of religious or racial harmony or equality and diversity; (i) the advancement of environmental protection or improvement; (j) the relief of those in need by reason of youth, age, ill-health, disability, financial hardship or other disadvantage; (k) the advancement of animal welfare; (l) the promotion of the efficiency of the armed forces of the Crown, or of the efficiency of the police, fire and rescue services or ambulance services; (m) any other purposes within subsection (4)".
} 
Nos termos da Charities Act 1993, alterada pela Charities Act 2006 e que criou originalmente a Charity Comissioners for England and Wales, atualmente Charity Comission for England and Wales, este é o órgão é responsável pelo registro das entidades

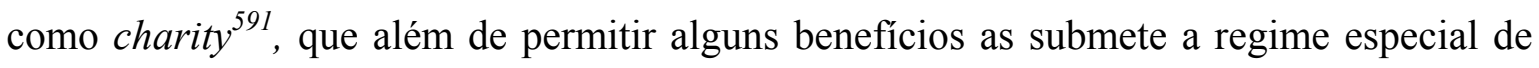
regulação (prestação de contas, publicidade do registro, etc.). Além disso, é o órgão responsável.

A Charity Comission é entidade independente, "não se submetendo à direção ou controle de qualquer Ministro da Coroa ou outro departamento do governo"592. Suas funções estão resumidas em cinco grande objetivos definidos na lei:

(2) Os objetivos são:

1. O objetivo da confiança pública.

2. O objetivo do benefício público.

3. O objetivo do cumprimento.

4. O objetivo dos recursos caritativos.

5. O objetivo do controle.

(3) Estes objetivos são definidos como segue:

1. O objetivo da confiança pública se destina a aumentar a confiança pública nas charities;

2. O objetivo do benefício público se destina a promover a consciência e a compreensão da exigência de benefício público para ser charity.

3. O objetivo do cumprimento se destina a promover o cumprimento das obrigações legais pelos administradores de charities quando no exercício do controle e gerenciamento da administração das entidades.

4. O objetivo dos recursos caritativos se destina a promover o uso efetivo destes recursos para os fins das charities.

5. O objetivo do controle se destina a melhorar o controle das charities pelos seus doadores, beneficiários e público em geral. ${ }^{593}$

Dos objetivos legais destinados à Charity Comission e do conteúdo do Charities Act se observa claramente a função dúplice que lhe é outorgada, tanto a de promoção das charities através de ferramentas de aumento da confiança em sua figura e de melhor

${ }^{591}$ PARTE 1, SEÇÃO 3, SUBSEÇÃO 1.

592 INGLATERRA. CHARITIES ACT. 2006. PART 2. CHAPTER 1. SECTION 6. SUBSECTION 1. Disponível na Internet: <http://www.opsi.gov.uk/acts/acts2006/ukpga_20060050_en_2\#pt1-11g1>. Acesso em: 03 mai. 2010. No original: "(4) In the exercise of its functions the Commission shall not be subject to the direction or control of any Minister of the Crown or other government department".

${ }^{593}$ INGLATERRA. CHARITIES ACT. 2006. PART 2. CHAPTER 1. SECTION 7. SUBSECTION 1-B. Disponível na Internet: <http://www.opsi.gov.uk/acts/acts2006/ukpga_20060050_en_2\#pt1-11g1>. Acesso em: 03 mai. 2010. No original: "(2) The objectives are-1. The public confidence objective. 2. The public benefit objective. 3 . The compliance objective. 4 . The charitable resources objective. 5 . The accountability objective. (3) Those objectives are defined as follows- 1 . The public confidence objective is to increase public trust and confidence in charities. 2. The public benefit objective is to promote awareness and understanding of the operation of the public benefit requirement. 3 . The compliance objective is to promote compliance by charity trustees with their legal obligations in exercising control and management of the administration of their charities. 4. The charitable resources objective is to promote the effective use of charitable resources. 5. The accountability objective is to enhance the accountability of charities to donors, beneficiaries and the general public". 
conhecimento de sua regulamentação, como o de regulação das charities envolvendo desde atividades de registro, proposta de alteração de nomenclatura, fiscalização, recepção de prestação de contas, etc. O Charities Act vai além, criando um tribunal administrativo Charity Tribunal - "que serve como instância julgadora de recursos, ou pedidos de revisão, interpostos contra algumas decisões da Charity Comission. Também lhe cumpre examinar controvérsias que lhe sejam endereçadas pelo Attorney General ou, com o consentimento do Attorney General, pela própria Charity Comission". 594

Além da Charity Comission, órgão independente regulador das charities, a regulação do Terceiro Setor inglês conta com outra importante ferramenta, esta de natureza governamental. É o Office of the Third Sector - OTS, criado em 2006 como parte do Cabinet Office, este sendo um departamento do Governo do Reino Unido responsável por auxiliar o Primeiro Ministro e o Gabinete dos Ministros (Cabinet of the United Kingdom). A estrutura do Office of the Third Sector

lidera o trabalho em todo o governo para auxiliar o ambiente para um terceiro setor (associações e grupos da comunidade, empresas sociais, instituições beneficentes, cooperativas e mutualidades) próspero, permitindo que o setor lute por mudanças, preste serviços públicos, promova o desenvolvimento social e fortaleça as comunidades. O OTS foi criado no centro do governo em maio de 2006, em reconhecimento do papel cada vez mais importante que o Terceiro Setor desempenha tanto na sociedade quanto na economia. ${ }^{595}$

O OTS representa a assunção, por parte do governo do Reino Unido, da importância social e econômica do Terceiro Setor e da necessidade de um trabalho integrado entre ele e o Estado, centralizando as ações em órgão do governo cujas competências principais são o fomento das ações de parceria entre a Administração Pública e o Terceiro Setor, a promoção deste, bem como buscar o cumprimento de políticas regulatórias que lhe permitam um bom ambiente de atuação. Seu principal objetivo é "desenvolver e auxiliar

${ }^{594}$ BRASIL. MINISTÉRIO DA JUSTIÇA. SECRETARIA DE ASSUNTOS LEGISLATIVOS. PNUD. INSTITUTO PRO BONO. OLIVEIRA, Gustavo Justino de (coord. acad.). Estado Democrático de Direito e Terceiro Setor. Série Pensando o Direito. Brasília, n. 16, 2009, p. 25. Disponível na Internet: $<$ http://portal.mj.gov.br/main.asp?Team=\%7B7393FACA\%2DF9C1\%2D42B0\%2DBE43\%2D8F8756A587 C8\%7D>. Acesso em: 20 abr. 2010.

${ }^{595}$ Disponível na Internet: <http://www.cabinetoffice.gov.uk/third_sector/about_us.aspx $>$. Acesso em: 03 mai. 2010, tradução nossa. No original: "As part of the Cabinet Office, the Office of the Third Sector (OTS) leads work across government to support the environment for a thriving third sector (voluntary and community groups, social enterprises, charities, cooperatives and mutuals), enabling the sector to campaign for change, deliver public services, promote social enterprise and strengthen communities. The OTS was created at the centre of government in May 2006 in recognition of the increasingly important role the third sector plays in both society and the economy". 
um ambiente que permita ao terceiro setor se desenvolver, aumentando sua contribuição para a sociedade, a economia e o meio ambiente britânicos". 596

c) Anteprojeto de Lei do Estatuto do Terceiro Setor: durante a elaboração da presente tese foi apresentado importante documento de análise do regime jurídico atual do Terceiro Setor e propositivo de Anteprojeto de Lei de Estatuto do Terceiro Setor. Referido Anteprojeto é fruto do Projeto Pensando o Direito, oriundo do acordo de colaboração técnico-internacional BRA/07/004 firmado em maio de 2007 entre a Secretaria de Assuntos Legislativos do Ministério da Justiça (SAL) e o Programa das Nações Unidas para o Desenvolvimento (PNUD). ${ }^{597}$ No bojo deste projeto, em 2008 foi aberta a Convocação n. 002/2008, para o desenvolvimento de pesquisa e elaboração legislativa sobre o tema Estado Democrático de direito e Terceiro Setor, tendo sido selecionado o Instituto Pro Bono para a sua realização, sob a Coordenação-Geral do Professor Doutor de Direito Administrativo da Universidade de São Paulo, Gustavo Justino de Oliveira, tendo sido elaborado rico trabalho de pesquisa sobre a legislação de diversos países e proposto excelente Anteprojeto de Lei de Estatuto do Terceiro Setor. Embora a tarefa executada seja de difíceis contornos, sobretudo pela heterogeidade do Terceiro Setor e da legislação que o regulamenta, o Anteprojeto teve muita competência ao tratar de todos os assuntos que povoam este cenário e tumultuam o ambiente regulatório.

Não somente o conteúdo do Anteprojeto, mas também a pesquisa completa realizada sob a batuta do Prof. Gustavo Justino de Oliveira, foram duplamente úteis ao presente trabalho: i) legitimou e, ao legitimar, ratificou a importância, a atualidade e a necessidade do tema; e ii) tecnicamente subsidiou em diversos tópicos levados em consideração na proposta apresentada.

A começar com a motivação da Convocação realizada pelo Ministério da Justiça, qual seja a de elaborar uma Lei Geral ou um Estatuto do Terceiro Setor. Extrai-se o cenário desta produção da Carta de Apresentação da Pesquisa, que em dado momento esclarece que

\footnotetext{
${ }^{596}$ Disponível na Internet: <http://www.cabinetoffice.gov.uk/third_sector/about_us.aspx>. Acesso em: 03 mai 2010, tradução nossa. No original: "Develop and support an environment which enables the third sector to thrive, growing in its contribution to Britain's society, economy and environment".

${ }^{597}$ Cf. BRASIL. MINISTÉRIO DA JUSTIÇA. SECRETARIA DE ASSUNTOS LEGISLATIVOS. PNUD. INSTITUTO PRO BONO. OLIVEIRA, Gustavo Justino de (coord. acad.). Estado Democrático de Direito e Terceiro Setor. Série Pensando o Direito. Brasília, n. 16, 2009. Disponível na Internet: $<$ http://portal.mj.gov.br/main.asp?Team=\%7B7393FACA\%2DF9C1\%2D42B0\%2DBE43\%2D8F8756A587 C8\%7D>. Acesso em: 20 abr. 2010.
} 
o presente trabalho de investigação, intenso e exaustivo, encontrava-se originalmente impregnado por este viés pragmático: o de culminar com a proposição de uma minuta de anteprojeto de lei, representando o que - na opinião do grupo de pesquisa, está muito atrasado no contexto nacional - possa a vir a ser conhecido como Lei Geral ou Estatuto Jurídico do Terceiro Setor. ${ }^{598}$

Destaca-se deste trecho a preocupação do grupo de pesquisadores com o atraso da legislação brasileira em relação ao Terceiro Setor, a ponto de justificar a elaboração de espécie de lei geral. Esta afirmação corrobora o quanto exposto no presente trabalho, no que diz respeito à necessidade de reformulação de nossa legislação no que diz respeito às atividades desenvolvidas pelo Terceiro Setor. Em outra passagem o documento reafirma que "as regras que disciplinam o Terceiro Setor encontram-se disseminadas em Códigos e textos legislativos esparsos, objetos de estudo específico de diversos ramos ou especialidades do Direito". 599

A proposta legislativa apresentada no âmbito do Projeto Pensando o Direito não difere conceitualmente da proposta apresentada no presente trabalho. Embora em âmbito mais restrito, a nossa proposta busca conferir ao Terceiro Setor "reconhecimento, identidade e segurança jurídicas" ${ }^{\circ 00}$.

E os 80 artigos propostos pelo Estatuto Jurídico do Terceiro Setor assim o fazem. Trilhando por todas as searas que envolvem o até então nebuloso universo do Terceiro Setor, clareia em linhas gerais boa parte das incongruências que sustentam a insegurança jurídica.

Partindo de uma base conceitual (Título I) que demarca o que é o Terceiro Setor e quais são as entidades que o compõem - o que inspirou a inserção de tópico próprio para este fim em nossa proposta -, no Título II define as Diretrizes, Princípios e Fins do

\footnotetext{
${ }^{598}$ BRASIL. MINISTÉRIO DA JUSTIÇA. SECRETARIA DE ASSUNTOS LEGISLATIVOS. PNUD. INSTITUTO PRO BONO. OLIVEIRA, Gustavo Justino de (coord. acad.). Estado Democrático de Direito e Terceiro Setor. Série Pensando o Direito. Brasília, n. 16, 2009, p. 2. Disponível na Internet: $<$ http://portal.mj.gov.br/main.asp?Team=\%7B7393FACA\%2DF9C1\%2D42B0\%2DBE43\%2D8F8756A587 C8\%7D>. Acesso em: 20 de abril de 2010. Para a fundamentação prévia à elaboração deste Estatuto, cf. OLIVEIRA, Gustavo Justino. Estatuto jurídico do Terceiro Setor e desenvolvimento: conectividade essencial ao fortalecimento da cidadania, à luz dos 20 anos da Constituição de 1988. Revista de Direito do Terceiro Setor - RDTS, Belo Horizonte : Fórum, ano 3, n. 5, jan.-jun. 2009, pp. 9-37.

599 BRASIL. MINISTÉRIO DA JUSTIÇA. SECRETARIA DE ASSUNTOS LEGISLATIVOS. PNUD. INSTITUTO PRO BONO. OLIVEIRA, Gustavo Justino de (coord. acad.). Estado Democrático de Direito e Terceiro Setor. Série Pensando o Direito. Brasília, n. 16, 2009, p. 70. Disponível na Internet: $<$ http://portal.mj.gov.br/main.asp?Team=\%7B7393FACA\%2DF9C1\%2D42B0\%2DBE43\%2D8F8756A587 C8\%7D $>$. Acesso em: 20 abr. 2010.

${ }^{600}$ BRASIL. MINISTÉRIO DA JUSTIÇA. SECRETARIA DE ASSUNTOS LEGISLATIVOS. PNUD. INSTITUTO PRO BONO. OLIVEIRA, Gustavo Justino de (coord. acad.). Estado Democrático de Direito e Terceiro Setor. Série Pensando o Direito. Brasília, n. 16, 2009, p. 71. Disponível na Internet: $<$ http://portal.mj.gov.br/main.asp?Team=\%7B7393FACA\%2DF9C1\%2D42B0\%2DBE43\%2D8F8756A587 C8\%7D>. Acesso em: 20 abr. 2010.
} 
Terceiro Setor (artigos $7^{\circ}$ a 10). O Título III cuida da Estrutura, Organização e Funcionamento das Entidades do Terceiro Setor, legislando importantes questões como a boa governança das entidades. O Título IV trata das Relações Trabalhistas, do Voluntariado e da Prestação de Serviços no Terceiro Setor. O Título V envereda para a tormentosa questão da Tributação do Terceiro Setor.

O Título VI, por sua vez, prevê conceitos relacionados às Parcerias do Terceiro Setor com o Estado, as Empresas e a Sociedade Civil, o que por si só auxilia em nosso trabalho pela legitimação expressa deste tipo de relacionamento fundado na mútua colaboração. Especialmente nos artigos 34 a 36, o Anteprojeto trata da Parcerias do Terceiro Setor com o Estado, trazendo três propostas que se relacionam diretamente com a nossa proposta: i) necessidade de cadastro da entidade para fins de parcerização com a Administração Pública, o que em nossa proposta fazemos através da qualificação de Organização do Terceiro Setor; ii) aplicação da Lei de Improbidade Administrativa às entidades que se relacionem com o Estado, o que foi inserido em nossa proposta; e iii) " $o$ Poder Executivo encaminhará projeto de lei ao Congresso Nacional disciplinando normas relativas às parcerias do Estado com o Terceiro Setor e ao processo de seleção pública das entidades do Terceiro Setor parceiras do Estado"601 (artigo 36).

A justificativa para o artigo 36 é a seguinte:

Embora premente a disciplina jurídica das Parcerias do Estado com as entidades do Terceiro Setor - hoje regulamentadas de modo difuso, desconcentrado e não sistematizado por regras esparsas contidas na Lei de Diretrizes Orçamentárias anuas, Lei Orçamentária, Lei Federal n. 4.320/65, Lei Federal n. 9.790/99, entre outras - entendeu-se não ser o ETS o diploma adequado para conferir tratamento normativo exaustivo e detalhado sobre a temática. As regras aqui veiculadas dizem respeito a questões específicas, alinhadas com o âmbito formal e material do ETS. Por isso a redação do art. 36 ora proposto, segundo o qual deverá tratar de uma questão crucial para a transparência das relações entre Estado e Terceiro Setor. ${ }^{602}$

Além de o documento legitimar a proposta de regulamentação das parcerias entre o Estado e o Terceiro Setor de que tratamos em nosso trabalho, por sua premência, abre

${ }^{601}$ BRASIL. MINISTÉRIO DA JUSTIÇA. SECRETARIA DE ASSUNTOS LEGISLATIVOS. PNUD. INSTITUTO PRO BONO. OLIVEIRA, Gustavo Justino de (coord. acad.). Estado Democrático de Direito e Terceiro Setor. Série Pensando o Direito. Brasília, n. 16, 2009, p. 96. Disponível na Internet: $<$ http://portal.mj.gov.br/main.asp?Team=\%7B7393FACA\%2DF9C1\%2D42B0\%2DBE43\%2D8F8756A587 C8\%7D>. Acesso em: 20 abr. 2010.

${ }^{602}$ BRASIL. MINISTÉRIO DA JUSTIÇA. SECRETARIA DE ASSUNTOS LEGISLATIVOS. PNUD. INSTITUTO PRO BONO. OLIVEIRA, Gustavo Justino de (coord. acad.). Estado Democrático de Direito e Terceiro Setor. Série Pensando o Direito. Brasília, n. 16, 2009, p. 96. Disponível na Internet: $<$ http://portal.mj.gov.br/main.asp?Team=\%7B7393FACA\%2DF9C1\%2D42B0\%2DBE43\%2D8F8756A587 C8\%7D>. Acesso em: 20 abr. 2010. 
margem à complementariedade dos trabalhos; a proposta de Anteprojeto que apresentamos é complementar ao Anteprojeto de Estatuto do Terceiro Setor apresentado, especialmente no que toca ao artigo 36 deste último.

Enfim, o Título VII trata dos controles e o VIII, que também nos chamou a atenção, institui a Política Nacional para o Desenvolvimento do Terceiro Setor e do Conselho Nacional do Terceiro Setor. A inspiração para termos proposto a criação da Agência Nacional do Terceiro Setor veio destes dispositivos, que muito embora não tratem de Agência Reguladora - não se fala em fiscalização e controle - criam ambienta propício à centralização do controle e do fomento das atividades do Terceiro Setor.

O Título IX trata do Cadastro Nacional das Entidades do Terceiro Setor e do Fundo Nacional para o Desenvolvimento do Terceiro Setor, também importantes instrumentos de manutenção de uma Política Nacional como propõe o Anteprojeto.

Sucintamente, a análise do Anteprojeto de Lei de Estatuto do Terceiro Setor ratificou o quanto vínhamos propondo na presente tese, quanto à necessidade de revigorar a legislação concernente ao Terceiro Setor e, mais do que isso, da legislação que diz respeito ao relacionamento da Administração Pública com o Terceiro Setor, haja vista a insegurança jurídica que decorre do ordenamento atual, que propicia a má utilização das ferramentas existentes. Além disso, inspirou em muitos pontos a nossa proposta de Anteprojeto, além dos conteúdos complementares de uma à outra.

\section{d) Anteprojeto de Lei Orgânica da Administração Pública Federal e Entes de}

Colaboração: também durante a elaboração da presente tese foi divulgado Anteprojeto de Lei que da mesma forma auxiliou sob duas óticas, a exemplo do Anteprojeto de Lei de Estatuto do Terceiro Setor antes visto.

O Anteprojeto em referência é o Anteprojeto de Lei Orgânica da Administração Pública Federal e Entes de Colaboração, elaborado por uma comissão de notáveis juristas constituída através da Portaria n. 426, de 6 de dezembro de 2007, do Ministério do Planejamento, Orçamento e Gestão, com a finalidade de elaboração do Anteprojeto. Participaram da comissão os professores Almiro do Couto e Silva, Carlos Ari Sundfeld, Floriano de Azevedo Marques Neto, Paulo Eduardo Garrido Modesto, Maria Coeli Simões Pires, Sergio de Andréa e Maria Sylvia Zanella Di Pietro. Não é a toa, portanto, a qualidade do Anteprojeto elaborado, dada a formação de verdadeira seleção de administrativas. 
E o resultado do texto produzido, inclusive a exposição de motivos, é tranquilizadora em face do quanto apresentado no presente trabalho. Os resultados da Comissão de Juristas foram apresentados ao Ministério do Planejamento, Orçamento e Gestão no dia 16 de julho de 2009, exatamente durante a elaboração da presente tese. E ratificam as preocupações aqui expostas.

A começar pela apresentação, que assevera que "o trabalho dos juristas atende à constatação das autoridades do governo de que há um esgotamento no modelo atual da administração pública que tem gerado dificuldades para a ação estatal ágil e com qualidade no atendimento às demandas sociais e do mercado". ${ }^{603}$ Vê-se, pois, que as autoridades do governo estão preocupadas com a qualidade no atendimento às demandas sociais, considerada insatisfatória em virtude do atual regime de atuação da Administração Pública. Legitima-se, pois, a inserção de mecanismos de flexibilização da gestão pública, sobretudo em temas de relevância social inconteste como aqueles em que atua o Terceiro Setor.

Tanto que, já na Exposição de Motivos do referido Anteprojeto, afirma-se que

[a Comissão] considerou altamente relevante abranger, no anteprojeto, determinadas entidades que, embora instituídas no âmbito não estatal - ainda que, em alguns casos, com impulso estatal - desenvolvem atividades de interesse público, que as habilitam a atuar como parceiras do Estado. Elas estão a meio caminho entre o estatal e o não estatal, gerindo, muitas delas, verbas públicas. Por isso mesmo, sua atuação está sujeita, sob alguns aspectos, a normas de dirieto público, especialmente no que diz respeito ao controle. Tratase das entidades paraestatais e das entidades de colaboração (estas últimas pertencentes ao chamado terceiro setor). ${ }^{604}$

Reconhece-se expressamente, em exposição de motivos de Anteprojeto de Lei que tem como função reordenar o funcionamento da Administração Pública brasileira, elaborado por uma plêiade de administrativistas de escol, a importância das entidades de colaboração no desempenho de atividades de interesse público. E mais, arrisca-se, demonstrando vertente absolutamente modernizadora da Comissão, a utilização da expressão terceiro setor na Exposição de Motivos. Embora o texto do Anteprojeto não

603 BRASIL. MINISTÉRIO DO PLANEJAMENTO, ORÇAMENTO E GESTÃO. Comissão de juristas constituída pela Portaria n. 426, de 6 de dezembro de 2007, do Ministério do Planejamento, Orçamento e Gestão. Resultado final. p. 1. Disponível na Internet: $<$ http://www.planejamento.gov.br/secretarias/upload/Arquivos/seges/comissao_jur/arquivos/090729_seges_ Arq leiOrganica.pdf $>$. Acesso em: 20 abr. 2010.

604 BRASIL. MINISTÉRIO DO PLANEJAMENTO, ORÇAMENTO E GESTÃO. Comissão de juristas constituída pela Portaria n. 426, de 6 de dezembro de 2007, do Ministério do Planejamento, Orçamento e Gestão. Resultado final. p. 3. Disponível na Internet: $<$ http://www.planejamento.gov.br/secretarias/upload/Arquivos/seges/comissao_jur/arquivos/090729_seges_ Arq_leiOrganica.pdf>. Acesso em: 20 abr. 2010. 
utilize a expressão, podemos dizer que onde diz entidades de colaboração pode-se ler entidades do Terceiro Setor.

Outro ponto importante a ser destacado diz respeito à visão da importância dada pela Comissão às parcerias do Estado com o Terceiro Setor e à ampliação dos serviços sociais, no que toca ao funcionamento do aparato administrativo do Estado. E mais ainda, a necessidade de revisão deste conjunto de coisas para o bem do funcionamento da máquina administrativa em prol do bem comum.

O trabalho considerou as insuficiências, contradições e imprecisões do Decreto-lei 200, de 25-2-67, a necessidade de dispor sobre aspectos relevantes das emendas constitucionais 19/98 e 32/01, o crescimento da agenda organizatória, sobretudo com a emergência das parcerias com o terceiro setor e a ampliação dos serviços sociais, a fragmentação de iniciativas em matéria de organização e perda de visão de conjunto das alternativas no modo de funcionamento do aparato administrativo do Estado. Este estado de coisas produziu a confusão conceitual que atualmente impõe obstáculos à gestão pública e promove desencontros entre órgãos de controle sobre aspectos fundamentais da organização e funcionamento das entidades administrativas. ${ }^{605}$

Demonstra-se claramente, o que nos permite apropriar como apoio ao nosso trabalho, a importância da redemarcação de conceitos relacionados às parcerias da Administração Pública com o Terceiro Setor, especialmente de forma a clarear as responsabilidades administrativas de cada órgão envolvido no procedimento de seleção da entidade parceira, prestação de contas, etc.

Novamente quanto às parcerias entre a Administração Pública e o Terceiro Setor, o reconhecimento de sua importância aparece em nova passagem:

\begin{abstract}
Ademais, sentiu-se a necessidade de tratar, de forma sistematizada, dos entes que atuam paralelamente ao Estado - as chamadas entidades paraestatais - e os entes que compõem o hoje denominado terceiro setor, batizado, no anteprojeto, quando em parceria com o poder público, de entidades de colaboração. Sem desconsiderar a legislação específica que rege algumas dessas entidades, houve a preocupação em estabelecer regras indispensáveis para garantir que a sua atuação e os seus vínculos com a Administração Pública não destoem, antes se amoldem aos princípios constitucionais a que a mesma se submete. ${ }^{606}$
\end{abstract}

${ }^{605}$ BRASIL. MINISTÉRIO DO PLANEJAMENTO, ORÇAMENTO E GESTÃO. Comissão de juristas constituída pela Portaria n. 426, de 6 de dezembro de 2007, do Ministério do Planejamento, Orçamento e Gestão. Resultado final. p. 4. Disponível na Internet: $<$ http://www.planejamento.gov.br/secretarias/upload/Arquivos/seges/comissao_jur/arquivos/090729_seges_ Arq leiOrganica.pdf $>$. Acesso em: 20 abr. 2010.

606 BRASIL. MINISTÉRIO DO PLANEJAMENTO, ORÇAMENTO E GESTÃO. Comissão de juristas constituída pela Portaria n. 426, de 6 de dezembro de 2007, do Ministério do Planejamento, Orçamento e Gestão. Resultado final. p. 5. Disponível na Internet: $<$ http://www.planejamento.gov.br/secretarias/upload/Arquivos/seges/comissao_jur/arquivos/090729_seges_ Arq_leiOrganica.pdf $>$. Acesso em: 20 abr. 2010. 
Assumindo, portanto, a necessidade de regulamentação da participação das entidades do Terceiro Setor nas questões sociais, notadamente seus vínculos jurídicos com a Administração Pública, o Anteprojeto destina o Título IV especificamente às entidades de colaboração, assim consideradas as "pessoas jurídicas de direito privado não estatais, sem fins lucrativos, constituídas voluntariamente por particulares, que desenvolvam atividades de relevância pública, essenciais à coletividade, objeto de incentivo e físcalização regular do Poder Público" (artigo 73).

$\mathrm{O}$ Anteprojeto destina 10 artigos às entidades de colaboração. $\mathrm{O}$ artigo 73 trata do conceito de tais entidades e seus requisitos. O artigo 74, inspirador direto da proposta feita neste trabalho, define o objeto do vínculo de colaboração entre a Administração Pública e as entidades de colaboração, que deverá ser formalizado através de contrato público de colaboração, regulado pelos artigos $75,76,77,78,79,80,81$ e 82 . Dentre os tópicos objeto destes artigos estão o processo de chamamento público previamente necessário à assinatura de contrato de colaboração; o fomento público ou privado a entidades estatais; a não aplicação da Lei n. 8.666/93 aos contratos de colaboração; a disponibilização de servidores, etc.

Como dito anteriormente, este instrumento legal auxilia duplamente o presente trabalho. Ajuda a justificar o tema abordado, apontado a necessidade efetiva de repensamento do marco jurídico relativo ao relacionamento entre a Administração Pública e o Terceiro Setor, especialmente sob o ponto de vista do reconhecimento legal da importância deste ator social. Em segundo lugar, auxilia na formatação de proposta de anteprojeto de lei, que muito se abeberou da fonte dos ilustres juristas da Comissão.

\subsection{Proposta de Anteprojeto de Lei sobre as parcerias entre a Administração Pública e o Terceiro Setor}

\section{PROPOSTA DE ANTEPROJETO DE LEI}

LEI N. , DE $\mathrm{DE}$ $\mathrm{DE}$

Cria a qualificação de Organização do Terceiro Setor, estabelece normas gerais sobre as parcerias entre os órgãos da Administração Pública e as entidades qualificadas como Organização do Terceiro 
Setor, cria a Agência Nacional do Terceiro

Setor e dá outras providências.

\section{TÍTULO I \\ DAS DISPOSIÇÕES PRELIMINARES}

Artigo $1^{\circ}$. Esta Lei cria a qualificação de Organização do Terceiro Setor, estabelece normas gerais sobre as parcerias entre os órgãos da Administração Pública e as entidades qualificadas como Organização do Terceiro Setor, cria a Agência Nacional do Terceiro Setor e dá outras providências.

\section{TÍTULO II \\ DOS CONCEITOS}

\section{CAPÍTULO I \\ DA ADMINISTRAÇÃO PÚBLICA}

Artigo $2^{\circ}$. São considerados integrantes da Administração Pública os órgãos da Administração Pública Direta e Indireta, nos termos da Lei Orgânica da Administração Pública Federal.

\section{CAPÍTULO II DO TERCEIRO SETOR}

Artigo $3^{\circ}$. O Terceiro Setor é composto das pessoas jurídicas de direito privado, sem fins lucrativos, criadas pela iniciativa privada, que tenham por finalidade:

I - o desenvolvimento de atividades prestacionais relativas a direitos fundamentais;

II - o desenvolvimento de atividades de garantia de direitos fundamentais;

III - o desenvolvimento de atividades de defesa do conteúdo constitucional.

Artigo $4^{\circ}$. Consideram-se pessoas jurídicas de direito privado, sem fins lucrativos, criadas pela iniciativa privada, nos termos da legislação civil e especial:

I - as associações civis, inclusive os sindicatos;

II - as fundações privadas; 
III - as cooperativas sociais;

IV - as organizações religiosas; e

$\mathrm{V}$ - os partidos políticos.

$\S 1^{\stackrel{o}{ }}$. Considera-se sem fins lucrativos a pessoa jurídica de direito privado que não distribui, entre os seus sócios ou associados, conselheiros, diretores, empregados ou doadores, eventuais excedentes operacionais, brutos ou líquidos, dividendos, bonificações, participações ou parcelas do seu patrimônio, auferidos mediante o exercício de suas atividades, e que os aplica integralmente na consecução do respectivo objeto social.

$\S 2^{\underline{o}}$. Consideram-se criadas pela iniciativa privada as pessoas jurídicas acima referidas cuja criação seja de caráter voluntário das pessoas físicas ou jurídicas de direito privado que a compõem, excluindo-se, portanto:

I - pessoas jurídicas autorizadas ou criadas por lei ou por órgãos ou entidades públicos, mesmo que de natureza jurídica privada;

II - pessoas jurídicas em que representantes do Poder Público tenham participação compulsória em órgãos de direção, deliberação ou administração;

III - pessoas jurídicas mantidas por contribuições fisscais e parafiscais do Poder Público, como as entidades do Sistema S;

IV - outras hipóteses que afastem a voluntariedade privada da criação.

Artigo $5^{\circ}$. Consideram-se atividades prestacionais relativas a direitos fundamentais aquelas prestadas diretamente à população que tenham por objeto a promoção de pelo menos um dos seguintes direitos:

a) educação, em caráter complementar ou suplementar aos serviços estatais;

b) saúde, em caráter complementar ou suplementar aos serviços estatais;

c) a assistência social, assim compreendidas as atividades previstas no art. $3^{\underline{o}}$ da Lei Orgânica da Assistência Social;

d) proteção à família, à maternidade, à infância, à adolescência e à velhice;

e) amparo às crianças e adolescentes carentes;

f) integração ao mercado de trabalho;

g) habilitação e reabilitação das pessoas portadoras de deficiência e a promoção de sua integração à vida comunitária;

h) complementação da renda da pessoa portadora de deficiência e do idoso, nos termos do artigo 203, da Constituição Federal;

i) cultura; 
j) desporto;

k) ciência e tecnologia;

1) comunicação social;

m) meio ambiente;

n) dos índios;

o) moradia;

p) lazer;

q) segurança;

r) previdência;

s) assistência aos desamparados;

t) direitos dos trabalhadores;

u) direitos civis;

v) direitos políticos;

w) de crença religiosa;

x) promoção do voluntariado;

y) experimentação, não lucrativa, de novos modelos sócio-produtivos e de sistemas alternativos de produção, comércio, emprego e crédito.

Parágrafo único: Também são consideradas atividades prestacionais relativas a direitos fundamentais as atividades de apoio às entidades abrangidas por este artigo, portanto de execução indireta destas atividades.

Artigo $6^{\circ}$. Consideram-se atividades de garantia de direitos fundamentais aquelas destinadas a garantir à população a fruição de um dos direitos listados no artigo anterior e no artigo $5^{\circ}$, da Constituição Federal.

Artigo $7^{\circ}$. Consideram-se atividades de defesa do conteúdo constitucional aquelas destinadas a garantir o cumprimento dos direitos e deveres previstos na Constituição Federal.

TÍTULO III

DA QUALIFICAÇÃO COMO ORGANIZAÇÃO DO TERCEIRO SETOR 
Artigo $8^{\circ}$. Podem ser qualificadas como Organização do Terceiro Setor, para os fins previstos nesta lei, as entidades que se enquadrem no disposto nos artigos $3^{\circ}$ a $7^{\circ}$ e nos demais requisitos previstos nesta lei, salvo:

I - os sindicatos, as associações de classe ou de representação de categoria profissional;

II - as instituições hospitalares privadas não gratuitas e suas mantenedoras;

III - as escolas privadas dedicadas ao ensino formal não gratuito e suas mantenedoras;

IV - as instituições religiosas ou voltadas para a disseminação de credos, cultos, práticas e visões devocionais e confessionais;

V - as organizações partidárias e assemelhadas, inclusive suas fundações;

VI - as entidades de benefício mútuo destinadas a proporcionar bens ou serviços a um círculo restrito de associados ou sócios;

VII - as entidades que comercializam planos de saúde e assemelhados;

VIII - as organizações sociais;

IX - as cooperativas, exceto as cooperativas sociais;

$\mathrm{X}$ - as organizações creditícias que tenham qualquer tipo de vinculação com o sistema financeiro nacional a que se refere o art. 192 da Constituição Federal.

Parágrafo único. É expressamente vedada às entidades qualificadas como Organização do Terceiro Setor a participação em campanhas de interesse político-partidário ou eleitorais, sob quaisquer meios ou formas.

Art. $9^{0}$ Exige-se ainda, para qualificarem-se como Organizações do Terceiro Setor, que as pessoas jurídicas interessadas sejam regidas por estatutos cujas normas expressamente disponham sobre:

I - a observância dos princípios da legalidade, impessoalidade, moralidade, publicidade, economicidade e da eficiência;

II - a adoção de práticas de gestão administrativa, necessárias e suficientes a coibir a obtenção, de forma individual ou coletiva, de benefícios ou vantagens pessoais, em decorrência da participação no respectivo processo decisório;

III - a constituição de conselho fiscal ou órgão equivalente, dotado de competência para opinar sobre os relatórios de desempenho financeiro e contábil, e sobre as operações patrimoniais realizadas, emitindo pareceres para os organismos superiores da entidade;

IV - a previsão de que, em caso de dissolução da entidade, o respectivo patrimônio líquido será transferido a outra pessoa jurídica qualificada nos termos desta Lei, preferencialmente que tenha o mesmo objeto social da extinta; 
V - a previsão de que, na hipótese de a pessoa jurídica perder a qualificação instituída por esta Lei, o respectivo acervo patrimonial disponível, adquirido com recursos públicos durante o período em que perdurou aquela qualificação, será transferido a outra pessoa jurídica qualificada nos termos desta Lei, preferencialmente que tenha o mesmo objeto social;

VI - a possibilidade de se instituir remuneração para os dirigentes da entidade que atuem efetivamente na gestão executiva e para aqueles que a ela prestam serviços específicos, respeitados, em ambos os casos, os valores praticados pelo mercado, na região correspondente a sua área de atuação;

VII - as normas de prestação de contas a serem observadas pela entidade, que determinarão, no mínimo:

a) a observância dos princípios fundamentais de contabilidade e das Normas Brasileiras de Contabilidade;

b) a realização de auditoria por auditores externos independentes caso receba repasses públicos superiores a $\mathrm{R} \$ 600.000,00$ (seiscentos mil reais) no ano;

c) a prestação de contas, aos respectivos órgãos repassadores, de todos os recursos e bens de origem pública recebidos através de Termo de Fomento ou de Parceria, bem como a ciência da sujeição à fiscalização da Agência do Terceiro Setor e do Tribunal de Contas da União, neste caso nos termos do artigo 70, parágrafo único, da Constituição Federal;

d) a prestação de contas anual à Agência do Terceiro Setor.

Parágrafo único. É permitida a participação de servidores públicos na composição de conselho de Organização do Terceiro Setor, vedada a percepção de remuneração ou subsídio a este servidor, a qualquer título.

Art. 10. Cumpridos os requisitos, a pessoa jurídica de direito privado sem fins lucrativos, interessada em obter a qualificação instituída por esta Lei, deverá formular requerimento escrito à Agência Nacional do Terceiro Setor, instruído com cópias autenticadas dos seguintes documentos:

I - estatuto registrado em cartório;

II - ata de eleição de sua atual diretoria;

III - balanço patrimonial e demonstração do resultado do exercício;

IV - declaração do imposto de renda;

V - inscrição no Cadastro Geral de Contribuintes. 
Art. 11. Recebido o requerimento previsto no artigo anterior, a Agência Nacional do Terceiro Setor decidirá, no prazo de trinta dias, deferindo ou não o pedido.

$\S 1^{\circ}$ No caso de deferimento, a Agência Nacional do Terceiro Setor emitirá, no prazo de quinze dias da decisão, certificado de qualificação da requerente como Organização do Terceiro Setor.

$\S 2^{\underline{0}}$ Indeferido o pedido, a Agência Nacional do Terceiro Setor, no prazo do $\S 1^{\underline{o}}$, dará ciência da decisão, mediante publicação no Diário Oficial.

$\S 3^{0} \mathrm{O}$ pedido de qualificação somente será indeferido quando:

I - a requerente enquadrar-se nas exceções previstas no art. $8^{\circ}$ desta Lei;

II - a requerente não atender aos requisitos descritos nos arts. $3^{\circ}$ a $7^{\circ}$ desta Lei;

III - a documentação apresentada ou o estatuto social estiverem incompletos.

Art. 12. Perde-se a qualificação de Organização do Terceiro Setor nas hipóteses de inobservância à presente lei e demais normas que regem seus instrumentos, a pedido ou mediante decisão proferida em processo administrativo ou judicial, de iniciativa popular ou do Ministério Público, no qual serão assegurados a ampla defesa e o devido contraditório.

Art. 13. Vedado o anonimato, e desde que amparado por fundadas evidências de erro ou fraude, qualquer cidadão, respeitadas as prerrogativas do Ministério Público, é parte legítima para requerer, judicial ou administrativamente, a perda da qualificação instituída por esta Lei.

\section{TÍTULO IV}

\section{DAS PARCERIAS ENTRE A ADMINISTRAÇÃO PÚBLICA E AS ORGANIZAÇÕES DO TERCEIRO SETOR}

Art. 14. Reconhecendo-se a importância da participação do Terceiro Setor no desenvolvimento de ações de natureza social, ficam instituídos dois instrumentos de parceria possíveis de serem firmados entre o Poder Público e as entidades qualificadas como Organizações do Terceiro Setor, destinados à formação de vínculo de cooperação entre as partes, para o fomento e a execução das atividades de interesse público previstas nos artigos $3^{\circ}$ a $7^{\circ}$ desta Lei:

I - Termo de Fomento;

II - Termo de Parceria. 


\section{CAPÍTULO I DO TERMO DE FOMENTO}

Art. 15. O Termo de Fomento tem por finalidade o fomento, pela entidade estatal, de projeto específico de duração não continuada de iniciativa da Organização do Terceiro Setor, necessariamente relacionado a uma das atividades previstas nos artigos $3^{\circ}$ a $7^{\circ}$ desta Lei.

$\S 1^{\underline{o}}$. Considera-se duração não continuada a atividade cujo objeto constitua conduta específica e definida da Organização do Terceiro Setor.

$\S 2^{\underline{o}}$. Os termos de fomento terão prazo não superior a 06 (seis) meses, no qual o objeto deverá ser consumado de acordo com o Plano de Trabalho.

$\S 3^{\underline{0}}$. As verbas repassadas em virtude do termo de fomento deverão ser aplicadas em exata conformidade com o Plano de Trabalho apresentado, limitadas as despesas de custeio a $30 \%$ (trinta por cento) do fomento.

$\S 4^{\circ}$. É permitida a previsão de taxa de administração, incluída no percentual das despesas de custeio, de até 5\% (cinco por cento) do valor do termo de fomento.

$\S 5^{\circ}$. Os recursos oriundos de Termo de Fomento não poderão ser utilizados para a aquisição de bens imóveis pela Organização do Terceiro Setor.

$\S 6^{0}$. A Organização do Terceiro Setor deverá adotar, para a contratação de obras e serviços e para as compras, com emprego dos recursos públicos oriundos de Termo de Fomento, no mínimo a realização de cotação prévia de preços no mercado antes da celebração dos contratos, dando efetividade aos princípios previstos no artigo $9^{\circ}$, I, desta Lei, não the sendo aplicável o regime da Lei n. 8.666/93.

\section{CAPÍTULO II DO TERMO DE PARCERIA}

Art. 16. O Termo de Parceria tem por finalidade:

I - a atribuição, a Organização do Terceiro Setor, da execução de ação ou programa de iniciativa estatal, relacionada a uma das atividades previstas nos artigos $3^{\circ}$ a $7^{\circ}$ desta Lei, mediante contrapartidas da entidade estatal;

II - a execução conjunta, por entidade estatal e Organização do Terceiro Setor, de uma das atividades previstas nos artigos $3^{\circ}$ a $7^{\circ}$ desta Lei. 
Parágrafo único. A celebração do Termo de Parceria será precedida de consulta aos Conselhos de Políticas Públicas das áreas correspondentes de atuação existentes, nos respectivos níveis de governo.

Art. 17. A organização interessada em firmar Termo de Parceria disporá, como requisito para a seleção, de regulamento próprio contendo os procedimentos que adotará para a contratação de obras e serviços, bem como para compras com emprego de recursos provenientes do Poder Público, observados os princípios estabelecidos no artigo $9^{\circ}$, I, desta Lei, não lhe sendo aplicável o regime da Lei n. 8.666/93.

Art. 18. Caso a organização adquira bem imóvel com recursos provenientes da celebração do Termo de Parceria, este será gravado com cláusula de inalienabilidade.

\section{CAPÍTULO III}

\section{DAS DISPOSIÇÕES APLICÁVEIS AOS TERMOS DE FOMENTO E AOS TERMOS DE PARCERIA}

\section{Seção I - Das cláusulas essenciais dos Termos de Fomento e de Parceria}

Art. 19. Os Termos de Fomento e de Parceria, firmados de comum acordo entre o Poder Público e as Organizações do Terceiro Setor, discriminarão direitos, responsabilidades e obrigações das partes signatárias.

$\S 1^{\circ}$ São cláusulas essenciais dos Termos de Fomento e de Parceria:

I - a do objeto, que deverá ter pertinência temática com os objetivos institucionais da Organização do Terceiro Setor, e conterá a especificação do Plano de Trabalho proposto pela Organização do Terceiro Setor;

II - a de estipulação das metas e dos resultados a serem atingidos e os respectivos prazos de execução ou cronograma;

III - a de previsão expressa dos critérios objetivos de avaliação de desempenho a serem utilizados, mediante indicadores de resultado;

IV - a de previsão de receitas e despesas a serem realizadas em seu cumprimento, estipulando item por item as categorias contábeis usadas pela organização e o detalhamento das remunerações e benefícios de pessoal a serem pagos, com recursos 
oriundos ou vinculados ao Termo de Fomento ou de Parceria, a seus diretores, empregados e consultores;

\section{Seção II - Da seleção de projetos}

Art. 20. O órgão estatal responsável pela celebração do Termo de Fomento ou de Parceria verificará previamente o regular funcionamento da organização e a pertinência do objeto do termo com os objetivos institucionais da organização.

Art. 21. A escolha da Organização do Terceiro Setor, para a celebração de Termo de Fomento ou de Parceria, deverá ser feita por meio de publicação de edital de concurso de projetos pelo órgão estatal parceiro, não sendo aplicável o regime da Lei n. 8.666093.

$\S 1^{\circ}$. O concurso de projetos será realizado mesmo na hipótese de projetos apresentados por iniciativa de Organização do Terceiro Setor ao órgão estatal parceiro, que caso demonstre interesse deverá realizar o concurso.

$\S 2^{\underline{o}}$. Instaurado o processo de seleção por concurso, é vedado ao Poder Público celebrar Termo de Fomento ou de Parceria para o mesmo objeto, fora do concurso iniciado.

$\S 3^{\circ}$. Fica dispensado o concurso de projetos nas seguintes situações:

I - para a celebração de Termo de Fomento ou de Parceria cujo valor total de repasses de recursos públicos seja inferior a $\mathrm{R} \$ 50.000,00$ (cinqüenta mil reais);

II - para a celebração de Termo de Fomento ou de Parceria que atenda a necessidade urgente, devidamente motivada;

III - para a celebração de Termo de Fomento cujo objeto seja marcado pela pessoalidade absoluta da Organização do Terceiro Setor, devidamente motivada, e desde que não supere a quantia de $\mathrm{R} \$ 200.000,00$ (duzentos mil reais).

Art. 22. Para a realização de concurso, o órgão estatal parceiro deverá preparar, com clareza, objetividade e detalhamento, a especificação técnica do bem, do projeto, da obra ou do serviço a ser obtido ou realizado por meio do Termo de Fomento ou de Parceria, fazendo publicar edital na imprensa oficial e em página eletrônica.

Art. 23. Do edital do concurso de projetos deverá constar, no mínimo, informações sobre:

I - prazos, condições e forma de apresentação das propostas;

II - especificações técnicas do objeto do Termo de Fomento ou de Parceria; 
III - critérios de seleção e julgamento das propostas;

IV - datas para apresentação de propostas;

V - local de apresentação de propostas;

VI - datas do julgamento e data provável de celebração do Termo de Fomento ou de Parceria; e

VII - valor máximo a ser desembolsado.

Art. 24. A Organização do Terceiro Setor deverá apresentar seu projeto técnico, Plano de trabalho e o detalhamento dos custos a serem realizados na sua implementação ao órgão estatal parceiro.

Art. 25. Na seleção e no julgamento dos projetos, levar-se-ão em conta:

I - o mérito intrínseco e adequação ao edital do projeto apresentado;

II - a capacidade técnica e operacional da candidata;

III - a adequação entre os meios sugeridos, seus custos, cronogramas e resultados;

IV - o ajustamento da proposta às especificações técnicas; e

V - a regularidade jurídica e institucional da Organização do Terceiro Setor.

Art. 26. Obedecidos aos princípios da administração pública, são inaceitáveis como critério de seleção, de desqualificação ou pontuação:

I - o local do domicílio da Organização da Sociedade Civil de Interesse Público ou a exigência de experiência de trabalho da organização no local de domicílio do órgão parceiro estatal;

II - a obrigatoriedade de consórcio ou associação com entidades sediadas na localidade onde deverá ser celebrado o Termo de Parceria;

III - o volume de contrapartida ou qualquer outro benefício oferecido pela Organização da Sociedade Civil de Interesse Público.

Art. 27. O julgamento será realizado obrigatoriamente sobre o conjunto das propostas das Organizações do Terceiro Setor participantes do concurso, de forma comparativa, não sendo aceitos como critérios de julgamento os aspectos jurídicos, administrativos, técnicos ou operacionais não estipulados no edital do concurso. 
Art. 28. O órgão estatal parceiro designará a comissão julgadora do concurso, que será composta, no mínimo, por um membro do Poder Executivo, um especialista no tema do concurso da Agência Nacional do Terceiro Setor e um membro do Conselho de Política Pública da área de competência, quando houver.

$\S 1^{0} \mathrm{O}$ trabalho dessa comissão não será remunerado.

$\S 2^{\underline{0}} \mathrm{O}$ órgão estatal deverá instruir a comissão julgadora sobre a pontuação pertinente a cada item da proposta ou projeto e zelará para que a identificação da organização proponente seja omitida.

$\S 3^{0}$ A comissão pode solicitar ao órgão estatal parceiro informações adicionais sobre os projetos.

$\S 4^{\underline{0}}$ A comissão classificará as propostas das Organizações do Terceiro Setor obedecidos aos critérios estabelecidos nesta Lei e no edital.

Art. 29. Após o julgamento definitivo das propostas, a comissão apresentará, na presença dos concorrentes, os resultados de seu trabalho, indicando os aprovados.

$\S 1^{\underline{o}} \mathrm{O}$ órgão estatal parceiro:

I - não examinará recursos administrativos contra as decisões da comissão julgadora;

II - não poderá anular ou suspender administrativamente o resultado do concurso nem celebrar outros Termos de Fomento ou de Parceria, com o mesmo objeto, sem antes finalizar o processo iniciado pelo concurso.

$\S 2^{\circ}$ Após o anúncio público do resultado do concurso, o órgão estatal parceiro o homologará, sendo imediata a celebração do Termo pela ordem de classificação dos aprovados, devendo a Organização do Terceiro Setor publicar extrato do Termo sob pena de não receber os recursos relativos a ele.

\section{CAPÍTULO III - DA PRESTAÇÃO DE CONTAS DOS TERMOS DE FOMENTO E DE PARCERIA}

Art. 30. A Organização do Terceiro Setor contemplada com recursos públicos através de Termo de Fomento prestará contas do Termo de Fomento ao respectivo órgão público parceiro ao término do prazo previsto no termo, que ao final do exercício submeterão à Agência do Terceiro Setor com parecer sobre a utilização dos recursos e o cumprimento das metas estipuladas. 
Parágrafo único. O órgão público e a Organização do Terceiro Setor indicarão, no ato da assinatura do Termo de Fomento, um representante de cada para o acompanhamento e execução do termo, ficando o representante indicado pelo órgão público responsável pela elaboração do parecer a que se refere o caput.

Art. 31. A Organização do Terceiro Setor contemplada com recursos públicos através de Termo de Parceria prestará contas do Termo de Parceria ao respectivo órgão público parceiro ao término de cada exercício, e este submeterá à Agência do Terceiro Setor com parecer sobre a utilização dos recursos e o cumprimento das metas estipuladas.

Parágrafo único. Considerando a natureza continuada de suas atividades, a execução do objeto do Termo de Parceria será acompanhada por Comissão de Avaliação, formada de comum acordo entre o órgão público e a Organização do Terceiro Setor parceiros e constituída no ato da assinatura do Termo de Parceria, necessariamente composta por dois membros do órgão público parceiro, um membro da Organização do Terceiro Setor e um membro indicado pelo Conselho de Política Pública da área de atuação correspondente, quando houver, competindo à Comissão de Avaliação o monitoramento da execução do Termo de Parceria e a elaboração do parecer a que se refere o caput.

Art. 32. Para efeito do disposto nos artigos 29 e 30, considera-se prestação de contas dos Termos de Fomento e de Parceria a comprovação da correta aplicação dos recursos públicos recebidos e do adimplemento do objeto do termo, mediante a apresentação dos seguintes documentos:

I - relatório sobre a execução do objeto do Termo de Fomento ou de Parceria, contendo comparativo entre as metas propostas e os resultados alcançados;

II - demonstrativo integral da receita e despesa realizadas na execução;

III - parecer e relatório de auditoria independente, caso o valor total do Termo de Fomento ou o valor do repasse anual do Termo de Parceria tenha sido superior ao previsto no art. $9^{\circ}$, VII, "b"; e

IV - entrega do extrato da execução física e financeira do termo, preenchido de acordo com modelo a ser disponibilizado.

Art. 33. Os responsáveis pela fiscalização do Termo de Fomento e de Parceria, conforme indicações dos artigos 29, parágrafo único e 30, parágrafo único, ao tomarem conhecimento de qualquer irregularidade ou ilegalidade na utilização de recursos ou bens 
de origem pública pela organização parceira, darão imediata ciência ao Tribunal de Contas respectivo e ao Ministério Público, sob pena de responsabilidade solidária.

Art. 34. Sem prejuízo da medida a que se refere o art. 32 desta Lei, havendo indícios fundados de malversação de bens ou recursos de origem pública, os responsáveis pela fiscalização representarão ao Ministério Público, à Advocacia-Geral da União, para que requeiram ao juízo competente a decretação da indisponibilidade dos bens da entidade e o seqüestro dos bens dos seus dirigentes, bem como de agente público ou terceiro, que possam ter enriquecido ilicitamente ou causado dano ao patrimônio público, além de outras medidas consubstanciadas na Lei $\mathrm{n}^{\circ} 8.429$, de 2 de junho de 1992, e na Lei Complementar $\mathrm{n}^{\mathrm{o}} 64$, de 18 de maio de 1990.

$\S 1^{\circ} \mathrm{O}$ pedido de seqüestro será processado de acordo com o disposto nos arts. 822 e 825 do Código de Processo Civil.

$\S 2^{0}$ Quando for o caso, o pedido incluirá a investigação, o exame e o bloqueio de bens, contas bancárias e aplicações mantidas pelo demandado no País e no exterior, nos termos da lei e dos tratados internacionais.

$\S 3^{\mathrm{o}}$ Até o término da ação, o Poder Público permanecerá como depositário e gestor dos bens e valores seqüestrados ou indisponíveis e velará pela continuidade das atividades sociais da organização parceira.

\section{TÍTULO V - DA PRESTAÇÃO DE CONTAS ANUAL DAS ENTIDADES QUALIFICADAS COMO ORGANIZAÇÕES DO TERCEIRO SETOR}

Art. 35. Ao final de cada exercício, nos termos do art. 9º , inciso VII, alínea "d", desta Lei, todas as entidades qualificadas como Organização do Terceiro Setor deverão apresentar prestação de contas à Agência do Terceiro Setor, independentemente de terem recebido verbas públicas.

$\S 1^{\underline{0}}$ As prestações de contas anuais serão realizadas sobre a totalidade das operações patrimoniais e resultados de todas as entidades qualificadas como Organização do Terceiro Setor nos termos desta Lei.

$\S 2^{2}$ A prestação de contas será instruída com os seguintes documentos:

I - relatório anual de execução de atividades;

II - demonstração de resultados do exercício;

III - balanço patrimonial; 
IV - demonstração das origens e aplicações de recursos;

V - demonstração das mutações do patrimônio social;

VI - notas explicativas das demonstrações contábeis, caso necessário;

VII - parecer e relatório de auditoria independente, caso o valor total de repasses públicos oriundos de Termos de Fomento ou de Parceria, no exercício anterior, tenha sido superior ao previsto no art. $9^{\circ}$, VII, "b"; e

VIII - cópias de todos os extratos de execução física e financeira dos termos assinados, exatamente como entregues aos órgãos públicos parceiros.

\section{TÍTULO VI - DO CONTROLE SOCIAL}

Art. 36. A Agência Nacional do Terceiro Setor manterá cadastro atualizado das entidades qualificadas como Organização do Terceiro Setor em seu site da Internet, bem como cópia dos extratos de execução física e financeira de todos os termos por elas assinados, para consulta pública.

Art. 37. A Agência Nacional do Terceiro Setor permitirá, mediante requerimento dos interessados, livre acesso público a todas as informações pertinentes às Organizações do Terceiro Setor.

Art. 38. Qualquer cidadão ou entidade do Terceiro Setor, qualificada ou não, tem legitimidade para denunciar aos órgãos competentes quaisquer irregularidades e ilegalidade envolvendo a atuação de entidades do Terceiro Setor.

\section{TÍTULO VII - DAS DISPOSIÇÕES GERAIS}

Art. 39. Às entidades previstas no artigo $8^{\circ}$, II, III e VI, mesmo que não possam obter a qualificação como Organização do Terceiro Setor, aplicam-se as regras relativas aos Termos de Fomento.

Parágrafo único. Estas entidades, equiparadas às Organizações do Terceiro Setor para fins de celebração de Termos de Fomento, deverão observância ao disposto nos artigos $9^{\circ}$, I, II, III, IV, VI, VII, parágrafo único, e somente poderão celebrar Termos de Fomento após a análise dos documentos previstos no artigo 10 e submissão ao processo de seleção e 
prestação de contas previsto nesta Lei, inclusive a prestação de contas anual à Agência Nacional do Terceiro Setor.

Art. 40. As entidades qualificadas como Organizações do Terceiro Setor, bem como as equiparadas a elas conforme o artigo anterior, estarão sujeitas à Lei de Improbidade Administrativa.

Art. 41. As entidades qualificadas como Organização da Sociedade Civil de Interesse Público, nos termos da Lei n. 9.790/99, passarão automaticamente à condição de Organização do Terceiro Setor para os fins desta lei, extinguindo-se aquela qualificação para todos os fins de direito.

Art. 41. Na lei $* * * * *$, onde se lê, OSCIP, leia-se OTS

Art. 42. As entidades detentoras do título de utilidade pública federal e/ou dos Certificados Ministeriais criados pela Lei n. 12.101/2009, gozarão destes títulos até no máximo o dia $31 / 12 / 2011$, oportunidade em que ficam extintos.

Parágrafo único. Estas entidades, desde que cumpram os requisitos desta lei, poderão solicitar a qualificação como Organização do Terceiro Setor e mantê-la simultaneamente aos títulos até 31/12/2011.

Art. 43. Fica proibido às Leis Orçamentárias a previsão de transferência voluntária para entidades privadas sem fins lucrativos diversa das seguintes hipóteses, que serve de sugestão para a redação legal:

I - repasses financeiros por meio de Termo de Fomento firmado com Organizações do Terceiro Setor ou entidades equiparadas, nos termos da Lei n. ********;

II - repasses financeiros por meio de Termo de Parceria firmado com Organizações do Terceiro Setor, nos termos da Lei n.

III - repasses financeiros por meio de Contrato de Gestão firmado com Organização Social, nos termos da Lei n. 9.637/98.

Art. 44. Ficam revogados todos os dispositivos legais e infralegais que prevejam a assinatura de convênios, contratos de repasse ou outros instrumentos jurídicos de natureza colaborativa entre o Poder Público e quaisquer entidades privadas sem fins lucrativos, 
qualificadas ou não como Organização do Terceiro Setor, que serão regidos exclusivamente pelo regime criado por esta Lei, salvo:

I - os contratos de gestão com as Organizações Sociais;

II - as hipóteses de celebração de contratos administrativos entre o Poder Público e as entidades privadas sem fins lucrativos, que por não serem instrumentos jurídicos de natureza colaborativa continuam regidas pelas leis próprias;

III - os repasses do Poder Público para pessoas jurídicas autorizadas ou criadas por lei ou por órgãos ou entidades públicos, mesmo que de natureza jurídica privada sem fins lucrativos.

Parágrafo único. A legislação que regulamenta os convênios e contratos de repasse se aplicará somente às relações entre entes da Administração Pública, não se aplicando às relações entre a Administração Pública e entidades privadas sem fins lucrativos.

\section{TÍTULO VIII - DA AGÊNCIA NACIONAL DO TERCEIRO SETOR}

Art. 45. Fica criada a Agência Nacional do Terceiro Setor - ANATS, autarquia especial vinculada ao Ministério da Justiça, órgão de fomento das atividades do Terceiro Setor e de regulação e fiscalização das relações entre a Administração Pública e as entidades qualificadas como Organização do Terceiro Setor nos termos da Lei.

$\S 1^{\circ}$ A ANATS, dotada de autonomia administrativa e financeira, terá sede e foro no Distrito Federal, podendo instalar unidades administrativas regionais.

$\S 2^{0}$ O Ministério da Justiça supervisionará as atividades da ANATS, conforme regulamento.

Art. 46 A ANATS terá os seguintes objetivos:

I - Fomentar os debates sobre os temas afetos às atividades do Terceiro Setor;

II - Fomentar a cultura do voluntariado, do associativismo, do empreendedorismo, entre outros temas relacionados à cultura do Terceiro Setor;

III - Estimular a participação da sociedade civil nas questões sociais;

IV - Promover encontros entre o Terceiro Setor, a Administração Pública e empresas, com a finalidade de fortalecer as discussões críticas sobre o relacionamento de todos os atores sociais;

V - Promover a autosustentabilidade das entidades do Terceiro Setor, bem como as parcerias com a Administração Pública e as empresas; 
VI - Estimular o debate sobre formas de participação ativa da sociedade civil na formatação, execução e controle de políticas públicas;

VII - Estimular os Estados, Distrito Federal e Municípios a instituírem órgãos colegiados com competências similares à Agência Nacional do Terceiro Setor-ANATS, e integrá-los na Política Nacional de Desenvolvimento do Terceiro Setor;

VIII - Estimular a participação das empresas do setor privado, das organizações da sociedade civil e da população na formulação, implementação e avaliação da Política Nacional de Desenvolvimento do Terceiro Setor;

IX - Incentivar a realização de acordos, alianças e parcerias bilateriais e multilaterais entre as entidades do Terceiro Setor, empresas do setor privado, entes governamentais, organismos internacionais de financiamento, visando a implementação da Política Nacional de Desenvolvimento do Terceiro Setor;

$\mathrm{X}$ - Estimular a capacitação dos recursos humanos e a profissionalização consciente do quadro de pessoal das entidades do Terceiro Setor;

XI - Estimular a legitimação institucional do Terceiro Setor como importante ator no desempenho de ações de interesse público;

XII - Zelar pela lisura e pela aplicação da lei no relacionamento entre as entidades qualificadas como Organizações do Terceiro Setor e a Administração Pública.

Art. 47. A ANATS terá as seguintes competências:

I - Formular a Política Nacional de Desenvolvimento do Terceiro Setor;

II - Executar a Política Nacional de Desenvolvimento do Terceiro Setor;

III - Estabelecer diretrizes, elaborar normas e articular a coordenação da Política Nacional de Desenvolvimento do Terceiro Setor;

IV - Planejar, coordenar, supervisionar e financiar estudos, levantamentos, pesquisas e publicações sobre o Terceiro Setor no Brasil, gerando informações atualizadas sobre este segmento;

V - Promover simpósios, seminários e encontros sobre o Terceiro Setor, intermediando o intercâmbio de experiências e troca de informações entre o Brasil e outros países, assim como entre os entes da Federação;

VI - Estimular a criação da Rede Nacional do Terceiro Setor-RENATS;

VII - Avaliar e fornecer os certificados de qualificação como Organização do Terceiro Setor, nos termos da Lei, mantendo cadastro atualizado das entidades qualificadas e dos respectivos termos de fomento e de parceria, para consulta pública; 
VIII - Ser representado nas Comissões de Avaliação de Termos de Fomento e de Parceria, no âmbito do concurso de projetos para a seleção da Organização do Terceiro Setor ou equiparada selecionada para este fim;

IX - Regular as atividades de fomento às entidades qualificadas como Organização do Terceiro Setor ou equiparadas;

$\mathrm{X}$ - Receber dos órgãos da Administração Pública os pareceres com as prestações de contas apresentadas pelas Organizações do Terceiro Setor e equiparadas, fiscalizando a correta utilização dos recursos públicos;

XI - Aprovar as prestações de contas anuais das Organizações do Terceiro Setor e equiparadas e, se reprovadas, encaminhar ao Tribunal de Contas da União;

XII - Fornecer as informações que disponha sobre as Organizações do Terceiro Setor e equiparadas a qualquer cidadão que o solicitar, para consulta na sede da ANATS;

XIII - Estudar, analisar e sugerir alterações na legislação pertinente ao Terceiro Setor; e XIV - outras atribuições a serem estabelecidas por decreto do Poder Executivo.

Art. 48. O Poder Executivo expedirá decreto para regulamentar a Agência Nacional do Terceiro Setor-ANATS, estabelecendo sua composição, organização, funcionamento e outras atribuições.

\section{TÍTULO IX - DAS DISPOSIÇÕES FINAIS E TRANSITÓRIAS}

Art. 49. A Agência Nacional do Terceiro Setor - ANATS formulará a Política Nacional do Terceiro Setor no prazo de 180 (cento e oitenta) dias.

Art. 50. O Poder Executivo regulamentará esta Lei no prazo de 30 (trinta) dias.

Art. 51. Esta Lei entra em vigor 30 (trinta) dias após a sua publicação. 


\section{CAPÍTULO 6. CONCLUSÕES}

O tema das parcerias entre a Administração Pública e o Terceiro Setor tem tomado força nos últimos anos, pegando carona propriamente nos intensos debates em torno de seus elementos de concreção: a Administração Pública e o Terceiro Setor.

Fenômenos que andam concomitantemente e acabam por repercutir efeitos conjuntos, os debates sobre a redefinição das funções do Estado e sobre o papel desenvolvido pela sociedade civil têm figurado na pauta já há algum tempo, e mais recentemente a interseção destes assuntos.

O Estado passa a se adaptar a um modelo de convivência baseado no policentrismo, dotando a Administração Pública de ferramentas menos autoritárias para a execução das suas ações com vistas ao interesse público; em paralelo, a sociedade civil se ergue como ator legitimado a compartilhar esta busca pelo interesse público, apresentando-se como opção para a ação administrativa. É neste ponto que ocorre a interseção entre a redefinição das funções do Estado e o papel da sociedade civil, cuja conseqüência sumária é a busca da aproximação entre estes atores para obter os resultados a que estão propostos.

Este resumo, no entanto, não é reflexo da realidade jurídico-normativa brasileira atual; é, antes disso, uma antecipação do que se espera como conseqüência dos debates que vêm sendo levados a efeito sobre a Administração Pública Consensual, Paritária, e a importância do papel do Terceiro Setor neste contexto.

E entre a expectativa e a realização deste cenário há diversos obstáculos que pretendemos apontar no presente trabalho, que se encontram exatamente no campo dos debates sobre os temas circundantes ao das parcerias entre a Administração Pública e o Terceiro Setor. É neste ponto que nos encontramos e que esperamos, passo a passo, superar em direção à efetivação de um verdadeiro regime de participação da sociedade civil em assuntos de relevante natureza social.

Estes obstáculos se iniciam já na compreensão das reformas discutidas quanto às funções do Estado, encontrando barreiras para a superação dos paradigmas exclusivamente burocráticos e autoritários que permeavam a Administração Pública tradicional. As propostas que apontam para uma Administração Pública Consensual ou Paritária, em que se inserem os debates sobre o relacionamento entre o Poder Público e entidades privadas, ainda encontram resistência de implementação tanto na doutrina como na prática. Como aponta Maria Tereza Fonseca Dias, 
as reações dos juristas à questão da relação do Estado com o Terceiro Setor são diversas. A primeira enxerga no fenômeno da parceria do poder público com as entidades privadas sem fins lucrativos clara ruptura com a ordem jurídica vigente, com a conseqüente burla do regime jurídico-administrativo. Outra perspectiva reconhece essa relação como uma das poucas alternativas que restam para solucionar os problemas da gestão pública e, em virtude das alterações constitucionais e legislativas, encontra-se perfeitamente albergada pela ordem jurídica vigente. Certos juristas, por sua vez, entendem que as relações de cooperação entre o setor público e o setor privado sem fins lucrativos é alternativa juridicamente aceitável, desde que alguns ajustes - às vezes de fundo - sejam feitos, não só na legislação que rege o tema no direito pátrio, mas na própria percepção sobre o fenômeno. ${ }^{607}$

Trata-se, portanto, de fenômeno cuja aceitação jurídica ainda não se estabeleceu definitivamente, carecendo ainda de intensos debates que cristalizem os limites e a abrangência da atuação consensual ou paritária entre a Administração Pública e a sociedade civil. No entanto, a flagrante evolução de ferramentas consensuais já implementadas em outros ordenamentos jurídicos e mesmo no âmbito nacional dão conta de sua maturidade, a depender somente de sintonia fina para sua calcificação.

Desde ordenamentos jurídicos que assumiram expressamente o princípio da subsidiariedade e responsabilizaram o Estado pelas ações de fomento para o pleno exercício da cidadania pela sociedade através do desenvolvimento de ações de interesse geral, passando por ordenamentos jurídicos que previram expressamente o papel do Terceiro Setor no desempenho de ações de interesse social, reconhecendo a sua importância e destinando-lhe regulamentação específica, chegando em países que criaram mecanismos jurídico-normativos específicos de regulação das atividades consensuais entre a Administração Pública e o Terceiro Setor, com órgão específico de fomento e controle de suas atividades, todas estas experiências servem para auxiliar na consolidação da idéia de Administração Pública Consensual.

Servem, também, para fortalecer o importante papel desenvolvido pelas entidades privadas sem fins lucrativos que atuam nos segmentos de interesse público compartindo a responsabilidade estatal, e que no decorrer deste trabalho definimos juridicamente como toda ação voluntária, sem intuito lucrativo, praticada por pessoa física ou jurídica de natureza privada, que tenha por finalidade a prestação ou a garantia de direito fundamental, ou a defesa do conteúdo constitucional. O Terceiro Setor, ator social que aos poucos vem recebendo legitimação doutrinária e, como visto, em alguns países, legislativa,

${ }^{607}$ DIAS, Maria Tereza Fonseca. Terceiro setor e Estado: legitimidade e regulação. Belo Horizonte : Fórum, 2008, p. 427. 
já integrando algumas importantes normas jurídicas. É verdade, ainda de forma bastante tímida e isolada.

Terceiro Setor que, como pudemos verificar, recebe um espaço de participação em nosso ordenamento jurídico constitucional que, direta ou indiretamente, define os campos de compartilhamento de ação entre as entidades que dele fazem parte e o Estado.

Deste conteúdo constitucional, aliás, se extrai a imperatividade de atuação conjunta do Estado e do Terceiro Setor em determinadas matérias de interesse público, o que não significa a desresponsabilização do Estado. ${ }^{608}$

Ocorre que a (re)descoberta desta atuação conjunta prevista em nossa Constituição de 1988, que encerra o monopólio estatal da ação pública social, começa a maturar tardiamente somente no âmbito do Plano Diretor de Reforma do Aparelho do Estado ocorrida em meados da década de 1990, propulsora da superação do paradigma bipolar e da proposta de uma Administração Pública Paritária no âmbito nacional

Uma das formas de expressão desta nova modelagem é a das parcerias entre a Administração Pública e o Terceiro Setor, desenvolvidas sobretudo como expressão da função de fomento da Administração Pública. Embora se tenha tentado a criação de novas ferramentas de relacionamento sob este prisma no decorrer da década de 1990 do século passado, "foi atingido o ponto em que se torna absolutamente obrigatória a ordenação e a sistematização das matrizes jurídico-normativas do Terceiro Setor em nosso país". 609

E disto não escapam as parcerias entre a Administração Pública e o Terceiro Setor. A edição da Lei n. ${ }^{\circ}$ 9.637, de 15 de maio de 1998 (Lei das Organizações Sociais), que em princípio estaria inserida neste contexto, ao exigir a participação de funcionários públicos no Conselho de Administração das entidades acabou por demonstrar a sua vinculação com o modelo autoritário de Administração Pública, embora seja importante - não isento de críticas, é verdade - instrumento de flexibilização da atuação administrativa.

A edição da Lei n. 9.790, de 23 de março de 1999 (Lei das Oscips), por sua vez, é expressão do marco em direção à consolidação da Administração Pública consensual no que tange às atividades do Terceiro Setor. Dissemos, aliás, que a criação da qualificação como Organização da Sociedade Civil de Interesse Público e da ferramenta do termo de

\footnotetext{
608 "Naturalmente, a intervenção das organizações sem fins lucrativos deve ser vista como integrativa e não como substitutiva do âmbito público" (RICCI, Sergio. Appalti e convenzioni fra Terzo Settore ed enti pubblici. Terzo settore: le regole per il non profit. Milano : Il Sole 24 Ore, n. 10, out. 2006, p. 50, tradução nossa). No original: "Naturalmente, l'intervento delle organizzazioni non profit deve essere visto come integrativo e non come sostitutivo dell'ambito pubblico".

609 OLIVEIRA, Gustavo Justino de. Direito do terceiro setor. Revista de Direito do Terceiro Setor RDTS, Belo Horizonte : Fórum, ano 1, n. 1, jan.-jun. 2007, p. 36.
} 
parceria deve ser tida como pioneira no reposicionamento da relação do Estado com o Terceiro Setor no bojo de uma Administração Pública Consensual.

Mas isto não significa que o regime jurídico-normativo aplicável às parcerias entre a Administração Pública e o Terceiro Setor no Brasil seja satisfatório; aliás, muito pelo contrário.

Por diversos motivos ainda não há um regime jurídico que traga segurança na aplicação das parcerias entre a Administração Pública e o Terceiro Setor; nem as entidades conseguem conhecer satisfatoriamente a legislação, tampouco a Administração Pública se sente confiante na aplicação desta legislação. Passados mais de dez anos da edição da Lei n. 9.790/99, a necessidade de reforço legislativo é inequívoca.

Desde que, é claro, a opção política seja pelas parcerias. Ou seja, desde que politicamente se chegue à conclusão de que a atuação compartilhada entre o Estado e o Terceiro Setor é possível e legítima como instrumento de desenvolvimento de políticas públicas. Isto porque é possível observar que

o direito vigente e as tendências legislativas acerca da composição do terceiro setor, das atividades estatais que podem ser transferidas às entidades privadas sem fins lucrativos e dos mecanismos de fomento existentes não estão aptos a conferir legitimidade às ações da administração pública. ${ }^{610}$

Como abordado no decorrer do presente trabalho, a produção legislativa brasileira até o presente momento não logrou legitimar a interface entre a Administração Pública e o Terceiro Setor, embora tenha dados os primeiro passos. A começar com a não assunção da existência de um Terceiro Setor, não assumindo a sua concepção jurídica e se escondendo na limitação da qualificação como Oscip a certas atividades sem traçar o ponto comum que as une. É ponto importante a criação de uma mínima homogeneidade jurídica às entidades que a Administração Pública considera legitimadas a manter parcerias, criando uma identidade que molda a atuação do setor.

Além disso, instrumentos de formalização de parcerias mais próximos da vertente consensual da Administração Pública (estamos falando, em verdade, dos termos de parceria) convivem com instrumentos inadequadamente adaptados para este fim (em síntese, os convênios e os contratos de repasse) e que funcionam sob uma ótica que passa longe da objetividade, movidos por interesses políticos. Os repasses financeiros feitos pelo

${ }^{610}$ DIAS, Maria Tereza Fonseca. Terceiro setor e Estado: legitimidade e regulação. Belo Horizonte : Fórum, 2008, p. 430. 
Estado para o Terceiro Setor, no atual momento legislativo, sofrem com a ausência de um choque de regulação. A legislação orçamentária que regula estes repasses não economiza em mudanças ano a ano, ajudando a confundir o regime jurídico aplicável a tais situações. Não há homogeneidade de tratamento legislativo em relação às entidades merecedoras de repasses, aos requisitos exigíveis para tanto, aos documentos necessários à avaliação da competência da entidade, etc. Não há um marco jurídico seguro, permitindo a utilização do expediente dos repasses financeiros para, em não poucas oportunidades, desvio de recursos públicos a entidades apadrinhadas por políticos mal intencionados. Isto tudo, em boa medida, devido à ausência de sistematização legislativa do tema.

A intenção do presente trabalho, portanto, em um primeiro momento, foi o de legitimar juridicamente a atuação do Terceiro Setor através da análise do espaço de participação que lhe é outorgado constitucional. Aliás, esta competência constitucional que é outorgada às entidades sem fins lucrativos permite que desenvolvam atividades próprias - com alguns limites constitucionais em algumas delas, como a saúde e a educação, por exemplo -, independentemente de relacionamento com o Estado.

O Terceiro Setor desempenha papel de fundamental importância, desde que se lhe sejam dispensados, como conseqüência do reconhecimento desta importância, instrumentos jurídicos adequados. Instrumentos que devem servir não somente para que as entidades tenham condições de prosperar, mas também para que o Estado disponha de aparatos suficientes para fazê-las desempenhar seu papel com transparência e eficiência.

A fortalecer esta assertiva, o jurista português Vital Moreira afirma que

as fundações e o chamado 'sector não lucrativo' (non profit), em geral, têm um papel cada vez mais relevante na sociedade e na economia dos países mais desenvolvidos, quer em termos dos serviços por elas prestados nas mais diversas áreas, quer pelo volume de emprego por que são responsáveis. Devem ser obviamente encorajadas e apoiadas. Mas não devem servir de capa a iniciativas empresariais apócrifas nem de fuga às responsabilidades públicas. ${ }^{611}$

É nesta esteira que se propõe uma nova regulação das parcerias entre a Administração Pública e o Terceiro Setor, partindo da constatação de que o regime atual assistemático não permite nem o desenvolvimento do setor, nem as necessárias ferramentas de fiscalização e controle ao Estado.

${ }^{611}$ MOREIRA, Vital. A regulação das fundações. In: MOREIRA, Vital; MARQUES, Maria Manuel Leitão. A mão visível: mercado e regulação. Coimbra : Almedina, 2003, p. 243. 
Parte-se, evidentemente, do atual regime jurídico destinado a estas relações, encontrado em leis esparsas e no mais das vezes adaptadas para um fim para o qual não foram criadas. É o exemplo, mais uma vez, dos convênios, criados para regular as relações entre a Administração Pública em seus variados níveis e que passaram a ser utilizados indevidamente para as relações entre a Administração Pública e entidades privadas. Esta sistematização proposta pelo presente trabalho tem o intuito de marcar o estado da arte do tema abordado, especialmente para justificar a necessidade de intervenção legislativa tendente a uma nova regulação do tema.

Regulação que passa, como dito, pela legitimação jurídica do Terceiro Setor, assumindo a sua importância e outorgando-lhe conceituação jurídica de modo a definir o seu espaço de participação. E fruto desta legitimação jurídica do Terceiro Setor e da redefinição das funções do Estado, buscou-se o reposicionamento das atividades passíveis de serem desenvolvidas por estes atores conjuntamente, nas áreas cuja competência constitucional é compartida por eles, sob a ótica do consensualismo. Marca-se uma unidade legislativa a todas as entidades qualificáveis como Terceiro Setor, para em segundo momento explicitar os requisitos e os benefícios desta qualificação.

Mais ainda, propõe-se a unificação e a centralização desta qualificação em órgão certificador responsável por regular as atividades das chamadas Organizações do Terceiro Setor. Órgão, aliás, proposto sob a forma de agência reguladora, com as funções de fomento e regulação das atividades das entidades.

Encerra-se, neste ponto, a duplicidade ou triplicidade de regimes jurídicos aplicáveis às entidades do Terceiro Setor; extinguem-se as outras qualificações existentes em determinado prazo; unifica-se o procedimento de seleção de projetos das entidades aptas a firmarem parcerias com a Administração Pública; simplifica-se o controle das atividades destas entidades através da centralização do órgão de controle e da redução das prestações de contas das entidades; etc. Parte-se, assim, na direção de uma unidade jurídica das relações entre a Administração Pública e o Terceiro Setor, dotando-as da segurança jurídica necessária ao seu pleno e legitimado desenvolvimento.

Até hoje o Terceiro setor e a Administração pública se moveram de forma independente, às vezes se encontrando, mais por acaso e de modo esporádico, às vezes se afastando. Este encontrar-se se inicia no final dos anos oitenta, graças a um mudado clima que apresentava, de um lado, a reivindicação, por parte das organizações com papel de "relevância pública" autonomamente constituídas pelos cidadãos para enfrentar problemas sociais e, do outro, uma maior sensibilidade e atenção por parte das instituições políticas para um mundo composto por milhões de cidadãos. A idéia que vai gradativamente se afirmando naqueles 
anos é que o Terceiro setor possa ser um recurso para um renovado desenvolvimento do país dentro de uma lógica de superação de uma concepção estatalista da iniciativa pública. (...) Um percurso, aquele iniciado no final dos anos oitenta, que viu nos anos sucessivos a produção de ulteriores intervenções normativas e momentos de encontro e diálogo entre os sujeitos envolvidos como, por exemplo, na organização do Fórum do Terceiro setor em 1999, em 2000 - seguida da aprovação da lei quadro para a realização do sistema integrado de intervenções e serviços sociais - a emanação da lei n. 328/1991 com a qual se reconheceu ao Terceiro setor o papel de partnership da Administração pública nas atividades de programação das intervenções sociais, percurso culminado em 2001, com a reforma do Título $\mathrm{V}$ da Constituição e em particular com a aprovação do inovado artigo 118 da Constituição, com a qual foi sancionada a introdução do princípio da subsidiariedade horizontal e vertical. ${ }^{612}$

É um movimento, o da renovação do arcabouço jurídico do Terceiro Setor e, especialmente, de sua relação com a Administração Pública, que toma contornos mundiais e cujos problemas enfrentados em outros países são semelhantes: uma legislação não sistematizada que prejudica o ambiente regulatório ${ }^{613}$.

O caminho percorrido dá conta de uma vontade até aqui consolidada de considerar o Terceiro setor uma das alavancas sociais e econômicas do nosso país; evidencia, todavia, certos problemas que foram focalizados nos capítulos próprios. Entre os aspectos mais problemáticos apontados, certamente relevante é a questão concernente à ausência de organização e sistematização na legislação do setor, o que impõe a aprovação de um Texto Único das leis do Terceiro setor, com o escopo de superar as leis especiais ainda existentes e eliminar as contradições normativas e as duplicações e, sobretudo, favorecer um relacionamento entre os diversos sujeitos que compõem o mundo do Terceiro setor promovendo a participação e a co-programação. ${ }^{614}$

${ }^{612}$ CITTADINO, Caterina et al. Conclusioni. In: CITTADINO, Caterina (org.). Dove lo Stato non arriva: pubblica amministrazione e terzo settore. Firenze : Passigli, 2008, p. 335, tradução nossa. No original: "Questo incontrarsi ha avvio sul finire degli anni Ottanta, grazie ad un mutato clima che vedeva, da un lato, la rivendicazione, da parte delle organizzazioni autonomamente costituite dai cittadini de un ruolo di 'rilevanza pubblica' per affrontare problematiche sociali e, dall'altro, una maggiore sensibilità ed attenzione da parte delle istituzioni politiche verso un mondo composto da milioni di cittadini. L'idea che gradatamente si va affermando in quegli anni è che il Terzo settore possa essere una risorsa per un rinnovato sviluppo del Paese entro una logica di superamento di una concezione statalista dell'iniziativa pubblica. (...) Un percorso, quello iniziato sul finire degli anni Ottanta, che ha visto negli anni successivi la produzione di ulteriori interventi normativi e momenti di incontro e dialogo fra i soggetti coinvolti quali, per esempio, nel 1999 l'organizzazione del Forum del Terzo settore, nel 2000 - a seguito dell'approvazione della legge quadro per la realizzazione del sistema integrato di interventi e servizi sociali - l'emanazione della legge n. 328/1991 con la quale si è riconosciuto al Terzo settore il ruolo di partnership della Pubblica amministrazione nelle attività di programmazione degli interventi sociali, percorso culminato nel 2001, con la riforma del Titolo V della Costituzione ed in particolare con l'approvazione del novellato articolo 118 della Costituzione, con la quale si è sancita l'introduzione del principio di sussidiarietà sia orizzontale sia verticale".

${ }^{613}$ Sobre a regulação social, cf. LA SPINA, Antonio; MAJONE, Giandomenico. Lo Stato regolatore. Bologna : Il Mulino, 2000, pp. 38 e ss. Dizem os autores que "na regulação social se incluem também medidas anti-discriminação e a garantia dos direitos de cidadania” (ibidem, p. 39).

${ }^{614}$ CITTADINO, Caterina et al. Op. cit., p. 335, tradução nossa. No original: "Lo strada percorsa dà contezza di una volontà ormai consolidata di considerare il Trezo settore una delle leve sociali e economiche del nostro Paese; evidenzia, tuttavia, talune problematicità che nel corso della trattazione sono state focalizzate nei singoli capitoli. Fra gli aspetti maggiormente problematici emersi, certamente rilevante è la questione concernente l'assenza di organicità e sistematicità nella legislazione di settore che, impone l'emanazione di un Testo Unico delle leggi del Terzo Settore, con lo scopo di superare le leggi speciali ancora esistenti ed 
Este longo percurso em busca de um ambiente jurídico-normativo adequado para o desenvolvimento das atividades do Terceiro Setor e das suas parcerias com a Administração Pública na consecução das finalidades públicas que compartem deve ser iniciado é a proposta final a que nos dedicamos, com a crença de que "a construção de um novo marco jurídico do terceiro setor, calcado na judicidade, legitimidade e regulação, sob a ótica discursiva e democrática, é um horizonte possível, ainda que tardio". ${ }^{615}$

eliminare le contraddizioni normative e le duplicazioni e, soprattutto, favorire un confronto fra i diversi soggetti che compongono il mondo del Terzo settore promuovendo la partecipazione e la coprogrammazione".

615 DIAS, Maria Tereza Fonseca. Terceiro setor e Estado: legitimidade e regulação. Belo Horizonte : Fórum, 2008, p. 430. 


\section{REFERÊNCIAS BIBLIOGRÁFICAS}

ALLEGRETTI, Umberto. L'amministrazione dall'attuazione costituzionale alla democrazia partecipativa. Milano : Giuffrè, 2009.

ALVES, Francisco de Assis. Fundações, organizações sociais e agências executivas: organizações da sociedade civil de interesse público e outras modalidades de prestação de serviços públicos. São Paulo : LTr, 2000.

ANDRADE, Alessandro Purcino. As organizações religiosas como pessoas jurídicas de direito privado. Revista de Direito do Terceiro Setor - RDTS, Belo Horizonte : Fórum, ano 3, n. 5, jan.-jun. 2009, pp. 93-113.

ARAGÃO, Alexandre Santos de. Direito dos serviços públicos. Rio de Janeiro : Forense, 2007.

. Princípio da legalidade e poder regulamentar no Estado Contemporâneo. Revista de Direito Administrativo, vol. 225, jul.-set. 2001.

As parcerias público-privadas - PPP's no direito positivo brasileiro. Revista Eletrônica de Direito Administrativo Econômico, Salvador : IDPB, n. 2, mai.-jun.jul. 2005. Disponível na Internet: <http://www.direitodoestado.com.br $>$. Acesso em: 19 mar. 2007.

ARAÚJO, Geraldo Bonnevialle Braga. A responsabilidade social da empresa e as fundações privadas. Revista de Direito do Terceiro Setor - RDTS, Belo Horizonte : Fórum, ano 1, n. 1, jan.-jun. 2007, pp. 113-132.

ARENA, Gregorio. Cittadini attivi: un altro modo di pensare all'Italia. Roma-Bari : Laterza, 2006.

AZEVEDO, Marcos de. O terceiro setor e o direito ambiental. ONG's: desenvolvimento, estratégia de atuação e gestão. São José do Rio Preto : Meio Jurídico, 2006.

BALEEIRO, Aliomar. Limitações constitucionais ao poder de tributar. $7^{\mathrm{a}}$ ed. Rio de Janeiro : Ed. Forense, 1999.

BARACHO, José Alfredo de Oliveira. O princípio da subsidiariedade: conceito e evolução. Rio de Janeiro : Forense, 1997.

BARBETTA, Gian Paolo e MAGGIO, Francesco. Nonprofit. $2^{\circ}$ ed. Bologna : Il Mulino, 2008.

BARBIERI, Carla Bertucci. Terceiro setor: desafios e perspectivas constitucionais. Curitiba : Juruá, 2008. 
BARBOSA, Maria Nazaré Lins. Os termos de parceria como alternativa aos convênios aspectos jurídicos. In: SZAZI, Eduardo (org.). Terceiro setor: temas polêmicos 1. São Paulo : Peirópolis, 2004, pp. 25-44.

BARROS, Sérgio Resende de. Contribuição dialética para o constitucionalismo. Campinas : Millennium, 2008.

BARZELAY, Michael. The new public management: improving research and policy dialogue. New York : Russel Sage Foundation, 2001.

BASSANINI, Franco. Postfazione. In: CITTADINO, Caterina (org.). Dove lo Stato non arriva: pubblica amministrazione e terzo settore. Firenze : Passigli, 2008, pp. 353-376.

BENTO, Leonardo Valles. Governança e governabilidade na reforma do Estado: entre eficiência e democratização, Barueri : Manole, 2003.

BENVENUTI, Feliciano. Per um Diritto Amministrativo Paritario. In: Studi in onore di Enrico Guicciardi. Padova : CEDAM, 1975, pp. 807-851.

II nuovo cittadino: tra libertà garantita e libertà attiva. Venezia : Marsilio, 1994.

BERTOLDI, Marcelo M.; RIBEIRO, Marcia Carla Pereira. Curso Avançado de Direito Comercial. $3^{\mathrm{a}}$ ed. São Paulo : RT, 2006.

BINENBOJM, Gustavo. Uma teoria do Direito Administrativo: direitos fundamentais, democracia e constitucionalização. Rio de Janeiro : Renovar, 2006.

BOBBIO, Norberto. Estado, governo, sociedade: para uma teoria geral da política. $9^{\text {a }}$ ed. São Paulo : Paz e Terra, 2001, trad. Marco Aurélio Nogueira.

et al. Democracia. In: (coord.). Dicionário de Política. $8^{\mathrm{a}}$ ed. Brasília : Ed. UnB, 1995, pp. 319-329, vol. 1, trad. Carmem C. Varriale et al.

BONAVIDES, Paulo. Curso de direito constitucional. $12^{\mathrm{a}}$ ed., São Paulo : Malheiros, 2002.

. Do Estado liberal ao Estado social. $7^{\mathrm{a}}$ ed. São Paulo : Malheiros, 2001.

. Teoria constitucional da democracia participativa: por um direito constitucional

de luta e resistência; por uma nova hermenêutica; por uma repolitização da legitimidade, $2^{\mathrm{a}}$ ed. São Paulo : Malheiros, 2003.

BRAGA, Luziânia C. Pinheiro. Organizações da Sociedade Civil de Interesse Público (OSCIP): promoção e construção de (novos) direitos e assessoria jurídica de caráter suplementar. In: OLIVEIRA, Gustavo Justino de (coord.). Terceiro Setor, empresas e Estado: novas fronteiras entre o público e o privado. Belo Horizonte : Fórum, 2007, pp. 261-280.

BRASIL. Constituição da República Federativa do Brasil, de 05 de outubro de 1988. Brasília, DF: Senado, 1988. 
BRASIL. MINISTÉRIO DA JUSTIÇA. SECRETARIA DE ASSUNTOS LEGISLATIVOS. PNUD. INSTITUTO PRO BONO. OLIVEIRA, Gustavo Justino de (coord. acad.). Estado Democrático de Direito e Terceiro Setor. Série Pensando o Direito. Brasília, n. 16, 2009. Disponível na Internet: $<$ http://portal.mj.gov.br/main.asp?Team=\%7B7393FACA\%2DF9C1\%2D42B0\%2DBE 43\%2D8F8756A587C8\%7D>. Acesso em: 20 abr. 2010.

BRASIL. MINISTÉRIO DO PLANEJAMENTO, ORÇAMENTO E GESTÃO. Comissão de juristas constituída pela Portaria n. 426, de 6 de dezembro de 2007, do Ministério do Planejamento, Orçamento e Gestão. Resultado final. Disponível na Internet: $<$ http://www.planejamento.gov.br/secretarias/upload/Arquivos/seges/comissao_jur/arq uivos/090729_seges_Arq_leiOrganica.pdf>. Acesso em: 20 abr. 2010.

BRUSCUGLIA, Luciano; ROSSI, Emanuele (coord.). Terzo settore e nuove categorie giuridiche: le organizzazioni non lucrative di utilità sociale. Milano : Giuffrè, 2000.

CABALLERÍA, Marcos Vaquer. La acción social: un estudio sobre la actualidad del Estado social de Derecho. Valencia : Tirant lo Blanch, 2002.

CABRA DE LUNA, Miguel Ángel; LORENZO GARCIA, Rafael de. El Tercer Sector en España: ámbito, tamaño y perspectivas. Revista Española del Tercer Sector, n. 1, out.-dez. 2005. Disponível na Internet:

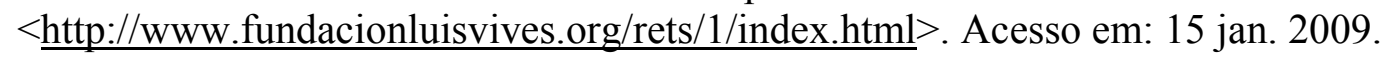

CARINCI, Franco (org.). Non profit e volontariado: profili giuridico istituzionali 1. Milano : IPSOA, 1999.

CARVALHO, Cristiano; PEIXOTO, Marcelo Magalhães (coord.). Aspectos jurídicos do Terceiro Setor. $2^{\mathrm{a}}$ ed., São Paulo : MP, 2008.

CAFAGGI, Fabrizio (org.). Modelli di governo, riforma dello stato sociale e ruolo del terzo settore. Bologna : Il Mulino, 2002.

Governare per contratto o per organizzazione? Alternative istituzionali nella riforma dello stato sociale. In: (org.). Modelli di governo, riforma dello stato sociale e ruolo del terzo settore. Bologna : Il Mulino, 2002, pp. 75-135.

. Modelli di governo e riforma dello stato sociale. In: CAFAGGI, Fabrizio (org.). Modelli di governo, riforma dello stato sociale e ruolo del terzo settore. Bologna : Il Mulino, 2002, pp. 7-72.

CANOTILHO, J. J. Gomes. "Brancosos" e interconstitucionalidade: itinerários dos discursos sobre a historicidade constitucional. $2^{\text {a }}$ ed. Coimbra : Almedina, 2008.

. Direito constitucional e teoria da Constituição. $5^{\text {a }}$ ed. Coimbra : Almedina.

CARDOSO, Ruth. Fortalecimento da sociedade civil. In: IOSCHPE, Evelyn Berg (org.). $\mathbf{3}^{\mathbf{o}}$ setor: desenvolvimento social sustentado. Rio de Janeiro : Paz e Terra, 1997, pp. 712 . 
CASSESE, Sabino. L'arena pubblica: nuovi paradigmi per lo Stato. Rivista trimestrale di diritto pubblico, Roma : Giuffrè, n. 3, 2001, pp. 601-650.

CASTELLS, Manuel. A era da informação: a sociedade em rede. $5^{\mathrm{a}}$ ed., São Paulo : Paz e Terra, 2001.

CASTRO, Rodrigo Pironti Aguirre de. O sistema de controle interno e as entidades do terceiro setor: perspectiva gerencial e o princípio da eficiência. In: OLIVEIRA, Gustavo Justino de (coord.). Direito do Terceiro Setor. Belo Horizonte : Fórum, 2008, pp. 163-176.

- Terceiro Setor e responsabilidade social. In: OLIVEIRA, Gustavo Justino de (coord.). Direito do Terceiro Setor: atualidades e perspectivas. Curitiba : OAB/PR, 2006, pp. 147-156.

CHEVALLIER, Jacques. L’État de Droit. Paris : Montchrestien, 1992.

CICONELLO, Alexandre. O conceito legal de público no Terceiro Setor. In: SZAZI, Eduardo (org.). Terceiro setor: temas polêmicos 1. São Paulo : Peirópolis, 2004, pp. 45-66.

CITTADINO, Caterina (org.). Dove lo Stato non arriva: pubblica amministrazione e terzo settore. Firenze : Passigli, 2008.

et al. Conclusioni. In: CITTADINO, Caterina (org.). Dove lo Stato non arriva: pubblica amministrazione e terzo settore. Firenze : Passigli, 2008, pp. 335-352.

COELHO, Fábio Ulhoa. Curso de direito comercial. $6^{a}$ ed. São Paulo : Saraiva, 2002, vol. 1.

COELHO, Simone de Castro Tavares. Terceiro setor: um estudo comparado entre Brasil e Estados Unidos. São Paulo : SENAC, 2000.

COMUNIDADE ECONÔMICA EUROPÉIA. Tratado da Comunidade Econômica Européia. 1957. Disponível em: <http://eur-lex.europa.eu/pt/treaties/index.htm>. Acesso em: 03 fev. 2010.

CORBELLA, Luigi. Riforma del Terzo Settore: il confronto necessario fra enti e legislatore. Terzo Settore: le regole per il non profit, Milano : Il Sole 24 Ore, n. 1, jan. 2007, pp. 51-54.

CRUZ, Rachel Pellizzoni da. A prática da responsabilidade social empresarial no Brasil: dilemas e perspectivas. Revista de Direito do Terceiro Setor - RDTS, Belo Horizonte : Fórum, ano 1, n. 1, jan.-jun. 2007, pp. 97-112.

CYMBALISTA, Tatiana Matiello; LOUREIRO, Caio de Souza; NASCIMENTO, Mariana Chiesa Gouveia. A operação de hospitais por meio de PPP's: nova fronteira na prestação dos serviços de atenção à saúde. Disponível na Internet: 
$<$ http://www.manesco.com.br/website/portugues/litteraExpress/default.asp?ltxCode=D 51237EA-2B18-4DAE-B2B5-8DCD7F9CD704>. Acesso em: 20 de março de 2010).

DALLA MURA, Franco. Pubblica amministrazione e non profit: guida ai rapporti innovativi nel quadro della legge 328/2000. Roma : Carocci Faber, 2003.

DALLARI, Adilson de Abreu. Cobrança de taxa para custeio da TV educativa. Revista de Informação Legislativa, Brasília : Senado Federal, ano 35, n. 138, abr.-jun. 1998, pp. 113-125.

DALLARI, Dalmo de Abreu. Elementos de teoria geral do Estado. 23a ed., São Paulo : Saraiva, 2002. . 25ª ed. São Paulo : Saravia, 2006, $2^{\mathrm{a}}$ tir.

DEFARGES, Philippe Moreau. La gouvernance. $3^{\mathrm{a}}$ ed., Paris : Presses Universitaires de France, 2008.

DELGADO, José Augusto. Reflexões sobre o sistema tributário aplicado ao Terceiro Setor. Revista Fórum de Direito Tributário - RFDT, Belo Horizonte, ano 3, n. 17, set.-out. 2005, pp. 09-38.

DEMO, Pedro. Solidariedade como efeito de poder. São Paulo : Cortez; Instituto Paulo Freire, 2002.

DERZI, Misabel Abreu Machado. Notas. In: BALEEIRO, Aliomar. Limitações constitucionais ao poder de tributar. $7^{\text {a }}$ ed. Rio de Janeiro : Ed. Forense, 1999.

DI PIETRO, Maria Sylvia Zanella. Direito Administrativo. $19^{a}$ ed. São Paulo: Atlas, 2006.

Discricionariedade administrativa na Constituição de 1988. $2^{\mathrm{a}}$ ed., São Paulo : Atlas, 2001.

Parcerias na administração pública: concessão, permissão, franquia, terceirização, parceria público-privada e outras formas. $5^{\text {a }}$ ed. São Paulo : Atlas, 2006.

. Temas polêmicos sobre licitações e contratos. $4^{\mathrm{a}}$ ed. São Paulo : Malheiros, 2000.

DIAS, Maria Tereza Fonseca. Terceiro Setor e Estado: legitimidade e regulação: por um novo marco jurídico. Belo Horizonte : Fórum, 2008.

DINIZ, Eli. Governabilidade, governance e reforma do Estado: considerações sobre o novo paradigma. Revista do Serviço Público, ano 47, v. 120, n. 2, mai.-ago. 1996.

EGLER, Tamara Tania Cohen (org.). Ciberpólis: redes no governo da cidade. Rio de Janeiro : 7Letras, 2007.

EISENMANN, Charles. O Direito Administrativo e o princípio da legalidade. Revista de Direito Administrativo, vol. 56, abr.-jun. 1959, pp. 47-70, traduzido da revista 
"Études et Documents", Conseil d’Etat, fascículo n. ${ }^{\circ} 11$, p. 47 e ss., por Ruth Barbosa Goulart.

ESPING-ANDERSEN, Gosta. As três economias políticas do Welfare State. Lua Nova Revista de Cultura e Política, n. 24, set. 1991, pp. 85-116.

. O futuro do welfare state na nova ordem mundial. Lua Nova - Revista de Cultura e Política, n. 35, 1995, pp. 73-111.

ESTORNINHO, Maria João. A fuga para o direito privado. Coimbra : Almedina, 1999.

. Requiem pelo contrato administrativo. Coimbra : Almedina, 1990.

FALCÃO, Joaquim; CUENCA, Carlos (coord.). Mudança social e reforma legal: estudos para uma nova legislação do terceiro setor. Brasília, DF : Conselho da Comunidade Solidária : UNESCO, 1999.

. Diretrizes para nova legislação do Terceiro Setor. In: (coord.). Mudança social e reforma legal: estudos para uma nova legislação do terceiro setor. Brasília, DF : Conselho da Comunidade Solidária : UNESCO, 1999, pp. 17-54.

FARIA, Juliana Campos de. Contratação de entidades de portadores de deficiência física: releitura da dispensa de licitação à Luz da função social do contrato administrativo, do direito à educação especial e conforme ADPF $\mathrm{n}^{0}$ 45. Boletim Jurídico, n. 188, 28/07/2006. Disponível na Internet: < http://www.boletimjuridico.com.br/doutrina/texto.asp?id=1445>. Acesso em: 13 abr. 2010).

FERLIE, Ewan et al. A nova administração pública em ação. Brasília : Editora Universidade de Brasília, 1999, pp. 26 e ss., trad. de Sara Rejane de Freitas Oliveira.

FERNANDES, Jorge Ulisses Jacoby. Contratação direta sem licitação. $4^{\mathrm{a}}$ ed., Brasília : Brasília Jurídica, 1999.

FERNANDES, Luciana de Medeiros. Reforma do Estado e Terceiro Setor. Curitiba : Juruá, 2009.

FERNANDES, Rubem César. O que é o terceiro setor? In: IOSCHPE, Evelyn Berg (org.). $3^{\mathbf{0}}$ setor: desenvolvimento social sustentado. Rio de Janeiro : Paz e Terra, 1997, pp. $25-$ 34.

Privado porém público: o Terceiro Setor na América Latina. $3^{\mathrm{a}}$ ed. Rio de Janeiro : Relume Dumará, 2002.

FERRAREZI, Elisabete. O novo marco legal do terceiro setor no Brasil. 2001. Disponível na Internet: < http://www.lasociedadcivil.org/docs/ciberteca/ferrarezi.pdf $>$. Acesso em: 24 abr. 2010.

; REZENDE, Valéria. OSCIP - Organização da sociedade civil de interesse público: a Lei n. ${ }^{\circ}$ 9.790/99 como alternativa para o terceiro setor. $2^{a}$ ed. Brasília : 
Comunidade $\quad$ Solidária, Disponível na Internet: <http://www.comunidadesolidaria.org.br $>$. Acesso em: 29 jan. 2003.

FERRARI, Paola Nery; FERRARI, Regina Maria Macedo Nery. Controle das organizações sociais. Belo Horizonte : Fórum, 2007.

FERREIRA FILHO, José Alexandre. Examinando o papel do terceiro setor como provedor de serviços públicos e sua relação com o estado de bem estar social: uma análise comparativa entre as experiências recentes dos Estados Unidos, Alemanha, França e Brasil. Revista Economia, Negócios e Finanças, ano 1, n. 1, jul.-dez. 2002.

FICI, Antonio. I contratti tra pubblica amministrazione ed enti non profit nel settore dei servizi alla persona. In: CAFAGGI, Fabrizio (org.). Modelli di governo, riforma dello stato sociale e ruolo del terzo settore. Bologna : Il Mulino, 2002, pp. 137-178.

FISHMAN, James J.; SCHWARZ, Stephen. Nonprofit organizations: cases and materials. $2^{\mathrm{a}}$ ed. New York : Foundation Press, 2000.

FRANCO, Augusto de. Prefácio à primeira edição: o que está por trás da nova lei do terceiro setor. In: FERRAREZI, Elisabete; REZENDE, Valéria. OSCIP Organização da sociedade civil de interesse público: a Lei n. ${ }^{\circ}$ 9.790/99 como alternativa para o terceiro setor. $2^{\mathrm{a}}$ ed. Brasília : Comunidade Solidária, 2002, pp. 7-18. Disponível na Internet: $<$ http://www.comunidadesolidaria.org.br $>$. Acesso em: 29 jan. 2003.

FREITAS, Juarez. Discricionariedade administrativa e o direito fundamental à boa Administração Pública. 2a ed. São Paulo : Malheiros, 2009.

GABARDO, Emerson. Interesse público e subsidiariedade: o Estado e a sociedade civil para além do bem e do mal. Belo Horizonte : Fórum, 2009.

GAGLIARDUCCI, Francesca et al. Pubblica amministrazione, acquisti etici e terzo settore. In: CITTADINO, Caterina (org.). Dove lo Stato non arriva: pubblica amministrazione e terzo settore. Firenze : Passigli, 2008, pp. 199-270.

GAUDIN, Jean-Pierre. Gouverner par contrat. Paris : Presses de Sciences PO, 1999.

GERONE, Acyr de. As organizações religiosas e o Terceiro Setor. In: OLIVEIRA, Gustavo Justino de (coord.). Direito do Terceiro Setor. Belo Horizonte : Fórum, 2008, pp. 127-161.

. As organizações religiosas e o terceiro setor. Revista de Direito do Terceiro Setor

- RDTS, Belo Horizonte : Fórum, ano 2, n. 3, jan.-jun. 2008, pp. 61-85.

GIACINTI, Roberto; NADDI, Donatella. Agenzia per Le Onlus e Agenzia delle Entrate si contendono l'attività ispettiva e di controllo. Terzo Settore. Milano : Il Sole 24 Ore, n. 10, out. 2005.

GIUFFRÈ, Felice. Declínio del Parlamento-legislatore. In: LABRIOLA, Silvano (org.). Le autorità indipendenti. Milano : Giuffrè, 1999, pp. 177-214. 
La solidarietà nell'ordinamento costituzionale. Milano : Giuffrè, 2002.

GIULIANI, Barbara. New public governance e diritto amministrativo nel governo del território. Bari : Cacucci, 2006.

GOLA, Marcella. L'organismo di controllo degli enti non commerciali e delle Onlus nella Legge n. 662/96. In: CARINCI, Franco (org.). Non profit e volontariado: profili giuridico istituzionali 1. Milano : IPSOA, 1999, pp. 91-105.

GOMES, Maurício Augusto. Ministério Público e serviços de relevância pública na Constituição e na revisão constitucional. Revista Justitia, São Paulo : APMP, n. 161, jan.-mar. 1993, p. 23. Disponível na Internet: $<\mathrm{http}: / /$ www.revistajustitia.com.br/revistas/58w8z5.pdf>. Acesso em: 15 mar. 2010.

GONÇALVES, Pedro. A concessão de serviços públicos. Coimbra : Almedina, 1999, pp. 145-146).

GOZZI, Gustavo. Estado Contemporâneo. In: BOBBIO, Norberto et al. (coord.). Dicionário de política. $11^{\mathrm{a}} \mathrm{ed}$. Brasília : UnB, 1998, vol. 1, trad. Carmem C. Varriale et al.

GRAU, Eros Roberto. A ordem econômica na Constituição de 1988. $5^{\mathrm{a}}$ ed. São Paulo : Malheiros, 2000, p. 140

Constituição e serviço público. In: Direito Constitucional: estudos em homenagem a Paulo Bonavides. São Paulo : Malheiros, 2003.

HABERMAS, Jürgen. Direito e Democracia: entre facticidade e validade. Rio de Janeiro : Tempo Brasileiro, 1997, v. 2.

HEEKS, Richard. Reinventing government in the information age. London : New York : Routledge, 1999.

HELLER, Herman. Teoria del Estado. México : Fondo de Cultura Económica, 1990, trad. Luis Tobio.

IAMICELI, Paola. Servizi alla persona e forme privatistiche di gestione: il modello delle organizzazioni miste. In: CAFAGGI, Fabrizio. Modelli di governo, riforma dello stato sociale e ruolo del terzo settore. Bologna : Il Mulino, 2002, pp. 179-253.

IHL, Olivier (coord.). Les "sciences" de l'action publique. Grenoble : Presses universitaires de Grenoble, 2006.

INGLATERRA. CHARITIES ACT. 2006. PART 1. SECTION 2. SUBSECTION 2. Disponível na Internet: $<$ http://www.opsi.gov.uk/acts/acts2006/ukpga_20060050_en_2\#pt1-11g1>. Acesso em 03 mai. 2010. 
IOSCHPE, Evelyn Berg (org.). $\mathbf{3}^{\text {o }}$ setor: desenvolvimento social sustentado. Rio de Janeiro : Paz e Terra, 1997

ITÁLIA. La Costituzione italiana. Con introduzione di Saulle Panizza e Roberto Romboli. Corredata da: struttura del texto della Costituzione italiana, articoli della Costituzione, in ordine numérico, interessati da leggi costituzionali e di revisione costituzionale intervenute trai 11948 e il 2008. Aggiornata a giugno 2008. Pisa : PLUS, 2008.

JUSTEN FILHO, Marçal. Teoria geral das concessões de serviço público. São Paulo : Dialética, 2003.

- As diversas configurações da concessão de serviço público. Revista de Direito Público da Economia - RDPE, Belo Horizonte : Fórum, ano 1, n. 1, 2003.

. Comentários à lei de licitações e contratos administrativos. $14^{\mathrm{a}}$ ed. São Paulo : Dialética, 2010.

. Curso de direito administrativo. $2^{\mathrm{a}}$ ed. São Paulo : Saraiva, 2006.

KISIL, Marcos. Organização social e desenvolvimento sustentável: projetos de base comunitária. In: IOSCHPE, Evelyn Berg (org.). $\mathbf{3}^{\mathbf{0}}$ setor: desenvolvimento social sustentado. Rio de Janeiro : Paz e Terra, 1997, pp. 131-156.

KLIKSBERG, Bernardo. Repensando o Estado para o desenvolvimento social: superando dogmas e convencionalismos. São Paulo : Cortez, 1998, p. 45, trad. Joaquim Ozório Pires da Silva.

KURZ, Robert. Os últimos combates. 4ª ed. Petrópolis-RJ : Vozes, 1998.

. Para além de Estado e Mercado. In: . Os últimos combates. $4^{\mathrm{a}}$ ed. PetrópolisRJ : Vozes, 1998, pp. 151-157;

LA SPINA, Antonio; MAJONE, Giandomenico. Lo Stato regolatore. Bologna : Il Mulino, 2000.

LEONARDO, Rodrigo Xavier. A reforma do direito das associações sem fins econômicos pela Lei n. 11.127 de 2005 e o Terceiro Setor. Revista de Direito do Terceiro Setor RDTS, Belo Horizonte : Fórum, ano 1, n. 1, jan.-jun. 2007, pp. 39-52.

LOPES, Licínio. As instituições particulares de solidariedade social. Coimbra : Almedina, 2009.

LUPPI, Silvia A. Frego. Il principio di consensualità nell'agire amministrativo alla luce della legislazione e della giurisprudenza più recenti. Diritto amministrativo: rivista trimestrale, Milano : Giuffrè, anno XVI, n. 3, 2008.

MAÑAS, José Luis Piñar. Tercer Sector, sector público y fundaciones. Revista Española del Tercer Sector, n. 1, out.-dez. 2005. Disponível na Internet:

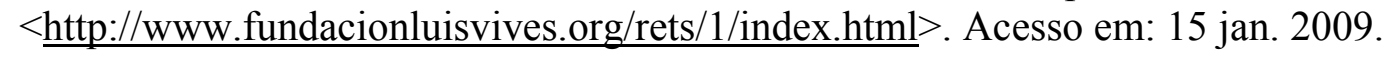


MÂNICA, Fernando Borges. Negócio jurídico para a prestação de serviços por entidade do terceiro setor: natureza jurídica, requisitos, critérios e procedimento para a celebração do ajuste. Revista de Direito do Terceiro Setor - RDTS, Belo Horizonte : Fórum, ano 1, n. 2, jul.-dez. 2007, pp. 141-164.

. Panorama histórico-legislativo do Terceiro Setor no Brasil: do conceito de Terceiro Setor à Lei das OSCIP. In: OLIVEIRA, Gustavo Justino de (coord.). Terceiro Setor, Empresas e Estado: novas fronteiras entre o público e o privado. Belo Horizonte : Fórum, 2007, pp. 163-194;

. Terceiro Setor e imunidade tributária. Belo Horizonte : Fórum, 2005.

MANNORI, Luca; SORDI, Bernardo. Storia del diritto amministrativo. $4^{\mathrm{a}}$ ed. Roma-Bari : Laterza, 2006.

MARQUES NETO, Floriano de Azevedo. As parcerias público-privadas no saneamento ambiental. Revista Eletrônica de Direito Administrativo Econômico, Salvador : IBPB, n. 2, mai.-jun.-jul. 2005. Disponível na Internet: $<\mathrm{http}: / / \mathrm{www}$.direitodoestado.com.br>. Acesso em: 19 mar. 2007.

. Concessão de serviço público sem ônus para o usuário. In: WAGNER JUNIOR, Luiz Guilherme Costa (coord.). Direito público: estudos em homenagem ao Professor Adilson Abreu Dallari. Belo Horizonte : Del Rey, 2004, pp. 331-351.

MARTINS, Ives Gandra da Silva (coord.). O Estado do futuro. São Paulo : Pioneira : Associação Internacional de Direito e Economia, 1998.

O Estado do Futuro. In: Internacional de Direito e Economia, 1998, pp. 13-28.

MATTEUCI, Nicola. Liberalismo. In: BOBBIO, Norberto et al. (coord.). Dicionário de política. $11^{\text {a }}$ ed. Brasília : UnB, 1998, vol. 1, trad. Carmem C. Varriale et al.

MEDAUAR, Odete. Direito administrativo em evolução. 2a ed. São Paulo : RT, 2003.

. Direito administrativo moderno. 10ª ed. São Paulo : RT, 2006.

MEIRELLES, Hely Lopes. Direito Administrativo brasileiro. 26 a ed. São Paulo : Malheiros, 2001, atual. por Eurico de Andrade Azevedo, Délcio Balestero Aleixo e José Emmanuel Burle Filho.

. Licitação e contrato administrativo. $15^{\mathrm{a}}$ ed. São Paulo : Malheiros, 2010.

MELLO, Celso Antônio Bandeira de. Curso de direito administrativo. $18^{\mathrm{a}}$ ed. São Paulo : Malheiros, 2005.

MENDONÇA, J. X. Carvalho de. Tratado de Direito Comercial brasileiro $5^{\text {a }}$ ed., Livraria Freitas Bastos, 1953, vol. 1, p. 492. 
MICHIARA, Paolo. Le convenzioni tra pubblica amministrazione e terzo settore: considerazioni sulle procedure selettive a concorrenza limitata nell'ambito dei rapporti a collaborazione necessaria. Roma : Istituto Editoriale Regione Italiane S.R.L., 2005.

MODESTO, Paulo. Reforma do Estado, formas de prestação de serviços ao público e parcerias público-privadas: demarcando as fronteiras dos conceitos de serviço público, serviços de relevância pública e serviços de exploração econômica para as parcerias público-privadas. Revista Eletrônica de Direito Administrativo Econômico, Salvador : Instituto de Direito Público da Bahia, n. 2, mai.-jun.-jul. 2005. Disponível na Internet: $<$ http://www.direitodoestado.com.br>. Acesso em: 08 mar. 2010.

. Reforma do marco legal do Terceiro Setor no Brasil. In: FALCÃO, Joaquim; CUENCA, Carlos (org.). Mudança social e reforma legal: estudos para uma nova legislação do Terceiro Setor. Brasília : Conselho da Comunidade Solidária : UNESCO : BID : FBB, 1999, pp. 137-160.

MONTAÑO, Carlos. Terceiro setor e questão social: crítica ao padrão emergente de intervenção social. São Paulo : Cortez, 2002;

MOREIRA, Egon Bockmann. Organizações Sociais, Organizações da Sociedade Civil de Interesse Público e seus "Vínculos Contratuais" com o Estado. In: MOREIRA, Egon Bockmann; CUÉLLAR, Leila. Estudos de Direito Econômico. Belo Horizonte : Fórum, 2004, pp. 259-278.

- Desenvolvimento econômico, políticas públicas e pessoas privadas (passado, presente e futuro de uma perene transformação). Revista de Direito do Estado RDE, ano 3, n. 10, abr.-jun 2008.

MOREIRA NETO, Diogo de. Mutações do Direito Público. Rio de Janeiro : Renovar, 2006.

- Mutações do direito administrativo revisitadas: novas considerações, avaliação e controle das transformações. In: . Mutações do Direito Público. Rio de Janeiro : Renovar, 2006, p. 223).

; CASTRO, Paulo Rabello de. O futuro do Estado: do pluralismo à desmonopolização do poder. In: MARTINS, Ives Gandra da Silva (coord.). O Estado do futuro. São Paulo : Pioneira : Associação Internacional de Direito e Economia, 1998, pp. 45-61.

MOREIRA, Alexandre Mussoi. A transformação do Estado: neoliberalismo, globalização e conceitos jurídicos. Porto Alegre : Livraria do Advogado, 2002.

MOREIRA, Vital. A regulação das fundações. In: MOREIRA, Vital; MARQUES, Maria Manuel Leitão. A mão visível: mercado e regulação. Coimbra : Almedina, 2003.

MORISON, John. The Government-voluntary sector compacts: governance, governmentality, and civil society. Journal of law and society, Oxford : Blackwell Publishers, vol. 27, n. 1, mar. 2000, pp. 98-132. 
NERY JÚNIOR, Nelson; NERY, Rosa Maria de Andrade. Novo Código Civil e legislação extravagante anotados. São Paulo : RT, 2002.

NÓBREGA, Theresa Christine de Albuquerque. A regulação do Terceiro Setor no Brasil: uma reflexão sobre o regime jurídico dos termos de parceria. In: CARVALHO, Cristiano; PEIXOTO, Marcelo Magalhães (coord.). Aspectos jurídicos do Terceiro Setor. $2^{\text {a }}$ ed., São Paulo : MP, 2008, pp. 403-430.

OLIVEIRA, Gustavo Justino de. Direito do Terceiro Setor. In: Revista de Direito do Terceiro Setor - RDTS, Belo Horizonte : Fórum, ano 1, n. 1, jan.-jun. 2007, pp. 1138.

Estado contratual, direito ao desenvolvimento e parceria público-privada. In: TALAMINI, Eduardo et al. (coord.). Parceria público privada: uma abordagem multidisciplinar. São Paulo : Revista dos Tribunais, 2005, pp. 83-119.

(coord.). Terceiro Setor, empresas e Estado: novas fronteiras entre o público e o privado. Belo Horizonte : Fórum, 2007.

. Gestão privada de recursos públicos para fins públicos: o modelo das OSCIP. In: (coord.). Terceiro Setor, empresas e Estado: novas fronteiras entre o público e o privado. Belo Horizonte : Fórum, 2007, pp. 213-260.

(coord.). Direito do Terceiro Setor. Belo Horizonte : Fórum, 2008. 2006 .

(coord.). Direito do Terceiro Setor: atualidades e perspectivas. Curitiba : OAB/PR,

OSCIPS e licitação: ilegalidade do Decreto n. 5.504, de 05.08.05. Revista Eletrônica sobre a Reforma do Estado - RERE, Salvaldor : IBDP, n. 12, dez.-jan.fev. 2008, p. 36. Disponível na Internet: $<$ http://www.direitodoestado.com/revista/RERE-12-DEZEMBRO-2007GUSTAVO\%20JUSTINO.pdf>. Acesso em: 20 abr. 2010.

. Taxa de administração prevista em contratos de gestão firmados com organizações sociais: típicos instrumentos de fomento público para entidades do terceiro setor. Revista de Direito do Terceiro Setor - RDTS, Belo Horizonte : Fórum, ano 3, n. 5, jan.-jun. 2009, pp. 117-141.

. Contrato de gestão. São Paulo : RT, 2008, p. 33.

. Parceria público-privada e direito ao desenvolvimento: uma abordagem necessária. Revista Eletrônica de Direito Administrativo Econômico - REDAE, Salvador : IDPB, n. 3, ago.-set.-out. 2005. Disponível na Internet: $<$ http://www.direitodoestado.com/revista/REDAE-3-AGOSTO-2005GUSTAVO\%20JUSTINO.pdf>. Acesso em: 22 abr. 2010.

; MÂNICA, Fernando Borges. Organizações da Sociedade Civil de Interesse Público: termo de parceria e licitação. Boletim de Direito Administrativo, São Paulo : NDJ, ano XXI, n. 9, set. 2005. 
; SCHWANKA, Cristiane. A Administração consensual como a nova face da Administração Pública no séc. XXI: fundamentos dogmáticos, formas de expressão e instrumentos de ação. In: XVII ENCONTRO PREPARATÓRIO PARA O CONGRESSO NACIONAL DO CONPEDI, 2008, Salvador. Anais eletrônicos, p. 126. Disponível em:

http://conpedi.org/manaus/arquivos/anais/salvador/gustavo_henrique_justino_de_olivei ra.pdf $>$. Acesso em: 08 fev 2010.

OTERO, Paulo. Legalidade e administração pública: o sentido da vinculação administrativa à juridicidade. Coimbra : Almedina, 2003.

PAES, José Eduardo Sabo. Fundações e Entidades de Interesse Social: aspectos jurídicos, administrativos, contábeis e tributários. Brasília: Brasília Jurídica, 1999. . $4^{\mathrm{a}}$ ed. Brasília : Brasília Jurídica, 2003, p. 88;

PASTORI, Giorgio. L'organismo di controllo delle ONLUS. In: Studi in onore di Umberto Pototsching. $2^{\circ}$ vol., Milano : Giuffrè, 2002,

PAULA, Ana Paula Paes de. Por uma nova gestão pública: limites e potencialidades da experiência contemporânea. Rio de Janeiro : FGV, 2005.

PELLIZZER, Franco; SANTI, Giacomo. La "convenzione" con gli enti non profit fra sistema contrattualistico comunitário, normative nazionali ed intervento attuativo regionale. In: CARINCI, Franco (org.) Non profit e volontariado: profili giuridico istituzionali 1. Milano : IPSOA, 1999, pp. 139-173.

PEREIRA, Cláudia Fernanda de Oliveira. Os tribunais de contas e o Terceiro Setor: aspectos polêmicos do controle. In: OLIVEIRA, Gustavo Justino de (coord.). Terceiro Setor, Empresas e Estado: novas fronteiras entre o público e o privado. Belo Horizonte : Fórum, 2007, pp. 309-332.

PEREIRA, Luiz Carlos Bresser. Reforma do Estado para a cidadania: a reforma gerencial brasileira na perspectiva internacional. São Paulo : Ed. 34; Brasília : ENAP, 1998 ;

PERFETTI, Luca R. Corso di diritto amministrativo. 2a ed. Padova : CEDAM, 2008.

PERICU, G. L'attività consensuale dell'amministrazione pubblica. In: MAZZAROLLI, L. et al. (coord.). Diritto amministrativo. $3^{\text {a }}$ ed. Bologna : Monduzzi, 2001, cap. IV.

PINTO JUNIOR, Mario Engler. Parceria público-privada: antigas e novas modalidades contratuais. In: PAVANI, Sérgio Augusto Zampol; ANDRADE, Rogério Emílio de (coord.). Parcerias público-privadas. São Paulo : MP Editora, 2006.

PIOVESAN, Flávia; BARBIERI, Carla Bertucci. Terceiro Setor e direitos humanos. In: CARVALHO, Cristiano;PEIXOTO, Marcelo Magalhães (coord.). Aspectos jurídicos do Terceiro Setor. $2^{a}$ ed. São Paulo : APET : MP Editora, 2008, pp. 89-122. 
PORTO NETO, Benedicto. Concessão de serviço público no regime da Lei n. 8.987/95: conceitos e princípios. São Paulo : Malheiros, 1998.

QUELHAS, Ana Paula Santos. A refundação do papel do Estado nas políticas sociais, Coimbra : Almedina, 2001.

QUERMONNE, Jean-Louis. Gouvernance et gouvernment: deux lectures d'une politique institutionnelle européenne. In: IHL, Olivier (coord.). Les "sciences" de l'action publique. Grenoble : Presses universitaires de Grenoble, 2006, p. 122, tradução nossa).

RAFAEL, Edson José. Fundações e direito: $3^{\circ}$ setor. São Paulo : Companhia Melhoramentos, 1997.

RAWLS, John. Justiça e democracia. São Paulo : Ed. Martins Fontes, 2000, trad. de Irene A. Paternot.

REALE, Miguel. O renascimento do liberalismo. In: MARTINS, Ives Gandra da Silva (coord.). O Estado do Futuro. São Paulo : Pioneira : Associação Internacional de Direito e Economia, 1998, pp. 32-44.

REGONINI, Gloria. Estado do Bem-estar. In: BOBBIO, Norberto et al. (coord.). Dicionário de política. $11^{\mathrm{a}}$ ed. Brasília : UnB, 1998, pp. 416-419, vol. 1, trad. Carmem C. Varriale et al.

REGULES, Luis Eduardo Patrone. Terceiro setor: regime jurídico das OSCIPs. São Paulo : Método, 2006.

RESENDE, Tomáz de Aquino. Roteiro do Terceiro Setor. $2^{\text {a }}$ ed. Belo Horizonte : Fundação Newton Paiva, 2003.

RIBEIRO, Marcia Carla Pereira. Sociedade de Economia Mista e Empresa Privada: estrutura e função. Curitiba : Juruá, 1999.

RICCI, Sergio. Appalti e convenzioni fra Terzo Settore ed enti pubblici. Terzo settore: le regole per il non profit. Milano : Il Sole 24 Ore, n. 10, out. 2006.

. Controlli e verifiche: stretta sulle Onlus. Terzo Settore, Milano : Il Sole 24 Ore, n. 3, mar. 2007, pp. 33-36.

RIVERO, Jean. Direito Administrativo. Coimbra : Almedina, 1981, p. 93, trad. Rogério Ehrhardt Soares.

ROCHA, Sílvio Luís Ferreira da. Terceiro Setor. São Paulo : Malheiros, 2003.

SALAMON, Lester M. et al. Global Civil Society: dimensions of the nonprofit sector. Bloomfield : Kumarian Press, 2004.

. Estratégias para o fortalecimento do terceiro setor. In: IOSCHPE, Evelyn Berg (org.). $\mathbf{3}^{\mathbf{0}}$ setor: desenvolvimento social sustentado. Rio de Janeiro : Paz e Terra, 1997, pp. 89-112. 
The State of nonprofit America. Washington : Brookings Institution Press, 2002.

SALINAS, Natasha Schmitt Caccia. Avaliação legislativa no Brasil: um estudo de caso sobre as normas de controle das transferências voluntárias de recursos públicos para entidades do terceiro setor. Dissertação de mestrado. São Paulo, Faculdade de Direito da USP, 2008.

SANTAMARÍA PASTOR, Juan Alfonso. Princípios de derecho administrativo. $3^{\mathrm{a}}$ ed., Editorial Centro de Estúdios Ramón Areces, vol. I.

SANTIN, Valter Foleto. Controle judicial da segurança pública: eficiência do serviço na prevenção e repressão ao crime. São Paulo : RT, 2004.

SANTOS, Boaventura de Sousa. Para uma reinvenção solidária e participativa do Estado. In: PEREIRA, Luiz Carlos Bresser; WILHEIM, Jorge; SOLA, Lourdes (orgs.). Sociedade e Estado em transformação. São Paulo : Brasília : Unesp/ENAP, 1999.

SANTOS, José Anacleto Abduch. Licitação e terceiro setor. In: OLIVEIRA, Gustavo Justino de (coord.). Terceiro setor, empresas e Estado: novas fronteiras entre o público e o privado. Belo Horizonte : Fórum, 2007, pp. 271-308.

SCHIERA, Pierangelo. Estado moderno, In: BOBBIO, Norberto et al. (coord.), Dicionário de política, $11^{\mathrm{a}}$ ed. Brasília : UnB, 1998, vol. 1, trad. Carmem C. Varriale et al.

SCHOENMAKER, Janaína. O Terceiro Setor e a proteção dos direitos fundamentais. Revista de Direito do Terceiro Setor - RDTS, Belo Horizonte : Fórum, ano 1, n. 2, jul.-dez. 2007, pp. 25-50.

SCOCA, Franco Gaetano. Autorità e consenso. In: Autorità e consenso nell'attività amministrativa. Milano : Giuffrè, 2002, pp. 21-48.

SEN, Amartya. Development as freedom. New York : Anchor Books, 1999.

SÉRVULO CORREIA, José Manuel. O princípio da legalidade administrativa no direito comparado. In: Legalidade e autonomia contratual nos contratos administrativos. Coimbra : Almedina, 1987, pp. 33-55.

SHAFRITZ, Jay M.; RUSSELL, E.W. Introducing public administration. New York : Longman, 1996.

SILVA, José Afonso da. Curso de direito constitucional positivo. $18^{\mathrm{a}}$ ed. São Paulo : Malheiros, 2000.

SILVA, Maria das Graças Bigal Barboza da; SILVA, Ana Maria Viegas da. Terceiro Setor: Gestão das entidades sociais. Belo Horizonte : Fórum, 2008.

SILVANO, Ana Paula Rodrigues. Fundações Públicas e Terceiro Setor. Rio de Janeiro : Lumen Juris, 2003. 
SOARES, Laura Letsch. Oscip's - Organizações sociais da sociedade civil de interesse público: resultados práticos alcançados após a promulgação da Lei 9.790/99. In: $\mathbf{1 8}^{\mathbf{0}}$ CONGRESSO BRASILEIRO DE CONTABILIDADE, Gramado, 24-28/2008. Trabalhos. Disponível na Internet: <www.congressofc.org.br/hotsite/trabalhos_11449.pdf>. Acesso em: 22 abr. 2010.

SOARES, Luiz Eduardo. Prefácio. In: COELHO, Simone de Castro Tavares. Terceiro setor: um estudo comparado entre Brasil e Estados Unidos. São Paulo : SENAC, 2000.

SORACE, Domenico. La buona amministrazione. In: RUOTOLO, Marco (coord.). La Costituzione há 60 anni: la qualità della vita sessant'anni dopo. Napoli : Editoriale Scientifica, 2008, pp. 119-135.

SOUTO, Marcos Juruena Villela. Direito administrativo em debate. Rio de Janeiro : Lumen Juris, 2004.

. Contratos administrativos no Brasil. In: . Direito administrativo em debate.

Rio de Janeiro : Lumen Juris, 2004.

. Direito administrativo das parcerias. Rio de Janeiro : Lumen Juris, 2005.

. Parceria para divulgação do desporto. In: . Direito administrativo das parcerias. Rio de Janeiro : Lumen Juris, 2005.

SOUZA, Leandro Marins de. Terceiro setor e cooperativas sociais. In: SZAZI, Eduardo (org.). Terceiro Setor: temas polêmicos 2. São Paulo : Peirópolis, 2005, pp. 163-196.

. Tributação do terceiro setor no Brasil. São Paulo : Dialética, 2004.

SUNDFELD, Carlos Ari. Guia jurídico das parcerias público-privadas. In:

Parcerias público-privadas. São Paulo : Malheiros, 2005.

SUPERIOR TRIBUNAL DE JUSTIÇA, RESP n. 942.412/SP, $2^{\text {a }}$ Turma, Rel. Min. Herman Benjamin, DJe de 09/03/2009.

SUPREMO TRIBUNAL FEDERAL, ADI 3366-2, Tribunal Pleno, Relator para acórdão Min. Eros Grau, DJ 02/03/2007).

SUPREMO TRIBUNAL FEDERAL, Recurso Extraordinário n. 424.227-3, Segunda Turma, Relator Min. Carlos Velloso, DJ 10/09/2004.

SZAZI, Eduardo. Terceiro Setor: regulação no Brasil. São Paulo : Peirópolis, 2000. . $3^{\mathrm{a}}$ ed. São Paulo : Peirópolis, 2003. (org.). Terceiro setor: temas polêmicos 1. São Paulo : Peirópolis, 2004. (org.). Terceiro Setor: temas polêmicos 2. São Paulo : Peirópolis, 2005. 
TÁCITO, Caio. Temas de Direito Público (estudos e pareceres). Rio de Janeiro : Renovar, 2002.

- Constituições reconstituídas. In: pareceres). Rio de Janeiro : Renovar, $20 \overline{02,3^{\circ}}$ vol..

. Direito administrativo de amanhã. In: pareceres). Rio de Janeiro : Renovar, 2002, $\overline{3^{\circ} \text { vol.. }}$

Temas de direito público (estudos e

. Direito Administrativo Participativo. In: pareceres). Rio de Janeiro : Renovar, 2002, $3^{\circ}$ vol..

. Temas de direito público (estudos e

. Transformações do Direito Administrativo. In:

(estudos e pareceres). Rio de Janeiro : Renovar, 2002, $\overline{3^{\circ} \text { vol.. }}$

TEIXEIRA, Josenir. Parcerias entre o Estado e o Terceiro Setor na saúde. Revista de Direito do Terceiro Setor, Belo Horizonte : Fórum, ano 1, n. 1, jan.-jun. 2007, p5372.

THOMPSON, Andrés A. Do compromisso à eficiência? Os caminhos do terceiro setor na América Latina. In: IOSCHPE, Evelyn Berg (org.). $3^{\text {o }}$ setor: desenvolvimento social sustentado. Rio de Janeiro : Paz e Terra, 1997, pp. 41-48.

TIBERI, Giulia. La dimensione costituzionale del Terzo settore. In: CITTADINO: Caterina (org.). Dove lo Stato non arriva: pubblica amministrazione e terzo settore. Firenze : Passigli, 2008.

TOLEDO, Juliana Amaral; SILVA, Fernando Moraes Quintino da. A empresa social - o crescimento do empreendedorismo social e a retomada dos valores sociais no setor empresarial. Revista de Direito do Terceiro Setor - RDTS, Belo Horizonte : Fórum, ano 3, n. 6, jul.-dez. 2009, pp. 93-112.

TORRES, Sílvia Faber. O princípio da subsidiariedade no direito público contemporâneo. Rio de Janeiro : Renovar, 2001.

TREZZA, Valéria Maria. O papel das organizações da sociedade civil na democracia. Revista de Direito do Terceiro Setor - RDTS, Belo Horizonte : Fórum, ano 3, n. 6, jul.-dez. 2009, pp. 09-36.

- O termo de parceria como instrumento de relação público/privado sem fins lucrativos: o difícil equilíbrio entre flexibilidade e controle. Dissertação de mestrado. São Paulo, Escola de Administração de Empresas de São Paulo, Fundação Getúlio Vargas, 2007. Disponível na Internet:

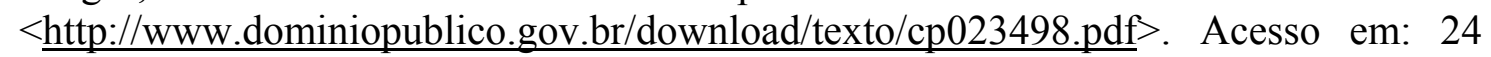
abr. 2010).

UNIÃO EUROPÉIA. Tratado da União Européia. Jornal Oficial n. C 191 de 29 de julho de 1992. Disponível em: <http://eurlex.europa.eu/pt/treaties/dat/11992M/htm/11992M.html>. Acesso em: 03 fev 2010. 
VALLE, Vanice Lírio do. Terceiro Setor e parcerias com a Administração Pública: desafios ao controle das OS e OSCIPs. Revista de Direito do Terceiro Setor - RDTS, Belo Horizonte : Fórum, ano 2, n. 4, jul.-dez. 2008, pp. 47-64.

VAN DER PLOEG, Tymen J.. Legislación del tercer sector social en la Unión Europea. Revista Española del Tercer Sector, n. 9, mai.-ago. 2008. Disponível na Internet:

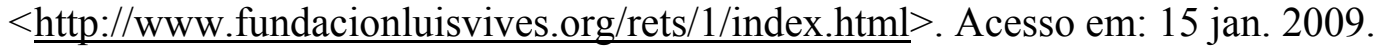

VIOLIN, Tarso Cabral. A terceirização ou concessão de serviços públicos sociais. A privatização de creches municipais. Jus Navigandi. Disponível na Internet: $<$ http://jus2.uol.com.br/doutrina/texto.asp?id=3515>. Acesso em: 06 abr. 2010.

O "Terceiro Setor" e as cooperativas sociais. In: OLIVEIRA, Gustavo Justino de (coord.). Direito do Terceiro Setor: atualidades e perspectivas, Curitiba : OAB/PR, 2006, pp. 197-221.

Terceiro setor e as parcerias com a Administração Pública: uma análise crítica. Belo Horizonte : Fórum, 2006.

WAGNER JUNIOR, Luiz Guilherme Costa (coord.). Direito público: estudos em homenagem ao Professor Adilson Abreu Dallari. Belo Horizonte : Del Rey, 2004.

WEICHERT, Marlon Alberto. Saúde e federação na Constituição brasileira. Rio de Janeiro : Lumen Júris, 2004.

ZAMAGNI, Stefano. Introduzione. In: CITTADINO, Caterina (org.). Dove lo Stato non arriva: pubblica amministrazione e terzo settore. Firenze : Passigli, 2008.

. L’Agenzia per le Onlus al sua secondo mandato. Terzo Settore, Milano : Il Sole 24 Ore, n. 3, mar. 2007, pp. I-VI.

ZEN, Marcela Rosa Leonardo. Licitação e Terceiro Setor: reflexões sobre o concurso de projetos da Lei das OSCIPs. In: OLIVEIRA, Gustavo Justino de (coord.). Direito do Terceiro Setor. Belo Horizonte : Fórum, 2008, p. 76

. Licitação e Terceiro Setor: reflexões sobre o concurso de projetos da Lei das OSCIPs. Revista de Direito do Terceiro Setor - RDTS, Belo Horizonte : Fórum, ano 2, n. 4, jul.-dez. 2008, pp. 65-84.

ZUQUIM, Sávio de Faria Caram. Impossibilidade de dispensa de licitação para a contratação de entidades de ensino visando à realização de concursos públicos. Revista do Tribunal Regional Federal da 1 ${ }^{a}$ Região, Brasília, v. 11, n. 2, abr.-jun. 1999. Disponível na Internet: $<$ http://bdjur.stj.gov.br/xmlui/bistream/handle/2011/21895/impossibilidade_dispensa_li citacao_contratacao.pdf?sequence=1>. Acesso em: 12 abr. 2010. 